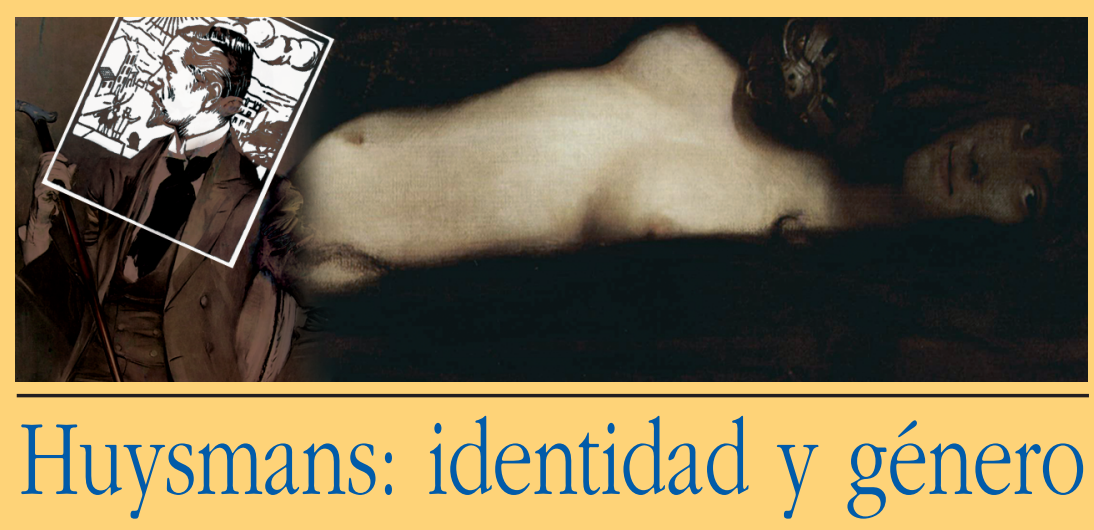

Francisco Domínguez González

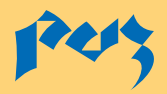

Prensas Universitarias de Zaragoza 

HUYSMANS: IDENTIDAD Y GÉNERO 



\section{HUYSMANS: IDENTIDAD Y GÉNERO}

Francisco Dominguez González

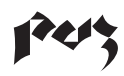

Prensas Universitarias de Zaragoza 
DOMÍNGUEZ GONZÁLEZ, Francisco

Huysmans : identidad y género / Francisco Domínguez González. — Zaragoza : Prensas Universitarias de Zaragoza, 2009

523 p. ; $22 \mathrm{~cm}$. - (Humanidades ; 74)

Bibliografía: p. 479-518 - ISBN 978-84-7733-141-4

Huysmans, Joris-Karl-Crítica e interpretación

821.133.1Huysmans, Joris-Karl1.06

Cualquier forma de reproducción, distribución, comunicación pública o transformación de esta obra solo puede ser realizada con la autorización de sus titulares, salvo excepción prevista por la ley. Diríjase a CEDRO (Centro Español de Derechos Reprográficos, www.cedro.org) si necesita fotocopiar o escanear algún fragmento de esta obra.

(C) Francisco Domínguez González

(C) De la edición espańola, Prensas Universitarias de Zaragoza

1. ${ }^{\text {a }}$ edición, 2009

Ilustración de la cubierta: José Luis Cano

Colección Humanidades, n. ${ }^{\circ} 74$

Director de la colección: José Ángel Blesa Lalinde

Prensas Universitarias de Zaragoza. Edificio de Ciencias Geológicas, c/ Pedro Cerbuna, 12 50009 Zaragoza, España. Tel.: 976761 330. Fax: 976761063

puz@unizar.es http://puz.unizar.es

Prensas Universitarias de Zaragoza es la editorial de la Universidad de Zaragoza, que edita e imprime libros desde su fundación en 1542.

Impreso en España

Imprime: Servicio de Publicaciones. Universidad de Zaragoza

D. L.: Z-1745-2009 
Einsam aber froh

J. BRAHMS 



\section{PRÓLOGO}

El año 2007 se celebró el centenario de la muerte del escritor JorisKarl Huysmans, nacido en París en 1848, el mismo año de la muerte de René de Chateaubriand. Las celebraciones suelen ser un buen momento para el recuerdo o el redescubrimiento de ciertos escritores. Así, la obra del escritor francés fue objeto durante este año de estudios, de coloquios, de disertaciones, de reediciones. Queremos destacar entre esas manifestaciones necrológicas la jornada que le dedicó el congreso de la AIEF (Association Internationale des Études Françaises). En ella la obra y la personalidad del escritor fueron analizadas desde diferentes puntos de vista metodológicos. ${ }^{1}$ En cierto modo, la publicación de este libro se inscribe en el epílogo de las efemérides con deseos de perdurar más allá de un hecho puntual. Para profundizar en la obra de Huysmans pueden privilegiarse multitud de aproximaciones que tratan de explicar la doble figura del escrito que va del real Charles-Marie-Georges a Joris-Karl creado por el propio autor o del puntual funcionario del Ministerio del Interior al creador de ficciones atormentadas en las que él era siempre el protagonista tras los personajes inventados. Ambas personalidades se yuxtaponen pero lo curioso es que la que perdura en la vida literaria y cultural es la segunda, mientras que la primera solo posee algún interés en tanto que exponente o complemento de la misma. Per Buvik presenta en la introducción de la mencionada jornada un completo e interesante estado actual de los estudios dedicados a Huysmans y detalla con acierto las distintas líneas de investigación privilegiadas

1 Huysmans, en Cahiers de l'Association internationale des études françaises, n. ${ }^{\circ}$ 60, mayo 2008, pp. 275-427. 
por los eruditos que se dedican a la obra de este autor, incidiendo en la evolución sufrida por la crítica en las últimas décadas. ${ }^{2}$

Abordar la obra de Huysmans desde una perspectiva de género es bastante novedoso, sobre todo en nuestro país, pese a que los estudios sobre la identidad masculina tengan una excelente tradición en otras latitudes. En este sentido la elección de Francisco Domínguez es arriesgada y atrevida. Arriesgada porque poca gente podía valorar y apreciar un parecido trabajo y atrevida porque quería romper moldes y todos sabemos que en el mundo universitario salirse, en ocasiones, de la línea trazada de antemano por la costumbre y la tradición puede costar caro, o si más no, tropezar con varios obstáculos y dificultades.

El autor del presente libro ha sabido sortear los escollos aunque no siempre ha sido capaz de eludir la controversia y ahí estriba, sin duda alguna, uno de sus méritos principales puesto que sin polémica es difícil que el saber humano pueda progresar.

Género analizado a partir del punto de vista de la masculinidad constituía la primera opción. La segunda, aunque más tradicional, no era menos problemática: consistía en la utilización del psicoanálisis freudiano, revisado, corregido y aumentado por Francisco Domínguez, lo que lo convertía en un arma explosiva. El resultado de ambos caminos convergentes lo tienen entre las manos. Evidentemente no puede ser considerado anodino, aunque sí puede ser contradicho, discutido, minuciosamente analizado.

De todas maneras, el autor nos lleva con mano firme y segura a admirar y a valorar la obra de este autor decadente, que abandonó las directrices naturalistas para elaborar una estética personal y original. Y lo digo por mi propia experiencia. Pocas cosas, exceptuando la perspectiva de género, podían llevarme a asumir la dirección de un estudio parecido. Siempre me ha interesado la literatura femenina, pero desde un punto de vista

2 Por el intento de divulgación y de acercamiento al público que supone, merece una mención especial la edición realizada por un equipo de investigadores, bajo la dirección de Pierre Brunel, de las novelas de este autor en dos volúmenes: Joris-Karl Huysmans, Romans I: Marthe, Les Sceurs Vatard, Sac au dos, En ménage, À vau-l'eau, À rebours, En rade, Un dilemme, La Retraite de Monsieur Bougran, Bouquins, París, Robert Laffont, 2005. Hasta el momento solo ha visto la luz el primer volumen. 
mucho más clásico, en la línea seguida por Béatrice Didier. ${ }^{3}$ Autoras como Simone de Beauvoir, Suzanne Lilar o Marguerite Duras están muy presentes en mis investigaciones. Huysmans era para mí un autor interesante pero no me atraía demasiado ni su espíritu decadente y misógino ni su lenguaje elaborado y artificioso. Cuando Francisco Domínguez llamó a mi puerta, era consciente que no había sido su primera opción. Tras una conversación inicial me di cuenta que tendría que vencer no pocas reticencias de su parte. Y de la mía existía el peligro de caer en las garras de Huysmans... Demasiado bien sé que cuando conocemos profundamente un autor acabamos por amarlo, por compartir emociones, sentimientos y a veces incluso ideas. Es sumamente difícil mantenerse al margen... Huysmans, por otra parte, es lo suficientemente seductor como para inspirar pasiones. Pese a todo, me decidí por aceptar el reto. Trabajar con el doctorando fue sumamente enriquecedor. Intercambiamos conocimientos y pareceres. Ello me permitió descubrir toda la variedad de posibilidades que ofrecía la obra de Huysmans y a él adentrarse un poco más en los vericuetos del trabajo científico. Logramos terminar felizmente la andadura que culminó con la presentación de la tesis doctoral Huysmans: identidad y género que obtuvo la máxima calificación en la Universidad de Lérida: sobresaliente cum laude por unanimidad. De ella surge el presente libro. Cabe señalar que el intento de dar cartas de nobleza al escritor en nuestro país es muy loable y debe valorarse muy positivamente. Ello se sitúa en la línea seguida por Juan Herrero, uno de los introductores de este autor en el campo universitario español. ${ }^{4}$

El estudio de Francisco Domínguez es muy completo ya que sitúa a Huysmans en el siglo XIX, desde la perspectiva de género, incidiendo en el papel relevante de la masculinidad, pero al mismo tiempo y de refilón ello le permite trazar un amplio panorama de la literatura de este siglo incluyendo en ella a su autor con precisión y acierto. El mito de Napoleón, el del dandi con su representación literaria baudeleriana son hitos que configuran el trabajo dándole consistencia. Todo ello realizado con una palabra incisiva, directa y de manera brillante a la vez que provocadora.

3 Béatrice Didier, L'écriture-femme, Écriture, París, P.U.F., 1999.

4 Juan Herrero, Traducción, introducción y notas a J.-K. Huysmans, A contrapelo, Cátedra, Madrid, 1984. 
Porque la interpretación que de Hysmanns hace el autor es provocadora, incidiendo en el campo de la autobiografía, poniendo de relieve unas difíciles relaciones con el entorno familiar; el padre y la madre desempeñan un importante papel en la creación del imaginario del escritor decadente.

Luego viene el análisis de su sexualidad; Huysmans es un hombre obsesionado por el sexo y sus realizaciones más primitivas, un hombre dominado por la libido, incapaz de controlarla, y sin embargo, las aspiraciones hacia el infinito desgarran su alma llenándola de contradicciones; aspiraciones concretizadas en su afición por el canto gregoriano. La música religiosa es el puente hacia lo espiritual, el sendero que le permite acceder a lo religioso desde la miseria de una carne nunca satisfecha ni domeñada. A través de un cuidado y minucioso análisis de cada una de sus obras, la mano de Francisco Domínguez nos lleva a profundizar en el espíritu del escritor, ofreciéndonos magistrales interpretaciones con una brillantez que es una de las características de su estilo.

La masculinidad del escritor se halla en el primer plano del estudio. Masculinidad que puede evidenciarse gracias al enfrentamiento con la figura femenina. Huysmans es un pintor nada despreciable de esta figura. Encontramos en primer lugar, a lo largo de sus obras, la figura de la madre; madre a la que el autor reprocha el abandono y la tristeza de una infancia de la que la figura del padre también estaba ausente. El análisis del niño abandonado que sufre en su carne la ausencia y el dolor que ella produce ocupan buena parte del estudio de Francisco Domínguez, quien sabe ponerlo de relieve con pertinencia. Sigue las personalidades de las mujeres que compartieron en cierta manera su vida, como Anne Meunier, mujer desequilibrada y enferma, amante durante mucho tiempo de Huysmans, que no pudo o no supo proporcionarle el equilibrio afectivo que él necesitaba. En Marthe (Marthe, histoire d'une fille), en Jeanne Jayant (En ménage), o en Louise Marles (En rade) existen numerosos rasgos y características que la recuerdan.

Más satánica es Hyacinthe Chantelouve (Là-bas) en quien está la huella de Henriette Maillat (amante que compartió con su amigo Léon Bloy), de la misteriosa Mme. X o de Henriette du Fresnel. Domínguez describe la dependencia de Durtal (Huysmans) con respecto a ella de esta forma: "Desde luego, Durtal no puede finalmente negarse a los avances de Mme. Chantelouve a causa de su carácter peligroso y casi masculino. Ojos sulfurosos, boca expoliadora y terrible: castradora. No dejan de ser, este en- 
cuentro y los siguientes con Hyacinthe, sino la aceptación de una sexualidad refinada, salpimentada con las especias más picantes». ${ }^{5}$ En la otra cara de la medalla se encuentra Lidwina de Schiedam, mártir mística a quien el escritor consagró un libro que, juntamente con la Virgen y la madre, configuran los aspectos positivos de la feminidad, aunque nada es nunca tan sencillo en nuestro autor y en la santa holandesa puede encontrar elementos obscuros que le exaltan y le turban. Así, Huysmans realiza el retrato completo de la mujer, presentándola como demonio, pero también como ángel, siguiendo el imaginario masculino más primitivo. Tentado por una sexualidad que no puede controlar, atraído por la espiritualidad, busca en ocasiones escapar al dilema refugiándose en el fantasma decadente de la homosexualidad que acecha a muchos de sus héroes como des Esseintes o Durtal.

Francisco Domínguez nos propone una nueva lectura de Huysmans, «lectura en la que el género no es sino el fruto de un terrible conflicto - consecuencia de la biografía del autor- de indeleble marca». ${ }^{6}$ Propuesta sugerente y atractiva, que puede ser discutible pero que en ningún caso deja indiferente. Por ello nos parece acertado recorrer la obra de Huysmans de la mano del autor de este ensayo, puesto que nos aporta una visión enriquecedora en profundidad.

Torredembarra, junio de 2008

Àngels SANTA

(Universidad de Lérida)

5 Vid. p. 126.

6 Vid. p. 241. 



\section{INTRODUCCIÓN}

\subsection{El autor Huysmans}

Joris-Karl Huysmans (París 1848-1907), autor de la controvertida À rebours (1884), es uno de los escritores más heterodoxos del fin-de-siècle decimonónico francés. Y esto, principalmente, porque su trayectoria artística evoluciona desde la prosa poética de raigambre bertrandiana ${ }^{1}$ de su Drageoir à épices (1874), pasando por su adscripción a la escuela zoliana de Médan y sus posteriores renuncia y abominación de la estética naturalista, hasta abrazar la escritura de inspiración religiosa en los últimos veinte años de su vida literaria. Es decir, extremos opuestos que Huysmans fue cultivando a medida que se acercaba a una mejor definición de sus objetivos artísticos.

Considerado como figura de proa del movimiento que dio en llamarse "decadentismo", su obra capital apareció en una fecha crucial para el cambio estético que se produjo en las artes y las letras francesas del último cuarto del siglo XIX. Es 1884 no solo el año de publicación de À rebours, sino también el del Salon des Indépendants y del primer Salon des XX en Bélgica: es decir, el germen de lo que para Jean Cassou sería el estilo moderno europeo del siglo XX. ${ }^{2}$ Un germen que se complacería en una preocupada huida del presente hacia un pasado evocador y misterioso, como fue el de la decadencia latina, que atrajo a un gran número de escritores admiradores de

1 De Aloysius Bertrand, autor del Gaspard de la nuit, considerada la obra que inaugura el poema en prosa tal y como lo entendemos hoy en día.

2 J. Cassou, Les sources du XXe siècle, les Arts en Europe de 1884 à 1914, Jean Cassou Editorial-Réunion des musées nationaux, París, 1990, pp. XX-XXI. 
Baudelaire, Gautier, Verlaine y Mallarmé. ${ }^{3}$ Laforgue, Péladan, D’Annunzio, Wilde..., cultivaron esta vía mediante una especie de hedonismo estético que, más tarde, vendría a conocerse como simbolismo — pero que en el campo de la prosa, dominado entonces por el Flaubert de La Tentation y seguido de Villiers de l'Isle-Adam, ha pasado a los anales como decadentismo. $^{4}$

La influencia de Huysmans sobre los epígonos de este exiguo movimiento - que se citaban en ese templo del decadentismo que fue el parisino Panier Fleuri- fue decisiva. Por una parte, por su declarada ruptura con el ideario tanto estético como filosófico del naturalismo de Zola - que convenía perfectamente al estetismo finisecular- $;^{5}$ por la otra, por su decidida y valiente exposición de una nueva sensibilidad — que era la de des Esseintes, el personaje único de $\grave{A}$ rebours - que dio en convencer a la juventud de escritores expectantes ante un cambio. Su liderazgo decadente quedó definitivamente asegurado gracias —o a causa- a Max Nordau, quien en su obra Entartung (Dégénérescence, 1893) tachaba al autor de Marthe, histoire d'une fille de decadente ideal — por el comportamiento de sus personajes y la exposición de sus gustos y hábitos de vida. ${ }^{6}$

La clase médica contrajo la costumbre, a partir de la aparición de la obra de Nordau, de estudiar detenidamente al autor de las obras de Huysmans, que, debido a sus particularidades, parecía merecer un análisis detallado de índole psicológica. Así fue el caso del doctor Lavalée — con su Essai sur la psychologie morbide de Huysmans—, del doctor Veysset — con su estudio Huysmans et la médecine - y, finalmente, del doctor Rolland -Étude

3 J. Lethève, "Le thème de la décadence dans les lettres françaises à la fin du XIXe siècle», Revue d'Histoire littéraire de la France, 1963, n. ${ }^{\circ} 1$.

4 Gustave Kahn afirmaría que «aunque todas las etiquetas son vanas, nos sentimos obligados a recordar, para la exacta información de los interesados, que decadente se pronuncia simbolista», en E. Bornay, Las hijas de Lilith, Ensayos Arte Cátedra, Madrid, 1995, p. 102. Vid., asimismo, L. Badesco, La génération poétique de 1860, Nizet, París, 1971. P. Martino, Le roman réaliste sous le Second Empire, Hachette, París, 1913. C. Charle, La crise littéraire à l'époque du naturalisme, PENS, París, 1979. Y A. Cassagne, La théorie de l'art pour l'art en France chez les derniers romantiques et les premiers réalistes, Slatkine Reprints, Ginebra, 1979.

5 Adolphe Baju dirá: «Un certain nombre de jeunes gens, las de lire toujours les mêmes tristes horreurs dites naturalistes...", A. Baju, Hommes d'aujourd'hui, n. o 332, p. 38.

6 M. Nordau, Dégénérescence, Alcan, París, 1894, vol. II, p. 107. 
psychopathologique sur le mysticisme de J.-K. Husymans. Tres ejemplos del interés que despertó en la sociedad de su tiempo el autor y que, en cierto modo, desviaron la atención del valor verdadero de su obra literaria.

En cualquier caso, la heterodoxia de Huysmans queda patente, precisamente, por poco que arrojemos luz sobre su evolución literaria. Si su cultivo de la tradición clásica del poema en prosa se da ya en su Drageoir de 1874, su verdadera adscripción al naturalismo no se da hasta la publicación de Marthe, histoire d'une fille dos años más tarde. A ella le seguiría ese otro étude de mours social que es la obra del 79 Les Soeurs Vatard, así como su participación en el volumen de Les Soirées de Médan (al lado de Zola, Céard, Hennique, Alexis y Maupassant) con Sac au dos (1880). Este relato de temática militar, que narra las vicisitudes de un soldado en la batalla de Sedán, inaugura las narraciones en torno a un personaje solitario y de mínimo entorno social que no dejará de ser habitual durante el resto de la producción huysmansiana. Es el tipo de personaje típico del fin-de-siglo, que rompe en parte con las convenciones sociales y familiares, y decide llevar una vida en solitario - cuya tipología será tan bien referida por Jean Borie en su célebre estudio Le célibataire français. ${ }^{7}$

La continuación del relato naturalista en torno a un personaje se da en la novela En ménage, de 1881, en la que se narra un tiempo de la vida de André Jayant: desde que sorprende a su mujer, Berthe, con su amante hasta que, incapaz de llevar una existencia independiente, decide volver con ella olvidando el incidente. La temática de la soltería se vería reforzada en la obra de Huysmans con la aparición, al año siguiente, de la nouvelle À vaul'eau, en la que se relata las tribulaciones del célibe Folantin en relación con la cobertura de los hábitos cotidianos: gestión de la alimentación, gestión del cuidado de la casa, gestión del amor. Para asegurarse la primera, este antihéroe de la literatura decimonónica recurre a la visita continuada a restaurantes y tabernas; para la segunda, el soltero vocacional contrata los servicios de personal doméstico — normalmente mujeres pero sin excluir el concurso de porteros y conserjes; finalmente, y en lo tocante a la gestión amorosa, el soltero retraído que es Folantin, que intentó ser Jayant, debe acudir a las casas de lenocinio, pues desconfía de los posibles vínculos sen-

7 J. Borie, Le célibataire français, Sagittaire, París, 1976. 
timentales que podrían establecerse entre él y una amante no venal habitual. Así, restaurantes, bonnes y prostitutas resumen el universo de este soltero irredento obra de la pluma de Huysmans.

Entre estas dos obras, el escritor se ocupa de otros menesteres literarios. Decimos otros por su alejamiento de la temática principal y que, en lo sucesivo, ya no abandonará nuestro autor. En 1881, y en colaboración con su amigo Léon Hennique (que ya estuvo con él en Les Soirées de Médan) publicó una obrita de título Pierrot sceptique. A pesar de su aparente distancia con el resto de la producción huysmansiana, esta plaquette encierra muchas más concomitancias con el imaginario de nuestro autor de lo que podría parecer en un estudio somero - pues la importancia del personaje de la Commedia dell'arte en el universo huysmansiano no es desdeñable, como veremos posteriormente. En 1883, el descendiente de pintores holandeses que es Joris-Karl Huysmans publica un estudio de arte en el que, bajo el título de L'art moderne, analiza con detallada profundidad la obra pictórica de algunos pintores de la época.

Y, en 1884, su editor saca a los estantes la obra que mayor permanencia ha dado a nuestro autor en los manuales de literatura escolar: $\grave{A}$ rebours. En ella Huysmans coloca a un clon enriquecido y noble de Folantin, el famoso des Esseintes — al que Mallarmé dedicaría una oda-, quien, huyendo del bullicio de la vida moderna, se recluye en una pequeña mansión del extrarradio parisino. En esta peculiar novela, que con tan poca intención novelística fue alumbrada, ${ }^{8}$ nuestro autor quiso plasmar, amén de sus rebuscados gustos, un inventario de lo que para él representaría la modernidad del arte finisecular. La sombra de Baudelaire, de Poe, de Gustave Moreau, de Villiers de l'Isle-Adam, Barbey d'Aurevilly, de Schumann, de Schubert... planea por entre sus páginas, creando un universo en el que los colores, los sonidos y los sabores se responden los unos a los otros. Des Esseintes es el cuarto avatar de este soltero recalcitrante y esteta que consigue, por fin, aislarse del mundo en una especie de retiro espiritual y, sobre todo, estético. La consecuencia de esta separación de la vida común será la enfer-

8 Huysmans expresaría en ese tiempo su deseo de hacer una obra en que se eliminase cualquier atisbo de intriga y, por la tanto, de desenlace novelesco: «supprimer l'intrigue traditionnelle, voire même la passion, la femme, concentrer le pinceau de lumière sur un seul personnage, faire à tout prix du neuf» («Préface écrite vingt ans après le roman», en J.-K. Huysmans, À rebours, ed. de Pierre Waldner, Garnier-Flammarion, París, 1978, p. 55). 
medad, que, iniciándose con un episodio dispéptico, termina en una neurosis diagnosticada por un profesional de la medicina —al que daría más tarde la razón Nordau en su libro ya referido. La curación, le dice su médico, solo podrá ser alcanzada mediante el abandono de esos hábitos solipsistas y el reingreso en la sociedad y sus pasatiempos. Victoria momentánea de la naturaleza sobre el intelecto — que intentará ser solventada gracias a una mejor preparación para el retiro por parte de ese continuum de personajes solitarios que hemos dado en llamar el «heterónimo ficcional huysmansiano".

En 1886, Huysmans publica una obra heterogénea, compuesta de muchos y variados frescos ciudadanos, que recibe el título de Croquis parisiens. Algunos de sus fragmentos ya serían compuestos en 1880, pero no verían la luz más que en esta fecha. Esta incidencia no dejaría de producir sobre el conjunto de su obra un elemento de ruptura y de desorientación para sus lectores y lectoras. Para el estudioso de la misma, los Croquis suponen una riquísima cantera de elementos de análisis sobre la estética y el ideario huysmansianos. Su importancia, por ello, no es menor, ya que en estos Croquis se puede observar numerosos componentes en estado de germen, de cuya funcionalidad literaria dependería su ulterior utilización. ${ }^{9}$ Así, aparecen en esta obra fragmentaria las primeras incursiones de Huysmans en el onirismo; sus obsesiones más recurrentes en cuestiones de índole fetichista y psicosexual —que hacen las delicias de quien, como nosotros, se interesa por la lectura psicologizante.

En 1887, el soltero al que se le receta compañía y diversiones para salir de su enfermedad y su encierro se ha convertido en un hombre casado. Jacques Marle es el protagonista de En rade, una nebulosa novela en la que este nuevo avatar del heterónimo ficcional huye de sus acreedores a un castillo provincial. Propiedad de la familia de Louise, su enferma esposa, el castillo se convierte en motivo habitual de las pesadillas y de las obsesiones de Marle. Es una de las obras en que con mayor profusión aparecen las metáforas de tipo acuático: muros que sudan humedad, sótanos inundados, sudores fríos... Metáforas que, como veremos más adelante, tienen una importancia crucial en la psicología huysmansiana. También es En rade la

9 Vid. F. Domínguez, «Los Croquis parisiens como primera formulación de algunas obsesiones de Huysmans», Anales de Filología, n. ${ }^{\circ}$ 16, Universidad de Murcia, Murcia, 2008. 
puesta en escena privilegiada de un potente onirismo, por lo que sería motivo de la más alta consideración de los escritores que le sucedieron. ${ }^{10}$ Pero, sobre todo, es la demostración de la inalcanzable estabilidad emocional a través de la vida de pareja: a partir de esta novela, la soltería de Huysmans —o, mejor dicho, de su heterónimo ficcional definitivo, de Durtal— será duradera.

Ese mismo año, las librerías son testigos de la llegada de otra obrita de nuestro autor. Un dilemme es una nouvelle en la línea naturalista, en la que la denuncia social vuelve a ser tema central. El desahucio de una mujer embarazada a manos del padre de su amante, ayudado por la experiencia de un notario, pone de manifiesto la crueldad de la maquinaria legal para con los más desfavorecidos.

1889 es el año de publicación de otro de los estudios pictóricos huysmansianos. Con Certains, Huysmans realiza una serie de semblanzas de artistas que se hallan, para él, en su misma línea estética. De dichos artistas, tres merecen especial mención por su frecuente recurrencia en las digresiones del heterónimo ficcional: los pintores Félicien Rops - a quien ya alabara Baudelaire-, Odilon Redon — amigo personal—y, cómo no, Gustave Moreau, su admirado pintor de salomés.

La Bièvre, obra de 1890, es, de nuevo, una pequeña composición. El tema central es el paisaje, que Huysmans intentó describir según el gusto pictórico flamenco, atravesado en el extrarradio parisién por ese riachuelo, pozo de inmundicias y espejo de pordioseros. Ejemplo móvil del agua y la naturaleza sometidas al dictado de la civilización, la Bièvre ya fue objeto de trabajo en los Croquis parisiens: esta vez, el escritor profundiza en la inspiración en torno a este arroyo.

$\mathrm{Al}$ año siguiente, nuestro prolífico escritor entrega a su editor la célebre novela de satanismo y metaliteratura que es Là-bas. En ella, el defini-

10 Como, por ejemplo, André Breton, quien lo hizo responsable de las leyes que rigen la afectividad moderna (A. Breton, Anthologie de l'humour noir, Jean-Jacques Pauvert-Livre de Poche, París, 1966, p. 191), así como de asestar el primer gran golpe a la fabulación novelesca (Nadja, Gallimard-Folio, París, 1964, p. 20). Luis Buñuel también glosó la importancia de Huysmans en su universo literario; no en vano, siempre deseó llevar a la pantalla su adaptación de Là-bas — de cuya intención solo nos ha dejado el guion, recientemente editado en España. 
tivo alter ego de Huysmans, Durtal, se ve inmerso en la escritura de un estudio sobre el noble Gilles de Rais —el Barbazul con que se atemorizaba a los niños de la Francia atlántica. Para conocer con mayor detalle los motivos de este carnicero medieval, Durtal indaga en la actualidad de los ritos demoníacos en el París finisecular. Súcubos, íncubos, misas negras, sacerdotes excomulgados, enigmáticos hagiógrafos; $L \grave{a}-b a s$ pone en escena un desfile de personajes y situaciones marginales y «ex-céntricas». La proyección de $L \grave{a}$-bas fue tal que Huysmans pasó a ser conocido por un reputado satanista en los círculos intelectuales - y que propició que se le encargara el prólogo de una obra dedicada al culto al demonio. ${ }^{11}$ Pero las repercusiones para el escritor no fueron menores, pues el estudio de lo sobrenatural le acercó a la religión, su lado positivo, en la que vio la posibilidad de redimir su atormentada vida.

Cuatro años más tarde, en 1895, las librerías se vieron invadidas por el libro de conversión de Huysmans, En route. En él se narra, con toda suerte de detalles según la técnica naturalista, ${ }^{12}$ el camino que llevó a Durtal de la zozobra existencialista al abrazo de la fe en Cristo; de los denodados intentos por alejarse de la nefasta influencia de las filles al acercamiento a la Iglesia. Durtal se interna, durante un breve período, en la Trapa d'Igny, en la que intentará hacerse a la vida monástica y alcanzar, por fin, su sueño de retiro y aislamiento. La experiencia es dura, no solo por las condiciones de vida del monasterio, sino por deber someterse a los sacramentos de la confesión y eucaristía - temidos por la carga psicológica que conlleva su práctica para el imaginario edípico del autor. Tan solo el arte litúrgico y la excelencia del canto gregoriano le permiten un respiro. La vuelta a París le deja convencido de la altura moral y espiritual de sus hermanos monjes.

La Cathédrale, editada en 1898, es el siguiente de sus relatos religiosos. En este, Durtal se desplaza a Chartres para acompañar a su amigo el abbé Gévresin, y disfrutar al mismo tiempo de la cercanía de esa inmensa obra

11 J. Bois, Le satanisme et la magie, ed. Léon Challey, París, 1895.

12 Huysmans jamás abandonaría el naturalismo en su vertiente operativa, como modo de trabajo. Y eso, a pesar de sus numerosas diatribas contra el naturalismo con afán de cientifismo a lo Zola - quien extrajo su metodología, como se sabe, del método experimental del doctor Bernard. Huysmans, huyendo de las pseudo-verdades de la ciencia, adoptaría un tipo de naturalismo que él llamaría "espiritualista» —que hallaría su correspondencia en el pintor alemán Grünewald. 
arquitéctonica que es el templo de Notre-Dame. La Cathédrale es una obra de estudio y alabanza, en la que Durtal se acerca a la Virgen María más que en ninguna otra; por lo demás, se le ofrece la oportunidad de residir un tiempo en la comunidad de los monjes negros de Solesmes, cuna del canto gregoriano.

La Bièvre et Saint-Séverin es una obra de ese mismo año de 1898, que se vería ampliada en 1901 con la glosa de les Gobelins (La Bièvre, les Gobelins et Saint-Séverin). Son obras de análisis y estudio de templos urbanos. 1899 vería la publicación de un libro que el mismo Durtal querría haber firmado: La magie en Poitou: Gilles de Rais, que estructura las notas tomadas durante la redacción de Là-bas para ilustrar el papel del noble medieval en esa «novela de una novela».

Sainte Lydwine de Schiedam es una obra hagiográfica en la que se narran las vicisitudes de esta santa medieval holandesa. Aunque pueda no parecerlo en un primer momento, la importancia de esta composición no es menor en el trazado de la psicología sexual de Huysmans - por motivos que tendremos en cuenta más adelante. De tout es, de nuevo, un compendio de estudios y comentarios sobre literatura y pintura. Ese mismo año de 1902, Huysmans publica su Esquisse autobiographique sur Dom Bosco, que no es sino un homenaje a ese prior benedictino rendido por el escritor con el fin de participar a la perpetuación de su figura.

El año siguiente, 1903, vería la aparición de la última obra publicada en vida de Huysmans, L'Oblat. En esta, Durtal ingresa en Val des Saints, un monasterio situado en Ligugé (Poitou), pero no como monje, sino como oblado. Esta es la solución que encuentra el personaje para evitar el estricto régimen monacal, y así poder vivir en el exterior del recinto religioso atendido por Mme. Bavoil, la asistenta que en su día atendiera a Gévresin. Al final de la novela, una ley recientemente promulgada sobre las congregaciones religiosas obliga a desmantelar el convento y a todos sus moradores a expatriarse en Bélgica. Durtal vuelve a París, donde se instala en un piso con su asistenta, resignado a contentarse con la limitada calidad de la liturgia en los templos parisienses.

Huysmans muere en París en 1907, víctima de un cáncer. Con carácter póstumo aparece veinte años más tarde su último opúsculo, Les Foules de Lourdes (1928-1934), fruto de su viaje a la ciudad santuario del sur de 
Francia. Sería la última vez que el escritor arremetiese contra la clase eclesiástica y su denunciado fariseísmo en este centro del comercio religioso — así como contra los fieles, embrutecidos por la acción misma de una fe de carácter pedigüeño y utilitario.

\subsection{Revolución de la modernidad en Huysmans}

Huysmans ha pasado a los anales de la historia literaria como el jefe de fila de ese movimiento no fundado, el decadentismo, que abrazó tras abjurar del naturalismo zoliano, y que le sumió en la oscuridad de una celda monacal en los diez últimos ańos de su vida. Su influencia en la literatura del siglo XX es, sin embargo, crucial: por una parte, por ser el primer erosionador de la trama novelesca — que conduciría a la aventura técnico-estética del Noveau Roman; por otra parte, su gusto por la digresión de todo tipo, que permite la ruptura del orden determinista de la novela naturalista, conduce directamente a la Recherche proustiana — cuyas digresiones, como dirá Jacques Dubois, ponen en juego un tipo de realismo superior- ; $^{13}$ finalmente, y como ya hemos señalado antes, es Huysmans uno de los primeros en introducir el onirismo en la novela, aspecto este tan utilizado a la postre por el surrealismo.

En cuanto a su incardinación en la progresión del pensamiento occidental, podemos afirmar sin ningún tipo de rubor que Huysmans es uno de los primeros ejemplos de escritor al que se podría tildar de 'postmoderno'. Según Jesús Ballesteros, ${ }^{14}$ la crisis de las ideas y de las referencias culturales que se produjo al final de la II Guerra Mundial - y que venía siendo anunciada por numerosos autores con antelación-y que ha sido denominada 'postmodernidad' puede ser distinguida en dos corrientes diferentes: postmodernidad como decadencia y postmodernidad como resistencia. La segunda podría ser considerada un fenómeno exclusivamente contemporáneo, surgido a partir de mayo del 68: las preocupaciones por la lucha en favor de la paz y en contra de los bloques militares, la defensa de la frugalidad ecológica contra el despilfarro consumista y de la solidaridad

13 J. Dubois, Les romanciers du réel, Seuil, Points, París, 2000, p. 253.

14 J. Ballesteros, Postmodernidad: decadencia o resistencia, Tecnos, Madrid, 1989, p. 13. 
ecuménica contra la indiferencia individualista, la hacen plenamente actual, sin ocurrencias visibles anteriores a la época a que nos referimos. Sin embargo, y en relación con la decadencia, podemos incluir a Huysmans como creador de un germen postmoderno - previo incluso a las corrientes artísticas conocidas como 'modernismo' en las que se ha englobado al Art Nouveau, al Jugend Stil, a la Secesión vienesa y al Modernisme catalán. La lógica de la fragmentación que Huysmans introduce frecuentemente en sus obras — que influyó a unos cuantos epígonos en la década de 1880 — ${ }^{15}$ así como del simulacro hace de él un temprano creador postmoderno avant l'heure y avant la lettre. Esto va perfectamente en el sentido indicado por François Lyotard, según el cual ningún significado global es necesario y solo cabe admitir una multiplicidad de significados (petits récits) que se encuentran en los intersticios mismos de la existencia. ${ }^{16}$

Esta posible inclusión de Huysmans en la nómina postmoderna, huelga decirlo, jamás ha sido contrastada por nosotros mediante la lectura de los postestructuralistas franceses - Foucault, Deleuze, Derrida, Lyotard, Baudrillard... - ni de los teóricos italianos del pensiero debole Vattimo y Rovatti. Tal vez sería más aceptable su influencia dentro de lo que el mismo Ballesteros prefiere llamar 'tardomodernidad' — tomándolo prestado de Charles Jencks—; ${ }^{17}$ o 'antimodernidad', que es como lo llama Habermas. ${ }^{18}$ Lo cierto es que el rechazo de Huysmans de las constantes del progreso científico y materialista de su siglo le hacen merecedor de esas denominaciones - tanto como de las otras por lo que ya hemos señalado unas cuantas líneas más arriba.

Sirvan estas consideraciones para reclamar para la obra de Huysmans una mayor consideración como uno de los forjadores del pensamiento contemporáneo. Es esta necesaria reivindicación uno de los motores de este trabajo.

15 Como por ejemplo el primer Gide, Bertrand, Biron, Dubois y Paque —como señala J. Dubois, ob. cit., p. 253.

16 J.-F. Lyotard, La condición postmoderna. Informe sobre el saber, Cátedra, Madrid, 1984. Vid. también la obra del español V. Sáinz Gutiérrez, La cultura urbana de la posmodernidad. Aldo Rossi y su contexto, Alfar, Sevilla, 1999.

17 C. Jencks, Arquitectura tardomoderna y otros ensayos, Gustavo Gili, Barcelona, 1982.

18 J. Habermas, "La modernidad, un proyecto incompleto», en H. Foster (ed.), La Posmodernidad, Kairós, Barcelona, 1985, y su obra de 1993, El discurso filosófico de la modernidad, Taurus, Madrid, 1993. 


\subsection{Género e identidad}

Dentro de los estudios de la postmodernidad, el género y su dinámica han ocupado un importante espacio. Un estudio de la obra y la personalidad de Huysmans con este enfoque puede parecer un tanto extraño para quien vea en los estudios de género y feministas una focalización exclusiva sobre las obras escritas por y para mujeres. ${ }^{19}$ No obstante, el empuje que están conociendo los Men studies en el mundo entero dan ya completa carta de naturaleza a los trabajos que, en base a consideraciones de género, se hacen sobre la literatura escrita por (¿y para?) hombres. Esto es tanto más posible en el caso de un estudio sobre Huysmans, obra a nuestro parecer movida por muy potentes impulsos sexuales.

La dinámica del género en Huysmans es fácilmente detectable aunque solo se tuviera en cuenta la importancia dada al celibato militante en su obra. Hombre activo sexualmente, heterosexual practicante si bien no siempre del todo convencido, el erotismo de Huysmans —o de lo que hemos llamado su heterónimo ficcional— es fuente de tremendos sufrimientos. Aun asumiendo la práctica de su heterosexualidad como parte integrante de su identidad masculina, dicha práctica es puesta en tela de juicio constantemente, siendo percibida como una obligación inherente a su rol sexual en lugar de como un placer. Este hecho no puede dejar de provocar zozobra en la personalidad del escritor, pues le impide la constitución sólida de su identidad —esté esta centrada en el género o no. Según los sociólogos Anthony Giddens y Manuel Castells, las identidades son fuentes de sentido más fuertes que los roles debido al proceso de autodefinición y de individualización que suponen. En términos sencillos, las identidades organizan el sentido, mientras que los roles organizan las funciones. ${ }^{20}$ Esto significa que la exis-

19 "Pero la crítica feminista se define por su exclusivo interés hacia las obras de mujeres?», se pregunta Françoise Collin. "¿Presupone que esas obras son siempre diferentes de las obras de los hombres, por el contenido, la forma, el estilo, o el procedimiento de desarrollo? ¿Será que las mujeres mantienen, incluso, una relación con lo escrito distinta a la de los hombres?», en F. Collin, "Poética y política, o los lenguajes sexuados de la creación», en N. Ibeas y M. A. Millán (eds.), La conjura del olvido. Escritura y feminismo, Icaria Antrazyt, Barcelona, 1997, p. 67.

20 A. Giddens, Modernity and Self-identity: Self and Society in the Late Modern Age, Polity Press, Cambridge, 1991, pp. 32, 35, 53 (versión castellana: La transformación de la identidad, Cátedra, Madrid, 1996). Y M. Castells, La era de la información. Economía, sociedad y cultura (vol. 2: El poder de la identidad), Alianza Editorial, Madrid, 1999, p. 28 y ss. 
tencia de una ruptura entre la función y el sentido puede provocar desajustes muy difíciles de compensar —a menos que se tomen decisiones en principio violentas pero necesarias para la construcción propia del sentido (que no es otra cosa sino la definición de identidad propuesta por Castells).

Dentro de esta construcción del sentido, la decisión que toma tímidamente Huysmans coincidiría con uno de los procesos de construcción de identidad que aparecen en la tipología establecida por Castells $-\mathrm{y}$ basada en los cuatro rasgos sugeridos por Alain Touraine. La «identidad proyecto» buscada por Huysmans en su zozobra se da como «cuando los actores sociales, basándose en los materiales culturales de que disponen, construyen una nueva identidad que redefine su posición en la sociedad». ${ }^{21}$ Siguiendo a Touraine, solo este tipo de proceso permite la creación de sujetos à part entière, pues según el sociólogo francés, «sujeto [es el] deseo de ser un individuo, de crear una historia personal, de otorgar sentido a todo el ámbito de las experiencias de la vida individual». ${ }^{22}$ Giddens será todavía más explícito en esta vía al afirmar que "ser un ser humano es comprender [...] tanto lo que se está haciendo como porqué se está haciendo [...] En el contexto del orden postradicional, el yo se convierte en un proyecto reflexivo». ${ }^{23}$ Esto significa que la búsqueda de la identidad a través de la praxis sexual es una difícil aventura, pues debe efectuarse frecuentemente al margen de las imposiciones funcionales que ejerce el patriarcado. Lo que nos importa ahora es tener en cuenta que la sociedad, mediante esa imposición, crea la desazón que Freud ya contempló en dos de sus obras, La moral sexual «cultural» y la nerviosidad moderna (1908) y El malestar en la cultura. ${ }^{24}$

Esta búsqueda de una función sexual que no contravenga la propia identidad llevará a Huysmans a coquetear con la homosexualidad. A pesar de que,

21 M. Castells, ob. cit., p. 30. Los otros dos tipos de identidades son la identidad legitimadora y la identidad de resistencia.

22 A. Touraine, "La formation du sujet», en F. Dubet y M. Wieviorka (eds.), Penser le sujet, Fayard, París, 1995, pp. 29-30.

23 A. Giddens, ob. cit., p. 35.

24 S. Freud, La moral sexual "cultural» y la nerviosidad moderna, en Obras Completas, traducción de Luis López-Ballesteros y de Torres, edición de Jacobo Numhauser Tognola, Biblioteca Nueva, Madrid, 1972, tomo IV, pp. 1249-1261. Y El malestar en la cultura. Alianza 30 aniversario, Madrid, 1997. 
en confesiones a amigos íntimos a los que le unía una gran confianza, declarara no sentirse jamás preparado para abordar una relación de corte homoerótico, su obra arroja suficientes datos sobre la latencia de esta tendencia. Aceptar esa vía de satisfacción sexual podría haber supuesto una mayor adecuación con su proyecto vital y, por ende, con su verdadera identidad.

Otro elemento que permite vislumbrar la posibilidad de un enfoque de género son las relaciones familiares referidas por Huysmans a través de sus textos. Lo cierto es que la presencia de las figuras tanto paterna como materna es más bien rara - lo que no deja de ser tan ilustrativo como si las referencias parentales fueran frecuentes. Esta circunstancia hace entrever un tipo de relaciones con la memoria familiar que el análisis de los textos mostrará positivo o negativo. De ese tipo de relaciones dependerá la fijación a modelos paterno y materno determinados, y sus representaciones en la obra literaria. Siguiendo a Jean-Paul Weber, cabe afirmar que en Huysmans también se da un "tema único", pues "toda obra se centra sobre un recuerdo privilegiado, único, que escribir es despertar, y a la vez exorcizar, un tema singular, en cualquier derecho». ${ }^{25}$ Estos «rasgos estructurales obsesivos» — como los llama Weber- son los que estructuran la escritura de Huysmans, a nuestro modo de ver, en torno al eje familiar — que marcará, como sabe bien el psicoanálisis, su relación al mundo y a las personas. Será labor, pues, de la crítica literaria, desentrańar el significado de esos rasgos para conformar un retrato del escritor a través de su obra.

Si estamos convencidos de que uno de los principales rasgos de la escritura de Huysmans es la búsqueda de un lugar en que rol sexual e identidad sexual se den la mano, deberemos convenir en que nuestra lectura debe centrarse no exclusivamente, pero sí con especial atención, en los aspectos relacionados con la construcción de esa identidad sexual. Nos hallamos ante un tipo de lectura, un tipo de crítica literaria, que centra su interés en el análisis de las relaciones de deseo y placer — que son las que determinan la autoasignación de roles y de la identidad. El placer, sostiene Ileana Rodríguez muy acertadamente, es un "tópico [sic] de reflexión novedoso" ya sea en su vertiente que estudia los placeres de lo cultural popular o los de la jouis-

25 J.-P. Weber, Néocritique et paléontocritique ou contre Picard, J. J. Pauvert, París, 1966, p. 36. Vid. también su otra obra Genèse de l'œuvre poétique, Gallimard, París, 1960. 
sance barthesiana, considerándolos como «desestabilizantes, subversivos, carnavalizantes». ${ }^{26}$

De allí nuestra elección del enfoque para abordar la obra y la figura de Huysmans. No obstante el vigor que están cobrando los estudios sobre masculinidad, los Men studies, tanto a nivel académico como cognitivo, gran parte de su aparato teórico ha sido tomado prestado, en gran medida, al feminismo. La crítica feminista, por su ya secular preocupación por estudiar el papel de la literatura escrita por (¿y para?) mujeres, se ha dotado de un inmenso bagaje conceptual, tan variado como lo son las diferentes corrientes del feminismo - lo que nos llevaría a hablar más bien de 'feminismos'. El uso de este aparato teórico para el tratamiento de la obra de un hombre - tan misógino, además, como Huysmans, lo que no deja de formar parte de esos rasgos estructurales obsesivos - puede suscitar ciertas reservas por parte de la crítica feminista más exclusivamente femenina: los hombres no estarían capacitados, según algunas estudiosas de la «écriture féminine», para estudiar los hechos y las razones del feminismo. Tal vez la célebre escritora y crítica feminista francesa Hélène Cixous rebatiría esta tajante afirmación por su personal recelo hacia el término de "escritura femenina» — que haría de la especificidad femenina coto privado de la crítica femenina. Considera Cixous ${ }^{27}$ que términos como 'masculino' o 'femenino' nos aprisionan en una lógica binaria, dentro de la visión clásica de la oposición sexual entre el hombre y la mujer. Por tanto, ha preferido hablar de "escritura que llaman femenina» (o masculina), o más recientemente, de «una feminidad libidinosa que se puede leer en obras de autor de sexo masculino o femenino». ${ }^{28}$ No es al parecer el sexo verdadero del autor lo que cuenta, sino su estilo. De hecho, una de las razones por las que parece tan convencida de la necesidad de terminar con la oposición entre lo masculino y lo femenino, e incluso de estos términos, es su firme creencia en la naturaleza inherentemente bisexual de todo ser humano.

26 I. Rodríguez (comp.), Cánones literarios masculinos y relecturas transculturales (lo trans-femenino/masculinolqueer), Anthropos, Barcelona, 2001, p. 21.

27 H. Cixous, La risa de la medusa. Ensayos sobre la escritura, trad. de Ana María Moix, Anthropos/Dirección General de la Mujer/Editorial de la Universidad de Puerto Rico, Barcelona, 1995, p. 42. Vid. asimismo las preguntas al respecto de Françoise Collin (nota n. ${ }^{\circ} 18$ ).

28 En V. A. Conley, Hélène Cixous: writing the feminine, University of Nebraska Press, Lincoln y Londres, p. 129. Vid. también T. Moi, Crítica literaria feminista, Cátedra, Madrid, 1988 , p. 118 y ss. 
En realidad, el concepto que Cixous tiene, finalmente, de escritura femenina está relacionado con el análisis de la escritura como différance de Derrida. Para Cixous, los textos femeninos «tratan de la diferencia», están orientados en el sentido de la diferencia, pues se posicionan en contra de la crítica dominante: binaria, falocéntrica, patriarcal.

Si nos posicionáramos en una estricta crítica femenina — dejemos por el momento la crítica feminista_-, ¿podríamos tratar la obra de Huysmans? Analicemos lo expuesto por la crítica literaria Biruté Ciplijauskaité y la tipología que establece sobre la novela femenina contemporánea. ${ }^{29}$ Esta autora destaca los siguientes procedimientos de escritura: 1) la subversión a través del uso de la ironía, la inversión y la ambigüedad; 2) la importancia del yo y su vinculación con lo fantástico, lo sobrenatural y lo utópico; 3) reacción contra la forma de contar tradicional, frecuentemente identificada con el modelo realista; 4) mezcla de géneros; 5) preferencia por la insinuación y la alusión; 6) descentralización y composición de estructuras polifónicas; 7) narración fluctuante y relativa. Menos en los elementos cuarto y sexto - sería cuestión de deternernos para observar la mezcla de géneros y la polifonía en la producción huysmansiana-, la obra que nos ocupa cumple rigurosamente los puntos enunciados por Ciplijauskaité.

Otras críticas que analizan el hecho diferencial femenino en literatura son las ya célebres Gilbert y Gubar y su obra $A$ Madwoman in the attic. ${ }^{30}$ Señalan las dos autoras que se produce en la literatura hecha por mujeres la frecuente aparición de un personaje excéntrico, la «loca del altillo» — de la que el paradigma sería Bertha Mason en Jane Eyre-, cuya finalidad es la de deconstruir alterándola la imagen de la mujer heredada de la literatura masculina. "De hecho, gran parte de la poesía de la novela hecha por mujeres evoca a esta criatura loca para que las autoras puedan afrontar su sentimiento de fragmentación propio y único de las mujeres», dicen las autoras, «su propia conciencia de las discrepancias que existen entre lo que son y lo que deberían ser». ${ }^{31}$ Creemos que estos motivos expuestos se adaptan per-

29 B. Ciplijauskaité, La novela femenina contemporánea (1790-1985), Anthropos, Barcelona, 1994.

30 S. M. Gilbert y S. Gubar, The Madwoman in the attic. The woman writer and the nineteenth-century literary imagination, Yale University Press, New Haven, 1979.

31 Vid. T. Moi, ob. cit., p. 170. 
fectamente al tipo de planteamientos de Huysmans en relación con: a) su sentido de fragmentación; b) su discrepancia entre rol patriarcal e identidad; y c) excéntrico personaje parapetado en su cubil. ¿Sería por ello la obra de Huysmans englobable dentro de la escritura femenina?

Interroguemos a una teórica más de este tipo de escritura. Annete Kolodny señala varios modelos estilísticos típicos de la novela escrita por mujeres, de los que los más importantes son la percepción reflexiva y la inversión. ¿ No son estos elementos primordiales de la escritura huysmansiana? La percepción reflexiva, según Kolodny, ocurre cuando «un personaje se descubre a sí mismo o encuentra partes de sí mismo en actividades que no había planeado, o en situaciones que no llega a comprender del todo", y la inversión cuando «las imágenes literarias tradicionales y estereotipadas de la mujer aparecen del revés en las novelas de mujeres, como elemento cómico, [...] para revelar su escondida autenticidad [o] [...] connotación de sus opuestos». ${ }^{32}$ El viaje de des Esseintes a Londres cumple a la perfección con la primera premisa; ${ }^{33}$ en cuanto al cumplimiento de la segunda se da en la tan frecuente aparición de elementos oníricos y/o fantasmáticos en la obra de Huysmans por los cuales se modifica la imagen habitual de la virilidad.

A través de estas tres autoras podríamos llegar a determinar que la obra de Huysmans es femenina. Pero esto no nos va a interesar por las mismas razones que a Cixous, a quien recurrimos de nuevo para englobar a Huysmans dentro de una escritura que opta por subrayar la diferencia, que trata de la diferencia que el heterónimo ficcional de sus novelas debe al final asumir entre sí y el resto de los individuos centrados en los valores de la burguesía.

Nosotros reivindicamos mejor la terminología de crítica feminista defendida por Françoise Collin, según la cual «es un doble trabajo de vigilancia y de análisis», ${ }^{34}$ en el sentido de lo que Paul Ricœur llamó «Filosofía de la sospecha» aplicada a Kant —y que Posada Kubissa cree, más aplicable incluso que a Marx, Freud o Nietzsche, le cuadra al pensamiento feminista,

32 A. Kolodny, «Some notes on defining a 'feminist literary criticism'», Critical Inquiry (revista en Internet), 2, 1, pp. 79-80.

33 Vid. nuestra pequeña aportación en F. Domínguez, «El placer del desplazamiento que no existe. Diálogo viajero entre Huysmans y Baudelaire», pendiente de publicación en L'Ull Critic, n. ${ }^{\circ}$ 9, Universidad de Lérida, 2006.

34 F. Collin, ob. cit., p. 66. 
en cuanto pensamiento crítico y desenmascarador. ${ }^{35}$ Se trata, en definitiva, de un tipo de lectura que hace de la sospecha un móvil, al poner en tela de juicio las mismas categorías que el patriarcado crea para asentar su dominación. Por eso será tan importante en este tipo de crítica el estudio de personajes y de sus representaciones, pues de estas depende su posicionamiento a la hora de perpetuar o de desmontar la dominación.

Por todas estas razones hemos adoptado, en nuestro enfoque de género, un tipo de lectura feminista - o de tensión sexual, como prefiere llamarla Collin y que analizaremos casi al final de nuestro trabajo. Para ello debíamos hacer nuestro todo el aparato teórico-crítico del feminismo - como aparato útil y valioso para el estudio las categorías genéricas.

Por su posible convergencia con la identidad del individuo —en la dirección señalada por Touraine de otorgar sentido a las experiencias de la vida-, el rol sexual puede identificarse con el género. Pero en la medida en que este rol —en su sentido funcional- puede verse modificado por el juego de los deseos, ${ }^{36}$ el género es cambiante en la dirección que nos marque la dinámica del placer. Sin embargo, el principio de realidad freudiano nos adscribe a un tipo de categoría, frecuentemente relacionada con el determinismo anatómico, que no es sino el fruto de una construcción social.

Si finalmente se acepta como hipótesis válida que el género es una construcción interesada de una parte de la humanidad para someter a la otra, ${ }^{37}$ la eliminación de dicha categoría solo puede abrir grandes las puertas de la indefinición liberadora — o, cierto, dolorosa y desestabilizante para algunos y algunas. Solo en esa indefinición cada individuo puede elegir libremente su opción fuera de los condicionantes que el género reproductor impone a la sociedad. Como diría Monique Wittig, la liberación de los grilletes del género permitiría entrar en una fase de humanismo de la persona ${ }^{38}$

35 Vid. L. Posada Koubissa, Sexo y esencia. De esencialismos encubiertos y esencialismos heredados: desde un feminismo nominalista, Horas y Horas, colección Cuadernos Inacabados, Madrid, 1998, p. 17. Vid. asimismo lo que dice al respecto A. Valcárcel, Sexo y Filosofía. Sobre 'mujer' y 'poder', Anthropos, Barcelona, 1991, p. 101.

36 J. Weeks, El malestar de la sexualidad, Talasa, Madrid, 1985, p. 275.

37 Esa es la tesis defendida por algunas teóricas de la deconstrucción, como la estadounidense Judith Butler en El género en disputa. El feminismo y la subversión de la identidad, Paidós, México D. F., 2001.

38 M. Wittig, Le corps lesbien, Minuit, París, 1973. 
—algo en lo que parece que algunas corrientes feministas no están dispuestas a ceder. Huysmans, como constructor de «bioficciones» en las que se evidencia la búsqueda de dicha liberación genérica, se convierte en un paradigma de escritura emancipadora y ejemplificadora: ejemplo de que la transgresión de las normas del patriarcado (heterosexualidad obligatoria y libido de origen estrictamente masculino) no se puede llevar a cabo sino mediante grandes esfuerzos, que provocan intensas zozobras existenciales a quien los acomete.

Para contrastar estas hipótesis nos hemos servido, frecuentemente, de la opinión de psicólogos, sociólogos, antropólogos, historiadores y literatos: el campo es tan amplio que ningún discurso se puede considerar completo si no incluye estas diferentes disciplinas. Especialmente, cabe señalar el uso frecuente que hacemos de los planteamientos del psicoanálisis — tan utilizados por el feminismo para el apuntalamiento de sus propias convicciones.

\subsection{La masculinidad en su evolución}

En el capítulo II nos hemos planteado situar la masculinidad en el tiempo que vivió Huysmans, el siglo XIX. Hay una serie de elementos, específicos de esta época, que determinaron el rumbo que tomó la masculinidad en ese período. En primer lugar, nos ha interesado hablar de la importancia de Napoleón en el imaginario de los hombres: su figura contribuyó de manera decisiva a forjar el nuevo individuo, hijo exclusivo de su propio esfuerzo, como interesaba a la sociedad nacida al calor de la Revolución Industrial. También observaremos, aun someramente, el golpe que asestó al Ancien Régime la redacción del código civil napoleónico, sobre todo en lo concerniente al régimen de sucesiones. Esta sería la erosión definitiva del concepto de la familia como institución en la cual el individuo creía poder basar su promoción social y económica. Y si es la familia basada en la autoridad patriarcal la que se pone en tela de juicio, la figura del padre no puede sino salir perjudicada. El psicoanálisis aparecería precisamente en el momento de mayor entredicho de la familia centrada en el padre, en el momento que Freud llamó el umbral de la familia edípica. 
La masculinidad basada en la transmisión de un capital cultural centrado en la dominación se derrumbaba, al tiempo que aparecía la corriente liberadora de las mujeres. Los avances del feminismo, así como la reciente rivalidad laboral de las mujeres, creó una intensa ola de misoginia en las letras europeas. El industrialismo acrecentó, de manera indirecta, este odio desmedido contra las mujeres y su nuevo asentamiento en la sociedad. Al instalar en las ciudades sus fábricas, el capital requirió no solo mano de obra femenina, sino que llenó las grandes aglomeraciones fabriles de mujeres venidas del campo — con los consiguientes problemas de desempleo, puesto que la industria no podía absorber tantos trabajadores. La consecuencia de esto fue que las calles de París y Londres, entonces las capitales del mundo, se llenaran de mujeres desocupadas, que habían vendido todo su patrimonio para desplazarse del campo a la ciudad, de las que muchas eligieron el camino de la prostitución para ganarse la vida. La misoginia ambiente solo pudo realimentarse de este hecho, atribuyendo a las mujeres marginadas por la respetabilidad burguesa el carácter de la fatalidad.

En este contexto, una de las soluciones que podía adoptar la masculinidad decimonónica era su redefinición. El dandismo fue una nueva opción que tomaron muchos caballeros para diferenciarse tanto de la ramplonería como de la respetabilidad burguesas. Su afán de transgresión incitó a los dandis a buscar en la experimentación de nuevos placeres otros parámetros de vida. Aun siendo una tendencia heterogénea, el dandismo encierra algunas constantes que nos serán de enorme utilidad en la definición de la psicología de Huysmans. Por ello mismo le dedicamos un largo espacio en este estudio.

\subsection{La novela familiar de Huysmans}

En el capítulo III nos centraremos exclusivamente en la figura de Huysmans. En primer lugar, analizaremos su evolución desde el naturalismo hasta su deserción del grupo de Médan. Como hemos comentado ya, nuestro autor jamás abandonaría la técnica naturalista, basada en la documentación tanto erudita como extraída de la observación; él prefirió adoptar un tipo de naturalismo que llamaría 'espiritualista', y que le serviría mejor en el objetivo principal que perseguía en la literatura. 
Basándonos en el concepto de «novela familiar del neurótico» forjado por Freud, ${ }^{39}$ así como en el desarrollo que de él hace Marthe Robert en su estudio sobre los orígenes de la novela, ${ }^{40}$ podemos proponer una hipótesis que pretende explicar el alejamiento de Huysmans de la estética naturalista propiamente dicha. Nuestro autor experimenta la terrible necesidad de hablar de sí mismo, por lo que cambia, entre 1879 —fecha de publicación de Les Scurs Vatard - y 1881 - En ménage - el tipo de personajes por los que se interesa. Su apuesta por la eliminación de la intriga y el desenlace novelescos esconde, en realidad, uno de los mayores proyectos de autorreferencia que se hayan producido en la historia de la literatura.

Todo parece indicar que es del mismo Huysmans, travestido bajo distintos nombres, de quien se habla en la serie de novelas iniciada con En ménage. André Jayant, Folantin, des Esseintes y, sobre todo, Durtal, no son sino diferentes avatares de lo que me he atrevido a llamar el «heterónimo ficcional huysmansiano».

Esta denominación viene, en parte, favorecida por la tipología que Philippe Lejeune hace del género autobiográfico, ${ }^{41}$ en base a la cual se puede considerar la obra de Huysmans como una «novela autobiográfica impersonal» - y que nosotros preferiríamos denominar «autobiografía ficcional» o, incluso, «bioficción».

Los motivos que mueven a Huysmans para escribir tanto y tan detalladamente sobre sí mismo son de la misma índole que los descritos por Freud en su ensayo sobre la novela familiar. Se trata, como en el caso de los neuróticos analizados por el médico vienés, de la reconstrucción de la propia vida según unos nuevos parámetros que el paciente - el escritor - considera más amables con el concepto que él se hace de lo que debería haber sido su existencia. De ahí la enorme importancia que tiene la niñez en la reconstrucción, mediante un relato, de sus antecedentes familiares.

39 S. Freud, La novela familiar, en Obras Completas, traducción de Luis López-Ballesteros y de Torres, edición de Jacobo Numhauser Tognola, Biblioteca Nueva, Madrid, 1972, tomo IV, pp. 1361-1363.

40 M. Robert, Roman des origines et origines du roman, Grasset, París, 1972.

41 P. Lejeune, ob. cit., pp. 19-25. 
Como uno de los paradigmas del «niño expósito» cuyas características comenta Marthe Robert, Huysmans tenderá a borrar la senda que le lleva a sus orígenes, como hijo pretendido de una generación espontánea —al igual que el self-made-man de la era industrial.

Tras el análisis de las referencias a las imagos jungianas del padre y de la madre, proponemos la sexualidad como elemento privilegiado de análisis de la obra de Huysmans. Esta se despliega en un sinfín de referencias — unas más claras que otras_- tanto de orden fetichista como de orden castrador. Todo revela que la sexualidad huysmansiana adolece de un componente sadomasoquista debido a la jamás completada liquidación del Edipo. Sus alusiones tanto veladas como abiertamente explícitas de su misoginia no hacen sino abrirnos la vía del estudio de las imagos de la madre «mala» —en denominación de Gérard Mendel—; ${ }^{42}$ por otra parte, la gran profusión de imágenes acuáticas asociadas a los personajes femeninos o que han sufrido feminización indica un complejo de castración depositado en la madre y proyectado en los personajes femeninos.

En otro orden de cosas, el eterno afán de aislamiento del heterónimo ficcional revelaría una nostalgia del hogar materno, en el que la presencia silenciosa de la madre ocupada en los quehaceres de la vida doméstica es un excelente elemento generador de melancolía.

La entrada en lo sobrenatural, por otro lado, sería fruto de la nostalgia de una autoridad indiscutible y peligrosa — recuerdo de la amenaza de castración inherente a todo triángulo edípico. El deseo cada vez mayor de abrazar la religión católica, donde conviven un padre inflexible pero misericordioso con una madre fuente de amor y medición, es el resultado de la necesidad creciente de Huysmans —o de Durtal— de reconciliarse consigo mismo y con sus orígenes Acabará así con el sufrimiento continuo que provocaba en su psique la práctica de la heterosexualidad, pues creía con esa obligación de la cultura patriarcal traicionar tanto el ideal de la madre como del padre.

La vida y la obra de Huysmans terminan en un convento en el que las barreras de género son abolidas; los frailes, y con ellos Huysmans-Durtal, han podido sublimar su libido en el ora et labora monacal, al tiempo que

42 G. Mendel, La rebelión contra el Padre. Una introducción al Sociosicoanálisis, Península, Barcelona, 1971. 
rinden culto a unas superprestigiadas imágenes del padre y de la madre. La paz tan ansiada ha sido, por fin, alcanzada, y el individuo se hunde en los efectos de la agresiva represión cultural.

\subsection{Huysmans y el discurso de género}

En la conclusión intentaremos exponer de nuevo la necesidad de Huysmans, en su práctica heterosexual, de excluir todo tipo de vínculo afectivo con el objeto elegido. Esta exclusión, decimos, es una consecuencia directa de la misma ley patriarcal, ley del padre, que arroja al hijo a la dolorosa sensación de traición al prohibirle la elección de objeto en la madre.

Mediante la teoría de la horda primordial expuesta por Freud en Tótem $y$ tabu ${ }^{43}$ creemos poder aseverar que la única satisfacción libidinal verdaderamente aceptada por el dictado del padre es la opción homosexual —que el adolescente debe abandonar por imperativo social. Intentamos contrastar este extremo mediante la comparación con culturas diferentes de la occidental, en las que la homosexualidad es una opción no castigada previa a la elección de objeto necesaria para la reproducción y, por ende, al mantenimiento del grupo social.

Sometemos la reproducción a nuestra crítica, como tributo a la especie que marca las diferencias sexuales y la dominación de un género sobre el otro. Practicante de una heterosexualidad culpabilizante, Huysmans asume la atribución social de su opción sexual con dolor - y en la que subyace continuamente la posibilidad de otra sexualidad menos dolorosa. Porque si la reproducción deja de ser una motivación del individuo sexuado, la definición de su sexualidad depende exclusivamente de la búsqueda del placer. En este contexto es posible decir, con Manuel Puig, que no existen ni la homosexualidad ni la heterosexualidad, puesto que se tratan de conceptos forjados por la convención patriarcal que sitúa a hombres y mujeres a un lado o a otro del dictado reproductor. ${ }^{44}$

43 S. Freud, Tótem y tabú, Alianza, Madrid, 2000.

44 En "An interview with Manuel Puig», en P. Bacarisse (ed.), Carnal Knowledge. Essays on the flesh, sex and sexuality in Hispanic letters and film, Tres Ríos, Pittsburgh, 1986. 
Huysmans se convierte, tal vez a su pesar, tal vez sin desearlo, en un emisario de lo que varios autores han denominado «nuevo desorden amoroso», ${ }^{45}$ en el que todas las posibilidades de elección están abiertas. Su postura, otra vez, es de avant-coureur de las ideas de la postmodernidad - $\mathrm{O}$ tardomodernidad, o antimodernidad-, tanto como lo es en sus motivos literarios. Por todo ello, su obra, su figura y su personalidad, son tan útiles para desarrollar un discurso de género.

\subsection{Metodología de estudio}

Hemos intentado llevar adelante este proyecto de lectura, interpretación y crítica mediante dos vías de trabajo diferentes, a las que llamaremos 'psicocrítica' —en denominación del psicoanalista francés Charles Mauron- y 'crítica de corte feminista'.

La psicocrítica desarrollada por Charles Mauron en obras como Des métaphores obsédantes au mythe personne ${ }^{46} \mathrm{y}$ otras ${ }^{47}$ se basa, principalmente, en la búsqueda de lo que él llama los «mitos personales del autor»; es decir, «un fantasme persistant qui presse constamment sur la conscience de l'écrivain lorsqu'il s'adonne à son activité creatrice» ${ }^{48}$ — similar a lo que Weber llamaba «rasgos estructurales obsesivos». Este método permite, mediante la superposición de los diferentes textos del autor, observar una serie de «redes de asociación» que no son otra cosa sino grupos de imágenes obsesivas, que se repiten, precisamente, por su importancia en la imaginación creadora del autor. Son estas redes las que permitirán entrever el universo de mitos personales - basados la mayor parte en alusiones, ocultaciones, metáforas y otros tropos- perfectamente detectable en la producción del autor elegido.

45 P. Bruckner y A. Finkielkraut, Le nouveau désordre amoureux, Points Seuil (versión española: El nuevo desorden amoroso, Anagrama, Barcelona, 1989).

46 C. Mauron, Des métaphores obsédantes au mythe personnel, José Corti, París, 1966.

47 Otras obras de Charles Mauron en que se desarrolla la psicocrítica: L'inconscient dans la vie et l'œuvre de Jean Racine (ed. Ophrys, Gap., 1957); "La psychocritique et sa méthode», Orbis litterarum, Revue Internationale d'Études littéraires (Copenhague, 1958); Psychocritique du genre comique (José Corti, París, 1963); Le dernier Baudelaire (José Corti, París, 1966) y Phèdre (José Corti, París, 1968).

48 C. Mauron, Des métaphores obsédantes au mythe personnel, ob. cit., p. 35. 
Huelga comentar que la psicocrítica de Mauron es deudora en grado sumo del psicoanálisis freudiano, y que su análisis de las metáforas obsesivas se realizan en clave del pensamiento de Freud. Nuestro discurso está, por ello mismo, frecuentemente habitado por la terminología y el aparato teórico del psicoanálisis clásico.

Lo que diferencia el método de Mauron de otros basados también en el análisis del inconsciente en la obra literaria — como la crítica del método biográfico de la psicoanalista Janine Chassenet-Smirgel, o la psicobiografía de Dominique Fernandez — ${ }^{49}$ es que la psicocrítica contrasta solo en última instancia con la biografía los resultados extraídos del examen literario. Este es uno de los motivos por los que nos interesó la psicocrítica como método: más que poner al escritor estudiado en el centro del análisis, es su obra lo que le interesa - lo cual permite aseverar que es uno de los métodos que explota menos elementos extraliterarios.

En cuanto a nuestro otro tipo de crítica, la hemos denominado 'de corte feminista' por escapar un tanto de las tipologías de algunas autoras que reclaman para 'la mitad del cielo' — como diría Mao- la exclusividad de la lectura feminista.

Elaine Showalter distingue dos tipos de crítica feminista en su artículo "Towards a feminist poetics». El primero, que Showalter denomina directamente "crítica feminista", trata de la mujer como lectora; el segundo es el que trata de la mujer como escritora, al que llama "ginocrítica»..$^{50}$

Nuestro determinismo como individuo masculino nos impide adscribirnos a cualquiera de las dos corrientes, aunque tal vez prefiriésemos adherirnos a lo expuesto por Christine Planté acerca de la "ética feminista de la lectura». Apuesta Planté no por la afirmación de la identidad o la exigencia de la igualdad, sino por una responsabilidad lectora en la

49 J. Chassenet-Smirgel, Pour une Psychanalyse de l'art et de la créativité, Payot, París, 1971. D. Fernández, "Incidences de la psychanalyse», Nouvelle Revue de Psychanalyse, 1, París, 1970. Vid. el estudio que sobre los diferentes métodos se hace en A. Clancier, Psicoanálisis. Literatura. Crítica, Cátedra, Madrid, 1976.

50 E. Showalter, «Towards a feminist poetics», en Jacobus, Mary (ed.), Women writing and writing about women, Croom Helm, Londres, 1979, p. 25. 
que los individuos — sea cual sea su sexo- dejen «de sentirse conminados(as) a reconocerse en modelos concretos y a situarse frente a tradiciones e identidades sexuadas». ${ }^{51}$

Esta ética de la lectura parece acordarse a la perfección con el tipo de crítica planteado por Ileana Rodríguez, quien, siguiendo a Nelly Richard, dice abogar por una aproximación hermenéutica desde el posfeminismo (sic), que tiene como fin «desidentificar las identidades y poner en tela de juicio juicios y prejuicios sobre las diferencias sexuales». ${ }^{52}$ Esto se acopla perfectamente con la corriente de pensamiento que entiende el género como una construcción y que, como categoría que somete al individuo a un determinismo injusto, merece ser deconstruido.

En esta vía nos encontraremos con consideraciones sobre el género extraídas tanto del feminismo racionalista o liberal a lo Beauvoir como del feminismo postmoderno y deconstruccionista a lo Butler, ambos ampliamente influidos por el psicoanálisis y la cultura de izquierdas. ${ }^{53}$

\subsection{La crítica huysmansiana hasta nuestros días}

Desde incluso antes de su muerte en 1907, la crítica literaria no ha dejado de interesarse por analizar la vida y la obra de Huysmans. Ya sea como jefe de fila de un pretendido movimiento decadentista, ya por su original bibliografía, el autor de $\grave{A}$ rebours ha ocupado el afán exégeta de no pocos estudiosos. Todo ello desde diversas perspectivas y enfoques, que no hacen

51 C. Planté, «La sospecha del género», en N. Ibeas y M. A. Millán (eds.), La conjura del olvido. Escritura y feminismo, ob. cit., p. 79.

52 I. Rodríguez, ob. cit., «Introducción», p. 13.

53 Las denominaciones que reciben todas las corrientes del feminismo difieren dependiendo del autor que las comente. Digamos que todavía no se ha establecido un verdadero consenso en torno a la terminología. Resulta interesante la tipología que hace Manuel Castells de los movimientos feministas, en la que clasifica 6 tipos diferentes: Derechos de las mujeres (liberal, socialista); Feminismo cultural; Feminismo esencialista (espiritualista, ecofeminismo); Feminismo lesbiano; Identidades específicas de las mujeres (étnica, nacional, autodefinida; ej.: feminista lesbiana negra); y Feminismo práctico (trabajadoras, defensa personal, maternidad, etc.). «Nuestros" 'feminismo racionalista o liberal' y 'postmoderno y deconstruccionista' corresponderían con los feminismos 'cultural' y 'lesbiano' respectivamente en la tipología de Castells. Vid. M. Castells, ob. cit., p. 221. 
sino enriquecer el universo huysmansiano y, par ricochet, hacerlo más atractivo si cabe para los nuevos lectores.

Vamos a intentar trazar una historia de la crítica en torno a Huysmans, no desdeñando aquellos análisis que, si bien someros, incidieron en la subsiguiente consideración de su obra por el público.

El primero de los ensayos en que la obra de Huysmans es juzgada como indicio de su personalidad es, sin duda alguna, Entartung ${ }^{54}$ («degeneración»), del alemán Max Nordau. En esta obra de 1893, y publicada en Francia un año después, se tilda al autor de $L \grave{a}$-bas de degenerado histérico a través del estudio de los hábitos de, especialmente, el duque des Esseintes. Esta obra es doblemente interesante, pues abre también la lista de análisis literarios basados en una visión psicologizante. En ese mismo final de siglo se editaron, asimismo, otros dos opus, de corte religioso, sobre la figura de nuestro autor: La conversion de M. Huysmans, ${ }^{55}$ del abbé Belleville, y La littérature religieuse de M. Huysmans, ${ }^{56}$ del también abbé Georges Peries (ambos de 1898). Este enfoque cristianizante dominó ampliamente la crítica huysmansiana durante un cierto tiempo, considerando al escritor como ejemplo de conversión desde las filas del más amplio escepticismo.

La primera década del siglo XX, la obra de Huysmans es analizada junto a la de otros por Firmin van der Bosch, en el volumen aparecido en 1905 en Bruselas y titulado Impressions de littérature contemporaine. ${ }^{57}$ Tres ańos más tarde, la que ya fuera antigua filiación de Huysmans con el satanismo lleva a Jean Caldain a glosar su figura en un artículo en Le Matin con el título, «Le satanisme est-il pratiqué aujourd'hui?». ${ }^{58} \mathrm{Y}$ ese mismo año aparece en París Huysmans intime, ${ }^{59}$ del religioso Dom A. Du Bourg, que sigue en la vía cristianizante.

En los años diez crece el número de obras dedicadas a la figura y la producción de Huysmans. La década comienza con la aparición, en 1910,

54 M. Nordau, Dégénérescence, ob. cit., p. 236.

55 F. Belleville, La conversion de M. Huysmans, Bourges, 1898.

56 G. Peries, La littérature religieuse de M. Huysmans, Lamulle et Poisson, París, 1898.

57 F. Van der Bosch, Impressions de littérature contemporaine, Vromant, Bruselas, 1905.

58 J. Caldain, «Le satanisme est-il pratiqué aujourd'hui?», Le Matin, 21 de abril de 1908.

59 A. du Bourg, Huysmans intime, Librairie des Saints-Pères, París, 1908. 
de Huysmans et l'âme des foules de Lourdes, ${ }^{60}$ de Raymond Vroncourt. El año 1912 ve la publicación de cuatro obras diferentes sobre Huysmans: JorisKarl Huysmans, l'homme, l'écrivain, l'apologiste, ${ }^{61}$ del abbé Henri Blandin; Le vrai J.-K.Huysmans, ${ }^{62}$ de Gustave Coquiot (con un interesante prefacio póstumo del propio Huysmans); el estudio múltiple de Jules Pacheu sobre Études d'idéalistes et mystiques: Dante-Spenser-Bunyan-Shelley-VerlaineHuysmans; ${ }^{63} \mathrm{y}$, por fin, quien fuera su amigo íntimo, Johnny Bricaud, publica dos obras en las que sigue la senda abierta por Jean Caldain sobre el satanismo: J.-K. Huysmans et le satanisme y Huysmans occultiste et magicien, ${ }^{64}$ de 1912 y 1913, respectivamente. También en el ámbito de lo sobrenatural, esta vez referido a lo que se puede calificar de «fiebre» de conversiones a finales del siglo XIX, Alexis Crosnier publica en 1913 la que sería cuarta edición de su Les convertis d'hier / Alexis Crosnier, François Coppé, J. K. Huysmans, Paul Bourget, Ferdinand Brunetière. ${ }^{65}$ En esa misma década aparece el primer estudio médico en que se analiza a fondo la personalidad de Huysmans a través de su obra; se trata de Essai sur la psychologie morbide de Huysmans ${ }^{66}$ del doctor Lavelée, quien la presenta como tesis para su doctorado en medicina en 1917. Año en que sale a la luz el libro Joris-Karl Huysmans ${ }^{67}$ del reverendo Dom Besse. Dos años más tarde, hace aparición una curiosa obrita sobre Les logis de Huysmans, ${ }^{68}$ en el que la editorial La Maison Française encarga a los autores Poinsot y Langé la descripción de la decoración del domicilio del escritor.

60 R. Vromcourt, Huysmans et l'âme des foules de Lourdes, Menard, Tours, 1910.

61 H. Blandin, Joris-Karl Huysmans, l'homme, l'écrivain, l'apologiste, París, 1912.

62 G. Coquiot, Le vrai J.-K.Huysmans, préface de J.-K.Huysmans, C. Bosse, París, 1912.

63 J. Pacheu, De Dante à Verlaine. Études d'idéalistes et mystiques: Dante-SpenserBunyan-Shelley-Verlaine-Huysmans, A. Tralin, París, 1912.

64 J. Bricaud, J.-K. Huysmans et le satanisme, Bibliothèque Chacornac, París, 1912. Y Huysmans occultiste et magicien, Bibl. Chacornac, París, 1913.

65 A. Crosnier, Apologétique vivante. 2, Les convertis d'hier/Alexis Crosnier, François Coppé, J. K. Huysmans, Paul Bourget, Ferdinand Brunetière, Levé, París, 1913.

66 G. Lavelée, Essai sur la psychologie morbide de Huysmans (thèse pour le doctorat en médecine), París, 1917.

67 Révérend Père Dom Besse, Joris-Karl Huysmans, Librairie de l'Art Catholique, París, 1917.

68 R. Poinsot y M. Langé, Les logis de Huysmans, La Maison Française, París, 1919. 
Pasan cinco años hasta que vuelve a aparecer otro estudio sobre Huysmans: André Thérive publica, en 1924, su J.-K. Huysmans, son æuvre. ${ }^{69}$ Dos años después, un interesante estudio crítico que Henri Bachelin expone con el título de J.-K. Huysmans. Du naturalisme littéraire au naturalisme mysti$q u e^{70}$ En 1927, Johnny Bricaud sigue explotando su relación amistosa con el autor mediante la publicación de un volumen sobre quien fuera amigo de Huysmans y consejero en asuntos sobrenaturales. L'Abbé Boullan ${ }^{71}$ se publica en París y pone fin al interés de Bricaud por el satanismo huysmansiano. Ese mismo año, sería el abbé Mugnier, confesor y orientador personal de Huysmans, el que expondría sus impresiones sobre el paso del escritor por la trapa de Igny en su J.-K. Huysmans à La Trappe. ${ }^{72}$ También en 1927, J.-K. Huysmans sous divers aspects ${ }^{73}$ aparece firmada por Léon Deffoux, en un intento de captación global del autor. En 1928, dos obras se pueden ver en los estantes: En marge d'A rebours, ${ }^{74}$ obra colectiva a cargo de Brunner y de Conninck, y el segundo aperçu sobre los domicilios de Huysmans: Un logis de J.-K. Huysmans, ${ }^{75}$ de Grolleau y Garnier.

La década de los treinta es especialmente prolífica en la exégesis huysmansiana, comenzando con el libro de 1930 Au pays d'En rade, ${ }^{76}$ de Gabril-Ursin Langle — que sería el primero que iría tras las huellas de Huysmans fuera de París, al que le seguiría, ya en 1933, Itinéraires huysmansiens. ${ }^{77}$ En 1931, tres estudios diferentes ven la luz: el ensayo de Ernest Seillière titulado simplemente $J .-K$. Huysmans; ${ }^{78}$ la ronda de comentarios reunidos por Frédéric Lefèvre bajo el lema Entretiens sur J.-K. Huysmans, ${ }^{79}$ y, finalmente, el monográfico sobre la primera de las obras de conversión

69 A. Thérive, J.-K. Huysmans, son æuvre, Nouvelle Revue Critique, París, 1924.

70 H. Bachelin, J.-K. Huysmans. Du naturalisme littéraire au naturalisme mystique, Perrin, París, 1926.

71 J. Bricaud, L'Abbé Boullan, Bibl. Chacornac, París, 1927.

72 A. Mugnier, J.-K. Huysmans à La Trappe, Le Divan, París, 1927.

73 L. Deffoux, J.-K. Huysmans sous divers aspects, Crès, París, 1927.

74 P. Brunner y M. de Conninck, En marge d’À rebours, Derbon-Aimé, París, 1928.

75 P. Grolleau y A. Garnier, Un logis de J.-K. Huysmans. Les prémontrés de la Croix Rouge, Crès, París, 1928.

76 G.-U. Langle, Au pays d'En rade, Fécamp, París, 1930.

77 G.-U. Langle, Itinéraires huysmansiens, Fécamp, París, 1933.

78 E. Seillère, J.-K. Huysmans, Grasset, París, 1931.

79 F. Lefèvre, Entretiens sur J.-K. Huysmans, Horizons de France, París, 1931. 
La publication d' "En route», ${ }^{80}$ a cargo de René Dumesnil. El mismo número en 1932, cuando el doctor Rollands presenta en París su Etude psychopathologique sur le mysticisme de J.-K. Huysmans, ${ }^{81}$ que incidiría de nuevo en la brecha abierta 30 ańos atrás por Nordau en su Degeneración; otro estudio religioso, Joris-Karl Huysmans, l'homme et l'oblat de Saint-Benoit,, ${ }^{82}$ por C.-B. Ribes, y el comparativo entre Huysmans, Lemaitre y France que con el título de Trois ombres ${ }^{83}$ publica en París la autora Myriam Harry. Dos ańos más tarde el religioso Dom Jean-Baptiste Monnoyeur narra las vicisitudes de Huysmans en el Poitou con su J.-K. Huysmans convers et oblat de Ligugé. ${ }^{84}$ Dos estudios más en 1935, el segundo de Léon Deffoux sobre Flaubert, Zola, Huysmans. Critique et morceaux choisis, ${ }^{85}$ y otro sobre la repercusión e influencia del autor de $\grave{A}$ rebours en el "plat pays», que su autor, Gustave Vanwelkenhuyzen, titularía J.-K. Huysmans et la Belgique. ${ }^{86}$ Otros estudiosos continúan centrándose en el componente religioso de Huysmans, como Mlle. d'Armagnac con su Huysmans ou les frontières du Chrétien,${ }^{87}$ de 1937 . Pero la década de los treinta también conoce la publicación de dos importantes obras para la consideración póstuma de nuestro autor, como son Esthétique de J.-K. Huysmans, ${ }^{88}$ de Hélène Trudgian (obra de 1934) y, sobre todo, por el efecto que tuvo en la difusión al gran público, Anthologie de l'humour noir ${ }^{89}$ de André Breton, en la que el papa del Surrealismo responsabiliza a Huysmans de la renovación de la novela tanto técnica como temáticamente.

En 1941, Lucien Descaves, amigo íntimo de Huysmans, inicia su personal análisis sobre la figura del escritor, mediante Les dernières années de J.-K.

80 R. Dumesnil, La publication d' "En route», SFELT, París, 1931.

81 P. Rollands, Etude psychopathologique sur le mysticisme de J.-K. Husymans (thèse pour le doctorat en médecine), París, 1932.

82 C.-B. Ribes, Joris-Karl Huysmans, l'homme et l'oblat de Saint-Benoît, París, 1932.

83 M. Harry, Trois ombres: Huysmans-Lemaître-France, Flammarion, París, 1932.

84 J.-B. Monnoyeur, J.-K. Huysmans convers et oblat de Ligugé, Photocopie parue à Ligugé en 1934 .

85 L. Deffoux, Flaubert, Zola, Huysmans. Critique et morceaux choisis, París, 1935.

86 G. Vanwelkenhuyzen, J.-K. Huysmans et la Belgique, Mercure de France, París, 1935.

87 M. d'Armagnac, Huysmans ou les frontières du Chrétien, Maison de la bonne presse, París, 1937.

88 H. Trudgian, L'esthétique de J.-K. Huysmans, Conard, París, 1934.

89 A. Breton, Anthologie de l'humour noir, Jean-Jacques Pauvert, París, 1966. 
Huysmans y Deux amis: J.-K. Huysmans et l'Abbé Mugnier. Documents inédits ${ }^{90}$ — publicada cinco años más tarde. En ellas se sigue insistiendo sobre el carácter religioso de la obra de Huysmans, de gran importancia para el mercado de lectores cristianos. Ese mismo año de 1941 Maurice Garçon propondría una visión divergente con su Huysmans inconnu. ${ }^{91}$ André Billy sacaría su obra sobre las andanzas del autor en la capital lyonesa, con Huysmans et ses amis lyonnais, ${ }^{92}$ con el que no dejaría de guardar algún punto de encuentro el libro de 1943, Un personnage de roman: le chanoine Docre de Là-bas, ${ }^{93}$ de Herman Bossier. Meurgey de Tupingy publicaría su indagación sobre las relaciones entre Huysmans y la heráldica (Le sentiment héraldique dans l'œuvre de J.-K. Huysmans, ${ }^{94}$ de 1946). Léon Daudet sacaría su À propos de J.-K. Huysmans ${ }^{95}$ en 1947, el mismo ańo en que Albert Garreau publicaría su biografía J.-K. Huysmans. ${ }^{96} \mathrm{Al}$ año siguiente, Antoine Rigaud sacaría a la luz los documentos que daban fe de la fluida relación de nuestro autor con otro sacerdote, en L'Abbé Gabriel-Eugène Ferret et J.-K. Huysmans. ${ }^{97}$ Esa década sería también la de la aparición del primer estudio de Pierre Cogny, quien iniciaría con él el tratamiento de la obra del autor de En rade desde una visión psicologizante pero no médica; aparecería en el Bulletin, n. 21 de la sociedad de amigos de J.-K. Huysmans, con el título de "Le pessimisme 'physiologique' de J.-K. Huysmans»" (de 1949).

Los años cincuenta comienzan con la publicación de otra obra de vocación religiosa, Les débuts bénédictins de J.-K. Huysmans, a cargo de Joseph Daoust — quien sacaría, ya en 1953, otro opus sobre Huysmans directeur de conscience, ${ }^{99}$ relevantes a la hora de analizar la evolución religiosa de nues-

90 L. Descaves, Les dernières années de J.-K. Huysmans, Albin Michel, París, 1941. Y Deux amis. J.-K. Huysmans et l'Abbé Mugnier, Documents inédits, Plon, París, 1946.

91 M. Garçon, Huysmans inconnu, Albin Michel, París, 1941.

92 A. Billy, J.-K. Huysmans et ses amis lyonnais, Lardanchet, Lyon, 1942.

93 H. Bossier, Un personnage de roman: le chanoine Docre de Là-bas, Les Écrits, París, 1943.

94 C. Meurgey de Tupingy, Le sentiment héraldique dans l'œeuvre de J.-K. Huysmans, París, 1946.

95 L. Daudet, À propos de J.-K.Huysmans, Du Cadran, París, 1947.

96 A. Garreau, J.-K. Huysmans, Casterman, París, 1947.

97 A. Rigaud, L'Abbé Gabriel-Eugène Ferret et J.-K. Huysmans, S. I. París, 1948.

98 P. Cogny, «Le Pessimisme 'physiologique' de J.-K. Huysmans», Bulletin, n. ${ }^{2}$ 21, 1949.

99 J. Daoust, Les débuts bénédictins de J.-K. Huysmans, Fontenelle, París, 1950. Y J.-K. Huysmans directeur de conscience. Lettres inédites, Plaquette de 1953. 
tro autor. El estudioso Jean Jacquinot encuentra cómo publicar tres obras diferentes sobre Huysmans en esta década del medio siglo: Huysmans et la médecine, En marge de J.-K Huysmans y Un procès de J.-K. Huysmans: l'affaire du journal "La Comédie Humaine», ${ }^{100}$ en el 51, 52 y 53 respectivamente. Ese 1953, Gustave Vanwelkenhuyzen publica otro ensayo sobre los Insurgés des lettres, ${ }^{101}$ en el que da cuenta y compara a tres grandes de la literatura del XIX: Verlaine, Bloy y Huysmans. Ese mismo año, Pierre Cogny publicaría un libro capital en la crítica huysmansiana, como es el clásico J.-K. Huysmans à la recherche de l'unité, que se vería completado con comentarios sobre el "Huysmans intime» de Henry Céard et Jean de Caldain ${ }^{102}$ — de 1957. Esa década también vería la publicación de otra obra de obligada referencia, todavía hoy considerada como la más válida y profunda biografía de Huysmans realizada hasta la fecha. Se trata de La vie de J.-K. Huysmans, del inglés Robert Baldick, ${ }^{103}$ obra canónica en los estudios sobre nuestro autor y de obligada consulta. Asimismo, Christiane Aimery sacaría a la luz su monografía sobre la vida y la obra del autor con el simple título de Huysmans. ${ }^{104}$ Y, casi terminando la década aparece J.-K. Huysmans et Lyon de Charles Guillemain, ${ }^{105}$ obra que vería la luz en el año 1958 en París.

La década de los sesenta ve la aparición de un estudio sobre Huysmans en una colección lyonesa titulada «Singuliers et mal connus», en la que, con el título de Huysmans ou le témoin écorché $e^{106}$ se hace una semblanza biográfico-literaria del autor con afán sensacionalista. Es una obra de divulgación que no hace sino evidenciar hasta qué punto el literato había quedado por detrás del convertido. En 1963, y como muestra de esta evidencia, se in-

100 J. Jacquinot, Huysmans et la médecine, Chez Durtal, París, 1951. En marge de J.-K. Huysmans, Chez Durtal, París, 1952. Y Un procès de J.-K. Huysmans: l'affaire du journal "La Comédie Humaine», Chez Durtal, París, 1953.

101 G. Vanwelkenhuyzen, Insurgés des lettres: Verlaine-Bloy-Huysmans, La Renaissance du Livre, París, 1953.

102 P. Cogny, J.-K. Huysmans à la recherche de l'unité, Nizet, París, 1953. Y Le "Huysmans intime" de Henry Ceard et Jean de Caldain (avec de nombreux inédits et une préface de René Dumesnil), Nizet, París, 1957.

103 R. Baldick, La vie de J.-K. Huysmans, Denoël, París, 1958.

104 C. Aaimery, Huysmans, Caritas, París, 1956.

105 C. Guillemain, J.-K. Huysmans et Lyon, Albums du Crocodile, París, 1958.

106 M. Lobet, Huysmans ou le témoin écorché, E. Vitte, coll. Singuliers et mal connus, Lyon, 1960. 
cluye en la colección «Promenades littéraires» un escrito de Remy de Gourmont sobre el autor, titulado "M. Huysmans, écrivain pieux». ${ }^{107}$ También en la vía religiosa se publica el estudio de Maurice Belval Des ténèbres à la lumière: étapes de la pensée mystique de J-K. Huysmans, ${ }^{108}$ de 1968, interesante también para captar el desarrollo de la metafísica huysmansiana. Asimismo, se expone en los escaparates de las librerías dos semblanzas de nuestro autor: Huysmans et Cie, ${ }^{109}$ de André Billy, y Huysmans, de Pié Duployé, ${ }^{110}$ publicado en Brujas en 1968.

En los setenta el espectro de producciones en torno a la obra de Huysmans se abre considerablemente. Se vislumbra un nuevo interés por los aspectos más literarios de su producción, que hasta entonces habían pasado desapercibidos para la crítica, subsumidos tras la pesada cortina de la lectura religiosa. Michael Issacharoff inicia la nómina con la aparición, en 1970, de su Huysmans devant la critique en France (1874-1960); ensayo que se vería continuado por el de 1976 L'espace et la nouvelle: Flaubert, Huysmans, Ionesco, Sartre, Camus, ${ }^{111}$ Entre ambos se publicarían un estudio de Anita Brookner sobre Huysmans crítico de arte (The genius of the future: studies in French art criticism: Diderot, Stendhal, Baudelaire, Zola, the brothers Goncourt, Huysmans ${ }^{112}$ y el de Richard M. Griffiths Révolution à rebours: le renouveau catholique dans la littérature en France de 1870 à $1914^{113}$ — ambos de 1971. A partir de entonces, no hay casi ningún año en que los escaparates no se pueblen con alguna obra crítica sobre el autor de Les Sours Vatard. En 1973, Fernande Zayed publica en Nizet

107 R. de Gourmont, «M. Huysmans, écrivain pieux», Promenades littéraires, vol. 3, Mercure de France, París, 1963.

108 M. M. Belval, Des ténèbres à la lumière: étapes de la pensée mystique de J-K. Huysmans, Maisonneuve et Larose, París, 1968.

109 A. Billy, Huysmans et Cie, La renaissance du livre, coll. La lettre et l'esprit, Bruselas, 1963 .

110 P. Duployé, Huysmans, Desclée de Brouwer, Brujas, 1968.

111 M. Issacharoff, Huysmans devant la critique en France (1874-1960), Klincksieck, París, 1970. Y L'espace et la nouvelle: Flaubert, Huysmans, Ionesco, Sartre, Camus, José Corti, París, 1976.

112 A. Brookner, The genius of the future: studies in French art criticism: Diderot, Stendhal, Baudelaire, Zola, the brothers Goncourt, Huysmans, Phaidon, Londres, 1971.

113 R. M. Griffiths, Révolution à rebours: le renouveau catholique dans la littérature en France de 1870 à 1914, Desclée de Brouwer, París, 1971. 
su Huysmans, peintre de son époque, ${ }^{114}$ al que le sigue, ya en 1975 las Mélanges Pierre Lambert dedicadas a Huysmans y editadas por Pierre Cogny ${ }^{115}$ — publicadas también en Nizet. En ese mismo 1975, Marcel Cressot saca un curioso estudio sobre la particularísima escritura de nuestro autor, titulado La phrase et le vocabulaire de J.-K. Huysmans: contribution à l'Histoire de la Langue Française pendant le dernier quart du XIXe siècle ${ }^{116}$ y publicado en Ginebra. Al ańo siguiente, el erudito Jean Borie publicaría uno de sus celebrados ensayos sobre temas del siglo XIX, sobre los que planea constantemente la sombra de Huysmans; este primero llevaría el título de Le célibataire français, ${ }^{117}$ y otorgaba a nuestro autor la centralidad de un fenómeno que se dio en la Francia finisecular: la soltería cuasi militante de una serie de escritores extremos. En ese mismo año 1976 aparece otra de las obras más relevantes en la bibliografía huysmansiana: J.-K. Huysmans. À rebours et l'esprit décadent, de François Livi, ${ }^{118}$ interesante aportación a la consideración de nuestro autor y del contexto en que se produjo su obra. Un año después, Nizet sacaría un opus de Charles Maingon sobre L'univers artistique de J.-K. Huysmans, ${ }^{119}$ al que le sigue, ya en 1978, otro estudio sobre la 'decadencia': se trata del estudio de Jürgen Sänder Aspekte dekadenter Sensibililität: J.-K. Huysmans' Werk von "Le Drageoir aux épices» bis zu "À rebours», ${ }^{120}$ publicado en Fráncfort del Meno - donde también se publica, un año después, el interesante estudio de Rita Thiele, Satanismus als Zeitkritik bei Joris-Karl Huysmans - ${ }^{121}$ en el que se aborda la acogida de la producción huysmansiana en su tiempo a la luz —o bajo la sombra- de su consideración como escritor interesado por temas sobrenaturales. Ese mismo ańo, René-Pierre Colin introduce en un estudio sobre La femme au XIXe siècle

114 F. Zayed, Huysmans, peintre de son époque, Nizet, París, 1973.

115 P. Cogny (ed.), Mélanges Pierre Lambert (consacrés à Huysmans), Nizet, París, 1975.

116 M. Cressot, La phrase et le vocabulaire de J.-K. Huysmans: contribution à l'Histoire de la Langue Française pendant le dernier quart du XIXe siècle, Slatkine Reprints, Ginebra, 1975.

117 J. Borie, Le célibataire français, ob. cit.

118 F. Livi, J.-K. Huysmans. À rebours et l'esprit décadent, La Renaissance du Livre, Bruselas, 1976.

119 C. Maingon, L'univers artistique de J.-K. Huysmans, Nizet, París, 1977.

120 J. Sänger, Aspekte dekadenter Sensibililität: J.-K. Huysmans' Werk von «Le Drageoir aux épices» bis zu «À rebours», Lang, Fráncfort del Meno, 1978.

121 R. Thiele, Satanismus als Zeitkritik bei Joris-Karl Huysmans, Peter D. Lang, Fráncfort del Meno, 1979. 
(editada por Roger Bellet en Lyon) una aportación sobre «Huysmans et les saluts du vieux garçon» ${ }^{122}$ que insiste en la soltería militante y la misoginia que de ella resulta del escritor parisién.

Ya en los años ochenta, la editorial nantesa Minard publica un compendio sobre L'esprit de décadence, ${ }^{123}$ en el que Paul Matthias aportaría un interesante comentario: «De l'imaginaire au psychosomatique dans la sensibilité décadente». En él se dan cita las consideraciones sobre ese movimiento sin jefe ni filas que vino a bautizarse como 'decadencia' unidas a aspectos deudores de la psicología del escritor. Una vía que se vería continuada por el enfoque que desde los preceptos freudianos utiliza Frederick Garber y su Autonomy of the selffrom Richardson to Huysmans ${ }^{124}$ —de 1982. Muestra de que crecía el interés por la figura y la obra de Huysmans fue la publicación, en 1983 y 1986, de dos textos de quien fuera su coetáneo Léon Bloy; hablamos del panegírico Le sang du pauvre; sur la tombe de Huysmans; la résurrection de Villiers de L'Isle-Adam y del estudio más amplio Sur J.-K. Huysmans ${ }^{125}$ —que incluye un interesante prólogo de Raoul Vaniegen. En 1984, el crítico especializado en psicoanálisis Charles Bernheimer publica en Romantisme un pertinente estudio sobre «L'exorbitant sexuel: castration et sublimation chez Huysmans», ${ }^{126}$ que continuaría el camino abierto dos años antes por Garber en la vía del diván freudiano. Ese mismo año, Henri Pevel publicaría un estudio sobre la relación epistolar entre Huysmans y Henriette Maillat — quien serviría de modelo a las encendidas cartas de Mme. Chantelouve en Là-bas_; hablamos de Henriette: "Pour l'amour de Huysmans", ${ }^{127}$ de 1984. Ese mismo año, productivo donde los haya en la crítica huysmansiana, se celebra en noviembre el coloquio sobre Huysmans

122 R.-P. Colin, «Huysmans et les saluts du vieux garçon», en R. Bellet (ed.), La femme au XIXe siècle. Littérature et idéologie, Presses Universitaires de Lyon, Lyon, 1979.

123 P. Mathias, "De l'imaginaire au psychosomatique dans la sensibilité décadente», L'esprit de décadence, I, Minard, Nantes, 1980.

124 F. Garber, The autonomy of the self from Richardson to Huysmans, Princeton University Press, Princeton, N. J., 1982.

125 L. Bloy, Le sang du pauvre; sur la tombe de Huysmans; la résurrection de Villiers de L'Isle-Adam, Union Générale d'Éditions, París, 1983. Y Sur J.-K. Huysmans, préface de Raoul Vaniegen, Complexe, Bruselas, 1986.

126 C. Bernheimer, "L'exorbitant sexuel: castration et sublimation chez Huysmans", Romantisme, n. ${ }^{\circ}$ 45, 1984.

127 H. Pevel, Henriette: "Pour l'amour de Huysmans», Atelier du Gué, Villelongue d'Aude, 1984. 
en las ciudades de Basilea, Mulhouse y Colmar. Con interesantes aportaciones de, entre otros, Jeanne Bem, Michel Raimond, Alain y Philippe Roger y, desde luego, Pierre Brunel. El año siguiente Philippe Audoin saca a las librerías su monográfico Huysmans, ${ }^{128}$ de interesante y amena lectura, que incluye no pocos documentos gráficos sobre el mundo y la figura del escritor. Michel Viegnes publica en 1986 una obra que aporta un enfoque sociológico a la obra de Huysmans, como es Le milieu dans la trilogie de J.-K. Huysmans: En Route, La Cathédrale, L'Oblat. ${ }^{129}$ En 1987, cuatro son los ensayos que sobre Huysmans aparecen en librerías y bibliotecas: el estudio de Françoise Court-Pérez, Joris-Karl Huysmans, "À rebours», ${ }^{130}$ Huysmans: de l'écriture à l'Écriture ${ }^{131}$ de Pierre Cogny, J.-K. Huysmans et Léon Bloy. Histoire d'une amitié orageuse, ${ }^{132}$ de Saint-Brice y Marfée, y, por si hubiera sido poco, el novedoso La littérature et la hantise du Mal. Lectures de Barbey d'Aurevilly, Huysmans et Baudelaire, ${ }^{133}$ de Alain Toumayan y publicado en Estados Unidos. En 1988 aparecería Huysmans et l'intimité protégée, ${ }^{134}$ de Jean-Pierre Vilcot, al que le seguiría otra masiva publicación de textos sobre Huysmans en 1989: Une visite avec Huysmans, ${ }^{135}$ publicado por los museos nacionales franceses y por Andrés Labarrère; el más general de Jean Borie - pero siempre centrado de manera clara en Huysmans- Un siècle démodé. Prophètes et réfractaires au XIXe siècle, ${ }^{136} \mathrm{y}$, sobre todo, La luxure et la pureté. Essai sur l'œuvre de Joris-Karl Huysmans ${ }^{137}$ del sueco Per Buvik, que resulta

128 P. Audoin, Huysmans, Éditions H. Veyrier, col. Les Plumes du temps, París, 1985.

129 M. Viegnes, Le milieu dans la trilogie de J.-K. Huysmans: En Route, La Cathédrale, L'Oblat, Nizet, París, 1986.

130 F. Court-Pérez, Joris-Karl Huysmans, "À rebours», Presses Universitaires de France, París, 1987.

131 P. Cogny, Huysmans: de l'écriture à l'Écriture, Tequi, París, 1987.

132 R. Saint-Brice y L. Marfée, J.-K. Huysmans et Léon Bloy. Histoire d'une amitié orageuse, À rebours, París, 1987.

133 A. Toumayan, La littérature et la hantise du Mal. Lectures de Barbey d'Aurevilly, Huysmans et Baudelaire, French Forum Publishers, Lexington, Kentucky, 1987.

134 J. P. Vilcot, Huysmans et l'intimité protégée, Lettres modernes, coll. Archives des lettres modernes, París, 1988.

135 A. Labarrère, Une visite avec Huysmans, Réunion des musées nationaux, coll. Carnets parcours du Musée d'Orsay, n. ${ }^{\circ}$ 17, París, 1989.

136 J. Borie, Un siècle démodé. Prophètes et réfractaires au XIXe siècle, Essais Payot, París, 1989.

137 P. Buvik, La luxure et la pureté. Essai sur l'œuvre de Joris-Karl Huysmans, Didier Erudition-Solum Forlag, Oslo, 1989. 
ser el primer intento serio, riguroso y exhaustivo de acercamiento a la obra del escritor desde una perspectiva psicologizante. Una década realmente prodigiosa en lo concerniente a la publicación de estudios sobre Huysmans.

\subsubsection{La crítica huysmansiana en los últimos quince años}

Tras la fructífera década de los ochenta, la importancia de Huysmans en la consideración de los estudiosos de la literatura no ha hecho sino aumentar. Escritor olvidado durante tanto tiempo, relegado al limbo de una nómina de autores menores, los años noventa y los primeros del siglo XXI han conocido una profusión de ensayos sobre el autor que no hacen sino dar fe de su cada vez más reconocida influencia en las letras del siglo XX.

En 1990 aparecieron tres obras: una, Le désir d'emprise dans À rebours de J.-K. Huysmans, ${ }^{138}$ de Nathalie Limat-Letellier, otra, Joris-Karl Huysmans, ${ }^{139}$ de Alain Vircomdelet, y otra más, J.-K. Huysmans and the fin-desiècle novel, ${ }^{140}$ donde el escocés Christopher Lloyd sitúa a nuestro autor en el centro de las nuevas técnicas novelísticas que se iniciaron en el fin de siglo decimonónico. Más prolífico fue aún el ańo 1991, en el que Hubert de Phalèse publicaría su Comptes à rebours: l'œuvre de Huysmans à travers les nouvelles technologies ${ }^{141}$ —en la que se ofrece una visión del autor desde la cibernética. Jean Borie estrenó su monográfico Huysmans, le Diable, le célibataire et Dieu, ${ }^{142}$ en el que reunía el grueso de sus obsesiones más recurrentes de sus ensayos sobre el XIX. También en ese año era él el encargado de glosar su figura en un interesante artículo: "La conversion d'un esthète», aparecido en el Magazine littéraire, n. ${ }^{\circ} 228$ y dedicado a "Les énervés de la Belle-Époque», en el que Noël Arnaud glosaría asimismo su figura en «Huysmans le précurseur». Pierre Jourde publicaría en Ginebra su Huysmans, $A$ rebours, l'identité impossible, ${ }^{143}$ que seguía en parte la vía abierta

138 N. Limat-Leteller, Le désir d'emprise dans À rebours de J.-K. Huysmans, Lettres Modernes, París, 1990.

139 A. Vircomdelet, Joris Karl Huysmans, Plon, París, 1990.

140 C. Lloyd, J.-K. Huysmans and the fin-de-siècle novel, University Press for the University of Durham, Edimburgo, 1990.

141 H. de Phalèse, Comptes à rebours: l'auvre de Huysmans à travers les nouvelles technologies, Nizet, París, 1991.

142 J. Borie, Huysmans, le Diable, le célibataire et Dieu, Grasset, París, 1991.

143 P. Jourde, Huysmans, À rebours, l'identité impossible, Slatkine, Ginebra, 1991. 
por Cogny, haciéndose eco de la fragmentación del individuo en la contemporaneidad. Al año siguiente, 1992, se publican las actas del Coloquio de la Sociedad de Estudios Románticos celebrado en París, centrado en la figura de Huysmans. ${ }^{144}$ En 1993 aparece otro estudio centrado en la religión de nuestro autor, La conversion de J.-K. Huysmans et son cuvre religieuse, ${ }^{145}$ firmado por Daniel Brennan — quien conseguiría su doctorado por la Universidad de Montpellier. 1995 vería la publicación de un nuevo tratado sobre las relaciones que establecía Charles Maingon entre la ciencia de Galeno y nuestro autor: La médecine dans l'œuvre de J.-K. Huysmans, ${ }^{146}$ publicado por Nizet. Alain Vircomdelet repetiría en 1995 con Huysmans, entre grâce et péché, ${ }^{147}$ que analizaba el efecto de la religión en su siempre inmoderado impulso sexual. El año siguiente, 1996, Jean-Pierre Bertrand, Michel Biron Jacques Dubois y Jeannine Paque incidirían en la militancia soltera del fin-de-siècle con Le roman célibataire. D' ${ }^{\prime A}$ rebours» à «Paludes», ${ }_{148}$ en el que Huysmans era tratado con el mismo respeto que siempre mereciera Gide. En 1998, la Universidad de Montreal concede el grado de doctor a David Tacium por un estudio comparado de Huysmans, Pater y Dossi con el título de Le dandysme et la crise de l'identité masculine à la fin du XIXe siècle ${ }^{149}$ —obra sobre la que volveremos más adelante.

Ya en el nuevo siglo, un estudio sobre lo sobrenatural huysmansiano a cargo de Bertrand, Duran y Grauby y como Actas del coloquio celebrado en Cerisy en 2000: Huysmans, à côté et au-delà. ${ }^{150}$ Gérard Peylet también se ocupa de ese aspecto en la obra de Huysmans, aunque tangencialmente, en

144 VV.AA., Joris-Karl Huysmans. À rebours. Colloque de la Société des Etudes Romantiques, S.E.D.E.S., París, 1992.

145 D. Brennan, La conversion de J.-K. Huysmans et son auvre religieuse (thèse pour le doctorat de l'université), Montpellier, 1993.

146 C. Maingon, La médecine dans l'eeuvre de J.-K. Huysmans, Nizet, París, 1994.

147 A. Vircomdelet, Huysmans, entre grâce et péché, Beauchesne, París, 1995.

148 J.-P. Bertrand, M. Biron, J. Dubois y J. Paque, Le roman célibataire. D' «À rebours» à «Paludes», José Corti, París, 1996.

149 D. Tacium, Le dandysme et la crise de l'identité masculine à la fin du XIXe siècle: Huysmans, Pater, Dossi, Université de Montréal, Département de littérature comparée, Faculté des arts et sciences, Thèse présentée à la Faculté des études supérieures en vue de l'obtention du grade de Philosophiae Doctor (Ph. D.) en littérature comparée, janvier 1998 (thèse consultée sur Internet). S. d.

150 J.-P. Bertrand, M. Duran y A. Grauby, Huysmans, à côté et au-delà, Actes du Colloque de Cerisy, Peetres-Vrin, 2001. 
su J.-K. Huysmans: la double quête. ${ }^{151}$ Jean-Marie Seillan publica sus Interviews (avec J.-K. Huysmans) ${ }^{152}$ en 2002, al que le siguen tres libros en 2003: la que pretende ser edición crítica defintiva de Le Drageoir aux épices suivi de textes inédits, a cargo de Patrice Locmant — con innumerables inexactitudes, errores y afirmaciones gratuitas. ${ }^{153}$ También en Honoré Champion Gilles Bonnet saca su L'écriture comique de J.-K. Huysmans, ${ }^{154}$ en el que ofrece una visión completamente desacostumbrada de la obra del autor, la del humor - pues Huysmans ha sido siempre considerado como un escritor dado exclusivamente al doliente lamento y a la crítica corrosiva. ${ }^{155} \mathrm{Fi}$ nalmente, Marc Smeets publica entre Ámsterdam y Nueva York su estudio sobre la fe de nuestro autor en Huysmans l'inchangé: histoire d'une conversion, ${ }^{156}$ en el que el estudioso apunta que si bien la conversión supuso en la vida y la psicología del autor de $\grave{A}$ rebours un cambio más que considerable, la personalidad profunda de Huysmans seguiría siendo la misma en su colección de hábitos y obsesiones.

Las últimas muestras del interés que Huysmans despierta todavía en la crítica y el mercado literarios las hemos hallado en dos obras bien diferentes de 2004: un ensayo biográfico, a cargo de Ghislain de Diesbach sobre la persona de L'abbé Mugnier ${ }^{157}$ — cuya posteridad solo se puede cifrar sobre la influencia que tuvo, como confesor personal, en Huysmans; y, por fin, la reedición crítica anotada de $\grave{A}$ rebours ${ }^{158}$ a cargo de Daniel Grojnowski en Garnier-Flammarion, en la que se aborda la obra con gran rigor filológico y literario, dejando de lado la consideración que el Huysmans católico mos-

151 G. Peylet, J.-K. Huysmans: la double quête, L'Harmattan, París, 2002.

152 J.-M. Seillan (ed.), Interviews (avec J.-K. Huysmans), Honoré Champion, París, 2002.

153 P. Locmant, édition critique présentée, établie et annotée de Le Drageoir aux épices suivi de textes inédits, Honoré Champion, París, 2003. Vid., a este respecto, la demoledora reseña que del libro de Locmant hace Jean-Marie Seillan en el Romantisme, n. ${ }^{\circ}$ 126, 2004, pp. 103-104.

154 G. Bonnet, L'écriture comique de J.-K. Huysmans, Honoré Champion, París, 2003.

155 Jean-Marie Seillan alabará esta obra en su reseńa sobre la misma en el Romantisme, n. ${ }^{\circ} 127,2005$.

156 M. Smeets, Huysmans l'inchangé: histoire d'une conversion, Rodopi, ÁmsterdamNueva York, 2003.

157 G. De Diesbach, L’abbé Mugnier, Perrin, París, 2004.

158 J.-K. Huysmans, À rebours, présentation, notes, dossier, chronologie et bibliographie par Daniel Grojnowski, GF, París, 2004. 
trara 20 años más tarde en su "Préface écrite vingt ans après le roman» - $y$, con ella, la crítica cristiana que durante tanto tiempo intentó monopolizar el legado huysmansiano a la historia de las bellas letras.

A todo ello hay que añadir los 96 números del Bulletin de la Société J.-K. Huysmans, que entre 1927 y 2003 han mantenido vivo el interés por nuestro autor. Asimismo, los ya mencionados coloquios de Basilea, París y Cerisy han significado el encuentro de muchos estudiosos de la obra de Huysmans, con lo que ello supone de nuevos ánimos insuflados recíprocamente. Todo esto demuestra que la obra de Huysmans, sigue, pues, viva, objeto como es de nuevas reediciones y ediciones críticas que la reactualizan y ponen al alcance del público actual.

\subsubsection{Huysmans en España}

La obra de Huysmans ha suscitado leves pasiones entre los eruditos españoles, más bien considerado como un escritor de segunda fila y escasa influencia que como artífice de la nueva sensibilidad novelesca. Lo que queda de manifiesto con la incompleta traslación de sus obras a la lengua castellana: muchas de las obras menos conocidas del autor de En ménage — entre ellas esta misma - no figuran en el catálogo de traducciones españolas.

La primera consideración que sobre Huysmans hemos encontrado en las letras españolas figura en una recopilación que hace Francisco Contreras sobre Los modernos: Eugenio Carriere, Pablo Verlaine, Enrique Ibsen, JorisKarl Huysmans, Augusto Rodin, J. M. de Heredia, Juan Lorrain, Mauricio Barrès, los pintores franceses de hoy, ${ }^{159}$ de 1909 . En ella, el español aúna en un todo sensibilidades tan distintas y disciplinas variadas. Nótese, por otra parte, la castellanización de los nombres de pila extranjeros. Es esta, más bien, una muestra de textos que se pretende reunir bajo un mismo afán modernizador.

La primera traducción al castellano digna de mención es la que llevó a cabo en 1919 Germán Gómez de la Mata en la editorial valenciana Pro-

159 F. Contreras, Los modernos: Eugenio Carriere, Pablo Verlaine, Enrique Ibsen, JorisKarl Huysmans, Augusto Rodin, J. M. de Heredia, Juan Lorrain, Mauricio Barrés, los pintores franceses de hoy, Sociedad de Ediciones Literarias y Artísticas, París, 1909. 
meteo con $A$ r rebours — que tituló Al revés. ${ }^{160}$ Como curiosidad, cabe señalar el prólogo deVicente Blasco Ibáńez, en el que el autor de La barraca glosaba la obra de Huysmans desde una cierta distancia filológica, tan alejada como estaba de su universo estético.

Habría que esperar hasta 1984 para encontrar una buena traducción de la obra más célebre de Huysmans, que no fue otra más que la realizada por Juan Herrero para Cátedra con el título de $A$ contrapelo. ${ }^{161}$ No es solo importante la traducción sino el amplio y riguroso estudio crítico, primer y verdadero intento espańol de dar a Huysmans la relevancia merecida en el contexto de las letras españolas.

Ese mismo año, el sevillano Francisco José Morales Gil editaría en la Universidad de Sevilla su tesis de licenciatura titulada Un exemple de décadentisme: Huysmans et la cuisine. ${ }^{162}$ Este breve estudio que no llega a las 150 páginas no deja de ser una muestra del interés naciente de nuestro autor entre los académicos españoles. Todo lo relacionado con la alimentación fue de especial importancia para Huysmans, aquejado como estaba de una dispepsia crónica, encontrando en su obra sabrosos ejemplos de enunciación.

Otro estudio con afán catalogador de uno de los campos semánticos explotados por nuestro autor es Papel de Armenia en la Farmacia benedictina de Joris-Karl Huysmans, ${ }^{163}$ obra de 1988 publicada por Antonio Limage en Sepúlveda.

El ámbito universitario andaluz propició la edición de dos tesis sobre nuestro autor en 1988: en Málaga, J. K. Huysmans, del naturalismo al misticismo, ${ }^{164}$ de M. ${ }^{a}$ José Jiménez Tomé; y en Sevilla, La inscripción pictórica en la obra de Joris Karl Huysmans, ${ }^{165}$ de Ana María Medrano Dorantes.

160 V. Blasco Ibáñez, «Prólogo» a J.-K. Huysmans, Al revés, trad. de Germán Gómez de la Mata, Prometeo, Valencia, 1919.

161 J. Herrero, «Introducción» a J.-K. Huysmans, A contrapelo, trad. de Juan Herrero, Cátedra, Madrid, 1984.

162 F. J. Morales Gil, Un exemple de décadentisme: Huysmans et la cuisine, tesis de licenciatura, Universidad de Sevilla, Sevilla, 1984.

163 A. Limage Conde, Papel de Armenia en la Farmacia benedictina de Joris-Karl Huysmans, Sepúlveda, 1988.

164 M. J. Jiménez Tomé, J. K. Huysmans, del naturalismo al misticismo, tesis de la Universidad de Málaga, Málaga, 1988.

165 A. M. Medrano Dorantes, La inscripción pictórica en la obra de Joris Karl Huysmans (tesis doctoral), Universidad de Sevilla, Sevilla, 1998. 
Para terminar con la crítica española de Huysmans, cabe citar el trabajo de doctorado para la Universidad de Valladolid de la interesante Huysmans en el fin de siglo hispánico, ${ }^{166}$ en la que su autora, Julia Amezúa, traza un mapa de la influencia que tuvo nuestro escritor para la creación de la literatura moderna en nuestro Estado. Una obra que debería ser tenida en cuenta por los huysmansianos y que, por fin, sentaría las bases de un más amplio reconocimiento en España.

Nosotros, por nuestra humilde parte, hemos mostrado nuestro interés investigador por Huysmans en varios trabajos incluidos en diferentes publicaciones universitarias. La Universidad de Lérida en su revista L'Ull Critic incluyó en el índice del número 10 el texto «El placer del desplazamiento que no existe. Diálogo viajero entre Huysmans y Baudelaire»; en él, damos cuenta de la especial manera de viajar de nuestro autor, en unos textos puestos en relación con poemas de su admirado Baudelaire. Laurence Richer, editora en Lyon III de una serie de excelentes monográficos que relacionan la literatura con otras artes, ha incluido en la entrega de 2005 (Littérature et Musique aux XIXe et XXe siècles) nuestra aportación sobre "Huysmans et le Plain-Chant». La revista Cédille, editada por la Asociación de Profesores de la Universidad Española APFUE, publicó «La deserción de Huysmans del Naturalismo zoliano» en su número 3; los Anales de Filología de la Universidad de Murcia incluyeron, en su número 16, «Los Croquis parisiens como primera formulación de algunas obsesiones de Huysmans»; Cuadernos de Filología de la Universidad de Extremadura, «Dandismo y misoginia en Huysmans», finalmente, «Biofiction chez Huysmans: cronique d'une démangeaison» fue el título de una conferencia pronunciada durante el congreso organizado por la Universidad de Chipre en noviembre de 2008 bajo el lema "Auto-Bio-Phagies».

166 J. Amezúa Amezúa, Huysmans en el fin de siglo hispánico, tesis de la Universidad de Valladolid, Valladolid, 2002. 



\section{EVOLUCIÓN DE LA MASCULINIDAD EN EL SIGLO XIX}

La historia del siglo XIX es en todo deudora del convulso panorama del final del siglo que le precede. La Revolución de 1789 marcó de manera indeleble los acontecimientos políticos, sociales y económicos que se produjeron en Francia durante el siglo por venir. Para el tema que a nosotros nos interesa - la evolución de la ideología de la virilidad a lo largo del siglo XIX-, la decapitación de Luis XVI, el 21 de enero de 1793, fue decisiva.

El detonante de la gran revuelta popular de 1789 fue el malestar del pueblo al observar cómo los privilegios de la aristocracia cargaban sobre aquel el peso del Estado francés. El sistema de pensiones concedidas por el gobierno a las grandes familias de la nobleza y al clero no se veía contrarrestado por una fiscalidad equitativa: ambos estamentos estaban eximidos de pagar impuestos. El proletariado y la burguesía emergente eran los únicos contribuyentes de una estructura impositiva altamente desigual. Este hecho, unido a las hambrunas sobrevenidas tras los rigurosos inviernos, creó una conciencia en el pueblo llano apta para la denuncia y la exigencia -que Robespierre, Danton y Marat tan bien supieron aprovechar en su escalada terrorista.

El pueblo, en definitiva, se sentía desvalido ante todos los vaivenes políticos que se producían en las altas instancias del poder parisino. Fueran cuales fuesen las circunstancias en que un nuevo gobierno hubiese advenido, el pueblo obrero - al que se dio el sobrenombre de classes dangereuses durante largo tiempo- sufría las consecuencias de su opresión en varios frentes: hambrunas como consecuencia de las malas cosechas y de los crudísimos inviernos; inmolación en el altar napoleónico que fueron los nu- 
merosos campos de batalla en que el emperador mostró su poderío; durísimas condiciones de trabajo, pagadas con salarios ínfimos cuya continuidad dependía de la convulsionada y cambiante economía.

Todo un sistema de gobierno, el Ancien Régime, se desmoronaba con el acontecimiento de la Bastilla. Un sistema que giraba en torno a la indiscutible figura del rey, bajo cuya luz trabajaba, crecía y se multiplicaba la totalidad de la población francesa. Se puede decir que el pueblo francés quedó huérfano con la muerte violenta de Luis XVI en la guillotina, y que el signo de la historia de las décadas siguientes no fue sino la búsqueda desesperada de un monarca - coronado o no- en quien recayese la completa responsabilidad del Estado.

Porque para Francia, el rey fue siempre un padre déspota: un soberano que no estuviese al servicio del pueblo, sino que se sirviera de él para lograr sus altos designios. Incluso cuando Luis XVI es llevado, en julio de 1789, al ayuntamiento parisién para hacerle renegar de la bandera fleurdelisée y acoger la cocarde tricolor, fue saludado allí mismo y a voz en grito como

Honnête homme, père des Français, roi d'un peuple libre

— según refiere Chateubriand en sus Memorias. ${ }^{167}$ Esta paternidad atribuida al rey revela la profunda psicología servil del pueblo francés, que le hacía dependiente y le ponía a merced de cualesquiera decisiones venidas de un soberano que considerase legítimo.

El monarca moriría guillotinado meses más tarde, lo que no dejó de suscitar ciertas dudas acerca del pretendido carácter divino e inmutable de la monarquía. Cuánto más se completó la desmistificación de la institución cuando Luis Napoleón Bonaparte participó en las elecciones de 1848 y tuvo que salir a la calle en busca de votos... El mismo Chateaubriand, defensor a ultranza de la monarquía, dudaba sobre la legitimidad de la institución. "Qui conserve la moindre illusion sur la couronne?» — dice en sus Memorias—, ${ }^{168}$

167 F. R. Chateaubriand, Mémoires d'outre-tombe, Librairie Générale Française-Le Livre de Poche, París, 2000, p. 113.

168 Ib., p. 329. 
depuis que sur une place publique un souverain, les cheveux coupés, les mains liées derrière le dos, a abaissé sa tête sous le glaive, au son du tambour; depuis qu'un autre souverain, environné de la plèbe, est allé mendier des votes pour son élection, au bruit du même tambour, sous une autre place publique.

El pueblo francés se sentía huérfano sin rey, de ahí que fuera tan ardua y continuada la búsqueda de un nuevo soberano-padre a quien entregarle el poder en masa.

El paradigma de esta búsqueda del padre fue el señalado general durante las refriegas revolucionarias Napoleón Bonaparte, «le seul roi dont le peuple ait gardé la mémoire» —-como dice Julien Sorel en un momento de su estancia en el seminario de Besançon. ${ }^{169}$ Su ascensión supuso para el pueblo llano francés una imperturbable esperanza de promoción social; su defección significó motivo de nostalgia permanente. Con la pérdida definitiva del general corso, Francia perdía de nuevo a su padre, quedando huérfano - otra vez- de un cabeza de estado suficientemente poderoso y convincente.

La figura del padre se iba desmoronando poco a poco en el imaginario francés. Por una parte, las numerosísimas guerras a que Napoleón sometió a su pueblo provocaron la orfandad de muchos niños; una política de natalidad acorde a la dinámica bélica del Estado napoleónico repoblaba los campos de nuevos nińos, quienes se convertían en huérfanos por la imparable máquina de la guerra. ${ }^{170}$

Por otra parte, tanto las expropiaciones forzosas de la Revolución de la Bastilla — solo compensadas durante el reinado de Carlos X-como las continuadas crisis financieras agotaron el patrimonio de muchas familias francesas. Eso significaba que los hijos de dichas familias ya no gozarían de los privilegios de sus antecesores, sino que deberían ser hijos de sus propios éxitos. Por otra parte, la Revolución cambiaría la legislación sobre la herencia, de manera a obstaculizar, mediante el fin de la primogenitura, el modelo de herencia de las haciendas que ayudaba a la nobleza a mantener su hegemonía económica.

169 Stendhal, Le Ronge et le noir. Chronique du XIXe siècle, Gallimard Folio, París, 1972, p. 204.

170 Como lo señalan David I. Kertzer y Marzio Barbagli, en su «Introducción» a D. I. Kertzer y M. Barbagli (comps.), La vida familiar desde la Revolución hasta la Primera Guera Mundial (1789-1913), Paidós Orígenes, Barcelona, 2003, p. 11. 
Por último, la creciente Revolución Industrial — que en Francia no arrancaría en verdad hasta bien mediado el siglo XIX- modificó por completo los antiguos modos de producción. La industrialización urbana atrajo a cantidades ingentes de pequeños agricultores, que abandonaron tierras, cultura y, en muchas ocasiones, familia. En todos los casos, los extenuantes horarios industriales impedían una presencia continuada de los padres en los hogares — con su correspondiente incidencia sobre la educación de los niños. El padre proletario o pequeño-burgués era un verdadero ausente para su descendencia, ocupado como estaba en ascender social y económicamente.

Ya por orfandad, por pérdida del patrimonio o por ausencia continuada, el padre dejó de ser esa figura providente y magnánima que la educación clásica había inculcado. Las ideologías de la virilidad se vieron resentidas por este hecho.

\subsection{El ejemplo de Napoleón}

El papel de Napoleón en la historia posterior a la Revolución francesa fue inmenso, sobre todo a nivel simbólico. Del general de artillería que fue, caído en desgracia tras ayudar a Dugommier a liberar Toulon, se convirtió en salvador de la República al atajar la insurrección realista del 13 vendémiaire ( 5 de octubre de 1795). Dos años más tarde volvería a asegurar la continuidad republicana desbaratando la tentativa realista del 18 fructidor (4 de septiembre de 1797). Posteriormente, el éxito de sus campañas italianas le concedió un recibimiento con todos los honores de vuelta a París. Señaladísimo y popular, Napoleón entró a formar parte, como Cónsul, de la Commission consulaire exécutive que gobernaría el país a partir de 1799. Sin embargo, su popularidad haría olvidar a los otros dos cónsules, Moreau y Jourdan. El general corso era objeto de adoración, por aquel entonces, de sus soldados, quienes extendían la leyenda de su invencibilidad. Su entrega al trabajo, su temible carácter, su asombrosa memoria que le permitía reconocer a un soldado en medio de un inmenso batallón, su arrojo, su suerte en definitiva, que le permitió escapar del ejército inglés cuando volvía de Egipto, todo ello contribuía a hacer de Napoleón el inesperado salvador de la patria, en contraste con el gran desprecio que el pueblo profesaba a los elegantes miembros del Directoire. 
Tras su nombramiento, Napoleón dictó los 95 artículos de una Constitución que cambiaba de arriba abajo todo el sistema de gobierno francés. Los Códigos civil y penal fueron transformados profundamente, llegando hasta la actualidad salvo modificaciones; la administración del territorio en regiones y departamentos fue obra suya. En resumen, toda la obra del popular personaje ha marcado de manera tenaz el imaginario francés, de tal manera que sus obras, sus batallas y las gentes que junto a él transformaron la historia de Francia en esos convulsos tiempos de cambio de siglo nombran la toponimia urbana del país galo.

Tanta actividad bélica como desplegó el emperador coronado en 1804, dejó el campo francés lleno de antiguos combatientes — que fueron quienes debieron de extender la «leyenda imperial» tras la derrota de Waterloo. ${ }^{171} \mathrm{La}$ necesidad de nuevas tropas se traducía en continuados llamamientos a filas, pero con diferencias con respecto a llamamientos precedentes. Mientras las posibilidades de promoción de los jóvenes agricultores en el ejército fueron muy limitadas en el pasado — solo adquirían el grado de oficiales los hijos de familias notables_-, la armada napoleónica abrió el acceso a todo el mundo. Se aseguraba así la llegada masiva de jóvenes a cada nuevo llamamiento. Rompiendo de esta manera con un injusto determinismo social, el ejército contribuyó no poco a engrandecer el mito de Napoleón. Quedaba claro que el corso era un hijo del pueblo que permitía a sus hermanos de clase acceder a los más altos puestos de responsabilidad. Así lo evidenció Stendhal en la conversación que sorprende Julien Sorel entre dos seminaristas de Besançon, quienes aseguran que un simple albañil puede convertirse en general a las órdenes del Otro:

—Eh bien! y faut partir, v'là une nouvelle conscription.

-Dans le temps de l'autre, à la bonne heure! un maçon y devenait officier, y devenait général, on a vu ça.

—Va t'en voir maintenant! il n'y a que les gueux qui partent. Celui qui a de quoi reste au pays.

—Qui est né misérable, reste misérable, et v'là.

-Ah ça, est-ce bien vrai, ce qu'ils disent, que l'autre est mort? reprit un troisième maçon.

—Ce sont les gros qui disent ça, vois-tu! l'autre leur faisait peur.

171 O por lo menos este es el parecer de Pierre Miquel, en P. Miquel, Histoire de la France, Marabout Université, París, 1976, p. 301. 
—Quelle différence, comme l'œuvre allait de son temps! Et dire qu'il a été trahi par ses maréchaux! Faut-y être traître! ${ }^{172}$

El ejemplo de Napoleón, pues, fue válido para toda una juventud ávida de promoción social y de gloria. Su figura imprimió a la novela del siglo XIX el más formidable impulso que la literatura puede recibir de un hecho histórico, abriendo terrenos de acción ilimitados para la imaginación novelesca. El siglo XIX se puebla de arribistas seductores, de héroes inteligentes que ansían la libertad y el poder que su clase no les permitiría en condiciones normales. Marthe Robert, en su muy interesante Roman des origines, origines du roman, ${ }^{173}$ señala una serie de características «napoleónicas» de la novela del XIX, de las cuales la más importante es el violento deseo de promoción del protagonista: "[...] par les femmes naturellement, et aussi rapidement que possible, afin de changer en supériorité sociable incontestable une médiocrité native ressentie comme une malédiction».

Esta descripción se da a la perfección en los héroes juveniles stendhalianos, de los cuales Julien Sorel centra nuestra atención como paradigma del admirador napoleónico. El joven guarda en su habitación un retrato del emperador, con todo el peligro que conlleva tal hecho en la mansión de un hombre que hacía semejante profesión de odio hacia el usurpador. ${ }^{174} \mathrm{Y}$ es que la figura del general y su ascenso desde la nada consuelan al joven Sorel de sus inalcanzables aspiraciones a la gloria:

depuis bien des années, Julien ne passait peut-être pas une heure de sa vie sans se dire que Bonaparte, lieutenant obscur et sans fortune, s'était fait le maître du monde avec son épée. Cette idée le consolait de ses malheurs qu'il croyait grands, et redoublait sa joie quand il en avait. ${ }^{175}$

Era Napoléon una especie de hombre enviado de Dios, que permitía soñar siquiera a los jóvenes franceses con la posibilidad del éxito y de la gloria, pero cuyo ejemplo, difícilmente igualable, les sumía en la imposible emulación. Así exclama de nuevo Julien Sorel en Le Rouge et le noir ${ }^{176}$ — título que simboliza los colores del uniforme napoleónico:

172 Stendhal, ob. cit., p. 204.

173 M. Robert, ob. cit., p. 243.

174 Stendhal, ob. cit., p. 72.

175 Ib., p. 39.

176 Ib., p. 104. 
ah!, que Napoléon était bien l'homme envoyé de Dieu pour les jeunes Français! [...] Quoi qu'on fasse, ajouta-t-il avec un profond soupir, ce souvenir fatal nous empêchera à jamais d'être heureux!

Ejemplo de difícil seguimiento que mina la esperanza de los jóvenes y les imposibilita un desarrollo armónico con su propia personalidad. Así lo ve el sacerdote español Carlos Herrera de las Illusions perdues de Balzac cuando se detiene en Angulema evitando el suidicio de Lucien Chardon de Rubempré: «c'est le défaut des Français dans votre époque. Ils ont été gâtés tous par l'exemple de Napoléon». ${ }^{177}$ Y como Lucien, aparentemente, toda la juventud francesa nacida y/o crecida en el primer cuarto de siglo. Balzac lo expresa de nuevo, desde su óptica de narrador que se permite un comentario ilustrativo en La Peau de chagrin. Raphaël entra en el bazar donde encontrará la terrible piel, cuando la visión del viejo tendero le hace temblar como ante un extraño poder:

il trembla donc devant cette lumière et ce vieillard, agité par l'inexplicable pressentiment de quelque pouvoir étrange; mais cette émotion était semblable à celle que nous avons tous éprouvée devant Napoléon. ${ }^{178}$

Fuerza de la naturaleza inaccesible e inigualable, Napoleón ha supuesto un referente, un ejemplo y, a la vez, una quimera - como la de los extraños personajes del poema en prosa de Baudelaire, "Chacun sa chimère». $\mathrm{Su}$ papel en la historia europea ha sido, como hemos venido diciendo, crucial para la formación del individuo en la grandeur francesa. Su rol de usurpador — que le atribuye, por ejemplo, el M. de Renal stendhaliano- no lo es tanto si se tiene en cuenta que su función política empezó a la cabeza de un triunvirato y que todos sus ascensos en el gobierno del Estado vinieron refrendados por la mayoría de la clase dirigente francesa. ${ }^{179} \mathrm{Tal}$ vez en un

177 H. de Balzac, Illusions perdues, Gallimard Folio, París, 1961, 1971, 1974, p. 628.

178 H. de Balzac, La Peau de chagrin, Gallimard, coll. Folio Classique, París, 2003, p. 53.

179 Vid. H. Guillemin, Napoléon tel quel, ed. de Trévise-Livre de Poche, París, 1969. El autor desmonta el gran fiasco napoleónico, señalando que el rápido ascenso del corso fue objetivo principal de su vida. Su capacidad para salir triunfante de todas las situaciones se debió antes a su habilidad para cambiar de chaqueta que a su actitud heroica. Su pretendido amor a la patria queda en entredicho cuando se sabe que, por una parte, se ausentó de su batallón siendo joven tanto como le permitían las ordenanzas; y por la otra, que sus expresiones de amor a Francia dependían del tono de la política corsa. Su indiscutible autoridad una vez que se hubo coronado emperador se construyó acallando y reprimiendo cualquier crítica a sus decisiones. Jamás la prensa estuvo más oprimida que bajo su imperio. Consideraciones históricas que Guillemin creyó necesario puntualizar para deshacer de una vez por todas un mito injustamente construido. 
alarde de megalomanía - y para alimentar el imaginario de sus súbditosse autoproclamó y autocoronó emperador por encima del poder del Papa; pero, hecha esta salvedad, el camino que llevó a Napoleón al imperio fue consecuencia de la evolución de la política en la Francia del primer cuarto de siglo. ${ }^{180}$

Asunción Valero Gancedo ${ }^{181}$ traza un curioso paralelismo entre la figura del emperador que asumió el destino del Estado francés y el asesinato del padre por parte de la freudiana horda primigenia. ${ }^{182}$ Según esta pensadora, solo quien se atreviera a llevar con mano férrea la política del país sería asimilado a la paternal idea del rey que se hacían los franceses del $A n-$ cien Régime. Y en base a esta convicción, establece este cuadro de semejanzas entre ese tramo de la historia francesa y el asesinato inaugurador de la civilización por parte de los primates primigenios. Obsérvese este cuadro comparativo:

$\begin{array}{lll}\text { Totemismo } & \rightarrow & \text { Antiguo Régimen } \\ \text { Tótem } & \rightarrow & \text { Rey absoluto } \\ \begin{array}{l}\text { Muerte del Tótem por la } \\ \text { comunidad de los hijos }\end{array} & \rightarrow & \text { Ejecución de Luis XVI } \\ \begin{array}{l}\text { Desaparición } \\ \text { del Totemismo }\end{array} & \rightarrow & \text { Abolición Monarquía absoluta }\end{array}$

180 Heinrich Heine, en el contexto alemán, también se hace eco del efecto de deslumbramiento que Napoleón produjo en su generación y en él mismo. Vid. para ello H. Heine, Reisebilder, Hoffmann y Campe, Dusseldorf, 1827 (versión al castellano: Cuadros de viaje, Gredos, Madrid, 2003. Vid. especialmente la tercera sección de «El Mar del Norte», pp. 184 y ss.): «eternamente admirado, eternamente compadecido».

181 A. Valero Gancedo, «Napoleón Bonaparte y el mito de la paternidad en el romanticismo francés», pp. 277-292, en A. Ramos Santana (ed.), La identidad masculina (en los siglos XVIII y XIX), Servicio de Publicaciones de la Universidad de Cádiz, Cádiz, 1997, pp. 23-34.

182 Este concepto de "horda primigenia» proviene de la obra Tótem y tabú de S. Freud (ob. cit.). En ella, el psicoanalista retoma una hipótesis del antropólogo británico Atkinson tendente a explicar el origen de la sociedad civilizada. Esta tendría sus cimientos en el asesinato, por parte de un grupo de primates jóvenes sin satisfacción sexual dentro de la manada, del macho dominante. A consecuencia del mismo, los jóvenes habrían comenzado a albergar sentimientos de culpa por el crimen cometido, donde estaría el origen de las comidas totémicas, los rituales de ensalzamiento paterno de las religiones monoteístas y del tabú del incesto; es decir, del sistema patriarcal en que se asienta ideológicamente nuestra civilización. 


$\begin{array}{lll}\text { Comunidad de Hermanos } & \rightarrow & \text { Revolución } \\ \text { Paso hacia el monoteísmo } & \rightarrow & \text { Consulado } \\ \text { Monoteísmo } & \rightarrow & \text { Imperio } \\ \begin{array}{l}\text { Héroe, Gran Hombre } \\ \text { Director de multitudes, } \\ \text { reencarnación del Padre, } \\ \text { surgido de comunidad } \\ \text { de hermanos }\end{array} & \rightarrow & \text { Napoleón Bonaparte } \\ \end{array}$

Su figura es, pues, la del valeroso hermano, salido de la misma casta de oprimidos, que ha osado levantarse contra la figura de ese padre autoritario que ponía coto a las aspiraciones de libertad del pueblo. Con ese asesinato simbólico, Napoleón pasó a encarnar la figura del padre, pero no por herencia, sino por méritos propios. De ahí que su poder solo fuera posible contemplarlo desde la autoproclamación: nada debía a nadie este prodigio del coraje y del arrojo militares. De ahí que, según Chaptal — quien formara parte de su entorno en el destierro de Santa Helena-, refiriera que al emperador le diera en momentos por exclamar con rabia «que je suis malheureux de n'être pas bâtard!». ${ }^{183}$

\subsection{El hijo bastardo que niega al padre}

«Desdichado por no haber nacido bastardo». Un bastardo que no tuviera que rendir cuentas de sus propios logros a ninguna instancia ajena a él mismo, porque el único autor de la gloria que hizo sus días era él. El padre de Napoleón, de cuyas circunstancias tan apenas se conoce nada, es un personaje silenciado por la historia, para mayor alcance de las gestas de su hijo. Porque el mérito de alguien tan autosuficiente como el emperador no debía ser atribuido a los desvelos de un padre - abuelo por consiguiente de la patria - por procurarle la mejor educación o darle los mejores consejos.

Para Marthe Robert, solo hay dos formas de construir una novela - entendida esta como necesario exutorio de las obsesiones del autor, lo que le da inevitablemente el carácter de novela familiar en el sentido freu-

183 Citado por M. Robert, ob. cit., p. 240. 
diano- y las dos desde la perspectiva del bastardo: una sería la del hijo pródigo o enfant trouvé, quien esquivaría el combate por falta de medios para ello; otra, la del bastardo realista, quien secundaría al mundo mientras no dejaría de atacarlo de frente. Napoleón encarna, dentro de esta dualidad, al bastardo realista, «le rénégat parfait qui bouleverse le monde en accomplissant sans scrupules ni remords ce que ses parents osent à peine rêver». ${ }^{184}$ De allí que para sus contemporáneos, Napoleón sea el ídolo inspirador, autosuficiente y capaz de acometer todo tipo de empresa sin el concurso de nadie. Únicos responsables de sus acciones, a veces los personajes salidos del molde napoleónico construirán complicadas defensas de sí mismos, pues tienden a sentirse culpables de esa negación de un pasado que les haya guiado a ellos mismos, formado o, incluso aconsejado.

\subsubsection{Negación del nombre del padre}

El ejemplo más claro de esta negación de un principio formador-informador del personaje napoleoniano, del self-made-man que luego veremos como fruto de la modificación en los modos de producción por la Revolución Industrial, se halla sin lugar a dudas en la obra de Balzac. Se trata, en su caso, de la negación del nombre del padre - que tan interesante podría haber sido para Lacan.

Toda la evolución del personaje de Lucien de Rubempré en Illusions perdues y su continuación Splendeurs et misères des courtisanes no es sino el intento desesperado de deshacerse de su pasado burgués — que él sitúa en el apellido de su padre, Chardon. Una vez ido de Angulema gracias a la ayuda de Mme. de Bargeton, Lucien hace todo lo posible por eliminar ese estigma nominal: cambia de amistades, renuncia a la gloria adquirida en el periodismo junto a los radicales, enamora a las grandes damas del boulevard Saint-Germain, se alinea con los ultras... Cualquier cosa con tal de que ese «maldito» Chardon desaparezca y le permita utilizar el apellido de su madre - perteneciente a un antiguo linaje meridional.

De esta manera, no son pocas las ocasiones en que el orgullo del joven y ambicioso Lucien se ve comprometido ante el insulto de quien le interpela por el nombre de su padre. Así, cuando Michel Chrestien, uno de los periodis-

184 Ib., p. 238. 
tas que más tarde serían amigos y compañeros de francachelas, se dirige a él, le dice: «vous êtes monsieur Chardon? lui dit Michel d'un ton qui fit résonner les entrailles de Lucien comme des cordes». ${ }^{185}$

Finalmente, Lucien consigue que el rey le dé derecho al uso del título de su madre — que incluye blasón nobiliario—— ${ }^{186}$ llenándole de orgullo. Su evolución a partir de entonces es eliminar la herencia de su padre quien, arruinado en mil y una investigaciones farmacéuticas, solo le pudo dejar su apellido. Cuando, en una ocasión, vuelve a Angulema y pasa delante de la antigua farmacia de su padre, ocupada ahora por otro boticario, en Houmeau, «il vit avec plaisir (tant sa vanité conservait de force) le nom de son père effacé». ${ }^{187} \mathrm{O}$, en una de las ocasiones en que, gracias a sus relaciones, entra en el palacio de la influyente familia de los Granlieu, Lucien se dice, en un acto de rebeldía retrospectiva: «quoique mon père ait été simple pharmacien à l'Houmeau, j'entre pourtant là....». ${ }^{188}$ ¿Cómo no ver en todos estos rechazos del nombre paterno otros tantos actos de venganza sobre un patrimonio desestimado y/o venido a menos? Lucien, cuya imaginación romántica y novelesca le hace soñar con altos destinos, habría deseado (o necesitado) fortuna familiar y buen nombre para acceder a la gloria destinada únicamente para la antigua nobleza.

\subsubsection{Negación del patrimonio del padre}

Sin embargo, pobre, aislado del gran mundo en su provincia recóndita, y sin nombre, Lucien solo puede optar a ser reconocido por sus acciones en un ambiente en el que su soberbia necesita brillar. La negación del estrecho patrimonio del padre abre las posibilidades de ascenso social al advenedizo muchacho. ¿No significa eso negar por completo la impronta familiar para deberse y ser deudor solamente de sus propias obras?

La ideología del hombre-que-se-hace-a-si-mismo que más tarde consagraría el capitalismo empieza a dar sus primeros pasos en estas novelas de

185 H. de Balzac, Illusions perdues, ob. cit., p. 460.

186 «Gueules, au taureau furieux d'argent, dans le pré de sinople», según le cuenta al conde de Châtelet, en H. de Balzac, Splendeurs et misères des courtisanes, edición de Pierre Citron, G.F.-Flammarion, París, 1968, p. 54.

187 H. de Balzac, Illusions perdues, ob. cit., p. 572.

188 H. de Balzac, Splendeurs et misères des courtisanes, ob. cit., p. 134. 
iniciación. Ideología del bastardo que reniega de unos orígenes demasiado humildes para su ambición; ruptura con un marco infantil tal vez opresor, pero innegablemente vivo en el inconsciente del individuo - como supo tan bien ver Freud en su ensayo «La novela familiar del neurótico».

El mismo Balzac fue testigo de una época en que el pasado podía contar muy poco en el futuro de un individuo. Las fortunas se perdían, un golpe de Estado repentino podía dar al traste con toda una fortuna familiar amasada desde siglos. Así lo expresa en Illusions perdues:

époque où le rapetissement général des choses et des hommes atteint tout, jusqu’à leurs habitations. À Paris, les grands hôtels, les grands appartements seront tôt ou tard démolis; il n'y aura bientôt plus de fortune en harmonie avec les constructions de nos pères. ${ }^{189}$

O incluso en este pasaje, más violento todavía, de La Recherche de l'absolu balzaciano, en que Marguerite Claës se lamenta ante su padre, completamente obsesionado por la química, de comprometer varias veces la fortuna familiar. El patrimonio paterno corre el inmenso peligro de ser devorado o aniquilado por los avatares de la nueva sociedad. Así, le dice Marguerite a su progenitor ante su despreocupación y egoísmo: «si vous vous armez de votre paternité qui ne se fait que pour nous tuer, j'ai pour moi vos ancêtres et l'honneur qui parlent plus haut que la Chimie». ${ }^{190}$

El legado del cabeza de familia, que se esfuerza toda su vida por amasar un patrimonio digno del nombre que heredan sus hijos, deja de tener importancia. La movilidad de los individuos que permiten y alientan los nuevos modos de producción hace que cada uno sea dueño de su destino. Y para ir a buscarlo se alejan del hogar paterno, perdiendo con ello todo interés por la tierra y la hacienda familiares. El triunfo personal pasa a ser la nueva medida del futuro que espera a cada uno, y el desarraigo del individuo una constante de la nueva sociedad industrial.

¿Por qué nos hemos de llamar príncipes? Príncipes de nacimiento, sí; pero, en realidad, ¿ ¿ónde está nuestro principado? No somos singularmente ricos, y la riqueza es lo primordial; en nuestros días, el príncipe de los príncipes es Rothschild.

189 H. de Balzac, Illusions perdues, ob. cit., p. 131.

190 H. de Balzac, La Recherche de l'absolu, Librairie Générale Française-Le Livre de Poche, París, 1999, p. 234. 
—dice Aliocha a su padre, el príncipe Valkovski, en Humillados y ofendidos, de Dostoyevski. ${ }^{191}$

El éxito, en esta incipiente sociedad industrial, depende de unos saberes que el padre ya no domina — anclada como sigue la institución paterna en sus viejos privilegios. A ello también contribuye el cambio en la vida de las personas que supuso el florecimiento del capitalismo. La casa paterna ya no es el centro de producción como lo había sido durante la sociedad precapitalista. Para alimentar a los suyos, el padre debe dejar el hogar, provocando una importante disociación en el imaginario de los hijos entre la vida profesional y la vida familiar. Por ello mismo, su labor se torna invisible para los descendientes, quienes ya no pueden apreciar ni los méritos ni los resultados de la labor paterna. El hijo decimonónico aparece, pues, como un huérfano en su trayectoria vital, al no depender en el aspecto simbólico de los logros del padre.

\subsubsection{Régimen de sucesiones}

Uno de los mayores golpes que asestó la Revolución a la institución paterna se produjo mediante la promulgación del nuevo Código civil, sobre todo en lo tocante al régimen de sucesiones. La herencia de propiedades durante el Ancien Régime se había regido por costumbres locales a la vez diversas y complejas. Los historiadores ${ }^{192}$ dividen, a este respecto, el país en dos zonas con el fin de sistematizar las costumbres referentes a la herencia: el tercio meridional del reino estaba bajo la influencia del derecho romano; los dos tercios del norte se regían por un texto políglota del derecho consuetudinario germano con variaciones regionales.

Con este escenario se encontró el período revolucionario de 1789. La primera medida que tomó la Asamblea, tras abolir los privilegios de la nobleza en el mes de agosto, fue derogar el antiguo modelo, basado en la primogenitura y la indivisibilidad de la herencia: dicho modelo era entendido por los revolucionarios como el método más eficaz para que la clase adine-

191 F. Dostoyevski, Humillados y ofendidos, Nauta, Barcelona, 2002.

192 Vid. L. Bonfield, «La familia en la legislación europea», en D. I. Kertzer y M. Barbagli (comps.), La vida familiar desde la Revolución Francesa hasta la Primera Guerra Mundial (1789-1913), ob. cit., p. 217 y ss. 
rada mantuviera su hegemonía económica. En abril de 1791, la misma Asamblea ordenaba una división igualitaria entre los herederos, manteniendo a la vez la libertad testamentaria en zonas que respetaban el derecho romano. ${ }^{193}$

Las medidas del code civil en la herencia reforzaban aún más la unidad de la familia. Aunque las leyes aprobadas limitaban a una décima parte la porción de los bienes del difunto de la que se podía disponer libremente, dicha porción fue incrementada mediante una ley de marzo de 1800; de este modo, la porción individual de libre disposición disminuía a medida que aumentaba el tamaño de la familia.

Estas medidas no dejaron de modificar el imaginario social en torno a la figura del padre, contribuyendo en gran medida a su decadencia. El heredero del siglo XIX ya no recibía, en función de su posición primogénita, el grueso del patrimonio legado por su padre, sino una porción alícuota a la de sus hermanos. Por consiguiente, a menos que la herencia paterna fuera de enorme importancia, la muerte del progenitor no cambiaba de manera determinante el estatus socioeconómico del heredero: tan solo el nombre y, en todo caso, un título nobiliario, permitían al hijo una promoción en la escala social.

El concepto de la institución paterna se vio herido, con esta transformación del régimen sucesorio, en sus propios cimientos, puesto que uno de estos reside en la transmisión de bienes tanto simbólicos como materiales. La herencia, como sostiene el sociólogo Bourdieu, es un proceso en el que se produce una superación de la figura del padre mediante su negación; el hijo, al aceptar el legado, acepta convertirse en el instrumento del proyecto paterno de conservación de su figura. Esto no deja de ser, en opinión del sociólogo, sino el «meurtre du père accompli sur l'injonction du père, un dépassement du père destiné à le conserver». ${ }^{194}$ Con lo cual el heredero se convierte, simbólicamente, en un asesino que saca provecho de la muerte de su padre. «Est-ce que nous ne vivons pas des morts? Qu'est-

193 Esta diferencia no fue subsanada hasta dos siglos después, momento en el que se impuso la partición igualitaria en todo el país. En J. Brissaud, A History of French Private Law, Little, Brown and Co., Boston, 1912, pp. 342-350.

194 P. Bourdieu, «Les Contradictions de l'héritage», en Pierre Bourdieu (dir.), La misère du monde, Seuil, París, 1993, p. 1093. 
ce donc que les successions?» — llegará a afirmar el avaricioso tonelero padre de Eugénie Grandet. ${ }^{195}$

Si aceptamos como válidas estas aseveraciones, no podemos sino constatar la perturbación del ideal de la figura paterna tendente a perpetuar el sistema de herencias. Al heredar, es posible que el hijo acepte la inmolación del padre para asegurarle un futuro más próspero, y que se haga a sí mismo agente de la transmisión de sus valores. No obstante, si es escaso el patrimonio transmitido, la imagen del padre como proveedor queda puesta en entredicho. Lo único que deja es su nombre - $\tan$ devaluado en algunos ejemplos pero tan rico de consonancias en otros, como el de Marius, el hijo de un teniente napoleónico, quien acepta el título de barón de Pontmercy y lo lleva con tierno orgullo en Les Misérables.

Encontramos, empero, otro ejemplo en esta misma novela de Victor Hugo en que se rechaza el legado de un importante personaje, Jean Valjean. Recordemos cuando, tras la boda de Marius y Cosette - la hija de Fantine recogida por el forçat Jean Valjean, a quien cedería toda su fortuna acumulada durante su período como Sr. Madeleine, alcalde de Montreuil y esforzado industrial—, el origen incierto del ex presidiario lleva al joven esposo a rechazar su enorme herencia. Siendo producto de su propio esfuerzo, el legado de Jean Valjean no puede sino poseer oscuras cualidades que lo hacen inaprovechable para quien ya ha contraído, como Marius, los oropeles de la nobleza napoleónica.

Cosette, nous avons trente mille livres de rente. Vingt-sept que tu as, trois que me fait mon grand-père. J'ai répondu: Cela fait trente. Il a repris: Auraistu le courage de vivre avec les trois mille? ${ }^{396}$

- le dice Marius a su esposa. El lector de Les Misérables no deja de removerse en su asiento al asistir a la falta de reconocimiento que se inflige a la vida del abnegado ex presidiario: por este rechazo, la existencia completa del legatario queda reducida a la nada, completamente desposeída de su sentido y finalidad. La revelación, in extremis, de un disfrazado Thénardier permite descubrir a Marius la calidad personal de quien le salvara

195 H. de Balzac, Eugénie Grandet, Maxi-Livres, París, 2002, p. 75.

196 V. Hugo, Les Misérables, Maxi Livres, París, 2002, vol. 3, p. 489. 
de una muerte segura en las barricadas de París; en un último esfuerzo, la joven pareja acepta el legado del padre, quien muere en paz sabiendo a sus hijos felices.

En cualquier caso, sea escasa o abundante en términos económicos, la herencia supone para el heredero la asunción de un capital simbólico que no es siempre grato recibir. Se trata, como ya hemos señalado a través de Bourdieu, de aceptar continuar la obra del padre, lo que conlleva, en caso de aceptar la herencia simbólica y/o económica, abandono de los propios proyectos personales. En este sentido, Stendhal se quejaba amargamente de su padre, de quien decía ver en él un simple y funcional continuador de su linaje: «No me amaba como individuo sino como el hijo que había de continuar la familia». Flaubert, en la misma línea, expresaría la liberación que sintió a la muerte de su progenitor de las aspiraciones que este había puesto en él: «Todo esto ha hecho el efecto de una quemadura que hubiese acabado con una verruga $[. .$.$] ¡Por fin! ¡Por fin voy a trabajar!». { }^{197}$

A medida que el siglo iba avanzando y se extendía el industrialismo, la individualización a la que sometía al capitalismo al trabajador se convertía en asunto de preocupación de algunos filántropos franceses. Una sociedad basada en la producción y consumo de bienes debía aspirar, como la historia ha mostrado, a que todo ciudadano y toda ciudadana se convirtiesen en unidades de consumo autónomos. De ahí que al poder económico le haya interesado que el mismo dinero que pagaba a sus obreros le fuera devuelto mediante la compra de los productos generados por la industria. Tan evidente se hacía este afán consumista en ese período protocapitalista que observadores como el conde Alban de Villeneuve-Bargemont, en su Économie politique chrétienne, lamentaran la degradación del obrero industrial que «si tiene una familia, la descuida o abandona como una pesada carga. Sus hijos no le prestan los servicios que él no consiguió prestar a sus padres». ${ }^{198} \mathrm{La}$ continuidad de la institución familiar quedaba afectada por el mismo in-

197 Ambas citas referidas por M. Perrot, en: «Figuras y funciones», en P. Ariès y G. Duby, Historia de la vida privada, tomo 7: La Revolución francesa y el asentamiento de la sociedad burguesa. Volumen dirigido por Michelle Perrot, Taurus, Madrid, 1991, pp. 154 y 137, respectivamente.

198 Citado por Katherine Lynch en K. Lynch, Family, Class and Ideology in Early Industrial France: Social Policy and the Working-class Family, 1825-1848, University of Wisconsin Press, Madison, 1988, p. 34. 
dustrialismo, que en principio debía proporcionarle una mejora de su calidad de vida. Otros escritores se hicieron eco de su decepción, subrayando concretamente el papel de la transmisión intergeneracional de la propiedad en la consolidación de los lazos entre padres e hijos:

Es imposible concebir la propiedad sin la familia, y también la familia sin propiedad. Es tal la fuerza de los lazos [...] que las une [...] [Sin propiedad que se pueda heredar] no hay familia -y el nombre es una prueba [...] Los hijos se dispersan, pronto las sucesivas generaciones olvidan sus nombres. No tienen nombres. Pregunta a un hombre pobre por su genealogía. Pensará que bromeas. La familia no es nada. ${ }^{199}$

Esto quiere decir que, en ausencia de un legado económico, la herencia simbólica significaba muy poco tanto para los obreros como para los pensadores de la época del conde Alban de Villeneuve-Bargemont. En una época erosionada por el mercantilismo y el economicismo a ultranza, solo el capital pecuniario se convertía en cimiento necesario e insoslayable de la transmisión intergeneracional. En pocas palabras, sin dinero no hay familia, pues los valores que esta había transmitido hasta la época precapitalista habían sido completamente erosionados por el capitalismo. Este y no otro fue la principal hipótesis de investigación del sociólogo francés Frédéric Le Play, quien indagó los efectos del Código civil napoleónico así como los de la nueva economía en las familias de la Francia decimonónica.

Durante la segunda mitad del siglo XIX, la estabilidad del orden patriarcal se vio amenazada por el avance de la modernización y los impulsos individualistas que esta trajo consigo. Como señala el historiador Ben Eklof, ${ }^{200}$ la emancipación disparó el resentimiento, ampliamente difundido, contra la autoridad patriarcal, contribuyendo a que la familia fuera considerada como una fuente de ingresos económicos para el individuo ávido de separarse de su campo simbólico. Como apuntara Loftur Guttormsson, ${ }^{201}$

199 Ib., p. 37. Vid., asimismo, M. J. Maynes, "Culturas de clase e imágenes de la vida familiar correcta», en D. I. Kertzer y M. Barbagli (comps.), La vida familiar desde la Revolución Francesa hasta la Primera Guerra Mundial (1789-1913), ob. cit., pp. 297-340.

200 B. Eklof, «Worlds in conflict: patriarchal authority, discipline and the russian school, 1861-1914», en B. Eklof (comp.), School and society in Tsarist and Soviet Russia, St. Martin's Press, Nueva York, 1993, pp. 95-97. L. Guttormsson, «Las relaciones paterno-filiales», en D. I. Kertzer y M. Barbagli (comps.), La vida familiar desde la Revolución hasta la Primera Guerra Mundial (1789-1913), ob. cit., p. 405.

201 L. Guttormsson, ob. cit., p. 405. 
la emancipación que el capitalismo promovió aceleró el proceso de división o escisión del hogar, por el cual el hogar original dio lugar a dos o más unidades conyugales. Anteriormente, este tipo de escisión implicaba el reparto de las propiedades del hogar entre los hermanos; normalmente se posponía hasta la muerte del patriarca, pero de ahora en adelante se ejecutaba más a menudo mientras vivía el patriarca, jefe del hogar (escisión pre mortem). Las razones más comunes para la escisión eran los conflictos entre padres e hijos, así como entre nueras y suegras. Sin embargo, si la escisión pre mortem era ejecutada contra la voluntad del padre, un hijo impaciente corría el riesgo de perder el derecho sobre la parte del patrimonio que le correspondía de acuerdo con el principio de la herencia indivisible.

Esto significa que la herencia fuera utilizada frecuentemente por el poder paterno como cortapisa a las ambiciones emancipadoras de los hijos. La herencia no era un hecho de consecución natural, sino que, según el Código civil francés, se concedía mediante el respeto a una serie de normas familiares. Sin embargo, la promoción económica que procuraba y prometía la sociedad industrial empujaba a muchos hijos a la separación de su familia, en un impulso auto-referencial en el que el individuo pudiera considerarse a sí mismo como responsable de su propio futuro: el self-made-man que comentaremos más adelante. En el ámbito familiar, esto supuso una difuminación constante de la autoridad del pater familias como proveedor de todos los bienes de la familia, tanto económicos como simbólicos.

\subsubsection{Normas de respetabilidad}

En ese mismo tiempo, y según refiere también Guttormsson, la emancipación económica provocó otro fenómeno de importancia no menor en la dinámica familiar, como se verifica en la progresiva implantación de las normas de respetabilidad en la clase media. A medida que se incrementaban los sectores de la clase trabajadora que se beneficiaban del aumento de los ingresos, la promoción social se convirtió en motivo de distinción entre clases: la familia trabajadora que había ascendido al escalón de familia burguesa o de clase media deseaba mostrarlo a sus convecinos. La respetabilidad devino un síntoma de ascensión, cuya demostración pasaba por la adopción de unas costumbres 
determinadas como medio para distinguirse de los sectores que seguían manteniendo un comportamiento «rudo». ${ }^{202}$

Parte de ese nuevo comportamiento consistía en la atribución a la mujer, a la esposa, a la madre, de la responsabilidad de mantener la respetabilidad del hogar. La competencia del hombre pasaba por su capacidad para aportar pecunio a casa, lo que permitía que la mujer permaneciera en el hogar —en el que estaría recluida en lo sucesivo para mayor gloria de la institución familiar, con la consiguiente separación de las esferas masculina-pública y femenina-privada. La mujer casada que no realizaba un trabajo remunerado personificaba, así, la respetabilidad con su competencia doméstica. Se sentía orgullosa de la casa y la familia y adquiría autoestima demostrando que era capaz de llevar la economía familiar, cuidar debidamente de sus hijos y cerciorarse de que asistían regularmente a clase.

Como refiere Mary Jo Maynes, ${ }^{203}$ la separación entre lo público y lo privado proporcionó también un medio adecuado para abordar la esquizofrenia moral creada por el capitalismo industrial. Esta escisión provenía del componente de amoralidad existente en la actividad económico-industrial desde las postrimerías del siglo XVIII. Según Maynes, la moralidad burguesa necesitó buscar refugio en otro lugar que no fuera el ámbito de los negocios - refugio que encontró en el seno de la familia. Como recomendaba Sarah Ellis en un exitoso manual de gestión hogareña publicado en 1839, el objetivo del hogar era proporcionar un «luminoso, sereno, tranquilo y jubiloso retazo del cielo en un mundo que no tiene nada de celestial». ${ }^{204}$ De ahí que la domesticidad y su primorosa gestión cobraran tanta importancia en el imaginario de la clase media — de lo que la respetabilidad era un elemento más. Su implantación y exaltación, como señala de nuevo Maynes, estuvieron determinadas por el cambio económico.

A medida que las mujeres casadas abandonaban el trabajo remunerado, aumentaban las exigencias impuestas a los maridos en su papel de sustentadores y proveedores de la familia. La dignidad y el respeto debidos al padre

202 Ib., p. 398.

203 M. J. Maynes, ob. cit., p. 306.

204 Ib., p. 306. 
a veces podía hacer de él un miembro de la familia ajeno a ella - excepto en la mesa, a la hora de comer, y en los paseos del domingo por la tarde. «Mostrándote apenas una vez al día creabas en mí una impresión tanto más profunda en la medida en que era excepcional...» — decía Franz Kafka en su «Carta al padre». ${ }^{205}$

Este fenómeno comenzó a operar la separación entre los progenitores y sus hijos, quienes vieron a partir de esa segunda mitad de siglo XIX a su padre como un ser extraño al que jamás se llegaría a conocer en profundidad. Es el «padre ausente» de la sociedad industrial del que habla Robert Bly: que se va de casa temprano por la mańana y no vuelve hasta muy tarde por la noche, dejando una impresión de desamparo en el niño. ${ }^{206}$ Según historiadores, psicólogos y psicoanalistas, este abandono paterno de sus responsabilidades afectivas provoca fantasmas y obsesiones ${ }^{207}$ en el hijo desprovisto de modelo masculino — de ahí que se le haga culpable de su desvirilización paulatina. El psicoanalista estadounidense Samuel Osher$\operatorname{son}^{208}$ habla de un profundo "dolor de padre» que se da en los hijos de la era industrial. La ausencia del progenitor provocaría en sus vástagos una curiosa ambivalencia polarizada en la nostalgia y el odio, entre el miedo y el desprecio. Miedo a la aplicación de su autoridad: latente en todas las normas silenciosas que rigen la vida del hogar y de la sociedad; visible de manera demasiado patente cuando, a su tardía vuelta a casa, debe someter al niño mediante castigo al dictado de su poder. Nostalgia, en su constante ausencia. «La profunda necesidad que siente el hijo de que su padre le reconozca y confirme como tal choca con la ley del silencio», dice Badinter. «Su masculinidad, que necesita un refuerzo constante, queda inacabada debido a la huida paterna». ${ }^{209}$

Todo indica que la erosión de la figura del padre produjo una huella indeleble en el imaginario del niño decimonónico. Desprovisto de modelo,

205 Citado por Elisabeth Badinter en XY. La identidad masculina, Alianza Editorial, Madrid, 1993, p. 179.

206 R. Bly, Iron John: a book about men, Element Books, Shaftesbury, Dorset, 1991.

207 Abbot se referirá al padre como de una «figura demoníaca»: "What Men really want", en New Men, New Minds, p. 178 (cf. E. Badinter, ob. cit., p. 181).

208 S. Osherson, Finding Our Fathers: How a Man's Life is Shaped by His Relationship with His Father, Fawcett Columbine, Nueva York, 1987.

209 E. Badinter, ob. cit., p. 181. 
de atenciones afectivas de su progenitor, el infante crece en una total desorientación que, finalmente, el mercado se encargará de encauzar en la vía del consumo. El padre pierde, por ello, su función simbólica, deja la familia a la deriva y, a sus miembros, a merced de las potentes corrientes económicas. El legado del hijo del capitalismo, industrialismo y economicismo del siglo XIX es, como señala Roudinesco, «haber recibido en herencia la gran figura destruida de un patriarca mutilado» ${ }^{210}-\mathrm{y}$ que el psicoanálisis intentará desentrañar con su método.

Balzac supo plasmar a la perfección los intentos de un padre por contrarrestar este inevitable impulso social en contra de la paternidad. El Père Goriot —en la novela homónima de Balzac, de 1834 - se esfuerza lo indecible por sentirse responsable de los éxitos de su hija, Delphine, posteriormente Mme. de Nucingen. Antiguo fabricante de pasta italiana y de almidón, el Père Goriot se desvive por procurarle a su hija todos los vestidos, carruajes y demás accesorios necesarios para su esplendor como hija casadera - digna de los mejores partidos cuanto mejor aparezca en sociedad. La misma defección de la institución se comprueba en la progresiva decadencia del Père Goriot.

Ante este fenómeno de rarefacción de la presencia e influencia paternas, el centro de gravedad en la familia se desplaza hacia la madre - quien asume responsabilidades progresivamente mayores, incluso en el caso de los varones. Es en este contexto de declive de la familia tradicional, de «umbral de la familia edípica» — como señala Yvonne Knibiehler— ${ }^{211}$ en el que Freud crea sus teorías psicosexuales. ${ }^{212}$

Una escenificación estupenda de la asunción de estas responsabilidades, mediante la competición entre padre y madre, se da en El padre, de Au-

210 E. Roudinesco, La familia en desorden, Anagrama, Barcelona, 2004, p. 84.

211 Y. Knibiehler, «Madres y nodrizas», en S. Tubert (ed.), Figuras de la madre, Cátedra Feminismos, Madrid, 1996, pp. 95-118.

212 Vid. un ejemplo de este desplazamiento progresivo del polo de atención hacia la mujer, hacia la madre, en la balzaciana Eugénie Grandet, en particular en el pasaje en que la madre de Eugénie está en su lecho de muerte: el Père Grandet se da cuenta, alertado por su abogado, de que tiene bienes gananciales con su mujer. Su patrimonio depende, en adelante, de la decisión de su hija, símbolo patente del avance femenino en las decisiones patrimoniales. H. de Balzac, Eugénie Grandet, ob. cit., p. 179. 
gust Strindberg 213 — una «escenificación violenta de la 'guerra de los sexos'», como dirá Silvia Tubert. ${ }^{214}$ Preocupado por los avances del feminismo, cuyas reivindicaciones defendían también algunos hombres como Ibsen, Strindberg presenta una imagen apocalíptica de los estragos que habría de producir una modificación de las relaciones de poder entre los sexos (en este caso, en lo que respecta a la patria potestad) que él solo puede concebir como inversión de los términos, es decir, como la imposición del dominio de las mujeres sobre los hombres. La obsesión, la locura, el derrumbe, se originan en la duda acerca de la paternidad: «un hombre no tiene hijos. Solo las mujeres los tienen, por eso el futuro les pertenece, mientras que nosotros morimos sin hijos». La locura del capitán es una metáfora de la destrucción de la paternidad y de la masculinidad que, según Strindberg, sería el corolario del triunfo de la reivindicación de los derechos de las mujeres y de las madres. ${ }^{215}$

La consecuencia socio-política de esta destrucción simbólica de la omnipotente paternidad es la promulgación en Francia de la ley sobre la inhabilitación de la patria potestad cuando se reconoce la indignidad del padre. Con esta ley se derrumba un principio sacrosanto: el poder del padre sobre sus hijos dejó de ser algo intocable y pasó a estar sometido a criterios de seguridad y utilidad pública bajo el control de la colectividad. Françoise Hurtel ${ }^{216}$ glosa la importancia de este hecho como la «escena inaugural» de la paternidad contemporánea.

El caso del abandono de la responsabilidad paterna en su crianza y su educación se hace manifiesto en Stendhal. Cuánto sufre Julien ante la iniquidad a la que le somete su padre. Comparado con sus dos hermanos, mus-

213 A. Strindberg, El padre, M. K., Madrid, 1979.

214 S. Tubert, «Sacralización y ocaso de la figura paterna», pp.183-202, en C. SánchezPalencia y J. C. Hidalgo, Masculino plural: construcciones de la masculinidad, Ediciones de la Universidad de Lérida, Lérida, 2001, p. 194.

215 Ana Iriarte explica en A. Iriarte, "Ser Madre en la cuna de la democracia o el valor de la paternidad», en S. Tubert (ed.), Figuras de la madre, ob. cit., pp. 73-93, cómo las sociedades preclásicas evolucionaron desde un respeto por la maternidad -parejo al que profesaban al soldado para la construcción y mantenimiento de la polis- hasta la neutralización de su poder. Ello puede verse en los continuos ejemplos que aporta Iriarte sobre la afirmación reiterada de que era el hombre quien finalmente tenía mayor importancia en la reproducción que la mujer. Gracias a este giro cultural en la concepción de la paternidad, pudo darse la evolución hacia la filiación paterna de los hijos. Vid. asimismo A. Goldman-Amirav, «Mira, Yahveh me ha hecho estéril», en S. Tubert (ed.), Figuras de la madre, ob. cit., pp. 41-51.

216 Citada por S. Tubert, ib., p. 193. 
culosos trabajadores que hacen las delicias del patrón de la serrería familiar, Julien no es más que un gañán inútil, que pasa su tiempo leyendo estúpidas novelas en lugar de ejercitarse en los juegos viriles. "Je vais être délivré de toi; et ma scie n'en ira que mieux», ${ }^{217}$ le dice su padre al anunciarle que le ha encontrado un empleo de preceptor en casa del M. de Renal. El padre se libra de él, pues su presencia no deja de ser una molestia —o, lo que es más, un gasto superfluo en la dinámica familiar, únicamente basada en el afán de lucro y en la productividad. Criar un hijo, alimentarlo y proporcionarle una educación — basada, eso sí, en los designios paternos — solo se puede concebir si con ello se proporciona un nuevo obrero a la economía familiar. Julien, improductivo desde el punto de vista paterno, le es costoso a su padre, quien no ve el momento de desembarazarse de él y de terminar así con el pago de su alimentación. Una obligación que, como progenitor, acepta el padre siempre y cuando le sea devuelta en capital de trabajo; de lo contrario, no será sino un suma y sigue consignado en el debe de la contabilidad paterno-filial: «Dieu sait, maudit paresseux, lui dit son père, si tu auras jamais assez d'honneur pour me payer le prix de ta nourriture, que j'avance depuis tant d'années». ${ }^{218}$

Ante la cuantificación —o mercantilización — de los cuidados que el padre dispensa al hijo, este no puede sino huir en busca de un prestigio que le devolviera la consideración del padre. Lo que el padre no ha podido hacer de su hijo, este deberá hacerlo de sí mismo para mostrarse digno de su afecto. De ahí que el empleo en la casa señorial sea una liberación para Julien así como una posibilidad de promoción. Pero, lejos de volver para mostrar sus triunfos al padre cuando se halla de regreso en Verrières, Julien olvida a toda su familia como si fuera el objeto de un mal sueño: «la jalousie de ses frères, la présence d'un père despote et rempli d'humeur avaient gâté aux yeux de Julien les campagnes des environs de Verrières». ${ }^{219}$

Julien no solo es el bastardo por excelencia, sino, casi se podría decir, hijo de una generación necesariamente espontánea. Expulsado, casi repudiado por su padre, el héroe de Le Rouge et le noir debe re-hacerse a sí mismo a partir de una generación indeseable y claramente obviable, digna de ser relegada al olvido.

217 Stendhal, ob. cit., p. 34.

218 Ib., p. 37.

219 Ib., p. 65. 
No es de extrañar, por todo ello, que cualquier influencia positiva sobre su futuro - pues se supone, que el padre forma al hijo para ser un hombre autónomo e independiente - sea recibida por Julien con la alegría del hijo pródigo. Y así se da cuando, en el seminario de Besançon, el abate Pirard promete ayudarle en su carrera eclesiástica. La posibilidad de que un hombre de tamaña autoridad como el abate se muestre dispuesto a compartir los beneficios de su curia, o incluso a cedérsela en caso de que su nuevo empleo - esta vez en la parisina casa del marqués de la Mole- no vaya tan bien como se espera, no puede sino resquebrajar el corazón de fina factura de Julien, ${ }^{220}$ dejando entrar en él las miríficas luces de la felicidad y de la comunión con la humanidad. "A sa grande honte, Julien se sentit les larmes aux yeux; il mourait d'envie de se jeter dans les bras de de son ami». ${ }^{221}$ De ahí que, ante semejante anuncio, Julien le haga partícipe de su emoción: «j’ai été haï de mon père depuis le berceau; c'était un de mes grands malheurs; mais je ne me plaindrai plus du hasard, j'ai retrouvé un père en vous, monsieur». Sin embargo, como sabemos, el porvenir de Julien pasa por varias vicisitudes que ponen a prueba sus habilidades como estratega.

\subsubsection{Responsabilidad del triunfo}

El reto que se hace a sí mismo el hijo que niega al padre es de gran magnitud. Una vez descontado el patrimonio, una vez olvidada la posibilidad de heredar algo — un cargo, una renta, una suma importante- la responsabilidad del triunfo recae exclusivamente sobre este hombre-que-sehace-a-si-mismo. Su futuro le pertenece porque solo depende de él medrar o empeorar. ${ }^{222}$ Sin embargo, en algunas ocasiones en que la influencia del

220 Así es como define Stendhal, una de tantas veces, la sensibilidad de Fabrizio del Dongo: «c'était un de ces cœurs de taille trop fine qui ont besoin de l'amitié de ce qui les entoure», en Stendhal, La Chartreuse de Parme, Librairie Générale Française-Le Livre de Poche, París, 1983, p. 124.

221 Stendhal, Le Rouge et le noir, ob. cit., p. 244.

222 Alain de Botton señala una serie de textos que se consideran precursores en la filosofía del "hombre-que-se-hace-a-sí-mismo»: Autobiografía, de Benjamin Franklin (incompleta tras su muerte en 1790); Progresar en el mundo, de William Matthews (1874); De camino a la riqueza, de William Maher (1876); El secreto del éxito en la vida, de Edwin T. Freedley (1881); Cómo triunfar, de Lyman Abbott (1882); La ley del éxito, de William Speer (1885); El problema del éxito para el hombre joven y cómo solucionarlo, de Samuel Fallows (1903). Cfr. A. de Botton, Ansiedad por el estatus, Taurus Pensamiento, Madrid, 2004, pp. 67-68. 
padre proveedor falta, la responsabilidad personal del triunfo se ve cargada con las esperanzas de bienestar que otras personas, dependientes de la evolución del héroe bastardo, depositan en él. La adquisición de un nuevo patrimonio se encomienda al joven que parte a la capital en busca de las aventuras y de los negocios que le permitan medrar; de ello se beneficiará la familia que se quedó en la profunda provincia, cuyos miembros hacen todos los esfuerzos posibles para dotar al héroe de lo necesario en su ascensión. "Le Français aime le péril, parce qu'il y trouve la gloire, a dit monsieur de Chateaubriand...» ${ }^{23}$ — refiere el Rastignac de Le Père Goriot a Mme. de Béauséant. Un peligro que consiste no solo en arriesgar su propia vida y su propio porvenir, sino el de toda la familia. Y es que este dandi en ciernes que es Rastignac se instala provisionalmente en la pensión de la señora Vauquer, venido de su Angulema natal a París para estudiar derecho; su familia, para financiar sus estudios, «se soumettait aux plus dures privations afin de lui envoyer douze cents francs par an». ${ }^{224}$ Privaciones de todo tipo que pasaban por el ahorro inmoderado en los vestidos de las hermanas - quienes esperaban días mejores para lucir sus encantos y encontrar un buen marido; en las necesarias reparaciones de la antigua y desvencijada mansión familiar; en los caprichos que sus padres, ya mayores, se habían acostumbrado a permitirse. Todo se detiene a la espera de que el hermano, el hijo varón, consiga esos éxitos que devuelvan la perdida prestancia a la familia.

La stricte économie de ce mariage rendait à peine suffisante cette somme, presque entièrement absorbée par Lucien. Mme. Chardon et sa fille Ève croyaient en Lucien comme la femme de Mahomet crut en son mari; leur dévouement à son avenir était sans bornes. ${ }^{225}$

Lucien, el otro paradigma del héore bastardo, viste sus noches angoumoises de gala para gustar a la bella Mme. de Espard, cuyo amor le conducirá finalmente a París. Y aunque al llegar a la capital proveedora de todas las fortunas por crearse, Lucien sea abandonado a su suerte, no ceja por ello en su empeño de escalar. Y lo hace no solo porque de su escalada más o menos rápida depende su soñado futuro de éxitos y gloria, sino también el

223 H. de Balzac, Le Père Goriot, Librairie Générale Française-Le Livre de Poche, París, 1983 , p. 146.

224 Ib., p. 14.

225 H. de Balzac, Illusions perdues, ob. cit., p. 47. 
de su familia. Por eso, sus deseos de triunfar pasan por encima de todo, de sus estudios, de su dignidad —en ocasiones por encima de su familia incluso. Como sabemos, Lucien traiciona finalmente la confianza que en él deposita su familia por atender las cuestiones del honor de un dandi que conoció las mieles del éxito social y se ve sometido de repente a la amargura de la pobreza. Cómo no sentir el peso de la ignominia cuando se sabe que se ha gastado alegremente el dinero que la familia, allá en Angulema (el mismo país que Rastignac), amasa día a día para satisfacer sus deudas de jeune désouvré.

Triste condición la del deudor, quien se ve siempre cargado con la obligación de pagar - de una manera u otra- el depósito que en él hicieron. Cómo no soñar — como el Napoleón de Santa Helena - con el estado de hijo bastardo, de niño expósito a todos los niveles, únicamente dependiente de su suerte y de su trabajo —únicamente dependiente de sí mismo.

\subsubsection{Hijo de una generación necesariamente espontánea}

Hijo de una generación necesariamente espontánea, el héroe bastardo reniega de padre y de familia para sentirse, por una parte, únicamente deudor de su propio esfuerzo; por la otra, solo responsable de sí mismo. «Tout tend dans ce siècle à jeter de l'odieux sur l'autorité légitime. Pauvre France!», exclama airado el señor de Renal. ${ }^{226} \mathrm{Y}$ no protesta únicamente ante la ascensión del ilegitimo, del bastardo Napoleón; también ante la autoridad que, como padre, él mismo va perdiendo ante sus hijos. Ya no son los valores patrimoniales, la figura de autoridad indiscutible y legítima que debería significar el padre ante sus hijos. Cualquier advenedizo es capaz de ganarle la partida a ese pater familias huidizo y ausente, cuya figura se difumina como modelo en el camino que lleva al éxito social. Todo cambia, la época está llamada a la transformación social. La posibilidad de éxito lo mina todo, ofreciendo a los jóvenes franceses ("gâtés tous par l'exemple de Napoléon») el espejismo de nada deber al pasado y todo a su propio esfuerzo. Ni el patrimonio, ni el nombre, ni los hechos que merecieron un escudo nobiliario valen lo que procura una gloria arrancada al porvenir con el duro esfuerzo, con la puesta a prueba de la propia valía, con el propio carácter. El viejo mundo se derrumba para dejar paso al mundo de los méritos en constante

226 Stendhal, Le Rouge et le noir, ob. cit., p. 153. 
evolución. El padre, como consecuencia de ello, ve bascular su papel de autoridad hasta hace poco innegable: «møurs de voisinage, habitudes religieuses, fidélités traditionnelles se sont effritées devant l'exaltation de la 'réussite'» — como dice André Rauch ${ }^{227}$ en su interesante estudio sobre la historia de la masculinidad. La tierra pierde gran parte de su importancia con el desarrollo de la civilización industrial, para pasar a ser las propiedades inmobiliarias las que cobren una presencia otrora impensable en la Francia del Ancien Régime. ${ }^{228}$ Unas propiedades que, por su naturaleza móvil, son más el fruto de una acción decidida y personal que de la Providencia.

\subsubsection{Nuevo código masculino}

El nuevo orden de ciudadanos alejados de las expectativas sucesorias o hereditarias, reunidos en torno a la expresión de las hazańas militares (¿qué mejor manera de forjarse un futuro que mediante el ejercicio de las armas?) crea un nuevo código masculino basado en el honor, en el que el mérito ya no proviene de la ciudadanía ni de la opinión pública. Esta nueva clase de hombres que necesitan construirse a sí mismos se reúne en círculos de iniciados, cuya fidelidad se basa en los valores viriles. Las hazańas, el valor y el código de honor del héroe son monopolio exclusivo del hombre.

Sin embargo, no todos los hombres participan de esta nueva virilidad auto-realizada. La difuminación de la imagen del padre también da nacimiento a otra clase de hombres, que supone la transgresión del código de honor viril. Como señala André Rauch, "la transgression de ce code passe pour effémination, et provoque mépris ou dédain. La mysoginie peut ici servir de paradigme à la virilité». ${ }^{229}$

Esto explica en parte la gran corriente de misoginia que se produjo en la Europa post-revolucionaria: corriente de exaltación de la virilidad en un

227 A. Rauch, Le premier sexe. Mutations et crise de l'identité masculine, Hachette, París, 2000 , p. 256.

228 Así lo expresa Simone de Beauvoir en su Deuxième sexe: «Par suite du rapide développement de la civilisation industrielle, la propriété foncière se trouve en recul par rapport à la propriété mobilière: le principe de l'unité du groupe familial perd de sa force. La mobilité du capital permet à son détenteur au lieu d'être possédé par sa fortune de la posséder sans réciprocité et de pouvoir en disposer», en S. de Beauvoir, Le deuxième sexe, vol. I "Les Faits et les Mythes», Gallimard Folio, París, 1949, p. 209.

229 A. Rauch, ob. cit., p. 255. 
mundo cambiante. Una reafirmación de lo masculino llevada a cabo mediante la negación de lo femenino - especialmente en una época que vería el nacimiento del pensamiento dignificador de la condición femenina. En efecto, el feminismo fue uno de los fenómenos que mayormente influyeron sobre la masculinidad del siglo XIX, dotando de argumentos de peso a la corriente misógina de afirmación viril. Así lo observa Erika Bornay en su interesante estudio Las hijas de Lilith, ${ }^{230}$ proponiendo como las dos primeras causas productoras de la corriente misógina del siglo XIX la rivalidad laboral y el avance feminista. La tercera causa sería, siempre según Bornay, el relieve y presencia en la sociedad de las prostitutas, cuyo número y extensión se reveló como un fenómeno no solo inquietante, sino también desconocido hasta la fecha. El cuarto motivo de desconfianza masculina estaba en parte relacionado con la prostitución, pues la sífilis, tan presente y mortífera durante todo el siglo, se cebó principalmente sobre las profesionales y sus clientes. Por último, cabe señalar la influencia de unas teorías de carácter profundamente antifeminista (Schopenhauer, Nietzsche, Nordau, Weininger y Lombroso, entre otros), que intentaron racionalizar y dar autoridad socio-filosófica a aquellas reacciones y actitudes masculinas, misóginas.

Por otra parte, Katharine Rogers señala otras tres causas como reactivos de la misoginia masculina: a) rechazo o sentimiento de culpabilidad por la actividad sexual; b) reacción contra la idealización a la que los hombres han elevado a las mujeres; c) sentimiento machista, deseo de mantener a la mujer sometida al hombre. Esta última razón es, según afirma Rogers, «la causa más importante de la misoginia, porque es la más arraigada en la sociedad» (272). ${ }^{231}$

Intentemos, pues, analizar algunas de las causas enumeradas antes, teniendo en cuenta la tercera de las causas enumeradas por Rogers como transversal al resto: interesaba al poder masculino someter a la mujer por los motivos que hemos examinado en el capítulo anterior. Nos ocuparemos de la rivalidad laboral, el avance del feminismo y la creciente presencia de la prostitución en la sociedad del siglo XIX.

230 E. Bornay, ob. cit., p. 16.

231 K. M. Rogers, The trouble some Helpmate. A History of misogyny in literature, University of Washington Press, Seattle, p. 272, citada por Moi, Toril, ob. cit., p. 40. 


\subsection{Causas de la misoginia decimonónica}

\subsubsection{La rivalidad laboral}

La Revolución Industrial del siglo XIX provocó la entrada masiva de las mujeres en el mundo laboral asalariado. La creciente industrialización se alimentó de la mano de obra femenina, más barata que la masculina debido —no únicamente- a su menor vigor y a los inconvenientes de su físico: indisposiciones y embarazos mantenían separadas a las féminas de sus puestos, siendo este un motivo de gran utilidad para someterlas a una dolorosa discriminación.

De todas maneras, el primer colectivo con el que tuvieron que enfrentarse las mujeres no fue el del empresariado - a este le interesaba contar con tan barata mano de obra- sino con el de sus compañeros obreros. Como comenta el historiador británico Roger Fulford, «la mujer hubo de luchar contra el hombre, y no tanto contra el empresario; tuvo que afrontar a su patrón doméstico, y no a su patrón económico». ${ }^{232}$ Así lo estimó también Sheila Rowbotham, quien comentaba que la competencia entre los hombres se intensificó, haciendo que las mujeres fueran expulsadas de los trabajos más ventajosos y rentables, siendo relegadas a aquellos de remuneración más baja. En sus trabajos históricos centrados en la Revolución Industrial, Rowbotham observó que hacia 1630, si bien los jóvenes impresores no protestaban contra la presencia de las mujeres en los trabajos de imprenta no especializados, a mediados de siglo ya habían cambiado de idea consiguiendo expulsarlas. En la industria cervecera, una tal Mary Arnold fue encarcelada por haber seguido fabricando cerveza a pesar de una orden de los fabricantes de Westminster; hacia finales de ese siglo, las mujeres fueron excluidas de dicha producción. En otros oficios considerados más nobles, como la medicina, los requisitos para ingresar en su ejercicio excluían a las mujeres a medida que la profesión se iba convirtiendo en una ciencia. El oficio de Galeno solo fue ejercido a la postre por los hijos de las familias que pudieran permitirse su instrucción. Incluso en el ámbito de la partería, monopolio tradicional de las mujeres, eran los hom-

232 R. Fulford, Votes for Women, Londres, Faber, 1957, p. 101 (citado por K. Millet, Politica sexual, Cátedra-Instituto de la Mujer, Madrid, 1995, p. 141). 
bres los que se ocupaban de ayudar a dar a luz a las mujeres ricas: como comenta Rowbotham, la experiencia aducida por las mujeres no fue útil en su confrontación con «la abstracta teoría de los hombres. Pero en el Nuevo Mundo, la ciencia suponía un control de las ideas que proporcionaba poder». ${ }^{233}$

Como podemos observar, la oposición masculina fue enorme para evitar la ocupación femenina de los puestos de trabajo que, tradicionalmente, habían desempeñado conjuntamente ambos sexos. Incluso la conveniencia del oficio textil para las mujeres, monopolio femenino desde la noche de los tiempos, estaba siendo puesta en entredicho. El mismo Freud vio en él una cualidad femenina por excelencia, siendo esta actividad, que en principio tendría como finalidad cubrir los defectos de los genitales imitando la pilosidad de la zona bajoventral, una de las pocas contribuciones de las mujeres a los avances de la civilización. ${ }^{234}$ Sin embargo, el Congreso Obrero de Marsella de 1866 denuncia la peligrosa potencia erótica de las máquinas de coser, culpables, según los términos de una memoria de la Academia francesa de Medicina de 1866, de ocasionar:

una excitación genital lo bastante viva como para que [las obreras] precisen dejar momentáneamente todo trabajo [...] y recurran a lociones de agua fría [...] Semejante instrumento, por su continuo movimiento, excita el delirio histérico. ${ }^{235}$

233 A. Moresno Sardà, El arquetipo viril protagonista de la historia, Lasal, Edicions de les Dones, Barcelona, 1987, p. 34.

234 «Al pudor, en el que se ve una cualidad par excellence femenina, pero que es algo mucho más convencional de lo que se cree, le adscribimos la intención primaria de encubrir la defectuosidad de los genitales. Aunque nos olvidamos que el pudor ha tomado después a su cargo otras funciones. Se cree que las mujeres no han contribuido, sino muy poco, a los descubrimientos y los inventos de la historia de la civilización; pero quizá sí han descubierto, por lo menos, una técnica: la de tejer e hilar. Si así ha sido, en efecto, podríamos indicar el motivo inconsciente de tal rendimiento. La Naturaleza misma habría suministrado a la mujer el modelo para tal imitación, haciendo que al alcanzar la madurez sexual crezca la vegetación pilosa que oculta sus genitales. El paso inmediato habría consistido en adherir unas a otras aquellas hebras que salían aisladas de la piel». En S. Freud, "La feminidad", en Nuevas lecciones introductorias al psicoanálisis, en Obras Completas, ob. cit.; tomo VIII, pp. 3164-3178.

235 C. Alzon, Mujer mitificada, mujer mistificada, Ruedo Ibérico-Ibérica de Publicaciones, París-Barcelona, 1982, p. 56. Cómo no recordar, por otra parte, la famosa frase de Lautréamont en la que daba cita a una máquina de coser y un paraguas en una mesa de disección. 
Ni siquiera esta actividad, que ha supuesto tradicionalmente una extensión de las actividades desarrolladas en el interior del hogar, escapa a la susceptibilidad masculina. La consecuencia que podemos sacar de esta continuada reticencia de los hombres decimonónicos es que solo veían conveniente el encierro de las mujeres en el domicilio, excluidas de toda labor remunerada y exterior que les dotase de una cierta autonomía, peligrosa para la institución familiar. Incluso hoy día, el trabajo femenino exterior adolece de los mismos problemas, más cualitativa que cuantitativamente. Así lo comenta el sociólogo francés Pierre Bourdieu, ${ }^{236}$ quien señala la conveniencia sexista de que el trabajo de la mujer en las esferas masculinas responda a tres principios prácticos. Por una parte, debe ser una extensión de las labores domésticas: enseñanza, cuidados, servicio — las relacionadas con la política del acercamiento, como señala Victoria Camps parafraseando a otros autores. ${ }^{237}$ Por la otra, una mujer no ha de tener autoridad sobre los hombres: debe ser relegada a posiciones subordinadas. Y, finalmente, debe ser separada de la manipulación de máquinas y demás aparatos tecnológicos, que permanecen como funciones monopolizadas por los hombres.

Nuestra sociedad contemporánea ha contemplado el avance de la mujer con un cierto escepticismo, sabiendo que es necesario para su emancipación y su autonomía económicas; sin embargo, el inconveniente secular para el desarrollo de una carrera profesional que es la maternidad se ha convertido también en una exigencia, en un derecho femenino. Es lo que se llama, hoy en día, el «síndrome de las dos cosas a la vez» (do both syndrome). ${ }^{238}$ Las mujeres no entienden deber renunciar a una cosa para acceder a la otra, so pena de perder esa parte de su esencia femenina que pasa,

236 P. Bourdieu, La domination masculine, Seuil, París, 1998, p. 101.

237 «Para llevar a cabo esta política del acercamiento sin duda la mujer está mejor preparada que el hombre que ha vivido al margen de tantas cosas para ocuparse exclusivamente de las únicas que consideró importantes» - dice V. Camps, El siglo de las mujeres, CátedraFeminismos, Madrid, 1998, p. 39. «Con las palabras de Noddings, la idea de que las mujeres 'están mejor equipadas que los hombres para prestar cuidado y atención'» (p. 73). Reivindicación esta perfectamente encuadrable dentro de la que algunos sectores del feminismo hacen de la ética del cuidado, como explicamos en el capítulo 3.7.4: «Importancia de la bonne».

238 M. E. Giménez, «Feminism, pronatalism, and motherhood», en Joyce Trebilcot (ed.), Essays on Feminist Theory, Rowman y Allanheld, 1983, p. 288 y ss. Y Raquel Osborne, La construcción sexual de la realidad, Cátedra Feminismos, Madrid, 1993, p. 140. 
irremisiblemente, por la maternidad. En caso contrario, caen en la masculinidad, según expresión de alguna especialista en feminismo de planteamientos harto simplistas:

algunas mujeres han decidido ser hombres, imitarlos en todo: descuidan la casa, no cocinan, no van a la compra, no se ocupan del marido más de lo que este se ocupa de ellas, renuncian a tener hijos. Son solo profesionales, buenas profesionales. Mujeres que han hecho suya la cultura masculina.

Así lo considera la catedrática Victoria Camps ${ }^{239}$ de manera un tanto reduccionista y, sobre todo, normativa: ser mujer pasa inexorablemente por el ejercicio de la maternidad, pues la programación de la especie así lo ha decidido. Desean estas mujeres hacer compatible la vida privada - el hogar - con la vida pública — la profesión-, sin que deban preocuparles las lógicas colusiones entre ambos mundos.

«Descartada la idea de abandonar la vida privada, la compatibilidad entre una y otra es la primera tarea», dice de nuevo Camps. ${ }^{240} \mathrm{Y}$ todo ello porque, en una bien entendida igualdad, la mujer debe equipararse al hombre en el ejercicio de las labores públicas, ya que el varón siempre quiere trabajar, pues tiene que hacerlo por definición ontológica. ${ }^{241}$

La práctica laboral femenina ha sido por fin aceptada por la sociedad actual, aunque a regañadientes: si quiere dedicarse a una labor profesional, deberá hacerlo sin menoscabo de sus «deberes de mujer»: el cuidado del hogar y la maternidad obligatoria. Siendo esto así, el desgaste que sufre la mujer en esta doble función es tanto mayor cuanto menor es la actividad del hombre en el ámbito doméstico. Y aun siendo este otro tema, no deja de mostrar claramente cuál es el fundamento de la oposición del patriarcado a la emancipación económica: el control sobre los vientres.

\subsubsection{El avance del feminismo}

El imparable avance del feminismo fue uno de los principales hitos políticos del siglo XIX. En el nuevo mundo creado a partir de la Revolu-

239 V. Camps, ob. cit., p. 14.

240 Ib., p. 20.

241 «Nadie cuestiona ni duda, en cambio que el varón 'quiera' trabajar. Tiene que hacerlo». Ib., p. 64. 
ción de 1789, los hombres observaron cómo todas las referencias ancestrales que avalaban su dominio se iban desmoronando una a una. Las mujeres consiguieron, bajo el telúrico impulso revolucionario, adquirir un estatus idéntico, por lo menos sobre el papel, al de sus compańeros. Bajo la denominación de ciudadano se cobijó a todos los súbditos de la nación francesa, sin exclusión por género o raza: todos fueron idénticos ante la nueva ley que proclamaba la libertad, la igualdad y la fraternidad. Como afirma Elisabeth Sledziewski, ${ }^{242}$ la Revolución dio a las mujeres la idea de que no eran niñas; les reconoció una personalidad civil que el Antiguo Régimen les negaba y se convirtieron en seres humanos completos, capaces de gozar de sus derechos y de ejercerlos. ¿Cómo?, convirtiéndose en individuos.

Esta transformación del reflejo en negativo de una masculinidad segura hasta entonces de sus valores propios empujó al hombre finisecular a redefinirse. Y la única manera que encuentra es a través de la definición, nueva definición, de las mujeres. "C'est à travers le discours sur la femme que la masculinité est contrainte de se constituer parfois explicitement comme telle, de se définir». ${ }^{243}$ Se produce así una reacción redefinitoria de lo masculino, pues, al abrir las puertas de la ciudadanía a las mujeres, la preeminencia de la virilidad sobre la feminidad queda puesta en entredicho. Como recuerda Annelise Maugue, el hombre del período post-revolucionario se encuentra en una encrucijada dialéctica: por una parte no renuncia a los mitos que sostienen su dominio; por la otra no termina de creer en ellos completamente. Se debate en una continua lucha entre términos contradictorios, en busca de una coherencia que se reveló inalcanzable.

El comienzo no oficial del feminismo se puede datar a mediados del siglo XVII. Nos estamos refiriendo a las «Précieuses» francesas, cuyo apogeo entre 1650 y 1660 dio lugar a la primera crisis de la identidad masculina. $\mathrm{La}$ «Précieuse» es, como comenta Elisabeth Badinter ${ }^{244}$ una mujer emancipada que propone soluciones feministas a su deseo de emancipación y que

242 E. G. Sledziewski, «Revolución Francesa. El giro», en VV.AA., Historia de las mujeres, vol. 4, siglo XIX, Santillana, Madrid, 2000.

243 A. Maugue, L'identité masculine en crise au tournant du siècle, Payot, París, 2001, p. 9.

244 E. Badinter, XY. La identidad masculina, ob. cit, p. 26 y ss. Vid. también G. Mongrécien, Les précieux et les précieuses, Mercure de France, París, 1939, pp. 149-150. 
invierte totalmente los valores sociales tradicionales. Nacida como reacción a la brutalidad y grosería de los hombres de Enrique IV y los de la Fronda, la "Précieuse» parece proponer una revisión del amor cortés renacentista: ella exige del hombre enamorado una sumisión sin límites, cercana al masoquismo, invirtiendo el modelo masculino dominante, que es el del hombre brutal y exigente o el del marido grosero que cree que todo le está permitido.

Posteriormente, la situación de la mujer fue tema de debate y reflexión entre muchos de los philosophes de la Francia ilustrada del siglo XVIII. En contraposición a la mujer de la nobleza — la Précieuse culta, formada, con una preclara inteligencia, y con un innegable poder en las intrigas palaciegas-, la situación social de la mujer burguesa y del pueblo llano evidenciaba un doble rasero en la consideración de los individuos a la luz de la Razón. La inteligencia moderna del siglo de las Luces no podía concebir que un ciudadano cualquiera fuera considerado como de segundo orden; y lo que es más, maltratado con la normativa vigente en la mano. "iMujeres, os compadezco!», decía Diderot: «Dans toutes les coutumes la cruauté des lois civiles s'est réunie contre les femmes à la cruauté de la nature. Elle ont été traitées comme des êtres imbéciles». ${ }^{245}$ Seres imbéciles cuya propia naturaleza les impelía a actuar con más corazón que cerebro - llevadas por la sentimentalidad en que el interesado patriarcado las había recluido. Y en un tiempo en que tan seguro se estaba de que la Razón diferenciaba a la especie humana de la animalidad, ningún ciudadano filósofo debería poder aceptar ser hijo de una criatura infrahumana. El matemático Condorcet daría en el blanco al declarar lo siguiente:

On a dit que les femmes [...] n'avaient proprement le sentiment de la justice, qu'elles obéissaient plutôt à leur sentiment qu’à leur conscience[...] (Mais) ce n'est pas la nature, c'est l'éducation, c'est l'existence sociale qui cause cette différence. $^{246}$

El terreno estaba abonado para que el movimiento ciudadano de liberación que fue la Revolución de 1789 acogiera a las mujeres en el seno de la ciudadanía. Y así fue, en efecto, aunque con limitaciones. Prueba de ello es que la activista Olympe de Gouges exigió en el mismo año de la Decla-

245 Citado por S. de Beauvoir, ob. cit., vol. I, p. 187.

246 Ib., p. 88. 
ración de los Derechos de l'Homme una «Déclaration des Droits de la femme», gracias a la cual, equiparando ambos géneros, se destruyeran los privilegios masculinos.

La lucha feminista nació de forma oficial en los Estados Unidos, durante la convención de Seneca Falls que se desarrolló entre el 19 y 20 de julio del año $1848 .{ }^{247} \mathrm{El}$ origen de dicha reunión también se remonta al abolicionismo, ya que Lucretia Mott y Elizabeth Cady Stanton llegaron a unirse y a lanzarse a la aventura de Seneca Falls por haberse visto excluidas de la convención mundial antiesclavista que se celebró en Londres en 1840. Posteriormente, la corriente feminista alcanzó todos los puntos de la Europa industrializada para señalar una situación de opresión de la mujer trabajadora: víctima por ser mujer y por ser obrera.

En la Francia del XIX — que es la que, en definitiva, centra el interés de nuestro estudio- , apareció un buen número de mujeres decididas a romper una lanza en favor de la (re)consideración de sus compañeras. A ellas les acompañó una cantidad no despreciable de publicaciones de corte feminista que, como ha señalado Li Dzeh Djen, ${ }^{248}$ funcionaron a modo de catalizador de las reivindicaciones feministas.

La más importante de todas estas revistas fue, sin lugar a dudas, Le Droit des femmes, que disfrutó de una vigencia bastante amplia. En sus páginas cabían actitudes y declaraciones de todo tipo; desde el primer número, en el que Maria Deraismes clamaba por la equiparación de hombres y mujeres ante la Razón:

lo que quieren las mujeres es que se renuncie de una vez por todas a esa distribución arbitraria y ficticia de las cualidades humanas que afirma que el hombre representa la razón y la mujer el sentimiento,

hasta las intervenciones en los números 21 y 22 de Angélique Arnaud que parecen contradecir las anteriores:

247 Como señala Millet en K. Millet, ob. cit., p. 158.

248 Li Dzeh Djen, La presse féministe en France de 1869 à 1914, París, 1934 (sin referencia editorial en el libro de Claude Alzon, Mujer mitificada, mujer mistificada, cuyas hipótesis sobre la evolución del feminismo sigo a continuación, C. Alzon, ob. cit., pp. 52-73). 
las obligaciones maternales son más numerosas, más especiales, más absolutas que las de la paternidad, y ello porque la mujer está más dotada de amor [...] En el corazón de la mujer, una voz interna dice: yo soy el socorro, yo tengo amor a la justicia, pasión por la verdad [...] Y ese deber, cosa que cabe imaginarse, será de índole apostólica.

Como vemos, ya en aquellos primeros compases del pensamiento feminista se observaban distintas tendencias, cuyas diferencias han seguido perdurando hasta nuestros días. Una de las activistas más conspicuas del siglo XIX, Hubertine Auclert, se encuadraría hoy en día dentro del feminismo de la diferencia, abogando por una psicología y una carga actitudinal distintas en hombres y mujeres. Desde las páginas de La Citoyenne, esta activa pensadora intentaba despertar la conciencia de sus compañeras recordándoles la importancia de su capacidad genitora para la civilización — lo que décadas más tarde vendría a llamarse política del acercamiento. Como decía desde las páginas de esa revista en 1881, Auclert plantea una alternativa al Estado minotauro masculino, al que sustituiría "por el Estado maternal, que asegura mediante su previsora solicitud seguridad y trabajo a los válidos, asistencia a niños, ancianos e inválidos... El Estado maternal no es opresor». ${ }^{249}$

La importancia de Auclert en el debate feminista del siglo XIX no es poco importante. Sus habilidades oratorias, su fuga y su brío le llevaron a ser invitada por los obreros al Congreso de Marsella de 1883 como representante de la sociedad sufragista Le suffrage des femmes — que ella misma fundaría en el 73 bajo el nombre de Le droit des femmes (que no hay que confundir con la revista previamente citada).

La tendencia generalizada será la de ofrecer a la sociedad la imagen de una mujer providente y hogareña, dedicada casi exclusivamente a la insigne labor de concebir y cuidar de los hijos. Una psicología de madre que provocaría con la fuerza del amor la transformación de la sociedad («la regeneración de la sociedad por la mujer», como decía Clémence Royer en La Fronde del 4 de septiembre de 1900). Cuando no era así, la nueva mujer presentada por las publicaciones femeninas era una convencida estudiante o militante que no había perdido por ello el gusto por la vida de familia y los deberes de la maternidad. Así describía la periodista decimonónica Sévérine a las participan-

249 En La Citoyenne, 17 abril 1881, «El servicio militar de las mujeres». Citada por Li Dzeh Djen, en C. Alzon, ob. cit., p. 73. 
tes en el Congreso de Derecho de la Mujer: «[...] bajo los guantes, más de un índice hubiera dado testimonio gracias a imperceptibles pinchazos, de que la aguja había librado los combates domésticos antes que la pluma». $\mathrm{O}$, como muestra, de esta manera describía el semanario feminista La Française a Marie Curie en 1906: «simple y dulce, daba la mano a su hija, la pequeña Irene, a la que, como todos los días, se disponía a llevar a la escuela».

El origen de esta idiosincrasia — según señala Dominque Godineau— reside en el convulso tiempo que vivió la sociedad del siglo XIX, constantemente azotada por las guerras y acontecimientos de diversa índole que harían tambalear los índices demográficos de los países industrializados. Ante la ausencia de los hombres, las mujeres eran llamadas a asegurar la supervivencia de las familias destruidas. El llamamiento que se hizo en un primer momento a las mujeres era a formarse para equipararse a los hombres —que ejemplificarían Maria Deraismes y la estadounidense Judith Sergent. Godineau ha llamado a este nuevo tipo de mujer Penélope, que es una joven pragmática, que desprecia la moda y la frivolidad, y que no construye su futuro en base a la posible llegada de un príncipe azul: «antes que cultivar los artificios de la seducción física, prefiere levantarse con el sol y consagrar el día al estudio, fuente de placer y de independencia». ${ }^{250}$ Sin embargo, conforme avanzaba el tiempo y los conflictos bélicos se hacían cada vez más presentes en las sociedades occidentales, se reserva otro tipo de tarea para las mujeres en la construcción del país: vigilar la virtud y la moralidad, que permitieron ganar la guerra y sin las cuales la República no podía sobrevivir. Intensa contradicción que fue perfectamente asumida, como hemos visto, por la más activa militancia feminista y que haría propias las necesidades del Estado basado en la guerra y el desarrollo económico.

\subsubsection{Avance de la prostitución}

Como consecuencia de la Revolución Industrial, un gran número de mujeres se desplazó a los grandes centros industriales. De entre ellas, muchas se quedaron sin trabajo remunerado tras la "gran depresión» que azotó la economía europea en el segundo cuarto de siglo. Las calles se llenaron de mujeres desempleadas que buscaban acomodo en la prostitución.

250 D. Godineau, «Hijas de la libertad y ciudadanas revolucionarias», en VV.AA., Historia de las mujeres, vol. 4, siglo XIX, Santillana, Madrid, 2000, p. 47. 
Las prostitutas empiezan a ocupar espacios que hasta entonces les habían estado absolutamente vedados, apoderándose cada vez más del centro de la vida social — como señala acertadamente Erika Bornay. ${ }^{251}$ Así lo atestigua el gran fresco de época que es la balzaciana Splendeurs et misères des courtisanes. Compuesta entre 1838 y 1847, su narrador señala cómo había cambiado la otrora noble calle de Langlade, en el corazón del París previo a la reestructuración haussmanniana:

cette partie d'un des plus brillants quartiers de Paris conservera longtemps la souillure qu'y ont laissée les monticules produits par les immondices du vieux Paris [...] La prostitution a depuis longtemps établi là son quartier général. ${ }^{252}$

El paseante que se aventure a transitar por esta calle y sus adyacentes — que separan el Palais Royal y la calle de Rivoli- no puede figurarse, de día, su fisionomía nocturna: «elles sont sillonnées par des êtres bizarres qui ne sont d'aucun monde; des formes à demi nues et blanches meublent les murs, l'ombre est animée».

Huysmans considerará, por su parte, a la prostituta como una especie de síntesis de la época que le tocó vivir: su lugar es la ciudad, su oficio el comercio, y su producto la carne humana. ${ }^{253} \mathrm{Y}$ es que en la Francia de todo el siglo XIX, el papel de la prostituta sirve no solo para apagar los incendios que una pasión sin freno provoca en los hombres — progresivamente más estimulados por una sociedad mercantil que ya sabe utilizar el erotismo como recurso publicitario (baste contemplar algunas imágenes de Épinal de la época que publicitaban licores y otros artículos de lujo dejando imaginar

251 E. Bornay, ob. cit., p. 15. Comenta en su ensayo que fue a partir de los años sesenta cuando las calles parisinas se llenaron de prostitutas; sin embargo, su presencia era ya importante a partir de los ańos veinte y en adelante, como lo atestiguan Stendhal y Balzac en las novelas a que nos referimos.

252 H. de Balzac, Splendeur et misères des courtisanes, ob. cit., p. 68.

253 David Tacium dirá en su tesis que la prostituta es el equivalente comercial de la mujer en la sociedad mercantil del siglo XIX, en D. Tacium, ob. cit. Pierre Bourdieu seńalará, con acierto, que el escritor finisecular ve en la prostituta ciertas similitudes consigo mismo, en una época en que el campo artístico (en la terminología sociológica adoptada por Bourdieu) empezaba a fraguarse como un campo autónomo: «la homología de la posición contribuye sin duda a explicar la propensión del artista moderno a identificar su destino social con el de la prostituta, 'trabajador libre' del mercado de los intercambios sexuales", en P. Bourdieu, Les règles de l'art. Genèse et structure du champ littéraire, Seuil, París, 1992, versión espańola: Las reglas del arte, Anagrama Ensayo, Barcelona, 1995, p. 90, nota n. ${ }^{\circ} 2$. 
qué se encontraba bajo los encajes de tantas lucidas señoritas). Su papel sería también el de formar a los jóvenes burgueses en su necesaria educación sexual — que el colegio, la iglesia ni la familia se dignaban acometer.

Pero, sobre todo, la prostitución es la salvaguarda por excelencia del bonheur burgués basado en la familia y la monogamia. Sabemos que era contumbre de muchos hombres burgueses del XIX alegrar sus tardes y sus noches con la compañia de grisettes, lorettes o actrices, que en gran parte de los casos, ponían en peligro el peculio familiar. El recurso a la prostitución como apaga-fuegos se hizo aconsejable para evitar la entrada de la libertad sexual en la parte más visible de la sociedad. Así lo veía san Agustín: ${ }^{254}$ «supprimez les prostituées, vous troublerez la société par le libertinage». Un gremio necesario para limpiar de sus inmundicias la sociedad: «Les prostituées sont dans une cité comme le cloaque dans un palais: supprimez le cloaque et le palais deviendra un lieu malpropre et infect».

Años más tarde, otros autores incidían de nuevo en este papel de guardianas de la virtud de las prostitutas. El matrimonio, basado en la castidad de la esposa que solo se violentaba para la sacrosanta y necesaria función reproductora, debía permitir la existencia de estas fontaneras del amor, que libraban a los hombres de sus humores no saciados y a las virtuosas mujeres de sufrir los ataques sexuales de sus maridos. Tal y como lo percibe en 1869 el historiador británico Lecky, quien ve en las prostitutas, a la par que «el tipo supremo del vicio», "las guardianas más activas de la virtud burguesa»:

de no ser por ella, la inmaculada pureza de numerosos hogares felices se vería contaminada; $y$ no pocas personas que, orgullosas de su intocable castidad, piensan en ella con un escalofrío de indignación, habrían conocido la agonía del remordimiento y la desesperación. ${ }^{255}$

La relación de la prostitución con el crecimiento industrial parece bastante clara si se tienen en cuenta un par de cosas. Por una parte, los hombres desplazados a los polos fabriles, lejos de sus hogares, hallaban en la prostitución acomodo a su virilidad siempre necesitada de pruebas reafir-

254 S. de Beauvoir, ob.cit., vol. I, p. 171.

255 W. E. H. Lecky, History of European Morals, citado por Erika Bornay, ob. cit., p. 58, y vid. S. de Beauvoir, ob. cit., vol. I, p. 171. 
madoras, así como consuelo a la separación de sus señoras. Por la otra, las técnicas y las ofertas del oficio más viejo del mundo conocieron un mayor desarrollo en las zonas urbanas - de mayor recepción de trabajadores solitarios- que en las zonas agrícolas - menos explotadas industrialmente. De esta manera Stendhal, en 1820, compara la prostitución parisina con la valenciana (de Espańa), con clara ventaja para la que era capital del mundo por aquel entonces:

quand on n'a que des désirs physiques, on trouve les filles, et c'est pourquoi les filles de France sont charmantes, et celles d'Espagne fort mal. En France les filles peuvent donner à beaucoup d'hommes autant de bonheur que les femmes honnêtes, c'est-à-dire du bonheur sans amour. ${ }^{256}$

A ello debía coadyuvar la mayor influencia de la moral católica en un país como España, netamente basado en el sector primario y todavía excluido de la gran ola mercantilista y productivista de la Europa decimonónica.

Esta gran expansión produce una reacción conservadora en el seno de la sociedad fabril. Toda sexualidad no conducente a proveer de nuevos sujetos la nación y la industria debía ser duramente condenada; de ahí que se diera una estruendosa retórica moralista a partir de los años setenta - momento en que la prostitución parece llegar a su momento álgido debido a las particulares condiciones económicas de la Francia de los sesenta: el Second Empire napoleónico, la abertura de París a los grandes bulevares y la consiguiente especulación económica (tan evidente en algunas obras de la época como La Curée de Zola). Un período de pujanza económica unida a la defensa de los valores patrios del Empire: conservadurismo en lo moral y ultraliberalismo en lo económico.

Por su calidad de personaje residual y marginado de la sociedad burguesa, la prostituta llega a ser considerada como la manifestación de la estructura criminal latente de la mujer - como la definió el criminólogo italiano Cesare Lombroso. Pues toda mujer debidamente desarrollada que no haya inmolado su cuerpo en el altar de la maternidad será poseedora de una fuerza que, mal utilizada, puede volverse contra ella misma. Sobre

256 Stendhal, De l'Amour, édition de V. Del Litto, Gallimard Folio, París, 1980, XLI, De la France, p. 148. 
todo si la criminalidad es reforzada mediante la proximidad al vicio: entonces la mujer puede convertirse en una criminal más temible que el más peligroso de los hombres. ${ }^{257}$

Los ejemplos no faltan en la literatura de la época. Uno de los escritores que más se ceban en la prostituta es, de nuevo, el parisino Balzac, quien en su Splendeurs et misères des courtisanes arremete constantemente contra Esther, La Torpille, de cuya extrema belleza se enamora el dandi Lucien de Rubempré. Para poner de relieve la altura del personaje de Lucien, el sacerdote Carlos Herrera - que se revelará más tarde como Jacques Collin Trompe-la-Mort - arroja sin parar inmundicia sobre la fille.

La prostituta debe poseer, según Herrera, para que su pensamiento no oponga oposición al sucio trabajo de su cuerpo, "cette perfection de l'animal chez une créature à qui la volupté tenait lieu de la pensée»; ${ }^{258}$ ser completamente iletrada y analfabeta: «La Torpille est la seule fille de joie en qui s'est rencontrée l'étoffe d'une belle courtisane; l'instruction ne l'avait pas gâtée, elle ne sait ni lire ni écrire». ${ }^{259}$ Es un ser inabordable e indomable, de quien ningún hombre puede decir haber sido su amante: «elle peut toujours vous avoir, vous ne l'aurez jamais». ${ }^{260}$ Un personaje diabólico «qui ne peut pas faire un pas sans que les pavés ne se lèvent pour l'accuser». ${ }^{261} \mathrm{Su}$ belleza, aunque reine un tiempo sobre los hombres, habrá de ser, finalmente, pasto o de la locura o del suicidio; pues solo el ejercicio de la sacrosanta maternidad puede sacarles del agujero y reintroducirlas en el mundo de la virtud y la moral. Así lo sabe Esther, La Torpille, quien no hace otra cosa más que tratar a Lucien como si fuera una madre para él: completamente devota a él, sacrificada a su éxito. Sabe sin embargo que la reproducción la sacaría de su maldición. De esta manera, exclama la joven prostituta:

\footnotetext{
257 «Ma se una eccitazione morbosa dei centri psichici viene ad acuire le qualità cattive e a cercare nel male uno sfogo; se la pietà e la maternità mancano, se vi si aggiungono le forti passioni e i bisogni derivanti da un intenso erotismo, una forza muscolare abbastanza sviluppata e una intelligenza superiore per poter concepire il male ed eseguirlo, è chiaro che da quella semi-criminaloide innocua che è la donna normale dovrà escire una criminale-nata più terrible d'ogni delinquente maschio». Citado por Bornay, ob. cit., p. 87.

258 H. de Balzac, Splendeur et misères des courtisanes, ob. cit., p. 88.

259 Ib., p. 62.

260 Ib., p. 63.

261 Ib., p. 78.
} 
la vue d'une mère et de sa fille est un de nos plus grands supplices, elle réveille des remords cachés dans les replis de nos cœurs et qui nous dévorent! [...] Je ne sais que trop ce qui me manque. ${ }^{262}$

En el caso de Zola, los ejemplos de odio hacia la mujer prostituida no faltan. Símbolo activo del vicio y de la degradación a través de la carne, Nana cumple el papel de agente activo sobre la denigración completa de una sociedad, a quien esclaviza con los rigores y las exigencias de su sexo. Mujer venida de lo más remoto de los arrabales para posicionarse por encima de la civilización construida en base a la ciencia y al progreso. Como en un gólgota rezumante de calaveras de sus víctimas, la prostituta se eleva por encima de sus despojos:

elle demeurait seule debout [...] avec un peuple d'hommes abattus à ses pieds. Comme ces monstres antiques dont le domaine redouté était couvert d'ossements, elle posait les pieds sur des crânes; [...] la mouche envolée de l'ordure des faubourgs [...] avait empoisonné ces hommes, rien qu'à se poser sur eux. ${ }^{263}$

Porque la relación de la prostituta con la muerte debe acercarnos al siguiente punto. No solo como transmisora de enfermedades, sino como mujer maléfica que es, la prostituta es capaz de actuar como una peste negra. Y ese es el caso en el universo de Maupassant, sobre todo en su relato Le Lit 29: historia de una meretriz que durante la ocupación alemana de Rouen se entrega, sabiéndose sifilítica, a un gran número de soldados enemigos $\mathrm{y}$, a su manera, produce tantas víctimas como una batalla. $\mathrm{O}$ en ese otro titulado Les Tombales, en el que viene ilustrado un especial tipo de prostituta que no practica la retape por las aceras, sino, más provechosamente, en los cementerios, vestida de viuda y al pie de las tumbas.

Así, la prostituta se convierte en un portaestandarte visible de la condición que subyace en toda mujer que toma parte activa en la sexualidad. Se trata de una potencia maléfica y peligrosa, capaz de esclavizar al hombre en lo más oscuro de la humanidad. La carne y el sexo serán las grandes armas de la mujer para atenazar al hombre bajo su influencia. Y si en el ám-

262 Ib., p. 86.

263 Esta imagen zoliana recuerda vivamente a un cuadro de Gustav-Adolf Mossa, titulado Elle (de 1905), en el que se puede observar a una joven de rostro impasible sentada sobre un montículo hecho de cadáveres humanos. Museo Jules Chéret de Niza. 
bito público esta mujer activa se llama prostituta, en general será la decimonónica figura de la mujer fatal la catalizadora de las obsesiones misóginas de los hombres.

\subsection{La mujer fatal como construcción misógina}

La base psicológica de la creación de una figura femenina negativa se halla en el miedo del niño a la castración. Si en el primer tiempo del bebé, la madre es considerada fuente de bienestar, vida y alimento, poco a poco su imagen se va tornando maléfica a medida que la unión incestuosa es imposibilitada por la presencia del padre. Y aun siendo este quien debiera operar la castración —al ver en su hijo varón un competidor- el psicoanálisis atribuye la acción castradora a la madre. El niño alberga a partir de este cisma con su genitora una agresividad reaccional, que está en la base de la formación de una imago ${ }^{264}$ de la madre "mala». Esta violencia latente se convierte en una angustia continuada, creada por el binomio destruir - ser destruido. Se trata de una angustia de muerte que, según $\mathrm{Mendel}^{265}$ y otros ortodoxos freudianos, jamás abandonará la psicología profunda de las relaciones de los hombres con su madre.

El género masculino proyectaría entonces su complejo de castración en las mujeres: al estar más relacionadas con un orden cósmico inasible que con la seguridad y la predictibilidad de la ciencia, su poderío es inmenso e incontrolable - y por eso mismo altamente peligroso. La mujer guardaba en el imaginario primitivo una estrecha relación con los antepasados y los dioses, con el mundo de los muertos y su peligroso poder: "de ahí le deriva su poder maléfico y la necesidad de controlarlo», como señala Ida Magli. ${ }^{266}$ Este poder maléfico hace que el hombre desarrolle

264 Concepto creado por Jung, reutilizado por Gérard Mendel en G. Mendel, ob. cit., y que, según explican Laplanche y Pontalis, designa una supervivencia de los participantes en la vida familiar en el imaginario del individuo. Vid. J. Laplanche y J. B. Pontalis, Vocabulaire de la psychanalyse, P.U.F., París, 1981, p. 196.

265 G Mendel, ob. cit., p. 77 y ss.

266 I. Magli, La femina dell'uomo, Laterza, Roma, 1985, p. 83. Vid. también M. A. González de Chávez, Feminidad y masculinidad. Subjetividad y orden simbólico, Biblioteca Nueva, Madrid, 1998, p. 19 y ss. 
técnicas que permitan el control de lo imprevisible: herramientas y diferentes tipos de tecnología, con los que entiende extender su dominio sobre la naturaleza.

La mujer fatal aparece, en principio, directamente ligada a la muerte, por ser depositaria del poder de dar la vida, de administrar los ritos funerarios, pero sobre todo, por ser quien domina la naturaleza más oculta e indomable del varón, la sexualidad. Este principio de muerte — que llamarían los psicoanalistas - en que Eros se antepone a Tánatos, parece una de las condiciones sine qua non del erotismo decadente: la estimulación nerviosa conducente a la excitación sexual no se da. De ello se ríe abiertamente Hélène Cixous, pues no ve en esta necesidad más que un subterfugio para la edificación de la familia.

ellos dicen que hay dos cosas irrepresentables: la muerte y el sexo femenino. Pues necesitan que la feminidad vaya asociada a la muerte; jse excitan de espanto!, ¡por sí mismos!, necesitan tenernos miedo. ${ }^{267}$

En la literatura del XIX, la asociación de la mujer con la muerte se va forjando poco a poco. Uno de sus catalizadores es Théophile Gautier, sobre todo en el relato titulado La Morte amoureuse, en la que el pobre Romuald - un sacerdote novel — sucumbe a los encantos de Clarimonde: hermosa difunta que solo vive gracias al amor del joven cura. Esta mujer fatal avant la lettre es, en primer lugar, de una belleza incomparable, hasta el punto de arrebatar el sentido al novicio de camino al seminario: «je pâlissais, je rougissais, j'avais des éblouissements. Un de mes camarades eut pitié de moi, il me prit et m'emmena; j'aurais été incapable de retrouver tout seul le chemin du séminaire» — relata Romuald. ${ }^{268}$ Pero el aspecto más enfermizo y morboso de la atracción que Clarimonde ejerce sobre el cura es el aura de la muerte. La joven difunta posee una gran perfección en sus formas, "quoique purifiée et sanctifiée par l'ombre de la mort». ${ }^{269}$

En otro relato, "Arria Marcella» — ubicado en la ciudad muerta de Pompeya-, Octavien relata su experiencia amorosa vivida con una sepul-

267 H. Cixous, La risa de la medusa. Ensayos sobre la escritura, ob. cit., p. 21.

268 T. Gautier, La Morte amoureuse, en Récits fantastiques, G. F.-Flammarion, París, 1981, p. 123.

269 Ib., p. 133. 
tada por las lavas del Etna. Y es que la muerte, más que la vida, estimula el erotismo del joven viajero:

à mon dégoût des autres femmes, répondit Octavien, à la rêverie invincible qui m'entraînait vers ses types radieux au fond des siècles comme des étoiles provocatrices, je comprenais que je n'aimerais jamais que hors du temps et de l'espace. ${ }^{270}$

El rasgo más importante, pues, de la mujer fatal novecentista es su relación natural con la sexualidad. Su poder es capaz de traspasar incluso la frontera de la vida y la muerte, debido a su especial comunicación con las potencias ocultas del cosmos y de la tierra. Es imposible no ver en ello una proyección de la repugnancia masculina por la atracción de la libido: una instancia que no puede controlar. Estando sometido a una coerción tan intensa, es lógico que haga recaer sobre el objeto de su sexualidad la culpa de sus tropiezos.

En el patriarcado, el intenso sentimiento de culpa que inspira la sexualidad recae inexorablemente sobre la mujer, quien en toda relación se considera la parte responsable, cualesquiera que sean las circunstancias atenuantes desde el punto de vista cultural.

Así lo considera Kate Millet, ${ }^{271}$ quien ve claro este enfrentamiento entre el hombre y su libido. La mujer fatal es el teatro de una sexualidad sobrecargada, desbordante, que provoca en su dueña un estado de paroxismo cercano a la enfermedad nerviosa. Un arrebato de los sentidos que no se detiene ante nada con tal de satisfacer, con tal de descargar ese exceso de libido. Tal es el caso de la actriz — mujer fatal de la modernidad urbanapintada por Edmond de Goncourt bajo los rasgos de La Faustin.

Il n'y avait plus, dans son être ardent et moite, que le désir sensuel, l'appétit déréglé d'une jeune bête en folie, et cela dans un emportement sourd, une contraction torpide, une immobilité ramassée, un croisement nerveux des jambes qui ressemblait à une défense contre elle-même. ${ }^{272}$

Cuando el ansia erótica le ataca, la mujer fatal no dispone de ningún mecanismo de retención, pues ella es solo naturaleza, carne desprovista de control sobre su propia persona: el deseo ocupa el lugar del pensamiento

270 T. Gautier, Arria Marcella, en Récits fantastiques, ib., p. 267.

271 K. Millet, ob. cit., p. 118.

272 E. de Goncourt, La Faustin, Actes Sud, Arles, 1995, p. 110. 
— como ya habíamos visto en el caso de La Torpille balzaciana. Cuando La Faustin siente la llamada imperiosa de la voluptuosidad, nada le impide la consecución de su deseo:

un furieux besoin d'aimer, qui s'était d'abord retourné vers le souvenir de William Rayne, demeurait en elle, déchaîné et sans objet, et prêt à tomber sur n’importe qui. [...] La tragédienne se sentait mordue de la soudaine et irrésistible envie de l'adultère avec un inconnu fourni par l'occasion. ${ }^{273}$

No importa si con ello ha de romper una familia, pues es al adulterio al que conduce el deseo de estas mujeres independientes y autónomas. Dueñas de su presente, su libertad solo puede ser peligrosa para una sociedad que entiende recluir a las mujeres en la seguridad del hogar. Porque siendo sexualidad pura, instinto puro, el poder de la mujer fatal no tiene límite: tan solo el de su propia constitución y de su resistencia al placer. Y el hombre, sabedor de que el placer femenino, enorme si es administrado son sabiduría, separará todavía más del ámbito de lo incontrolable la naturaleza sexual de la mujer.

Caso paradigmático de este excesivo placer femenino es el de Tiresias. En la Melanopodia, este personaje, que había conocido tanto la condición masculina como la femenina, afirmaba que de diez partes de placer a la mujer le correspondían nueve y al hombre tan solo una. ${ }^{274} \mathrm{Y}$ es que la libido femenina es, a juicio de varios autores, poderosísima: «supera los límites de lo que las palabras pueden expresar, límite de todo lenguaje, límite de toda corporeidad» — dirán Bruckner y Finkielkraut; ${ }^{275}$ esa «delicia, la invasión del cuerpo por unos flujos de goce que se deslizan por todas partes como si fueran lava». ${ }^{276} \mathrm{La}$ atribución de un poder maligno a la capacidad femenina para el placer parece empujar irremisiblemente a la ideología patriarcal a controlar esa voluptuosidad, la de hacerla domeñable. Con ello el macho indefenso ante esos "flujos de goce» que invaden el cuerpo de su compañera se escuda de dos posibles males: aliviar la sospecha de que su vigor sexual no sea suficiente para mi-

273 Ib., p. 100.

274 Comentado en T. Blesa, "Sé más que un hombre, menos que una mujer», en

N. Ibeas y M. A. Millán (eds.), ob. cit., pp. 17-38.

275 P. Bruckner y A. Finkielkraut, ob. cit., p. 166.

276 Ib., p. 179. 
tigar la libido de su partenaire; denostar la búsqueda activa de satisfacción fuera del ámbito del hogar —algo que, sin embargo, al hombre no le está vedado.

De ahí que algunas autoridades se hayan pronunciado, en el siglo XIX, contra el placer que la mujer pretendía encontrar en el acto amoroso. Como indica Bornay, un doctor inglés se pronunció al respecto en estos términos: "de cada diez mujeres, a nueve les desagrada el acto sexual, y la que hace el número diez es una prostituta». ${ }^{277}$ En la enciclopedia Ree, inglesa también, se quitaba hierro a la posibilidad del placer femenino aduciendo pruebas fisiológicas. El orgasmo era tan solo cosa de mujeres de mal vivir, puesto que las virtuosas hallaban en el orgasmo síntoma de enfermedad: «es innegable que a veces se forma un fluido mucoso en los órganos internos y en la vagina durante el coito, pero esto solo ocurre a las mujeres lascivas o que llevan una vida lujuriosa». ${ }^{278} \mathrm{Y}$, no obstante esto, cuántos placeres relatan las mujeres sabias, las mujeres que viven para y por el placer sexual, que han hecho de ello oficio y beneficio. Como debió de oír el Balzac todavía joven de La Peau de chagrin: celebración de la cortesana, sagrado colofón de la cena que ofrece Taillefer a sus amigotes de francachelas, postre delicioso aromatizado con las más misteriosas especias. Aquilina, una de las prostitutas contratadas por el generoso convitador, es descrita así en su sabiduría sexual:

monstre qui sait mordre et caresser, rire comme un démon, pleurer comme les anges, improviser dans une seule étreinte toutes les séductions de la femme, excepté les soupirs de la mélancolie et les enchanteresses modesties d'une vierge; puis en un moment rugir, se déchirer les flancs, briser sa passion, son amant; enfin, se détruire elle-même comme fait un peuple insurgé.

Es decir, peligrosa y ausente, orgullosa encima de la zoliana pila de cadáveres que su sexo voraz ha sembrado a sus pies:

elle était là comme la reine du plaisir, comme une image de la joie humaine, de cette joie qui dissipe les trésors amassés par trois générations, qui rit sur ses cadavres, se moque des aïeux, dissout des perles et des trônes, transforme les jeunes gens en vieillards, et souvent les vieillards en jeunes gens. ${ }^{279}$

277 E. Bornay, ob. cit., p. 82.

278 Ib., p. 61.

279 H. de Balzac, La Peau de chagrin, ob. cit., p. 101 (ambas citas). 
Un poder majestuoso que subyuga a los hombres y les recuerda un más allá de placeres inauditos; que les arrastra a la perdición como sirenas sin corazón que son. Y como las sirenas homéricas, la mujer fatal bebe de fuentes clásicas su sabiduría amorosa. Como Afrodita, a quienes las Parcas asignaron este deber divino: sexualidad veleidosa, exuberante, caprichosa, ajena a vínculos. Es inmanencia pura. Es peligro. ${ }^{280}$

Esta será la característica inalienable e inevitable de la mujer fatal: el peligro que encierra su sexualidad, capaz de atraerse las más grandes maldades con tal de satisfacerla. Un mito que viene forjándose desde los comienzos de la civilización, de la que Pandora con su caja es uno de los principales antecedentes.

\subsubsection{La caja de Pandora}

En el mito de Pandora se halla la creación misma del género femenino. Zeus, para vengarse de los hombres, ordena la creación de la primera mujer a Hefesto. Su imagen es proporcionada por la diosa Afrodita, quien la dota de hermosos ornamentos: collares de oro y guirnaldas de flores entregadas por las Gracias y las Horas, y un hermoso vestido blanco con un largo velo nupcial, sujeto con una bellísima diadema, regalo de Atenea. Por otra parte, Pandora posee una cajita que encierra todos los males y miserias, que acabará abriendo, causando así el infortunio de la Humanidad. Las mujeres todas serán entonces castigadas por este desliz de la primera representante de su género: serán condenadas por curiosas, por querer saber, un privilegio que debe serles negado a las mujeres; su acceso al conocimiento solo se puede dar en relación con los misterios de la vida y la muerte, con las emociones, con la vulnerabilidad de los seres humanos.

Cómo no ver en este mito el germen de la misoginia masculina. Un relato mítico que tiene como finalidad eximir a los hombres de dejarse llevar por su animalidad — que se convierte en monopolio exclusivo de la mujer. Un mito que sobreviviría, transformado, en el ideario judeocristiano bajo los rasgos de diablesas y de la primera madre: Eva.

280 Vid. R. Graves, Los mitos griegos, Losada, Buenos Aires, 1967, p. 80 y ss. 


\subsubsection{Diablesas y mujeres fatales en los Testamentos: Eva, Lilith y otras}

Como señala Jung — parafraseando a Dorneus - Eva aparece como dotada de una dualidad que la debilitaba ante los envites del diablo. Puesto que Adán estaba marcado por el unarius, no fue tentado con la manzana sabiendo que su unidad era indestructible, indivisible. Por eso el diablo primero tentó a Eva, y esta, a su vez, tentó a Adán haciendo recaer sobre la humanidad toda la cólera del Dios padre.

Es esta una fábula basada en la cábala hermética, tan aficionada a la numerología, que ve en los números pares símbolo de feminidad, y de masculinidad en los impares. En ello es fácil encontrar el punto diferencial del falo, que él solo es capaz de separar, ordenar y clasificar el mundo y su lógica matemática — claro exponente de una visión falogocéntrica del mundo.

Por este hecho primordial de la civilización, la mujer aparecería íntimamente ligada a las instancias diabólicas, como señala el gran estudioso de los arquetipos que fue Jung: «Dorneus, con gran astucia, descubre que el binario es el secreto parentesco entre el diablo y la mujern. ${ }^{281}$

El antecedente de Eva, la incauta mordedora de la manzana, es Lilith, una diablesa de posible origen asirio-babilónico que pasó a ocupar una posición de importancia en la demonología hebraica.

Como comentan Bornay y González de Chávez, ${ }^{282}$ Lilith fue la mujer que se acoplaría con Adán antes de la llegada de Eva al Paraíso. Siempre se quejaba de que su esposo ocupase la posición superior durante la cópula, por lo que este intentó obligarla a aceptarla por la fuerza. Ella se negó, pronunciando para ello el nombre mágico de Dios, tras lo cual se elevó en el aire y lo abandonó. Desde entonces se le atribuye la muerte de niños, como espíritu maligno que atacaba a las parturientas y a los recién nacidos.

281 C. G. Jung, Psicología y religión, Paidós Studio, Barcelona, 1981, p. 101.

282 E. Bornay, ob. cit., p. 25. M. A. González de Chávez, Feminidad y masculinidad. Subjetividad y orden simbólico, Biblioteca Nueva, Madrid, 1998, p. 27. También cabe citar R. Graves y R. Patai, Los mitos hebreos, Alianza Editorial, Madrid, 1986, p. 59. 
La psicoanalista Silvia Tubert dirá de ella que constituye una representación de la Diosa madre, rebajado a personaje maldito en función de su rebeldía. ${ }^{283}$

La lista de mujeres malditas por su atrevimiento a actuar por sí mismas demandando una igualdad y un placer que creen corresponderles se completa, en el imaginario judeocristiano, con Herodías o Salomé - estilizada por Wilde, Mallarmé, Gustave Moreau y, a comienzos del siglo XX, por el vienés Klimt-; y con Judith, quien libró a Betulia del látigo del general Holofernes seduciéndolo y cortándole la cabeza mientras dormía. Ejemplos de una feminidad asesina y castradora que erizaba el vello de los decadentes finiseculares. Naturaleza extremadamente sexual que por la búsqueda activa del placer aterroriza al compungido hombre decimonónico, como si en la cópula con estas mujeres les fuera la suerte de su miembro viril: enfrentados al sexo de las mujeres como si estas estuvieran dotadas de una vagina dentada. ${ }^{284}$

Todas estas diablesas encontraron ecos en la literatura de la segunda mitad del siglo XIX. Hasta el punto de convertirse en una referencia indiscutible en toda obra que pretendiese entrar en la nómina decadente. Tal vez un caso interesante - aparte de los ya citados de Wilde y otros, incluido Huysmans - sea el de los personajes femeninos seducidos por la influencia diabólica de Drácula, del escocés Bram Stoker. ${ }^{285}$ Las dos jovencitas deseadas por el viejo vampiro, Lucy Westenra y Mina Murray, representan —antes de la entrada en juego del monstruo- el estereotípico ángel del hogar: la promesa de la esposa fiel y abnegada, prudente, contenida y reservada. Sin embargo, a lo largo de todo el relato, es su honor el que está en juego: la primera muere, demonizada, atravesada por la es-

283 S. Tubert, «Los monstruos femeninos de la cultura europea», en Vidal, Alarcón y Lolas (comps.), Enciclopedia Iberoamericana de Psiquiatría, Editorial Médica Panamericana, Buenos Aires, 1995, pp. 976-979.

284 La expresión de Vagina dentata ha sido analizada por Lederer, en W. Lederer, La peur des femmes ou Gynophobia, Payot, París, 1970. Vid. también F. Monneyron, "Le dandy fin de siècle: entre l'androgyne et le mysogine», en A. Montandon, L'honnête homme et le dandy, Gunter Narr Verlag, Tubinga, 1993. Vid. más adelante, en nuestro texto, lo que expresa Simone de Beauvoir sobre ese innato miedo masculino a profundizar en la intimidad femenina.

285 B. Stoker, Dracula, Penguin Books, Londres, 1994. 
taca de la justicia humana; la segunda, Mina, es salvada por el sacramento del matrimonio y el ajusticiamiento final del conde transilvano.

Sin embargo, lo que realmente pone de relieve esta exitosa novela es la exhumación del ser voluptuoso y pecaminoso que hay en toda mujer desde tiempos adánicos. ${ }^{286} \mathrm{La}$ facilidad de su contacto con las fuerzas más oscuras de la naturaleza y del más allá la convierte en ese ser impredecible y peligroso que se apodera del cuerpo de los hombres y, lo que es más, de su alma. En medio de una escenografía de marcado carácter sexual, las vampiresas, habitadas por el mal del monstruo, chupan la sangre de sus víctimas, y, como Lilith, se alimentan de niñitos recién nacidos que hacen las delicias de sus viciosos colmillos.

Se trata, pues, de una revisión moderna del mito de la mujer diabólica: una hembra poseída por las tenebrosas fuerzas de la lujuria, que la metamorfosean en un ser venido de un inalcanzable más allá del que los hombres están excluidos. ${ }^{287}$

En el ámbito francés — que es el que nos interesa para el bosquejo de la psicología de Huysmans_-, la parte demoniaca en la mujer fatal se cumple a la perfección. La actriz La Faustin — de la novela homónima de Goncourt - es un ser cambiante, que, como buena diabólica, sufre transformaciones y modificaciones que la hacen imprevisible: «être divers et multiple, dans lequel, tout à tour, la duchesse alternait avec la grisette». ${ }^{288}$ Otro personaje femenino más caracterizado como diabólico dentro de esta misma novela es Marie la Bonne-Âme, amiga de la Faustin. Hay una curiosa escena en la que la joven se pone a hablar de los amantes que ella misma escoge para su propio placer. Al hacerlo parece recuperar el tono y la pose dignas de una diablesa, transformada de mujer

286 J. Serna, «Simpatía por el vampiro», en Claves de Razón Práctica, n. ${ }^{\circ}$ 125, septiembre 2002 .

287 Otra exitosa revisión de este mito de la mujer diabólica lo tenemos en la novela $E l$ exorcista, de William Peter Blatty, en la que una niña es poseída por el diablo, sometiéndola a las más extrañas torturas y vejaciones, así como las más curiosas metamorfosis en su aspecto. W. P. Blatty, The Exorcist, Bantam Books, Nueva York, 1972 (versión española, El exorcista, Planeta, Barcelona, 1984) (Film The Exorcist, dir. William Friedkin, guion de W. P. Blatty, Los Ángeles, 1973).

288 E. de Goncourt, La Faustin, ob. cit., p. 196. 
civilizada en mujer poseída por un espíritu maligno que la pervierte: la naturaleza femenina, salvaje e indómita, de las cortesanas de Lucifer:

elle se mit à tourner par la chambre comme une bête fauve dans une cage: le noir que prenait le bleu de ses yeux en ses pensées mauvaises, le rutilement de sa tignasse tout fraîchement teinte sous les lueurs de la lampe, lui mettant au front queque chose du caractère, de la farouche grandeur de la prostituée de l'Apocalypse. ${ }^{289}$

No obstante, el más famoso glosador de la mujer diabólica de la segunda mitad del XIX es, sin duda alguna, Barbey d'Aurevilly. Su libro Les Diaboliques, publicado en 1874, y que fue una influencia declarada y confesada por el propio Huysmans (o por su alter ego des Esseintes), ${ }^{290}$ fue una colección de relatos que conoció un cierto éxito, convirtiéndose en una referencia inexcusable en el culto de la mujer fatal de la literatura francesa. "Une femme, c'est l'aimant du diable!», 291 —dice uno de los comensales de esa ripaille que es "À un Dîner d'athées». Es precisamente en este relato donde las referencias al componente diabólico de la mujer fatal quedan más patentes. En él se comentan las hazañas de una mujer prodigiosa, la Rosalba: la más brillante, la más fascinante cristalización de todos los vicios que los comensales hubieran conocido jamás: «dans le mal, une perfection!» — dicen de ella.

La Rosalba, como buena diabólica, es una mujer de carácter inestable, que puede pasar de un estado de ánimo a otro completamente diferente bajo el imperio de la lujuria. "Rosalba, cette catin arrosée de pudeur par le Diable, qui avait, malgré ses mœurs, conservé la faculté, qui tenait du prodige, de rougir jusqu'à l'épine dorsale deux cents fois par jour! » ${ }^{292}$ ¡Doscientas veces al día! Metamorfosis esas que, por su frecuencia, solo deben de poder estar al alcance de una naturaleza sobrehumana. Mujer metamorfoseada, pues, en prostituta satánica, que por ello mismo procuraba al hombre que la gozase un número inimaginable de placeres sexuales:

289 Ib., p. 22

290 J.-K. Huysmans, À rebours, ob. cit., p. 189.

291 J. Barbey d'Aurevilly, Les Diaboliques, edición de Jacques Petit, Gallimard Folio, París 1973, p. 267.

292 Ib., p. 279. 
c'était sûrement ce Diable-là qui, dans un accès de folie, avait créé la Rosalba, pour se faire le plaisir... du Diable, de fricasser, l'une après l'autre, la volupté dans la pudeur et la pudeur dans la volupté, et de pimenter, avec un condiment céleste, le ragoût infernal des jouissances qu'une femme puisse donner à des hommes mortels. ${ }^{293}$

La Rosalba, aun siendo un caso especial, guarda concomitancias con el resto de sus compañeras de sexo, pues todas ellas («une femme [...] quelconque», podría decir Aurevilly) son capaces de perder a los hombres en los meandros de su voluptuosidad sin límite. «Elles font bien tout ce qu'elles veulent de leurs satanés corps, ces couleuvres de femelles, quand elles ont le plus petit intérêt à cela», ${ }^{294}$ como dice de Hauteclaire de Stassin en "Le Bonheur dans le crime». Y es que solo las mujeres tocadas por la des-gracia diabólica son capaces de salir de su marasmo pasivo — propio de la mujer tradicional— y adoptar una actitud activa y dinámica — por ello mismo peligrosa para la autoridad masculina. "Chose étrange! dans le rapprochement de ce beau couple, c'était la femme qui avait les muscles, et l'homme qui avait les nerfs», ${ }^{295}$ dice el narrador de Mlle. de Stassin en el mismo relato. Porque, lo que verdaderamente admira Aurevilly en las mujeres, aunque parezca que se haya complacido en pintar estos retratos magnificentes de sus diaboliques, es la sumisión y la docilidad. Así lo comenta de esa prodigiosa amante que es la Rosalba, de bellísimos ojos, pero que «ils n'étaient jamais plus beaux que quand ils étaient baissés». ${ }^{296}$

Por mucho que sea digna de admiración la soberbia y la indocilidad en las mujeres, jamás serán consideradas como características puramente femeninas. Como dice Victoria Sau, la actividad es masculina y 'fea' en la mujer. Y si el hombre admira tímidamente esta activa amenaza femenina es porque pone en peligro su carácter dominante y acepta gustoso el reto: «sabe que él ganará y ella o será destruida o se convertirá a la belleza pasiva de una buena esposa y madre» ${ }^{297}$ — que será el resultado de la justicia poética que el sistema patriarcal impone finalmente en la ideología de los escritores y es-

\footnotetext{
293 Ib., p. 270

294 Ib., p. 137.

295 Ib., p. 117.

296 Ib., p. 272.

297 V. Sau, «De la facultad de ver al derecho de mirar», pp. 29-40, en M. Segarra y A. Carabì (eds.), Nuevas masculinidades, Icaria, col. Mujeres y Culturas, Barcelona, 2000, p. 31.
} 
critoras decimonónicos. Así se resuelve la azarosa vida de Germinie Lacerteux, la protagonista de la novela homónima de los hermanos Goncourt: a fuerza de independencia con respecto al hombre, Germinie pasa por momentos de embriaguez en los que se permite buscar al macho y solo al macho, dejando al hombre-individuo de lado. Haciendo un uso casi masculino de ellos, "como si hubiera perdido las características de su propio sexo, ella misma atacaba, reclamaba la brutalidad, se aprovechaba de la embriaguez, y era ella a quien se le entregaban». ${ }^{298} \mathrm{La}$ suerte que corre Germinie es, como no podía ser de otro modo, la de una temprana muerte - que no se puede sino relacionar con lo que vaticinaba Carlos Herrera a La Torpille en Illusions perdues.

La actividad femenina, pues, es un sinónimo de muerte de ascendencia diabólica. Incluso la petición de un beso proyectando los labios hacia delante pasa por una amenaza casi fálica: esos labios rojos y eréctiles de Alberte sobre los que el vizconde de Brassard pone su beso y que finalmente penetran los suyos —en "Le Rideau cramoisi» de Les Diaboliques. Fantasías masculinas que les hacen sentirse poseídos cuando los hombres se aventuran a poseer una mujer fatal; complejo de muerte que nace por el miedo a la castración que puede inflingirles una voluptuosidad sometida a su libre impulso. Como el mito de la mantis religiosa, que debe decapitar a su amante para que este expulse su semilla y se haga efectiva la inseminación, la mujer fatal tiene en su sexo ese cepo de lobo, esa vagina dentata tan temida por los hombres. A veces en demostraciones tan evidentes como esta cita de la novela Monsieur de Phocas, de Jean Lorrain, en la que en un pasaje Fréneuse contempla una estatuilla demoníaca: «ses seins hardis et ronds point[ai]ent dans une lueur au-dessus du ventre sombre, un ventre étroit et plat qui se renfl[ait] à la place du sexe au-dessus d'une petite tête de mort». ¡Una cabeza de muerto subrayando un bajo vientre femenino! El miedo masculino a esta instancia diabólica es como la del adolescente que aprende el arte de amar en los brazos de una prostituta: la primera vez acude tembloroso, temiendo lo peor de su rite de passage hacia la condición viril.

298 E. y J. de Goncourt, Germinie Lacerteux, Cátedra, Letras Universales, Madrid, 1990, p. 218 . 
Il y a beaucoup de jeunes gens qui ne s'aventurent pas sans angoisse dans les ténèbres secrètes de la femme; ils retrouvent leurs terreurs d'enfant au seuil des grottes, des sépulcres, leur effroi aussi devant les mâchoires, les faux, les pièges à loup: ils imaginent que leur pénis gonflé restera pris dans le fourreau des muqueuses.

Qué bien demostró saberlo Simone de Beauvoir con la redacción de estas frases. ${ }^{299}$ Una angustiosa investigación espeleológica, poblada de demonios y de monstruos come-niños en la que el hombre jamás se aventurará sin miedo, a menos que consiga considerar a su compañera como su semblable, son frère... Todo un mundo de húmedas profundidades que tanto obsesionaba a Huysmans y que tan profusamente poblaron las obsesiones de sus personajes de novela. Un mundo subterráneo al que se teme porque se desconoce, al que se desconoce porque se le separa de sí, al que se le separa porque hay que controlar... La solución pasa por cesar el férreo y estricto control o por empeñarse en continuar en ejercerlo de manera más ardua aún si cabe...

\subsubsection{Otras manifestaciones de la reacción misógina}

La misoginia, como paradigma de la virilidad, crece como reacción a los avances de las mujeres en lo laboral, en lo social y en lo sexual. Una actitud comprensible en quien cree que están afilando la guillotina por él; en quien observa con preocupación cómo la mitad de la población, hasta entonces mantenida sojuzgada y sometida, campa por sus fueros y ocupa terrenos hasta entonces vedados para ella. Comprensible - aunque no compartible ni defendible - cuando algunos hombres ven cómo el mundo les niega la primacía que la cultura tradicional les había concedido sin discusión ni oposición.

Para hallarse y perpetuarse en tal primacía se hizo necesario educar a esa otra parte en unos comportamientos que le fueran propios, que coadyuvaran a su sumisión. Comportamientos y actitudes que pretenderían exclusivos de las mujeres y en los que estas fueron programadas y preparadas desde tiempo inmemorial. Toda actividad humana relacionada con lo sentimental, lo intuitivo, lo natural fue considerada por el patriarcado

299 S. de Beauvoir, ob. cit., vol. II, «L'Expérience vécue», p. 164. 
como monopolio femenino inalienable - mientras que los hombres se arrogaban el privilegio (¡tan discutible!) de la Razón, de la Ciencia, de la Cultura. El ámbito masculino fue siempre lo público: ese salir de casa para proyectarse en foros y reuniones, en la remuneración salarial, en la construcción de imperios que significaran una extensión de su yo, en el que poder alienarse sin sonrojo. El ámbito femenino fue lo doméstico: ella es el ángel del hogar, la proveedora de alimento y de afectos, debiendo alienarse en la crianza de los nińos y en el buen mantenimiento de la casa. Esa «espèce de poésie qu'une femme aimante et spirituelle peut et doit introduire dans son ménage» — como dice Balzac de Eve Séchard, la hermana de Rubempré. ${ }^{300}$

Consideradas de importancia menor, todas las actividades relacionadas con lo doméstico son inabordables para los hombres. Incapaces tanto de freír un huevo como de coser un botón, los solteros de la novela decimonónica deben recurrir a personal doméstico o a la incertidumbre de la alimentación en restaurantes: almas en pena que vagan por entre las cartas de bares y cafés o por entre les petites annonces para encontrar sirvienta que les saque del apuro. Queda descartado que un hombre se ocupe de faenas femeninas, faltaba más - como queda patente en el retrato de época que hace Jean Borie del soltero francés. ${ }^{301}$ También por eso, parte de la reacción masculina ante los avances de las mujeres pasa por criticar esa descompensación: las mujeres ocupan poco a poco el ámbito público, mientras que el doméstico sigue estando vedado para los hombres. Estos se ven en una ridícula inferioridad de condiciones con respecto a sus mujeres. Como Rousseau, quien exclamaba en su Émile:

no satisfechos con afianzar sus derechos (los del sexo femenino) también hacen que se apropien de los nuestros, pero, dejarla superior a nosotros en las cualidades propias de su sexo y hacerla igual a nosotros en todo lo demás, ¿qué otra cosa es sino conceder a la mujer la primacía que la naturaleza le da al marido? ${ }^{302}$

300 H. de Balzac, Splendeurs et misères des courtisanes, ob. cit., p. 309.

301 J. Borie, Le célibataire français, ob. cit.

302 E. Bornay, ob. cit., p. 51. Sobre la influencia de Rousseau en la concepción del género femenino en el siglo XIX, vid.: L. Posada Koubissa, Sexo y esencia, ob. cit. Y C. Amorós, Hacia una crítica de la razón patriarcal, Anthropos, Barcelona, 1985. 
Al hombre se le escapa la primacía que estaba siendo sustentada, precisamente, por la sumisión a la que las mujeres ya no entendían plegarse sin oposición. Se da en la sociedad del siglo XIX una ruptura entre hombres y mujeres en el sentido de que estas ya no aceptan la reclusión a que su programación como «ángeles del hogar» les obliga.

Un ejemplo que debió de incidir poderosamente sobre las mentalidades de la época fue la obra de Ibsen, Casa de muñecas. ${ }^{303}$ En ella, el momento de ruptura se da cuando Nora deja el hogar conyugal sin razón aparente, simplemente movida por un irrefrenable impulso de libertad: "aquí he sido tu mujer-muneca, así como en casa de papá era hija-muñeca». ${ }^{304}$ Muñeca doquiera que estuviese, juguete de la voluntad y de los designios masculinos, Nora huye sumiendo en el marasmo a su familia, quien no entiende los motivos de tal huida.

Una reacción típicamente misógina consiste en burlarse de esas mujeres que adoptan actitudes y ropajes poco femeninos $-\mathrm{o}$, nos atreveremos a decir, masculinos. Mujeres que, revistiendo esa imagen, hacen reivindicación de igualdad de derechos o se niegan a llevar falda por considerarla elemento de sumisión al poder masculino. Asimismo se cortaban los largos cabellos y llevaban antiestéticas gafas, denotando con ello la práctica de actividades diferentes a lo que la tradición les había acostumbrado — pero que, sobre todo, había acostumbrado a los hombres.

Los hombres de la Belle Époque — como nuestros contemporáneos, en eso las cosas no parecen haber cambiado demasiado- solían plantarse en las terrazas de los cafés para despotricar de las mujeres con aspecto de feministas que por allí pasaban. Así lo comenta el francés Joran, autor de varios libros sobre mujeres, en su obra Autour du féminisme (1906): «blaguer des femmes laides à cheveux courts et à lunettes qui vous prennent l'air d'apôtres est un de ces passe-temps auxquels nous renoncerions le moins volontiers». ${ }^{305} \mathrm{Y}$ aunque de estas palabras se pudiera inferir que es el humor el registro con el que Joran denuncia la mentira que él dice ver en el femi-

303 H. Ibsen, Casa de muñecas en Teatro completo, vol. I, Aguilar, Madrid, 1959, pp. $1235-1282$.

304 Ib., p. 1256.

305 T. Joran, Autour du féminisme, Plon, París, 1906, p. 69. 
nismo, las émancipées de sus cuatro libros no son cómicas, sino más bien peligrosas. ${ }^{306}$ De ahí que todos los comentarios que suscitan en Joran estén más teñidos de odio irracional que de crítica razonada.

Este odio también es netamente perceptible en la «biblia» de la misoginia que significó el Sexo y carácter de Weininger. En esta obra de 1903, el alemán proclama con todos los medios a su alcance las bondades del patriarcado en el momento en el que ve —o cree ver- cómo se impone el matriarcado triunfante. "Weininger ne hait la femme que parce qu'il en a peur —ou parce qu'il en conserve la nostalgie», — dice de él Jacques Le Rider. ${ }^{307}$ Con toda esa fastuosa celebración de lo masculino, Weininger no hace sino certificar la decadencia de la virilidad moderna.

Y es que la reivindicación feminista del siglo XIX provoca una escalada de tensiones en los hombres por poner en peligro los valores de su masculinidad tan querida. Como señala William Vogt en 1908, ${ }^{308}$ el feminismo a ultranza no hace sino envenenar un conflicto en el que el hombre sólo podrá triunfar mediante el recurso a la fuerza y a una represión arbitraria. Como si fuera una advertencia, Vogt y los que coinciden con él parecen prevenir a las mujeres de que, en caso de no cejar en su insidioso griterío de gallinero, sufrirán las consecuencias. La declaración de guerra está hecha, cada uno expone sus estandartes para identificación del adversario: la igualdad solo puede engendrar la lucha que los privilegiados entienden deber hacer para mantenerse en sus privilegios. Así lo veía el escritor Albert Cim en 1899, quien advertía que "l'égalité des sexes engendrera la bataille et naturellement la victoire sera du côté du biceps». ${ }^{309}$ Como si lo realmente humano fuera la imposición del músculo. La misma fibra que moldeó la tierra para que pariera sus frutos se expone ahora como mantenedora del statu quo. Dónde quedó la Razón tantas veces expuesta para distinguir a los lógicos machos de las intuitivas hembras... Habríamos de preguntarle a Mau-

306 Leer, a este respecto, la interesante obra de A. Maugue, L'identité masculine en crise au tournant du siècle, ob. cit., p. 173 y ss.

307 J. Le Rider, "Misères de la virilité à la Belle Epoque», en Le genre humain, n. ${ }^{\circ}$ 10, París, 1984, p. 118.

308 W. Vogt, Le sexe faible, M. Rivière, París, 1908, p. v. Vid. también A. Maugue, «La nueva Eva y el viejo Adán. Identidades sexuales en crisis», en VV.AA., Historia de las mujeres, vol. 4, siglo XIX, Santillana, Madrid, 2000, p. 176.

309 A. Cim, L'emancipée, Flammarion, París, 1899, p. 54. 
passant, quien no puede evitar hacer subir a un improvisado orador a la tribuna de un mitin feminista en su relato «Les Dimanches d'un bourgeois de París»:

comme nous sommes incontestablement les plus vigoureux et les mieux doués pour les sciences et les arts, votre infériorité apparaìtra et vous deviendrez véritablement des opprimées.

La misoginia — ya no por las feministas en particular, sino por las mujeres en general - de Balzac es bien conocida de los estudiosos de la literatura decimonónica. Las peroratas de Trompe-la-Mort en Splendeurs... son antológicas. Esta fiera del presidio solo entiende el mundo como un alimento para su avidez; es un bulímico vital que, a pesar de su fuerza y su inteligencia, sería capaz de conseguir todo lo que se propusiera; pero no entiende que alguien tan lúcido como Théodore, su compañero corso, se haya dejado capturar por la justicia a causa de la influencia de una mujer:

les hommes assez bêtes pour aimer une femme périssent toujours par là!... C'est des tigres en liberté, des tigres qui babillent et qui se regardent dans des miroirs... [...] Elles nous ôtent notre intelligence!.... ${ }^{310}$

Él entiende el sometimiento a una mujer como una tiranía infantil, como una revisión del vínculo con la madre, al que el hombre debe sustraerse so pena de caer de nuevo en la dependencia. Se trata, como señala David Gilmore, del eterno miedo a la regresión: la masculinidad entendida como una batalla contra estos deseos y fantasías regresivos, una difícil renuncia a los anhelos del idilio infantil. ${ }^{311}$ La mujer es la pérdida del hombre, porque es pasional, cándida pero perversa, salvaje e intrigante. ${ }^{312}$ Un ser que fagocita al hombre cuando se hace dependiente de él; inferior cuando solo obedece a su fisiología. Ahora bien, Vautrin, este ange déchu del realismo romántico, gusta de las mujeres independientes y autónomas, dotadas de sus mismas fuerza e inteligencia: "pour moi la femme n'est belle que

310 H. de Balzac, Splendeurs et misères des courtisanes, ob. cit., p. 544.

311 D. D. Gilmore, Hacerse hombre. Concepciones culturales de la masculinidad, trad. de Patrick Ducher, Paidós Básica, Barcelona, 1994, p. 38.

312 H. de Balzac, Splendeurs et misères des courtisanes, ob. cit., p. 629. Así habla Trompela-Mort cuando acude al lecho de Mme. de Sérisy para cerciorarle del amor que le profesaba Lucien de Rubempré antes de morir. La noble señora languidecía pensando en que su querido Lucien no le habría perdonado antes de quitarse la vida en un calabozo. 
quand elle ressemble à un homme!» dice con seguridad. ${ }^{313}$ Igualdad en las cualidades y en las posibilidades de cada uno, dice Jacques Collin necesitar para admirar a una mujer. Una mujer dandi como él, en quien la astucia y la agilidad sean connaturales. Su tía, tan pronto transformada en vieja vendedora ambulante como en rica boutiquière de bulevar, como en opulenta señora, Jacqueline Collin, es una dandi con las mismas capacidades que su sobrino — si exceptuamos el vigor físico.

$Y$ es que la mujer también puede ser un dandi, siempre y cuando se observe en ella esa pose anti-convencional, esa inteligencia y ese cinismo que el mejor Baudelaire supo destilar. La dandi baudelairiana es sutil y sofisticada como su antecedente del siglo XVII, la Précieuse; pero a su carácter hay que ańadirle la frialdad inteligente, el decoro y la nobleza diríamos satánica del ángel caído. La mujer es lo contrario del dandi cuando — como dice el poeta en Mon cour mis à nu-:

(elle) a faim et elle veut manger. Soif, elle veut boire.

Elle est en rut et elle veut être foutue.

Le beau mérite!

La femme est naturelle, c'est-à-dire abominable.

Aussi est-elle toujours vulgaire ... ${ }^{314}$

Sin embargo, cuando se halla en ella esa nobleza maldita, esa tristeza fría que no le permite la exposición de ningún sentimiento, entonces la mujer es dandi. Como en este pasaje de Fusées en el que el poeta parece esbozar el guión de una pieza; un hombre llora desconsoladamente cerca de su amante:

il se mit à pleurer; et ses larmes chaudes coulèrent dans les ténèbres sur l'épaule nue de sa chère et toujours atirante maîtresse. Elle tressaillit; elle se sentit, elle aussi, attendrie et remuée. Les ténèbres rassuraient sa vanité et son dandysme de femme froide. Ces deux êtres déchus, mais souffrant encore de leur reste de noblesse, s'enlacèrent spontanément. ${ }^{315}$

Seres destronados, nobles en una tristeza sin atisbo de pusilanimidad: seres demoníacos por situarse al margen de una sociedad que quiere la confrontación, que odia al miserable y lo hunde todavía más en su miseria. El

313 Ib., p. 591.

314 C. Baudelaire, Mon cour mis à nu, Éditions Arcadia, París, 1996 (III), p. 9.

315 C. Baudelaire, Fusées, Éditions Arcadia, París, 1996 (XV), p. 65. 
dandi es un proyecto vital que entiende separarse de la tediosa sociedad burguesa, marginándose por arriba. La batalla de los sexos termina con el dandi, quien entiende que la equiparación de los seres se hace en función de su inteligencia y no en función de su posición social.

Al igual de los hombres del XVII, los Précieux nacidos de las exigencias de las Précieuses, los dandis del XIX crearon un mecanismo de repliegue y defensa que, lejos de explotar la virilidad tradicional, la ponían en tela de juicio. Cómo podían avalar una masculinidad insensible y maquinadora. El dandi Baudelaire, visto en las barricadas de la Comuna gritar contra su padrastro el general Aupick, no entendía un régimen masculino en que el poderoso cargase sobre el pobre haciéndole sentir todo el peso de su poder. El proyecto del dandi pretende romper con la masculinidad primaria, barriobajera y procaz para proclamar un nuevo humanismo. ${ }^{316}$

\subsection{El dandismo}

El dandismo quizá sea la más original construcción de la masculinidad del siglo XIX. Producto original del refinamiento de la sociedad precapitalista y de sus salones, el dandi es un ser excesivo que revoluciona la virilidad. Propone, en primer lugar, una definición original de qué puede ser también el hombre, sin por ello renunciar completamente a algunas de las constantes viriles. En segundo lugar, ofrece un nuevo marco actitudinal a partir del que la masculinidad puede evolucionar. Por último, toda esta puesta en cuestión de la masculinidad tradicional permite replantearse los hábitos sexuales, convirtiendo la práctica de la sexualidad más en una búsqueda de sí mismo que en simple extensión de la virilidad.

La genealogía del concepto 'dandi' es incierta. En inglés, la lengua en que se acunó el término, 'dandi' viene a significar 'lechuguino, petimetre'. Por extensión, se fue aplicando a los jóvenes urbanos que esmeraban al máximo su atuendo y sus maneras, que mostraban un exagerado afán por medrar en la sociedad elegante. El dandi, en su acepción paradigmática, es

316 Monique Wittig abogará en su Corps lesbien por la abolición de los grilletes de la denominación en base al género para entrar en un nuevo tipo de humanismo: un humanismo de la persona. M. Wittig, Le corps lesbien, Minuit, París, 1973, p. 238. 
sinónimo de elegancia excéntrica y singular, cuyo buen gusto para la innovación vestimentaria le convierte en un Petronio moderno, árbitro de la elegancia.

Sin embargo, y en paralelo a este fenómeno meramente estetizante, el dandi abraza actitudes románticas. Nos hallaríamos, en este caso, frente a la corriente byroniana del dandismo — que es la que más nos va a interesar por su relación con la literatura y con el dandismo netamente francés.

\subsubsection{La corriente brummelliana del dandismo}

Aunque cronológicamente posterior — pues la actitud romántica de algunos excéntricos ingleses, como Byron, antecedió a la acuñación del término-, la corriente preciosista del dandismo fue la que más rápidamente cuajó en el imaginario masculino. Por una parte, si a esta tendencia la llamamos 'brummelliana' es por la enorme influencia que el elegante inglés ejerció sobre todos los fashionables de ambas orillas del Canal de La Mancha. Pero, por la otra, no hay que olvidar la herencia que los précieux dejaron en la masculinidad del fin de siglo octocentista y comienzos del XIX.

Como ya hemos comentado más arriba, los précieux era la respuesta de algunos hombres a las exigencias de finura y elegancia de las précieuses del siglo XVII. Esta respuesta masculina al preciosismo y sofisticación femeninos consistió en la adopción de una moda refinada y feminizante: pelucas largas, plumas extravagantes, golillas, lunares postizos, perfumes, colorete... El refinamiento y la distinción incluyó entre sus reglas el parecer civilizados, corteses y delicados.

Como era de esperar, la adopción de estos usos sociales feminizantes despertó un miedo a la homosexualidad que no se dio entre los detractores de estos "preciosos». Sin embargo, lo más importante de esta moda pasajera —que realmente solo influyó a las clases nobles, visitantes y merodeadores habituales de los salons - es que contribuyó a dar de la masculinidad una visión rompedora y, en definitiva, liberadora. El hombre culto que entraba en el siglo XVIII ya no poseía el único modelo del hombre tradicional alimentado en los ideales de la virilidad ruda, cruel y sin sentimientos: otra masculinidad era posible — con todo su corolario de dudas sobre la construcción de la «verdadera» masculinidad. 
Y es que esa virilidad grosera, curtida en los ejércitos y el trabajo físico, había sido el único modelo posible de la juventud francesa. Aun con mucho tiempo de diferencia, Stendhal pinta perfectamente el tipo viril de las provincias de la Francia decimonónica.

[Mme. de Renal] se figurait que tous les hommes étaient comme son mari, M. Valenod et le sous-préfet Charcot de Maugiron. La grossièreté, et la plus brutale insensibilité à tout ce qui n'était pas intérêt d'argent, de préséance ou de croix; la haine aveugle pour tout raisonnement qui les contrariait lui parurent des choses naturelles à ce sexe, comme porter des bottes et un chapeau de feutre. ${ }^{317}$

Grosería, insensibilidad, codicia sin límites, odio por el razonamiento: constantes de las que participarían, a ojos de Mme. de Renal, la inmensa mayoría de los hombres, verdaderos autómatas que responden igualmente a los mismos estímulos. De ahí que la entrada de Julien en su entorno vital sea como un chorro de agua fresca: tonificante, vivificante, este gentle-man permite a la melancólica señora reconciliarse con la vida y, sobre todo y a su pesar, con el amor.

La figura de Brummell fue decisiva para muchos dandis y demás advenedizos. George Bryan Brummell (Londres, 1778-Caen, 1840) marcó la moda durante muchos ańos, tanto en Inglaterra como en Francia. Como tantos otros hijos de familia adinerada, Brummell ingresó en Eton en 1790, donde conoció a Georges, Príncipe de Gales, con quien trabó una sólida amistad. Esto le sirvió para que, años más tarde, el príncipe le diera un puesto en su propio regimiento.

Sus apariciones públicas junto a Georges le hicieron merecedor de una consideración social al alcance de pocos plebeyos. Ya fuera por justificar su presencia en tan altos círculos, ya por una natural disposición a la extravagancia, las costumbres vestimentarias de Brummell asombraban a todos cuantos les rodeaban. Sus exigencias llegaban a exagerados excesos, como el ya conocido de sus guantes, que necesitaban tres artesanos para los dedos y otro diferente para el pulgar. ${ }^{318}$ Estos dispendios, que debían saquear la

317 Stendhal, Le Rouge et le noir, ob. cit., p. 51.

318 Referido en J. d'Ormesson, Revue de métaphysique et de morale, octubre-diciembre, París, 1963, p. 19. 
mejor dotada de las bolsas, fueron motivo de la persecución de sus deudores - lo que, unido a sus crecientes enfrentamientos con el Príncipe Georges, hizo que su estrella se fuera apgando poco a poco.

Por motivo de deudas, Brummell debió abandonar el Reino Unido y refugiarse en Francia, donde fue nombrado cónsul de Inglaterra en Caen. Sin embargo, la fortuna no sonreiría al dandi, pues sería encarcelado en 1835 por motivo de deudas — siendo liberado por sus amigos quienes le proporcionarían unos ingresos mínimos pero seguros. A partir de esta fecha, el gusto de Brummell por el aparato y la vestimenta entró en franca decadencia, hasta su muerte en la ciudad normanda en 1840. Dejó tras de sí, aparte de un buen número de deudas, una estela de admiradores y un renombre que, aún hoy en día, está lejos de desaparecer.

Como Brummell, había otros fashionables que, si bien no tan reconocidos mundialmente, sí lo fueron a menor escala. Nos estamos refiriendo, desde luego, a Orsay; o al príncipe de Kaunitz, de quien Jean d'Ormesson comenta la curiosa ceremonia en que consistía su poudrage, su empolvamiento: «des valets posés aux portes, tout le long d'une enfilade de salons, le poudraient juste le temps qu'il passait afin d'obtenir la nuance exacte». O también al más tardío conde Robert de Montesquiou, faro del dandismo finisecular y modelo en el que un buen número de literatos hallaron inspiración. Así fue en el caso de Marcel Proust, quien confesaría haber extraído de su conocimiento del noble elegante varios elementos para la creación de su barón de Charlus. O incluso Huysmans, quien, aun negando al mismísimo Zola en una misiva que su des Esseintes estuviera basado en Montesquiou, afirmaba: «[...] si j'avais fait Montesquiou des Esseintes — (il eût été trop bouché!) j’aurais exprimé son inénarrable dégoût pour le naturalisme», ${ }^{319}$ François Livi reconoce el préstamo de algunos detalles para la construcción de su célebre héroe solitario: ${ }^{320}$

il montait sur une chaire magistrale et prêchait le sermon sur le dandysme, adjurant ses bottiers et ses tailleurs de se conformer de la manière la plus absolue, à ses brefs en matière de coupe... ${ }^{321}$

319 J.-K. Huysmans, Lettres inédites à Emile Zola, publicadas y anotadas por Pierre Lambert, introducción de Pierre Cogny, Librairie Droz, Ginebra, 1953. Carta del 25 de mayo de 1884 , p. 223.

320 F. Livi, J.-K. Huysmans. À rebours et l'esprit décadent, ob. cit., p. 143.

321 J.-K. Huysmans, $A$ r rebours, ob. cit., p. 70. 
Esta excentricidad en el gusto vestimentario, este exceso en la búsqueda de la singularidad, que se dan cita repetidamente en todos los profesionales del dandismo, no hace sino abrir el debate entre el ser y la apariencia, el être y el paraître. El dandi no puede sentirse seguro de su existencia si no es en la mirada que los demás le devuelven de sí mismo. Baudelaire lo entendería perfectamente al aseverar que la vocación del dandi es existir a través de su excelencia, de su condición sublime - cuya interrupción supondría la extinción de su ser-: «le Dandy doit aspirer à être sublime sans interruption; il doit vivre et dormir devant un miroir», 322 dice el poeta en Mon cœur mis à nu. En ello coincide Albert Camus, en el apartado titulado "La révolte des dandys» de su Homme révolté, percibiendo esa necesidad inevitable del dandi por mirarse y saberse mirado: los demás son el espejo en que se mira. Es este, empero, un espejo que se ensombrece con rapidez, pues la capacidad de asombro del hombre es limitada. Por eso mismo debe ser constantemente aguijoneada, siempre renovada por acción de la provocación: «le dandy est donc forcé d'étonner toujours. Sa vocation est dans la singularité, son perfectionnement est dans la surenchère», dice Camus. ${ }^{323}$ Su necesidad de renovación continuada no deja de ser un doloroso tributo a la singularidad, incluso para quien no tiene otra profesión más que la elegancia, como señala el Baudelaire de Peintre de la vie moderne. ${ }^{324}$ Fatigante profesión, finalmente, de quien vive exclusivamente en la obsesión de ser visto para existir: obsesión barroca por excelencia, como observa Luis Puelles Romero, ${ }^{325}$ que para ser cumplida requiere de aunar las competencias del flâneur y del voyeur: prestarse a la vista y ver. Un programa vital costoso que aspira no solo a lo sublime, sino a hacer de la propia existencia una obra de arte admirable y admirada, cuya exposición da fe y asegura la existencia del dandi en los valores más altos.

Hacer de la propia existencia un fenómeno estético, única justificación, a ojos de Nietzsche, de la propia vida en este mundo: «únicamente como fenómeno estético puede justificarse eternamente la existencia y el

322 C. Baudelaire, Mon cœur mis à nu, ob. cit., p. 10.

323 A. Camus, L'Homme révolté, Gallimard, París, 1951, p. 73.

324 C. Baudelaire, «Le peintre de la vie moderne», en Écrits sur l’art, Librairie Générale Française-Le Livre de Poche, ed. de François Moulinat. París, 1992, p. 396. Apartado «Le Dandy».

325 L. Puelles Romero, «La voluntad de apariencia: estética del dandysmo», en A. Ramos Santana (ed.), La identidad masculina (en los siglos XVIII y XIX), ob. cit., p. 23. 
mundo». ${ }^{326}$ Es esta una proclama esteticista que el dandi suscribe y que ha glosado Thomas Mann al encontrar afinidades entre el credo artístico de Oscar Wilde y el filósofo alemán: "como rebeldes en nombre de la belleza, Nietzsche y Wilde se hallan relacionados». ${ }^{327}$

Oscar Wilde representa uno de los paradigmas del eterno dandi. Este irlandés de nacimiento supuso y supone para muchos jóvenes la realización perfecta del ideal tantas veces acariciado en sus sueños de Eton o de Oxford; un ideal que concilia — como señala Émilien Carassus_ ${ }^{328}$ lo mejor de la cultura humanista con la gracia, la distinción y la perfecta educación de un ciudadano del mundo. El programa vital de Wilde aspira no solo a la autocontemplación como individuo excepcional, sino también a la búsqueda incansable de una vida plena y hermosa - que proporcionaría a la humanidad la alegría necesaria para la renovación humanista: la vuelta a la Arcadia ideal, a la Edad de Oro en que el Hombre se olvidara por siempre de esa espesa niebla que supuso el advenimiento del cristianismo:

si un homme osait vivre sa vie pleine et entière, s'il osait manifester tous ses sentiments, exprimer toutes ses pensées, réaliser tous ses rêves, le monde en recevrait un tel renouveau de joie, que nous oublierions tous les insanités du Moyen Âge, pour revenir à l'idéal hellène. ${ }^{329}$

El dandi de Wilde no es un simple petimetre que se cree por encima del común de los mortales por su poder de decidir sobre lo chic en joyas, corbatas o bastones. El dandi Dorian Gray, al buscar en la belleza la revelación del verdadero secreto de la vida, aspira a llegar a través de una filosofía razonada a la espiritualización de los sentidos: «un nouvel hédonisme allait paraître qui transformerait la vie et la sauverait de ce puritanisme rêche et grimaçant dont notre époque voit le curieux réveil». ${ }^{330}$ Nuevo hedonismo que busca una vida más alta —en contraposición a la rimbaldiana réalité rugueuse à étreindre— ${ }^{331} \mathrm{y}$ que supone la confirmación de las inquietudes

326 F. Nietzsche, El nacimiento de la tragedia, Espasa-Calpe, Madrid, 1969, p. 44.

327 T. Mann, Schopenhauer, Nietzsche, Freud, Bruguera, Barcelona, 1984, p. 192.

328 E. Carassus, Le Mythe du dandy, Armand Colin, París, 1971, p. 257.

329 O. Wilde, Le Portrait de Dorian Gray, trad. de Edmond Jaloux y Félix Frapereau, prólogo de Dominique Fernandez, Stock-Le Livre de Poche, París, 1983, p. 35.

330 Ib., p. 171.

331 A. Rimbaud, "Adieu», en Une saison en enfer, Poot et Compagnie, Bruselas, 1873. 
filosóficas del dandi. Intentaremos continuar por esta vía más adelante, pues en estos momentos nos debemos a la configuración del dandi clásico.

Es, pues, esta simple y en apariencia sencilla pasión por la elegancia la que caracteriza al dandi clásico, más brummelliano que précieux. Personaje, pues, por su singularidad, al que se le perdonan bravatas y malos modos, pues de él depende la fijación de las reglas de la etiqueta de cada nueva temporada. Y este es el modelo que más fácilmente se extendió por la Europa decimonónica: el dandi seguro de sí mismo y bravucón, convencido de que nadie va a osar recriminarle una actitud de cuya conveniencia solo él puede pronunciarse. René de Chateaubriand así lo observó a su vuelta de Inglaterra en 1822:

le dandy doit avoir un air conquérant, léger, insolent; il doit soigner sa toilette, porter des moustaches ou une barbe taillée en rond comme la fraise de la reine Elisabeth, ou comme le disque radieux du soleil; il décèle la fière indépendance de son caractère en gardant son chapeau sur sa tête, en se roulant sur les sofas, en allongeant ses bottes au nez des ladies assises en admiration sur des chaises devant lui; il monte à cheval avec une canne qu'il porte comme un cierge, indifférent au cheval qui est entre ses jambes par hasard. ${ }^{332}$

Una indiferencia que él lleva como marca de la casa, como regla de oro del dandismo. Ahora bien, por momentos esa capacidad para la contención, para preservar su impasibilidad y cuidarse de las pasiones irrefrenables - como señala Carassus — ${ }^{333}$ se deja de lado en favor de un programa vital diferente. El dandi puede entonces pasar al bando de la actividad, de la acción; en ese caso, el elegante es el más valiente de todos, se señala — cual $\mathrm{Na}$ poleón- como el más valeroso y arrojado. Un caso tal vez paradigmático de esta nueva factura del dandi se halle en el vicomte de Brassard creado por Barbey d'Aurevilly en "Le rideau cramoisi» de sus Diaboliques. Observemos esta descripción de la actitud dandi de Brassard: ${ }^{334}$

le capitaine de Brassard rangea ses soldats sur deux lignes, le long et le plus près possible des maisons, de manière que chaque file de soldats ne fût exposé qu'aux coups de fusil qui lui venaient d'en face;

332 F.-R. de Chateaubriand, Mémoires d'outre-tombe, ob. cit., p. 295.

333 E. Carassus, ob. cit., p. 9.

334 J. Barbey d'Aurevilly, ob. cit., p. 32. 
él, sin embargo, con la voluntad inquebrantable de crear un retrato de sí mismo en el teatro bélico, "plus dandy que jamais, prit le milieu de la chaussée». ¿Cabe mayor demostración de singularidad? Este dandi de d'Aurevilly se destaca por su hombría (en su acepción tradicional), por su gusto por el exceso barroco, ocupando constantemente un escenario en que él se vea visto por sus semejantes. Un hombre exagerado y excesivo que no conoce la tregua en su histriónica instalación en el mundo. Excès homo —en fórmula acuñada por el profesor Steinmetz- ${ }^{335}$ en todo, que no conoce reposo ni comedimiento; pues regados como están por la sangre febril de los leones - como el Vautrin de la Comédie humaine balzaciana_, ${ }^{336}$ demuestran un apetito y una sed fuera de toda norma: «dandy en tout, il était dans sa manière de boire comme dans tout le reste [...] il buvait comme un Polonais». 337

Nos hallamos, pues, frente a un dandi decididamente alejado de la finura de los précieux del XVII. En el caso de Barbey d'Aurevilly, fiel seguidor del dandismo brummelliano — no en vano publicó en 1845 un interesante Du Dandysme et de George Brummell-, la elegancia del dandi reside en su carácter individualista, autónomo y viril; un hombre exagerado que todo lo hace con la falta de comedimiento de quien sabe que, un día, la vida ha de terminar. Su determinación a la hora de acometer cualquier empresa es tal que por ello mismo queda señalado con la marca de la singularidad. El dandi de Barbey d'Aurevilly es más un héroe militar —elegante y altivo— que un icono de la elegancia; más un hombretón educado y mujeriego que cumplidor de la contención y de la impasibilidad dandiescas.

El modelo de dandi que mayormente se extendió, a medida que avanzaba el siglo XIX, fue el de la distinción, el de la elegancia rebuscada: el de casi femenina búsqueda de la belleza personal. Como revisión de los précieux del XVII, el dandi parisiense de la primera mitad del siglo XIX es un joven elegante, vestido con un cuidado y una gracia absolutos. Pero lo que le caracteriza por encima de todo es su finura femenina, que marca precisamente la diferencia entre el modelo viril al uso y la singularidad dandiesca. «Vous êtes un beau

335 Expresión recogida por quien firma este trabajo durante una clase impartida por Jean-Luc Steinmetz, y centrada en las relaciones entre psicoanálisis y literatura, en la Faculté des Lettres et des Sciences Humaines de la Université de Nantes durante el curso 199293.

336 H. de Balzac, Le Père Goriot, ob. cit., p. 126.

337 J. Barbey d'Aurevilly, ob. cit., p. 36. 
jeune homme, délicat, fier comme un lion et doux comme une jeune fille», le dice Vautrin a Rastignac en la pensión Vauquer del Père Goriot. ${ }^{338} \mathrm{Y}$ es que es esa mezcla curiosa de tenaz voluntad de gustar junto al componente objetual que el dandi pone a disposición de la admiración ajena: orgullo y dulzura.

Si citamos a Balzac para ilustrar esta faceta del dandi afeminado no es accidentalmente: la Comédie humaine balzaciana, como novela de costumbres y fresco de una época que pretende ser, está plagada de esos jóvenes advenedizos que cambiaron la fisonomía de la masculinidad por venir. Basta con observar con un poco de detenimiento la factura de todos los personajes masculinos que pueblan el París elegante de los salones y los restaurantes caros, los teatros y los camerinos de las actrices, el mundo de las letras y del periodismo. Toda una caterva de jóvenes que, en su deseo de parvenir, imitan el modelo del héroe social, del ídolo de escritores y de mujeres. Y como no podía ser de otra manera, el muchacho advenedizo intenta seducir a una dama de la alta burguesía o de la nobleza que le abra las puertas del gran mundo. Así lo intentan Eugène de Rastignac con Mme. de Nucingen — esposa del ávido banquero-y Lucien de Rubempré con Clotilde de Granlieu —hija de un par de Francia.

En el primer caso, Rastignac encuentra en la figura de un tal Maxime un serio competidor por la belleza de Mme. de Nucingen. Eugène es un bello joven, todavía tocado por la mágica varita del candor provincial. Maxime, al contrario, es un dandi achevé, dotado de todas las características del fashionable parisién: contención, impasibilidad... Amén de un peinado y una mise excelentes e impecables:

les beaux cheveux blonds et bien frisés de Maxime lui apprirent combien les siens étaient horribles. Puis Maxime avait des bottes fines et propres, tandis que les siennes, malgré le soin qu'il avait pris en marchant, s'étaient empreintes d'une légère teinte de boue.

Eugène compara con desagrado su estilo con el de su competidor, de quien además se ofrece un nuevo rasgo definitivo del dandi, el afeminamiento: «enfin Maxime portait une redingote qui lui serrait élégamment la taille et le faisait ressembler à une jolie femme». ${ }^{339}$

338 H. de Balzac, Le Père Goriot, ob. cit., p. 190.

339 Ib., p. 70. 
¿Acaso no es curioso que el modelo que desearan seguir todos estos jóvenes poseyera rasgos de feminidad? Otro personaje en el que estos jóvenes con pretensiones elegantes se mirarán con envidia es Henri de Marsay, quien aparece en dos novelas del ciclo de la Comédie: La Fille aux yeux d'or y Les Illusions perdues. Un joven aristócrata de quien sus más duros rivales decían ser le plus joli garçon de Paris: «une peau de jeune fille, un air doux et modeste, une taille fine et aristocratique, de fort belles mains». Una belleza de señorita, muelle y afeminada, pero, como señalaba Vautrin a Rastignac, "corrigée par un regard fixe, calme, fauve et rigide comme celui d'un tigre». ¿Qué más da tigre o león, si en el dandi se lee la fiera determinación de gustar - aun aparentando para ello no mover ni una sola pestaña? Y por mucho que, como en el caso del Raphaël de La Peau de chagrin, se trate de una "coquetterie recherchée», ${ }^{340}$ tal es la naturalidad con que se muestra que el dandi parece haber sido criado entre ámbares y princesas.

Se trata, en todos estos ejemplos, de la imitación de un modelo de joven frecuentemente noble o de familia adinerada, que integraba lo que vino a llamarse la jeunesse dorée del siglo XIX. Estos muscadins - como también se les llamó en la época - recibieron el apelativo de petits crevés - término que fue acogido con agrado por la sociedad, hasta el punto de que un vodevil en cuatro actos fue programado en París con ese título. Así lo recoge Maxime du Camp en su Paris, ses organes, ses fonctions et sa vie dans la seconde moitié du XIXe siècle, obra de 1875, quien señala asimismo la existencia de una caricatura del petit crevé en el periódico L'Éclipse del 4 de octubre de 1868, realizada por un tal Pépin. ${ }^{341}$ Zola se ocuparía de ellos, en la persona de Maxime - hijo del especulador Aristide Saccard- en su novela $\mathrm{La}$ Curée. Recordemos que este joven había permanecido largo tiempo oculto en la provincia profunda mientras su padre, ya viudo, no estuviera en condiciones de ofrecerle un patrimonio extraordinario.

Maxime es un joven elegante típico de la época, que se desplaza al Lycée Condorcet en un ágil tilbury — como el resto de sus compañeros de clase social—, que fuma finos cigarrillos ingleses sacados de elegantísimas pitilleras, y que, sobre todo, extrema los ciudados de su atuendo. Cuando

340 H. de Balzac, La Peau de chagrin, ob. cit., p. 258.

341 Notas tomadas de la edición crítica realizada por Henri Miterrand de É. Zola, La Curée, Gallimard-Folio, París, 1981. 
se dirigía, todas las tardes, a ese escaparate social que era el Bois de Boulogne, "pincée à la taille comme une femme» (observar la similitud con la redingote del Maxime balzaciano), bailando ligeramente sobre la silla de su montura, «il était le dieu de cet âge, avec ses hanches développées, ses longues mains fluettes, son air maladif et polisson, son élégance correcte et son argot des petits théâtres». ${ }^{342}$ Dios afeminado y muelle, de anchas caderas, de largas y ociosas manos... la decadencia misma de la especie humana, como se lamentaba Zola. En efecto, todo este exagerado refinamiento estético es, según el jefe del Naturalismo, síntoma de una degeneración completa de la masculinidad tradicional en un tiempo en que el ocio capitalista no hace sino engendrar monstruos. Clase social en la que se incuban todos los vicios, pues el aburrimiento provocado por la inactividad debe ser llenado con dulces cada vez más azucarados, con sensaciones cada vez más extasiantes. "Le vice chez lui n'était pas un abîme, comme chez certains vieillards, mais une floraison naturelle et extérieure», — dice, en el mismo párrafo, de Maxime. En efecto, Zola denunciaría en el periódico de La Tribune del 6 de diciembre de 1868 la actitud de esos jeunes désoeuvrés afectados de un cierto éréthisme nerveux. Dos años más tarde, y desde las páginas de Le Rappel, Zola asocia este modelo a un tipo de ascendencia balzaciano, y ataca a esos

hommes femelles grandis dans les jupons des dames [...] ces gentilshommes pourris, ces misérables gantés de blanc, souples comme des femmes [...] [con] leur sourire vague de viveurs épuisés. ${ }^{343}$

Vividores agotados: esperable diatriba de un revolucionario de las letras que veía en el trabajo la única vía para la liberación personal. Sea como fuere, el afeminamiento entró a formar parte del paradigma del dandi decimonónico. La elegancia, el gusto por el detalle, la extravagancia llamativa, iban perfectamente de la mano con una actitud femenina, indolente e incluso un tantinet histérica. Ya tendremos tiempo de desarrollar la feminidad del dandi en el momento en que tratemos la sexualidad de estos nuevos hombres, tallados en una piedra doliente y fina en base a un modelo alternativo de masculinidad.

342 É. Zola, La Curée, ob. cit., p. 152.

343 Citado por Henri Miterrand, en su edición crítica de La Curée, ob. cit., p. 374. 


\subsubsection{La corriente byroniana del dandismo}

Esta corriente hizo su aparición con anterioridad al modelo de corte brummelliano. Como relata Chateaubriand en la crónica de su estancia en Inglaterra, el primer tipo de dandi estaba integrado por un hombre cuya singularidad residía en su aspecto doliente y melancólico, de mirada perdida y fatal. Es, como no podía ser menos, la influencia romántica en la masculinidad del siglo XIX, que producía esa caterva de personajes de pathos terrible y desesperado que parecían cargar con los remordimientos de una existencia sufriente. A diferencia del dandi brummelliano y précieux, el dandi de corte byroniano no cuidaba su vestimenta más que en los detalles que le podían conferir una cierta peculiaridad individual — que hoy en día los trend-setters han bautizado como dirty chic:

il devait avoir quelque chose de négligé dans sa personne, les ongles longs, la barbe non pas entière, non pas rasée, mais grandie un moment par surprise, par oubli, pendant les préocupations du désespoir; mèche de cheveux au vent, regard profond, sublime, égaré et fatal; lèvres contractées en dédain de l'espèce humaine; cœur ennuyé, byronien, noyé dans le dégoût et le mystère de l'être,

señalaba Chateaubriand. ${ }^{344}$ La elegancia de este dandi romántico se basa más en la actitud, estudiada y depurada, que en el aspecto exterior — que, como sabemos, era irreprochable en el caso de, por ejemplo, un Brummell. El dandi byroniano busca más bien hacerse reprochar, ser reprochable por su capacidad, precisamente, de provocación. Para muchos creadores de moda de aquella época, esta actitud denotaría, sin duda, un mal gusto terrible. Ahora bien, esa actitud consistente en separarse y desmarcarse mediante un gusto otro de la elegancia de conveniencia no dejaba de ser reivindicativa de otra elegancia peculiar y personal. Allí radica el vínculo del dandismo con el romanticismo: la búsqueda de la singularidad personal, incluso a través de la tan manida fórmula cien años después de épater le bourgeois. El dandi romántico busca, de esta manera, posicionarse en una aristocracia del gusto alternativo, superando así la pose de la elegancia al uso. Es el aspecto de la distinción que comenta el sociólogo Pierre Bourdieu: la singularidad pierde la posibilidad de ser distintiva en la medida en que es adoptada por más individuos. ${ }^{345}$ De ahí que el mal gusto sea la distinción

344 F.-R. de Chateaubriand, ob. cit., p. 295.

345 P. Bourdieu, Notions de sociologie, Minuit, París, 1984. 
verdadera frente al buen gusto estipulado — desagradar es lo realmente distintivo frente al gustar. Así lo veía también el Baudelaire de Fusées: "ce qu’il y a d'enivrant dans le mauvais goût, c'est le plaisir aristocratique de déplaire». ${ }^{346}$ En ese gusto aristocrático de desagradar cabe toda actitud alternativa. Si el desagrado es la regla, la vestimenta no deja de ser importante para significar el rechazo a una convención de elegancia burguesa. Este nuevo dandi se reconocerá en el habit râpé, en la ropa desgastada por la vida y las experiencias. "Voilà un véritable fait de dandysme: l'habit n'y est pour rien: il n'est presque plus», señala Baudelaire en su Peintre de la vie moderne. $Y$ hasta tal punto este signo de reconocimiento era esencial a la vestimenta del dandi que, según señala, era frecuente que estos elegantes se estropearan el abrigo con un trozo de vidrio. ${ }^{347}$

Como estamos viendo, la indumentaria tenía un valor negativizante, pues su tratamiento de conversión en harapo cumplía una función identificativa. Aun con eso, cabe señalar que la profesión de fe del dandi iba por dentro. A medida que el dandismo se interioriza, cada vez se recurre menos a estos signos de una distinción superficial. La elegancia del nuevo dandi — del dandi byroniano, romántico — gana la partida al dandi estereotípico en el campo de batalla de la pose, del posicionamiento. Mientras la elegancia convencional se había convertido en una trivialidad al alcance de cualquier bolsillo pudiente, el dandismo otro era una cuestión de actitud: corazón anegado en los misterios profundos del ser — como diría Chateaubriand. Se trata de un don que el dinero no puede comprar; una serie de características que se adquieren solo con una cierta experiencia de la vida.

Ese dandi pobre, fatal, heroico y sombrío - que recibe en el café y cuya galería de espejos está en la calle, como dice Patrick Waldberg-348 huye de los salones, de las carreras y del Bois: lugares predilectos del petit crevé parisién. Porque su huida de la trivialidad elegante le lleva a posicionarse en una actitud de protesta ante la sociedad en general: negar la eminencia de esa elegancia trivial le llevaba a protestar ante los valores que esa misma clase personificaba. Los dandis franceses — como señala Hans

346 C. Baudelaire, Fusées, ob. cit., Fusée, n.o XII, p. 18.

347 E. Carassus, ob. cit., p. 277.

348 P. Waldberg, "Les rois frivoles», en Dandies and dandism, United States Lines, 1962, p. 133. 
Hinterhäuser- ${ }^{349}$ se convertirían en marginados sociales, en individuos solitarios y opuestos al dominio de aquella masa hostil al arte y al espíritu. La aceptación de este destino se traduce en orgulloso aislamiento: para compensar esa pérdida en el orden social, el dandi se refugia en una agresiva conciencia de elite y en una actitud esteticista sin imitación posible. Típica de tal actitud será la búsqueda de un utópico ( $u$-topos, porque no existe) anywhere out of the world baudelairiano; o de la Tebaida gloriosa y tranquila del san Antonio flaubertiano. O, todavía más centrados en nuestro tema: en el Fontenay-aux-Roses donde se refugia des Esseintes huyendo del mundanal, ramplón e incómodo ruido.

Je vois en toi quelque chose qui offense le vulgaire. La jalousie et la calomnie te poursuivront. En quelque lieu que la Providence te place, tes compagnons ne te verront jamais sans te haïr; et s'ils feignent de t'aimer, ce sera pour te trahir plus sûrement.

Así vaticina el abate Pirard a Julien Sore ${ }^{350}$ su separación del mundo de las personas normales y simples. $Y$ al verse separado de sus congéneres por obra de la difamación y la calumnia, rechazado por su singularidad, la única posibilidad para este dandi romántico — que no puede evitar ser un sentimental- es la rebelión. Rebelión contra los valores establecidos, contra la ramplonería ambiente asentada en la moralidad al uso -mayormente establecida por la cultura religiosa occidental, el catolicismo.

Como sostiene Carassus, ${ }^{351}$ la transgresión moral del dandi concierne los valores morales de la comunidad. Un dandi virtuoso es inconcebible, pues la virtud convencional no puede sino resbalarle. Su escala de valores es diferente, su actitud se basa en la negación de lo trivial y la afirmación de sí: solo hallará pleno de dignidad el acto que transgreda la virtud habitual, proponiendo con ello una ruptura con la moral convencional. ¿Cómo entender sino desde esta óptica ese acto cruel y despiadado que realiza Baudelaire contra un viejecito en "Assommons les pauvres»? No deja de ser, como demuestra el poeta al final del texto, la puesta en prác-

349 H. Hinterhäuser, Fin de siglo. Figuras y mitos, trad. de M. a Teresa Martínez, Taurus, Madrid, 1980, p. 75 y ss.

350 Stendhal, Le Rouge et le noir, ob. cit., p. 203.

351 E. Carassus, ob. cit., p. 158. 
tica de un principio filosófico revolucionario que plantea la fraternidad del dandi con el miserable, con el harapiento, con ese viejo saltimbanqui que se pudre en su caseta de feria. ${ }^{352}$

Sin embargo, la relación del dandi con el crimen es puramente retórica. La participación activa en cualquier acto significante y violento es, por regla general, evitada: la crueldad debe sublimarse por su aspecto verbal, refinarse gracias a su aspecto estético, gracias a la belleza del acto por sí mismo. Amante de la pose y la actitud, las acciones excesivas del dandi serán, por lo general, demostraciones de estilo.

Aún y todo, existe un tipo de dandi en el que se dan cita estos dos aspectos de rebelión romántica y de excepción social y que sí que lleva a la práctica sus postulados filosóficos. Se trata de una ideología de reivindicación del fuera de la ley, del facineroso generoso y de estricta moral: peligroso pero justo con quien lo merece, porque su singularidad le permite crear un nuevo código basado en normas aconvecionales. ${ }^{353}$

\section{a) El dandi facineroso: el Vautrin de Balzac}

Balzac fue uno de los primeros que esbozó al figura de este dandi «peligroso", cuasi mefistotélico, en el personaje de Vautrin: el héroe en negativo que hace el penchant a los jovencitos de la Comédie humaine. Hinterhäuser lo llama el dandi sobrehumano, ${ }^{354}$ a causa de su capacidad fuera de toda medida para sobreponerse a los avatares del destino.

Por su habilidad para el disfraz — recordemos que pasa gran parte de Splendeurs et misères des courtisanes transmutado en el sacerdote español Carlos Herrera-, Jacques Collin/Vautrin es un personaje que se renueva y se crea a sí mismo continuamente. Su poder de decisión sobre su futuro, su capacidad para influir sobre las circunstancias para que estas se decanten en el sentido del fin buscado, hacen de Vautrin un semi-dios capaz de todo.

352 C. Baudelaire, Le Spleen de París (suivi de La Fanfarlo), G. F.-Flammarion, París, 1987. Los poemas referidos son "Assommons les pauvres» (XLIX) y "Le Vieux Saltimbanque» (XIV).

353 Así lo supo ver perfectamente Albert Camus, en su ensayo L'Homme révolté, más precisamente en el capítulo «La Révolte des dandys», en A. Camus, ob. cit., p. 74.

354 Ib., p. 72. 
«Un homme qui, après avoir examiné les choses d'ici-bas, a vu qu'il n'y avait que deux partis à prendre: ou une stupide obéissance ou la révolte» —-dice Vautrin de sí mismo en Le Père Goriot. ${ }^{355}$ Esa actitud le ha llevado a ser ingresado en prisión en numerosísimas ocasiones; tantas que, por su carácter maquinador y su inteligencia fuera de lo común, se convierte en el tesorero y jefe de la gente del presidio: una especie de comisionado de los presos en el mundo exterior, cuya rectitud salvará a las familias de los presidiarios de la miseria. Y lo que es más, se presta como garante de la seguridad de los suyos en el presidio: en la tercera parte de Splendeurs et misères... lo vemos salvar de la guillotina a su camarada corso. Más tarde, y en razón de los servicios que dispensa a Mme. de Sérisy —en profunda depresión por la muerte de Lucien en Splendeurs...-, es nombrado policía, función que ejerce durante 15 años y que le valió el sobrenombre de «le Napoléon de la police». ${ }^{356}$

La persona en quien confían todos los fuera de la ley no puede sino haber crecido en una moral diferente; la moral de una sociedad hecha de gente que ha entendido medrar a costa de los ladrones legales: banqueros, políticos, grandes funcionarios. Jamás Vautrin toma la defensa de una causa que le parezca injusta: «je suis comme don Quichotte, j’aime à prendre la défense du faible contre le fort», apunta en otro pasaje del Goriot. ${ }^{357}$ Sin embargo, no pestañea cuando se trata de ajusticiar a un traidor, de hacer justicia contra una injusticia. Y es que no comprende una vida sin honor, sin la dignidad humana. Prueba fehaciente de ello es cuando, en conversación profunda y detenida con Rastignac, le señala la necesidad de tener dinero para cumplir buena parte de sus propósitos vitales. Ahora bien, ¿`cómo albergar siquiera la idea de hacerlo casándose con una mujer?: «si vous vous mariez pour de l'argent, que deviennent nos sentiments d'honneur, notre noblesse!

355 H. de Balzac, Le Père Goriot, ob. cit., p. 124.

356 Este era el sobrenombre de François Vidocq, presidiario y policía después, tal y como se señala en M.-H. Parinaud, Vidocq, le Napoléon de la police, Taillandier, París, 2001. No en vano, fue el modelo en que se inspiró Balzac para la creación de su Vautrin; Hugo para la de su Jean Valjean de Les Misérables; Maurice Leblanc para su Arsène Lupin (uno de los pseudónimos de Vidocq); y, finalmente, Arthur Conan Doyle para dar vida a su Sherlock Homes. «Son elementos suficientes para entrar a formar parte de la leyenda», dice la profesora Àngels Santa, en su reseña del estudio de Parinaud, en A. Santa, «Ressenyes», en L'Ull Crític, Universidad de Lérida, n. ${ }^{\circ}$ 8, 2003, p. 310.

357 H. de Balzac, Le Père Goriot, ob. cit., p. 134. 
Autant commencer aujourd'hui votre révolte contre les conventions humaines». ${ }^{358}$ Honor, nobleza... En la boca de un condenado a trabajos forzados y escapado de un presidio podría sonar a cinismo puro. Nada más lejos de ello: la actitud de Vautrin está habitada por el más serio y más estricto de los códigos éticos que puedan hallarse en toda la literatura del siglo XIX.

Vautrin es dandi por su actitud rebelde, por su autonomía e independencia, por la admiración que despiertan sus acciones, por su imperio absoluto sobre todo lo que le rodea: capaz hasta de burlar la muerte - de ahí su sobrenombre, Trompe-la-Mort. Es un aristócrata del presidio, de la nobleza de la moral alternativa: marca la distinción en un mundo de convenciones.

Esa alianza entre su carácter transgresor pero justo - y por eso mismo sometido por una sociedad que se convierte, par ricochet, en injusta - hace de Vautrin la perfecta encarnación del ángel caído: el demonio en la Tierra que va a clamar y a luchar con uñas y dientes por la reparación de su honor. Y no faltan las referencias diabólicas en la obra de Balzac señalando la personalidad de este presidiario sobrehumano. Su rabia, su fuerza, su determinación — que premanece humana por su consideración de los sentimientos- le aportan un aura de "poème infernal»: «son regard était celui de l'archange déchu qui veut toujours la guerre». ${ }^{359} \mathrm{Y}$ como buen arcángel demoniaco, a su disposición se hallan siempre esos «dix mille frères prêts à tout faire pour vous»: ${ }^{360}$ su nombre es Legión - como el nombre que dio el poseso preguntado por Jesucristo en el Nuevo Testamento (San Marcos 5, 9). ${ }^{361}$ Huestes demoniacas que acompañan siempre al diablo en su errática reconquista del mundo y el universo.

b) Dandismo y romanticismo: la figura clave de Baudelaire

Es en este punto donde el carácter sobrehumano (Hinterhäuser) del dandi balzaciano alcanza su grado máximo: en su identificación con el diablo. Y es allí precisamente donde se demuestran las concomitancias entre el dandismo y el romanticismo:

358 Ib., p. 127.

359 Ib., p. 238.

360 Ib., p. 240.

361 Y Jesús le preguntó: «¿Cómo te llamas?». Él respondió: «Mi nombre es Legión, pues somos muchos», en La Santa Biblia, trad. de Evaristo Martín Nieto, Ediciones Paulinas, Madrid, 1964, p. 1191. 
— soledad del héroe romántico;

- soledad del ángel caído;

- soledad del creador romántico;

- actitud rebelde y de protesta contra todo y todos.

En realidad, el romanticismo inaugura las líneas de una estética que todavía tienen cierta vigencia: la del creador solitario, rival obstinado - como dice Camus - ${ }^{362}$ de un dios a quien condenan y a quien quieren sustituir con la moral de su obra: un orden nuevo en que los valores de justicia pasen ante todo. La rebelión se produce contra el orden impuesto por un dios injusto y cruel, que predica la bondad pero solo administra miseria. De ahí toda la relación del dandi romántico con el mal: por nostalgia del bien, en base a una reivindicación casi infantil de las expectativas frustradas, se ve forzado a cometer el mal. "Puisque Dieu revendique ce qu'il y a de bien en l'homme, il faut tourner ce bien en dérision et choisir le mal» - señala de nuevo Camus. Por eso, el dandismo puede ser considerado, a la par que una apuesta estética y/o estetizante, una réplica al orden establecido, una insumisión a los designios del tirano creador: una filosofía, en puridad, de la ascesis, que busca la pureza, la nobleza y el honor en la rebelión completa.

La herencia del romanticismo, como hemos podido ver hasta ahora, no es recogida por Hugo — par de Francia, poeta «oficial» y condecorado-, sino por otros creadores: "poetas del crimen», como les llama Camus, ${ }^{363}$ Baudelaire y Lacenaire.

Baudelaire fue el más profundo teórico del dandismo, aportando fórmulas definitivas a una de las conclusiones de la rebelión romántica. Por eso, el autor de Les Fleurs du mal es, fuera de toda duda, un autor romántico - en las postrimerías del romanticismo, pero romántico: es ocioso colocarlo dentro de la categoría de poeta simbolista que algunos se afanan en darle. Baudelaire es un faro ${ }^{364}$ en medio de toda la poética del siglo XIX: una figura de transición, un punto de inflexión entre la modernidad y la contemporaneidad.

362 A. Camus, ob. cit., p. 74.

363 Ib., p. 73.

364 Faro: referencia a uno de sus poemas más célebres: «Les Phares» (Spleen et Idéal-VI). 
Glosar en profundidad la figura de Baudelaire está fuera de las intenciones de este trabajo; no hay que dejar de lado, sin embargo, su influencia en la literatura de la segunda mitad del siglo XIX y, sobre todo, en Huysmans y las estéticas decadentes, en un estudio que pretenda sondear la evolución de la masculinidad durante dicho siglo.

Como decíamos, Baudelaire es, por una parte, romántico: por su estética dolorosa, su delectación en unos temas sacados directamente del imaginario romántico, su gusto por una estética del fracaso frente a la más trivial estética del triunfador medio, el autor de Les Fleurs du mal es el último de los románticos. Su gusto por la rebelión, por la provocación, por su odio a Dios y a todo el poder establecido, por sus deseos de justicia social... Baudelaire es un moralista que sólo encuentra útil el recurso al grito y la blasfemia para convencer al ciudadano medio de la iniquidad de la sociedad del momento. Parece, en su obra, cantar las alabanzas de un mundo podrido y olvidado, pero aun con todo poblado de seres con un pasado y un presente, cuyo futuro da escalofríos a cualquiera que esté dotado de una mínima sensibilidad humanista.

Por estas razones llama la atención que un humanista que se llena la boca de las máximas revolucionarias haya elegido al ultraconservador Joseph de Maistre como su maître à penser. Y esto es así por la lógica que establece el filósofo entre el verdugo y la muerte: «le vrai saint est celui qui fouaille et tue le peuple pour le bien du peuple» — dirá el poeta. Pues el vulgo - y en esta denominación incluye a todo aquel que no participa de la exclusiva aristocracia baudelairiana - no parece enmendarse más que con el correctivo propuesto por el garrote o el látigo. Así lo demuestra el poeta en prosa en su texto "Assommons les pauvres» —ya comentado anteriormente. Y es que los demás ya han hecho gala de su crueldad en la persona del sensible dandi, en el corazón de piedra fina del poeta:

Tous ceux qu'il veut aimer l'observent avec crainte,

Ou bien, s'enhardissant de sa tranquilité,

Cherchent à qui saura lui tirer une plainte,

Et font sur lui l'essai de leur férocité. ${ }^{365}$

365 «Bénédiction», en Spleen et Idéal. C. Baudelaire, Les Fleurs du mal, Librairie Générale Française-Le Livre de Poche, París, 1972, p. 11. 
Así se lamenta de la mala suerte que corren sus buenos sentimientos por los demás: él, que observa a sus semejantes con la piedad de quien cree poder comprenderles y empatizar con sus miserias, recibe, como premio a su acercamiento, golpes y mordiscos: sobre él se ensañan mostrándole su fiereza. Porque la humana condición, criada en la maledicencia y el rencor, educada en el odio hacia el prójimo, en la práctica de la crueldad gratuita, solo merece recibir los mismos golpes que el poeta ha recibido. Cómo no recordar esos versos del célebre poema "L'Albatros», en que el poeta es comparado al ave que se debate, torpe e ingenua, entre las risas de los marineros de un barco «qui prend le large»:

Le Poëte est semblable au prince des nuées

Qui hante la tempête et se rit de l'archer;

Exilé sur le sol au milieu des huées,

Ses ailes de géant l'empêchent de marcher. ${ }^{366}$

Se dan, si hacemos caso de todo lo expuesto aquí, tres características típicas en la estética dandiesca baudelairiana: sensibilidad vengativa, desdicha serenamente aceptada, melancolía vital. ¿No son estas las características del dandi que él reclama en sus Fusées?:

— l'idée d'une puissance grondante, et sans emploi —quelquefois l'idée d'une sensibilité vengeresse;

- le Malheur - je ne prétends pas que la Joie ne puisse pas s'associer avec la Beauté, mais je dis que la Joie (en) est un des ornements les plus vulgaires;

- la Mélancolie en est pour ainsi dire l'illustre compagne, à ce point que je ne conçois guère $[. .$.$] un type de Beauté où il n'y ait point de Malheur. { }^{367}$

El dandi desdichado, dotado de esa puissance grondante et sans emploi - que en el caso del dandi patibulario balzaciano habíamos llamado, siguiendo a Hinterhäuser, «sobrenatural»— reviste en la poética de Baudelaire dos figuras posibles: el vampiro y el diablo.

\section{c) El vampiro}

El vampiro se convirtió en un leitmotiv habitual en la literatura gótica que nació a finales del siglo XVIII e instaló sus ramificaciones a lo largo de

366 «L'Albatros», en Spleen et Idéal, ib., p. 180.

367 Las tres citas extraídas del mismo párrafo en C. Baudelaire, Fusées, ob. cit., n. ${ }^{\circ}$ X, p. 56. 
todo el siglo XIX. Asociado a todas las criaturas maléficas, el mito parece alimentarse de la personalidad del rumano Vlad Dracul ${ }^{368}$ — cuya crueldad con sus enemigos, durante la guerra de liberación de Rumanía del Imperio turco, fue proverbial: gustaba de empalar a sus prisioneros masivamente, diciéndose de él —extremo jamás comprobado— que bebía la sangre de sus sacrificadas víctimas.

El personaje del vampiro sufrió varios avatares hasta su fijación en la célebre novela del irlandés Bram Stoker, en 1895. Cabe decirse que los antecedentes de esta novela están, mayormente, en el ámbito anglosajón. Citemos algunos de ellos:

La primera obra de tintes marcadamente vampíricos es el poema Thalaba the Destroyer, composición de resonancias épicas escrito por Robert Southney en 1799. Dos décadas más tarde, en 1819, Lord Byron publicaría Fragment of a Story como apéndice al poema Mazeppa. Es esta una obrita que parece ser el esquema de un proyecto nunca llevado a cabo, y en el que dan ya en esbozo los elementos que debían ser inseparables del mito: dos jóvenes ingleses que realizan su iniciático viaje de Grand Tour del continente; escala prolongada en Grecia; separación de los amigos; enamoramiento de una bella local, cuyo amor no puede completarse debido a su muerte repentina; reencuentro de los amigos; muerte de uno de ellos; y, por fin, vuelta a Inglaterra donde el amigo difunto lleva una intensa vida social.

Otra vez Byron se ocuparía del tema vampírico en su poema The Giour (el infiel), A Fragment of a Turkish Tale. También Yeats trataría el tema, con su Lamia - que incluye el ya tópico cruce entre lo vampírico y lo helenístico.

Pero, sin duda alguna, el verdadero precursor del género fue John Polidori, a la sazón médico particular de Byron cuando este se instaló en la Villa Diodati, en Ginebra -mítico lugar del encuentro entre los Shelley y Byron, del que saldrían, como todo el mundo sabe, el Frankenstein de Mary Shelley, y este The Vampyre.

368 Parece más históricamente acertado el nombre de Vlad Tepes, según indica el mismo título de R.-P. Märtin, Los Drácula. Vlad Tepes, el Empalador, y sus antepasados, Tusquets Andanzas, Barcelona, 2001. 
Se trata, en la obra de Polidori, del definitivo ensamblaje de todos los rasgos del género, que serían copiados y plagiados hasta la saciedad, contribuyendo con ello a la creación de un mito - como señala Antonio Ballesteros en Vampire Chronicle. ${ }^{369}$ Escrita en 1816, fue publicada en una revista en 1821 con firma de Byron. Este, sabedor de que el escrito pertenecía a su médico — con quien rompió en una de sus múltiples peleas-, escribió a la revista indignado por haber sido asociado con un género que decía detestar. La autoría fue devuelta a Polidori, cobrando por ello una ridícula cantidad. Es el caso de Polidori el más claro de injusticia literaria que se haya hecho en el mundo literario - cuya responsabilidad en la construcción del mito debería ser reconocida y puesta en su debido sitio.

Sea como fuere, el vampiro es un personaje interesante por su capacidad para simbolizar la fatalidad máxima. Condenado a vagar durante toda la eternidad, su no-vida consiste en alimentarse de la sangre que recoge de sus víctimas humanas - a quienes convierte, automáticamente tras intercambio del rojo fluido vital, en miembros de su desdichada especie.

Por su biología nocturna y fantasmal, el vampiro se adapta perfectamente a la personalidad transgresora y alternativa del dandi de corte byroniano. Su moral va en contra de la moral convencional. Y lo que es más; como ańos después de la muerte de Baudelaire señalaría Stoker, la humanidad positivista y garante de las buenas costumbres perseguiría al vampiro para expulsarlo de la sociedad — como paso previo a su definitiva destrucción. La injusticia se abate sobre este desdichado muerto viviente, quien, lejos de contar con la bondad y la fraternidad de sus semejantes los hombres, es denostado y martirizado como el poeta o el dandi.

Baudelaire debió de tomar contacto con la temática vampírica sin ningún género de dudas: el género era suficientemente célebre en el París de la segunda mitad de siglo. Tras la difusión que conoció la obra de Polidori atribuida a Byron - atribución que debió de interesar a los programadores de espectáculos de la época-, los escenarios de París se llenan de piezas teatrales del mismo tema, con posteriores adaptaciones de Nodier y de Alejandro Dumas, que contribuiría a consolidar esta vertiente con una versión dramática de Le Vampire de Nodier titulada de manera homónima (1851).

369 A. Ballesteros, Vampire Chronicle. Historia natural del vampiro en la literatura anglosajona, Unaluna, Zaragoza, 2000, p. 50. 
La tipología del vampiro decimonónico, según el estudioso Christopher Frayling, ${ }^{370}$ es varia. Por una parte, el vampiro puede revestir los ropajes de un aristócrata demoníaco o satánico; puede encarnarse en la persona de una mujer fatal; puede convertirse en una especie de fuerza invisible - el vampiro psíquico, del que en la literatura francesa podemos encontrar un eco en Le Horla de Maupassant; y, finalmente, el vampiro folclórico, que se daba exclusivamente en los cuentos y leyendas de transmisión oral del ámbito rural.

Baudelaire, aun cuando el personaje podría haberle sido muy útil para la transmisión de su estética, solo trata con vampiros en unas pocas composiciones de Les Fleurs du Mal. En «L'Héautontimorouménos» (Spleen et Idéal-LII), el dandi byroniano parece empatizar con la suerte del personaje:

Un de ces grands abandonnés

Au rire éternel condamnés,

Et qui ne peuvent plus sourire! ${ }^{371}$

y que coincide perfectamente con la estética siniestra del poeta. Dice, sin embargo, ser él el propio vampiro de su corazón —como si estuviese habitado por una especie de Döppelganger que se alimentase de las energías que el spleen le arrebata. Así, dice en el verso anterior "Je suis de mon cœur le vampire» - lo que puede entenderse mejor si se contrasta con el último cuarteto de «Le Vampire» (Spleen et Idéal-XXIX), en el que, tras hablar del imperio al que le somete la mujer amada — fuente de todos los placeres y, por ende, de la esclavitud-,${ }^{372} \mathrm{el}$ poeta pide consejo al veneno y a la espada. Estos le responden que, de hacerse efectiva su acción, el cadáver de su vampiro resucitaría a un mundo de desdicha — que sería el del sometimiento a la propia soledad:

Imbécile! — de son empire
Si nos efforts te délivraient,
Tes baisers ressusciteraient
Le cadavre de ton vampire!

370 C. Frayling, Vampyres, Faber, Londres, 1991, p. 62. Recogido por Antonio Ballesteros, ob. cit., p. 38 .

371 C. Baudelaire, Les Fleurs du mal, ob. cit., p. 81.

372 Vv. 7-12: «Infâme à qui je suis lié / Comme le forçat à la chaîne, / Comme au jeu le joueur têtu, / Comme à la bouteille l'ivrogne, / Comme aux vermines la charogne, /Maudite, maudite sois-tu!». Ib., p. 58. 
No obstante esta identificación del poeta —o de su doble- con el personaje, la estética baudeleriana adopta sin ningún tipo de problema una de las figuras que describe la tipología de Frayling: la de la mujer fatal. Así, en el poema "Les Métamorphoses du vampire» (Fleurs du Mal-LXXXVII), la mujer amada es identificada con el sanguíneo personaje. Una figura maldita, poseedora de saberes ocultos tal vez por su estereotípica relación de la mujer con los poderes de la Tierra: «[...] je sais la science / De perdre au fond d'un lit l'antique conscience». Esta vampira provoca el temor en el poeta de ser succionado hasta perder la totalidad de su fluido vital — que no deja de revelarnos un complejo de castración bastante frecuente en la obra del poeta: "Quand elle eut de mes os sucé toute la moelle [...]».

A la luz de estas consideraciones, el personaje del vampiro en la estética baudeleriana es un figurante que sirve para la principal actuación que es la del dandi de corte byroniano. Figurante que tan pronto se asimila a la personalidad oculta del poeta — peligrosa y generadora de malestar-, como a la amada que, por su vigor sexual, es capaz de acabar con su vida. Es un figurante que actúa a modo de espejo sobre el poeta, en una clara proyección exterior de un imaginario basado en sus miedos y obsesiones. En ambos casos, se trata de figuras suficientes y poderosas, que transgreden el normal estado de cosas, y que participan de las características que el poeta había enunciado en Fusées: sensibilidad vengativa, desdicha y melancolía.

Desde un punto de vista psicológico, cabe pensar en la analogía que pueda existir entre la sangre — dadora de vida - y la leche materna. El personaje del vampiro simbolizaría, fuera de toda duda, el deseo del adulto en volver al cómodo seno materno que le devolvería la juventud y el vigor. Ya sea como vampiro activo - que extrae la sangre de sus víctimas- como víctima vampirizada, existe en el vampirismo literario esa aspiración a regresar a la fusión originaria con la madre.

Por otra parte, el vampiro, en su anhelo de resucitar el cuerpo, se puede convertir en un contraejemplo de Cristo - como sugiere Justo Serna: ${ }^{373}$ su utilidad como figura rebelde es, gracias a ello, enorme. Su cabida en una sociedad en trance de desarrollarse tecnológica y socialmente, el vampiro puede ser la personificación del hombre que no tiene cabida en la moder-

373 J. Serna, ob. cit., p. 65. 
nidad: un nostálgico de tiempos mejores. Su rebelión contra los tiempos modernos, hechos de ciencia y materia, encuentra en el vampiro, por ello, un perfecto actor. Así lo ha visto también el filósofo Peter Sloterdijk, quien señala en «El desprecio de las masas»: "El señor de ayer, que hoy ya no encuentra su lugar en ningún sitio, se transforma en un vampiro, es decir, en la visión metafísica de un hombre inútil del ancien régime». Su entroncamiento en el imaginario del dandi romántico es, con todo ello, perfecto: rebelión violenta, regresión agresiva a la madre, nostalgia militante del antiguo régimen... El vampiro es una figura de raigambre materna, mientras que Satán lo sería paterna.

d) Satán: modelo viril por excelencia

La encarnación perfecta del ideario estético de Baudelaire es, sin duda alguna, el Diablo. Por su cercanía al modelo ideal de personaje maldito, ángel caído que un día conoció la gloria, «le plus parfait type de Beauté virile est Satan —à la manière de Milton»-, como señala en Fusées. ${ }^{374} \mathrm{Y}$ es belleza viril por las cualidades inherentes al tópico: se trata de un révolté contra la injusta tiranía de bondad hipócrita del dios de los cristianos. Su naturaleza rebelde le lleva a encontrar en el mal una definición de lo que debería ser el bien, concepto este que ha sido viciado e indebidamente apropiado por la religión de la pena y el pecado. Su comisión del mal, que podría parecer gratuita, se convierte por ello en una apuesta filosófica, digna de un héroe romántico.

Y es que el diablo, Satán, será el paradigma del héroe rebelde por excelencia, más allá incluso de las hazañas del dandi patibulario — que, como hemos visto, reviste un carácter diabólico bastante evidente. Con una gran capacidad para la rebelión, Satán es un revolucionario en medio del injusto sistema divino, del que fue echado por protestar y criticar la política de Dios padre.

Siendo un ángel caído — ange déchu—, su origen es aristocrático. Pero, desclasado voluntariamente — por la fuerza de sus principios_-, Satán inaugura una nueva aristocracia, rompedora y transgresora, en la que se res-

374 C. Baudelaire, Fusées, ob. cit., p. 57, Fusée, n.o X. 
petan los valores de amor e igualdad. Valores que predica el catolicismo pero que ni su ministerio en la Tierra ni las acciones divinas recogidas en el Viejo Testamento parecen atestiguar.

El ministerio de Dios en la Tierra está regido por los sacerdotes, quienes, en lugar de favorecer a los dejados-de-la-mano-de-Dios, fortalecen la moral exclusiva, ramplona e insolidaria, de la burguesía emergente. De quién esperar ayuda, a quién encomendarse cuando la propia vida está plagada de infortunios y carente de un horizonte de salvación. Satán se convierte, por eso mismo, en un referente inexcusable para el mendigo y la prostituta, para el viejo borracho, el paria... el proscrito por todo y todos. La aristocracia de Satán se convierte en un faro, en una tierra de promisión para todos los repudiados de la sociedad, con cuyo ejemplo les muestra un camino de nobleza y dignidad: la del rebelde con causa.

Uno de los paradigmas de la admiración por el personaje de Satán es Alfred de Vigny. En dos de sus poemas, «Éloa ou la Soeur des Anges» (de 1823) y «Satan», el poeta romántico destila toda su teoría sobre la indefensión ante el mal en que ha sido creada la criatura humana. Como señala G. Bonnefoy en su ensayo La pensée religieuse et morale d'A. de Vigny, ${ }^{375}$ Dios es el único culpable ante la dejación que ha hecho del espíritu librado a la tiranía de la materia y la carne:

Tous les anges disaient: l'esprit est-il puni?

D'où vient qu'à la matière il passe réuni?

Pourquoi traverse-t-il cette existence impure?

Pourquoi la mort, la mort, et pourquoi la nature?

dice Vigny en «Satan». ${ }^{376}$ Por su necesidad de adulación y de poder, Dios es el único responsable del mal que se ha abatido sobre los humanos. Enfermedades, muerte, la esclavitud a la materia, son los efectos de esa necesidad de servilismo del Dios de la bondad en que ha sido sumido el Hombre.

Con esto, la rebelión satánica aparece, ante el poeta, como un acto de solidaridad hacia la humanidad; las demoniacas lágrimas se convierten

375 G. Bonnefoy, La pensée religieuse et morale d'A. de Vigny, Hachette, París, 1944.

376 A. de Vigny, Poésies, ed. A. Bouvet, Éditions de Cluny, París, 1937, p. 238. 
en un rasgo de piedad, en una voluptuosidad morbosa que no es otra cosa que un rasgo de la grandeza del Hombre frente a la iniquidad del Creador.

Vigny alaba las funciones liberadoras de la influencia diabólica sobre los parias de la tierra: los lloros de Satán por la suerte del esclavo consiguen liberarlo de su yugo, concediéndole al mismo tiempo una nobleza de alma, un charme que la influencia de Dios y su terrible credo había desbaratado. Es un personaje cuya vocación, en definitiva, es de consolar al desdichado. Así, dice el Satán de sí mismo en "Éloa ou la Sœur des Anges»:

Ce méchant qu'on accuse est un Consolateur Qui pleure sur l'esclave et le dérobe au maître, Le sauve par l'amour des chagrins de son être, Et, dans le mal commun lui-même enseveli, Lui donne un peu de charme, et quelquefois l'oubli.

Vigny ejerció una importante atracción sobre la imaginación poética de Baudelaire - en cuya obra se observan no pocas concomitancias con el discurso del romántico. Aristocracia del ángel caído, solidaridad con los que sufren, revuelta ante la iniquidad: elementos estos todos que el autor de Les Fleurs du mal, gran lector de poesía, debió de conocer en profundidad.

Valga como primer ejemplo de este culto al diablo el poema incluido en Les Fleurs du mal "Les Litanies de Satan" (Révolte-XCII), en el que, salpicadas de un estribillo a modo de invocación («O Satan, prends pitié de ma longue misère!»), figuran invocaciones varias al maligno en forma de misereres por el alma de esos transeúntes de la historia tan del gusto baudeleriano:

(vv. 10-11) Toi qui, même aux lépreux, aux parias maudits, Enseignes par l'amour le goût du Paradis

(vv. 19-20) Toi qui fais au proscrit ce regard calme et haut Qui damne tout un peuple autour d'un échafaud

(vv. 31-32) Toi qui, magiquement, assouplis les vieux os De l'ivrogne foulé par les chevaux

Leprosos, parias, proscritos, el borracho pisoteado por los caballos en plena calle: gentes de mal vivir, gentes olvidadas que solo puede proteger una potencia oscura, subversiva y rebelde.

En otros casos, el gusto por lo demoniaco de Baudelaire se manifiesta tan solo en la creación de ambientes: decorados sobre los que su estética se 
inscribe de manera más grandilocuente, donde su imaginario encuentra mejor acomodo. Es el caso de ese célebre pasaje de «Les Phares» (Spleen et Idéal - VI) en que glosa la figura de Goya:

Goya, cauchemar plein de choses inconnues,

De foetus qu'on fait cuire au milieu des sabbats,

De vieilles au miroir et d'enfants toutes nues,

Pour tenter les démons ajustant bien leurs bas

donde se observa esa especial delicuescencia, construida con figurantes infantiles, niñas fatales que seducirían al mismísimo Papa de Roma, pero que se dan al príncipe de las tinieblas, al redentor final de toda la especie humana, al único capaz de elevar el alma de sus súbditos hasta las mismas alturas de donde él cayó, castigado.

Una caterva de figuras diabólicas puebla el imaginario baudelairiano, de entre las cuales no cabe excluir a la amante, la bella capaz de robarle el alma, chuparle la sangre y adueñarse de su dicha. Mujer fatal donde las haya, conocedora de todos los misterios de la carne, extrae su conocimiento de su relación directa con el diablo: proveedor de dicha, dador de placeres, patrón de todos los excesos, santificador de la exclusión. En «Le Monstre ou Le Paranymphe d'une danse macabre» (Les Épaves-CXXXVIII), el poeta declara su ansiedad por no haber podido asistir a la ceremonia en que el diablo otorga a su amada sus mágicos poderes de seducción (obsérvese el ripio souffre-soufre):

Très sincèrement je souffre

De ne pas aller aux sabbats,

Pour voir, quand il pète du soufre,

Comment tu lui baises son cas!

Para algunos autores, el discurso satánico de Baudelaire le es útil para glosar de manera estetizante una posición no conformista ante la vida - la única, diría Walter Benjamin en sus Iluminaciones, ${ }^{377}$ sin llegar a tomarla del todo en serio sino como recurso retórico. Sin embargo, si se aborda la cuestión desde la psicología, las figuras de los desheredados y el diablo revelan un ansia de nobleza y dignidad que el poeta creía abolidos en él.

377 W. Benjamin, Poesía y capitalismo (Iluminaciones II), prólogo y traducción de Jesús Aguirre, Persiles-Taurus, Madrid, 1980, p. 35. 
En el célebre ensayo de Freud Una neurosis demoniaca del siglo XVII, ${ }^{378}$ se explica un caso extraño de posesión diabólica acaecido en la persona de un pintor, Cristóbal Haitzmann. Este parecía estar à court de recursos, sufriente además de la pérdida reciente de su providente padre, con lo cual empezó a tener (o a simular) visiones y convulsiones como consecuencia de un pacto con el diablo. Con este pretexto acude a una comunidad religiosa, en la que termina ingresando asegurándose, a pesar de esta falta de libertad que supone el convento, su pan de cada día.

El pintor había caído en honda melancolía a causa de la muerte de su padre, siendo entonces cuando se le apareció el demonio y, después de preguntarle por qué estaba tan triste, le prometió «ayudarle y favorecerle cuanto pudiera». Esta melancolía revela el tierno amor que el pintor sentía por su padre. Ahora bien, aun identificando la figura diabólica con el padre perdido, el mismo Freud confiesa cuán singular resulta que a Haitzmann se le haya ocurrido elegir al demonio como sustituto del padre amado.

Así, la eleción de Baudelaire del diablo como figura proveyente y génesis de todo su aparato estético-conceptual podría provenir de una nostalgia de un padre desaparecido - al que el poeta apenas conoció por haberle dejado huérfano a la edad de cinco años. Tan curiosa puede resultar la identificación del padre con el príncipe de las tinieblas en el caso comentado por Freud como en el que nos ocupa.

Aun teniendo en cuenta esta reserva, otros seguidores de la ciencia psicoanalítica parecen seguir esta vía. Según Charles Mauron en su obra Des métaphores obsédantes au Mythe personnel, ${ }^{379}$ el recurso de Baudelaire a este tipo de personajes - el gato, el príncipe, el diablo, figuras solitarias, autosuficientes y de un poder inferior al poder sumo - también revela esa nostalgia paterna. A estos personajes, el poeta les dota de una personalidad cargada de amor narcisista y de agresividad voluptuosa Son personajes machos, a quienes les horroriza la intrusión, y que sobre todo rechazan la pasividad y la subordinación. Figuras autosuficientes y poderosas que concuerdan perfectamente con el tan típico deseo dandiesco de autogeneración.

378 S. Freud, Psicoanálisis aplicado y Técnica psicoanalitica, Alianza Editorial, Madrid, 1979 , p. 58 y ss.

379 C. Mauron, Des métaphores obsédantes au Mythe personnel, ob. cit., p. 136 y ss. 
En su estudio sobre la naturaleza de Satán en el imaginario humano, Andrew Delbanco intenta explicar la naturaleza soberbia del diablo en $L a$ muerte de Satán. ${ }^{380}$ En algunos casos se trata de suplantar al padre; en otros, es la necesidad del propio Satán de suponer que se creó a sí mismo, o de no regirse por ninguna autoridad, o de alcanzar la apoteosis sin aguardar la autorización de Dios. Jung corroboraría semejante afirmación, pues él consideró -en su obra Psicología y religión — 381 al diablo como un ente autónomo, que no crece a la sombra de Dios sino que posee una personalidad autónoma, libre y eterna - lo que le permite posicionarse en contra del altísimo como enemigo en toda regla.

El padre perdido (Barthélémy Baudelaire) podría significar la instancia paternal rebelde y luchadora, cuyo recuerdo se yergue ante la autoridad del general Aupick — quien, como sabemos, contrajo matrimonio con la viuda madre del poeta. Cómo no apoyar esta aseveración teniendo en cuenta los gritos del joven Baudelaire contra su padre adoptivo durante los días de barricadas y revolución de 1848 .

Fuera de toda disquisición acerca de la identificación del diablo con el padre perdido es ese complejo de autogeneración el que seduce al dandi: una autosuficiencia que nada debe al mundo exterior y que halla en sí misma las bases de su génesis. Algo que, como ya habíamos visto más arriba, es una característica definitoria del carácter del dandi y que es, defendemos, una característica del héroe decimonónico.

\subsubsection{Filosofía del dandismo baudelairiano}

Hemos podido observar que el dandismo, sobre todo en su corriente más cercana al romanticismo, no se limita al cuidado del aspecto exterior; revela el dandi en todo su ser una actitud espiritual. Provocadora y aristocrática, la posición del dandi es la de una afirmación de sí mismo frente a un mundo que le ignora - o que ve en él un peligroso escollo contra la extensión universal de la moral burguesa.

Esa autoafirmación, esa exaltación de su singularidad, por su especial dificultad a ser llevada a cabo en todo momento y lugar, contra todos los

380 A. Delbanco, La muerte de Satán, trad. de Jaime Collyer, Andrés Bello, Barcelona, 1997 , p. 45 y ss.

381 C. G. Jung, Psicología y religión, ob. cit., p. 100 y ss. 
impedimentos, empuja al dandi a una cultura de lo bello. Belleza que será buscada en todos los lugares y que se vestirá con los ropajes de lo inusual y extraño. ${ }^{382}$ "Que tu viennes du ciel ou de l'enfer, qu'importe, ${ }^{383}$ / Ô Beauté! monstre énorme. Effrayant, ingénu!» — dice Baudelaire en su «Hymne à la Beauté» (Spleen et Idéal-CVI). El cultivo de esta belleza es un trabajo arduo, que pone al poeta - al esteta podríamos decir- en una constante búsqueda; este esfuerzo no impide que el dandi porfíe en su denodada labor. Como si de un Sísifo se tratara, el poeta dandi no ceja en su empeño para hacer de la suya una vida más digna, más alta, más cercana a los confines de esas "sphères étoilées» en las que el espíritu del poeta se mueve con agilidad —como apunta en "Élévation» (Spleen et Idéal-III). En "Les Plaintes d'un Icare» - bello poema incluido en lo que se vino a llamar las Pièces ajoutées en 1868-, el poeta reconoce lo doloroso y difícil de semejante tarea:

Les amants des prostituées

Sont heureux, dispos et repus;

Quant à moi, mes bras sont rompus

Pour avoir étreint des nuées.

Abrazar nubes: en eso se queda el trabajo de este poeta que hace de su vida un continuo rastreo de lo que pudiera contentar su sensibilidad estética. Y por mucho que se queme por amor de la belleza — «Brûlé par l'amour du beau", dice en el mismo poema-, el esteta no deja de perseguir, infatigablemente, lo que se ha convertido en leitmotiv primero y exclusivo. "Transformé, agrandi, purifié, (le dandysme) devient un sacerdoce qui distingue l'homme et le rapproche du héros et du saint» — como señala Ferran citado por Jean d'Ormesson. ${ }^{384}$ Un sacerdocio que se convierte, si evitamos la referencia religiosa, a un ascetismo que lleva a la propia vida al cumplimiento estricto de unos preceptos — de lo que

382 Bourdieu dirá que la revuelta de Baudelaire es tanto una ruptura estética como ética, en P. Bourdieu, Les règles de l'art, ob. cit., p. 98.

383 Verso fácilmente asimilable a una influencia de Gautier y de su cuento La Morte amoureuse, donde dice de los ojos de la bella y demoníaca Clarimonde: "Je ne sais si la flamme qui les illuminait venait du ciel ou de l'enfer», en T. Gautier, Récits fantastiques, G. F.-Flammarion, París, 1981, p. 120.

384 J. d'Ormesson, Revue de métaphysique et de morale, ob. cit., p. 15, citado por Émilien Carassus, ob. cit., p. 285. 
depende la dignidad que se confiera el dandi a sí mismo. Un asceta que hace de su cuerpo, de su comportamiento, de sus sentimientos y pasiones, de su existencia, una obra de arte. De estoica caracterizará el propio Baudelaire su actitud filosófica ante la vida: "on voit que, par certains côtés, le dandysme confine au spiritualisme at au stoïcisme». ${ }^{385}$ En una autonegación continua de los placeres fáciles de la existencia, el esteta estoico prefiere la flor rara, el fruto de las indagaciones profundas, la meta de tantas y tantas noches pasadas en vela: «Seigneur mon Dieu! accordezmoi la grâce de produire quelques beaux vers qui me prouvent à moimême que je ne suis pas le dernier des hommes,que je ne suis pas inférieur à ceux que je méprise» - dice en prosa el poeta en su composición «A une heure du matin». Después de haber estrechado tantas manos sucias, de haber mentido a propios y a extraños, de haber asegurado apreciar cosas que en su fuero interno sabía despreciables, el poeta se encomienda a su dios —el dios que le permitirá acceder a ese lugar elevado y digno donde encontrar la inspiración.

Por eso es en el aislamiento de la habitación, en compañía de la bella y demoníaca amada o no, donde el poeta halla su sustento emocional y su contento. Porque expuesto a la maldad de la vida, a la mezquinería y la crueldad de sus semejantes, la única salida posible es la del repliegue en sí mismo, separándose y evitando el contacto con el peligroso prójimo. Pero, siendo estas pretensiones prácticamente imposibles de ser llevadas hasta sus últimas consecuencias, el dandi prefiere, en lugar de exilarse, exponerse a las miradas de los demás: sentirse, de nuevo, especial, singular, único en medio de la multitud. "Qui ne sait pas peupler sa solitude, ne sait pas non plus etre seul dans une foule affairée» — comenta en "Les Foules» (XII de Le Spleen de Paris). Ese espacio retirado, esa Tebaida tranquila — donde todo sea «luxe, calme et volupté»— es también el refugio de un alma atormentada que no sabe sino mantenerse distante de todos los acontecimientos habituales en la vida de un individuo. Se trata aquí de un retraimiento querido y rebuscado, en el que el dandi puede ser como su sensibilidad lo requiera, sin tener que confrontarse a la tiranía y la crueldad de las relaciones humanas.

385 C. Baudelaire, Écrits sur l’art, ob. cit., p. 397, «Le Dandy». 


\subsubsection{El dandi, el amor y el género}

El ansia de soledad del dandi viene de una incapacidad extrema de tratar con las gentes que no comparten su concepto aristocrático de la vida. Es, en realidad, un miedo atroz a los demás el que le empuja al retiro de la sombría habitación, a la calma del trabajo disciplinado. Fuera de dicho retiro, la conducta del dandi está toda hecha de impostura y fingimiento, de pose y actitud: solo mediante una regla rígida de distanciamiento y singularización está seguro el dandi de marcar su diferencia con su prójimo. De ahí que las reglas de oro del dandi en sociedad — como refiere Carassus — ${ }^{386}$ sean provocar lo imprevisible, preservar su impasibilidad, cuidarse de las pasiones y hacerse esperar y buscar. "Le caractère de beauté du dandy consiste surtout dans l'air froid qui vient de l'inébrablable résolution de ne pas être ému» — señala Baudelaire en Le peintre de la vie moderne. ${ }^{387}$ Los dandis rechazan todo tipo de emoción, como diría Barbey d'Aurevilly en «Le Rideau cramoisi»: ${ }^{388} \mathrm{el}$ asombro jamás será una posición honrosa para el espíritu humano - donde el dandismo romántico se separa de Goethe y de los románticos alemanes.

$Y$ es que el dandi, al rechazar todo tipo de apasionamiento sensiblero, se separa de esa vía continuada por Alfred de Musset en sus Confessions d'un enfant $d u$ siècle, que hacen del amor el más potente chorro de energía que pueda conocer un individuo. El amor es un peligro para la integridad del dandi; significa para él un dejarse llevar por las circunstancias que podría descubrir ese frágil jardín interior que es la sensibilidad de un hombre atormentado por las circunstancias. Haciendo voto de reserva, el dandi encuentra en esa contención motivo complementario para despertar el interés y la curiosidad de los demás. Así, Julien Sorel se vanagloria de su frialdad en su trato con la tan deseada Matilde de la Mole, hasta el punto de considerar una flaqueza de carácter el dejarse llevar por la sentimentalidad de un momento: «j'ai su conserver la dignité de mon caractère. Je n'ai point dit que j'aimais» — comenta Julien. ${ }^{389} \mathrm{Y}$ de tal manera se muestran los dos

386 E. Carassus, ob. cit., p. 9.

387 C. Baudelaire, Écrits sur l'art, ob. cit., p. 400, «Le Dandy».

388 «Les dandys méprisent toute émotion, comme inférieure, et ne croient pas, comme ce niais de Goethe, que l'étonnement puisse jamais être une position honorable pour l'esprit humain", en Le Rideau cramoisi, J. Barbey d'Aurevilly, ob. cit., p. 40.

389 Stendhal, Le Rouge et le noir, ob. cit., p. 323. 
amantes serios en sus transportes que el joven dandi se pregunta por la calidad de su amor. Así, cuando sube la primera vez por la escalera del jardín hasta la habitación de Matilde - momento tan deseado y esperado, en el que Julien había depositado toda su felicidad—, el joven héroe se asombra de que tantas ternuras sean expresadas con la distancia de dos generales napoleónicos, todo estrategia y designio: «mais jamais l'on ne dit d'un ton plus froid et plus poli des choses aussi tendres». ${ }^{390}$ De esta manera, Julien, uno de los grandes enamorados de la novela decimonónica, lamenta la limitada espontaneidad de unos sentimientos que debieran transportar toda su alma y todo su cuerpo con ellos: «à la vérité, ces transports étaient un peu voulus. L'amour passionné était encore plutôt un modèle qu'on imitait qu'une réalité»» ${ }^{391}$ (el subrayado es de Stendhal).

Sin embargo, este es el tipo de relación al que mayormente puede aspirar un dandi. Temiendo la pérdida de sí mismo que supondría una entrega sin condiciones, el amor apasionado supondría una claudicación de sus máximas, una dejación de los preceptos que se había marcado para proteger su yo interno. «Un hombre puede ser feliz con cualquier mujer mientras no la ame», dirá el Dorian Gray de Oscar Wilde.

Ante la llegada tumultuosa de la pasión, el dandi puede optar por dos vías diferentes: una, señalada por Albert Camus en L'Homme révolté, asegura que el dandi sólo se empleará a fondo en el encuentro fugaz, para vivir la terrible exaltación de una acción breve y devoradora. «Aimer ce que jamais on ne verra deux fois, c'est aimer dans la flamme et le cri pour s'abîmer ensuite» —apunta Camus. ${ }^{392}$ No se vive más que en el instante, pues el dandi, incapaz de amar debido a su atormentada condición, solo apreciará como válida y exenta de peligro, "cette union courte mais vivante / d'un cœur tourmenté uni à la tourmente» — según un verso de Lermontov.

La segunda opción del dandi ante el amor es, según señala Luis Puelles en "La voluntad de apariencia: estética del dandysmo», ${ }^{393}$ el cultivo de una estudiada y rebuscada frivolidad. Tras ella se ocultará una inteligencia compleja que será la que permita dotar al dandi de unas calidades por en-

\footnotetext{
390 Ib., p. 342.

391 Ib., p. 343.

392 A. Camus, ob. cit., p. 70.

393 L. Puelles Romero, ob. cit., pp. 23-34.
} 
cima de la media. El ingenio, el rasgo de humor, la máxima aforística, son los rasgos típicos del discurso de Lord Harry del Dorian Gray de Wilde. Esta frivolidad intelectualizada será usada por el dandi como un arma nihilista en el sentido nietzscheano: un arma mundana contra el mundo, contra sus tradiciones y sus instituciones.

Esa actitud reservada ante el amor puede haber sobrevenido igualmente tras una relación sentimental desagradable. En este caso, el dandi expresa su promesa de no amar jamás para no exponerse de nuevo a las mismas humillaciones que la dependencia al ser amado provoca en el individuo. Normal, si se considera el ansia de independencia, autonomía e incluso autogeneración que hemos venido glosando a lo largo de estas trabajosas líneas.

De esta manera se expresa Sir Edward Bulwer-Lytton en su novela de 1828 Pelham ou Aventures d'un gentleman, más precisamente en el pasaje en que Lord Russelton cuenta su vida:

je ne lui en voulus pas; j'en eus pitié; mais à dater de ce jour je fis voeu de ne jamais redevenir amoureux. J'ai tenu mon serment, quoiqu'il m'en ait coûté, et je me suis vengé sur toutes les personnes du sexe de l'insulte que l'une d'elles m'avait faite. ${ }^{394}$

Promesa de no enamorarse nunca más, venganza sobre todas las mujeres... El compromiso de frialdad y contención tiene que ser respetado a costa de la consideración en que se tiene a las féminas. La misoginia dandiesca es proverbial, puesto que no se puede mantener una actitud de alejamiento sino es convenciéndose del carácter esencialmente negativo de en quien se deposita la culpa de su desgracia. Muchos de estos dandis decimonónicos, como observa Elisabeth Badinter en su ensayo La identidad masculina, ${ }^{395}$ revelarán una misoginia rampante debido a su deseo inquebrantable de mantener su masculinidad en unos términos soportables. El caso de Baudelaire es proverbial, pues jamás se vio tantos calificativos opuestos ofrecidos a las mujeres de su vida. Tanto en su correspondencia con su madre como en su obra poética, las mujeres son alternativa y sistemáticamente vapuleadas o idolatradas. Su compleja misoginia pasa, sin

394 Citado por E. Carassus, ob. cit., pp. 214-216.

395 E. Badinter, XY. La identidad masculina, ob. cit., p. 79 y ss. 
duda alguna, por un complejo de Edipo que le hace culpar a su madre de su situación de indefensión: diatribas contra la capacidad de concepción femenina, ascos al vientre, lamentos por ser responsables de tantos desgraciados echados al mundo... La mujer se convierte en «un outre... plein de pus».

Una consecuencia indirecta de la misoginia — así como de la huida de todo lo que no le parezca trivial y ramplón al dandi- es el deseo de acercamiento a almas gemelas: individuos, mayoritariamente hombres, que comulgan con el mismo ideario aristocrático, con quienes se puede conversar de arte y literatura, y a cuyo lado el sentido estético de la existencia puede ser glosado y amplificado. El dandi finisecular, en su rebelión contra el matrimonio y la familia, parece — según señala Frédéric Monneyron en su ensayo «Le dandy fin de siècle: entre l'androgyne et le mysogine»— ${ }^{396}$ tender a defender una cierta idea de androcracia. Es en los hombres en los que las cualidades queridas por el dandismo se dan cita: independencia, construcción de sí y de su futuro, autonomía... cualidades que difícilmente podían encontrarse en las mujeres de la época.

El dandismo solo podía desembocar, en su versión más espiritualizada, en la homosexualidad o en la androginia. La homosexualidad, en opinión de Françoise Coblence, ${ }^{397}$ no es sino una modalidad de articulación entre el personaje masculino y el femenino. No es la característica más específica del dandismo como hemos venido observando hasta ahora. Su posibilidad siempre es sugerida, evocada.., pero jamás explicitada de manera elocuente.

Otto Weininger, uno de los más leídos teóricos de la sexualidad durante el siglo XIX, relacionaba la degeneración de la sociedad con la feminización de las costumbres: el abandono del modelo unívoco y monolítico de la masculinidad: "la amplitud que han tomado desde hace algunos años el 'dandysmo' y la homosexualidad solo puede explicarse por una feminización generalizada». ${ }^{398}$

396 F. Monneyron, ob. cit., p. 63.

397 F. Coblence, «Le dandy, androgyne de l'histoire?», en H. Amigorena y F. Monneyron (eds.), Le masculin. Identité, fictions, dissémination, L'Harmattan, París-Montreal, 1998, p. 102.

398 O. Weinninger, Sexe et caractère, L'Âge de l'Homme, París, 1989, p. 73, citado por Badinter, ob. cit., p. 32. 
Fuera de toda duda, la intensa feminización del dandi révolté sería una respuesta lógica a su deseo de singularización por medio de la fineza. El nuevo hombre, señalado, señalable y elegantísimo —en su más amplia acepción- es el fruto de un deseo de separarse del modelo universal del hombre tosco, inculto, voraz y vulgar. En su huida de la vulgaridad y de la trivialidad ramplonas, el dandi se feminiza forzosamente para alcanzar un terreno al que solo el ingenio y la elegancia verdadera permiten el acceso. Se trata de un no man's land ideológico, una tierra de nadie de la caracterización sexual que no podía sino convencer al dandi. Lejos de limar las diferencias, el afeminamiento del dandi no hace sino exacerbarlas y agrandar todavía más el abismo que separa al vulgar común de los tocados por la mano de Satán.

Por otra parte, la consagración de la moral burguesa que se dio en ese siglo tan dinámico que fue el XIX, hizo del afeminado un transgresor, que ponía en peligro los logros de la nueva sociedad. Denostado por los unos, rechazado por los otros, el afeminamiento y la homosexualidad más o menos señalada le iban como anillo al dedo a la ideología dandiesca. Adquiría con ella una singularidad todavía más poussée, cada vez más individualizada.

La androginia será un decidido intento de la nueva masculinidad por situarse en un lugar de elección; en un lugar donde la caracterización sexual tradicional pierda su validez. En la medida en que el dandi se hace a sí mismo re-construyendo sus coordenadas vitales —haciendo de sí mismo una obra propia, en una especie de complejo de autogeneración-, la búsqueda de la indefinición no es sino una demostración histórica de que el género es una construcción social. Fuera de las concepciones monolíticas que pretenden encarcelar al hombre en una conducta y a la mujer en otra, el dandismo es un movimiento no suficientemente glosado de libertad sexual. Su carácter reivindicativo reside precisamente en la individualización a ultranza que hace de sus propias opciones: él es una pancarta viviente, todo él protesta y reivindicación.

Prueba viva de que el género no es una categoría útil para la identificación del indidividuo, el dandi refleja a la perfección la huida de los esquemas rígidos hombre-mujer y sus corolarios sexuales. Su actitud es una reclamación continua de libertad individual, de remisión de todos los denostados y desheredados del mundo, de protesta ante una moral que solo plantea las relaciones humanas en base a la producción. 
El dandi sale del esquema producción-reproducción por su crítica de la familia y el matrimonio. Su amor es libre, como ha de ser libre la elección de hombres y mujeres sobre la vida que deseen llevar.

Huysmans adoptará la estética del dandismo no solo por afán individualizador. A pesar de su discurso tremendamente conservador, su actitud no deja de ser reivindicativa de una nueva sociedad, alejada de las coordenadas de ramplonería burguesa. Por eso su discurso no es solo misógino — que lo es y mucho-, sino también misántropo. Ese nuevo hombre que él se vea en capacidad de amar y admirar lo intentará encontrar en su obra literaria, de la que a partir de este instante vamos a esforzarnos por descubrir sus aspectos más profundos. 


\section{HUYSMANS Y LA MASCULINIDAD CULPABLE}

\subsection{Huysmans y su evolución desde el naturalismo}

Una de las características más singulares de la evolución de Huysmans es la de su adscripción, en un primer tiempo, al Naturalismo, para pasar seguidamente a denostarlo - en el centro del movimiento que algunos historiadores de la literatura han llamado decadentismo-, asumir posteriormente posiciones espiritualistas y, por fin, ser considerado como un escritor religioso desde que en 1895 publicara el diario de su conversión —En route — hasta la póstuma Les Foules de Lourdes (publicada en 1928).

Esta variación constante en sus afinidades no deja de revelar la búsqueda de un espacio literario propio y personal a lo largo de toda su producción. Sobre todo desde que, cansado de la vacuidad de las camarillas literarias, decidiera elaborar su propio proyecto desde la soledad y la independencia. De esta manera, se hace evidente su alejamiento del grupo de Zola con la publicación de $\grave{A}$ rebours —obra de factura naturalista pero de intención personal.

Sin embargo, lo que más llama la atención a quien se haya adentrado un mínimo en la producción huysmansiana es la presencia continuada de un personaje masculino, soltero -o huyendo de la institución matrimonial-, con un continuum de dolencias y quejas sobre la ramplonería y estupidez ambiente. El Cyprien Tibaille de Les Sours Vatard (1879), el André 
Jayant de En ménage (1881), el Jean Folantin de À vau-l'eau (1882), el duque des Esseintes de $\grave{A}$ rebours (1884), Jacques Marle de En rade (1887) y el definitivo Durtal de quien se narra la conversión cristiana desde $L \grave{a}$-bas (1891) en adelante, son la encarnación heteronímica de un mismo personaje neurótico, tímido y retraído, visiblemente misógino, esteta y elitista. En dicho personaje de identidad múltiple, la crítica ha creído y querido ver la representación literaria del propio autor, quien vaciaba sus inquietudes y obsesiones en el texto literario.

Tal vez en esta idea resida la necesidad de Huysmans de abandonar el naturalismo de escuela y centrarse en un proyecto personal e ineludible. Aparte de ese primer opus preciosista que fue su Drageoir à épices (1874), se pueden encuadrar dentro de los temas y de la estética naturalistas sus dos siguientes novelas, Marthe, histoire d'une fille (1876), y Les Sours Vatard (1879), que le valieron su inclusión en la colección de relatos Les Soirées de Médan (1880) —en la que, como sabemos, participaron Zola, Léon Hennique, Pierre Céard, Maupassant... El compendio de relatos y pequeños cuadros de costumbres Croquis parisiens (1880) es naturalista por propio derecho: la elección de los temas y su tratamiento con analítico afán de disección así se lo conceden. Sin embargo, las dos siguientes En ménage y $A$ vau-l'eau, son naturalistas de factura, aunque no temáticamente. Como ya hemos señalado antes, la focalización sobre un personaje único y sus vicisitudes, más de corte psicologicista que costumbrista, convierten a estas obras en un avatar inédito del naturalismo, con cuyas máximas acabaría por romper la publicación de $\grave{A}$ rebours.

No obstante, la técnica naturalista consistente en la toma de notas y en la descripción detallada del ambiente que rodea las circunstancias de la historia jamás sería abandonada por Huysmans. Aun a pesar de la ruptura declarada que supuso $\grave{A}$ rebours, la publicación en 1887 de Un dilemme - nouvelle que gira en torno a una joven embarazada y la usura a la que la somete la avidez del padre de su difunto compañero- resitúa a Huysmans plenamente dentro del naturalismo: por método, por tema y por estética. Más tarde, el autor de Là-bas abogaría por un tipo diferente de naturalismo, en el que la técnica mise au point por Zola y sus epígonos fuera utilizada para otros fines más personales. A partir de esa novela, Huysmans defendería una estética de corte naturalista espiritualista, cuyos fundamentos serían sugeridos por la contemplación extasiada de la obra pictórica de Grüne- 
wald — de quien el parisién diría que era naturalista y místico a la vez, salvaje y civilizado. ${ }^{399}$

La técnica naturalista fue un instrumento de utilidad primordial en la obra de Huysmans, que le serviría de manera evidente incluso en los pasajes donde más abominaba de los dictados de la teoría zoliana. Las largas descripciones casi fotográficas, que daban cuenta del decorado de la acción con detallismo notarial, le servían a la perfección en su aspiración de construir una obra que no hablase de nada, sin argumento aparente, sin trama ni dénoument: «supprimer l'intrigue traditionnelle, voire même la passion, la femme, concentrer le pinceau de lumière sur un seul personnage, faire à tout prix du neuf», como decía en su "Préface écrite vingt ans après le roman» a $\grave{A}$ rebours. ${ }^{400} \mathrm{Y}$, sin embargo, con qué intensidad lo denostaría la escuela zoliana, en lo que podría reconocerse más como un ajuste de cuentas, orgulloso y pleno de vanidad, que otra cosa.

Huysmans fue siempre un escritor realista, que se sirvió de la transcripción fiel de su entorno como decorado de sus novelas. En esta transcripción fotográfica del entorno no deja de vislumbrarse su necesidad de aprehensión y comprensión de la realidad, imprescindibles para quien, como él, se había iniciado en la literatura como analista milimétrico de ambientes.

\subsubsection{Evolución de la novela realista en el siglo XIX}

Este hecho, la descripción milimétrica de ambientes, es deudor de la evolución de la escritura novelesca del siglo XIX, que a su vez lo es del ambiente positivista que propiciaron los avances de la Ciencia durante dicho siglo. La novela que nace con el siglo XIX se convierte en un extraordinario instrumento de exploración de la Historia y de análisis de la sociedad - que era, no en vano, uno de los grandes leitmotiv de la escritura naturalista. Ese conocimiento del mundo circundante, inspirado en las ciencias, denota un deseo de inscribirse en una amplia práctica social y

399 «Il est à la fois naturaliste et mystique, sauvage et civilisé, franc et retors», en J.-K. Huysmans, Les Grünewald du musée de Colmar, Hermann, Éditeurs des Sciences et des Arts, París, 1988, p. 54.

400 J.-K. Huysmans, À rebours, ob. cit., p. 55. 
política: el conocimiento científico del entorno puede contribuir, para los escritores de lo real, a reformar el mundo en el sentido que ellos crean necesario - como señala Jacques Dubois en su estudio sobre Les romanciers $d u$ réel. ${ }^{401}$ Aunque la inmensa mayoría de los autores del incipiente siglo XIX fueran de ascendencia burguesa, no eran menos conscientes por ello de la situación de enajenación a que estaba siendo sometida la clase obrera durante el desarrollo industrial de la época. Época convulsa en que se observaba la evolución de una sociedad a tres velocidades — nobleza, burguesía y classes dangereuses - , cuya repercusión en la política fue clara: tantos cambios de régimen respondían a la lucha que cada uno de estos grupos sociales llevaba a cabo ya sea en contra ya sea a favor de los sempiternos privilegios de la nobleza y el clero.

La inclusión del pueblo llano en la problemática novelesca es una innovación propia y exclusiva de la producción literaria del siglo XIX. Como observa finamente Erich Auerbach en su Mimésis, ${ }^{402}$ la doctrina clásica literaria imponía que los temas triviales o poco elevados fueran tratados de modo burlesco. Fue precisamente el empuje realista del siglo XIX el que propone el tratamiento serio de los temas «bajos»: vida popular, vida doméstica, vida carnal y sensual. El realismo ambiciona instaurar este universo inferior en nuevos territorios de la novela.

Recordar cabe la sentencia que en epigrama incluyó Stendhal al comienzo del capítulo XIII de su Rouge et le noir — atribuida por él mismo a Saint-Réal: «un roman: c'est un miroir qu'on promène le long du chemin». Él mismo explicará varios capítulos más adelante que si ese espejo que se pasea a lo largo de una carretera reflejara tan pronto el bello azul del cielo como el fango o los charcos del camino no debería acusarse al escritor de inmoral:

son miroir montre la fange, et vous accusez le miroir! Accusez plutôt le grand chemin où est le bourbier, et plus encore l'inspecteur des routes qui laisse l'eau croupir et le bourbier se former. ${ }^{403}$

401 J. Dubois, ob. cit., p. 22.

402 E. Auerbach, Mimésis. La représentation de la réalité dans la littérature occidentale, Gallimard, Tel, París, 1990.

403 Stendhal, Le Rouge et le noir, ob. cit., p. 357. 
Cómo no ver en este planteamiento una reivindicación de la solidaridad con el fango, con los problemas del arroyo; o el ataque directo a quien, disponiendo de los medios para acabar con el barrizal y convertir el camino en una vía practicable - el inspector de caminos- permite que perviva el barro. Stendhal, aun con su perfil esteta y artístico, prefigura con este tipo de aseveraciones la novela social, la obra de denuncia que el realismo más descarado a lo Balzac o a lo Zola explotaría en las décadas venideras. Un arte social que entraría en oposición con el parnasiano arte por el arte, que representaría la tendencia más formalista en la literatura del siglo XIX.

Los temas elevados - que, como hemos visto, echaba de menos nuestro Huysmans - pasaron a ser patrimonio histórico en la medida en que los nuevos escritores, los nuevos novelistas, se hacían con el apoyo de un público cada vez más amplio - gracias al desarrollo de las técnicas de impresión y distribución. El tratamiento convencional de las relaciones sentimentales daría paso, en este avatar de lo novelesco, a la descripción de las relaciones carnales, «leur nécessaire contrepoint dans l'impatience du désir et de la pulsion charnelle», como señala Dubois. ${ }^{404}$ Es decir, privilegio de lo bajo, de lo instintivo como parte integrante de la vida, amén de numerosísimas tramas y situaciones.

René Girard observa algo muy interesante en su estudio sobre la escritura novelesca. ${ }^{405}$ Un tema recurrente a lo largo de la historia de la novela occidental había sido la puesta en escena de un héroe animado por un potente deseo de parvenir, pero de tal manera que siempre se viese marcado por la imitación de un modelo exterior. Como sabemos, el gran modelo para la novela decimonónica fue Napoleón Bonaparte, verdadero revulsivo para la imaginación escritora y faro del individualismo de la época. Ahora bien, lo que hará el novelista realista del siglo XIX será poner en duda este modelo y establecer una dolorosa verdad en la evolución del ya descreído héroe. Este renunciará a sus vanas creencias y elegirá un retiro cualquiera del mundo, ya se dé este en el ascetismo, en la muerte o en la práctica de la escritura.

Esta aseveración queda patente a poco que se observe la evolución de dos personajes tan paradigmáticos de la escritura realista como son Fabri-

404 J. Dubois, ob. cit., p. 60.

405 R. Girard, Mensonge romantique et Vérité romanesque, ob. cit., p. 181. 
zio del Dongo de la Chartreuse stendhaliana y el Marcel de la Recherche. Ambos andaban en pos de un sueño aristocrático, de una búsqueda de libertad por encima de la sociedad de su tiempo; ambos terminan enamorándose de una hija de la burguesía, lo que les devuelve a la pura realidad de los hechos y, de rebote, les empuja a encerrarse en sus respectivos retiros. Curiosa evolución la de estos héroes que no conocen los laureles que, por sus cualidades personales, merecían más que ningún otro: dolorosa época que premia más las existencias planas y sin aventura.

Sin duda alguna, uno de los hitos de la novela decimonónica fue creado por Gustave Flaubert. Lejos de plantearse la escritura como un espejo del mundo, el autor de Madame Bovary propone más bien una mirada irónica y distanciada que prefigura la novela del siglo XX. Esta mirada queda patente, según Dubois, ${ }^{406}$ en el rechazo de un cierto tipo de «histeria del texto» que era propia del romanticismo - y en la que incluso caerá el propio Stendhal, como sabemos. Con Flaubert el discurso se construye desde la retención y la impersonalidad, con el fin de permitir que los personajes actúen por sí mismos y se liberen de los hilos con que los guiaba un narrador demasiado presente: el relato va por delante de sí mismo como si nadie lo dirigiese.

A este respecto dirá Flaubert de su Mme. Bovary a su corresponsal Mlle. Leroyer de Chantepie:

C'est une histoire complètement inventée; je n'y ai rien mis ni de mes sentiments ni de mon existence. L'illusion ( $s$ 'il en est une) vient au contraire de l'impersonnalité de l'œuvre. C'est un de mes principes qu'il ne faut pas sécrire. L'artiste doit être dans son œuvre comme Dieu dans sa création; invisible et tout puissant; qu'on le sente partout mais qu'on ne le voit pas. ${ }^{407}$

Desapego de la obra que no se podía imaginar en el siglo XVIII ni en los comienzos del XIX: difuminación completa del artista en su obra, desaparición de su persona en favor de sus personajes, sus criaturas, sus hijos. Y todo lo que la asunción de esta vida vicaria del artista deberá a la descripción exacta de los hechos de sus personajes: vidas hechas de miserias y de defectos, de aspiraciones frustradas y de dejaciones definitivas, de triunfos

406 J. Dubois, ob. cit., p. 213 y ss.

407 G. Flaubert, Correspondance, Gallimard, «Folio Classique», París, p. 324. Carta del 18 de marzo de 1857. 
de poca monta y de fracasos. El ideal del héroe clásico ha sido definitivamente perdido y enterrado.

Los temas elevados empiezan a ser considerados como demasiado burgueses por una parte del público, quien los percibe como una especie de concesión a la molicie. $\mathrm{Y}$ aunque resulte caricaturesca su pintura, el personaje del revolucionario Sénécal en la Éducation de Flaubert no deja de sentar las bases del naturalismo más acérrimo:

qu'avons-nous besoin de laborieuses bagatelles, dont il est impossible de tirer aucun profit, de ces Vénus, par exemple, avec tous vos paysages? Je ne vois pas là d'enseignement pour le peuple! Montrez-nous ses misères, plutôt! Enthousiasmez-nous pour ses sacrifices! ${ }^{108}$

Esta opinión no deja de establecer a las claras el nacimiento de una nueva sensibilidad, basada en el respeto a una parte de la población denostada por el arte como no fuera como figurante en los cuadros de costumbres. El pueblo, con todos sus problemas, sus enfermedades y su atosigada vida, comienza a ser objeto de las investigaciones de los novelistas de la realidad más dotados de conciencia social. En medio de corrientes de pensamiento influidas por el evolucionismo darwiniano y las teorías sobre el determinismo de Hyppolite Taine, la situación del proletariado empieza a ser considerada por los escritores burgueses como el fruto de una injusticia perpetuada para el sometimiento de los y las trabajadoras.

\subsubsection{Zola y el método científico}

La injusticia que Zola y la escuela naturalista se propondrán denunciar será la de la decadencia de la clase trabajadora, sometida a la alienación en los nuevos modos de producción. Por una parte, el determinismo social a que estaba sometida la clase obrera impide que optara esta siquiera a la ascensión social que le permitiera salir de su baja condición. Por la otra, el mismo ambiente en que nacen, crecen, se forman y trabajan los y las obreras les lleva a contraer los mismos defectos de clase que poseen sus compańeros. Para estudiar la miseria del pueblo y convertirla en materia didáctica, Zola tomó la responsabilidad de hacerlo desde una perspectiva científica

408 G. Flaubert, L'Éducation sentimentale, prólogo de Albert Thibaudet, Gallimard Folio, París, 1965, p. 71. 
que hiciera creíbles y palpables los cuadros denunciados en su obra. A su afán didáctico se unía su vocación humanizadora y libertaria, pues solo tras la exposición veraz y estudiada de las condiciones de vida y trabajo de los laissés-pour-compte era posible acometer su emancipación.

Su deseo de cientifismo le llevó a adoptar las enseñanzas del médico Claude Bernard y de su obra Introduction à l'étude de la médecine expérimentale, ${ }^{409}$ gracias a las cuales describió el medio vital del pueblo llano como si de un organismo se tratara:

notre héros n'est plus le pur esprit, l'homme abstrait du XVIIIe siècle, il est le sujet physiologique de notre science actuelle, un être qui est composé d'organes dans un milieu dont il est pénétré à chaque heure. ${ }^{410}$

El naturalismo, como pseudo-ciencia dedicada al estudio de las miserias del pueblo, basó gran parte de su trabajo en la toma concienzuda de notas de campo — como las podría llamar cualquier biólogo del siglo XX. La conveniencia de tales notas tomadas sobre el terreno ya había sido expuesta anteriormente por Flaubert y Goncourt, quienes veían en la documentación la única posibilidad para llevar adelante el proyecto realista. Así diría Flaubert en una carta a Louise Collet de 6 de abril de 1853: «il faut faire des tableaux, montrer la nature telle qu'elle est, mais des tableaux complets, peindre le dessous et le dessus». ${ }^{411}$ Edmond de Goncourt llegaría a decir: «Disons-le bien haut, seuls les documents font de bons livres». ${ }^{412}$ Documentación a base de notas que permitirían la gran profusión de descripciones que resultó ser una de las cartas de presentación del realismo naturalista a partir de 1850 . Unas descripciones necesarias para situar he-

409 Publicada en 1865. También cabe citar, como influencia médica decisiva en el método zoliano, la obra de 1850 de Prosper Lucas, titulada Traité philosophique et physiologique de l'hérédité naturelle dans les états de maladie du système nerveux, avec l'application méthodique des lois de la procréation au traitement général des affections dont elle est le principe: ouvrage où la question est considérée dans ses rapports avec les idées primordiales, les théories de la génération, les causes déterminant la sexualité, les modifications acquises de la nature originelle des êtres et les diverses formes de névropathie et d'aliénation mentale — tal y como lo dice el propio escritor en el prólogo a su novela Une Page d'amour, citada por E. Cobos Castro, La paradoja interna del Naturalismo francés, Córdoba, 1982, p. 26.

410 É. Zola, Nos auteurs dramatiques, citado por Esperanza Cobos Castro, ob. cit., p. 21.

411 G. Flaubert, Correspondance, ob. cit., p. 187.

412 Citado por E. Cobos Castro, ob. cit., p. 33. 
chos y personajes en su contexto, lo que les dotaba de una credibilidad casi científica. Como diría el mismo Zola: «nos descriptions n’ont plus un rôle purement pittoresque, elles sont là pour donner le drame entier, les personnages avec l'entourage qui agit sur eux». ${ }^{413}$

La validez de la aplicación de un método clínico a la novela puede parecer un tanto descabellada si se tiene en cuenta que, mientras que un médico puede variar las condiciones de un experimento, esto se eleva al arte del birlibirloque cuando se trata de una ficción novelesca. Por mucho que la toma de notas acerque la indagación del novelista a la observación del científico, la fijación a la realidad siempre queda mediatizada por la intención del escritor, quien, a modo de un demiurgo omnipotente, crea las condiciones para que tal o cual hipótesis se cumpla. Y lo que es más, en la crítica del pretendido cientifismo de Zola, el Dr. Ferdas encontró numerosos pasajes del Roman expérimental zoliano en los que el novelista había copiado enteros pasajes de la obra de Bernard tras sustitución del término «científico» por «novelista»:

leyendo la obra de Zola, es imposible no constatar que el pontífice del naturalismo termina por alcanzar las más altas cimas del ridículo. Deslumbrado por las bellas páginas de Bernard de las que no comprende el significado, Zola se lanza a lucubraciones científicas,

añadiría el médico. ${ }^{414}$

\subsubsection{Reacción antinaturalista}

De 1880 hasta mediados de 1890 se desarrolla una serie de tentativas dispersas que, inspirándose en el decadentismo de la época, apuntan a llevar a cabo una fórmula inédita de la novela. Unos se inscriben en el manierismo de los Goncourt; otros en el del Huysmans de $\grave{A}$ rebours.

Se trataba de un grupo de escritores que, como Poictevin, Rodenbach, Dujardin y el joven Gide intentaron oponerse al naturalismo de la escuela zoliana. Su modus operandi pasaba por plantear nuevos tipos de personajes y de situaciones en las que aquellos se vieran inscritos, en un sentido in-

413 É. Zola, Nos auteurs dramatiques, ob. cit., p. 78

414 Citado por E. Cobos Castro, ob. cit., p. 28. 
verso al del autor de Nana. Los héroes de las novelas de estos creadores suelen ser estetas solitarios que viven recluidos, dedicándose al cultivo de su propio yo; experiencia esta, la de la reclusión que, como en el caso de des Esseintes, fracasan en última instancia. Este héroe soltero ${ }^{415}$ se convierte en una imagen recurrente y obsesiva, quien se muestra orgulloso del declive de su masculinidad.

Este nuevo tipo de novela reniega, finalmente, de las amplias descripciones tanto de personajes como de ambientes, las acciones densas, la objetividad como punto de partida declarado y deseado. Como señala Jacques Dubois, ${ }^{416}$ la nueva novela se conforma en torno a un vacío, lo que le sirve para afirmar la autonomía de su propuesta. Ya no será un plan predeterminado, una intención didáctica, una reivindicación profunda, los motores de la trama, sino la incierta contingencia de los fenómenos. Este experimento conocerá su forma más decisiva —aunque más irónica también-en Paludes de Gide, que no reivindica el estatus de novela sino el de «sotie».

La publicación por Zola, en 1887, de su novela La Terre, así como el célebre Manifeste des Cinq que la sanciona, son percibidos por la historia de la literatura como el comienzo de la pérdida de influencia definitiva del naturalismo. El primer golpe ya había sido infligido con la publicación de $\grave{A}$ rebours en 1884, y su manifiesta dejación de las grandes líneas del cientifismo y del positivismo - las dos grandes ubres del naturalismo, como dirá Jacques Dupont-; ${ }^{417}$ esta nueva ola de creadores huye del tipo de mirada con pretensiones enciclopédicas, y más que a Taine o a Renan se refieren a Baudelaire o a Poe.

La contestación de los modelos novelescos extraídos del realismo o del naturalismo conocen su definitiva rarefacción gracias a la profusión de esta «nueva novela» o novela de "fin-de-siècle». Para ello se hace necesaria la puesta en funcionamiento de nuevas técnicas de formulación del estado mental de ese héroe esteta y soltero, que pasan, muy a menudo, por la exposición de motivos de modo fragmentario - en su afán por romper, de

415 Consultar la interesante y ya mencionada obra de J. Borie, Le célibataire français, ob. cit.

416 J. Dubois, ob. cit., p. 253 y ss.

417 J. Dupont, "Contre le Naturalisme», Magazine Littéraire, n. o 288, 1991, pp. 23-25. 
una vez por todas, con la intriga, la peripecia y la aventura. Esto se haría visible en la Madame Gervaisais de los Goncourt, o, sin ir más lejos, en el $\grave{A}$ rebours de Huysmans - donde la técnica basada en la exposición cercana al fragmento del tipo poema en prosa es alabada por el esteta des Esseintes:

maniée par un alchimiste de génie, elle devait, suivant lui, renfermer, dans son petit volume, à l'état d'of meat, la puissance du roman dont elle supprimait les longueurs analytiques et les stupéfactions descriptives. ${ }^{418}$

La crisis naturalista está servida, abriendo el paso a nuevas vías de exploración dentro del amplísimo — desde entonces— campo de la novela. Lo que queda claro es que la novela de raigambre psicológica ya no es del gusto de todos los autores. La nueva novela prefiere otro tipo de facturas, más acorde con el espíritu multiforme de la época, hecho a la necesidad de adaptación cada vez más creciente de su sociedad. En el caso de Huysmans, Jean Borie le dirá inapto para la fabricación de novelas al uso y gusto decimonónicos - que sería motivo de alabanza de Gourmont y, sobre todo, de André Breton. Al incluirlo en su Anthologie de l'humour noir, el líder del surrealismo le hace un gran favor de recuperación y prestigio dentro de las letras francesas como artífice de la nueva sensibilidad:

Huysmans, avec une clairvoyance sans égale (a) formulé de toutes pièces la plupart des lois qui vont régir l'affectivité moderne, pénétré le premier la constitution histologique du réel et se soit élevé avec En rade aux sommets de l'inspiration. ${ }^{419}$

En otro lugar, Breton atribuirá a Huysmans la revolución definitiva de la novela de componente psicologicista: «fort heureusement que les jours de la littérature psychologique à affabulation romanesque sont comptés. Il faut dire que le coup dont elle ne se relèvera pas lui a été porté par Huysmans». ${ }^{420}$

La recopilación de opiniones contra el imperio tiránico del naturalismo es amplia. Así Remy de Gourmont señalaba, en una encuesta, el hartazgo ya sin vuelta atrás de las nuevas generaciones de escritores por la factura zoliana:

418 J.-K. Huysmans, À rebours, ob. cit., p. 222.

419 A. Breton, Anthologie de l'humour noir, ob. cit., p. 191.

420 A. Breton, Nadja, ob. cit., p. 20. 
ll ne s'agit pas d'un parti pris, il n'y eut pas de mot d'ordre donné; nulle croisade ne fut organisée; c'est individuellement que nous nous sommes éloignés avec horreur d'une littérature dont la bassesse nous faisait vomir. ${ }^{421}$

François Livi reporta la opinión vertida por el poeta Adolphe Baju a propósito de la defección del naturalismo:

un certain nombre de jeunes gens, las de lire toujours les mêmes tristes horreurs dites naturalistes [...] s'avisèrent un jour de lire mes vers, écrits pour la plupart en dehors de toute préoccupation d'école, comme je les sentais [...] Bref, dès ce moment précis, 'décadent' — un mot vaguement né où? — signifiant en nous désignant, mes trois Maudits et moi. ${ }^{422}$

\subsubsection{Deserción de Huysmans}

En el caso de Huysmans, su adscripción al naturalismo, si fue decidida en sus comienzos, fue dejando paso poco a poco al cansancio de temas hasta el abandono total de las tesis zolianas. Sin embargo, y como ya hemos ido señalando antes, la metodología naturalista jamás será abandonada por el autor de Là-bas.

Por una parte, está la toma de notas «de campo»: algo necesario para todos los escritores salidos de la influencia de Flaubert, del primer Goncourt, y de Zola. Incluso cuando la ruptura con el naturalismo está muy avanzada, Huysmans sigue utilizando esta técnica de plasmación de la realidad para transportar datos a sus trabajos literarios. De esta manera le cuenta a su amigo Prins, en 1889, cuáles han sido sus impresiones tras la investigación en el mundo homosexual:

j'ai pénétré dans le monde des tapettes et ai enlevé la Camargo, la plus chic ou le plus chic d'entr'eux ou d'entr'elles. Ah! je vous jure que c'est bien étrange et jai recueilli de bonnes notes. Tout cela se passe dans des bauges affreux, chez des marchands de vins qui puent le meurtre. ${ }^{423}$

Es decir, que esta técnica sigue pareciendo útil al escritor incluso después de su anunciada ruptura en temas y postura con el naturalismo.

421 J. Huret, Enquête sur l'évolution littéraire, ob. cit., p. 135.

422 Citado por F. Livi, ob. cit., p. 49, nota n. ${ }^{\circ} 3$.

423 Carta del 26 de noviembre de 1889, citada por R. Baldick, La vie de J.-K. Huysmans, Denoël, París, 1958, p. 290. La cursiva es mía. 
Por otra parte, el mismo tipo de escritura naturalista conviene a las necesidades de plasmación de Huysmans. Como una proyección de su psicología, el texto literario de Huysmans presenta un carácter fragmentario que retoma en clave metafórica un esquema fetichista. Mediante la descripción de objetos, ambientes y decorados, Huysmans retrata a varios de sus personajes: presentándolos así los reifica, los convierte en objetos. En literatura, como dice David Tacium, ${ }^{424}$ el naturalismo tiende al fetichismo; Philippe Hamon sostiene esta aseveración al señalar que el naturalista mantiene «une esthétique du fragment, du morceau, de la tranche de vie, du tableau».

Los ejemplos no faltan, a lo largo de toda la obra huysmansiana, de la escritura a golpe de extracto, a golpe de tranche de vie - cuyas expresiones máximas se hallan en los Croquis parisiens y, cómo no, en $\grave{A}$ rebours.

Además, el gusto por los ambientes barriobajeros no dejará de atraer a Huysmans por mucho que abomine de su constante utilización por parte de la ortodoxia naturalista. Muestra de ello es — aparte de algunos textos de su Drageoir à épices - Marthe y Les Saurs Vatard — novelas perfectamente englobables dentro de dicha ortodoxia- su gusto por la gente miserable, por los laissés-pour-compte que poseen, para su estética aconvencional, valor estético. En esto sigue un tanto el ejemplo baudelairiano de elogio de la vieja callejera, del vagabundo, del borracho errante, del saltimbanqui venido a menos de la fête foraine cochambrosa y pobre. ${ }^{425}$ En Certains, Huysmans alaba el gusto del pintor Raffaëlli, en cuya obra ve una especie de

élixir de crapule, de l'extrait concentré d'urinoir transporté sur une scène, de la quintessence de berge, de dessous de pont, enrobée dans une musique poivrée de cymbales et salée de cuivres. ${ }^{426}$

Sea como fuere, el joven escritor Huysmans sentía una verdadera devoción por Zola, palpable en los primeros pasos de su carrera. Y no solo por la adscripción de sus dos primeras obras a las técnicas y a los temas de

424 D. Tacium, ob. cit., p. 211.

425 Vid. los comentarios que Federico Vercellone hace sobre la nueva sensibilidad estética de la segunda mitad del siglo XIX, en F. Vercellone, L'Estetica dell'Ottocento (versión española Estética del siglo XIX, Antonio Machado Libros, colección La Balsa de la Medusa-Léxico de Estética, Madrid, 2004).

426 J.-K. Huysmans, Certains, en Euvres complètes de J.-K. Huysmans, vol. X, Slatkine Reprints, Ginebra, 1972, p. 122. 
la ortodoxia naturalista — que luego se confirmaría con su inclusión en Les Soirées de Médan (1880)_. El biógrafo más señalado del autor de $\mathrm{La} C \mathrm{Ca}$ thédrale, Robert Baldick, ${ }^{427}$ señala en su reconocida obra que Huysmans adquirió la serie completa de los Rougon-Macquart con el dinero cobrado con los derechos de autor de su Drageoir (1874). Cómo no ver en este hecho un símbolo de la nueva tendencia tomada por Huysmans...

La publicación de Marthe, histoire d'une fille en 1876, supuso su entrada definitiva en esa literatura que narraba hechos de los bajos fondos y de sus habitantes. Y tal fue la convicción de Huysmans de que esto fue así que, a modo de homenaje, envió un ejemplar de su novela a Goncourt - quien acababa de publicar también La Fille Élisa. Este último revela en su Journal que el envío de Huysmans le había hecho pasar una pésima noche, por la competencia que Marthe podría significar para su Élisa; tanto fue así que soñó que la policía venía a buscar al novelista y le metía en la cárcel. ${ }^{428}$

En una carta, sin embargo, que Goncourt remitió a Huysmans posteriormente a la publicación de Les Seurs Vatard (1879), su inclusión en la nómina naturalista es clara al compararla a otros títulos ya reconocidos dentro de esta escuela. Gourmont, ya hastiado de barrios bajos y de pintura de la pordiosería, recomienda a su pupilo cambiar esa vía por temas más elevados: ese será el comienzo del cambio para el autor de En ménage.

Je crois que Germinie Lacerteux, L'Assommoir, Les Soeurs Vatard ont à l'heure qu'il est épuisé ce que j'appellerai la canaille litéraire, et je vous engage à choisir pour milieu de votre prochain livre une sphère autre, une sphère supérieure. ${ }^{429}$

En Les Scurs, el universo estético-temático es claramente naturalista. El personaje que podría representar la visión del narrador —ese alter ego huysmansiano que es Cyprien Tibaille, que sería posteriormente camarada de André Jayant en En ménage-, defiende en varias ocasiones el discurso realista de la ortodoxia zoliana. En concreto, la plasmación en su pintura de tan solo lo que su ojo podía ver - lo que le otorgaba un estatus de verosimilitud necesario para el proyecto naturalista: «il affirmait qu'un peintre

427 R. Baldick, ob. cit., p. 52.

428 Extremo relatado por R. Baldick, ib., p. 51.

429 Citado por R. Baldick, ib., p. 63. 
ne devait rendre que ce qu'il pouvait fréquenter et voir; or, comme il ne fréquentait et ne voyait guère que des filles, il ne tentait de prendre que des filles». ${ }^{430}$ Se trata de las prostitutas, las jóvenes grisettes o lorettes que poblaban las fábricas - las hermanas Vatard trabajan en el taller de una imprenta como el que Huysmans tenía debajo de su casa infantil-; pero lo que le interesaba era, como buen naturalista, captarlas en su medio habitual, «dans les lieux où elles foisonnent: bâillant, le soir, devant le bock d'un concert; en piste, à la table d'un café». 431

La siguiente publicación de Huysmans no sigue todavía el consejo de Gourmont, pues Huysmans, en Croquis parisiens, se complace en la plasmación de los ambientes típicos de la estética de Médan: la ciudad, la multitud que debe golpearse para subir a un autobús, las posibilidades de fabulación que residen en la existencia de cada integrante de esa multitud. Un ejemplo patente es el registrado en el relato titulado «Le Conducteur d'omnibus», en el que el chófer aparece como un envidiado testigo de los afanes y las preocupaciones de los usuarios de su vehículo: "cette assemblée de femmes et d'hommes ne lui donne-t-elle pas un spectacle vieux comme le monde mais toujours réjouissant?» ${ }^{432}$ —se pregunta el narrador. $\mathrm{O}$, mejor incluso, en el croquis que relata las erranzas del narrador por esa cloaca de París que es el río Bièvre, que es un ejemplo paradigmático de escritura naturalista. La pobreza, la suciedad, la cochambre de los habitantes del extrarradio más olvidado se convierten en figurantes de un escenario ennoblecido por la desgracia, en víctimas del progreso ciego y sordo a los problemas verdaderos de la humanidad...: «les gens qui ont décidé le pillage et le sac de ces rives, n’ont donc jamais été émus par l'inertie désolée des pauvres, par le gémissant sourire des malades?». ${ }^{433}$

Como sabemos, En ménage es la obra que da a Huysmans el toque personal y diferenciador dentro de la corriente. Novela sobre un único personaje, de clase media, con aspiraciones estéticas; novela sobre el fracaso de la

430 J.-K. Huysmans, Les Sours Vatard (précédées de Marthe, histoire d'une fille), préface d'Hubert Juin, Union Générale d'Éditions, París, 1975, p. 287.

431 Ib., p. 290.

432 J.-K. Huysmans, Croquis parisiens (suivis de À vau-l'eau et de Un Dilemme), Plon, París, 1908, p. 56. El relato pertenece a la serie «Types de Paris».

433 Ib., p. 84. Se trata del croquis «La Bièvre», perteneciente a la serie «Paysages». 
vida mediocre, sobre el descalabro del matrimonio, de la vida con una mujer; y de los reveses profesionales. André Jayant sería la primera representación de ese alter ego husymansiano que perviviría a lo largo de toda la novelística de nuestro autor.

En ménage y la nouvelle que le sigue en la cronología del autor, $\grave{A}$ vaul'eau (1882) no son obras típicamente naturalistas - como tampoco son estudios sociológicos en la línea de Zola. Se trataría más bien en ambos casos del tipo de novela a la Benjamin Constant, que prefiguraría la obra de Proust antes que Lejardin y otras experiencias del monólogo continuado.

Ese mismo año, y con motivo de la publicación de La Faustin, Huysmans enviaría a su autor, Goncourt, una carta que, en cierto modo, denota un nuevo gusto. Estimulado por la escena de los amores entre Lord Annandale y la actriz protagonista de la novela, dice nuestro autor haber reconocido una nueva sensualidad erótica, más basada en la excitación nerviosa del intelecto que en la más grosera del cuerpo:

Ce n'est plus le rut bestial et grossier, mais un rut de corps affiné par des excitations de cervelle [...] Aussi ai-je éprouvé un frisson, à la lecture de la nuit de Lord Annandale et de la Faustin, car cette analyse de la jouissance, pratiquée sur des cerveaux de délicats nerveux, m’ouvrait des horizons soupçonnés. ${ }^{434}$

Unos horizontes estético-temáticos que Huysmans estaba deseando poder explorar con anterioridad, pero que solo un empujón por parte de alguien del prestigio y de la autoridad del autor de Germinie Lacerteux podía proporcionarle con seguridad. Y aunque en L'Art moderne, publicado al año siguiente, continúe Huysmans defendiendo la estética de las fábricas humeantes, del ambiente industrial como metáfora de la modernidad, somos conscientes del gran vuelco que se iba a producir en la obra huysmansiana con la publicación de $\grave{A}$ rebours en 1884 .

El golpe asestado a la escuela naturalista por esta obra capital de nuestro autor fue enorme. Tanto fue así que Zola no pudo por menos que criticar directamente a su compańero de armas. La reacción fue amarga, poniendo el acento sobre el abandono de la obra de Huysmans de los escenarios queridos por la ortodoxia; sobre el olvido de todos los laissés-pourcompte que el naturalismo entendía necesario estudiar y defender; sobre

434 Citado por R. Baldick, ob. cit., p. 109. Carta del 19 de enero de 1882. 
haberse centrado en un personaje de la nobleza, egoísta y solipsista, tan lejano de las inquietudes socio-políticas del autor de Germinal—quien creyó ver en des Esseintes una réplica literaria del dandi tan en boga en la época Robert de Montesquiou. Contestando a los reproches que Zola le había lanzado, Huysmans le escribe una carta hacia el 25 de mayo de ese 1884 en la que le dice: «si j'avais fait Montesquiou des Esseintes - (il eût été trop bouché!) j'aurais exprimé son inénarrable dégoût pour le naturalisme». ${ }^{435}$ Donde se observa ya una decidida voluntad de ruptura de nuestro autor con la ortodoxia. Y aunque las máximas invectivas contra el naturalismo fueran expuestas por nuestro autor en su prefacio escrito «20 ans après le roman", el Huysmans de 1904 no hace sino rememorar los motivos que le llevaron a abandonar la línea marcada por Zola. Por una parte, se desmarca de la pintura de personajes marginales, de la «existencia común», ya que lo que él deseaba era precisamente hablar de lo excepcional, de lo remarquable, de lo digno de atención por su singularidad. Así lo expresa en dicho "préface»:

[cette école] n'admettait guère, en théorie du moins, l'exception; elle se confinait donc dans la peinture de l'existence commune, s'efforçait, sous prétexte de faire vivant, de créer des êtres qui fussent aussi semblables que possible à la bonne moyenne des gens. ${ }^{436}$

Recurso este que le parecía poco útil para las aspiraciones emancipatorias de Zola, ya que estos personajes de los bajos fondos, de las fábricas y de la miseria urbana, solo tenían cabida en el discurso naturalista como formando parte del decorado: «les êtres humains égarés dans ces milieux n’y jouaient plus que le rôle d'utilités et de figurants». ${ }^{437}$ Personajes reducidos al estatus de objetos, totalmente desprovistos de iniciativa propia ni capacidad de decisión; juguetes de una intención ajena - que no era otra que la del progreso fabril, la de la patronal y del capital—, cuando no lo eran tan solo de los bajos instintos, de la lubricidad y las pulsiones carnales: «ses héros étaient dénués d'âme, régis tout bonnement par des impulsions et des instincts, ce qui simplifiait le travail de l'analyse». ${ }^{438} \mathrm{Y}$ eso era a lo que finalmente se li-

435 J.-K. Huysmans, Letres inédites à Émile Zola, ob. cit. Vid. también François Livi, J.-K. Huysmans. A rebours et l'esprit décadent, ob. cit., p. 72 y ss.

436 J.-K. Huysmans, À rebours, ob. cit., p. 45.

437 Ib., p. 47.

438 Ib., p. 47. 
mitaba la exposición de los hechos, la trama de la novela: a conducir al flujo de la libido de unos personajes que no tenían otra notivación que «la foutrerie» — «le lyrisme du peuple», como diría Baudelaire. ${ }^{439}$ Según esto, el arte de la novela había llegado a un impasse en el que la carne lo era todo: «le roman se pouvait résumer en ces quelques lignes: savoir pourquoi monsieur Un tel commettait ou ne commettait pas l'adultère avec madame Une telle». ${ }^{440}$

La ruptura con Zola ya se había operado y era definitiva. ${ }^{441}$ A partir de ese momento, las invectivas contra el naturalismo serían continuas a lo largo de toda su obra — aun cuando el método de escritura le fuera necesario a Huysmans para plasmación y reconstrucción de su propia vida anímica.

La rebeldía de Huysmans para con las bases de la teoría naturalista encuentra otra muestra en el compendio Certains, en el que nuestro autor habla de la teoría del medio ambiente de Hyppolite Taine adaptada al arte: «(elle est) juste, mais juste à l'envers ou à rebours, lorsqu'il s'agit de grands artistes, car alors l'ambiance agit sur eux par la révolte et par la haine qu'elle les inspire».

El caso de $L \grave{a}$-bas es tal vez el más significativo en lo que se refiere a la exposición de su rechazo y deserción de las pautas naturalistas. Como sabemos, este roman d'un romancier narra la concepción por parte del novelista Durtal de una obra sobre Gilles de Rais: ese des Esseintes del siglo XV, una especie de dandi medieval, rudo, sensual y salvaje, la antítesis perfecta

439 C. Baudelaire, Mon cour mis à nu, ob. cit., p. 37.

440 J.-K. Huysmans, À rebours, ob. cit., p. 46.

441 Per Buvik, en su magnífico estudio La luxure et la pureté, demuestra la inanidad de los ataques a Zola, que muchas veces eran contradictorios y no hacían sino revelar la importancia que la figura del jefe revestía ante Huysmans. Así, en una carta, le dice: «J'ai jeté à l'eau mes idées personnelles et ai exprimé des idées diamétralement opposées aux miennes qu'il ne pourra venir à personne à l'idée de m'attribuer, puisque j'ai écrit tout le contraire dans l'Art Moderne» [...] «J'ai déclaré qu'il (des Esseintes) préférait La Tentation à L'Education, la Faustin à Germinie Lacerteux, La Faute de l'abbé Mouret à L'Assommoir —ça c'est clair [...] mais c'est à l'antipode de mes préférences». En esa misma carta califica de enfermizas las ideas de des Esseintes y de "une affable blague» su celebración de la gloria de Mallarmé. Ahora bien, si el entusiasmo de des Esseintes por el poeta, por aquel entonces desconocido, era efectivamente una broma, la admiración expresada en su carta del 27 de octubre de 1882 cobra carácter de falsedad, lo mismo que la intervención de Huysmans en favor de Mallarmé en el momento en que fuera atacado por Léon Bloy, en P. Buvik, La luxure et la pureté. Essai sur l'œuvre de Joris-Karl Huysmans, ob. cit., pp. 72-73. 
del hombre medio del siglo XIX tan querido por los naturalistas. Para sondear la influencia del satanismo en esta demoniaca personalidad medieval, Durtal intenta documentarse sobre el alcance y la vigencia de las ciencias ocultas en el momento, en pleno siglo XIX. Entra de este modo en contacto con el abbé Boullan, un cura que fue finalmente excomulgado, que conformaría el modelo del personaje de Johannès. Para convencerle de la confianza que el religioso puede depositar en el escritor, este le indica hasta qué punto se halla en disonancia con el materialismo de Zola y de toda la horda materialista:

je suis las des théories de mon ami Zola, dont le positivisme absolu me dégoûte. Je ne suis pas moins las des systèmes de Charcot, qui a voulu me démontrer que la démonialité était une rengaine, que, lui, développait ou mâtait en pressant sur les ovaires, le satanisme des femmes traitées dans les salles de la Salpêtrière. $^{442}$

Huysmans quiere creer en el satanismo, en lo sobrenatural no solo como nuevo material para su obra, sino, como veremos más adelante, como una necesidad de su psicología profunda.

En cualquier caso, satanismo o no, las invectivas contra el naturalismo son numerosas en esta, una de las obras más celebradas de Huysmans. Poniendo en boca del amigo de Durtal sus propiedades, nuestro autor hace que el médico des Hermies acuse al naturalismo de demasiado apegado al imperio de las ciencias, de haber limitado la literatura al estudio del placer carnal, de abolir lo sobrenatural y los sueños...:

ce que je reproche au naturalisme, ce n'est pas le lourd badigeon de son gros style, c'est l'immondice de ses idées; ce que je lui reproche, c'est d'avoir incarné le matérialisme dans la littérature, d'avoir glorifié la démocratie de l'art! [...] Vouloir se confiner dans les buanderies de la chair, rejeter le suprasensible, dénier le rêve, ne pas même comprendre que la curiosité de l'art commence là où les sens cessent de servir! ${ }^{443}$

No se quedan en eso las críticas al sensualismo y al materialismo zoliano; más adelante, el mismo des Hermies arremeterá contra el maestro de Médan:

442 Citada en J. Caldain, «Le satanisme est-il pratiqué aujourd'hui?», Le Matin, París, 21 de abril de 1908.

443 J.-K. Huysmans, Là-bas, Plon-Le Livre de poche, París, 1961, p. 5. 
il a tout mis sur le compte des appétits et des instincts. Rut et coup de folie, ce sont là ses seules diathèses. En somme, il n'a fouillé que des dessous de nombril et banalement divagué dès qu'il s'approchait des âmes. ${ }^{444}$

Todo eso además de predicar la vida moderna, las costumbres de color estadounidense, vulgares, bajas, para las que solo cuenta la banal diversión, el trabajo y la seguridad de la caja fuerte: «il prône cette vie moderne atroce, vanté l'américanisme nouveau des mœurs, aboutit à l'éloge de la force brutale, à l'apothéose du coffre-fort». ${ }^{445}$ Huysmans no quiere, no pretende abandonar el método naturalista — ya lo hemos visto- completamente: el estudio detallado del comportamiento humano le sigue interesando, pero más en su vertiente intelectual, profunda, íntima... De la misma manera que la vida humana se compone de una vida física y otra espiritual, nuestro autor sueńa con la concepción de una novela separada en dos partes, de las que una trataría de los reactivos del alma, de sus conflictos internos, de sus acuerdos... "de faire, en un mot, un naturalisme spiritualiste; ce serait autrement fier, autrement complet, autrement fort!». ${ }^{446}$ Un realismo, en suma, este naturalismo espiritualista, que fuera capaz de describir con detalle casi notarial los problemas y las contradicciones de toda vida humana. La descripción de los sufrimientos del individuo para alcanzar la dignidad necesaria para todo proyecto humano sería lo que dotaría al proyecto de una credibilidad máxima; el o los personajes ya no serían meros figurantes, sino actores, decorado y escenario mismo de toda una trama, profunda y compleja. De ahí que el ejemplo para Huysmans de este realismo exacerbado sea el pintor germano Grünewald y sus retablos con cristos llagados y malolientes, en los que la humanidad se captaba con total acuidad y a los que el creyente en ciernes que era nuestro autor podía sentirse más cercano:

444 Ib., p. 6.

445 Ib., p. 6. Esta afirmación de Huysmans podría asociarse con total acierto a las aseveraciones de Zola sobre el dinero, sobre esa psicología de caja fuerte. En contra de los partidarios de una concepción romántica de la vocación artística, apela a una percepción realista de las posibilidades que el dinero ofrece al escritor: «Hay que aceptarlo sin lamentaciones ni puerilidades, hay que reconocer la dignidad, el poder y la justicia del dinero, hay que dejarse llevar por el nuevo espíritu...» — que no sería otro que el del materialismo. En P. Bourdieu, Les règles de l'art, ob. cit., p. 144. Vid. también W. Asholt, «La question de l'argent. Quelques remarques à propos du premier texte littéraire de Vallès», Revue d'études vallésiennes, n. ${ }^{\circ} 1,1984$, pp. 5-15.

446 J.-K. Huysmans, Là-bas, ob. cit., p. 8. 
c'était excessif et c'était terrible. Grünewald était le plus forcené des réalistes; mais à regarder ce Rédempteur de vaudrouille, ce Dieu de morgue, cela changeait. De cette tête exulcérée filtraient des lueurs; une expression surhumaine illuminait l'effervescence des chairs, l'éclampsie des traits [...] Grünewald était le plus forcené des idéalistes $[\ldots]^{447}$

De estas propuestas solo había un paso a lo que, pocos párrafos más adelante él llamaría naturalismo místico («ah! non, par exemple, et si pourtant!») y que adoptaría como modus operandi en sus obras calificadas de 'religiosas': Sainte Lydwine de Schiedam, sobre todo.

En resumidas cuentas: ¿naturalismo sí o naturalismo no? Naturalismo sí, pero a su propia manera, lejos de la influencia perniciosa de Zola, libre de las ataduras de escuela: solo, singular, único, Huysmans se convertiría en un escritor bastardo o expósito - en el sentido de abandonado (ya sea activa o pasivamente) de cualquier familia literaria. Naturalismo sí, pero intelectual y profundo, con vocación perforadora de las simas del alma, pura espeleología del espíritu, cuya descripción necesitaba de un método suficientemente creíble y cuyo rigor ya había quedado demostrado en los aproximadamente 15 años del naturalismo. ${ }^{448}$

Ahora bien, sondeo del espíritu ¿de quién? ¿De quién si no de sí mismo? Como hemos podido ir viendo a lo largo de este capítulo, con Sac au dos y En ménage, el protagonismo de las novelas cambia de un sujeto-fille a un sujeto-célibataire (o, como André Jayant, con deseos de serlo pero sucumbiendo finalmente ante los inconvenientes del celibato). Y aun siendo esto así, es también claramente visible la presencia de un personaje masculino como contraste a las muchachas de sus dos primera novelas: Marthe, histoire d'une fille y Les Sours Vatard. Se trata de Léo, joven que vivía de su pluma; y de Cyprien Tibaille — que sería el amigo pintor del André de En ménage y que, como el propio Huysmans, fumaba con fruición. ${ }^{449}$

447 Ib., p. 12.

448 En las célebres encuestas de Jules Huret, en L'Echo de París, del 3 de marzo al 5 de julio de 1891, Huysmans proclamó decididamente: «le naturalisme est fini». Las preguntas planteadas eran: 1) «¿Está enfermo el naturalismo? ¿Está muerto?»; 2) «¿Se puede salvar?»y 3) «¿Qué lo sustituirá?». Vid. J. Huret, ob. cit., p. 125.

449 Pensando en la visita que debía hacer a un salón, «Il partait accablé par la perspective de rester, deux heures ou trois heures debout, sans fumer, auprès d'une porte». J.-K. Huysmans, Les Sours Vatard, ob. cit., p. 376. 
El cambio en el enfoque por parte de Huysmans no puede revelar otra cosa más que la importancia creciente que iba adquiriendo su propia persona ante sus propios ojos. No le debía de bastar aparecer como un comparsa, dibujarse a sí mismo como un negativo de la figura protagonista de sus jovencitas; la escritura tenía que servirle como exutorio de sus propios planteamientos vitales, del modo de vida que había elegido. Por eso la obra de Huysmans, por mucho que cambie el nombre de ese personaje central, esteta, escritor, soltero, antimoderno y, en el último período, acuciado por las inquietudes religiosas, es claramente autobiográfica — llegando a confesarlo él mismo sin ningún tipo de ambajes.

\subsection{Autobiografía novelada}

Un des grands défauts des livres de M. Huysmans, c'est selon moi, le type unique qui tient la corde, dans chacune de ses œuvres. Cyprien Tibaille, André, Folantin et des Esseintes ne sont, en somme, qu'une seule et même personne, transportée dans des milieux qui diffèrent. Et très évidemment cette personne est M. Huysmans, cela se sent.

Eso se siente. Así se describió Huysmans a sí mismo en esa finta que fue firmar como A. Meunier (homenaje a su amante Anna) para la serie de Les Hommes d'aujourd'hui, publicada por Léon Vannier. Sus propios biógrafos, como el insigne Robert Baldick, están convencidos de la identidad inequívoca de ese continuum de solteros estetas: «Huysmans est très certainement le mysanthrope aigre, l'anémo-nerveux de ses livres». ${ }^{450}$ Los veredictos son, desde luego, definitivos sobre este aspecto de la obra huysmansiana. Sin llegar a cumplir todas las características de la obra memorialística en la que, como indica Philippe Lejeune en su Pacte autobiographique, debe darse la unidad entre la identidad del autor, del narrador y del personaje, ${ }^{451}$ algunos estudiosos de la producción huysmansiana llegan a afirmarlo con rotundidad. Así Baldick, quien asevera que se trata de las memorias más penetrantes y sinceras que hayan salido de la pluma de un escritor moderno. Y no le falta razón cuando apunta que

450 R. Baldick, ob. cit., p. 57.

451 P. Lejeune, ob. cit., p. 15. 
(estas memorias) nous apportent un témoignage intime sur la vie matérielle et spirituelle d'un auteur dont l'inébranlable détermination de se montrer à nous sous le jour le plus véridique possible, dont la pénétration psychologique, dont l'habileté et l'honnêteté qu'il apporte à atteindre le but qu'il s'est proposé, continuent à susciter l'admiration des lecteurs contemporains, habitués pourtant aux romans introspectifs du XXe siècle. ${ }^{452}$

Alguien que lo conoció personalmente, Remy de Gourmont, afirma el carácter memorialístico de la obra de Huysmans. Y hasta tal punto esto es así que quien lo frecuentó en vida sabía que los acontecimientos narrados en sus libros no eran sino reflejos de su existencia:

ce ne sont pas des romans; ce sont des mémoires. Les rares événements qu'on y trouve ne sont pas inventés: c'est sa propre vie que l'auteur nous raconte avec une simplicité où il y a un peu de candeur et beaucoup d'orgueil. ${ }^{453}$

Per Buvik ha rastreado los análisis que sobre la obra de Huysmans han efectuado algunos doctores en medicina. En primer lugar, un tal Lavalée señaló, en su Essai sur la psychologie morbide de Huysmans, varios puntos que determinaban que ese personaje heterónimo que aparecía a lo largo de toda la novelística huysmansiana no podía dejar de asimilarse al autor: ${ }^{454}$

1) La obra de Huysmans, y en particular $\grave{A}$ rebours, presenta huellas morbosas que llaman la atención de un médico. Un mismo personaje evoluciona con nombres diferentes a lo largo de toda la obra. 2) Los amigos de Huysmans atestiguan y el mismo Huysmans confiesa que «rarement l'homme et l'auteur se sont tant identifiés». 3) Es legítimo completar e ilustrar un estudio sobre Huysmans a través del estudio de su obra. 4) Des Esseintes, el héroe de $\grave{A}$ rebours, es un "momento" del personaje en cuyos rasgos parece haberse descrito Huysmans. Huysmans dice que el otro está afectado de histeria. Parece tratarse antes, según las concepciones modernas, de desequilibrio mental.

Otro doctor en medicina, esta vez el Dr. Veysset, establece otras conclusiones sobre nuestro autor en su estudio Huysmans et la médecine — «le

452 R. Baldick, ob. cit., p. 405.

453 R. de Gourmont, "M. Huysmans, écrivain pieux», Promenades littéraires, vol. 3, Mercure de France, París, 1963, p. 73.

454 Seguimos aquí muy de cerca las conclusiones presentadas por P. Buvik, ob. cit., pp. 16-17. 
travail le plus sérieux consacré à Huysmans et à son œuvre» según señala de nuevo Buvik:

1) Es difícil, si no imposible, clasificar a Huysmans dentro de los síntomas o las constituciones admitidas actualmente por la psiquiatría. No podemos, como ciertos autores, encasillarlo dentro de los ciclotímicos. Fue un artista complejo de múltiples contrastes, caracterizado esencialmente por su curiosidad para investigar todos los ámbitos sensibles y ocultos, su gran imaginación, su necesidad de soledad e independencia, su pesimismo realista. Su erudición apasionada, incluso excesiva, su vida atormentada jamás alcanzaron el desequilibrio: en definitiva, Huysmans se acercó a la patología mental sin jamás entrar dentro de ella. 2) Su obra es el reflejo casi exacto de su carácter y su comportamiento. Se halla como si estuviera repleta de medicina en varios ámbitos: fisiología terapéutica, patología visceral y orgánica, psiquiatría y psicopatología.

Por último, un tal Dr. Rolland se dedicó más concretamente a las preocupaciones metafísicas de nuestro autor, en su obra Etude psychopathologique sur le mysticisme de J.-K. Husymans. En ella, el doctor indica que la mística huysmansiana lleva la huella de su personalidad; en ella se encuentran los elementos que marcan su psicología morbosa: hiperemotividad, ciclotimia y tendencias paranoicas.

En realidad, los elementos que nos permiten establecer las similitudes entre obra y vida de Huysmans son numerosos - hasta tal punto se confunden la una y la otra. Como hemos apuntado en otro lugar, ${ }^{455}$ los viajes acometidos por el escritor le sirvieron como material narrativo de primer orden, de tal manera que solo merecieron la pena los que le sirvieran en su posterior novelación. La realidad integra la ficción, aunque necesariamente modificada para servir a los fines perseguidos por la inteligencia creadora.

Del primer gran desplazamiento que supuso para el joven Huysmans la movilización militar de 1870 surge el relato Sac au dos - que Zola incluiría en sus Soirées de Médan. Sus estancias en Fontenay-aux-Roses y Lourps dan nacimiento a $\grave{A}$ rebours y a En rade, respectivamente. La visita

455 F. Domínguez, «El placer del desplazamiento que no existe. Diálogo viajero entre Huysmans y Baudelaire» (en prensa). 
al castillo de Tiffauges, morada del medieval Gilles de Rais —el Barbebleu del Pays de Retz, en Vendée-, le sirve como punto de partida para la redacción de Là-bas. Tras alojarse en las instituciones religiosas de La Salette y la Trapa de Igny, escribe En route. Chartres y Solesmes le dan pie a trabajar en una de sus obras más admiradas, La Cathédrale. Su instalación en Ligugé, en el Poitou, le inspiran la escritura de Sainte Lydwine de Schiedam y L'Oblat. Lourdes le sugiere Les Foules de Lourdes; la alemana Colmar el tratado artístico Les Grünewald du musée de Colmar...

Tranches de su vida que se metieron en su vida narrativa —o que él mismo introdujo en sus narraciones como material, como inspiración, ¿o como simple decorado? Porque un autor que en principio parecía tan necesitado de contarse, de novelar su propia vida, podría simplemente haber ocultado las referencias que le identificaban con los lugares, personas y hechos que jalonaron su existencia.

Pierre Cogny, uno de los grandes estudiosos de la obra de nuestro autor, afirma que «il n'y a pas de monument littéraire plus étroitement, plus effrontement personnel que celui de Huysmans a laissé après lui». ${ }^{456} \mathrm{Y}$ es que, como ya hemos señalado anteriormente, las referencias que apuntalan esta similitud entre vida y obra son numerosas. Cómo no ver en las referencias que da Huysmans sobre una de sus estancias en el castillo de Lourps — donde veraneó en cuatro ocasiones entre 1881 y 1885 - a su amigo Alexis Orsat la identidad perfecta con lo relatado en la obra que utiliza ese desplazamiento como fuente, En rade. Si recordamos el episodio sobre el chat-huant y el desasosiego que produjo en la pareja Jacques-Louise, no nos sorprenderemos al leer la carta que escribió el autor a Orsat: «Les gigantesques corridors noirs, l'échos de tous les pas là-dedans, les boucans d'oiseaux l'effraient, quand la pleine nuit arrive». ${ }^{457}$

456 En su prefacio a J.-K. Huysmans, L'Oblat, Pirot, París, 1992, p. 13.

457 En J. Jacquinot, "Louis-Alexis Orsat», Bulletin de la Société d'Amis de Huysmans, n. ${ }^{\circ}$ 23, 1951. Es este un acontecimiento vital perfectamente novelable y que, de hecho, lo fue por otros escritores: así por Colette en La Maison de Claudine, e incluso por Hergé en uno de sus Tintin: Les Bijoux de la Castafiore. Se trataba, en los tres casos, de ruidos escuchados en el altillo de una casa, que finalmente podían atribuirse a la presencia de un búho que había tomado residencia en esa zona elevada y abandonada, utilizada frecuentemente como trastero. La novela y su adaptación cinematográfica El exorcista utilizan el mismo recurso para señalar la presencia de un elemento étranger en la casa (William P. Blatty, Bantam Books, 
Otro acontecimiento perfectamente identificable a su propia existencia puede relacionarse con la génesis de $L \grave{a}$-bas. Como sabemos, uno de los leitmotiv de esta novela es la recepción por parte de Durtal de unas cartas de una anónima admiradora — que resultó ser Mme. Chantelouve, la siniestra satanista. Pues bien, en 1885, Huysmans recibió la primera de 19 misivas que le remitía una señora que firmaba con el pseudónimo de Isola, y que finalmente sería reconocida como Henriette Maillat (apellido de soltera, Picot). Pierre Cogny afirma con total seguridad que estas cartas fueron utilizadas previa modificación para convertirse en las que luego figurarían en la novela. La realidad entra, de nuevo, en la ficción como fuente, como inspiración, como material narrativo. ${ }^{458}$ Pero, ¿̇con qué fin? ¿Por qué actuaba así alguien dotado de semejante y prodigiosa imaginación?

Otra muestra más: en una carta a Charles Rivière, el autor afirma que En route es «nettement, furieusement même, catholique; j'y raconte, sans ambages, ma conversion». ${ }^{459}$ Cuenta sin reparos su conversión: afirmación que expresa claramente la intención del autor. La identificación entre vida y obra es, con esto, definitiva. Memorias, autobiografía, biografía novelada: ¿de qué se trata? Antes habíamos comentado la obligación establecida por Philippe Lejeune en su Pacte autobiographique ${ }^{460}$ de que, para ser considerada como autobiográfica, una obra debía presentar una identidad perfecta entre autor, narrador y personaje. La autobiografía, como producto literario, puede ser definida en estos términos: «récit rétrospectif en prose qu'une personne réelle fait de sa propre existence, lorsqu' elle met l'accent sur sa vie individuelle, en particulier sur l'histoire de sa personnalité». ${ }^{461}$ En el caso de la obra huysmansiana, ¿existe esta perfecta identificación? El autor firma como él mismo; ahora bien, sabemos que el narrador jamás se identifica - y suponer que hay concordancia entre autor y narrador rompería el pacto

1972. Film de William Friedkin — guion de Blatty, 1973-). Otra observación más: es dudoso que pueda ser un chat-huant, un mochuelo, el que haya ocupado una vivienda en el caso de la narración de Huysmans; antes se trataría de una lechuza (chouette) o incluso de un cárabo (hulotte) que de un mochuelo, más querente a zonas árboreas. V. F. Domínguez, "El Búho del desván», en Francofonía n. ${ }^{\circ}$ 17, Universidad de Cádiz, Cádiz, 2008.

458 Vid. P. Cogny, ob. cit., p. 56.

459 P. Buvik, ob. cit., p. 292.

460 P. Lejeune, ob. cit., p. 14.

461 Ib., p. 14. 
narrativo que se establece entre escritor y lector-, y que el protagonista recibe nombres diferentes a lo largo de toda su historia literaria: Léo, Cyprien, André, Folantin, des Esseintes, Jacques y, final y definitivamente, Durtal. Cualquiera que entrara en la obra de Huysmans sin sospechar siquiera esta posible identidad carecería de todo motivo para pensar que se trataba de un escrito autobiográfico. Y sin embargo...

Estaríamos más bien ante una novela autobiográfica stricto sensu que ante un trabajo memorialístico. Mientras este género obliga a la identificación explícita entre las tres instancias, aquel permite al autor la negación de su identificación con el personaje. Puede haber, siempre según Lejeune, ${ }^{462}$ en este subgénero, relatos personales —en los que se explicita la identidad entre narrador y personaje, por lo tanto redactados en primera persona- y relatos impersonales — no identidad, redacción en tercera persona.

El mismo Lejeune introduce una sutileza en referencia con los relatos impersonales. Si en toda ficción existe de hecho un pacto novelesco establecido entre autor — quien lo propone- y lector — quien lo acepta—, es posible crear entre ambos agentes del hecho literario un pacto referencial: en base a este, el texto propone la narración de hechos externos al mismo texto, como es el caso de los escritos científicos y técnicos en general. Dentro del pacto autobiográfico - que no es sino un pacto referencial puesto que se basa en la narración de asuntos externos al mismo acto narrativoLejeune propone acertadamente la inclusión de un pacto fantasmático (pacte fantasmatique), por el cual el lector es invitado a leer un texto que incluiría las obsesiones reveladoras del individuo (des fantasmes révélateurs d'un individu).

Todo lo que hemos visto hasta aquí en relación con la posible identificación del autor con su obra — proyección de su personalidad en sus escritos, que no serían finalmente sino una extensión de sí mismo en los que poder alienarse, ${ }^{463}$ que le permitirían captarse a sí mismo como un todo, como una unidad, de ahí el fetichismo autorreferencial de la obra escrita:

462 Ib., p. 25.

463 «L'existant ne réussit à se saisir qu'en s'aliénant», dice Simone de Beauvoir, en Le deuxième sexe. S. de Beauvoir, ob. cit., I, p. 103. 
la obra escrita como fetiche, como sustitución de uno mismo, en cuya progresión el escritor puede reconocerse mediante un simple "yo soy esto", reconocerse en una narración que, como observa Richard Sennet, es necesaria para la aprehensión de sí mismo a través de un complicado posicionarse en el exterior del yo para observarse desde fuera-, unido al deseo de forjar un naturalismo espiritualista que le permita sondear las profundidades del alma humana con la precisión de un cirujano, no puede más que empujarnos a creer en este pacto fantasmático. Huysmans se disecciona a sí mismo con exacerbado realismo, mostrando las llagas de su sufrimiento, el repetitivo ataque de sus obsesiones, el descarado parapetamiento contra la ramplonería de la gente que le rodea. No son precisamente lindezas que cualquiera que estuviese satisfecho de su existencia gustaría de mostrar para presentarse como alguien digno de alabanza. No. Todo lo contrario. El Huysmans de sus novelas autobiográficas es un hombre que se muestra sin excesivos ropajes — si exceptuamos los nombres tras los que se oculta—, que se toma a sí mismo como ámbito de investigación. Pues al hablar de sí en tercera persona — un rasgo de megalomanía—,${ }^{464}$ el sujeto se somete a una duplicación conducente a tratarse como ajeno a sí mismo, posibilitando así el paso del sujeto al objeto. La reificación del propio yo, proceso peligroso donde los haya y que requiere de una gran solidez psicológica, es lo que abre las puertas al estudio - que es lo que, sostenemos, busca el escritor Huysmans- de ese yo.

¿No habría sido más satisfactorio para el escritor proponerse directa y explícitamente como objeto de su narrativa — escribir en primera persona? Tal vez semejante acción de mise à nu habría dejado a las claras la intención diseccionadora del proyecto husymansiano. Sin embargo, proponerse a sí mismo como objeto de ficción comprende unas ventajas que no hay que dejar de tener en cuenta.

La primera de ellas sería la posibilidad de escamoteo: la revelación de aspectos demasiado oscuros, inconfesables —en una palabra, fantasmáticos (como señala Lejeune) - es un riesgo demasiado grande para la integridad psicológica. Aun estando seguro de que son sus obsesiones profundas las que están siendo expuestas, la propuesta mediante el pacto

464 Como señala Jean-Luc Steinmetz, en su edición de C. de Lautréamont, Les Chants de Maldoror, Les Chants de Maldoror y Poésies, Garnier-Flammarion, París, 1990, p. 420. 
referencial le permite una cómoda ocultación. En pocas palabras, que el autor siempre puede recurrir a un protector "ese no soy yo" perfectamente verificable en la no identificación nominal entre sujeto escritor y objeto escrito.

La segunda, y la que nos parece más interesante y productiva, es la que permite, no habiendo identidad explícita entre escritor-narradorpersonaje, proponer una corrección sobre los hechos narrados. Como señalaba ya Albert Camus en su Homme révolté, «l'essence du roman est dans cette correction perpétuelle, toujours dirigée dans le même sens, que l'artiste effectue sur son expérience». ${ }^{465} \mathrm{Ni}$ moral ni puramente formal, Camus sostiene que esta corrección aspira a alcanzar la unidad — de ahí que traduzca una necesidad metafísica. La novela, dirá el escritor en el mismo pasaje, «est d'abord un exercice de l'intelligence au service d'une sensibilité nostalgique ou révoltée». El mismo pacto referencial subyacente a la novela autobiográfica impersonal (recordemos: no identidad entre las tres instancias, redacción en tercera persona) permite una variación interesada de las propias circunstancias vitales — que son, en definitiva las que sirven de material narrativo. Y esta variación se puede hacer sin que historiador o biógrafo alguno tenga autoridad suficiente para rebatir los hechos narrados dentro de una ficción. Una autobiografía ficcional puede y no puede ser fiel a la realidad, sino todo lo contrario. Es la posibilidad de escamoteo y de corrección de lo real la que permite la inclusión de cuantiosos elementos de ficción no verificable mediante el estudio científico de la biografía del autor. Es una biografía no autorizada, sino propuesta como válida... ante sí mismo.

El autor sabe que la veracidad de ciertos hechos presentados — aunque lo sean como ficción - ligan el escrito a la biografía. La inclusión junto a esos hechos veraces de otros añadidos, que operen esa saludable corrección sobre la realidad, puede permitir al autor, mediante un esfuerzo de verosimilitud, albergar la posible inteligencia de los mismos como hechos ciertos y probados — por su misma existencia literaria.

Los elementos hallados en la realidad son redistribuidos, dentro de esta técnica, tendiendo con ello a re-crear el universo vital del artista. Camus apunta que es precisamente esa capacidad de recreación mediante el len-

465 A. Camus, ob. cit., p. 327. 
guaje lo que se conoce como 'estilo': «elle vise, chez tout révolté, et réussit chez quelques génies, á donner sa loi au monde». ${ }^{466}$

Gracias a esa operación de transfiguración de lo real, el escritor puede no solo aspirar a la unidad, sino la totalidad del mundo real. Al proponerse como objeto de estudio, el escritor se abarca a sí mismo; cosa que, antes de tal operación, se manifestaba inalcanzable. El mundo, tras esta modificación interesada, es más habitable, y sus circunstancias más aceptables para una personalidad atormentada consigo misma.

La exposición de los propios motivos y circunstancias contribuye a autentificar la propia existencia mediante la escritura — como señala Alain Finkielkraut hablando de una obra de Michel Leiris. La valentía necesaria para llevar a cabo semejante empresa y exponer la propia integralidad al examen y juicio del lector permite, asimismo, que el autor compense la falta de bravura que ha mostrado en su vida real. «Il ne s'agit pas tant d'écrire son existence, que de l'authentifier par l'écriture, selon un axiome implicite, sorte de cogito viril: je m'expose donc je suis» — señala el pensador francés. ${ }^{467}$

Pero, ¿y por qué operar esa transformación saludable en un relato en lugar de en la propia vida?, ¿por qué osarlo con total decisión? La difícil asunción y comprensión de la fragmentación de la persona llevan a desear un instrumento que asegure la unidad. Max Weber, en su célebre obra $L a$ ética protestante y el «espíritu» del capitalismo ${ }^{468}$ ya indicaba que el tipo de economía en que se basó el capitalismo primitivo obligaba a la adecuación de la propia biografía al desarrollo profesional. Mediante la postergación continuada de la gratificación (salvo en el salario) debida al esfuerzo en el trabajo, se conseguía que la vida de la persona avanzara fragmentada: el proyecto vital en que se embarca el individuo no llega nunca a su plena realización.

466 Ib., p. 323.

467 A. Finkielkraut, "La nostalgie de l'épreuve», Le genre humain, n. ${ }^{\circ}$ 10, París, 1984, p. 59. Esta bravura supondría la renovación de la dialéctica hegeliana entre el Amo y el Esclavo: la realidad humana se constituye y se crea en el acto voluntario de afrontar la muerte.

468 M. Weber, La ética protestante y el «espiritu» del capitalismo, Sociología Alianza Editorial, Madrid, 2001. 
Los relatos de la propia vida, como sugiere el sociólogo Richard Sennett, «son más que simples crónicas de los acontecimientos; dan forma al avance del tiempo, sugieren motivos que explicarían por qué ocurren las cosas, muestran sus consecuencias». ${ }^{469}$ Es decir, un perfecto instrumento para organizar una existencia constantemente a la deriva: hacerla objetivamente comprensible.

En estos dos fines se centra el proyecto autobiográfico de Huysmans: organización y corrección de la propia existencia, cuyo objetivo principal es hacerla inteligible y, sobre todo, asumible desde el punto de visto psicológico-afectivo. Este proyecto excede, por completo, las virtudes terapéuticas del relato externo al sujeto, señaladas por Bruno Bettelheim en su obra capital Psicoanálisis de los cuentos de hadas. Señala el germano que en ellos el paciente —el niño_ encuentra solución a sus propios problemas mediante la contemplación de lo que la historia parece aludir sobre él mismo y sobre sus conflictos internos. Y eso aunque la historia no tenga nada que ver con su vida externa - pero sí con sus problemas internos. ${ }^{470}$

\subsection{La novela familiar de Huysmans}

Virtudes terapéuticas del relato que también Freud supo reconocer en su célebre ensayo "La novela familiar del neurótico», de 1908. En este texto, el vienés comienza comentando lo doloroso que es para el adolescente el desprendimiento de sus padres —aunque necesario para el desarrollo del individuo:

Cuando el individuo, a medida de su crecimiento, libérase de la autoridad de sus padres, incurre en una de las consecuencias más necesarias, aunque una de las más dolorosas que el curso de su desarrollo le acarrea. ${ }^{471}$

Freud llama a este distanciamiento de los padres novela familiar, y consiste en la reconstrucción, por parte del adolescente resentido, de la vida real mediante sus juegos y sus sueńos diurnos. El objetivo principal de esta

469 R. Sennett, La corrosión del carácter. Las consecuencias personales del trabajo en el nuevo capitalismo, Anagrama, col. Argumentos, Barcelona, 2000, p. 29.

470 B. Bettelheim, Psicoanálisis de los cuentos de hadas, ob. cit., pp. 29-31.

471 S. Freud, La novela familiar del neurótico, en Obras Completas, ob. cit., p. 1361. 
sustitución es plenamente erótico, aunque muchas veces pueda aparecer bajo los colores de la ambición.

Siempre según Freud, el adolescente, al salir de la adolescencia, alberga tal odio hacia su padre que se imagina no haber sido engendrado por él, desarrollando así una fábula de hijo adoptivo. Esto explicaría que, siendo niño, hubiera sido objeto de pocas atenciones, que hubiera sido tratado con poco amor. Por eso mismo, esta fábula autobiográfica — como la llama Marthe Robert, en su ensayo Roman des origines, origines du roman — ${ }^{472}$ tiene como principal fin el arreglo interesado de la propia historia en clave de venganza, de consuelo y de queja.

La novela familiar es, en definitiva, una interrogación imaginaria sobre los orígenes del individuo. Mediante ella, este consigue objetivar su propia experiencia, historizándola — como dice Silvia Tubert—, ${ }^{473}$ conformándose a sí mismo como relato. En la medida en que este relato sobre los orígenes concierne la sustitución interesada de los padres, el niño escritor-reconstructor asume la textualidad edípica — que es, según la ortodoxia psicoanalítica, germen de la génesis del sujeto en nuestra cultura—, a la vez que la recrea según su manera particular.

Esto propone, según afirmación de todos los autores consultados, que el texto literario es fruto inevitable de la experiencia familiar — de allí ese estupendo título de la obra de Robert. Toda narrativa, en su aspecto de ajuste de cuentas con la realidad vivida, se remonta al Edipo - como sabemos, complejo de usurpación del padre en la objetualización libidinosa de la madre.

Roland Barthes coincide en el mismo dictamen, añadiendo en su Plaisir du texte $e^{474}$ que esto es válido en la medida en que contar historias es una forma de investigar los propios conflictos con la Ley paterna y el Orden simbólico lacaniano — de ahí que Tubert proponga la denominación de «novela familiar de la cultura patriarcal» a este fenómeno psíquico por el cual el adolescente re-construye su familia. ${ }^{475}$ Expliquémonos.

472 M. Robert, ob. cit., p. 46.

473 S. Tubert, «Sacralización y ocaso de la figura paterna», ob. cit., pp. 183-202.

474 R. Barthes, Plaisir du texte, Seuil, París, 1982, p. 50.

475 S. Tubert, «Sacralización y ocaso de la figura paterna», ob. cit., p. 189. 
El niño que recompone su experiencia familiar suele elevar a su padre al reino de la fantasía; la reconstrucción de aquella pasa por el encumbramiento de este a la altura de un personaje aristocrático. Es decir, que lejos de eliminar al padre, este neurótico freudiano lo exalta, convirtiendo su odio en una operación de nostalgia de un tiempo pasado en que la familia fue feliz.

En cuanto a la posible sustitución de la madre, el proceso es diferente - como no podía ser de otra manera en la ortodoxia psicoanalítica. Si no se da eliminación absoluta, el mismo deseo de ser hijo adoptivo para renegar de los propios orígenes lleva a albergar el deseo de que la madre haya cometido adulterio con otro hombre - ese hombre ficticio y de elevado origen que sería el verdadero padre para la imaginación sustitutiva del niño. "De reine qu' elle était, la mère tombe d'un coup à une condition sociale humiliée», señala Marthe Robert; ${ }^{476}$ y puesto que ha sido el deseo carnal el que ha provocado su denigración, es el mismo poder de atracción que posee la madre el que provoca su rechazo por parte del neurótico novelista.

Las implicaciones de esta óptica en la concepción del relato autobiográfico —o no, pero a mayor razón— son enormes. La justicia poética que aplique el autor-narrador en el interior de su relato serán, desde esta perspectiva, verdaderos ajustes de cuentas con la vida que le ha tocado vivir.

Marthe Robert sostiene — como ya vimos en el capítulo anteriorque únicamente existen dos maneras de construir una novela: la del bastardo realista y la del hijo adoptivo. El primero tendería a un enfrentamiento directo con el mundo; el segundo, carente de recursos o de medios de actuar, preferiría esquivar el combate mediante la huida o la burla (como el Bartleby de Melville: «preferiría no hacerlo»).

En el primer caso, el modelo paradigmático de héroe bastardo en el mismo siglo que nos ocupa fue Napoleón. Sus epígonos son novelistas de las características de Balzac, Dostoievski, Tolstoi, Proust, Faulkner y Dickens. Es decir, plena y concienzudamente realistas. En la línea del novelista «expósito» nos encontraríamos con Chrétien de Troyes, Cervantes, Hoffmann, Novalis, Melville y Kafka: novelistas de la ensońación, que permi-

476 M. Robert, ob. cit., p. 55. 
ten la entrada a lo onírico, a lo espiritual, a una realidad «otra»: la suya propia, la que les sirve en la persecución de sus fines de recomposición de la realidad.

¿Qué decir de Huysmans? ¿Estaría más bien en la línea de un novelista «bastardo» o en la de un novelista «expósito». Parece que su adscripción al segundo grupo es más evidente que al primero; no solo por su gusto - a partir de $\grave{A}$ rebours - en incluir en la trama el onirismo, ni porque sus novelas traten más de sí mismo que de cualquier otra cosa: la descripción que hace Huysmans de sus circunstancias familiares nos empuja a percibir una gran nostalgia de sus padres. La obra de nuestro autor no será sino la plasmación de su deseo de reconciliación con sus progenitores - y la consiguiente reconstrucción del triángulo edípico. Huysmans fue, desde lo más profundo de su psicología, un niño expósito, abandonado a su suerte por sus padres - aunque esto solo fuera cierto en su imaginación. La escritura le permitió una compensación que jamás alcanzó en vida — de ahí su necesidad de que la literatura fuese plasmación interesada de sus circunstancias.

\subsection{El niño abandonado}

Las referencias que a la familia se hacen en la obra de Huysmans no son numerosas pero sí muy significativas. En casi todas ellas se pone en escena a un niño que sus padres dejan a su suerte, ya sea en la soledad de los juegos infantiles, ya sea en el abandono del internado.

Así, en Croquis parisiens, presenciamos la evocación que hace el narrador de su triste infancia ante la mecha de una vela que se consume. Como si se tratara de la famosa magdalena de Proust, la vela le sugiere al niño crecido aquellas tardes de invierno en que su madre, hastiada de las exigencias infantiles, se lo quitaba de encima enviándole a la cocina:

devant ta mèche qui champignonne et bougeoie dans un lac de suif, je revois mon enfance, ces longues soirées d'hiver où, fatiguée par mes pleurs et par mes cris, ma mère me renvoyait dans la cuisine près de la bonne épelant à haute voix le gros livre des songes. ${ }^{477}$

477 J.-K. Huysmans, Croquis parisiens, ob. cit., p. 106. Se trata de la pieza «Ballade de la chandelle des six», dentro del capítulo titulado "Fantaisies et petits coins». 
Una situación parecida es referida en En ménage, en el momento en que el narrador refiere - en primera persona, excepción en la obra huysmansiana - la vuelta al internado cuando el día de salida tocaba a su fin:

ma famille consultait sa montre. 'Il faut se dépêcher, disait ma mère, l'heure avance.' Je quittais la table après le second plat, j'emportais mon dessert dans ma poche, et alors, après les recommandations et les embrassades, j'étais reconduit par Irma, la bonne. Les rues pleines de monde me serraient le cœur. ${ }^{478}$

De nuevo el abandono de la responsabilidad materna en la criada, quien se encargaría de las pequeńas minucias del cuidado de los hijos en las familias burguesas. Esta dejación de responsabilidad, aun cuando tradicionalmente aceptada durante el siglo XIX, no deja de producir en el recuerdo del novelista una viva amargura — «les rues pleines de monde me serraient le cœur»-, en una dolorosa comparación con el resto de la humanidad que se ama y se apoya mutuamente. Es el niño expósito que retorna al orfelinato: almacén donde se amontonan los chavales sin vínculo ninguno con sus congéneres. "Sa famille se préocupait peu de lui; parfois son père venait le visiter au pensionnat: 'Bonjour, bonsoir, soi sage et travaille bien'» - dice el narrador de $\grave{A}$ rebours a propósito de la infancia de des Esseintes. ${ }^{479} \mathrm{Y}$ esa es toda la cercanía que el niño puede aspirar a recibir de sus padres. Tal vez no podamos hablar, con estos pocos indicios, de una infancia de nińo abandonado a su suerte, pero estas escasas referencias así parecen indicarlo. Hay que tener en cuenta que, desde tiempos muy remotos, la burguesía y la nobleza dejaban sus niños pequeños en manos del cuidado de un ama nodriza, preferentemente en el campo. Como señala Yvonne Knibiehler, se consideró desde Montaigne que la simplicidad de la vida rústica es saludable para los niños pequeños — preferible, al menos, al lujo y a la agitación de las grandes ciudades. Como consecuencia de esto, la separación entre la madre y su hijo se convierte en un hecho casi obligatorio, puesto que la costumbre así lo contempla: los lazos afectivos se ven clara y definitivamente afectados por este detalle. Además, al término de la lactan-

478 J.-K. Huysmans, En ménage, prólogo de Hubert Juin, Union Générale d'Éditeurs, Collection 10/18, París, 1975, p. 66.

479 J.-K. Huysmans, À rebours, ob. cit., p. 62. Cabe establecer un paralelismo con el poema "Les Étrennes des orphelins», de Arthur Rimbaud, publicado en enero de 1870. 
cia se coloca al niño bajo la atención de un preceptor o en una institución religiosa. Como dice Knibiehler, el niño «solo conoce a su madre de lejos». ${ }^{480}$

Lo que podría parecer una costumbre estrictamente burguesa y de la nobleza se generaliza al resto de estratos sociales; las madres trabajadoras de las ciudades también recurren a esta «industria de la nodriza» a causa de la creciente especialización profesional en la primera Revolución Industrial: las esposas de los artesanos, obligadas a trabajar cada vez más para ayudar a sus maridos, ya no tenían tiempo de ocuparse de su progenitura.

Un ejemplo claro de este último extremo lo encontramos en la novela de los hermanos Goncourt Germinie Lacerteux (1861), en la que la protagonista deja a su niño al cuidado de una nodriza en el campo. Ahora bien, los esfuerzos que tienen que hacer Germinie para poder costearse este "lujo" son enormes. Por otra parte, su situación de madre soltera no le permite otra manera de mantener a su hijo; sin embargo, todos los domingos irá a pasear con su amante por la campińa cercana al hogar de la nodriza. Su hijo también correrá la suerte del resto de niños de su tiempo yendo a un internado; aunque Germinie sufrirá con no poco dolor la separación que la institución opera con su hijo.

El abandono que el niño sufre con respecto a sus padres no es, pues, algo que sufriera Huysmans en exclusividad, sino un hecho estructural. La separación de sus padres, sin embargo, sería vivida por Huysmans de manera tal vez más trágica — lo que justificaría la dramática y doliente referencia que hace nuestro escritor a esta circunstancia.

La presencia de los padres en la obra huysmansiana es, por esto mismo, difusa. Y esto se hace más evidente en el caso del padre que en el de la madre. Como primer ejemplo, nos encontramos con una curiosa y casi agresiva negación del nombre del padre en el Drageoir à épices (1874). Se trata de la historia del pintor holandés Cornélius Béga en que se escenifica el repudio del apellido paterno. Como el pintor llevaba una vida disoluta, su padre le dijo que si no cambiaba, le instaría a que abandonase su apellido, puesto que era un deshonor para el linaje. El pintor se hace rebautizar Béga, en lugar de Bégyn.

480 Y. Knibiehler, «Madres y nodrizas», en Silvia Tubert (ed.), Figuras de la madre, ob. cit., p. 104. 
En Sac au dos - la nouvelle que Huysmans coniguió incluir en el recueil dirigido por Zola Les Soirées de Médan - la ausencia del padre se hace evidente. Notemos que el narrador, el soldado Eugène Lejautel — hombre aficionado a las artes y a las letras-, vuelve a su hogar parisién pasando antes por casa de su madre; allí sacia su hambre con los platos cocinados por la criada. Esta ausencia cobra plena importancia en el imaginario familiar del autor; ninguna referencia se hace al padre, ya sea por su falta o por estar en ese momento fuera del hogar: «il n'y a pas de père dans cette histoire», señala Jean Borie en su ensayo sobre Huysmans. ${ }^{481}$

Esta circunstancia parece aclararse en cuanto asistimos al relato de las andanzas de André Jayant, el héroe de En ménage. Allí descubrimos que André es hijo de "une mère veuve et sans le sou». ${ }^{482}$ La ausencia de padre queda ya perfectamente aclarada.

Sin embargo, À rebours propone una paternidad para el héroe polifacético y heteronímico de Huysmans. Como diría en alguna ocasión el autor, des Esseintes no era sino un Folantin (héroe de $\grave{A}$ vau-l'eau) con dinero - lo que asegura la continuidad de la obsesiva pintura del personaje huysmansiano. Para asegurarle una fortuna, Huysmans coloca a des Esseintes en el seno de una familia nobiliaria en decadencia, de la que él sería el último representante. Linaje de guerreros bigotudos, él fue el resultado de matrimonios consanguíneos que no hicieron sino depositar al linaje en una caída irrefrenable: «la décadence de cette ancienne maison avait, sans nul doute, suivi régulièrement son cours; l'effémination des mâles était allé en s'accentuant». ${ }^{483}$ Él era el «seul rejeton [qui] vivait», «le duc Jean, un grêle jeune homme de trente ans, anémique et nerveux, aux joues caves, aux yeux d'un bleu froid d'acier, au nez éventé et pourtant droit, aux mains sèches et fluettes». Más adelante, el duque dice no haber conservado de sus padres más que "un souvenir apeuré, sans reconnaissance, sans affection». En cuanto a su padre, « il le connaissait à peine». A veces aparecía en el castillo de Lourps — que luego sería escenario de En rade — y mantenía con la madre del protagonista aburridas y breves conversaciones, al cabo de las cuales, «le duc s'éloignait indifférent et ressautait au plus vite dans le premier train».

481 J. Borie, Huysmans, le Diable, le célibataire et Dieu, ob. cit., p. 197.

482 J.-K. Huysmans, En ménage, ob. cit., p. 63.

483 J.-K. Huysmans, À rebours, ob. cit., p. 61. 
En cuanto a la madre del protagonista de multiples facetas y nombres, de esta conocemos poco también. Aparte de su viudedad — que solo es desmentida en el caso de $\grave{A}$ rebours, y cuán difusa es la figura paterna que la contradice-, sabemos del abandono en que rápidamente dejó al joven héroe. En uno de sus avatares - Léo, el amante de Marthe (Marthe, histoire d'une fille, 1876)—, nos enteramos de que la decadencia de su persona le viene por su temprana separación materna - que le había empujado al libertinaje y la usura de los sentidos: «ce garçon s'était affranchi de bonne heure de la servitude maternelle et il avait tant mésusé de la liberté aquise que, vengeresse des mœurs, la débauche l'avait flétri, corps et âme». ${ }^{484}$ Estas palabras, que poseen un tono cercano al reproche ("la servitude maternelle»), se ven amplificadas de nuevo por $\grave{A}$ rebours, en donde la descripción de la madre alcanza un nivel casi doloroso: «il se la rappelait, immobile et couchée, dans une chambre obscure du château de Lourps». Mujer fotosensible, doliente y depresiva, que no soportaba los excesos de la luz y vivía siempre entre tinieblas. En la penumbra se desarrollaban las espaciadas entrevistas entre la madre y el padre,

assis, en face l'un de l'autre, devant un guéridon qui était seul éclairé par une lampe au grand abat-jour très baissé, car la duchesse ne pouvait supporter sans crise de nerfs la clarté et le bruit; dans l'ombre, ils échangeaient deux mots à peine...

Y entre penumbras se desarrollaban también las visitas que, durante las vacaciones, el hijo hacía a su madre: nada, ni la alegre visita del hijo ausente tanto tiempo logra sacar a la enferma de su ambiente de penumbra:

sa présence ne tirait pas sa mère de ses rêveries; elle l'apercevait à peine, ou le contemplait, pendant quelques secondes, avec un sourire presque douloureux, puis elle s'absorbait de nouveau dans la nuit factice dont les épais rideaux des croisées enveloppaient la chambre. ${ }^{485}$

Abandono repetido del hijo por sus padres, quienes lo habrían engendrado por la natural continuidad del matrimonio. La noche de bodas exige la consumación, de la que vendría una concepción ni buscada ni deseada, pero necesaria para dar un heredero al linaje. Una responsablidad de los pa-

484 J.-K. Huysmans, Marthe, histoire d'une fille, prólogo de Hubert Juin, Union Générale d'Éditions, París, 1975, p. 61.

485 J.-K. Huysmans, À rebours, ob. cit., p. 62. 
dres para con la sangre que se torna irresponsabilidad absoluta para con la persona que representa esa continuidad heráldica. El niño, la persona, en este contexto, se convierte en un mero símbolo, en la exudación de un humor de sus padres - cuya responsabilidad hacia el nuevo ser se completará exclusivamente con la crianza encomendada a una persona ajena a la familia. El afecto necesario para el desarrollo de la persona brilla por su ausencia, puesto que el tiempo de progreso material y tecnológico tan solo espera de las familias la reproducción de fuerza de trabajo útil para la sociedad. En medio del materialismo ausente, el impulso individualizador de un Huysmans no puede ser tomado sino como un acto de rebeldía: una protesta contra el mundo de autómatas que estaban creando «les mœurs américaines», basado en el trabajo y la familia: «l'éloge de la force brutale, [...] l'apothéose du coffre-fort», como denuncia en Là-bas. ${ }^{486}$

La familia será por ello mismo blanco de las diatribas de Huysmans: como germen del espíritu moderno que vacía de alma al individuo. Con un vivo sentido de reproche, nuestro autor desgranará una serie de ataques que no hacen sino mostrar cuánto le debe su continua infelicidad al ser que sus padres hicieron de él. El nińo abandonado se lamenta de su suerte, de la falta de afecto que recibió durante su infancia y que provocó esa frialdad, esa altivez de costumbres, esa negación de todo atisbo de fraternidad universal — salvo cuando, por necesidades del guion naturalista, se ponía a cantar las alabanzas de la gente pobre- en su persona. La crueldad de sus semejantes se hizo ya patente en su adolescencia, cuando hijo de una viuda y sin dinero (En ménage), por causa de sus carencias económicas, «les camarades riches me lâchaient à la porte du bahut, les jours de sortie, parce que je n'avais pas, comme eux, des cravates d'azur et des cols droits». ${ }^{487}$ "C'est toute ma jeunesse, une jeunesse d'humiliation et de panne qui est là», dice el narrador auto-diegético de En ménage. Y los reproches pasan tanto por el plano afectivo, "pas de compliments, quand j'étais premier, un air rogue lorsque j'étais troisième —méprisant et furieux si j'étais onzième», como por el económico: ya sea en función de una alimentación más que deficiente («une bourse au lycée, un rabais à la pension, je ne pouvais réclamer quand la viande putridait et que des cafards submergés dansaient dans l'abondance»), ya en su vertiente vestimentaria:

486 J.-K. Huysmans, Là-bas, ob. cit., p. 6.

487 J.-K. Huysmans, En ménage, ob. cit., p. 73. 
des pièces et des béquets à toutes mes bottines. Des gilets taillés dans les vieux gilets qu'un oncle abandonnait à ma mère, pour moi, —un uniforme de dimanche toujours fané, faute de pouvoir en renouveler les pièces.

Todas estas circunstancias hicieron del autor de $\grave{A}$ rebours un resentido personaje con el reproche siempre en la punta de los labios, dispuesto a salir disparado a la primera oportunidad. Como comenta Michel Raimond a propósito de las invectivas de $\grave{A}$ rebours contra la familia, Huysmans hace gala en este examen de su infancia de un parafreudismo bastante acertado al sugerir que «tout était joué dès l'enfance». ${ }^{488}$ Así, en el episodio del grillo metido en una jaula colgada del techo de su boudoir parisién, des Esseintes reacciona en base al odio y el desprecio que siente por su infancia. El pasaje es altamente revelador:

quand il écoutait ce cri tant de fois entendu, toutes les soirées contraintes et muettes chez sa mère, tout l'abandon d'une jeunesse soufrante et refoulée, se bousculaient devant lui [...] un tumulte s'élevait en son âme, un besoin de vengeance des tristesses endurées, une rage de salir par des turpitudes des souvenirs de famille, un désir furieux de panteler sur des coussins de chair, d'épuiser jusqu'à leurs dernières gouttes, les plus véhémentes et les plus âcres des folies charnelles. ${ }^{489}$

Un tumulto se elevaba en su alma, necesidad de venganza contra las tristezas sufridas, rabia por ensuciar los recuerdos de familia... El repertorio es variado, dejando bien a las claras la naturaleza del proyecto huysmansiano: recomponer en oscuro su historia personal para justificar su ruptura con la familia y con el mundo. En En rade, el narrador comenta, a propósito del protagonista, Jacques Marle, y Louise, su mujer, los terribles pensamientos que asaltan al primero cuando piensa en su familia. La familia aparece en esta novela como decorado de la explotación de los vínculos familiares — sobre todo en su versión campesina, de la que el narrador parece odiar el sentido de la ambición que mueve a esta. En realidad, En rade es una crítica oscura al funcionalismo y al utilitarismo de la sociedad, que tan solo encuentra su motu en el afán lucrativo y en la satisfacción de los instintos lúbricos. En oposición a toda la sociedad, Jacques Marles, hombre

488 M. Raimond, "Huysmans et le discours psychologique», en Huysmans. Une esthétique de la décadence, Actes du Colloque de Bâle, Mulhouse et Colmar, 1984, Éditions Slatkine, Ginebra-París, 1987, p. 136.

489 J.-K. Huysmans, Â rebours, ob. cit., p. 70. 
frío, presa propiciatoria de la impotencia, inapto a conseguir ganarse la vida con holgura, aparece como un electrón libre en medio de tanta degeneración humana. Y es que la sociedad que les toca frecuentar, a él y a Louise, en la zona de Lourps es de lo más florido que un espíritu hipersensible como el suyo pueda asumir.

La ruptura con la familia se produce de manera decidida en esta novela. No solo se abomina de las relaciones interesadas de la familia campesina de Louise; también Jacques, para poder contraer matrimonio debe enemistarse con la suya, que le recomendaba no casarse con una mujer de más baja extracción social. Consciente de que son el dinero y la reputación los principales motores de su propia familia, Jacques rompe con ella, convencido de la divergencia de miras y sentir entre él y los suyos:

il avait fallu pour l'épouser se fâcher avec sa famille composée de négociants riches indignés de la basse extraction de cette femme issue d'une génération paysanne mal équarrie par la petite bourgeoisie d'un père. Il avait franchi ces haines, accepté sans regrets une entière rupture avec des parents dont il méprisait les appétits et les idées et qu'il ne visitait auparavant, du reste, qu'à de rares intervalles. ${ }^{490}$

La familia vuelve a ser vilipendiada en En rade mediante un extraño sueño que tiene Jacques en plena lectura de una revista científica. Subyugado por el descubrimiento de las "ptomaïnes» — que vendrían a ser los extractos concentrados de la carne y los huesos_-, su imaginación onírica construye una curiosa ficción que pone en escena una familia nuclear, una escena primordial, un triángulo edípico. Un padre, una madre y un niño pequeño están sentados a la mesa y, llegados a los postres, nace un diálogo a propósito del extracto de abuelo con que iban a aromatizar una crema. Consiguientemente, se dora el recuerdo del viejo antes de proceder a la ingesta de su esencia. Preguntado el nińo por si recuerda a su abuela — cuyas ptomaïnes exhalaban un ligero retufo a tabaco-, dice preferirla al abuelo porque el postre que aromatizaban con la esencia de abuela era más apetitoso. "Quelle délicieuse et touchante scène de famille!» — exclama, irónico, Jacques, al salir del marasmo en que estas ensońaciones le habían sumido. ${ }^{491}$

490 J.-K. Huysmans, En rade, Gallimard, París, 1984, p. 103.

491 Ib., p. 186. 
El mismo odio contra la familia se puede observar en $L \grave{a}-b a s$, esta vez proyectado en el retrato que de Gille de Rais hace el estudioso Durtal. Debido a los inmensos gastos en que incurría el caballero medieval para satisfacer sus excesos, su familia consiguió que el rey Carlos III promulgase un edicto que prohibiese la venta del patrimonio. Tan solo el duque de Bretaña fue conocedor de esta noticia, que no hizo trascender y que aprovechó para adquirir a precios ínfimos gran parte de las posesiones del noble caído en desgracia.

Cela explique aussi la fureur de Gilles contre sa famille qui avait sollicité des lettres patentes du roi —et pourquoi il ne s'occupa plus, durant sa vie, ni de sa femme ni de sa fille qu'il rélégua dans un fond de château, à Pouzauges. ${ }^{492}$

Como hemos podido ver hasta el momento, las características de la pintura que el narrador hace de su situación familiar nuclear es la siguiente: infancia de abandono; padre inexistente o ausente; madre enfermiza. Esto es lo que hemos encontrado siguiendo las pautas del método psicocrítico de Charles Mauron: la superposición de elementos dispares hallados a lo largo de toda la obra del autor. Cabe preguntarse si realmente se trata de una proyección de la vida del propio Huysmans en su obra o si es, por el contrario, tan solo una fabulación inocente. Como continuación a la superposición — que arroja el mito personal huysmansiano de la familiadeberíamos proceder a su comparación con la biografía de nuestro autor. Solo así nos aseguraremos de que nuestras hipótesis no son validadas a priori, sino tras contraste con la realidad. En caso de producirse coincidencia entre hipótesis formuladas al hilo de la lectura y los datos biográficos podrá establecerse una línea clara de mitología personal y obsesiva del autor en cuestión.

Siguiendo al gran biógrafo de Huysmans, Robert Baldick, así como a otros comentaristas de su obra — como por ejemplo Jean Borie-, descubrimos no pocas cosas. La principal de ellas es que el autor se quedó huérfano de padre a la temprana edad de ocho años. Ese mismo año de 1856, el joven Georges entraría en un internado de nombre Institution Hortus —que será evocada más tarde en En ménage. Su madre, Elisabeth, contrae en 1857 matrimonio de nuevo con el protestante Jules Og. Un año des-

492 J.-K. Huysmans, Là-bas, ob. cit., p. 48. 
pués, su padre adoptivo invierte su capital en un taller de imprenta sito en los bajos de su apartamento parisién, en el n. ${ }^{\circ} 11$ de la calle de Sèvres —que servirá como escenario a la trama de Les Sours Vatard.

Desde luego, la lectura que podemos extraer de estos esclarecedores datos es de gran valor. Sobre todo teniendo en cuenta su coincidencia perfecta con las hipótesis construidas a partir de la lectura de la obra de Huysmans. Todo el arsenal que nuestro autor descarga sobre la institución familiar no es sino un descarado ajuste de cuentas. Al ser abandonado en manos de una institución infantil, la imaginación creadora de Huysmans elabora una extraña compensación mediante la cual culpa de su trayectoria vital, por una parte, a su madre, y por la otra, a su padre adoptivo.

La sustitución de su padre por otro adoptivo a instancias de su madre desencadena una retahíla de consecuencias decisivas. El padre ficticio se convierte en un verdadero intruso que impide la liquidación del complejo de Edipo — que no hará sino actuar a lo largo de la acción compensatoria de su imaginación creadora. Con la desaparición del padre, el niño —que, ya sabemos, siempre desarrolla hostiles tendencias hacia su padre verdadero- se cree por un momento dueño absoluto de su madre; su irrupción en el escenario edípico no puede ser más inoportuna en el desarrollo anímico del chaval.

Las consecuencias para el niño son nefastas. No solo su resquemor al haber sido abandonado son enormes, sino que se siente falto de un padre que le dé el afecto y la seguridad necesarias en todo desarrollo. El padre adoptivo parece adoptar para Huysmans la figura que Samuel Osherson ${ }^{493}$ nombra como "padre Herido", pues, incapaz de mostrar un afecto que no siente por un hijo que no es suyo, le priva de un modelo que le permita acceder a la escala afectiva. Como señala Elisabeth Badinter ${ }^{494}$ al hilo de los argumentos de Osherson, el resultado de esto es que la imagen del padre oscila entre el "poder omnímodo ajeno" y una debilidad sin límites; los sentimientos del hijo se reparten entre el miedo (del odio y del rechazo del padre) y el desprecio. La profunda necesidad que siente el hijo de que su

493 S. Osherson, ob. cit., p. 107.

494 E. Badinter, XY. La identidad masculina, ob. cit., p. 181. 
padre le reconozca y confirme como tal choca con la ley del silencio. Su masculinidad, que necesita un refuerzo constante, queda inacabada debido a la huida paterna.

El poeta Robert Bly —inspirador del movimiento mitopoético de recuperación de la importancia de la figura paterna— ${ }^{495}$ dice que el padre ausente de la sociedad industrial es a menudo objeto de fantasmas para el niño, quien termina viendo en él una figura demoniaca. ${ }^{496}$ Jorge Belinsky, ${ }^{497}$ por su parte, observa que el lugar vacío de la función paterna desempeña una función semejante a la del asesinato del padre originario en el mito creado por Freud, en cuyo caso la angustia ante el vacío conduce al surgimiento del espacio de lo religioso. El padre es sacralizado - y tanto más si su desaparición es real y mal cubierta por un intruso que no cumple su papel - y tan pronto es tratado como una figura negativa — diabólicacomo positiva - padre sacralizado. Como señala Silvia Tubert con Belinsky, «el padre es asesinado porque tiene que ser inmortal o, más bien, eterno": de ahí que en la biografía novelada —o «bioficción»— de Huysmans el padre haya sido muerto por intereses no solo poéticos.

El nombre del padre y su negación — que tiene gran importancia, sostenemos, en la evolución de la masculinidad en el siglo XIX - no es sino un complemento a esta intención negativizante de la figura paterna. Observemos un pequeńo detalle que parece tener poca importancia: la segunda novela de Huysmans, que se desarrolla en la imprenta que tuvo como modelo en la que el Sr. Og invirtió debajo de la casa familiar, lleva el sugerente título de «las hermanas Vatard». Una cercanía fonética demasiado evidente con el término bâtard, que cobra pleno significado si se tiene en cuenta que dos eran las hermanastras que nuestro autor salió ganando en la unión de su madre con Og. Ese título, a la luz de esta sugerencia, puede leerse como «las hermanas del Bastardo», mediante una complementación del nombre muy frecuente en francés y que permite unir a un sustantivo con su complemento elidiendo la preposición (como en, por ejemplo, Bourg-la-Reine).

495 Vid. L. Bonino, «Los varones frente al cambio de las mujeres», Lectora. Revista de Dones i textualitat, 4: "Hombres y feminismo", Universidad Autónoma de Barcelona, Barcelona, 1998, pp. 7-22.

496 F. Abbot, "What Men really want", en New Men, New Minds, p. 178, citado por E. Badinter, ob. cit., p. 181.

497 S. Tubert, «Sacralización y ocaso de la figura paterna», ob. cit., pp. 183-202. 
Así pues, el joven 'bastardo' debe hacer suyo un nombre paterno que no es el propio; una situación que para Lacan podría ser generadora de una potente y destructiva psicosis por la laguna en el lenguaje que crea para el joven niño. En su estudio del caso Schreber, $\operatorname{Lacan}^{498}$ insiste sobre el papel que puede representar en la iniciación de la psicosis la presencia real, en esta tercera posición, de un personaje paternal. Para este autor, el carácter destructor y devastador de esta presencia se debe al hecho de que haya surgido en lugar de una ausencia, de una falta. Seguramente, no de la ausencia real del personaje paterno en la infancia del paciente, pues sería evidente que eso no sería lo más frecuente en la psicosis, sino una forma de carencia menos perceptible inmediatamente. De esta manera, el nombre del nuevo padre es incapaz de entrar en la cadena de significantes que constituyen el inconsciente del nińo, pues no pertenece a la ley del padre que había comenzado a construir el niño. Esto crearía un verdadero agujero en la subjetividad del autor-paciente, una falta casi imposible de llenar — como se produce frecuentemente en los casos de esquizofrenia.

Jean Laplanche, basándose en estas consideraciones lacanianas para su estudio sobre la carencia del «Nombre del Padre» que vanamente trata de encontrar Hölderlin en el poeta Schiller, ${ }^{499}$ estima que la falta de un significante, esa laguna del lenguaje, constituye la llave de la psicosis. Termina diciendo que en esa búsqueda casi desesperada, Hölderlin, frente a una imago materna castradora, intenta en vano encontrar una imago paternal que viniese a poner término a la relación dual aterradora con la madre, y que pudiese servir de mediadora.

Para otro psicoanalista, Charles Bernheimer, el nombre del padre, lejos de ser un privilegio fálico como postula Lacan, es una fuente potencial de angustia para el hombre. ${ }^{500}$ Para él, el problema no radica en la sustitución de un significante por otro, sino en el riesgo de que un pene haya sustituido a otro. En el caso de Huysmans, que se debió de ver en la necesidad

498 J. Lacan, Escritos, trad. de Tomás Segovia, Siglo XXI, Madrid, 1972, p. 201.

499 J. Laplanche, Hölderlin et la question du Père, P.U.F., París, 1961.

500 C. Bernheimer, "Penile Reference in Phallic Theory», Differences: A Journal of Feminist Cultural Studies, vol. 4, n. ${ }^{\circ}$ 1, 1992. Vid. también el comentario que hace Silvia Tubert a este respecto, en S. Tubert, Deseo y representación. Convergencias de psicoanálisis y teoría feminista, Síntesis, Madrid, 2001, p. 183. 
legal de adoptar el nombre de su padre putativo, la negación del nombre de este era no solo la manifestación de un deseo de mantener la memoria de su propio padre, sino también la de reivindicar su derecho de goce de su madre - que iba a ser detentado en lo sucesivo por el Sr. Og. La misma existencia de ese nombre del padre recuerda al joven Huysmans la posibilidad de ser castrado. De ahí su negación militante.

Para resumir y simplificar, la llegada de un nuevo padre no sirve para colmar la ausencia del padre biológico. Esa discontinuidad en la interiorización de la ley del padre, basada en el lenguaje, hace que el niño desarrolle una psicosis tendente a la esquizofrenia. La ausencia de padre en la ley que debe hacer suya el niño le enfrenta directamente a su madre, pues ya no hay barrera para sus deseos incestuosos. La figura paterna se sobrevalora como mediadora que podría ser entre la madre y el hijo, pues este corre el peligro de ser castrado por su propia madre.

La consecuencia fantasmática de la atribución de un papel castrador a la madre pasa por su configuración como mujer fatal y peligrosa, dotada o no de un pene - que sería la solución edípica a la necesidad de mediación que siente el nińo. El pene materno se convertirá, con ello, en un fetiche que permita la sustitución perfecta del atributo paterno. Pero no debemos adentrarnos en explicaciones más profundas de este tema por razones de estructuración de nuestro trabajo; permítasenos volver a él más tarde para centrarnos ahora en la sobrevaloración de la figura paterna.

\subsection{Sobrevaloración de la figura paterna}

El padre, como centro y representación de la ley, cumple un papel de mediador entre la madre y el hijo. No solo constituye ante este la instancia encargada de poner un freno a sus instintos incestuosos, sino que también es el que dicta la ley. La ausencia del padre real, a los ocho años de edad de nuestro autor, pudo suponerle un corte en la cadena de significantes necesaria para la conformación de su inconsciente. Se debió de crear así un vacío que la llegada de un nuevo padre —este, putativo — no consiguió colmar de ninguna manera. Es más, las necesidades afectivas del niño no se ven satisfechas con este nuevo padre, por lo que se produce también una laguna a ese nivel. 
Según la ortodoxia psicoanalítica, ${ }^{501}$ la formación de las tres instancias de la personalidad — superyó, yo e inconsciente- depende de la influencia de los progenitores en la vida infantil. La primera de ellas, el superyó, sabemos que se funda en base a una serie de prohibiciones que establece el padre, la Ley paterna, de las cuales la más importante y decisiva es la prohición del incesto. En pocas palabras, el padre es el encargado de evitar que el niño dé rienda suelta a su libido incestuosa y tome posesión carnal de su madre; en el inconsciente del infante se crea un curioso complejo consistente en el temor a que el padre le desprovea del apéndice que no solo crea la diferencia entre ellos dos y la madre, sino que es el centro del goce libidinoso que ambos consiguen en su contacto con ella. El complejo de Edipo se establece, pues, para evitar este contacto ilegal. El niño interioriza la ley como una serie de prohibiciones emitidas por el padre, creando con ello su conciencia social o, en la jerga freudiana, el superyó. La primera prohibición que recibiría el niño sería, por consecuencia, la de la deseada unión carnal con la madre; el nińo debe renunciar a la madre como primer mandato de la ley.

La muerte del padre pudo significar para el joven Georges-Charles la posibilidad de cumplir la unión carnal tan deseada con la madre - y que la presencia del padre había impedido hasta entonces. Mediante un sencillo ejercicio de asociaciones, si el niño gozaba de la madre gracias a la muerte del padre, la creencia oculta de haberlo asesinado podía encontrar cobijo en el inconsciente del infante. Como señala el psicoanalista Gérard Mendel, la conciencia del asesinato del padre crea un sentimiento de culpa que estaría «en el origen de las poderosas imágenes paternas externas que encarnan el Poder social». ${ }^{502}$ Este Poder social estaría representado bajo la figura de un Padre religioso o político, glorioso, y tendría una función de desculpabilización, de negación del asesinato.

Sin embargo, hay que tener en cuenta las indicaciones que da Freud sobre la culpabilidad en dos ensayos capitales de la teoría psicoanalítica

501 Vid., para ello, S. Freud, Abrégé de psychanalyse, P.U.F., París, 1967, donde se comenta de manera esquemática las grandes líneas de esa ortodoxia. Asimismo, consultar la entrada correspondiente en J. Laplanche y J.-B. Pontalis, Vocabulaire de la psychanalyse, P.U.F., París, 1981.

502 G. Mendel, ob. cit., p. 20. 
como son Tótem y tabú y Duelo y melancolía. ${ }^{503}$ En el primero de ellos, Freud desglosa ampliamente su teoría sobre el asesinato del gran macho a manos de la horda primordial. Este asesinato, que desencadenaría toda la serie de sentimientos ambivalentes hacia la figura del padre, hace que la sociedad entera repose sobre la responsabilidad común del crimen colectivo:

la religión sobre la conciencia de la culpabilidad y el remordimiento, y la moral sobre las necesidades de la nueva sociedad y sobre la expiación exigida por la conciencia de la culpabilidad. ${ }^{504}$

Con esto queremos señalar que existe ya un sentimiento de culpa según Freud -inherente a la misma condición humana, nacido de ese asesinato primordial. Para explicar la fijación que este crimen puede tener en el inconsciente colectivo, ${ }^{505}$ Freud estudia los reproches obsesivos que se dan en los pueblos primitivos cuando una mujer pierde a su marido o una hija a su madre. Sienten en ese caso una especie de remordimiento que se puede traducir en la duda de si se había atendido al enfermo con solicitud, si se había hecho todo lo posible por ayudarle. Añade Freud:

significa únicamente que la muerte del mismo ha procurado la satisfacción de un deseo inconsciente del sujeto que, si hubiera sido suficientemente poderoso, habría provocado dicha muerte. ${ }^{506}$

Es decir, que los remordimientos provienen de un deseo reprimido e inconsciente de ver llegar la muerte del difunto. Este es un caso prototípico, dice Freud, de «ambivalencia de la afectividad humana».

Este hecho se produce de manera visible en los neuróticos obsesivos, lo que pone de manifiesto una vez más que la vida afectiva de los pueblos primitivos es ambivalente en un grado semejante al que permite ver la investigación psicoanalítica en los casos de esta dolencia. El proceso suele terminar con la proyección de esa hostilidad contra el finado, transmitida desde la percepción interna hasta el exterior. De esta manera el enfermo y el pri-

503 S. Freud, Tótem y tabú, ob. cit., pp. 2091-2101.

504 Ib., p. 171.

505 El término de 'inconsciente colectivo' no es de Freud sino de Jung; nos servimos de él para denominar una fijación inconsciente que residiría en el conjunto de la sociedad como consecuencia de ese crimen.

506 S. Freud, Tótem y tabú, ob. cit., p. 76. 
mitivo se sacuden de encima los reproches, teniendo como consecuencia directa la demonización del difunto.

En resumidas cuentas, que se produce una ambivalencia clara hacia el difunto ser querido: por una parte se le entroniza por medio de los reproches obsesivos; por la otra, se le vitupera y demoniza para sacudirse de encima dichos reproches, generados por el deseo de verle muerto.

En el caso que nos ocupa, la infancia de Huysmans, los reproches obsesivos vendrían generados por el deseo connatural al nińo de ver morir a su padre - y apoderarse así de la madre. Una vez muerto el padre, los reproches contra sí mismo debieron de ser enormes, por sentirse doblemente culpable.

El siguiente de los ensayos del doctor vienés nos va a ser muy útil en la inteligencia de la psicología profunda de nuestro autor. En Duelo y melancolía, Freud establece una diferencia clara entre ambos conceptos: mientras el duelo remite al dolor provocado por la pérdida de algo conocido, la melancolía sería mucho más difusa, pues es generada por la pérdida de algo indefinible:

la melancolía se caracteriza psíquicamente por un estado de ánimo profundamente doloroso, una cesación del interés por el mundo exterior, la pérdida de la capacidad de amar, la inhibición de todas las funciones y la disminución del amor propio..$^{507}$

Esta disminución del amor propio es lo que constituiría la principal diferencia entre la melancolía y el duelo. Es su acción la que provoca los reproches y acusaciones típicas de que el paciente se hace objeto a sí mismo, y puede llegar incluso a una delirante espera de castigo. Freud aisla el mecanismo de la melancolía como un elemento esencial para la formación del yo y el carácter, pero solo alude a la importancia central de la melancolía para el género.

En su descripción de la melancolía, Freud analiza la experiencia de perder a alguien que uno ha querido. Afirma el vienés que el individuo incorpora a ese ser querido en la estructura misma del yo, asumiendo parte de sus atributos y manteniéndolo en vida mediante una serie de actos mágicos

507 S. Freud, «Duelo y melancolía», ob. cit., p. 2091. 
de imitación. La interiorización de amores perdidos se hace patente también en el tabú del incesto, que, entre otras funciones, inicia la pérdida del objeto amado para el yo; su recuperación se realizaría a través de la interiorización del objeto del deseo que es tabú. ${ }^{508}$

En el caso de la relación heterosexual clásica, surgida del triángulo edípico, se niega el objeto, pero no la modalidad del deseo. Es decir, que la libido del niño, pudiendo proyectarse tanto hacia la madre como hacia el padre, el repudio de la madre (fundadora de la ley paterna) sería capaz de investir de las características de objeto de deseo al padre.

Al deber renunciar a la madre dentro de la dinámica edípica, el repudio se convierte en el momento fundador de lo que Freud llama la consolidación del género. Sin embargo, al perder a la madre como objeto de deseo, el niño debe interiorizarla de la misma manera que hace quien ha perdido un ser querido: así una parte de ella habita al melancólico tras la pérdida. Interorizar desde niños la instancia femenina por excelencia dota a nuestro subconsciente de una feminidad reprimida por la cultura paterna. Como apunta Butler, el niño «establece un superyó femenino que disuelve y desorganiza la masculinidad y consolida en su lugar disposiciones libidinales femeninas». ${ }^{509}$ Es decir, la consolidación del género mediante el fenómeno de interiorización de la madre repudiada tendería más bien a contribuir a que la masculinidad generada mediante el Edipo fuera de carácter netamente femenino.

Aunque Freud introduce el complejo de Edipo para explicar por qué el niño debe repudiar a la madre y adoptar una actitud ambivalente hacia el padre, señala poco después que:

podría ser también que la ambivalencia comprobada en relación con los padres debiera referirse por entero a la bisexualidad, y no, como antes lo expuse, que se desarrollase por la actitud de rivalidad a partir de la identificación. ${ }^{510}$

508 Seguimos muy de cerca los razonamientos sobre la teoría psicoanalítica que hace Judith Butler en su obra J. Butler, El género en disputa. El feminismo y la subversión de la identidad, Paidós, Méjico, 2001, pp. 92-99.

509 Ib., p. 93.

510 S. Freud, «Duelo y melancolía», ob. cit., p. 2092. 
Ahora, hallándonos en un contexto de bisexualidad, debemos preguntarnos por el fenómeno que provoca la heterosexualidad normativa en la elección de objeto del niño. Freud señala claramente que el niño debe elegir no solo entre las dos opciones de objeto, sino entre las dos disposiciones sexuales, masculina y femenina. El niño suele elegir la heterosexual, lo cual sería entonces resultado no de que tema ser castrado por el padre, sino del temor a su feminización que en las culturas heterosexuales se asocia con la homosexualidad masculina. De hecho, lo que debe castigarse y sublimarse no es en primer término la lujuria heterosexual por la madre, sino la investidura homosexual que debe subordinarse a una heterosexualidad culturalmente sancionada. En realidad, si la bisexualidad primaria, más que el drama edípico de rivalidad, es lo que produce el repudio de la feminidad por el niño y su ambivalencia respecto del padre, entonces la primacía de la investidura materna se vuelve cada vez más sospechosa y, por consiguiente, también la heterosexualidad primaria de la investidura del objeto del nińo.

Con estas nuevas coordenadas, no es nada descabellado apuntar que la pérdida se refiere más al padre que a la madre. La interiorización del padre se hace entonces necesaria para el desarrollo del individuo, instalándose dentro del yo como una voz o instancia crítica, capaz ahora de censurarle: «los autorreproches son reproches contra un objeto amado que se han trasladado al yo del propio paciente» — como dice Freud. ${ }^{511}$ Recordemos que los reproches que el individuo se hace a sí mismo en el caso de la muerte real de un ser querido están basados en el deseo que albergaba de verlo morir; si unimos estos autorreproches de la muerte real a los que ya se hace todo sujeto que debe someterse a la prohibición del investimiento libidinoso del padre, comprenderemos el inmenso sentimiento de culpa que debía sentir el niño Huysmans.

Como observa Gérard Mendel, si sobreviene la muerte real del padre cierto número de años después de la etapa edipiana, esto crea un conflicto interior en el nińo muy difícilmente soportable:

en la medida en que la muerte real del padre era vivida como la realización del antiguo deseo edipiano de eliminación, la necesidad de llamar al personaje que se creía haber asesinado generaba un conflicto interior intolerable. A la aguda necesidad de presencia del muerto respondía el agudo temor a una venganza por parte de este. Entonces se realizó la contención en el objetivo que es el de pro-

511 Ib., p. 2093. 
teger al Yo contra representaciones demasiado angustiosas que lo pondrían en peligro. Fueron contenidas las dos imágenes opuestas del padre muerto: el protector y el vengador. ${ }^{512}$

La interiorización que resulta de la consecuencia de esa muerte real crea un sentimiento de culpa y de ira — como observa Butler con Freudque el sujeto, para protegerse, vuelve hacia sí mismo esos dos sentimientos negativos: «el yo intercambia su lugar con el objeto interiorizado, invistiendo así esta exterioridad interiorizada con la instancia moral y el poder». ${ }^{513}$ En esta manera de volverse contra sí mismo que encuentra el yo, las posibilidades hipermorales del Ideal del yo —o sea, la imagen buena del padre- pueden llevar incluso al sucidio.

En suma, cabe decir que las representaciones del padre que se den en una obra literaria alumbrada por los procesos psicológicos de reparación de la vida anímica estarán basados en la exposición de estos principios. Por una parte, el padre será demonizado, como sabemos, para compensar los autorreproches obsesivos que el individuo se hace: esto es necesario, pues, como reparación del deseo siempre latente de que el padre muera para apoderarse de la madre. Al morir el progenitor y ser sustituido por un padre putativo, la negación del nombre del padre es crucial en la construcción psicológica de la novela familiar: el individuo debe reconstruir sus orígenes en el sentido que más le convenga.

Sin embargo, el mismo proceso que ha conducido a negar la figura del padre en todos sus avatares — tras su muerte, tras su reaparición como putativo- lleva a entronizarlo. A esto contribuye también la interiorización que se hace de la figura del padre por una doble vía: 1) normal, pues la cultura heterosexual lleva a repudiar al padre huyendo de la homosexualidad; 2) en el caso del huérfano, como recuperación de la figura paterna como si fuera un rito mágico de imitación. En ambos casos - y en el que nos ocupa por partida doble-, la figura del padre es recuperada de manera obsesiva, como paso necesario para la reconstrucción anímica del individuo.

Teniendo en cuenta el contexto de ausencia del padre, la novela de Huysmans consistirá en una denodada y constante búsqueda. Claro está,

512 G. Mendel, ob. cit., p. 92.

513 J. Butler, ob. cit., p. 96. 
esto no siempre se da de manera evidente y explícita, sino por medio de sustitutivos que escondan al mismo autor la finalidad última de su escritura. Conseguirá así la psicología profunda del individuo restablecer un paisaje en que el nińo que todos llevamos dentro se sintiera feliz: la infancia transcurrida en compañía del padre y la madre. Podríamos arguir contra esto que, basándonos en el complejo de Edipo, el verdadero paraíso infantil consista únicamente en el apoderamiento en exclusividad de la madre; hay que tener en cuenta el sobreinvestimiento a que se somete al padre para comprender su necesaria presencia en el paisaje reconstruido del niño.

\subsection{Valoración de la madre}

Ya habíamos observado que la muerte del padre y el nuevo matrimonio de la madre había desencadenado una nueva concepción del hijo hacia su madre. Esta es considerada como traidora no solo a la memoria del padre biológico, sino al mismo hijo — quien había visto en esa muerte la posibilidad de apoderarse libidinalmente de su progenitora. La llegada del Sr. Og trastoca por completo los planes inconscientes del joven Georges-Charles; lejos de poder cumplir su aspiración a permanecer a solas con su madre, es enviado al internado. El niño se convertirá en un expósito bastardo: expósito, por su abandono; bastardo, por la negación que él mismo hace del nombre de su padre putativo.

El doble adulterio que ha cometido la madre - con el padre y con el niño que esperaba gozarla - provoca su caída desde el trono materno a una condición social servil y humillada. La reacción contra la madre, por parte del hijo, será de denigración ante la imposibilidad de disfrutarla; reacción comprensible si se entiende, como señala Marthe Robert, que «la mère tombe en effet à l'instant même où elle est reconnue en sa qualité de femme désirable». 514

El psicoanálisis considera como esencial en la formación y el desarrollo del individuo el abandono del deseo hacia la madre y la interiorización del principio de autoridad paterno. Eso, que la ortodoxia freudiana ha venido a llamar resolución del complejo de Edipo, marca el fin de esa aspi-

514 M. Robert, ob. cit., p. 55. 
ración libidinosa dirigida hacia la madre. Como observa el psiquiatra vienés, «en cuanto tal deseo permanece conservado en el inconsciente, constituye la base del sentimiento de culpabilidad». ${ }^{515}$ Culpabilidad, apuntaremos nosotros, que se une a los reproches obsesivos que el niño se hace por haber deseado la muerte de su padre. Este sentimiento de culpabilidad debió de ser, sostenemos, de enorme magnitud en el caso de nuestro autor, del que jamás se separaría del todo ni siquiera mediante decidida sublimación.

El deseo de poseer a la madre, nacido no solo desde el momento en que el niño se conformó como sujeto separado del objeto materno, sino desde que su padre murió, actúa constantemente y de manera fantasmática a lo largo del desarrollo de la sexualidad. En esta intentará encontrar satisfacción a su búsqueda, aunque no sin gastos dolorosos: la vaga memoria de un delito cometido — como señala Luciana Percovich— ${ }^{516}$ seguirá haciendo mella en el inconsciente del niño llegado a la edad adulta. Triste condición humana que la de deber acarrear constantemente sentimientos de culpa y angustia para conformarse como sujeto.

Por todo ello, el niño debe acometer enormes esfuerzos, de gran gasto psicológico, en su comprendida necesidad de separarse de la madre. La misma cultura, basada en el repudio a la madre, crea en él un temor insuperable a sucumbir a su deseo. Temor y deseo que solo denotan «una imborrable necesidad de volver a la simbiosis materna y miedo a instaurar la unidad arcaica» — como señala el psicólogo Gerard Fogel. ${ }^{517}$ Como imperativo vital aparece entonces la necesidad de deshacerse de la madre, de olvidarlo todo, y de comenzar una nueva vida libidinal por sí mismo. La psicóloga estadounidense Nancy Chodorow afirmaba que es la madre quien debe operar esta separación activamente, eliminando todo rastro de sentimiento que le atase al vínculo roto; Gil-Calvo añade que la madre debe

515 S. Freud, "Dostoyevski y el parricidio», en Obras Completas, trad. de Luis López-Ballesteros y de Torres, edición de Jacobo Numhauser Tognola, Biblioteca Nueva, Madrid, 1972, tomo VIII, p. 3008.

516 L. Percovich, «Posiciones amorales y relaciones éticas», en S. Tubert (ed.), Figuras de la madre, ob. cit., p. 227.

517 En G. Fogel, The Psychology of men, Basic Books, Nueva York, 1986, p. 10, citado por E. Badinter, XY. La identidad masculina, ob. cit., p. 71. 
matar al hijo para que este logre separarse de ella; el resultado es el de un autista emocional desprovisto de sentimientos como condición sine qua non para que se conforme su masculinidad. ${ }^{518}$

Herman Burger comenta que es el hijo quien debe proceder a dicho asesinato, con los problemas que acarrea deshacerse de alguien a quien se desea con todas las fuerzas de la especie.

Por un lado, proceder activamente contra la madre; por otro, sufrir pasivamente por ella [...] Debemos matarla y morir por ella. Haciéndolo el hombre protegerá su alma femenina de futuras heridas. ${ }^{519}$

De no proceder a esa separación decidida y definitiva, como señala Burger, la individualidad masculina no se conforma - hecha esta de renuncia a la placentera regresión-, y permanece en ese limbo libidinal que el psicólogo Ralph Hallman llamó «complejo de Peter Pan». ${ }^{520}$ Cuanto más se prolonga la simbiosis madre-hijo, más peligro se corre de que se infiltre la feminidad en el núcleo de la identidad de género. Puesto que encontramos este proceso - apunta Robert Stoller en un ensayo-,${ }^{521}$ aunque en una gradación menor, en la mayor parte de las maternidades, es probable que esta sea la causa originaria de los temores homosexuales, mucho más evidentes en el hombre que en la mujer, y de la mayoría de las raíces de lo que denominamos 'masculinidad', es decir, la preocupación por ser fuerte, independiente, duro, cruel, polígamo, misógino y perverso». Solo si puede separarse sin problemas de la feminidad y de la 'hembricidad' de su madre, el chico será capaz de desarrollar «esa identidad de género más tardío que denominamos masculinidad». Solo entonces podrá ver a su madre en tanto que objeto separado y heterosexual que podrá desear.

518 Vid. N. Chodorow, The Reproduction of mothering, The University of California Press, Berkeley y Los Ángeles, 1978 (versión española: El ejercicio de la maternidad, Gedisa, Barcelona, 1984, p. 147 y ss.), y E. Gil Calvo, El nuevo sexo débil. Los dilemas del varón posmoderno, Temas de Hoy, Madrid, 1997.

519 H. Burger, Die künstliche Mutter, Fisher Verlag, 1982. Citado por E. Badinter, XY, ob. cit., p. 74 .

520 R. Hallman, «The Archetypes of Peter Pan», Journal of Analytic Psychology, n. ${ }^{\circ}$ 14, 1969, en D. D. Gilmore, ob. cit., p. 38.

521 R. Stoller, "Faits et hypothèses. Un examen du concept freudien de bisexualité», Nouvelle Revue de Psychanalyse, n. ${ }^{\circ}$ 7, Gallimard, París, 1973, p. 150. 
La masculinidad resulta no ser otra cosa que una mascarada de ocultación y huida: una defensa contra el niño interior y la puerilidad — como comenta Gilmore— ${ }^{522}$ necesaria a la sociedad para que el hombre — artífice de un designio ajeno, que no autor, en la dicotomía que establece Hannah Arendt $-{ }^{523}$ produzca sin parar.

\subsubsection{La fijación a la madre y homosexualidad}

La fijación a la madre y su relación con la homosexualidad masculina es un fenómeno largamente estudiado por los psicoanalistas. En su estudio sobre Leonardo da Vinci, ${ }^{524}$ Freud establece un férreo vínculo entre ambas, que podría resumirse de manera muy sucinta: huyendo de la madre, por la que siente unos afectos desmedidos, el individuo no mantiene relaciones con mujeres - lo que podría significar una infidelidad; la relación con otros muchachos aparece natural y, lo que es más, necesaria para la estabilidad anímica del individuo.

En otro estudio, «Tres ensayos para una teoría sexual», 525 Freud trata el mismo tema, esta vez de manera más centrada sobre la homosexualidad -que él llama 'inversión'. Lo que nos interesa de este ensayo es una nota añadida en 1910 (el estudio sobre da Vinci es de ese mismo año) en la que señala que los homosexuales pasan en los primeros años de su infancia por una breve fase de intensa fijación a la mujer —a su madre, en la mayoría de los casos—, y que después de esta fase heterosexual se identifican con la mujer y se toman a sí mismos como fin sexual. Es decir, que buscan hombres jóvenes y semejantes a su propia persona, a los que quieren amar como la madre los amó a ellos. Para nada ajenos a los encantos femeninos, estos homosexuales trasladaban directamente a un objeto masculino la excitación producida por la mujer. De este modo, repetían durante toda su vida el mecanismo por el cual había nacido su inversión: «su obsesiva inclinación hacia el hombre se demostraba así condicionada por su incesante fuga de la mujer». ${ }^{526}$

522 D. D. Gilmore, ob. cit., p. 38.

523 H. Arendt, "¿Qué es la autoridad?", en Entre el pasado y el futuro. Ocho ejercicios sobre la reflexión politica, Península, Barcelona, 1996.

524 S. Freud, "Un recuerdo infantil de Leonardo de Vinci», en Obras Completas, ob. cit., tomo V, pp. 1577-1619.

525 S. Freud, "Tres ensayos para una teoría sexual», en Obras Completas, ob. cit., tomo IV, pp. 1169-1237.

526 Ib., p. 1178. 
Si Freud señala que esta excesiva fijación a la madre se da, sobre todo, cuando ha existido un alejamiento del padre de la vida infantil del hijo - como hace en el ensayo sobre da Vinci-, ¿̇no nos será posible extender estas aseveraciones a Huysmans, niño expósito y bastardo, necesariamente nacido de generación espontánea? ${ }^{527}$

Tras analizar la heterosexualidad obligatoria que instituye la sociedad patriarcal, nos costará poco trabajo considerar que eliminar esta fijación natural al seno de la madre - fuente de calor, alimento y placer- sea, cuando menos, traumática. La posterior vida sexual del individuo varón llevará, imborrable, la marca de esta fijación. La instalación obligatoria del individuo en la heterosexualidad genital deberá ser llevada a cabo venciendo la resistencia que el inconsciente pondrá en ello; de ahí que, como señala la psicoanalista Nunziante Cesaro, ${ }^{528}$ la unión con mujeres solo se podrá realizar mediando las componentes libídicas y agresivas. Es decir, en medio de una violencia suma contra sí mismo y, en el peor de los casos, contra el objeto.

Por ello, una solución a dicha violencia sea la adopción de la homosexualidad como salida honrosa al conflicto: con ella no se mancilla el honor de la madre ni se enfrenta la resistencia antes mencionada. Tendremos oportunidad de volver a tratar esta cuestión — la fijación a la madre como activante de la homosexualidad — en el apartado sobre la sexualidad. ${ }^{529}$

\subsubsection{Las imagos como representaciones de la madre}

Como ya vimos anteriormente, es el de imago un concepto creado por Jung y desarrollado por Gérard Mendel en su obra La rebelión contra el padre. ${ }^{530}$ Como comentan los autores Laplanche y Pontalis, este designa una supervivencia de los participantes en la vida familiar en el imaginario del individuo. ${ }^{531}$ Por eso nos va a resultar tremendamente útil en nuestra de-

527 Vid. punto 2.2.6 del capítulo anterior.

528 Citada por M. González de Chávez, ob. cit., p. 219.

529 Gilbert Durand, al analizar la fijación de la madre de Stendhal, considera que la pérdida temprana, por parte del autor, de su progenitora determinó su bloqueo sexual. G. Durand, Le décor mythique de la Chartreuse de Parme. (Les structures figuratives du roman stendhalien), José Corti, París, 1983, pp. 111-112.

530 G. Mendel, ob. cit., p. 10.

531 J. Laplanche y J.-B. Pontalis, Vocabulaire de la psychanalyse, ob. cit., p. 196. 
finición de la representación de la madre en el imaginario de nuestro autor. Nótese que, siguiendo como seguimos el método de la superposición de Mauron, procedemos ahora a una presentación de las posibles representaciones, para pasar a su incardinación en la obra huysmansiana. Esta exposición previa servirá para la comprensión posterior de las citas presentadas como definitivas.

Mendel, a partir de Jung, establece una diferencia dicotómica entre las imagos buenas y las imagos malas. En lo que nos concierne ahora, la representación de la madre, Mendel establece la tipología de la Imago de la Madre "buena» en base al impulso libidinal: la supervivencia materna en el inconsciente se da como fuente de vida, de calor, de alimento, de satisfacciones sensoriales diversas. La ausencia de respuesta gratificadora de la madre a estas necesidades-deseos crea frustraciones en el bebé, que le llevan a una agresividad reaccional dirigida contra la madre. La interiorización, la personificación y la unificación de estas pulsiones agresivas son la base de la formación de la Imago de la Madre «mala»: en base a esta, el niño desarrolla una agresividad excepcional, que corresponde al sadismo oral; su manifestación anímica se daría en el deseo canibalesco de comerse a la madre, de destruirla: Se trata, en última instancia, de la creación de una angustia mortífera que pasa por la destrucción completa del objeto y correlativamente la de ser completamente destruido por él. Es una angustia de muerte.

Según la prevalencia en cada sujeto de la imago materna «buena»o «mala», la relación fusional será fuente de «felicidad» — como para Prousto de «terror frenético» — como en Melville. Otros ejemplos de pervivencia de esta imago «buena» se dan en Rousseau cuando, hallándose en la isla de Saint-Pierre, exclama con arrobo su sensación de comunión con la naturaleza: «O Nature! ô ma mère!, me voici sous ta seule garde; il n’y a pas ici d'homme rusé et coquin qui s'interpose entre toi et moi». ${ }^{532}$

Rousseau experimenta tal felicidad porque puede dejar que la imago de la Madre buena aflore a la conciencia y, al mismo tiempo, contener, contrainvestir la imago de la madre hostil y las imagos paternas. Capacidad de regresión a una relación primaria con el medio ambiente es uno de los grandes encantos de la existencia para quienes puedan experimentarla.

532 J.-J. Rousseau, Les Confessions, Gallimard-Folio, París, 1979, p. 134. 
Otro ejemplo válido para ilustración de esta imago es el de Poe ante la Naturaleza, ya que ese placer proviene de una especie de júbilo, de orgasmo, mas, no placer de los sentidos, sino del aparato psíquico, de la psique, del alma. Observemos:

En el temblor de una hoja, en el color de una brizna de hierba, en la forma de un trébol, en el zumbido de una abeja, en el brillo de una gota de rocío, en el suspiro del viento, en los vagos olores que venían del bosque, se producía todo un mundo de inspiraciones, una procesión magnífica y abigarrada de pensamientos desordenados y rapsódicos. ${ }^{533}$

Chateaubriand se deja apoderar frecuentemente por ese canto encendido a la naturaleza, en el que se dan cita todas las pervivencias del concepto cultural y psicológico de la madre: dadora de vida, nutridora, dadora de muerte:

c'est une mère charmante que la terre; nous sortons de son sein: dans l'enfance, elle nous tient à ses mamelles gonflées de lait et de miel; dans la jeunesse et l'âge mur, elle nous prodigue ses eaux fraîches, ses moissons et ses fruits; elle nous offre en tous lieux l'ombre, le bain, la table et le lit; à notre mort, elle nous rouvre ses entrailles, jette sur notre dépouille une couverture d'herbes et de fleurs. ${ }^{534}$

En la representación materna en base a la imago de la madre "mala», esta se produce mayormente cuando, por mediación del padre, el varón observa la naturaleza como un terreno que modificar mediante la inteligencia. El falo se convierte en ese momento en agente activo en la roturación de la tierra, atributo identificativo de la acción paterna. En este caso la madre aparece representada bajo los rasgos de una maligna instancia natural, que el poder masculino entiende deber doblegar.

Puede aparecer bajo los ropajes de una bruja, que resulta ser — como señala Bettelheim-, «una reencarnación de la madre buena de la infancia y de la madre mala de las crisis edípicas». ${ }^{535} \mathrm{Su}$ cualidad inhumanamente destructiva y peligrosa hace que, en un arranque de furia vengativa, pueda volverse contra el héroe y convertirle en animal o piedra — es decir, criaturas privadas de toda cualidad humana.

533 Citado por G. Mendel, ob. cit., p. 86.

534 F.-R. de Chateaubriand, ob. cit., p. 140.

535 B. Bettelheim, ob. cit., p. 102. 
Uno de los fenómenos más curiosos de formación de representaciones maternas en base a esta imago "mala» es el consistente en dotar a la figura femenina del mismo atributo que, en el Edipo, hace retraer al niño de la posibilidad de apoderarse de su objeto de placer. En este caso, el padre - que asegura la pena de castración al niño- ve extender su imperio fálico a la madre, que se convierte también en castradora. La presencia de la madre fálica como representación del aspecto más peligroso de la instancia materna es algo largamente atestado en la obra de Huysmans, ${ }^{536}$ y consiste, simplemente, en el ańadido de un atributo viril a su figura. Este pene puede ser llevado por la madre tanto exteriormente como interiormente — en cuyo caso su presencia podría deberse, según señalan Pontalis y Laplanche, ${ }^{537}$ a haber retenido el del padre durante el coito.

Melanie Klein, la psicoanalista británica, dio al concepto de mujer fálica una extensión interesante con la noción de "padre(s) combinado(s)»; se trata de los padres inseparablemente confundidos en un coito eterno, gracias al cual la madre porta en sí y de manera continuada los atributos paternos - $\mathrm{O}$ al padre entero- - y el padre porta el seno materno o a la madre en su totalidad —algo que Freud ya observó en su estudio sobre Una neurosis demoniaca del siglo XVII.

En la obra de Huysmans no es difícil establecer una relación directa entre esta madre fálica definida por el psicoanálisis —especialmente en su concepción kleiniana - y la mujer fatal hermafrodita: figura nacida de una imago de la madre «mala», con su cortejo de angustias y traumas.

\subsection{La sexualidad como resolución de conflictos edípicos}

La práctica de la sexualidad debería, en principio, haber tenido por finalidad la satisfacción de estas pulsiones que, sabemos, son múltiples en el caso de Huysmans. La primera pulsión que necesitase satisfacción sería la referida al Edipo no liquidado, por el cual se daba una fijación edípica a la

536 Vid. especialmente C. Bernheimer, «L'exorbitant sexuel: castration et sublimation chez Huysmans», ob. cit., p. 109.

537 J. Laplanche y J.-B. Pontalis, Vocabulaire de la psychanalyse, ob. cit., p. 310. 
madre. La madre como objeto sexual vendría a estar representado por numerosas sustituciones, que no tendrían otro fin último que el cumplimiento de la tan deseada unión carnal con ella — entendida desde el punto de vista fantasmático.

Sin embargo, sabemos también que la misma fijación a la madre desencadenaría un fenómeno contrario, consistente en considerar a los hombres como objeto sexual para no sentirse infiel hacia la madre. En esta búsqueda de uniones homosexuales influiría de manera notable la profunda interiorización de la figura del padre. Esta homosexualidad necesaria, sostenemos, para la satisfacción de las pulsiones infantiles de Huysmans se vería coartada en la práctica por la cultura heterosexual — que obliga a la unión con objetos del sexo opuesto en base a la ley paterna. ${ }^{538}$

En este contexto, la práctica de la heterosexualidad normativa no supondría más que un dolor y una frustración constantes en la persona de Huysmans, quien se ve impelido a una práctica erótica no deseada por su inconsciente - pero a la que su superyó le obliga de manera decisiva. El nivel de insatisfacción debió de ser tal que a la práctica heterosexual le acompańaría constantemente un agudo sentimiento de culpa — sobrevenido por la traición infligida a la memoria del padre interiorizado, por una parte, y a la madre «ideal» por la otra. De ahí que la práctica heterosexual para Huysmans necesitara de aditamentos que acercaran al objeto del sexo opuesto al sexo del padre: la mujer fálica o la madre combinada (en terminología de Klein) dotada de ambos atributos tuvo vigencia continuada en el universo erótico de nuestro autor.

Si observamos atentamente la manifestación que de la sexualidad se hace en la obra de Huysmans - ya habíamos convenido en que esta era una reparación necesaria de la biografía del autor, en base al concepto de «novela familiar» freudiano—, nos percataremos de que se produce una ne-

538 En efecto, la heterosexualidad normativa está considerada por algunos psicólogos y estudiosos del género como parte de los dictados de una sociedad construida sobre la base del poder masculino y su dominación sobre las hembras. De ahí que la homosexualidad y/o la bisexualidad sean consideradas como perversiones por parte de algunos (por ejemplo, S. Freud, Tres ensayos para una teoría sexual y La feminidad en Nuevas lecciones introductorias al psicoanálisis, ob. cit., p. 1193) o como construcciones discursivas del mismo sistema que las alumbra (J. Butler, ob. cit., p. 38). 
gación continuada de la mujer — de la madre. Todas las realizaciones de la práctica heterosexualidad son altamente insatisfactorias para el heterónimo ficticio de Huysmans, quien, a pesar del odio y la repulsión manifiestos que expresa, continúa en esas prácticas. Pasemos a analizar este aspecto de la heterosexualidad insatisfactoria y todos sus avatares de frustración.

Ya hemos comentado que la concepción teleológica que el patriarcado establece sobre la sexualidad crea dos normas inamovibles: una, la adecuación de la libido femenina a la libido masculina; y, dos, la heterosexualidad obligatoria como única vía posible de dinámica sexual —las divergentes siendo consideradas como 'perversiones'. ${ }^{539}$

Así pues, esta obligación cultural a elegir objeto sexual en personas del género opuesto provocó en Huysmans terribles quebraderos de cabeza: dicha obligación le impelía a continuar en una vía que jamás le resultó satisfactoria — salvo elaboradas representaciones y puestas en escena fantasmáticas que le permitían encontrar satisfacción en la práctica de la heterosexualidad.

Establecemos un corte en el tratamiento de la sexualidad en la obra de Huysmans, que situaríamos inmediatamente después de la redacción de $\grave{A}$ rebours (1884). La conveniencia de tal corte viene dada por la diferencia de planteamientos del autor y en el recurso a la religión como fuente inspiradora de satisfacción edípica. De allí que, aunque en alguna ocasión se internen en la obra llamada 'religiosa', los ejemplos se refieren casi exclusivamente a la producción anterior a dicha fecha.

La manifestación de la sexualidad de Huysmans pasa, en un primer tiempo, por la necesidad de cubrir las exigencias de la carne en la persona de una joven. La presencia de la mujer es deseable, pues, por eso; pero tam-

539 Vid. nota anterior. Sobre la monovariedad de la libido, el médico español Gregorio Marañón decía que «en tanto que energía diferenciada, la libido es, podría decirse, una fuerza de sentido viril. Lo mismo diremos del orgasmo", citado por S. de Beauvoir, ob. cit., vol. I, p. 82: «En tant qu'énergie différenciée, la libido est, peut-on dire, une force de sens viril. Nous en dirons autant de l'orgasme». La traducción es mía. Lo que no venía sino a corroborar lo ya dicho por Freud (en S. Freud, Feminidad, ob. cit., p. 3176) y que retomaría más tarde Lacan: «La profundidad de la intuición de Freud: a saber por qué sugiere que no hay más que una libido, que, como lo demuestra su texto, él concibe como de naturaleza masculina», en J. Lacan, «La significación del falo», ob. cit., p. 289. 
bién para cubrir las necesidades del hogar donde el artista trabaja. Esto no deja de provocar contradicciones en el bienestar del artista, quien ve cómo la necesaria compañía de una mujer conlleva ciertas molestias.

La mujer aparece, por consiguiente, tour à tour como amante o como criada necesaria para la buena marcha del hogar. El matrimonio podría ser una solución que cubriese ambas necesidades; el esteta opta finalmente por una vida de recogimiento y trabajo, una soltería militante en la que, ocasionalmente, se presente una candidata a cumplir el papel o de criada o de amante. El recurso a la prostitución será habitual.

El sexo se le antoja motivo insuficiente, pues, para soportar la presencia de una persona inculta y caprichosa (que es como percibe su mentalidad misógina a toda mujer), con la que apenas se puede conversar de nada que no sea lo estrictamente actual, inmanente y bajo. De ahí que requiera los servicios de personal cualificado y de pago.

Poco a poco, la práctica convencional de la sexualidad le parece a este esteta menos interesante tanto desde el punto de vista libidinal como espiritual. Solo los escenarios de orgías que produzcan goce de nuevos y arriesgados placeres tienen visos de satisfacer al exigente amante. El artista sueña entonces con amantes lujosas, hechas de arte y sensibilidad, de refinamiento tanto en las costumbres como en el ars amandi. El amante insatisfecho se ve impelido a crear artificiosos escenarios en que su sexualidad se satisfaga en medio de goces espirituales. El peligro se introduce en la sexualidad: la exaltación de la mujer fatal, castradora instancia, aparece brillante en el horizonte libidinal huysmansiano.

Se dan, sin embargo, y a medida que las exigencias se enriquecen con nuevos contenidos, unos progresivos descontento y hartazgo. Lejos de introducirse en prácticas tendentes a recuperar el gusto por la sexualidad -que pudiesen tener como objeto el ensalzamiento de la masculinidad aburrida - la originalidad de Huysmans radica precisamente en lo contrario. A la par que abomina de la práctica sexual, celebra el posible término de su virilidad como un regalo, como la finalización de tantos y tantos suplicios, de tantas y tantas horas consumidas en pos de un placer que nunca llegaba.

Una reacción comprensible en medio de este contexto de refinamiento y de hartazgo es el desarrollo de sentimientos tremendamente mi- 
sóginos. Las mujeres son denostadas de manera escandalosa. Cabe decir a esto que semejante lapidación de la condición femenina viene dada por la época — como ya vimos en el capítulo $2-,{ }^{540}$ así como justificada por la infravaloración de la instancia materna en la psicología profunda de nuestro autor.

La infantil y tan deseada unión carnal con la madre le granjea al heterónimo ficcional huysmansiano numerosos conflictos internos. El fantasma de castración está constantemente presente en estas relaciones heterosexuales, así como una obsesión enfermiza por todo lo que le recuerda la identidad sexual femenina. La enorme profusión de metáforas líquidas en la obra de Huysmans atestiguan del temor y los recelos que el contacto con las mujeres despierta en su inconsciente. Abismos, cuevas, bodegas, profundidades, dan fe asimismo del terror que inspira todo lo obscuro. Aspectos todos estos que serán objeto de análisis más detallado en páginas posteriores y que solo presentamos aquí a modo de anuncio.

La mejor solución que la imaginación creadora de nuestro autor puede encontrar para terminar con estos conflictos es abogar por la finalización definitiva de la sexualidad. Para ello opta por una desvirilización casi militante que le salve de todos los conflictos desencadenados por la heterosexualidad —obligatoria y excluyente de otras prácticas libidinales que tal vez fueran más satisfactorias.

\subsubsection{La mujer, compañera sexual}

Desde la primera de las novelas de Huysmans, Marthe, histoire d'une fille (1876), la práctica de la sexualidad normativa aparece como inevitable. El heterónimo ficcional en esta ocasión reviste los ropajes de un joven esteta, de nombre Léo, que se instala en casa de la joven prostituta y actriz teatral. La frecuentación de artistas de los escenarios era un hecho habitual en el siglo XIX: lo conocemos de mano de los numerosos ejemplos de Nerval, Balzac, Goncourt. En el teatro los hombres de letras encuentran solaz a su sensibilidad artística, así como proyección de su deseo en las actrices.

540 Vid. apartado 2.3. 
Según revela Robert Baldick, ${ }^{541}$ Anna Meunier —la compañera sentimental de Huysmans - trabajó durante varios años en un taller de costura que estaba situado en la calle de la Sourdière, donde estaba situada la casa donde vivía el Sr. Le Hir, director del teatro du Luxembourg, o de Bobino. Este teatro fue frecuentemente visitado por Huysmans, quien se hacía pasar por redactor (en realidad lo era) de la Revue Mensuelle, cuando, en 1867, se enamoró de una actriz que actuaba en la pieza "Cocher, au Bobino». Esta actriz sería el modelo de Marthe: con ella viviría Huysmans y ella tendría un hijo de otro hombre. Nada se ha sabido de la suerte de ambas criaturas. La conexión entre la vida y la obra de nuestro autor encuentra, una vez más, su razón de ser.

Léo era un joven que se había liberado de las exigencias familiares, "s'était affranchi de bonne heure de la servitude maternelle», ${ }^{52}$ y que había abusado gracias a ello de su juventud: «la débauche l'avait flétri, corps et âme». ${ }^{543}$ Viviendo de su pluma como vivía, «autrement dit, il vivait de faim", cree necesario encontrar a una mujer que le permita no dilapidar sus escasos ingresos en el vicio. Deciden instalarse juntos para llevar una existencia menos onerosa y más feliz, en la que ella pudiera escapar de los peligros de su condición social — de la prostitución-y él de las numerosas tentaciones de la calle. La amenaza de fracaso se les presenta con sus dientes más agresivos: «un mois durant, ils crurent s'aimer, puis, un beau jour, une double catastrophe s'abattit sur eux. Le théâtre fit faillite et le journal où Léo écrivait suspendit ses payements». ${ }^{544} \mathrm{El}$ dinero hace que todos los proyectos se derrumben, dando fe de la naturaleza interesada de su unión.

Céline y Désirée Vatard (1879) son las dos jóvenes obreras en quienes se centra la novela de 1876 Les Scurs Vatard. Désirée es una joven tímida y buena trabajadora, que ve su futuro poblado de un pacífico hogar con marido y niños. El caso de Céline es diferente; es la hermana mayor, más experimentada y viva, con un background de encuentros callejeros con hombres y conocimiento de la vida. La novela está ambientada en un con-

541 R. Baldick, ob. cit., p. 27.

542 J.-K. Huysmans, Marthe, histoire d'une fille, ob. cit., p. 61.

543 Ib., p. 61.

544 Ib., p. 70. 
texto que cualquier naturalista suscribiría de buen grado: un taller de costura de libros, en el que el trabajo, el sexo y el alcoholismo accionan la existencia de obreros y obreras.

Como ya hemos señalado con anterioridad, ${ }^{545}$ este taller estaría inspirado en el que estuvo situado en los bajos de la casa —en el n. ${ }^{\circ} 11$ de la calle de Sèvres_- y en el que su padre putativo, el Sr. Og, invertiría parte de sus ahorros. Así como dos eran las hijas que Og aportaba al matrimonio contraído con la viuda del padre Huysmans, dos son las hijas del père Vatard.

Céline es, de las dos, la más viva, quien protagoniza varios episodios callejeros, y a quien los hombres recurren para dar rienda suelta a su fogosidad. A resultas de esto, sus costumbres, su lenguaje barriobajero, sus carcajadas desenfrenadas, se impregnan del color de la calle. El señor Vatard decide no inmiscuirse en la vida de su hija: su educación debería corresponder más bien a su mujer quien, incapaz y casi inválida, se desentiende. Así que «le meilleur parti qu’il eût à prendre était de fermer ses yeux sur ses cavalcades». ${ }^{546}$ Sus gritos y sus expresiones de júbilo divierten al padre durante las digestiones, pues le permiten acercarse al recuerdo de una amante que él tuvo y a quien podría haber amado realmente. Sin embargo, sus maneras de estibador portuario le habían echado atrás: «au temps où il comptait la marier, ces allures de débardeuse l'avaient inquiété». ${ }^{547}$ Pero esto es normal, porque en el contexto de producción industrial que aún está en estado incipiente en el último cuarto del siglo XIX, el obrero debe encontrar válvulas de escape para asegurar que esa energía contenida no va a ser usada en contra del sistema. "La femme, c'est le bonheur du prolétaire!», ${ }^{448}$ dice el père Vatard en una reflexión. La mujer es la criada del hogar que espera en la casa la llegada del marido trabajador, quien debe proveerle de la satisfacción que necesita su libido desenfrenada y chabacana. El sexo es la salvación no solo del proletario, sino también del sistema. Por eso gran parte de la intriga de las novelas del naturalismo era de carácter sexual: gran motor de las clases desfavorecidas, el sexo es una de las pocas cosas que motivan al obrero en su evolución — junto con el sexo y el alcohol, del que L'Assom-

545 Vid. apartado 3.4 de este mismo capítulo.

546 J.-K. Huysmans, Les Scurs Vatard, ob. cit., p. 173.

547 Ib., p. 173.

548 Ib., p. 80. 
moir sería una gran muestra de sus efectos perniciosos, en lo que Les Soeurs Vatard no le iría a la zaga. Los obreros parecen trabajar exclusivamente para beber; las mujeres, para satisfacer su gula y su gusto inveterado por las joyas:

le reste ne travaillait, les ouvrières que pour bâfrer des frites et s'acheter des bijoux en doublé, les ouvriers que pour s'enfourner à tire-larigot, dès l'aube, des chopines de vin blanc et laper, dès l'après-midi, des litres de vin bleu. ${ }^{549}$

Esta mujer libérrima y escandalosa, Céline, es con la que se relaciona el heterónimo ficcional de esta novela. Cyprien Tibaille, a quien también veremos participar en En ménage como adláter del protagonista, es un pintor habitual de la orgía y el desenfreno - necesaria escuela donde encontrar motivos para su arte. ${ }^{550}$ La pareja, desequilibrada por completo, está abocada al más estrepitoso fracaso. El papel de la mujer en el universo juvenil huysmansiano es el de mera comparsa, el de instrumento funcional que sirve para satisfacer la libido del artista — con las consecuencias que ya conocemos y que tendremos tiempo de analizar más detenidamente.

En Croquis parisiens, ese extraordinario fresco naturalista - pero tan personal- de los ambientes de la capital, el papel de las mujeres como excitantes de la imaginación libidinosa del artista queda bien patente. Como si de un mero observador se tratara, un notario de la realidad circundante — que toma notas según su manera de ver las cosas y de sentirlas_-, el autor parece posicionarse en una esquina del mundo para aportar su - ya sabemos - interesada y necesaria visión del universo.

Para ello, el café, el restaurante y el cabaret son lugares de observación privilegiados. A ellos se acerca el notario naturalista en busca de la sensación de contemporaneidad, del pulso de su tiempo — que con tanto ahínco intentaron captar estos cazadores de instantes.

La función que cumple la mujer en estos centros del ocio masculino es decisiva. Ella es la encargada de disparar los sentidos de los hombres en busca de placeres urbanos y mundanos. Los cafés-cantante de Montmartre,

549 Ib., p. 158.

550 «Il affirmait qu'un peintre ne devait rendre que ce qu'il pouvait fréquenter et voir; or, comme il ne fréquentait et ne voyait guère que des filles, il ne tentait de prendre que des filles». Ib., p. 287. 
los bar-à-vins en cuya trastienda se reunían los clientes habituales, los cabarés de Pigalle y de la place Blanche, eran los lugares idóneos para que el rico propietario de provincia, de negocios en París, el periodista teatral ocioso, el escritor deseoso de glosar las imágenes de su tiempo, se divirtieran y creyeran sacar de la vida parisiense el máximo provecho lúdico.

En esta perspectiva se acerca Huysmans al teatro de Les Folies Bergère. Las mujeres, las busconas que allí se encuentran, están soberbias en su atuendo de seducción, decoradas con un marcado y artístico maquillaje, vestidas para realzar todos los encantos que conformaban el gusto por la mujer en el último cuarto del siglo XIX:

elles sont inouïes et elles sont splendides, lorsque dans l'hémicycle longeant la salle, elles marchent deux à deux, poudrées et fardées, l'oeil noyée dans une estompe de bleu pâle, les lèvres cerclées d'un rouge fracassant, les seins projetés en avance sur des reins sanglés, soufflant des effluves d'opopanax qu'elles rabattent en s'éventant et auxquels se mêlent le puissant arôme de leurs dessous de bras et le très fin parfum d'une fleur en train d'expirer à leur corsage. ${ }^{551}$

Inauditas, espléndidas, con labios heridos de rojo sangre, con los senos proyectados hacia adelante, exhalando un aroma mezcla de perfume y de los efluvios de la carne sudada — recuerdo de las noches de lujuria pasadas en compañía de una de estas soberbias mujeres. Frente a tales atractivos, el hombre, el visitante y consumidor de estos espectáculos humanos, no puede por menos que sentir cómo hierve su sangre, cómo su animalidad se despierta de manera salvaje. En este contexto, el amante se asemeja a un semental que se acerca al establo donde le espera su ardiente yegua, lo que le provoca relinchos de excitación:

l'on hennit, en suivant le travail de ces dos de femmes se coulant entre les poîtrines des hommes [...] laissant entrevoir par les interstices des têtes, des derrières de chignons, allumés de chaque côté par le point d'or d'un bijou, par l'éclair d'une pierre. ${ }^{552}$

El perfume de esta mujer de teatro y cabaré, de café y de bulevar, es algo que ocupará a Huysmans a lo largo de su producción. Tanto es así que le dedica uno de sus croquis, en el que ensalza ese divino aroma — «fumet»,

551 J.-K. Huysmans, Croquis parisiens, ob. cit., p. 13. Se trata del croquis «Les Folies Bergère en 1879».

552 Ib., p. 14. 
dice el narrador-, en una clara asemejación de la mujer con la gastronomía - que rodea majestuoso a la mujer en todo momento y situación: «je veux simplement parler de l'exquis et divin fumet préparé par les femmes de nos villes, où qu'elles se trouvent et chauffent, dans un bal, l'hiver, ou dans une rue, l'été». 553

Si en alguna de las novelas de Huysmans la reificación de la mujer es más evidente, eso es en En ménage. Ya conocemos la historia de esta obra de 1881, en la que André Jayant se separa de su mujer Berthe tras haberla sorprendido cometiendo adulterio; sus aventuras subsiguientes consisten en la búsqueda de una cómoda soledad - iya! — en la que poder vivir sin la incómoda presencia de una mujer. Cuando parece que la suerte le sonríe y que, sin demasiados problemas, se ha separado de Berthe y encontrado une garçonnière a su medida, se da cuenta de que le falta la presencia tranquilizadora de una mujer: «l'aveu lui échappa, la femme manquait».

Se trataba de lo que, en lo sucesivo, Huysmans llamaría con su personal gusto por la acuñación de expresiones sabrosas, la "crise juponnière»: momento que se presenta frecuentemente en medio de un instante de quietud y estudio, y que consiste en el acoso permanente de la libido - lo que le hace, las más de las veces, partir a la desesperada en busca de una mujer:

cette tranquillité qu'il avait reconquise par si grand'peine, fit place à un indéfinissable malaise qui s'accentua aux alanguissements du printemps et aux troubles nerveux qui l'accompagnaient. ${ }^{554}$

Esta crisis faldera — si se le puede llamar crisis es porque significa una ruptura con el tiempo habitual de inactividad libidinal— no tiene una sintomatología estrictamente sexual. Se trata más bien de un malestar difícilmente definible producido por una extrańa melancolía. Su escenario es el de la soledad del apartamento, frecuentemente en medio de un momento de concentrado estudio. Sin duda alguna, una sensación de carencia se apodera del personaje, un malestar debido a una ausencia, lo que provoca un incómodo sentimiento de soledad en la frialdad de su siniestro apartamento de soltero. «C'était moins la hantise des spectacles lubriques qu'une appé-

553 Ib., p. 126. Se trata del croquis «Le Gousset» de la serie "Fantaisies et petits coins».

554 J.-K. Huysmans, En ménage, ob. cit., p. 157. 
tence nerveuse vague, qu'une rêverie confuse» — dice el narrador de En ménage. Desde luego, en esta crise juponnière deseaba con fuerza la presencia de la mujer, pero

non pour l'étreinte charnelle de son corps, mais pour le frôlement de sa jupe, la cliquette de son rire, le bruissement de sa voix, pour sa société, pour l'air enfin qu'elle dégage. Sans elle, son logement lui semblait maussade. ${ }^{555}$

El apartamento se le antoja frío y triste sin la presencia de esas faldas que rozan el embaldosado. Ausencia que se resuelve, a pesar de esa concreción de la naturaleza no libidinal de la crisis, en la búsqueda frenética del placer carnal. Primero, mediante el recuerdo de lascivas veladas en companía de la mujer recordada; segundo, mediante el recurso a la orgía, a la fiesta curativa: «il voulut tâter de noces guérissantes, s'aiguisa les sens par des souvenirs lascifs et, à diverses reprises il se livra, par raison, à de consciencieuses ribotes». ${ }^{556}$ Ribotes — de nuevo el símil gastronómico. El resultado de estas escapadas orgiásticas era el esperado: verse librado de esa llamada de la carne, acallar las voces que le venían del recuerdo de las faldas sobre el pavimento: «il obtint, en effet, une espèce de soulagement; il rentrait chez lui brisé et dormait d'une traite. Le lendemain il se sentait quelque lourdeur de tête, mais les jupes ne le tourmentaient plus». Fin del tormento: las faldas no le atormentaban ya y sus deseos de ternura quedaban satisfechos durante un tiempo: "ses désirs de tendresse demeuraient bien inassouvis, mais ils criaient moins haut dans la chair repue». ¿Cómo considerar que esas orgías desenfrenadas sean un remedio al ansia de ternura? El recuerdo casero del frufrú de las faldas y el ansia de ternura no pueden sino enviarnos a una nostalgia de esa presencia benefactora, a ese ángel del hogar que, en la imaginación del niño, solo puede identificarse con el recuerdo de la madre. Piénsese ahora en que la resolución a ese melancólico recuerdo se efectúa a través de la orgía sexual: ¿cómo no ver en ello un intento ficticio de puesta en escena de la satisfacción de un impulso incestuoso?

Es esta una muestra, por ahora solo esbozada, de cómo la sexualidad huysmansiana — o de su heterónimo ficcional — tiene como base una fijación a la madre. El desencadenante de la crise juponniére es, pues, el re-

555 Ib., p. 159.

556 Ib., p. 166. 
cuerdo de esa presencia femenina en la casa, benefactora y tranquilizante, cuyo remedio se halla en la satisfacción sexual. Esta crisis se mueve por el eje marcado por soledad-recuerdo-excitación-satisfacción. Se trata, en definitiva, de la resolución ficcional del drama edípico primordial.

\subsubsection{El matrimonio, dudosa solución}

Frente a esta necesidad fantasmática de llenar el espacio vacío dejado por la madre, el heterónimo huysmansiano creerá encontrar en el matrimonio - $\mathrm{o}$ en el concubinato sin decisión administrativa - una solución a sus carencias tanto de ternura como de soledad. El artista esperaba de la mujer con la que compartir su espacio vital una salida a esos problemas domésticos de los que el hombre solo no parece saber ocuparse. Zurcidos, cosidos, cocina, limpieza, tareas del hogar en general, parecen vedadas al hombre en una injusta concepción de la división del trabajo. Los trabajos de los que la mujer se encarga son una extensión de la ética del cuidado que tantas feministas reivindican hoy en día: «ces ineptes bêtises qu'une femme conjure en deux tours d'aiguille». ${ }^{557}$

En Marthe, histoire d'une fille, cuando la protagonista y Léo se instalan juntos, el profesional de la pluma se felicita de haber conseguido poner término a esos pequeños sinsabores que habían malogrado su existencia: la casa fría, la lámpara apagada...: «quand il revint pour dîner il trouva bon feu, lampe ne fumant pas comme d'habitude»; pero, sobre todo, la amante que ocupa un espacio que la ausencia materna había dejado vacío:

et, dans son fauteuil, une femme gentiment ébouriffée qui l'attendait, les pieds au feu, le dos à table. moi. $^{558}$

-Comme je vais travailler, se dit-il, maintenant que je suis si bien chez

Sin embargo, no pasa mucho tiempo antes de que esa presencia, en un principio tan deseada y esperada, se convierta en una molestia; una presencia que en nada contribuye a la necesaria paz que el escritor, que el artista, precisan para llevar a cabo su trabajo. Porque la compañera - sentimental o no- - una vez ha terminado las tareas que le han sido en-

557 J.-K. Huysmans, Marthe, histoire d'une fille, ob. cit., p. 94.

558 Ib., p. 71. 
comendadas en función de su género y de esa injusta división del trabajo que mencionábamos antes, se aburre; $y$, lejos de poderse dedicar a esa obra de arte que requiere horas de sosiego y reflexión, se da a la conversación sin meta ni objetivo, al relato de esas pequeñas cosas, insulsas cosas, que llaman la atención de quien no tiene otra cosa mejor en que ocuparse: los cotilleos del barrio, los hechos y aventuras de unos vecinos que para nada interesan al artista —ocupado como está en asuntos de índole espiritual o estética. Esta situación es inseparable de la misma división de trabajos y atribuciones; habiendo sido únicamente educada y formada en aquello que pudiese complacer al hombre, a su hombre, así como en los cuidados y mantenimiento de la casa, lo único que puede interesarle es, precisamente, aquello que rodea la inmanencia de la vida cotidiana.

Tan desinteresado de los cotilleos y de las miserias de la vida de todos los días, el artista Léo se da cuenta de que las promesas de felicidad y sosiego que se había hecho son imposibles de cumplirse en ese ambiente ramplón y comadre. Ese no es el ambiente que él necesita para llevar a cabo su importante obra artística — tanto más importante cuanto que en ello le va la reconstrucción de su vida afectiva y fantasmática. "Cette impossibilité de travailler près d'une maîtresse qui, n'ayant plus rien à faire, veut causer et vous raconte tous les cancans de la maison»,, 59 se lamenta Léo en pleno trabajo de composición literaria. La ilusión con la que se había instalado con la actriz se va difuminando poco a poco, enfrentándose como debe a la pura realidad de los hechos y de la personalidad de su amante. Cómo no imaginarse un interior, un chez soi cálido y confortable, ocupado por esa pareja de felices tortolitos que eran ellos dos, que creyeron amarse durante el primer mes antes de que llegara la convicción del tedio y del triste fin de la novedad que suponía vivir el uno junto al otro. Ante esta perspectiva, el lujo que el hombre decimonónico encontraba en hacer suya una actriz de teatro - con tantos ejemplos a lo largo de toda la literatura de este siglo-, la inmensa suerte de poder acostarse todas las noches con una bella señorita, en exclusividad y monopolio de su cuerpo y encantos, lujo y suerte se disipan en cuanto el amante se da cuenta de que se las tiene que ver con una mujer que enseguida rompe con esa preciosa posibilidad. Ya no se halla frente a la actriz —objeto del deseo de todos los espectadores ávidos de apo-

559 Ib., p. 73. 
derarse de la libertad de la mujer-, ni siquiera ante la deseada amante: lo que queda tras la defección de sus encantos es la pura funcionalidad doméstica de la compañera: la criada que se ocupa de esos pequeños riens de la casa: «la comédienne, la maitresse avait disparu, il ne restait que la bonne à tout faire». ${ }^{560} \mathrm{Y}$ es que, de ello Huysmans se hace plenamente consciente, la convivencia con la tan deseada amante se torna insípida por la fuerza de la rutina. Como señala tan acertadamente Celia Amorós, el matrimonio — sea cual sea su solución legal, pongamos la vida en pareja— «más bien que la tumba del amor es su Drácula, su estado cataléptico: lo parasita y lo hace revivir a la vez». ${ }^{561}$ Lo parasita chupándole la sangre porque, en su consumación, se encuentra el fin de la misma inseguridad que le daba calidad de algo vivo y de necesarias renovación y alimentación; por otra parte, lo hace revivir siempre en caso de que la convicción de la pareja por mantener ese pacto de convivencia les obligue a re-crear las causas y los motivos que les habían llevado a instaurar esa unión de hecho. El matrimonio y el concubinato se convierten, por arte de la rutina, en una institución cuyo mantenimiento se hará en base al exclusivo interés de sus integrantes.

Esta idea de matrimonio, de unión por fuerza fallida, es algo que, aun manifestando su desconfianza al respecto, Huysmans se empeña en mantener a lo largo de casi toda su obra. Esta necesidad de compañía habría dejado de ser siquiera esbozada tras un primer fracaso en Marthe, histoire d'une fille. ¿Cómo someter tantas veces a su heterónimo ficcional a la prueba de la convivencia, aun a sabiendas de su cantado y estrepitoso fracaso? Sabemos que no se trata únicamente de una necesidad literaria, sino de carácter fantasmático; la necesidad de puesta en escena de esta situación de vida en común viene del deseo de reconstrucción de las propias coordenadas vitales: de establecer una novela del origen a lo largo de toda su producción literaria.

En Les Sours Vatard, el caso vuelve a ser planteado en la persona de Auguste, quien ve de manera obsesiva la posibilidad de casarse con una de las hermanas, Désirée. Huysmans, al proponer de nuevo esta situación, sabe a priori que la cosa no va a funcionar, y sin embargo... Y es que la situación de Auguste es peculiar: hijo único de una madre anciana, de quien se ocupa

560 Ib., p. 74.

561 C. Amorós, Hacia una crítica de la razón patriarcal, ob. cit., p. 196. 
en exclusividad, el matrimonio se le antoja como la solución por antonomasia a su vida insulsa. La jovencita supondría un chorro de aire y luz en su vida, envejecida por el lastre de esa vieja madre. "Une seule idée surnageait dans cette débâcle, une idée obsédante et fixe: le mariage. Il voulait à tout prix, trouver une délivrance, un havre, où il pourrait s'échouer». ${ }^{562}$ El matrimonio como liberación, como puerto en que su barco podría descansar en dique seco, al abrigo de las inclemencias de la vida. Idea esta del puerto que encontraremos también en En rade.

Sea matrimonio o concubinato, Huysmans lo pinta como el fin de todos los deseos que el artista pone en la convivencia con la amante. Así lo expresa por boca de otro personaje, lo que no hace sino corroborar su idea negativa de la vida de pareja: la unión supone el fin de las alegrías y el comienzo del tedio y las molestias. Más que un puerto donde el navío viril podría dejarse reparar, la vida en pareja es antes el desguace de las pasiones. La capataz del taller de imprenta se queja, con ello, del poco cuidado que ponen las obreras casadas en su trabajo; como si fuera una extensión de su vida marital, la mujer que por fin encuentra marido — la salida habitual de todas las mujeres burguesas y no tanto- hace una completa dejación de las que habían sido hasta entonces sus obligaciones.

Les filles qui font la noce sont presque toujours de détestables ouvrières; celles qui ne la font pas, gagnent de bonnes journées, mais elles se marient et deviennent pis que les plus mauvaises, puisqu'elles ne viennent plus du tout. Comment faire?

—dice la capataz a propósito de la inminencia de la boda de Désirée: «une fois en ménage, Désirée sera comme les autres, elle lâchera le métier; il va falloir que je lui trouve comme remplaçante une jeunesse honnête». ${ }^{563}$ Ella abandonará el oficio: triste final de la vida laboriosa de la obrera que significa la vida en pareja. Y es este un reflejo casi automatizado en muchas mujeres, quienes encuentran en el matrimonio el fin de sus obligaciones como miembros de la colectividad. Al ofrecer su cuerpo y su compañía como materia de intercambio — como principal aportación a la unión—, suponen que pueden dejar de mostrarse hábiles y válidas; la misma educación diferencial las ha formado en ese sentido: mientras son independientes, se for-

562 J.-K. Huysmans, Les Sours Vatard, ob. cit., p. 398.

563 Ib., p. 445. 
man o trabajan para su porvenir; una vez eliminada su independencia, vuelven al limbo de la inactividad, al estatus de nińa consentida, cuando no enferma, que no sabe hacer nada, y que se auto-recluye en la animalidad más descarada, que no es sino su función de hembra de la especie. Así lo consideraba, con no poca virulencia, Engels en su famosa obra L'origine de la famille, de la propriété privée et de l'État: «si la bourgeoise se différencie de la courtisane ordinaire, ce n'est que parce qu'elle loue son corps à forfait, comme une salariée, mais parce qu' elle le vend une fois pour toutes, comme une esclave». ${ }^{564}$ Una vez que ha vendido su cuerpo como bien supremo, la esposa se cree capacitada para olvidar el resto de obligaciones que tiene todo individuo dotado de un proyecto vital. Inmanencia pura, la vida de la esposa burguesa —u obrera, como plantea Huysmans en sus Seeurs - consiste en un dejarse llevar por los vaivenes de la vida. Paul Lafargue lo observa también así, viendo en el matrimonio la institución que convierte a la mujer en una esclava de su propia inactividad, en la que ya puede darse, en virtud de la indisolubilidad de la institución conyugal, a su estatus de muñeca inactiva, dependiente y parásita. «Elle s'est débarrassé — dice Lafargue — des soins de la maison et de l'allaitement de l'enfant, les confiant à des mercenaires, pour se consacrer à se parer, afin de devenir les poupées les plus luxueusement présentées du monde capitaliste [...] métamorphosant son père et son mari en cumulateurs de millions, qu'elles gaspillent avec folie». ${ }^{565}$

El matrimonio, pues, considerado como el fin de la pasión y de las buenas intenciones, se convierte en una institución de todo menos altruista y desinteresada. Quien dice matrimonio, dice, como hemos señalado a lo largo de estas líneas, unión de hecho. La cuestión es que tanto el uno como el otro son el escenario de miles de pequeñas miserias; escenario tanto más decepcionante y frustrante cuanto que su origen se hallaba en un compromiso basado en el amor. Y poco importa que un alcalde o un sacerdote indique a los esposos la obligación a que se comprometen de respetar al cónyuge: la vida en pareja es para Huysmans, y para sus heterónimos ficcionales, una mentira en que toda traición es posible y esperable. Así lo ex-

564 F. Engels, L'origine de la famille, de la propriété privée et de l'État, Éd. Sociales, París, 1971 , p. 69.

565 P. Lafargue, «La femme et le communisme», en Anthologie des grands textes du marxisme, Éd. Sociales, París, 1951, p. 126. 
presa por boca de Cyprien, el amante de Céline Vatard, cuando vuelve al hogar y comprueba — no del todo apenado, pues esa posibilidad cabía por definición- que su querida lo ha abandonado. Hace entonces inventario de sus experiencias con otras mujeres:

Il se remémora les saletés que ses autres maîtresses lui avaient faites.

'Clémence, ah oui! elle m’a quitté sans même m’écrire; Suzanne, je n’ai jamais su pourquoi; Hélö̈se, parce que je la surveillais; Eugénie parce que je ne la surveillais pas!'566

Imposibilidad completa de comprensión de las aspiraciones y los deseos de la otra, de la mujer que estaba destinada a cumplir los sueños de lujo, calma y voluptuosidad del múltiple alter ego de Huysmans.

La exclusión del amor como connatural a la institución del matrimonio comportaba unos peligros que Balzac ya se preocupó de enunciar en su famosa obra Physiologie du Mariage. La misma naturaleza de la unión marital, en la que el amor deja de ser moneda de cambio entre los cónyuges, podía conducir a la mujer al adulterio, por lo que exhortará al marido a tenerla totalmente sujeta con el fin de evitar el ridículo del deshonor. ${ }^{567} \mathrm{Bal}-$ zac exhorta al esposo a mantener a su mujer en una completa sujeción para evitar esa incómoda situación de traición al pacto. Una de las estrategias conducentes a abolir en la mujer toda capacidad de iniciativa consiste, como apunta Beauvoir en sus comentarios a la "fisiología» balzaciana, ${ }^{568}$ en negarle el acceso a la instrucción y a la cultura, en prohibirle todo aquello que pueda permitirle desarrollar su personalidad y su individualidad; imponerle vestidos incómodos y poco prácticos, aconsejarle regímenes alimenticios anemizantes. Como compensación, Balzac recomienda honrarlas y homenajearlas sin descanso. "La femme mariée est une esclave qu'il faut savoir mettre sur un trône», dice Balzac.

La infidelidad se presenta, pues, en el horizonte burgués, como el principal escollo de la felicidad conyugal. Como buena institución patriarcal, en la que la participación de sus miembros está basada en el afianzamiento de

566 J.-K. Huysmans, Les Seurs Vatard, ob. cit., p. 438.

567 Vid. J. Borie, Un siècle démodé. Prophètes et réfractaires au XIXe siècle, ob. cit., p. 81 y ss.

568 S. de Beauvoir, Le deuxième sexe, vol. I, ob. cit., p. 191. 
la sucesión del nombre y patrimonio paternos, el matrimonio y la moral que lo alimenta reprende la infidelidad femenina, mientras que la masculina puede llegar a ser «motivo de presunción social para él». ${ }^{569}$ Solo la fidelidad a ultranza de la esposa puede garantizar la estabilidad familiar y el derecho sucesorio.

Esta obligación, Huysmans la tiene perfectamente presente cuando escribe una de sus principales novelas, puesto que con ella se inicia el ciclo de la soltería del artista solitario. En En ménage, el treintañero largo André Jayant (Huysmans tiene en el momento de su redacción 36) es un hombre casado desde hace dos ańos con Berthe. Una noche, de vuelta a casa tras un espectáculo, André sorprende a su esposa con un caballerete en pleno ébat amoroso. Con una voluntad férrea y una capacidad de decisión fuera de toda medida — en la que parece excluirse la posibilidad de comprensión del hecho consumado o de sus motivos-, André deja a su mujer y busca rehacer su vida de soltero. Toda la novela consistirá en esta reconstrucción del celibato: alquiler de un apartamento apto a sus necesidades de trabajo -André es escritor-, aprovisionamiento, y, cómo no, contratación de personal doméstico que le permita olvidarse de esas pequeñas naderías a las que la grandeza masculina no quiere verse abocada.

André consigue lo que tanto ansiaba: la separación con Berthe se consuma - sin mediar divorcio ni farsas administrativas, lo que no deja de satisfacerle; encuentra un apartamento a su medida; consigue que una señora se encargue de prepararle la comida. Una vez solo en su puerto de paz, en su saludable rada, la soledad hace de nuevo mella en este insatisfecho joven. Por mucho que intentara construir su tebaida pacífica y tranquila, por mucho que se convenciera de que esa era la solución única para él, debe confesarse a sí mismo que echa de menos esa presencia alegre, esa presencia viva: «l'aveu lui échappa, la femme manquait». ${ }^{570} \mathrm{Y}$ esa nostalgia de la presencia femenina no se basa tanto en la libido como en una apetencia nerviosa y vaga: «c'était moins la hantise des spectacles lubriques qu'une appétence nerveuse vague, qu'une rêverie confuse». La mujer que André echa de menos no es la hembra que satisface los retortijones eróticos, «il désirait la femme, non pour l'étreinte charnelle de son corps", sino porque su presencia colma una

569 E. González Duro, Represión sexual, dominación social, Akal, Madrid, 1976, p. 183.

570 J.-K. Huysmans, En ménage, ob. cit., p. 158. 
ausencia, un vacío finalmente insoportable en ese templo que es la casa para Huysmans; lo que André extraña es «le frôlement de sa jupe, la cliquette de son rire, le bruissement de sa voix, pour sa société, pour l'air enfin qu'elle dégage». Es decir, el sonido de la compañía en que el niño que jamás dejó de ser nuestro autor juega y se siente tranquilo. La nostalgia de la casa materna se intenta satisfacer en la búsqueda del alojamiento tranquilo; la nostalgia de la madre busca ser satisfecha en la presencia de esa amante entregada y poco exigente, que nada demanda en el desigual intercambio esposo-esposa o madre-hijo. "Sans elle, son logement lui semblait maussade», termina por decir André. ${ }^{571} Y$ es que las necesidades del artista son muy exiguas. Concediéndole una importancia cada vez menor al sexo, la convivencia con la esposa-amante deja de basarse en el pago del tributo sexual; la vida en pareja podría ser, según dice André, un mero pacto en que ambos cónyuges cumplieran debidamente su papel. ¿Para qué pretender mayores satisfacciones cuando lo único que interesa de la unión marital es la compañía, cuando la única exigencia es colmar un vacío?

On a joint son existence à celle d'une autre, qu'on s'est tout raconté, l'un à l'autre —l'homme au moins — et puis, qu'au bout de quelques années, l'oubli a tout effacé et que l'on n'a plus rien de commun ensemble. ${ }^{572}$

Definitivamente, nada más que la costumbre o el contrato —llámese pacto-, o el simple interés, pueden mantener unidas a dos personas que han dejado de interesarse la una a la otra, entre las que la usura del tiempo ha borrado toda comunión. En base a este pacto, en base a esa unión interesada, André deja de inquietarse por hallar el amor de una mujer: el subterfugio, la ficción, le bastan para creerse amado y cajolé; una buena interpretación le habría satisfecho ampliamente:

j'ai depuis longtemps atteint l'âge où les apparences d'affection suffisent; en admettant même qu'elle ne m’ait jamais aimé, si elle avait bien appris son rôle, ça m'aurait amplement satisfait. ${ }^{573}$

Para paliar su soledad hogareña, insoportable para ese nostálgico niño, André recurre a una vieja amante, Jeanne: una costurera de rasgos suaves y comportamiento discreto, quien parece desear, tanto como André, el en-

\footnotetext{
571 Ib., p. 159.

572 Ib., p. 165.

573 Ib., p. 165. La cursiva es mía.
} 
cuentro, la reconciliación y la vida en común. El modelo de esta Jeanne, como ya hemos apuntado más arriba, ${ }^{574}$ no puede hallarse sino en su compañera de por vida Anna Meunier. «Anna Meunier et Jeanne — señala Baldick - n'en font qu'un [...] Huysmans fit la connaissance d'Anna dès 1872, alors qu'elle était employée pour la maison Hentenaar». ${ }^{575}$ También ellos dos se pelearon, separándose al cabo de unos pocos meses, volviendo a encontrarse cinco años más tarde.

La composición de lugar que se hace André sobre la posible convivencia con Jeanne es de lo más triste. Cree que su presencia enturbiará su reconquistada vida de soltero: «il aperçut d'un coup, la tranquillité de son intérieur fuyant à vau-l'eau, remplacé par tout un enfer de cancans et de luttes ${ }^{576}$ — es decir, los mismos problemas que se planteaba el Cyprien de Les Sours Vatard: molestias debidas al tedio de la mujer, los cotilleos sin interés, extraño tributo que el soltero vocacional debe pagar para sentirse acompańado en esos momentos de soledad insoportable. Otro temor era el de pensar que, tras todo ese tiempo de separación (cinco años), el cuerpo de Jeanne hubiera perdido su encanto. Aunque parezca no dar importancia al asunto de la libido, André necesita que su amante, a la que deberá pagar también un tributo sexual, posea lo necesario para que su apetito se estimule. La compañera debe estar bien construida, poseer un cuerpo apto para los envites del sexo. Así, cuando los viejos amantes, André y Jeanne, se acuestan de nuevo, él comprueba las aptitudes de ella para el amor: «il fut subitement possédé d'une joie folle, Jeanne était solide comme du marbre, rebondie et moulée à point». ${ }^{577}$

Las exigencias de su amigo y confidente, Cyprien Tibaille, son diferentes. Ya completamente convencido de que la comunión con un ser del sexo opuesto solo es posible en la novelas à l'eau de rose, se plantea la convivencia con una mujer como algo meramente utilitario; intercambio de soledades, intercambio de calores, intercambio de simpatías. La carreras detrás de las caprichosas faldas de las jóvenes se le antojan a Cyprien tonterías más aptas para muchachotes ávidos de comerse el mundo que para adultos

574 Vid. apartado 3.7.1.

575 R. Baldick, ob. cit., p. 81.

576 J.-K. Huysmans, En ménage, ob. cit., p. 238.

577 Ib., p. 256. 
de vuelta ya de toda ambición o de toda aspiración a una felicidad utópica. Así, le dice a su amante Mélie, que hasta entonces se había encargado de cuidar su cuerpo y su estómago:

nous ne sommes plus jeunes, ma vieille branche, et le temps se gâte! Le moment me semble venu de jouer les Paul et les Virginie qui se fourrent sous le même jupon par les temps de pluie. T'es grosse et je suis maigre, t'es vaillante et moi je cane; réunissons ces qualités et, nous complétant l'un par l'autre, nous aurons au moins quelques chances de résister aux tourmentes des événements. ${ }^{578}$

Un contrato a todas luces en las que él y ella se comprometiesen a cuidar del otro, a proporcionarle calor y amistad. Él ya no necesita gran cosa: tan solo remedio a su insoportable soledad: «quant à moi, la vie de garçon m'embête; à être toujours seul, je me consterne et je me ronge; pour tout dire, je suis las et les latrines de mon âme sont pleines!». André toma buena nota de todo esto; el ejemplo de su amigo es altamente ilustrativo para él. Las aspiraciones de Cyprien a la tranquilidad son, en definitiva, las mismas de su alma artista y trabajadora. Incluso se ve capaz a olvidar, con una amante de esta naturaleza, el lujo y la voluptuosidad baudelairianos para conformarse perfectamente con la calma. Ese es el último ideal de Cyprien: encontrar la tranquilidad de espíritu en donde no tengan ya lugar las incómodas exigencias de la carne. Así, hablando de nuevo de Mélie dirá el pintor:

elle remplit enfin toutes les conditions d'un dernier idéal qui m'était poussé: trouver une dame, mûre, calme, dévouée, sans besoins amoureux, sans coquetterie et sans pose, une vache puissante et pacifique, en un mot.

Vaca potente y pacífica; señora tranquila y entregada, sin necesidades amorosas, sin coquetería ni pose... La perfecta sustitución de la madre, cuya memoria no va a ser manchada por los excesos de la carne; abolición de la posibilidad del incesto, pues, en esta madre de fortuna, en esta presencia muda en el interior del hogar huysmansiano.

Si hay una novela crítica con la institución matrimonial en la obra huysmansiana, esta es sin duda En rade. Este largo relato de las vicisitudes de una pareja de parisienses en la campiña provincial resultó ser

578 Ib., p. 323. 
- como ya hemos comentado con anterioridad en este mismo capítulomotivo de alabanza del papa del surrealismo, André Breton, por su entrada atrevida y sin ambages en el territorio de los sueńos. Y no podía ser de otra manera, pues la sombría vida que el narrador pinta de Jacques Marle - otro heterónimo ficional, escritor y esteta preocupado de artejunto a su esposa Louise solo podía dejar como escapatoria la vía del sueño.

La trama de En rade es sencilla: Jacques y Louise, acuciados tanto por las deudas como por la enfermedad de ella, deciden refugiarse en el castillo de Lourps, propiedad de la familia de Louise, y a cuyo cargo está la pareja de campesinos formada por la tía Norine y el tío Antoine. La estancia de los parisienses en el castillo, que debía resarcirles de la mala brecha en que estaban sumidos, se revela un pequeńo calvario debido al estado ruinoso de la vieja mansión, a la avidez de los campesinos por sacar partido de los recién llegados, y, sobre todo, a la creciente barrera que impone el estado de salud de Louise para la pareja.

Como no podía ser de otra manera, Jacques Marle se había unido a Louise buscando solución a esos pequeños problemas que asolan la vida del soltero vocacional del siglo XIX francés. Con todas las vicisitudes de la estancia en Lourps — donde, como sabemos, pasó varios veranos el propio Huysmans, y donde situaría también a la familia materna de des Esseintes-, Jacques se replantea su vida de casado. Y la primera cosa que tiene que reprocharle a la mala suerte que le ha venido persiguiendo es que él no se había casado para renovar el desorden de su vida de soltero.

Ce qu'il avait voulu, c'était l'éloignement des odieux détails, l'apaisement de l'office, le silence de la cuisine, l'atmosphère douillette, le milieu duveté, éteint, l'existence arrondie, sans angles pour accrocher l'attention sur des ennuis. ${ }^{579}$

Es decir, la solución a todos esos quebraderos de cabeza de los que el torpe soltero no sabe ni quiere ocuparse. Buscando como buscaba el resto de heterónimos huysmansianos colmar un vacío en la existencia recogida y contemplativa del artista; o sea,

579 J.-K. Huysmans, En rade, ob. cit., p. 120. 
la société de la femme, la jupe émouchant les inquiétudes des tracas inutiles, le préservant ainsi qu'une moustiquaire, de la piqûre des petits riens, tenant la chambre dans une température ordonnée, égale; c'était le tout sous la main, sans attentes et sans courses, amour et bouillon, linges et livres. ${ }^{580}$

Amor y caldo, coladas y libros; el sonido de unas faldas rozando el viejo parqué. La opción de haber elegido a Louise para colmar ese espacio le había parecido, en principio, óptima; sobre todo porque las características de la familia de ella evitarían a nuestro héroe las molestias de las visitas demasiado inoportunas o impositivas. Siendo huérfana de padres, sin familia que visitar, silenciosa y entregada, su sueńo de quietud parecía poder cumplirse junto a la compañía de esta triste y morosa mujer:

il avait incarné son rêve de quiétude, en épousant une bonne fille sans le sou, orpheline de père et de mère, sans famille à voir, silencieuse et dévouée, pratique et probe, qui le laissait fureter, tranquille, dans ses livres, tournant autour de ses manies, les sauvegardant sans les déranger. ${ }^{581}$

Sin embargo, la misma enfermedad, de origen nervioso, que aquejaba a la esposa, trocó la esperada atmósfera de quietud tranquila y alegre en un continuo crepúsculo invernal, largo y siniestro. Louise se convierte, a partir de la aparición de su mal, en una presencia dependiente de las muestras de cariño de Jacques, rogándole con una mirada melancólica que se apiadase de su estado enfermizo, sin echarle de su lado por ello:

Louise, taciturne, inerte, souriait, pourtant, témoignant à Jacques que son affection demeurait intacte, mais implorait, en quelque sorte, d'un oeil hésitant et câlin, pareil à celui d'une chatte couchée sur des habits, qu'on la laissât là, sans la chasser, sans la forcer à chercher une autre place. ${ }^{582}$

El sueño, pues, de quietud y armonía que esperaba encontrar al lado de Louise se disipa en el principio de realidad. No puede evitar Jacques imaginar cómo habría sido su vida de casado al lado de una mujer diferente, ahorradora y robusta. Empieza a lamentar haber unido su suerte al infortunio de esa joven silenciosa y enferma. «Ah! S'il était seul, comme sa vie s'arrangerait mieux! Si c'était à refaire, comme il ne se marierait plus!» — se dice a sí mismo. Aun a pesar de esto, y sabedor de la doble necesidad

$\begin{array}{ll}580 & \text { Ib., p. } 121 . \\ 581 & \text { Ib., p. } 121 . \\ 582 & \text { Ib., p. } 121 .\end{array}$ 
que tiene de la compañía de la mujer, Jacques imagina su vida al lado de esa mujer fuerte, con instinto de ahorro, que hubiese sido sirvienta de un cura y que, por ello, no hubiera sido demasiado exigente en las cuestiones de sexo —no demasiado, aunque el ayuno erótico al que les sometía su Louise fuera de naturaleza a hacerle sufrir más de una crisis. Una vaca potente y tranquila, como buscaba el André de En ménage.

Il pourrait peut-être découvrir une femme, râblée, solide, experte à diriger un ménage, une femme qui fût une servante de curé et avec cela une maîtresse qui n'imposât pas à son amant de trop longs jeûnes! eh oui! il en souffrait à la fin des fins de cette abstinence de la chair que le maladie de sa femme lui faisait subir! ${ }^{583}$

Pero, para que ello se produjera, antes debía imaginar la desparición de Louise. "A supposer, en effet, que Louise mourût, une fois le chagrin tari..." - se comenta con cínica impostura, a lo que debe reaccionar de manera violenta contra sí mismo: «il demeura ébahi de ce fuliminate d'ordures qui éclatait soudain en lui, car il aimait sicèrement sa femme et il eût donné tout ce qu’il possédait pour la guérir». ${ }^{584}$

Sea como sea, la experiencia aunque fuera literaria del matrimonio no satisface para nada a nuestro autor. Como sostenemos, el ejercicio de las letras sirve a Huysmans como hipótesis de existencia. Al proponerse a sí mismo como cobaya de sus propias inquietudes, no hace sino vivir de manera fantasmática esa posibilidad ficticia de existencia. En el caso de En rade, esta experiencia no puede sino ser negativa desde todos los puntos de vista. No solo la convivencia no había permitido que ambos cónyuges se conocieran mutua y profundamente; y es justo que se lo confiese Jacques, esto se debe precisamente a su egoísmo:

il comprenait que, depuis trois ans qu'ils s'étaient mariés, aucun des deux ne se connaissait.

Lui, parce que, malgré ses recherches, il n'avait pas eu l'occasion de sonder sa femme dans un de ces moments où les tréfonds de l'âme surgissent; elle, parce que'elle n'avait jamais eu besoin, dans le placide milieu d'une ville, d'un défenseur. ${ }^{585}$

$\begin{array}{ll}583 & \text { Ib., p. } 125 . \\ 584 & \text { Ib., p. } 125 . \\ 585 & \text { Ib., p. } 166 .\end{array}$


Sino que también había iniciado cada uno de los dos al odio y a la denigración del otro. Jacques se siente finalmente estafado, con su libido obligatoriamente acallada por la fidelidad definitoria del matrimonio, sin que por ello encontrase ninguna compensación. Louise se convierte, por todo ello, en una rémora, en un lastre a las aspiraciones del artista huysmansiano. Cómo cantar las alabanzas de la vida en pareja cuando se es tan estricto sobre la función de la esposa-amante: «avec Louise, malade et lasse, inquiète et froide, aucun désir n'était plus possible; la tare originelle de la femme restait seule, sans compensation d'aucune sortem. ${ }^{566}$ Tras estos experimentos de vida en común, el matrimonio o su equivalente funcional se revela como una dudosa solución a la soledad fantasmática que el heterónimo huysmansiano encuentra en el hogar. Ya sea la exigencia sexual, ya su incapacidad de entretenerle con cosas interesantes, la función que se espera cumpla la compañera del artista esteta, soltero vocacional, debería ser cumplida teniendo en cuenta exclusivamente las necesidades del hombre. De allí que la solución que toma finalmente el personaje huysmansiano sea la de hacerse con una sirvienta que se ocupe de esas pequeñas cosas, de esos detalles insignificantes de los que la pretendida y soberbia grandeza de la obra del artista no puede ocuparse so pena de incurrir en bajeza.

\subsubsection{Soltería y restaurantes}

Por eso las criadas toman tanta importancia en la vida del soltero vocacional, así como los pequeños restaurantes de barrio. El ejemplo más importante de esto es todo el relato de $\grave{A}$ vau-l'eau, en el que Jean Folantin busca desesperadamente solución a sus problemas de intendencia. Sus escasos ingresos económicos le llevan a frecuentar una serie de restaurantes a cual más infecto, con la esperanza siempre viva de encontrar por fin un lugar limpio y tranquilo, donde la comida no sea demasiado asquerosa y la compañía demasiado impositiva. El resultado es, ya lo sabemos, negativo. Presa del spleen y del pesimismo de raigambre schopenhaueriana, Folantin se deja llevar por el camino de la amargura.

En Croquis parisiens, esta obsesión por la búsqueda del restaurante ya no bueno, simplemente decente, se plantea de manera clara. Como en una

586 Ib., p. 211. 
teorización al respecto, el titulado «Poème en prose des viandes cuites au four» dibuja la situación del soltero vocacional a la caza de su cantina ideal: no demasiado cara, no demasiado sucia. Una vez encontrado este lugar ideal, hay que explotarlo hasta que el asco vuelva a instalarse de nuevo en la conciencia del cliente. En ese lapso, el soltero buscará la rutina del hogar en el restaurante: siempre la misma mesa — que a veces aparece ocupada por un desconocido - , la servilleta manchada de vino colgada en una clavija de la pared, el intercambio acostumbrado de frases sin importancia con vecinos de mesa o con el personal, y la misma carta en cuya lectura se enfrasca.

Le célibataire cherche la table où il se place d'habitude dans sa gargote coutumière et il souffre de la voir occupée déjà. Il retire du casier pendu au mur sa serviette tachée de vin, et, après avoir échangé des propos sans intérêt avec les clients voisins, il parcourt l'invariable carte et s'assied, morose, devant le potage que le garçon apporte, en y lavant, tous les soirs, un pouce. ${ }^{587}$

Qué feo detalle el del camarero que, indefectiblemente, noche tras noche, mete su dedo en la sopa. Y qué impotencia tener que verlo y aguantar sin decir absolutamente nada. La vuelta al triste piso de soltero tras la ingesta de tan poco suculento menú no puede ser sino deprimente. Qué no daría Folantin por contar con una compañía que le hubiera calentado la casa. Durtal cuenta con la colaboración de su conserje, quien le hace la cama y le limpia el polvo de los muebles, manteniendo viva la brasa para que, a su vuelta del restaurante, el fuego se recomponga de manera rápida.

El mayor éxito en el sueño de quietud y bienestar doméstico en la obra huysmansiana se realiza en la persona de des Esseintes: un individuo con las mismas exigencias que Folantin pero con unos ingresos económicos que le permiten cumplir sus aspiraciones de tranquilidad. Des Esseintes posee fortuna familiar, lo que le permite hacerse con una mansión apartada y con personal doméstico completamente entregado a su bienestar. En Fontenayaux-Roses, des Esseintes encuentra su «thébaïde raffinée, à un désert confortable, à une arche immobile et tiède où il se réfugierait loin de l'incessant déluge de la sottise humaine». ${ }^{58}$ Un lugar cerrado a las intrusiones y en el que la personalidad egoísta, solipsista y autosuficiente puede recrearse a sus

587 J.-K. Huysmans, Croquis parisiens, ob. cit., p. 113. Se trata del croquis «Le Poème en prose des viandes cuites au four", dentro del apartado "Fantaisies et petits coins».

588 J.-K. Huysmans, À rebours, ob. cit., p. 65. 
anchas. No en vano, Seul era el título que en principio Huysmans había pensado en dar a esta obra — según revela en su amplia biografía Robert Baldick. ${ }^{589}$

La cuestión de las comidas para des Esseintes era más motivo de preocupación que de placer, como para Folantin. Aun poseyendo los medios económicos para procurarse las mejores y más equilibradas combinaciones de platos, des Esseintes, quien se vería aquejado de una terrible dispepsia que le imposibilitaba toda ingesta placentera, prefiere ordenar sus hábitos alimenticios con regularidad británica.

[Ses repas] étaient d'ailleurs peu compliqués et très succints, les défaillances de son estomac ne lui permettant plus d'absorber des mets variés ou lourds.

A cinq heures, l'hiver, après la chute du jour, il déjeunait légèrement de deux oeufs à la coque, de rôtis et de thé; puis il dînait vers les onze heures [...] picorait une petite dînette, sur les cinq heures du matin, avant de se mettre au lit.

Il prenait ces repas, dont l'ordonnance et le menu étaient, une fois pour toutes, fixés à chaque commencement de saison. ${ }^{590}$

Podemos decir que el problema de la comida se resuelve, de esta manera, mediante el orden y la disciplina. Des Esseintes no deja de ser un inadaptado por voluntad de significación. Su ansia de separación, de enclaustramiento, no puede llevarle sino al spleen y a la neurosis. El resultado le atrae la visita del médico, quien le prescribe una dieta basada en aceite de hígado de bacalao, té de buey, vino de Borgoña y yema de huevo, en unas cantidades indicadas por él mismo. Sin embargo, el ánimo transgresor del noble excéntrico le empuja a variar las cantidades como si se tratara de un "faux gourmet», ${ }^{591}$ con el objeto de que la monotonía de los sabores no le condujera a la más terrible de las inapetencias. Una vez conseguido esto, des Esseintes parece que se encamina hacia su restablecimiento; sin embargo, su médico considera que eso no es sino el primer paso para la curación: necesitará seguir estrictos regímenes durante largo tiempo, al tiempo que se somete a curas hidroterápicas, para que la neurosis sea atajada debidamente. Como ya indicaba el poeta medieval Villon, «la danse vient de la panse»; des

589 R. Baldick, ob. cit., p. 105.

590 J.-K. Huysmans, À rebours, ob. cit., p. 77.

591 Ib., p. 231. 
Esseintes precisa tanto de mejorar sus hábitos estomacales como de procurarse momentos de júbilo normales y corrientes: «rentrer à la vie commune, tâcher enfin de se distraire comme les autres», ${ }^{592}$ según le dice su facultativo. Sin embargo, no todo son sinsabores en la limitada vida gastronómica de des Esseintes. En uno de los más prodigiosos pasajes que la literatura de viajes haya producido, este noble excéntrico se detiene en una taberna inglesa en pleno centro de París: etapa obligada en su viaje a Londres. Para entrar en materia y aclimatarse a la vida inglesa, des Esseintes se pega un verdadero atracón de platos de raigambre británica: potaje de rabo de buey, bacalao ahumado, un rosbif con patatas, dos pintas de ale, queso Stilton, una tarta de ruibarbo, y una cerveza porter. Copioso menú que debiera dejar en incómodo estado a quien, aquejado de problemas estomacales como des Esseintes, se atreviera con él. Sin embargo, antes que el malestar de una pesada digestión, es el bienestar que se apodera de nuestro héroe viajero. "Con los sentidos aplacados» — como diría un siglo más tarde Francisco Brines—, el viaje se completa, la sensación de desplazamiento se ha realizado verazmente. Felicidad del restaurante que ha sabido despertar de su letargo a un estómago aquejado de inapetencia severa.

\subsubsection{Importancia de la bonne}

Dentro de la dinámica que lleva la asunción de la soltería como modo de vida independiente, sin las molestias de diversa índole que conlleva la convivencia con una compañera sentimental (o no), el personal doméstico reviste la mayor importancia en el proyecto de soltería vocacional del héroe huysmansiano. Intentemos cernir con rigor la presencia de la bonne en la obra de nuestro autor.

La aparición del soltero comienza en En ménage, donde, como ya hemos observado, André Jayant requiere los servicios de una criada que se ocupe de esos pequeños y nimios asuntos del hogar: «ces terribles détails de la vie qui brisent les plus fiers [...] ces ineptes bêtises qu'une femme conjure en deux tours d'aiguille», como queda enunciado en Marthe, histoire d'une fille. ${ }^{593} \mathrm{La}$ criada es un personaje esencial en la vida del soltero vocacional, pues sin ella

592 Ib., p. 233.

593 J.-K. Huysmans, Marthe, histoire d'une fille, ob. cit., p. 94. 
la aventura del celibato sería, simplemente, inabordable para este inútil espécimen del género masculino. La salvadora de su vida de soltero en En ménage es Mélanie, quien «menait la maison sans qu'il eût à s'occuper, ni du blanchissage, ni de toutes ces harcelantes et menues sottises qui dégoûtent du célibat les plus opiniâtres et les plus braves». ${ }^{594}$ Mélanie proporcionará a André la paz necesaria para que si vida transcurra apaciblemente en el seno del hogar:

isolé des relations ennuyeuses et des corvées du monde, allégé des tracas du ménage, savourant la paix d'un homme constamment déboutonné et en pantoufles, il rappela peu à peu ses manies de garçon, s'épanouit dans un bonheur de sans-gêne et de bonne chère; il se trouva, en un mot, parfaitement heureux. ${ }^{595}$

Es precisamente gracias a su ayuda que el proyecto de la vida de garçon se hace factible.

A la criada, a pesar de la importancia que se le da en el imaginario ficcional huysmansiano, hay que vigilarla sin vergüenza, pues su propia condición de servidora le empujará, sin duda, al pequeño hurto. Así se produce en dos casos en la novelística huysmansiana: las criadas del matrimonio André-Berthe fueron ávidas, y cuando la señora de la casa bajaba la guardia, se envalentonaban y arramblaban con todo: «ses bonnes s'enhardirent, la pillèrent sans modération». ${ }^{596}$ Más adelante en la obra, cuando André intenta vivir en común con Jeanne, su antigua amante, la criada puede plantear más de un problema de indiscreción y, sobre todo, de competencia con la costurera. Los amantes hacen que Mélanie les sirva en la cama, después de haber pasado una dulce noche de amor. Las miradas entre la costurera y la criada parecen echar rayos y chispas. Jeanne, sin embargo, no puede evitar sentirse a disgusto al verse servida como una dama por una mujer del pueblo. Considera una humillación que ella, mujer impura y sin acomodo sentimental, se haga servir por alguien de su misma condición:

[Jeanne] souffrait presque de se voir, elle, une femme du peuple, ayant eu des amants, servie comme une dame, par une femme du peuple honnête et elle était malheureuse et presque révoltée, de même que si elle avait vu commettre une injustice ou infliger à quelqu'un devant elle une humiliation. ${ }^{597}$

\footnotetext{
594 J.-K. Huysmans, En ménage, ob. cit., p. 128.

595 Ib., p. 155.

596 Ib., p. 108.

597 Ib., p. 260.
} 
Sea como fuere, la necesidad del soltero vocacional por la criada revela no solo una necesidad práctica, sino fantasmática: el solitario encerrado en su puerto de paz y trabajo requiere no solo que alguien le haga la comida y le limpie la casa, sino que su presencia se haga sentir tímidamente. Solo así se conseguirá colmar ese vacío dejado por la madre en el imaginario del niño. ${ }^{598} \mathrm{Y}$ aunque esta instrumentalización de la presencia femenina fuera recriminable desde una perspectiva igualitaria, el feminismo parece consagrar esta ética del cuidado como algo bueno e inherente a las labores tradicionalmente ocupadas por las mujeres. Lo cierto es que, aun pudiendo abandonarlas, la mayoría de las mujeres que trabajan no renuncian a las obligaciones del cuidado de los demás "¿Por qué? — se pregunta Victoria Camps-: No solo porque si ellas no lo hacen no lo hace nadie, sino porque son tareas valiosas». .99

Mucho antes de que fuera esbozada la ética del cuidado como una vocación ineludible de la condición femenina, ${ }^{600}$ las sufragistas de comienzos del siglo XX pretendían la exclusividad de estas tareas del hogar para las mujeres. Así, en 1902, Linda Hull, presidenta de la American Home Association, decía: «afortunadamente, en el mundo que nos rodea hay unas cuantas personas razonables y progresistas, que creen tan firmemente como nosotros que las labores de la casa son la vocación más natural y, por tanto, la más deseable para las mujeres». ${ }^{601}$ Mensajes como este llevan a ciertas feministas de reciente cuño a afirmar que la ciencia de la economía doméstica es reivindicable dentro de un orden dado, y que su práctica — aun impuesta por la división del trabajo patriarcal— no debe ser desdeñada por las mujeres que aspiran a la construcción de una sociedad más justa y cuidadosa del prójimo. En esta perspectiva se sitúa Nuria Solsona al aceptar y considerar como positiva una de las consecuencias del sexismo. «El sexismo

598 Vid. el interesante apartado dedicado a las «Personas de servicio», en M. Perrot, «Figuras y funciones», en P. Ariès y G. Duby (eds.), ob. cit., pp. 184-191.

599 V. Camps, ob. cit., p. 19.

600 Es curioso que forme parte de las reivindicaciones incluso de los sectores más radicales de los movimientos ciudadanos. Vid., en este sentido, la aportación de S. del Río, "Globalización y feminismo», en A. Morán (coord.), El movimiento antiglobalización en su laberinto, CAES-La Catarata, Madrid, 2003.

601 N. Solsona i Pairo, El saber cientifico de las mujeres, Talasa, colección Ágora, Madrid, 2003, p. 30. 
— dice, Solsona - resulta favorecedor para algunas chicas que desde pequeñas aprenden a ser autónomas, ya que saben cuidarse a sí mismas y aprenden a cuidar a los demás». ${ }^{602}$

¿Cabría por ello acusar a Huysmans de proporcionar empleo a las mujeres con un marcado sesgo sexista? Tal vez Solsona diría que no. Yo afirmo que el egoísmo de nuestro autor no es defendible desde el momento que instrumentaliza a la mujer como proveedora de cuidados que solo los miembros de su género saben prodigar.

Aun instrumentalizada y reificada, completamente sustituible por otra profesional del cuidado que la superara en excelencia laboral, la bonne tiene una importancia no solo - ya lo hemos dicho- práctica. Otros personajes que cumplen funciones domésticas aparecen en La Cathédrale, obra de 1989. Recordemos que la primera criada de Durtal desplazado a su nuevo domicilio en Chartres, Mme. Mesurat, es una mujer que se le antoja insoportable al escritor. Entregada y con un celo profesional que rayaba el exceso, Durtal se ve obligado a fingir ensimismamiento en la lectura de un libro para evitar toda conversación con ella:

elle était imposante et dévouée, insupportable. Durtal se crispait, se retenait à quatre pour ne pas la renvoyer dans sa cuisine, finissait par se plonger le nez dans un livre, pour ne pas lui répondre, pour ne pas la voir. ${ }^{603}$

Fea, incómoda de ver, su complexión fuerte la asemeja a ojos de Durtal a un hombre - de quien le diferencia tan solo la vestimenta. Hasta tal punto se obsesiona que tiene una pesadilla con ella: su inconsciente se la propone como sustitución de la reina de Saba; «et sa laideur désole Durtal qui s'emporte contre les chanoines auxquels il demande en vain d'ôter sa femme de ménage et de ramener la reine». ${ }^{604}$

La llegada de Mme. Bavoil es, desde luego, providencial. Se trata de quien fuera la gobernanta del consejero religioso de Huysmans en París, el abbé Gévresin, quien le propuso que fuera a Chartres, y luego a la Val des Saints, en Ligugé (donde se desarrolla la acción de L'Oblat), «en qualité de

602 Ib., p. 133.

603 J.-K. Huysmans, La Cathédrale, Plon-Le Livre de Poche, París, 1964, p. 109.

604 Ib., p. 341. 
gouvernante et d'amie». ${ }^{605} \mathrm{La}$ conexión con Durtal es perfecta desde el principio, quien ve en ella una mezcla de altivez y humildad de alma; su sentido de la entrega y del deber es admirable, pues no solo se ocupa de su maître, sino que también cumple con todos los ritos del culto:

levée dès l'aube, après s'être approchée du Sacrément, elle savonne et blanchit elle-même le linge, fabrique les draps et les chemises, racommode les soutanes, vit avec une économie incroyable, tout en veillant à ce que son maitre ne manque de rien. ${ }^{606}$

Su celo religioso puede antojársele a Durtal un tanto excesivo, pues pretende la seńora Bavoil mantener relaciones (¿de qué tipo?) con Jesucristo, la Virgen y los ángeles del cielo. Ante esto, su confesor coyuntural le acusaba de estar poseída por el demonio. ${ }^{607}$ Este aspecto, el de las relaciones tal vez eróticas con el más allá — que podrían ser sencillamente una satisfacción de la libido de clave onírica - tiene su importancia en la construcción del personaje. Significa esto que Mme. Bavoil no está desprovista de una sexualidad latente, con el peligro que eso supone para la relación «incestuosa» de Durtal con la persona que le lava la ropa, le zurce los calcetines y, en definitiva, puebla la casa de sus movimientos.

Esta posibilidad es rápida y continuamente contrarrestada por el narrador, gracias a las cualidades de amor casto y puro de que dota a la gobernanta. Ocurre a veces a Durtal de quedarse extasiado ante la contemplación del rostro pacífico y franco de Bavoil: una calma mezclada de una actividad interior - fuego que ardía en el interior de sus pupilas negras:

elle haussait les épaules et il y avait un tel calme sur ce visage et un tel feu couvait sous l'eau noire de ses yeux que Durtal demeurait devant elle saisi, admirant la franchise, la pureté de cette âme qui s'avançait jusqu'au bord des paupières, qui sortait par ce regard. ${ }^{608}$

Incluso, a medida que envejece, Bavoil no pierde nada de ese fuego interior, lumbre del amor puro y casto, ese «je ne sais quoi qui l'exhaussait

605 J.-K. Huysmans, L'Oblat, ob. cit., p. 34.

606 J.-K. Huysmans, La Cathédrale, ob. cit., p. 49.

607 Ib., p. 48.

608 Ib., p. 409. 
quand l'âme, phosporée par les prières, prenait feu». ${ }^{609}$ Un fuego de santidad que, por fin lo sugerimos, acerca a la bonne de la santificación necesaria para evitar el incesto con la madre ansiada y esperada. El espacio vacío que deja la progenitora es llenado en la obra literaria: ejercicio de aprehensión, de práctica de sí mismo, a través del cual el escritor intenta comprenderse y, sobre todo, construirse — como señala Pierre Richard. ${ }^{610}$

Bavoil va adquiriendo la importancia creciente de una instancia materna que le prodiga los cuidados que el niño expósito siempre echaría de menos. Felicidad completa del infante que se sabe cuidado, que está convencido de que una persona poderosa y voluntariosa se ocupa de él sin apenas exigir nada a cambio. La madre que, tras darse en cuerpo y alma al cuidado y educación del niño, lo despide con un beso como imponiéndole su bendición materna. Así, cuando Durtal debe dejar Chartres para dirigirse a Solesmes — casi al final de La Cathédrale_, la gobernanta le besa afectuosamente, «maternellement», subraya Huysmans. ${ }^{611}$ ¿Y cómo no ver en estas últimas líneas de la novela la nostalgia del núcleo familiar primigenio, cuando Bavoil comenta a l'abbé Gévresin que Durtal es un poco como su hijo de ellos dos: «j'aurai bien gros cœur s'il quitte pour jamais notre ville, car il est un peu notre enfant, cet ami-là». ${ }^{612}$

Cuando vuelven a encontrarse, ya muerto el abbé Gévresin, Bavoil pasa al servicio exclusivo de Durtal, llamándole «hijo pródigo». ${ }^{613}$ Más todavía, con toda la importancia que da Durtal a su oblación, su conversión definitiva en un miembro interesado (puesto que eximido de cumplir los votos eclesiáticos), justo después de la ceremonia, la preocupación que asalta al recién oblado es la de avisar a su gobernanta de que ese mediodía comería en el monasterio:

une idée surgit, renvoyant Dieu, l'oblature, toutes les autres réfléxions dans les ténèbres de la mémoire, s'implantant, saillant, seule, en pleine lumière, l'idée qu'il avait oublié d'avertir la mère Bavoil qu'il déjeunait, à midi, au monastère. ${ }^{614}$

609 J.-K. Huysmans, L'Oblat, ob. cit., p. 54.

610 En J. P. Richard, Littérature et sensation, Seuil, París, 1954, p. 15.

611 J.-K. Huysmans, La Cathédrale, ob. cit., p. 488.

612 Ib., p. 489.

613 J.-K. Huysmans, L'Oblat, ob. cit., p. 56.

614 Ib., p. 258. 
¿Cómo no ver la importancia del papel de Bavoil en la reconstrucción del hogar perdido en el imaginario del escritor? Son estas últimas pruebas definitivas de que la bonne no es únicamente la proveedora de cuidados prácticos al soltero vocacional: ella es la sustitución más o menos dichosa de la instancia materna. Y aunque en francés sea habitual llamar a las personas mayores père o mère, creemos sustantivo que Huysmans, según revela su gran biógrafo Robert Baldick, llamara a una de sus gobernantas maman Thibault. ${ }^{615}$

En la bonne reside la consecución perfecta de las aspiraciones del niño expósito a la castidad: le brinda cuidados pero sin que por ello el deseo erótico arrebate a la criada su condición de madre carente de libido. Con ello, el inconsciente del niño consigue ahuyentar la amenaza de la castración que subyace en toda relación fantasmática con el otro sexo.

Esta sublimación del erotismo materno se verá maximizada en la adoración de Durtal —el último y definitivo heterónimo ficcional de Huysmans - por la Virgen María. Debemos, empero, volver al análisis de la sexualidad de nuestro autor para seguir el hilo argumental y expositivo que nos habíamos marcado.

\subsubsection{La convicción del fracaso en la práctica sexual}

Una de las principales novedades de la obra de Huysmans en materia sexual es la presentación de la actividad sexual como una obligación para nada satisfactoria. Mientras la mayor parte de la literatura de su tiempo exponía la sexualidad como una práctica placentera y que contribuía a la liberación del individuo, la sexualidad del heterónimo huysmansiano es realmente pobre y no por escasa, sino en la calificación de sus resultados.

La sensación que este heterónimo extraerá de la experiencia sexual será, mayormente, de fracaso, de tiempo perdido ante dicha práctica. La sexualidad masculina, de naturaleza preferentemente egoísta — pues su satisfacción pasa tradicionalmente por la instrumentalización del objeto de deseose basa en el orgasmo. En su orgasmo, puesto que la tradición patriarcal recomendaba que el placer femenino fuera relegado a su mínima expresión.

615 R. Baldick, ob. cit., p. 200. 
Los teóricos de la época veían en la libido femenina un peligro para la estabilidad familiar - lo que se desprende de sus consideraciones sobre el orgasmo de la mujer. ${ }^{616}$

Lo que nos va a interesar en las líneas que siguen es el análisis del placer que el heterónimo ficcional huysmansiano experimenta en la práctica de su sexualidad. Como ya hemos apuntado anteriormente, el placer masculino, centrado casi exclusivamente en el orgasmo, puede aparecer a algunos hombres como una experiencia de corto alcance. Bruckner y Finkielkraut, teorizando sobre la sexualidad del hombre en su interesante ensayo El nuevo desorden amoroso, vienen a decir que la práctica sexual ha de ser por fuerza decepcionante para el hombre: «la decepción es el resultado mismo del goce masculino peniano; el hombre goza para desilusionarse, gozando sabe que quedará decepcionado y acaba por convertir esta decepción en el único móvil de su goce». ${ }^{617}$

En al ámbito estrictamente literario, cabe señalar también la consideración que merece a Stendhal la consecución del acto amoroso. Así, en su Vie de Henry Brulard, el héroe exclama: «quoi le passage du Saint-Bernard, n'est-ce que ça?». Asimismo, y esta vez en Le Rouge et le noir, Julien profiere un desolador «Mon Dieu, être heureux, être aimé, n'est-ce que ça?» al salir de la habitación de Mme. de Renal. Por último, Lamiel expresa su decepción del acto amoroso entre risas al darse cuenta de la triste realidad: "Comment, ce fameux amour, ce n'est que ça?». Ejemplos todos estos de la decepción masculina ante la reacción fisiológica del coito y su impresión en el intelecto masculino. ${ }^{618}$

Intentemos indagar en esta decepción masculina aunque sea someramente. El orgasmo masculino, completado mediante la eyaculación, es minúsculo. Su propia consecución desencadena el término obligatorio

616 «De cada diez mujeres, a nueve les desagrada el acto sexual, y la que hace el número diez es una prostituta», decía un médico inglés. Por otra parte, la británica Enciclopedia Ree afirma: «es innegable que a veces se forma un fluido mucoso en los órganos internos y en la vagina durante el coito, pero esto solo ocurre a las mujeres lascivas o que llevan una vida lujuriosa». Ambas citas en E. Bornay, ob. cit., pp. 82 y 61, respectivamente.

617 P. Bruckner y A. Finkielkraut, ob. cit., p. 40.

618 Aunque, según Gilbert Durand, el amor para los héroes de Stendhal tiene más de hazaña que de otra cosa. En G. Durand, ob. cit., p. 90 y ss. En relación con el fiasco amoroso stendhaliano, el autor lo comenta en otro pasaje de su obra: p. 113 y ss. 
del placer, al que va unido el fin de la erección — que en caso contrario podría permitir la llegada de nuevos orgasmos penianos. «El hombre sólo goza para dejar de gozar, su voluptuosidad es una guillotina; cuando su deseo culmina es que ya ha desaparecido" — señalan de nuevo estos dos pensadores franceses. ${ }^{619} \mathrm{La}$ magra calidad del placer masculino en la práctica convencional del sexo, unida a la imposibilidad de su continuación obligan al hombre a considerar su experiencia como excluida del goce. Por ello mismo, el hombre debe paliar su insatisfacción con toda clase de técnicas complementarias que le ayuden a pensar el sexo como placer. En esas técnicas paliativas y complementarias podríamos recoger el ansia de dominación e incluso de sadismo que acompañan muchas actuaciones sexuales masculinas. Y también la consideración del placer femenino como un peligro; un placer que, eventualmente, el hombre puede desencadenar con sus caricias. Sin embargo, ese orgasmo femenino, que revoluciona la totalidad del cuerpo de la mujer y lo convierte en una verdadera experiencia telúrica, rara vez devuelve al hombre bajo forma de recompensa, regalo u otro el placer alcanzado. Ella permanece «indómita, salvaje, ajena a toda apropiación» — como dicen Bruckner y Finkielkraut; de ahí el temor que despiertan en el hombre las desmedidas capacidades eróticas de la mujer. ${ }^{620}$

En la obra de Huysmans, el placer no provoca sino una profunda decepción, ya sea por la corta dimensión de su experimentación para el hombre, ya sea por la incapacidad en que este se ve de procurar placer a sus amantes. Ese orgasmo, esa sacudida breve y aburrida de la carne, no hace sino depositar en una constante decepción al amante huysmansiano. Y ello aunque sea en el cuerpo de una mujer, en quien proyecta sus propias obsesiones y frustraciones.

Así comenta el narrador de Les Scurs Vatard la primera experiencia sexual de Céline. En discurso indirecto libre, Huysmans pone en boca de la obrera el desengaño ante una operación carnal que tantas voluntades mueve y que tan alabada es por todos sus practicantes:

619 P. Bruckner y A. Finkielkraut, ob. cit., p. 23.

620 Vid. el caso de Tiresias ya señalado en el apartado 2.4.3. 
alors c'était pour cela, c'était pour ces tâtonnements et pour ces douleurs, c'était pour cette trépidation d'une minute, pour ce cri arraché dans une secousse, qu'elles pleuraient et se laissaient caresser l'échine par les plus trapus des hercules brocheurs. $^{621}$

La experiencia sexual de André Jayant, el héroe de En ménage, es todavía más decepcionante. No olvidemos que André es el primero de los solteros vocacionales de la obra de Huysmans, por lo que su matrimonio con Berthe no puede ser sino el cumplimiento de una obligación. Sin embargo, cómo no esperar, en el caso de un hombre en plenas facultades mentales y físicas, un treintañero experimentado, que la compañía de una bella mujer durante la noche le atrajera los más sabrosos placeres. André, sin embargo, no ve en esa compañía nocturna más que molestias: las molestias que acarrea una obligación que se contrae no por convicción personal sino social.

La misma rutina de la compañía nocturna en el lecho conyugal desencadena un desengaño tedioso. La práctica sexual ya no tiene para André nada de placentero, sino que reviste los colores de lo conocido, de lo previsto. Escuchémosle: «la misère d'un coucher à deux, l'insomnie ou le ronflement d'un autre, les coups de coude et les coups de pied, la fatigue des caresses exigées, l'ennui des baiser prévus!». ${ }^{622}$

Nada de amor, ninguna ternura experimentada por nuestro héroe. Y, de la misma manera que André contempla su experiencia sexual conyugal con atormentados ojos, considera triste y penosa la de su desafortunada esposa. Y decimos desafortunada porque André tiene la profunda convicción de que Berthe no accede al paraíso del placer erótico en sus brazos. El fracaso se abre como un abismo frustrante ante la experiencia conyugal de Berthe:

le mariage fut célébré. Elle demeura interdite. Tous ses rêves de jeune fille se détachèrent, un à un; toutes les joies révélées par des amies, à voix basse, dans le coin des fenêtres, toutes les attentes du paradis brusquement ouvert sous des courtines ratèrent. Froide de sens, elle ne vit dans les transports autorisés par l'Église qu’une convention répugnante, une saleté pénible. ${ }^{623}$

621 J.-K. Huysmans, Les Søurs Vatard, ob. cit., p. 184.

622 J.-K. Huysmans, En ménage, ob. cit., p. 27.

623 Ib., p. 99. 
Una convención repugnante, una suciedad penosa. Al fin y al cabo, ¿no se trata aquí de la misma convicción expresada por André? El sexo se revela como una obligación impuesta por el sentido burgués de la unión de un hombre y una mujer; la heterosexualidad obligatoria y la reducción de la libido femenina a la masculina son los corolarios de esta imposición reproductiva que se opera sobre los amantes.

Sigamos con la visión que del placer pone Huysmans en la desencantada Berthe. Lejos de experimentar placer en la realidad del acto, Berthe entrevé su posibilidad en el intercambio de intimidades con sus amigas y confidentes. Es precisamente el poder de lo sugerido, el misterio de lo no dicho, lo que abre a Berthe la imaginación a un mundo sensual que ella desconoce en compañía de su marido.

Elle n'éprouvait réellement du plaisir que dans la compagnie de quelques camarades, jeunes mariées comme elle [...] Leurs yeux à elles toutes étincelaient lorsque insensiblement la conversation s'arrêtait aux intimités haletantes des nuits. Il y a avait des temps d'arrêt, des petits silences coupés par des chuchotements derrière les doigts, des invites à parler plus haut, des exclamations pudibondes et envieuses, des éclats frissonnants de rire. Berthe demeurait silencieuse, se demandant de quelle chair elle était pétrie, comment ses nerfs pouvaient rester détendus, comment ses élans n’aboutissaient pas. ${ }^{624}$

La confesión debía sobrevenir a esta convicción: sus aspiraciones a una cierta dicha carnal no se cumplen. La culpa se arroja sobre el hombre — quien detenta la llave, tradicionalmente, del placer femenino, puesto que la libido es patrimonio exclusivo suyo. La acusación cae como una lápida en el imaginario del narrador — quien comparte con André convicciones y averiguaciones: "Berthe arrivait à se convaincre que si elle avait épousé un autre homme, il n'en eût certainement pas été ainsi». ${ }^{625}$

La incapacidad cuelga como un sambenito de la reputación que André se atribuye a sí mismo. Es él quien desencadena la tristeza en el matrimonio por su propia falta de maestría en el asunto. El sexo practicado con exigencia será, a partir de esta convicción, un doloroso ejercicio de puesta a prueba de la propia excelencia, de la propia virilidad. Este no deja de ser un ejemplo de la habitual frustración masculina ante la convicción de fracaso

624 Ib., p. 109.

625 Ib., p. 110. 
que arroja su práctica sexual: decepción del placer que él alcanza; decepción por ser incapaz de procurarle placer a su pareja. La experiencia sexual masculina es un calvario de frustraciones. ${ }^{626}$

El fustigamiento a que se somete el heterónimo huysmansiano se extiende hasta la exigencia que el hombre aporte al matrimonio un cierto bienestar económico. El intercambio se opera a nivel de la dote, que se supone es la aportación de la esposa a la economía de la pareja.

En el caso de la desencantada pareja formada por Jacques y Louise en En rade, las mutuas aportaciones que ambos hacen al matrimonio son motivo de escarnio por parte de Jacques - cuya voz, como ocurre en casi toda la novelística huysmansiana, se confunde con la del narrador. Louise parece convencida de que su dote, sin ser económica, es de naturaleza carnal: "quoiqu'elle ne fût ni éprise d'elle-même, ni assottie par l'orgueil, elle pensait forcément, ainsi que toutes les femmes, que la possession de son corps était un inestimable don». ${ }^{627}$ Inestimable don que Jacques se permite de poner en duda, puesto que la enfermedad de su esposa le impide la satisfacción de sus instintos sexuales: «avec Louise, malade et lasse, inquiète et froide, aucun désir n'était plus possible; la tare originelle de la femme restait seule, sans compensation d'aucune sorte» ${ }^{628}$ - lo cual no deja de ser una liberación para el pauperizado y desengañado amante huysmansiano. Él, empero, considera que su aportación a la pareja ha sido también de corto alcance. La convicción de que, con otro hombre, Louise habría sido más feliz, planea sobre la conciencia de Jacques:

en fin de compte, elle avait fait, en se mariant, un marché de dupe, car il l'avait frustrée; il lui avait volé par son insouciance sa vie heureuse et criminellement aggravé les transes de sa maladie par le menaçant aspect de la misère! $!^{629}$

En esta misma novela, el sexo aparece como una práctica denigratoria, que pone a la especie humana a la altura del animal. En un primer tiempo pone en escena la sexualidad de los dos parientes de Louise, los tíos An-

626 Vid. las reflexiones al respecto en G. Deleuze y F. Guattari, El Anti-Edipo. Capitalismo y esquizofrenia, Paidós Estudio, Barcelona, 1985. Y en P. Bruckner y A. Finkielkraut, ob. cit.

627 J.-K. Huysmans, En rade, ob. cit., p. 127.

628 Ib., p. 211.

629 Ib., p. 127. 
toine y Norine, como paradigma de la animalización sexual. Esta representación del sexo de los dos ancianos le hace plantearse con repugnancia sus propios instintos carnales:

il s'éprenait même d'un immense dégoût pour ces ridicules secousses qu'il ne pouvait plus s'imaginer sans qu'aussitôt l'abominable image de ces deux vieillards s'agitant sous leur bonnet de coton, et dormant à la fin, repus dans leurs ordures. ${ }^{630}$

Ridículas sacudidas de los espasmos; descanso saciado en medio de sus propios deshechos. Qué visión más descarnada de la unión de dos cuerpos que se desean y se aman. La inutilidad de la práctica sexual en cuanto al desarrollo del individuo queda de manifiesto, todavía más si cabe, en el relato del apareamiento de un toro y una vaca en la campińa de Lourps. Ni siquiera una sacudida acompaña el orgasmo, el acto reproductor, de esos dos animales; el tributo que ambos pagan a la especie es incierto — aunque en el caso de la Barrée, la vaca, la experiencia sexual sea una experiencia temible:

et ce fut tout; sans un halètement, sans un cri, sans un spasme, le taureau retomba sur ses pattes et, tiré par son câble, rentra dans l'étable, pendant que la Barrée qui n'avait éprouvé aucune secousse, qui n'avait pas même exhalé un souffle, s'allégeait de peur, regardant, effarée, comme avec des yeux bouillis, autour d'elle. ${ }^{631}$

Ninguna sacudida, sin expresión alguna de solaz ni de placer. El sexo no deja de ser, pues, un acto exento de lirismo, en el que dos pedazos de carne se frotan y se separan con violencia inútil:

en fait de lyrisme, la saillie se composait d'un amas de deux sortes de viandes qu'on battait, qu'on empilait l'une sur l'autre puis qu'on emportait, aussitôt qu'elles s'étaient touchées, en retapant dessus. ${ }^{632}$

No creemos que quepa una consideración más fría, menos apasionada, de la experiencia sexual. Aun siendo necesaria, la sacudida hormonal no proporciona gran placer al masculino huysmansiano. Sabemos por la literatura psicoanalítica que la libido no satisfecha durante la vigilia ha de serlo durante el sueño por medio de poluciones nocturnas. Otra posibilidad es

630 Ib., p. 180

631 Ib., p. 209.

632 Ib., p. 210. 
la sublimación de la libido en otro tipo de obras, que completen de manera fantasmática ese hueco creado por la libido insatisfecha.

La cuestión es que, en Huysmans, el sexo no puede sino poseer todos los ingredientes de la obligación. Y aun proporcionando al amante esa tan esperada descarga hormonal, la desilusión aguarda al cabo del acto. La pintura de los encuentros de Durtal con Mme. Chantelouve no puede ser más triste. Un poco empujado por la iniciativa demoníaca de esta mujer, otro poco obligado por su condición de hombre, Durtal se entrega al sexo con un ansia poco habitual en la literatura del siglo XIX: poco habitual por ser de tan bajo perfil.

Recordemos cómo, en Là-bas, Durtal prepara el escenario para el encuentro amoroso. Tras concretar la primera cita en el domicilio del escritor, Durtal recompone su alcoba: quita el polvo, ordena sus cachivaches, dispone una servicio de té con los consiguientes licores... Ante tamańa preparación, el miedo a la decepción del hombre experimentado en frustraciones aparece antes de que se consuma el encuentro: «ce sera un désastre sans doute; une fois repu, la désillusion est probable; eh bien, tant mieux, je serai libre, car avec ces histoires-là je ne travaille plus! ${ }^{633}$ — se dice Durtal. La aceptación de tal encuentro reviste el tono de una obligación, a la que el escritor se da con tal de acallar en él la llamada del erotismo. Sin embargo, una vez aceptado el intercambio sexual, el temor de la desilusión reaparece, sumiendo a este bisońo amante en los sudores de quien teme la muerte. Y no podía ser menos tratándose de Mme. Chantelouve: mujer satánica y fatal, que toma la iniciativa y que pone en peligro la integridad de Durtal: «maintenant qu’elle se livrait, il ne la désirait plus! la désillusion lui vint avant même qu'il ne fût assouvi et non plus après, comme de coutume. Sa détresse d'âme fut telle qu'il faillit pleurer». ${ }^{634}$

El escritor, empero, accede al intercambio, encontrando en la mujer los argumentos más válidos para denigrarla; sus transportes le parecen tremendamente ridículos e insultantes: «d'une voix changée, plus gutturale, plus basse, elle proférait des choses ignobles ou des cris bêtes qui le gênaient, des 'mon chéri', des 'mon âme', des 'non, vraiment, c'est trop'». ${ }^{635}$ Reservas

633 J.-K. Huysmans, Là-bas, ob. cit., p. 144.

634 Ib., p. 172.

635 Ib., p. 174. 
estas de la castidad de la mujer que le parecen poco creíbles a nuestro héroe. El resultado, el balance del encuentro no puede resultarle a Durtal más que decepcionante. Se pregunta entonces por qué no podrían haber sido simples amigos, simples camaradas unidos por una serie de intereses comunes. Se fustiga a sí mismo por haber aceptado la propuesta carnal de quien le atrae la desilusión:

pourquoi fallait-il qu'elle éprouvât ces rages de luxure? On aurait peut-être pu sans cela rester camarades, pécher modérément ensemble, s'aimer mieux que dans la voirie des chairs; mais non, cela n'est pas possible, conclut-il, voyant ces yeux sulfureux, cette bouche expoliatrice, terrible. ${ }^{636}$

Desde luego, Durtal no puede finalmente negarse a los avances de Mme. Chantelouve a causa de su carácter peligroso y casi masculino. Ojos sulfurosos, boca expoliadora y terrible: castradora. No dejan de ser, este encuentro y los siguientes con Hyacinthe, sino la aceptación de una sexualidad refinada, salpimentada con las especias más picantes.

\subsubsection{Soluciones al fracaso: la masturbación}

La práctica onanista podría aparecérsele, a alguien que siente la actividad sexual profundamente insatisfactoria, como una solución, aun perentoria, a la sobrecarga de libido que sufre todo individuo. Como señala el filósofo contemporáneo Peter Sloterdijk, los tiempos modernos se caracterizan por la inflación de imágenes de carácter erótico; como consecuencia de ello, se produce una tendencia a existir de manera asexuada, pues la gente se obsesiona por la imagen volviéndose estéril. ${ }^{637}$ En esa castración afectiva, la libido debe encontrar válvulas de escape por las que descargarse; de lo contrario, el individuo se vería sometido a inmensas tensiones internas, pudiendo caer en la neurosis obsesiva. Así lo señala Freud en 1908, apuntando que la no satisfacción por el canal que sea de la carga libidinal puede exteriorizarse, "por lo menos en parte, bajo la forma de un síntoma patológico». ${ }^{638}$

636 Ib., p. 195.

637 P. Sloterdijk, Essai d'intoxication volontaire, Calmann-Lévy, París, 1999, p. 100.

638 S. Freud, Las fantasías histéricas y su relación con la bisexualidad, en Obras Completas, ob. cit., tomo VII, p. 1350. 
En la obra de Huysmans planea el fantasma de la masturbación, como práctica natural en quien huye del contacto continuado con el objeto del deseo y asume como negativa el ejercicio de la sexualidad entre dos. Cómo si no hallar la satisfacción solitaria en su retiro en Fontenay-aux-Roses: en À rebours parece ser sugerido de manera casi explícita:

il goûtait pour son propre compte, dans ce languissant milieu, des allégresses, des plaisirs que rendaient extrêmes et qu'activaient, en quelque sorte, les souvenirs des maux passés, des ennuis défunts. ${ }^{639}$

Aunque en ninguna novela haya relato alguno sobre práctica masturbatoria, sí que se indica de manera no del todo explícita. Tal vez por esta contemplación embelesada del objeto sexual —imaginario o no- a Huysmans le resulte tan interesante la pintura de Gustave Moreau. La representación por parte de este pintor de odaliscas y bellas damiselas intocables - Herodías, Salomé son dos ejemplos paradigmáticos - e inaccesibles proponen a nuestro autor un estímulo, una aspiración erótica de la que solo pretenderá gozar intelectualmente.

A este respecto, y refiriéndose a la obra de Moreau, Huysmans hablará de «onanismo espiritual». Centrándose en jóvenes castas y puras, los secretos pensamientos que inspiran en el espectador de sus cuadros llaman al estupro, a la comisión de actos impuros. Así lo dice él mismo en el pasaje dedicado al pintor francés en Certains:

une impression identique surgissait de ces scènes diverses l'impression d'onanisme spirituel, répété, dans une chair chaste; l'impression d'une vierge, pourvue dans un corps d'une solennelle grâce, d'une âme épuisée, par des idées solitaires, par des pensées secrètes, d'une femme assise en elle-même, et se radotant dans de sacrementelles formules de prières obscures, d'insidieux appels aux sacrilèges et aux stupres, aux tortures et aux meurtres. ${ }^{640}$

La satisfacción que este onanista espiritual encuentra en la contemplación sin acceso táctil le es suficiente para contentar su ánimo — cuando no su cuerpo mediante la automanipulación. La aparición de una mujer real en medio de esa fantasiosa puesta en escena tendría como indeseable efecto la frigidez del espectador; o, en caso de orgasmo, qué momento desaprovechado en el altar de una adoración falsa y poco creíble al cuerpo femenino.

639 J.-K. Huysmans, À rebours, ob. cit., p. 69.

640 J.-K. Huysmans, Certains, ob. cit., p. 102. 
De esta manera se expresa nuestro autor en la misma obra, Certains, cuando se refiere a uno de sus artistas faro, Félicien Rops. La incompatibilidad entre realidad y ensoñación se da en el estímulo que sugiere la obra de este pintor a Huysmans:

si pendant cet état inquiétant de l'âme qui se suggère à elle-même et pour ellemême et pour elle seule, ces visions échauffées des sens, le hasard veut que la réalité s'en mêle, qu'une femme en chair et en os, vienne, alors l'homme, excédé de rêve, reste embarrassé, devient presque frigide, éprouve, dans tous les cas, après une pollution réelle, une désillusion, une tristesse atroces. ${ }^{641}$

De allí que, en $L \grave{a}$-bas, Durtal confiese apesadumbrado a su amigo des Hermies que solo es válida la satisfacción que aportan las mujeres con las que jamás se ha disfrutado: «la mort dans le cœur, il se dit: 'Oui, j'avais raison d'écrire qu'il n'y a de vraiment bon que les femmes que l'on n'a pas eues». ${ }^{642}$

\subsubsection{Fetichismos: mujeres fálicas y campanas}

Tal vez valdría la pena detenernos un instante a analizar el fenómeno de la masturbación desde un punto de vista científico. Desde una perspectiva psicoanalítica, el padre de esta disciplina asegura que tales medios sustitutivos de satisfacción sexual no son nada inofensivos, pues "crean una disposición a [las personas que hacen uso de ellos] numerosas formas de neurosis y psicosis que tienen por condición la regresión de la vida sexual a sus formas infantiles». ${ }^{643} \mathrm{Y}$, lo que es más, eleva el ideal sexual, en las fantasías concomitantes a la satisfacción, a perfecciones difíciles de hallar luego en la realidad.

Esta elevación del ideal sexual lleva, en última instancia, a la creación de un sustitutivo suficientemente estimulante que sea capaz de reemplazar la presencia real. Este sustitutivo recibe, en la jerga psicoanalítica, la denominación de fetiche. Según Freud, el fetiche no es sino la sustitución del pene que el niño cree existir en el cuerpo de la madre. No significa esto que el niño, después de la observación que hace en la mujer, mantenga incólume

641 Ib., p. 72.

642 J.-K. Huysmans, Là-bas, ob. cit., p. 178.

643 S. Freud, La moral sexual «cultural» y la nerviosidad moderna, ob. cit., p. 1259 
su creencia del falo femenino. Sin embargo, «en el mundo de la realidad psíquica la mujer conserva, en efecto, un pene, a pesar de todo, pero este pene ya no es el mismo que era antes. Otra cosa ha venido a ocupar su plaza, ha sido declarada, en cierto modo, su sucedánea, y es ahora heredera del interés que antes había estado dedicado al pene». ${ }^{644}$

Aceptar que la propia madre ha sido castrada no deja de sugerir al imaginario del niño que su mismo pene corre el mismo peligro. De allí que el fetichista sienta nostalgia del pene materno con una insistencia casi patológica. Intentará captar su rastro en las sustituciones que, por asociaciones harto curiosas, le lleven a estimularse mediante la contemplación de unos zapatos. Freud señala, a propósito de este clásico fetiche, que es tan frecuente a causa del descubrimiento que muchos niños hacen de los genitales femeninos por debajo de las faldas, a la altura del calzado. ${ }^{645}$

En el caso de Huysmans, este proceso sustitutivo ha sido perfectamente reseñado pocas líneas más arriba. Cabe ahora preguntarse si existe en su obra rastro alguno de esa nostalgia del pene femenino, lo que corroboraría, desde una óptica psicoanalítica, su fijación al fetiche.

La respuesta a esta pregunta es afirmativa. Mediante comparación de varios textos, se comprueba la presencia obsesiva de ciertas mujeres dotadas de falo que cumplen una función esencial en la psicología profunda de nuestro autor. Según Charles Bernheimer, Huysmans aspira a la restauración de una imagen de la totalidad materna, dotada de pene, y a cuya realidad solo se puede acceder desde un ámbito puramente fantasmático: «le phallus de la mère doit être remis à la place que le fantasme lui désigne». ${ }^{646}$

Dos son los casos que Bernheimer cita como paradigmáticos de la madre fálica en la obra de Huysmans. Uno, en los simulacros constantes que constituyen los objetos fabricados que imitan a la naturaleza - como, principalmente, en $\grave{A}$ rebours; otro, en los numerosos y flagrantes casos en que Lydwine ve cómo sus llagas se convierten en pebeteros de bálsamos, o todas esas marcas de sufrimiento que le inflige su relación privilegiada con Dios.

644 S. Freud, Fetichismo, en Obras Completas, ob. cit., tomo VIII, p. 2994.

645 Ib., p. 2995.

646 C. Bernheimer, «L'exorbitant sexuel: castration et sublimation chez Huysmans», ob. cit., p. 110. 
Los casos de obsesión por el falo de la madre que nosotros hemos encontrado son más numerosos. En el sueño que tiene des Esseintes en el capítulo n. ${ }^{\circ}$ VIII de $\grave{A}$ rebours, aparece una mujer que camina a su lado:

elle avait des cheveux filasse, une face de bouledogue, des points de son sur les joues, des dents de travers lancées de travers sous un nez camus. Elle portait un tablier blanc de bonne, un long fichu écartelé en buffluetterie sur la poitrine, des demi-bottes de soldat prussien, un bonnet noir orné de ruches et garni d'un chou. ${ }^{647}$

Extraña condición hermafrodita de esta aparición calificada, a priori, como femenina. "Il se demandait quelle était cette femme qu'il sentait entrée, implantée depuis longtemps déjà dans son intimité et dans sa vie», dice unas pocas líneas más adelante. La aparición onírica resulta ser finalmente una encarnación de la "grande vérole», tras cuyo reconocimiento el soñador se sumerge en un sinfín de símbolos que sugieren tanto el miedo a la castración ( «d'immenses et blancs pierrots — qui faisaient des sauts de lapins»), como una obsesión fálica que rodea a la presencia de la enigmática mujer. Convertida en flor, el soñador se siente cada vez más atraído por ella; está a punto de tocarla, cuando:

de noirs Amorphophallus jaillirent de toutes parts, s'élancèrent vers ce ventre qui se soulevait et s'abaissait comme une mer. Il les avait écartés, repoussés, éprouvant un dégoût sans borne à voir grouiller entre ses doigts ces tiges tièdes et fermes.

Curiosa concreción de esa presencia femenina dotada de falo - ya sea directamente o indirectamente-, asediada por todas partes por esos «amorphophallus» cuya única meta es penetrarla. Como señalan Laplanche y Pontalis en su Vocabulaire de la psychanalyse, ${ }^{648}$ la mujer fálica posee un atributo fálico, interno o externo, como resultado de haber conservado el pene masculino tras la penetración. La psicoanalista inglesa Melanie Klein ampliará esta obsesión mediante la noción de "padres combinados»: se trata de los padres inseparablemente confundidos en un coito eterno, gracias al cual la madre porta en sí y de manera continuada los atributos paternos - o al padre entero-, y el padre porta el seno materno o a la madre en su totalidad. ${ }^{649}$

647 J.-K. Huysmans, À rebours, ob. cit., p. 138.

648 J. Laplanche y J. B. Pontalis, Vocabulaire de la psychanalyse, ob. cit., p. 310.

649 Referida por Laplanche y Pontalis en el mismo apartado de la obra citada. 
Por todo ello, no ha de extrañarnos encontrar esa presencia hermafrodita fantasmática rodeada de un aura de dolor y/o de amenaza.

En En rade se narran varios sueńos, en uno de los cuales se puede percibir perfectamente una enorme profusión de elementos fálicos que rodean a una presencia femenina. Se trata del capítulo $\mathrm{X}^{650}$ de esta enigmática novela, del que podríamos señalar tan solo aquellos elementos que nos sirvan para ilustrar nuestra hipótesis: «L'homme plongea son bras dans la poche de sa houppelande, ramena une poignée de cristaux qui crièrent en se concassant dans sa main» — complejo de castración, por el que el polvo que resulta más que de la castración de haber molido el pene resultan ser «les menstrues de la terre». Poco más adelante aparece, de nuevo, esa presencia cuasi militar, "un sergent de ville, sans képi, chauve», al que se asocian diversos elementos de carácter netamente femenino: unas calabazas con el vientre lleno de pepitas blancas, una belleza "constamment interompue et qui avoisinait la plus épouvantable des laideurs»... En defintiva, pesadilla de hermafroditismo en la que una presencia femenina se ve ignominiosamente dotada de atributos de naturaleza fálica.

Dentro de este sueño del capítulo $\mathrm{X}$ de En rade, podemos encontrar la huella de otro elemento que marca bien claramente su naturaleza hermafrodita. En medio de la horrible pesadilla, el soñador se ve evolucionar en medio de una estructura vertical, unos andamios de madera que resultan conformar un pozo. En el extremo superior de este pozo, se halla una campana: «cette cloche marchait, mais son battant ne frappait point le métal et pourtant des sons, étranges, s'entendaient répercutés par les échos de la tour». ${ }^{651}$

En las campanas, cómo no ver un sustitutivo, de naturaleza completamente fetichizante, de la feminidad. La asociación por la cual se establece un vínculo de gran fuerza entre campana y mujer es fácil de comprender. De la misma manera que Freud señalaba un corriente fetiche en los zapatos - porque es a la altura del calzado materno que el niño indaga con la mirada bajo la falda, en busca de los genitales de su progenitora-, ${ }^{652}$ podemos afirmar sin temor a equivocarnos que el cuerpo de la campana puede

650 J.-K. Huysmans, En rade, ob. cit., pp. 187-197.

651 Ib., p. 191.

652 S. Freud, Fetichismo, ob. cit., p. 2995. 
ser fácilmente asociado a unas faldas. Y, lo más curioso de todo, es que la campana, dotada de un badajo que cuelga, sirve perfectamente a la representación del fantasma de la mujer fálica, de la madre hermafrodita.

Es curioso cómo, en $L \grave{a}$-bas, queda descrito el ambiente de la torre de Saint-Sulpice donde vive y trabaja el campanero Carhaix. Cuando la campana suena, batida por Carhaix, la torre no puede por menos que temblar, casi hasta perder toda su consistencia:

et tout à coup elle sonna, prit son élan, et son battant, semblable à un gigantesque pilon, broya dans le bronze du mortier des sons terribles. La tour tremblait, la margelle sur laquelle il se tenait trépidait comme le plancher d'un train; un grondement continuel, énorme, roulait brisé par le fracassant éclat des coups. ${ }^{653}$

No es nada descabellado encontrar aquí una perfecta similitud entre la pesadilla de En rade antes comentada y el ambiente en que vive el matrimonio Carhaix. Pareja que, por otra parte, parece representar a la perfección el modelo de matrimonio dichoso, respetuoso y, en una palabra, feliz -que la imaginación creadora de nuestro autor siempre intentó recomponer para su beneficio. La campana simboliza la doble naturaleza de la pareja: femenina y masculina, con lo que la obsesión por los "padres combinados» de Melanie Klein.

La campana reviste, como no podía ser de otro modo, una importancia crucial en la felicidad del matrimonio — sin hijos_ Carhaix:

Carhaix dépérirait s'il perdait ses cloches! c'est tout de même curieux cette affection de l'homme pour l'objet qu'il aime; c'est l'amour du mécanicien pour sa machine; on finit par aimer, autant qu'un être vivant, la chose qui vous obéit et que l'on soigne. ${ }^{654}$

Qué estupendo deseo: cuidar un objeto de tamaña importancia para que a uno le obedezca...

Otro efecto curioso, digno de tener en cuenta, es cómo las campanas sirven, por un lado, para predecir el futuro («L'art de prédire l'avenir avec leurs sons est une des branches les plus inconnues et les plus abandonnéés

653 J.-K. Huysmans, Là-bas, ob. cit., p. 30.

654 Ib., p. 38. 
de l'occulte»), ${ }^{65} \mathrm{y}$, por el otro, están asociadas al anuncio de un acto reprensible; en este último caso, el miedo que el niño siente ante la posibilidad de su castración reaparece cuando ve en peligro el falo de la madre. Así, cuando el amigo des Hermies comenta a Durtal los sacrilegios que ciertos sacerdotes cometen durante la misa negra, «à ce moment, la cloche, mise en branle dans la tour, bôomba»; ${ }^{656}$ la torre, por efecto del monstruoso tañido, tiembla como si fuera a derrumbarse.

El mismo peligro parece observar Huysmans cuando señala que, según Gévingey — el clérigo que les ilustra sobre el satanismo en París—, si un ave nocturna vuela alrededor de una campana iluminada por la luna, "l'on peut être sûr qu'un vol sacrilège sera commis dans l'église ou que le curé risque la mort». ${ }^{657}$ Acto sacrílego consistente en violar la intimidad bajo la falda de la madre fálica, para más inri iluminada, como en una focalización digna de una escena de cine primitivo. Pájaro nocturno, de mal agüero, que pone en peligro la integridad de la madre y pone sobre aviso al niño ante la posibilidad de verse desprovisto de su atributo.

En resumen, la campana es una representación perfecta de la obsesión por la mujer fálica y, sobre todo, por los padres combinados teorizados por Klein. A través de ella, de la campana, la imaginación creadora de Huysmans se ve capacitada para poner en escena todo el aparato fantasmático que, en principio, le serviría para exorcizar una obsesión ciertamente dolorosa.

\subsubsection{Poluciones nocturnas}

Ya hemos observado la enorme importancia que tienen los sueños para la resolución de conflictos libidinales en la obra de Huysmans. Freud estaría de acuerdo con esta afirmación aplicada a cualquier individuo, pues el inconsciente encuentra una vía de escape en la experiencia onírica para dar rienda suelta a sus necesidades. Esto se realiza, frecuentemente, por medio de asociaciones más o menos justificadas por la trayectoria vital del soña-

$\begin{array}{ll}655 & \text { Ib., p. } 68 . \\ 656 & \text { Ib., p. } 66 . \\ 657 & \text { Ib., p. } 68\end{array}$ 
dor, o por juegos de lenguaje, o por contigüidad. «El sueño no reproduce fielmente el estímulo, sino que lo elabora, lo designa por una alusión, lo incluye en un conjunto determinado o lo reemplaza por algo distinto». ${ }^{658}$

Es lo que el padre del psicoanálisis concibió bajo la denominación de «transferencia»: se desplaza a un elemento en principio inofensivo y sin importancia la carga que, en realidad, debería ponerse sobre otro elemento en verdad decisivo para la construcción de ficciones oníricas. Con ello el sońador consigue elaborar un relato desplazado sin experimentar angustia. En caso de que la ficción onírica comprometiera demasiado la integridad psicológica del durmiente, dicha angustia provocaría el despertar.

Es lo que conocemos con el nombre de pesadilla, que no es sino una realización encubierta de un deseo, pero de un deseo que lejos de ser bien acogido por nosotros es rechazado y reprimido. La angustia que acompaña a esta realización toma entonces el puesto de la censura: el sentimiento de angustia que entonces experimentamos en el sueño, señala Freud, es un reflejo de la angustia que sentimos ante la fuerza de determinados deseos que hasta el momento habíamos conseguido reprimir. ${ }^{659}$

En relación con la satisfacción de los impulsos libidinosos, el psicoanálisis informa de que unas incorrectas o insuficientes satisfacción y sublimación durante la vida despierta hacen que esto encuentre solaz durante la vida onírica.

En la obra de Huysmans, las situaciones de onirismo que se saldan con una posible polución — satisfacción fisiológica - son varias. Y, como señala Bernheimer ${ }^{660}$ aunque sean a todas luces formadas por la intención artística, los relatos de los sueños revelan las pulsiones y las estructuras de su inconsciente de una manera menos disfrazada que en el resto de su obra.

Así, el inconsciente —o mejor dicho, la imaginación creadora- de nuestro autor halla una conveniente vía de satisfacción en la narración de estas experiencias oníricas. Decimos conveniente y no perfecta, pues

658 S. Freud, Introducción al Psicoanálisis, Alianza Editorial, Madrid, 1994, p. 96.

659 Ib., p. 228.

660 C. Bernheimer, «L'exorbitant sexuel: castration et sublimation chez Huysmans», ob. cit., p. 105. 
ya hemos mostrado cómo la exposición de ciertos sueños de carácter sexual sume al durmiente en situaciones de angustia elevada.

Uno de los ejemplos que se puede considerar paradigmático de estas poluciones nocturnas - no olvidemos, soluciones a la deficiente y poco satisfactoria sexualidad del heterónimo ficcional - lo hallamos en la obra de 1880 Croquis parisiens. Concretamente, en el capítulo titulado "Paraphrases», encontramos un croquis que, bajo el título de "Cauchemar» relata una extraña experiencia onírica. En esta "pesadilla» aparece una enigmática figura, dolorosa y altiva en la oscuridad de la habitación del durmiente. El escenario se convierte en un estanque de tenebrosas aguas de las que surge «la monstrueuse tige d'une impossible fleur» ${ }^{661} \mathrm{La}$ apariencia de ese tallo es la de una barra de acero rígido de la que salen como ramificaciones hojas metálicas, a la par que unos brotes que asemejan renacuajos.

Este contexto de elevación y de representación de un objeto rígido representa a la perfección los genitales masculinos - como señala Freud en el capítulo «El simbolismo en los sueños» de Introducción al psicoanálisis. ${ }^{662}$ Una erección en sueños provocada por el relato onírico y que desencadena, finalmente, una polución indeseada: «l'un de ces bourgeons, lumineux et comme enduit d'une huile phosporée, creva, s'arrondissant en una pâle tête qui se balança silencieuse sur la nuit des eaux». ${ }^{663}$

En el sueño de la mujer bulldog que es relatado en $\grave{A}$ rebours - y que hemos tenido oportunidad de comentar más arriba en relación con el fantasma de la madre fálica—, se produce una polución cuando los senos de esta extraña mujer estallan en el mismo momento en que esos «amorphophallus» la penetran en multitud. De sus muslos nace entonces una flor, una nidularium, cuyo inevitable contacto produce en el durmiente una angustia insoportable: «il frôlait avec son corps la hideuse blessure de cette plante; il se sentit mourir, s'éveilla dans un sursaut, suffoqué, glacé, fou de peur, soupirant. —Ah!, ce n'est Dieu merci, qu'un rêve». ${ }^{664}$

661 J.-K. Huysmans, Croquis parisiens, ob. cit., p. 148.

662 S. Freud, Introducción al Psicoanálisis, ob. cit., p. 16 y ss.

663 J.-K. Huysmans, Croquis parisiens, ob. cit., p. 148.

664 J.-K. Huysmans, $\grave{A}$ rebours, ob. cit., p. 141. 
La obra en que mayor importancia tienen los relatos oníricos es, sin ningún lugar a dudas, En rade. En el primero de todos ellos, que ocupa la totalidad del capítulo II, se pone en escena una hermosa adolescente, Esther, que danza voluptuosamente ante un rey. Aunque podamos encontrar en este relato todos los tópicos referidos al mito de Salomé pintado por Moreau, el sueño permite la estimulación fisiológica del durmiente. Cuando el rey observa a Esther, completamente desnuda y adoptando posiciones excitantes, blande su fálico cetro, obligando a la jovencita a besarlo: «l'œil du Roi vrilla cette nudité d'enfant et lentement il étendit vers elle la tulipe en diamant de son sceptre dont elle vint, défaillante, baiser le bout». ${ }^{665}$ Se produce entonces un aturdimiento, un éxtasis por el cual todo el escenario se pone a temblar, con multitud de efectos de carácter ascendente: humo, cohetes, fuegos artificiales; todo ello en medio de una extraña nevada de copos de bruma:

il y eut un vacillement dans l'énorme salle; des flocons de brume se déroulèrent, ainsi que ces anneaux de fumée qui, à la fin des feux d'artifice, brouillent les trajectoires des fusées et dissimulent les paraboles en flammes des baguettes.

La joven bailarina reaparece, el ojo vuelve a posarse sobre ella para contemplarla manchada de esos copos en medio de la bruma disipándose: «le brouillard se dissipa; la femme apparut, renversée, toute blanche». ${ }^{666}$

Esta no es el único recurso al sueño que se da en En rade: sabemos que durante toda la novela planea el fantasma de la insatisfacción sexual — que Jacques Marle achaca a la enfermedad de Louise, su mujer. Una segunda intervención del mecanismo onírico aparece como consecuencia de la contemplación del cielo nocturno. Este sueño lunar es uno de los raros ejemplos de experiencia onírica no angustiosa: el durmiente se introduce en el escenario selenita con total placidez, con toda la satisfacción que puede suponer ascender y desdender los cráteres lunares.

La asimilación del paisaje del satélite con el cuerpo femenino es meridiana, como por ejemplo en el caso de un mar contenido entre dos hinchazones ulcerosas: «vers le sud, la Mer des Humeurs, flanquée par deux chancres — les monts Gassendi et Agatarchites—». ${ }^{667}$ La tranquilidad en

665 J.-K. Huysmans, En rade, ob. cit., p. 63.

666 Ib., p. 63.

667 Ib., p. 108. 
que sume este sueño a nuestro durmiente es tal, que ni siquiera los temores que suelen acompañarle en relación con aguas muertas y estancadas hacen mella en su bienestar. Así, el durmiente es capaz de pasearse por el mar de la podredumbre, sin que ningún olor a carroña ni a sangre perturbe su sueño: «ils sont arrivés au Marais de la Putritude, qui ne sent pas la charogne en putrefaction ni de sang qui se décompose». ${ }^{668}$

En definitiva, los sueños son una herramienta imprescindible para nuestro autor en el sentido de la satisfacción de sus instintos carnales - que no dejo de tener plasmación en su obra literaria. Y ello a pesar de que, frecuentemente, el sueño derive en pesadilla. Lo importante de este uso del onirismo como recurso tanto literario como vital es que Huysmans fue creyendo cada vez con más fuerza en él a medida que se internaba en el estudio del satanismo. Las poluciones nocturnas necesarias al durmiente insatisfecho pasaron a ser protagonizadas por instancias demoníacas que cumplían, nominalmente, ese papel. Nos estamos refiriendo al papel que cumplían los súcubos en el onirismo sexual de Huysmans, sobre todo a partir de la redacción de Là-bas.

\subsubsection{Súcubos: poluciones demoníacas}

Los súcubos - ya hemos tenido oportunidad de hablar de ellos en la parte dedicada a la misoginia decimonónica - es una creación primitiva. Como ya indicamos, el primer súcubo considerado por la cultura judeocristiana fue Lilith: princesa de los súcubos que atacaba, seducía y devoraba a los hombres cuando estaban dormidos y solos. Su papel en el acto sexual es completamente activo, pues su genealogía se remonta al Edén, de donde fue despachada por pretender ocupar la posición superior durante la cópula. ${ }^{669}$

En el imaginario huysmansiano, el súcubo cumple ese mismo papel de visitador nocturno que se encarga de satisfacer las exigencias fisiológicas del inconsciente. Sueños eróticos, Huysmans siempre parecía haber tenido — por la importancia que, a la larga, les concedería en su producción literaria-; a partir de un cierto momento, considera que los relatos eróticos

\footnotetext{
668 Ib., p. 110.

669 Vid. E. Bornay, ob. cit., p. 25 y ss, y R. Graves y R. Patai, Los mitos hebreos, ob. cit., p. 59.
} 
que su inconsciente le propone como vía de escape de sus humores son de naturaleza exógena y, para mayor peculiaridad, demoníaca.

La primera manifestación que nuestro autor emite sobre el asunto de los súcubos la podemos situar en una obra tan temprana como Marthe, histoire d'une fille. En ella se pone de relieve los gustos literarios de Léo, el amante de la actriz, de quien se indica la delectación por los ambientes tenebrosos y siniestros que encarnaría la obra pictórica de Goya: «de temps à autre, dans les bons moments, il écrivait une page fourmillant de grotesques terribles, de succubes, de larves à la Goya». ${ }^{670}$ Con esto, Huysmans no mostraba todavía más que un interés literario por el asunto. Conocía el concepto, y la filiación diabólica del mismo le atraía desde un punto de vista artístico. No en vano Goya sería sustituido en el altar de la adoración estética por otro pintor aún más dado a la pintura de larvas, úlceras y llagas: Grünewald.

Sin embargo, y a partir de 1890, Huysmans comienza a interesarse por los fenómenos paranormales para la redacción de su $L \grave{a}-b a s$. Como sabemos, nuestro autor se documentó largamente sobre Gilles de Rais y, por extensión, sobre las ciencias ocultas y su práctica en el entorno parisién. Para ello buscó la ayuda y el consejo del que fuera otrora abbé Boullan: un sacerdote finalmente expulsado de la iglesia por sus prácticas poco ortodoxas desde el punto de vista canónico y que serviría como modelo para Johannès. Huysmans fue a visitarlo en numerosas ocasiones con el objeto de documentarse acerca de un fenómeno del que conocía la existencia pero en el que no podía creer sino era desde una perspectiva estetizante. La cuestión es que, a fuerza de frecuentar al demoníaco sacerdote, se estableció entre ambos individuos una sólida relación intelectual. Y hasta tal punto esa relación era estrecha que, cuando Boullan se halló à court de recursos para mantener su casa, le cedió a Huysmans a su gobernanta, Julie Thibault. Según comenta Baldick, lector de los diarios íntimos de nuestro autor, la Sra. Thibault —a la que llamaría maman Thibault- estaba iniciada en los secretos del satanismo. La misma noche que siguió a la primera entrevista entre la gobernanta y el autor, este experimentó por vez primera el fenómeno de los súcubos: «une sensation excessive, douloureuse et exquise», como refiere Pierre Lambert. ${ }^{671}$

670 J.-K. Huysmans, Marthe, histoire d'une fille, ob. cit., p. 61.

671 Vid. P. Lambert, "Un culte hérétique à París, 11 rue des Sèvres», La Tour SaintJacques, mayo-junio, 1957, p. 58; y R. Baldick, ob. cit., p. 200. 
Podemos proponer esa fecha como la fundadora del recurso a los súcubos como generadores de las experiencias oníricas eróticas de nuestro autor. Y sabemos la importancia que se le dio en lo sucesivo a esta fuente de satisfacción libidinosa en la obra huysmansiana.

La primera manifestación del sucubato que aparece en esa obra vértice que es $L \grave{a}$-bas es referida al personaje de Mme. Chantelouve. Como ya sabemos, esta diabólica mujer, esposa de un autor religioso, se prende de Durtal, a quien pretende seducir por todos los medios. En un primer momento, Hyacinthe — tal es su nombre de pila— ${ }^{672}$ inquieta la imaginación del escritor mediante el envío de varias cartas en las que le declara su admiración, primero, y su deseo más tarde. La fuente de inspiración de esta correspondencia galante está en la vida de nuestro autor. Según revela Pierre Cogny, Huysmans recibió hasta diecinueve cartas de una admiradora secreta, que firmaba con el nombre de Isola, y cuya verdadera gracia era Henriette Maillat (de soltera Picot). Cogny muestra en su obra capital ${ }^{673}$ cómo el escritor las modificó a su gusto para utilizarlas en su novela satánica por excelencia.

Sea como fuere, esta Isola fue el referente real de Hyacinthe Chantelouve. La posibilidad de su filiación diabólica es sugerida en una conversación que mantuvo con su marido y que es referida a Durtal:

ce matin, mon mari entre dans ma chambre; j'avais les yeux en sang; je me mets à rire comme une folle et quand je puis parler, je lui dis: que penseriez-vous d'une personne qui, questionné sur sa profession, répondrais: je suis succube en chambre. ${ }^{674}$

Ante tamaña cuestión, Chantelouve replica que debe de estar bastante enferma para decir eso. Durtal, por su parte, que se había mantenido en abstinencia carnal durante tiempo, se siente obsesionado por la visita de Hyacinthe, tras lo cual, su obsesión encuentra acomodo en su vida onírica: «je commence à subir les hantises du succubat, se dit-il; je vais essayer de l'e-

672 «Suivant Aristote et Pline, l'hyacinthe chasse l'insomnie; selon le symbolisme catholique, l'hyacinthe représente l'humilité; Porte dit que l'hyacinthe 'garantit de la foudre et éloigne les pestilences et les venins'» — según señala el propio Durtal en J.-K. Huysmans, Là-bas, ob. cit., pp. 270-271.

673 P. Cogny, J.-K. Huysmans à la recherche de l'unité, ob. cit., p. 218.

674 J.-K. Huysmans, Là-bas, ob. cit., p. 88. 
xorcisme des bromes». ${ }^{675}$ Esto significa que Durtal ha experimentado un típico sueño de carácter sexual en el que se veía visitado por una mujer que debía de tener cierta similitud fisonómica con Hyacinthe. La revelación que esta le hace de su conversación con el hagiógrafo Chantelouve y la disposición al satanismo que albergaba el escritor le llevan a atribuir sus sueños a la influencia del sucubado.

Acaso no le confiesa a su amigo des Hermies, tras una visita al campanero Carhaix y en base a la revelación de Gévingey de haber sido visitado por un súcubo, convencerse de la posibilidad de semejante fenómeno suprasensible. Al decirle a su camarada "puisque tout est soutenable et que rien n'est certain, va pour le succubat! Au fond c'est plus littéraire et plus propre!» ${ }^{676}$, Durtal no está dando su brazo a torcer. Con ello admite que el sucubato, como respuesta a sus sesiones de sexo onírico, sea más plausible desde un punto de vista estético que las simples necesidades del inconsciente — mucho más banales y menos explotables que el satanismo.

Hyacinthe le confiesa en varias ocasiones su carácter de súcubo, y que cada noche le visita para disfrutar de su cuerpo según le plazca: «je vous posséde quand et comment il me plait, de même que j'ai longtemps possédé Byron, Baudelaire, Gérard de Nerval, ceux que j'aime..." ${ }^{67}$ — que no deja de ser una nómina muy del gusto de nuestro autor; al proponerse a sí mismo como víctima de los impulsos de Hyacinthe, ¿no se está autoelevando a un imaginario olimpo de las letras demoníacas? Durtal, por otra parte, busca casi podríamos decir que denodadamente a creer en este fenómeno sobrenatural; y para ello se pregunta cómo una mujer tan ardiente como Hyacinthe puede conservar el cuerpo tan frío durante el acto sexual: «Dis donc, reprit Durtal en s'adressant à des Hermies, sais-tu si une femme qui reçoit la visite des incubes a nécessairement le corps froid?» A lo que su amigo des Hermies responde:

je me rappelle fort bien que le docteur Johannès, celui dont Gévingey t'a parlé, était souvent obligé, au moment où il tentait de délivrer la malade, de ramener le corps à sa température normale avec des lotions d'hydriodate de potasse étendu d'eau. ${ }^{678}$

$\begin{array}{ll}675 & \text { Ib., p. } 90 . \\ 676 & \text { Ib., p. } 139 . \\ 677 & \text { Ib., p. } 146 . \\ 678 & \text { Ib., p. } 183 .\end{array}$


Una prueba que nos parece definitiva de la conveniencia que Huysmans encuentra en el sucubato para enmascarar sus propios sueños eróticos le hamos hallado en una conversación que Durtal mantiene con Hyacinthe en casa de los Chantelouve. Nuestro héroe comparte con su amante una idea que, en cierto modo, le atormenta. Le cuenta que ha inventado un nuevo tipo de pecado, consistente en la relación incestuosa que un autor, un artista, un pintor, puede mantener con las criaturas que han salido de su intelecto. A esto Durtal lo llama Pigmalionismo, «qui tient tout à la fois, de l'onanisme cérébral et de l'inceste». Y para ilustrar de ejemplos su reflexión, cita a Herodías, a Judith, a Helena...: personajes bíblicos que, como ya sabemos por haber analizado su aparición en el contexto onírico de la obra huysmansiana, nuestro autor ha utilizado como materia libidinosa habitual.

Consultado sobre el asunto, el hagiógrafo Chantelouve le responde que la invención de nuevos pecados está limitada desde hace siglos; ese pigmalionismo no es sino una expresión refinada del sucubato - le dice-: "c'est tout bonnement une expresion raffinée du succubat; ce n'est pas l'œuvre enfantée qui s'anime, mais bien un succube qui en prend, la nuit, les formes!». ${ }^{679} \mathrm{El}$ súcubo es, finalmente, un argumento magnífico para atribuir toda la impureza de su espíritu a una fuerza exógena e incontrolable. Con ello Huysmans aspira a una limpieza de espíritu que le estaba negando con cada vez mayor fuerza su sentimiento de culpa con respecto a la práctica sexual. Un sentimiento de culpa cuyo origen no puede tener como origen sino una fijación a la madre ambivalente.

Sara Kofman ${ }^{680}$ considera que esta particular convicción del creador, consistente en considerarse padre de sus criaturas artísticas, tiene como fundamento el deseo de convertirse a sí mismo en su propio creador. El artista, de esta manera, se erige como autosuficiente, se hace equivalente a Dios, y, finalmente, se sustituye a su padre. Con esto, añade Kofman, parece que el creador tiene como fin principal negar la escena primitiva: la contemplación del coito entre los padres. La obra de arte se convertiría, con ello, en un don que el creador hace a su madre: como si le estuviera

679 Ib., pp. 167-168.

680 S. Kofman, L'enfance de l'art. Une interprétation de l'esthétique freudienne, Petite Bibliothèque Payot, París, 1975, pp. 169 y 170. 
ofreciendo un hijo. Fijación incestuosa a la madre que puede verse acompañada de una actitud homosexual. Ya tendremos tiempo de abundar en este extremo, crucial en la génesis de la obra de nuestro autor a partir de la redacción de Là-bas.

En En route, la influencia del súcubo, sin ser explícitamente nombrada, llega a ser incluso magnificada. Como mecanismo de sustitución, Durtal confiesa que es mejor que la misma experiencia real:

c'était ainsi et mieux que dans la nature, long, complet, accompagné de tous les préludes, de tous les détails, de toutes les sensations; et le déclic avait lieu, avec une acuité douloureuse extraordinaire, dans un spasme de détente inouï. ${ }^{681}$

La presencia del súcubo es hasta tal punto benefactora y esperada que el durmiente siente su presencia cálida en el lado de la cama abandonado por el pequeño demonio en el momento del despertar:

la sensation nette, précise, d'un être, d'une forme fluidique disparaissant avec le bruit sec d'une capsule ou d'un coup de fouet, d'auprès de vous, dès le réveil. Cet être, on le sentait distinctement près de soi, si près, que le linge, dérangé par le souffle de sa fuite, ondulait et que l'on regardait, effaré, la place vide. ${ }^{682}$

Lejos de referir su experiencia con el sucubato de manera triste o desgraciada, solo podemos observar aquí la dicha con que Durtal considera su vida onírica sexual. Ese espacio vacío que deja el súcubo al abandonar el lecho muestra a las claras la nostalgia por esas visitas nocturnas - cuyo rostro no nos ha sido revelado-, y que sumen al durmiente en una benéfica sensación de plenitud y calma.

Si situamos En route en su contexto de investigación religiosa —en la que Huysmans relataría sin ambajes su conversión- ${ }^{683}$ y de adoración por la Virgen María, ¿sería demasiado osado conceder el rostro de esa benefactora visitadora nocturna al modelo fantasmático de la madre de Cristo: la propia madre? Lo cierto es que, a pesar de que las revelaciones sobre el onirismo de Durtal sean frecuentes en las novelas del ciclo religioso, jamás se

681 J.-K. Huysmans, En route, Gallimard, París, 1996, p. 309.

682 Ib., p. 310.

683 Vid. P. Buvik, ob. cit., p. 292. 
comenta que el personaje haya sońado con la Virgen. Podemos calificar de sospechosa esta negación, cuando, a través de estas novelas, se reconoce la importancia suma que la madre de Cristo tiene en su conversión. Tal vez, consciente de la identidad de la visitadora nocturna, Durtal comenzase a considerar sus benéficos sueños como fuente de inmundicias y sufrimientos —y de ahí el terrible e insoportable complejo de culpa experimentado posteriormente a la práctica sexual:

il finit par s'assoupir, rêva encore d'immondices, mais il se reprit à temps pour rompre le charme, éprouva encore cette impression d'une ombre s'évaporant à temps pour qu'on ne puisse la saisir dans les draps. ${ }^{684}$

Al tener un sueño de carácter sexual por vez primera con una mujer a quien luego llamaría «mamá» (como es el caso con maman Thibault, su gobernanta), el súcubo se le aparece como un recurso plausible para condenar la satisfacción libidinosa con la madre a través del sueño: solo el diablo puede crear semejantes escenarios incestuosos. Sin embargo, y a medida que creyera en el carácter positivo de la experiencia religiosa, su búsqueda de la madre en las mujeres que frecuentaba debió tomar un componente positivo - necesario para instalarse en una benefactora nostalgia de la madre que evolucionaría desde lo libidinal hasta la sublimación de tal impulso mediante la conversión.

Es, pues, el paso a la religión, una necesidad fantasmática de reconciliación con la propia madre. De ahí que esta nostalgia de la madre que ha abandonado al niñito a su suerte revista la imagen de la Virgen María, madre y esposa de Dios. La liberación de la cada vez más dolorosa sexualidad de vigilia — que, como veremos más tarde, sume a Durtal en una culpabilidad insoportable - pasa por su eliminación en el ara mariana. Este fenómeno, denominado marianismo, es habitual en aquellos individuos homosexuales con una gran fijación a la madre. Volveremos más adelante sobre este asunto. Nos interesa ahora observar cómo se desarrolla ese potente sentimiento de culpabilidad en el heterónimo ficcional de Huysmans: de él depende la reconstrucción familiar que pretende la obra literaria de nuestro autor.

684 J.-K. Huysmans, En route, ob. cit., p. 311. 


\subsubsection{La sexualidad culpable}

El sentimiento de culpabilidad que confiesan tener los personajes de la obra de Huysmans tras las prácticas sexuales es digno de ser tenido en cuenta. En todas las ocasiones en que el heterónimo ficcional ha mantenido relaciones con alguna mujer, le ha sobrevenido una sensación de desamparo que solo puede provenir de una situación psicológica peculiar. Ya habíamos apuntado antes al sobreinvestimiento de la figura materna, que puede llevar al niño a no desear traicionar el recuerdo de la madre: esto le provocaría un intenso desasosiego; esa misma intención le puede empujar a buscar en los hombres satisfacción sexual con el fin de no incurrir en infidelidad. Según la ortodoxia psicoanalítica observada más arriba, muchos homosexuales masculinos pueden encontrar la razón de su tendencia sexual en esta fijación a la madre.

En el caso de los personajes de Huysmans, el intenso malestar tras el sexo parece indicar que la fijación a la madre produce esa convicción de estar traicionando su memoria. En cuanto a la tendencia homosexual debido a la misma causa, intentaremos analizarla más adelante a la luz de los ejemplos hallados en la obra de Huysmans.

El malestar ante el sexo aparece desde muy temprana fecha. Ya no se trata, en esta ocasión, de una vaga sensación de fracaso y decepción ante la experiencia sexual. Veíamos alguno que otro ejemplo correspondiente a Les Sours Vatard en que Céline comentaba su frustración tras el acto erótico: las expectativas que en él había puesto eran tan grandes que el coito se le antojó de mínimo alcance. ${ }^{685}$ En esa decepción, Huysmans pone tanto su propia frustración ante la actividad sexual como su miedo a la incapacidad de no proporcionar placer a sus compañeras de juegos eróticos.

En el tema que ahora nos ocupa, trataremos de ver cómo la práctica sume al amante saciado en un pozo de dolor inexplicable: lamento continuado que el heterónimo ficcional no comprende y que nosotros nos atrevemos a situar en la esfera de los remordimientos subsiguientes a la traición. Traición a la madre sobreinvestida, afirmamos.

685 J.-K. Huysmans, Les Sceurs Vatard, ob. cit., p. 184. 
Ya en Croquis parisiens encontramos un pequeño pasaje, como «Damiens» (perteneciente a la serie "Fantaisies et petits coins») en el que se narra una experiencia sexual que sume al amante en una profunda angustia. En este pasaje observamos también la sensación de fraude que provoca en el personaje la comisión del acto. Así, se habla de "cette expiatrice détresse que laissent, une fois commis, les fraudulents forfaits des sens». ${ }^{686}$

Otro caso, del cual ya habíamos utilizado algunos elementos para ejemplificar las recurrencias de la madre fálica, reside en el croquis titulado «Cauchemar» (del apartado "Paraphrases»). Recordemos que en este pasaje se ponía en escena una dolorosa y rígida flor que, súbitamente, estallaba en una especie de polución nocturna. Lo que nos interesa ahora es observar cómo esa polución provoca una sensación de dolor, «une douleur immense et toute personnelle émana de cette livide fleur. Il y avait dans l'expression de ses traits, tout à la fois du navrement d'un pierrot usé...» —incluso miedo; un miedo insoportable que inmovilizaba al soñador: «une peur irrépressible, intense, vous clouait, haletant, sur la banquette de pierre qui s'étendait, ainsi qu'un quai, le long de cette eau morte». ${ }^{687}$

Los casos en En ménage son unos de los más evidentes de toda la producción huysmansiana. Como sabemos, en esta novela se acuña el sabroso término de la crisis faldera - la «crise juponnière»— que, por su propio carácter de crisis, crea un indefinible malestar en el amante. Recordemos que esta crisis faldera tenía como principal componente la llamada insistente de la carne, al que se le unía la angustia consiguiente — que nosotros sí comprendemos y achacamos a una patológica convicción de traición a la querida y deseada madre.

Tras una de estas crisis que André consigue mitigar mediante el recurso a una profesional, la recaída la sorprende con dolorosa insistencia:

Alors la crise juponnière vint.

Cette tranquillité qu'il avait reconquise par si grand'peine, fit place à un indéfinissable malaise qui s'accentua aux alanguissements du printemps et aux troubles nerveux qui l'accompagnaient. ${ }^{68}$

686 J.-K. Huysmans, Croquis parisiens, ob. cit., p. 112.

687 Ib., p. 147.

688 J.-K. Huysmans, En ménage, ob. cit., p. 157. 
En otra ocasión, intenta paliar los efectos de la crisis mediante una concienzuda preparación intelectual: tal vez conseguiría así que el remedio tuviese un poder curativo mucho mayor. El problema era que, cuanto más uso se hiciese del antídoto, más inmune se presentaría el enfermo a los embates de la crisis:

loin de l'égayer, ces amours au grand trot, l'affligèrent; ses ennuis devinrent même plus impérieux et plus aigus, dans cette langueur de cerveau qui laissent après eux les excès charnels. ${ }^{689}$

No solo se siente más desgraciado, sino como usado, como inapto para cualquier cosa: vaciado del todo - en el puro sentido del concepto. Al final, tal era el mal sabor de boca que le dejaban que la búsqueda del placer se convertía en algo enfermizo, doloroso. Como si se tratara de una especie de holocausto en que se sacrificara un exvoto y que, lejos de proporcionarle el deseo solicitado de los dioses, le sumiera en una mayor depresión. La práctica en este flujo y reflujo de intenciones contrarias (respeto y holocausto) le empuja a la práctica erótica de manera compulsiva:

toutes laissaient un arrière-goût aigre, une soif nouvelle de douceurs propres.

La répugnance qui le prit accéléra encore sa hâte de posséder quelque chose de féminin qui simulait un plaisir, une grâce. ${ }^{690}$

La angustia ante la traición cometida por vía sexual es todavía mayor, si cabe, en $L \grave{a}$-bas. La explicación es fácil de aventurar: las necesidades de reconciliación con la instancia materna iban ocupando cada vez más importancia en el inconsciente de nuestro autor.

Recordemos que, como primer paliativo a las relaciones sexuales con Hyacinthe Chantelouve y el poso que deja en sus sueños, Durtal recurre a la ayuda de los súcubos: ya no es él, sino una fuerza exógena la que le provoca esos accesos de lujuria. La responsabilidad de la traición ya no es suya, sino de una instancia malhechora y demoníaca — la imago del padre malo-: esta convicción le exime de toda culpa.

Pero dentro de un límite, porque las relaciones sexuales reales que Durtal mantiene con la demoníaca mujer no dejan de sumirle en un profundo

689 Ib., p. 167.

690 Ib., p. 169. 
estado de duelo. Ni siquiera el recuerdo de los transportes —en principio, si se deja llevar por ellos, agradables y estimulantes - le sugiere ideas de bienestar: «ils roulèrent, accablés; lui haletait, la tête dans l'oreiller, surpris et effrayé, jugant ces délices exténuantes, affreuses». ${ }^{691}$ Delicias extenuantes, horrorosas... No cabe mayor competencia para mostrar ideas contradictorias. Sabedor de que no es capaz de oponer resistencia alguna a la llamada de Hyacinthe, se deja llevar por su libido: «était-il possible de tant désirer une femme pour en venir là? Il l'avait exhaussée en ses transports, il avait rêvé dans ses prunelles, il ne savait quoi!»; el resultado es una incomoda sensación de malestar: «et le tremplin s'était cassé; il demeurait les pieds dans la crotte, rivés au sol. Il n'y avait donc pas moyen de sortir de son être, de s'évader de son cloaque...?». ${ }^{692} \mathrm{Tal}$ es la angustia que siente ante la satisfacción de su excitación que llega a preguntarse por qué su cuerpo le lleva por esa derrota tan accidentada y dolorosa:

pourquoi fallait-il qu'elle éprouvât ces rages de luxure? On aurait peut-être pu sans cela rester camarades, pécher modérément ensemble, s'aimer mieux que dans la voirie des chairs; mais non, cela n'est pas possible, conclut-il, voyant ces yeux sulfureux, cette bouche expoliatrice, terrible. ${ }^{693}$

Cómo decir «no» ante esa boca «expoliadora y terrible». El fantasma de castración sobrevuela las relaciones con Hyacinthe. Y somos conocedores de hasta qué punto ese complejo tiene como origen un conflicto edípico - a todas luces latente en el inconsiente de Huysmans.

Ese tributo a la especie que el hombre debe hacer de manera diferente a la de la mujer — el tributo femenino pasa por la concepción, el masculino por la incontrolable libido invasora de tantos vientres como sea posible- es un enigma de la vida que al Durtal de En route le parece inasible. Y, como no podía ser de otro modo, la compensación de esa inmolación no es otra más que el dolor. La vida es una continua expiación digna de un Sísifo melancólico: escarabajo pelotero que constantemente carga con su bola y jamás deja de empujar. Solo puede ayudar al doliente pecador una figura de autoridad, de suficiente autoridad como para asegurarle el perdón, como para afirmarle que ese holocausto de la carne es finalmente

691 J.-K. Huysmans, Là-bas, ob. cit., p. 174.

692 Ib., p. 175.

693 Ib., p. 195. 
aceptado por la comunidad familiar, por el núcleo edípico. Fin del conflicto, fin de los miedos: aspiración a la totalidad, a la integridad tan largamente buscadas.

Ese es el balance que de su vida hace Durtal ante su Dios: la suya es un alma retorcida que solo ha hurgado en las bajas pasiones, que solo ha buscado las alegrías ilícitas:

mon âme est un mauvais lieu; elle est sordide et mal famée; elle n'a aimé jusqu'ici que les perversions; elle a exigé de mon malheureux corps la dîme des délices illicites et des joies indues. ${ }^{694}$

En route es una novela dolorosa, pues la conversión para un espíritu como el de Huysmans no debió de ser tarea fácil. En medio de sus aspiraciones a la pureza, la lujuria se le impone de manera insidiosa, sobre todo en la figura de una profesional —una tal Florence-, cuyo simple recuerdo excita su libido hasta niveles enfermizos. Primero la tentación de la carne le sobreviene como una horrible languidez, morbosa e invasora; su voluntad va cediendo poco a poco hasta que, desarmado, corre hacia ella:

elles lui collaient dans tout le corps, cette langueur affreuse de la tentation, cette dissolution de la volonté qui se traduisaient par une sorte de malaise au bout des doigts; et il cédait, suivait l'image de Florence, allait la rejoindre chez elle. ${ }^{695}$

El sentimiento siguiente a esa cesión es el de asco de sí mismo, no sin pasar previamente por la inculpación de Florence: son los deseos de la profesional y no los suyos propios los que le llevan a pecar de tan ignominiosa manera: «quelle honte que d'avoir été rivé à celle-là, quelle dégoûtation que d'avoir satisfait aux abominables exigences de ses vœux». ${ }^{696}$ La vergüenza cede finalmente el paso a sentimientos más dolorosos, en los que el arrepentimiento es más evidente: «il s’affaissa sur les dalles, demandant humblement pardon de souiller par sa présence la pureté de ce lieu» ${ }^{697}$ como practican habitualmente los monjes de la Trapa. El dolor de sí mismo, el sentimiento de culpa le hace sentirse como un rastrero animal: vil y traidor:

\footnotetext{
694 J.-K. Huysmans, En route, ob. cit., p. 271.

695 Ib., p. 273.

696 Ib., p. 322.

697 Ib., p. 314.
} 
il en suait d'angoisse; puis une nausée de son être, un remords de sa vie le souleva et il se rendit; le regret d'avoir si longtemps vécu dans ce cloaque le crucifia; il pleura longtemps, doutant du pardon, n'osant même plus le solliciter, tant il se sentait vil. ${ }^{698}$

Finalmente, el dolor se hace tan insoportable que lo que siente el pecador es miedo: el miedo de recibir un castigo por encima de su aguante psíquico. La neurosis llama a la puerta del creyente, para lo cual solo encuentra una salida: escapar, huir del introspectivo examen de sí mismo que es la preparación a la confesión: «ainsi qu'une bête traquée qui se croit découverte, il se dressa et, perturbé par la peur, emporté par un vent de déroute, il songea à fuir, à aller chercher sa valise, à s'élancer dans un train». ${ }^{699}$ Abandonar la posibilidad de su salvación habría sido una solución acomodaticia. Su entrada en la religión le ofrece una posibilidad de perdón. Ahora bien, entrar en el mundo de Dios significa plegarse a sus exigencias, soportar el castigo, prometer no recaer. Si Durtal cree necesario convertirse es por una necesidad interior de reconciliación: con la otrora denostada figura paterna, a quien busca entre los cantos gregorianos y la humildad de las capillas románicas. Pero, al buscar y no encontrar, es lógico que su voluntad flaquee, pues necesita el apoyo de quien ha venido a buscar. El dolor ante la imposibilidad de reconciliación por faltar a su cita es enorme. La noche oscura del alma hace presa en Durtal:

atterré aussi de se trouver ainsi abandonné, sans un mot de tendresse, sans un secours. Il lui semblait que tout croulait, qu'il était perdu, repoussé par Celuilà même qui l'avait pourtant envoyé dans cette abbaye. ${ }^{700}$

Pero este es tal vez otro tema.

En La Cathédrale, la evolución de la libido es más estable que en las obras precedentes. Parece que la fuerza de la liturgia y el ejercicio de la oración permiten a Durtal sublimar toda su energía sexual. La llamada del instinto es más silenciosa que antańo; tan solo el recuerdo le fustiga: el dolor de las faltas cometidas le sugiere un símil de procedencia poesca. Como en el relato de Poe, por el interior de Durtal vaga esa presen-

698 Ib., p. 322.

699 Ib., p. 323.

700 Ib., p. 325. 
cia maléfica, que en La caída de la casa Usher está representada por la hermana y, en Durtal, por los reproches maternos:

chez Durtal, les châteaux de l'âme étaient inhabités comme après un long deuil; mais dans les pièces encore ouvertes, circulait, ainsi que la sœur de l'inquiétant Usher, le fantôme des péchés avoués, des fautes mortes. ${ }^{701}$

Esta referencia a las moradas de Santa Teresa nos es muy útil para introducir uno de los temas más recurrentes de toda la obra huysmansiana, y en el que se concentran todos los miedos y todas las angustias ante la actividad sexual. El castillo, la casa, pero sobre todo, las mazmorras, son escenarios que acompañan frecuentemente la comisión del acto erótico. Mazmorras preferentemente inundadas o chorreantes de aguas estancadas.

\subsubsection{Angustias líquidas}

Uno de los campos semánticos de que Huysmans extrae con mayor frecuencia sus tropos es, sin lugar a dudas, el campo hídrico. Aguas, miles de aguas y líquidos, pueblan el imaginario huysmansiano cobrando una importancia decisiva en la construcción de sus escenarios. Su aparición es incluso más recurrente que la de términos del campo semántico de la alimentación — tan frecuente en, por ejemplo, À rebours. Este último caso podría comprenderse, sin querer por ahora entrar en profundizaciones que requirieran de largas observaciones, mediante una explicación gástrica: las molestias producidas por la dispepsia fueron tan intensas a lo largo de toda su vida que sus problemas de alimentación fueron un fecundo campo de referencias.

Ahora bien, el campo semántico del agua es utilizado por razones que vienen muy al caso de lo que hemos venido tratando hasta el momento. La fijación a la madre es perfectamente detectable en la obsesión de nuestro escritor por las metáforas líquidas. La relación que se puede establecer entre la instancia materna y el líquido elemento es, de tan clara, lugar común de los estudios literarios con vocación psicologicista. Uno de los críticos que con mayor imaginación y originalidad han estudiado la relación entre la psicología, la imaginación creadora y el agua es, sin ningún lugar a dudas,

701 J.-K. Huysmans, La Cathédrale, ob. cit., p. 40. 
el erudito francés Gaston Bachelard. En su celebrada obra L'eau et les rêves desarrolla todas las posibilidades que ofrece al trabajo de la imaginación el recurso a los líquidos. Para resumir e intentar ir al grano lo más directamente posible, diremos que, según Bachelard, la relación que el individuo establece entre el agua y la madre es de carácter netamente orgánico, estableciéndose una especie de "gramática de las necesidades" entre la comprensión que el niño hace del asunto hídrico: «tout liquide est une eau; ensuite toute eau est un lait» — sostiene el francés. ${ }^{702}$

Más adelante en su obra, Bachelard ilustra sus convicciones sobre el líquido elemento mediante ejemplos de la literatura: La Mer de Michelet no es sino el símil sensible de la alegría del chaval ante el acopio de alimento que le propone el generoso seno materno, que le lleva incluso a reconocer en el contorno de la costa el perfil de un pecho de mujer. Bachelard exclama asombrado que cómo es posible que el escritor haya entrevisto un seno femenino si no hubiera sido previamente subyugado por una fuerza de la imaginación material, por la imagen substancial de la leche. ${ }^{703}$

Con otros ejemplos extraídos de la obra de Poe y de Claudel, Bachelard concluye definitivamente que el vínculo que el escritor adulto siente con tan recurrentes metáforas es de orden materno: «l'eau nous porte. L'eau nous berce. L'eau nous endort. L'eau nous rend notre mère». ${ }^{704} \mathrm{El}$ agua nos acerca a nuestra madre - y esto para mal o para bien.

El recurso de Huysmans a la imaginación substancial acuática revestirá más bien el segundo tipo de connotación: colectores, cloacas, alcantarillas, aguas putrefactas y sin posibilidad de saneamiento discurren por la obra de nuestro autor. Casi todas las cosas que él considera negativas en su poética tienen una relación directa con el agua. Lejos de lavarle de la suciedad de la vida y del contacto con los demás, las aguas le depositan en un mundo de dolores y angustias. Veamos, como muestra, esta confesión que le hizo

702 G. Bachelard, L'eau et les rêves. Essai sur l'imagination de la matière, Librairie José Corti, París, 1942, p. 158.

703 Ib., p. 160. El texto de Michelet a que hacemos referencia reza así: «De ses caresses assidues, arrondissant le rivage (la mer) lui donna les contours maternels, et j'allais dire la tendresse visible du sein de la femme, ce que l'enfant trouve si doux, abri, tiédeur et repos».

704 Ib., p. 178. 
a su amigo Georges Landry en enero de 1891 — a punto de terminar la redacción de $L \grave{a}$-bas_ a propósito de su necesidad imperiosa de contarle sus pecados a un sacerdote:

Mais quels phénols, quelles solutions cuivrées assainiront le grand collecteur où mes saletés charnelles gargouillent? Faudrait des muids, faudrait des foudres de désinfectants; et quel Milleriot pourrait manœuvrer une assez extraordinaire pompe pour extraire ces eaux résiduaires des vieux égoûts? N'y en a plus de pompiers divins, que de tels labeurs réjouissent. Ainsi, vieux frère, il n'y a pas de raisons pour que cela cesse. ${ }^{705}$

Como podemos observar, el vocabulario acuático al que recurre tiene unas connotaciones en todo diferentes a las de un Michelet en relación con el agua de su mar. La riqueza del vocabulario huysmansiano en lo referente a aguas fecales es inmensa; una riqueza que parece extraída del interés puesto en caracterizar negativamente el recuerdo material del seno materno. Tratándose toda su obra de un intento desmedido por recuperar y reconstruir la historia de su vida, el tratamiento que Huysmans hace de las aguas es todo lo contrario de depurativo: hay en él un deseo expreso y recurrente de ensuciar ese recuerdo. Podríamos calificarlo de venganza acuática.

Ya en una obra de la primera época, las aguas sucias del extrarradio parisién llamaron la atención del escritor naturalista. Parecía que en ese pasaje tan curioso de Croquis parisiens titulado "La Bièvre», Huysmans se limitaba a describir el escenario del mundo obrero degradado tan caro a los epígonos de la escuela zoliana. Sin embargo, su croquis excede la mera pintura de paisajes y se extiende de manera morbosa en la suciedad de ese pequeńo curso de agua. El agua del río es un pozo de enfermedades y de males, que lleva en sí misma un estigma inlavable:

étrange rivière, cet exutoire de toutes les crasses, cette sentine couleur d'ardoise et de plomb fondu, bouillonnée ça et là de remous verdâtres, étoilée de crachats troubles, qui gargouille sur une vanne et se perd, sanglotante, dans les trous d'un mur? Par endroits, l'eau semble percluse et rongée de lèpre; elle stagne, puis elle remue sa suie coulante et reprende sa marche ralentie par les bourbes. ${ }^{706}$

705 Citado por R. Baldick, ob. cit., p. 215.

706 J.-K. Huysmans, Croquis parisiens, ob. cit., p. 84. 
Diríase que el escritor no se limita a contar las consecuencias del lavado de toda la industria banlieusarde en las aguas de este río. No. Hay, en su descripción, ánimo de señalar lo más asqueroso del afluente del Sena.

Mucho más lejos en la cronología de la obra huysmansiana encontramos otro ejemplo en que las aguas toman un sentido notoriamente putrefacto. Las aguas del Drac, el río de montaña por el que discurre el camino que asciende al monasterio de la Salette, son tan multicolores como las del pobre río suburbano. Las transformaciones que sufre el Drac en su tránsito por las gargantas y los desfiladeros son tales que las aguas son tan pronto blancas de cal, grises color de acero, brillantes por la acción del sol... Lo más interesante de este ejemplo —y lo más revelador- es el peligro que nuestro escritor asocia con su transcurrir por esas rocas. La connotación negativa que aplica a las aguas hace que todo lo que le rodea adquiera la misma consideración; así, el desfiladero tórnase colmillos, las rocas son envenenadas por dentadas..:

serpent liquide qui rampait et se tordait, colossal, entre des rocs, ainsi qu'entre les crocs d'un gouffre.

Par instant en effet, ce reptile se redressait, se jetait sur des quartiers de rochers qui le mordaient au passage, et, comme empoisonnées par ce coup de dents, les eaux changeaient.

Imágenes vivas del miedo a una agresión cumplida por dientes y colmillos. Los desfiladeros se convierten en el escenario del ataque de una boca dentada y peligrosa, cuyos rugidos de fiera hambrienta sumen a nuestro autor en el más profundo de los miedos. No es extraño, tras esto, que Durtal la tome con el Drac, calificándolo de pozo inmundo portador de todas las enfermedades:

il est hideux, pensait Durtal; cette rivière de bile doit charrier des fièvres; elle est maléficiée, pourrie, avec ses plaques savonneuses, ses teintes métalliques, ses fragments d'arc-en-ciel, échoués dans des boues! ${ }^{107}$

El maleficio parece haber sido conjurado mediante el simple insulto, mediante la pintura ignominiosa. El miedo a los dientes ha sido expulsado de la imaginación del escritor.

707 J.-K. Huysmans, La Cathédrale, ob. cit., pp. 13 y 15. 
Charles Bernheimer, uno de los estudiosos más agudos de la psicología huysmansiana, apreciará en el tratamiento de las aguas el germen de su horror por la sexualidad femenina. El mayor problema que las aguas encierran para nuestro autor reside en el hecho, según Bernheimer, de que ni ellas ni la libido de la mujer pueden ser contenidas ni dominadas: el agua "s'étend, elle suinte, elle saigne, elle s'infiltre, elle ronge». ${ }^{708} \mathrm{El}$ agua posee una acción corrosiva que espanta al escritor, una de cuyas manifestaciones es el odor di femina que exhala esa herida maloliente de la que Huysmans no puede desviar su mirada.

El origen de esta obsesión se encuentra en la convicción de que la madre ha sido castrada, y que tanto líquido que chorrea a borbotones solo puede tener como motivo la hemorragia causada por la mutilación. Según Bernheimer, este hecho crea un traumatismo en la psicología de Huysmans de suficiente intensidad como para empujarle a llevar a cabo la totalidad de su obra literaria; la liberación de tal fantasma sólo podrá conseguirse mediante su sublimación decidida. Ya que el descubrimiento de la castración de la madre le anuncia la posibilidad de su propia castración. Por eso toda esa agua le resulta secretamente dolorosa.

Un sentido paralelo vienen a proponer las consideraciones de Simone de Beauvoir sobre la sangre menstrual y las «tinieblas secretas de la mujer»; en ellas gran cantidad de jóvenes amantes se encuentran de nuevo con sus temores infantiles: grutas, sepulcros, mandíbulas, hoces, trampas...; «ils imaginent que leur pénis gonflé restera pris dans le fourreau des muqueuses». ${ }^{709}$ Una afirmación que hace del miedo al odor di femina algo universal.

Y es que las aguas suelen acompañar, en la poética de Huysmans, un acontecimiento de orden sexual. Su aparición indicaría, pues, y de manera fantasmática, el temor latente que el amante siente ante su acoplamiento con la fémina. Los ejemplos en En ménage — obra que inicia la soltería militante de nuestro heterónimo ficcional- son bastante elocuentes en este sentido. Recordemos, brevemente, que esta novela comienza con el descubrimiento por parte de André Jayant de la infidelidad de Berthe, su mujer,

708 C. Bernheimer, «L'exorbitant sexuel: castration et sublimation chez Huysmans», ob. cit., pp. 105-111.

709 S. de Beauvoir, Le deuxième sexe, ob. cit., vol. II, p. 164. 
y termina con su vuelta al hogar conyugal, harto de buscar un bienestar inencontrable y aceptando estoicamente los reveses de su fortuna amorosa. Así, cuando de vuelta a los brazos de Berthe, André la besa, el acto de reconciliación está presidido por un sintomático jarrón de agua. ¿Escenografía dramática? No: escenografía fantasmática: «Il embrassa sa femme devant la glace, au-dessus du pot à l'eau». ${ }^{710}$ Otro caso tan sintomático del horror acuático de nuestro escritor como el anterior lo encontramos cuando se da cita en un café con Blanche, una profesional de las caricias con la que André esperaba calmar su "crisis faldera». Se sientan ambos en torno a una copa y, como para estudiar el campo de operaciones, André deja caer su librillo de papel de fumar debajo de la mesa. Podemos observar en esta extrańa iniciativa una acción que sería reseñable dentro del repertorio de un fetichista. André mira, pues, bajo las piernas de la prostituta, ¿en busca de qué? Lo importante es que al recuperar su librillo lo halla completamente impregnado de los escupitajos que cubrían el suelo: «Il le ramena, trempé par les salives qui baignaient le plancher». ${ }^{711} \mathrm{La}$ experiencia es, cuando menos, repugnante, pero muy interesante desde el punto de vista de nuestro examen. El fetichista busca bajo las piernas de la mujer los genitales perdidos por la madre, y encuentra, como consecuencia de esa castración, el objeto secante manchado de una sustancia blanquecina y viscosa. Los líquidos pierden, para la imaginación material, toda identidad y se refieren exclusivamente a lo que sugiere el fantasma: la sangre de la herida. La saliva se convierte en una llamada de atención, en una alerta a lo que puede sucederle al amante en ciernes.

Las heridas tienen, en el imaginario huysmansiano, una amplia panoplia de recurrencias. Por una parte, en ellas se puede encontrar el rastro de la sorpresa del niño ante la pérdida del atributo fálico en la madre; en este caso, la herida se convierte en una llaga abierta, mayormente purulenta, que destila sin cesar líquidos de colores intensos y olores inéditos. Un ejemplo paradigmático de esta profusión de líquidos y colores la hallamos en $L \grave{a}-b a s$, en la primera descripción que encontramos sobre el Cristo de Grünewald. Asistimos, en la descripción de ese cuadro, a una delectación morbosa y enfermiza ante la contemplación de ese río de sangres y hu-

710 J.-K. Huysmans, En ménage, ob. cit., p. 363.

711 Ib., p. 191. 
mores, que se convierten en zumos de frutas y llegan hasta el vientre, donde el "cartel hervido" del trapo del taparrabos recoge todo el flujo, ávido, sediento.

L'heure des sanies était venue; la plaie fluviale du flanc ruisselait plus épaisse, inondait la hanche d'un sang pareil au jus foncé des mûres; des sérosités rosâtres, des petits-laits, des eaux semblables à des vins de Moselle gris, suintaient de la poitrine, trempaient le ventre au-dessous duquel ondulait le panneau bouillonné d'un linge. ${ }^{712}$

La herida tiene, en su relación con Cristo y su pasión, el sentido de la expiación necesaria de todos los pecados cometidos. El hijo de Dios, el hijo de Nuestra Señora, es un hombre, y su encarnación no podía por menos que conllevar la condena de su humana condición. La herida del hijo es el efecto de la castración, es la llaga que queda tras la mutilación, deseada, esperada, puesto que el atributo fálico es el que carga con la culpa del niño.

El mismo efecto se observa en la descripción de lo que llamaremos el delirio silvícola de Gilles de Rais, por el cual, durante su paseo alucinado por un bosque de Tiffauges, observa cómo explotan en los árboles las úlceras, las llagas, las caries: todo un inventario de heridas aplicado a una "clínica venérea» de los árboles —al cabo de la cual aparece, como una señal, un haya roja:

Il constate des exostoses et des ulcères, des plaies taillées à pic, des tuberculles chancrelleux, des caries atroces; c'est une maladrerie de la terre, une clinique vénérienne d'arbres dans laquelle surgit, au détour d'une allée, un hêtre rouge. ${ }^{713}$

Extraño y enigmático pasaje a través del cual Gilles aspira a la expiación de sus culpas - o, más bien es Durtal quien, al hacerle pasar por esa prueba, cree poderle salvar de la ignominia de sus acciones. Pero detengámonos un instante en este pasaje, pues es interesante analizar uno de sus elementos. Fijémonos en que el bosque es una clínica en que se curan o se tratan las enfermedades de índole sexual: enfermedades que han producido todo ese abanico de heridas. Y, enigmática presencia, un árbol rojo destaca al doblar una esquina del bosque. Rojo de sangre, sin duda, atrapado entre

712 J.-K. Huysmans, Là-bas, ob. cit., p. 10.

713 Ib., p. 159. 
las peligrosas mucosas de la llaga femenina, de esa vagina dentata ${ }^{714}$ que existe no solo en el recuerdo del sexo materno, sino en toda hendidura susceptible de albergar el acto sucio por excelencia.

También en $L \grave{a}$-bas encontramos otros ejemplos en que la imaginación doliente de Huysmans se extasía en la contemplación de la sexualidad desviada. No olvidemos que toda esta novela gira en torno a esa búsqueda de lo nuevo, de lo alternativo, de lo delicuescente, que estimulara la imaginación ya blasée, de vuelta de todo, del cuarentón Durtal. Así, el narrador describe lo que llama Durtal la "misa del esperma», que no es sino uno de los variados actos que encierra la celebración de una misa negra. Su realización es como sigue: una mujer indispuesta deposita parte de sus menstruas en un cáliz, del que se apodera un hombre para mezclar con ella su esperma; la sacerdotisa se va recogiendo esta pasta untuosa para utilizarla con fines mágicos.

Cette femme qui était indisposée donna de son sang; l'homme qui l'accompagnait se retira dans la ruelle de la chambre où se passait la scène et Guibourg recueillit de sa semence dans le calice; puis il ajouta de la poudre de sang, de la farine, et après des cérémonies sacrilèges, la Des Oeillets partit emportant sa pâte. ${ }^{715}$

Todo se resume en llagas, sangres, fluidos... Una colección de líquidos que indican lo enfermizo de las prácticas corporales, teñidas siempre de un aura de crimen, de sacrilegio. Asesinato o castigo acometido sobre la intimidad de la madre, por cuya comisión el individuo se ve poseído por la presencia maligna del padre demonizado. Como dice de Gilles de Rais, ¿acaso no es necesario que el alma de Durtal supure para que el maligno pueda vivir a gusto en su interior?: «Ne fallait-il pas que l'âme de Gilles purulât, pour qu'en ce rouge tabernacle, constellé d'abcès, le Très-Bas pût habiter à l'aise?». ${ }^{716} \mathrm{La}$ interiorización que el niño Huysmans hizo de su padre posteriormente a su temprana desaparición — que pasaba, como hemos visto más arriba, por su demonización- explica todo este hecho. La reconciliación con la instancia paterna se va manifestando poco a poco en la imaginación de nuestro autor.

714 Vid. al respecto de este término, nuestros comentarios en el apartado 2.4.3. Asimismo, W. Lederer, La peur des femmes ou Gynophobia, ob. cit., p. 125, y F. Monneyron, "Le dandy fin de siècle: entre l'androgyne et le mysogine», ob. cit., p. 204

715 J.-K. Huysmans, Là-bas, ob. cit., p. 60.

716 Ib., p. 152. 
Los ejemplos en En route son también ilustrativos de esta obsesión humoral. El pecador que es ya Durtal considera su interior lleno de una extraña substancia purulenta, que saltará a la cara del confesor en cuanto empiece a narrarle sus detalles. Ahora bien, si se tiene en cuenta que esa supurante presencia es el resultado de su intercambio erótico con la prostituta Florence —cuyas prácticas le obsesionaban más allá de lo soportable-, cabrá atribuir a todo ese universo de pus y llagas, de nuevo, una naturaleza puramente femenina. El comercio con el sexo femenino produce un superávit de sustancia viscosa en el interior de la imaginación de Durtal: «je ne peux pourtant pas lui faire gicler à la face des filets de pus», se dice antes de someterse al dictado de su confesor; «mes abcès étaient mûrs, mais il fallait un coup de lancette pour les percer», ${ }^{717}$ comenta, vencedor, tras la exorcización de todos esos dolorosos secretos. Los humores purulentos son, pues, extraídos del comercio con la mujer — que, como extensión de la madre, solo puede provocar en este doliente amante sentimiento de culpa.

Prueba de la reconciliación con la madre, necesaria a la estabilidad emocional del heterónimo ficcional, es el cambio de perspectiva en la consideración de la herida materna que se da en Sainte Lydwine de Schiedam, de 1901. En esta obra de carácter puramente hagiográfico, Huysmans se detiene, delectándose, en la descripción con todo detalle de todas las heridas que manan del cuerpo de esta santa holandesa. Ahora bien, la diferencia con respecto a la producción traumática anterior es que, ahora, las heridas no son necesariamente dolorosas, ni fruto de una relación pecaminosa con cualquiera de las otras dos instancias del triángulo edípico. Se trata, en esta caso, de una consideración mística del hecho libidinoso, claramente acorde con la reconsideración tanto de la figura del padre como de la madre. La invasión del cuerpo de esta es llevado a cabo ya no por una instancia dictatorial, que sería la del amo, sino por Dios. Como indica Simone de Beauvoir, Dios es una alternativa a la figura del amo y no un nuevo disfraz de este. ${ }^{718}$ De esta manera, la experiencia mística, y esta vez de acuerdo con Françoise Collin, está basada en la superación de la relación de dominación y servidumbre que caracteriza a la relación sexual. ${ }^{719} \mathrm{La}$ experiencia

717 J.-K. Huysmans, En route, ob. cit., pp. 322 y 326.

718 S. de Beauvoir, Le deuxième sexe, ob. cit., vol. II, p. 585.

719 F. Collin, "Nom du père. On de la mère. De Beauvoir à Lacan», Lectora. Revista de Dones $i$ Textualitat, Universitat Autònoma de Barcelona, Barcelona, 1998, p. 27. 
mística escapa a la sumisión, y resulta ser una liberación. «Au lieu de s'abandonner, ainsi que jadis, au désespoir, elle remerciait Dieu d'étancher enfin sa soif de tortures» ${ }^{720}$ — apunta Huysmans sobre los tormentos que el Altísimo inflige a su sierva. El castigo existe, pero resulta ser una expiación necesaria — sobre todo para la consideración de lo femenino por parte de nuestro autor, quien, por fin, acepta el componente libidinoso de su unión con una instancia masculina.

De ahí que Lidwina goce de su herida; de ahí que — aunque se trate de una literatura, las historias de santos, completamente estereotipadaHuysmans le permita disfrutar del tormento que, para él, significa la experiencia sexual. Por eso mismo Huysmans la contempla con piedad, con afecto y sin atisbo de deseos de flagelarla. En Lidwina no solo se realiza la expiación de los pecados de todo el mundo — los del escritor incluidos-, sino que el dolor de su herida ya no es percibido por Huysmans como una condena, sino como su salvación.

Los ejemplos en esta obra son numerosos. Desde los casos en que Lidwina se convierte en un depósito de agua — un agua que le viene, no podía ser de otra manera, del Altísimo: «il la mua en un squellette et bomba sur cette consternante maigreur le dôme ridicule d'un ventre rempli d'eau; il la promut, pour ceux qui ne voient que les apparences, hideuse»; ${ }^{721}$ ya sea conviertiendo su alma en líquido: «Jésus saisit l'âme pour la liquéfier dans la forge de l'Amour et la verser, alors qu'elle entre en fusion, dans le moule nuptial de sa croix». ${ }^{722}$ Otros casos en que, maravillas del amor divino, las heridas y las llagas se convierten en pebeteros e incensarios, mientras que todas las excrecencias — vómitos y pus— se tornan aromáticos néctares:

en un constant miracle, il fit de ces blessures des cassolettes de parfums; les emplâtres que l'on enlevait, pullulant de vermines, embaumaient; le pus sentait bon, les vomissements effluaient de délicats arômes. ${ }^{723}$

La aguas, en el imaginario colectivo, suponen una regresión insoportable para el desarrollo de la masculinidad. Tras haber sido sometido a tan-

720 J.-K. Huysmans, Sainte Lydwine de Schiedam, Plon, París, 1952, p. 70.

721 Ib., p. 53.

722 Ib., p. 56.

723 Ib., p. 54. 
tas pruebas que atestigüen su virilidad, el macho de la especie considera todo lo femenino como una vuelta atrás, como una vuelta al útero materno que le impedirá alcanzar la independencia necesaria a su emancipación. Como en las leyendas griegas, el «sueño de la quietud» es simbolizado por el hecho de ahogarse — que no deja de ser una metáfora universal de retorno al vientre femenino. David Gilmore, en su estudio antropológico sobre los ritos de iniciación a la masculinidad, observa la profusión de símbolos acuáticos que aparecen en, por ejemplo, el Tannhäuser de Jobst Gutknecht: en el momento en que el héroe debe decidirse entre quedarse con Venus en Venusberg en una eternidad de placeres y volver a la Tierra con sus peligros y conflictos, aparecen multitud de cuevas húmedas, estanques turbios y cascadas neblinosas que le alertan sobre ese «sueño de la quietud». ${ }^{724} \mathrm{El}$ peligro de regresión queda puesto de manifiesto, lo que significaría acabar de una vez por todas con la independencia y el poder masculinos - y, por qué no, con la vida. Otro ejemplo de regresión propuesto por Gilmore en que la regresión es equiparada con la muerte se da en el Bartleby, el escribiente de Herman Melville: el malogrado funcionario termina muriendo en un subterráneo llamado "the tumbs» — cuya cercanía fonética al término "wombs», úteros, es sintomática. ${ }^{725}$

Bachelard también incidirá en este punto, señalando que las aguas estancadas evocan a los muertos: las aguas inmóviles son las aguas durmientes. Solo gracias al sueño los vivos somos capaces de acceder a ese mundo más profundo que el mismo recuerdo que tenemos de nuestros difuntos; entonces podemos encontrarnos con nuestros seres queridos que han desaparecido, en ese reino de la noche al que accedemos mediante los sueños. ${ }^{726}$

Las aguas estancadas tienen, en la obra de Huysmans, una presencia constante que testimonia su carácter obsesivo. El peligro, no solo de regresión, sino de contacto con este símbolo de la naturaleza femenina se revela como una de las fuentes más prolíficas de metáforas creadoras de escenarios fantasmales.

724 D. D. Gilmore, ob. cit., pp. 48-49.

725 Ib., p. 114.

726 G. Bachelard, ob. cit., p. 90. 
Ya en Croquis parisiens aparecen ejemplos de esta obsesión acuática, digna de las mejores pesadillas y de las más tenebrosas puestas en escena del complejo de castración huysmansiano. Así, en la «Paraphrase» titulada "Cauchemar» aparece «un paysage atroce, un marais d'eau stagnante, morne et noire», agua tenebrosa de entre la que destaca un doloroso y monstruoso tallo: "de cette eau enténébrée, sous ce ciel opaque, jaillit soudain la monstrueuse tige d'une impossible fleur». La polución es anunciada por esta súbita estimulación onírica. Sin embargo, el episodio se convierte en pesadilla por la prohibición paterna que subyace a todo contacto con la instancia materna. En medio de este escenario, el estanque se convierte en una especie de bóveda con columnas, depósito de agua, catacumba acuática habitado por un ensordecedor silencio sepulcral, movido por un viento glacial de túnel. Estas aguas muertas solo podían provocar el más terrible de los miedos en la persona del soñador. La regresión y el incesto se convierten en leitmotiv principales de la reparación literaria de la obra huysmansiana.

Une nappe d'eau, teigneuse et sourde, mais sans firmament cette fois, une nappe d'eau baignant un immense bassin, un gigantesque réservoir à colonnes [...] Un silence de sépulcre tombait des voûtes; un jour fade filtrait par le verre dépoli des hublots cachés; un vent glacé de tunnel vous fripait les moelles et, dans cette solitude, une peur irrépressible, intense, vous clouait, haletant, sur la banquette de pierre qui s'étendait, ainsi qu'un quai, le long de cette eau morte. ${ }^{727}$

En En route, los ejemplos relacionados con las aguas muertas abundan. Y no podía ser de otra manera, pues es esta obra una profunda reflexión sobre la posibilidad de reconciliación a través de la religión, la confesión y la expiación, con las figuras del triángulo edípico. Recordemos que, en todos los paseos que Durtal da a lo ancho y largo del jardín conventual pasan por ese gran estanque que domina el locus amoenus monacal. En torno a este estanque, Durtal desarolla una ilustradora teoría acerca de las diferencias entre las aguas móviles y las inmóviles y su influencia sobre el ánimo de quien las observa. Señala Durtal que el río es el símbolo de la vida activa, pues fecundaba a lo largo de todo su recorrido antes de ir a morir al mar, ese sepulcro abierto («sépulcre béant des mers»). ${ }^{728}$ Pero, el estanque, agua hospitalizada, encarcelada entre los juncos que lo delimitan.., tiene como única función observar el silencio y reflejar el cielo sin tregua.

727 J.-K. Huysmans, Croquis parisiens, ob. cit., pp. 148 y 150.

728 J.-K. Huysmans, En route, ob. cit., p. 449. 
"L'eau sédentaire m'inquiète», exclama Durtal, añadiendo que todas las cosas que refleja se las apodera, sin devolverlas: «cette eau est pleine et non pas vide comme celles qui se distraient, en voguant dans les campagnes, en baignant les villes». ${ }^{729}$ Una de las cosas que refleja con mayor asiduidad es, como lo atestigua también En route, es la Luna, que fertiliza las aguas con una "myriade de poissons d'or». ${ }^{730}$ Aguas fecundas que terminan siendo venenosas por acción del reflejo de la Luna: para Paracelso, la Luna impregna la sustancia del agua de una influencia deletérea. Y así lo señala Bachelard valiéndose de nuevo de Michelet: «la Lune donne à ceux qu'elle influence le goût de l'eau du Styx». Nadie se despierta indemne tras haber dormido cerca de un agua durmiente. Se trata de una «ofelización» - en relación con el personaje del drama de Shakespeare Hamlet-, pues en esa agua nocturna reposan todas las potencias de la noche y de la muerte. ${ }^{731}$

Ese es el poder que se le confiere en este pasaje de La Cathédrale en el que Durtal compara el interior de su alma con las habitaciones vacías y gélidas de la casa Usher, que cualquier día las aguas de un estanque acabarían por ocupar: «un étang dont les brouillards finissaient par pénétrer, par fêler la coque usée des murs». Aguas ennegrecidas y envenenadas, «eaux noires de cet étang de péchés qui minait les murs»: ${ }^{732}$ pecados de los que Durtal no puede deshacerse - y menos en su relación con el mundo acuático, su mundo de perdición en la culpa y el remordimiento fantasmáticos.

En realidad, la casa, símbolo onírico que por excelencia se relaciona con la madre, aparece en la obra de Huysmans como muy frecuentemente asociada al agua. Este aspecto no haría sino acercar ambos elementos (agua y casa) a una común naturaleza femenina.

Si la casa está poblada por el agua, esto puede resolverse mediante esta existencia de aguas subterráneas, que ya hemos estudiado, o mediante la asociación directa de los tabiques y las paredes de la casa al líquido elemento. En este caso, los muros poseen una porosidad extrema, de tal manera que rezuman agua y le mojan a uno las manos con su contacto.

729 Ib., p. 450.

730 Ib., p. 505.

731 G. Bachelard, ob. cit., p. 123.

732 J.-K. Huysmans, La Cathédrale, ob. cit., pp. 39 y 43. 
Consiste este fenómeno en una curiosa licuefacción que sufren las paredes de la casa como si estuvieran sometidas a un proceso de descomposición. Una descomposición cercana a la psicología de la herida mediante la cual el cuerpo materno alcanza la purificación a través de su cambio de estado.

Esta porosidad está frecuentemente asociada, en las novelas de Huysmans, a pasajes en los que la acción está levemente teñida de carácter sexual. Un ejemplo mayúsculo de esta porosidad de una casa en descomposición, en el que el edificio simboliza la putrefacción de un cuerpo femenino -el de Louise - lo hallamos, sin duda alguna, en esa gran novela de interiores húmedos que es En rade.

El primer ejemplo lo encontramos desde el primer momento en que Jacques y Louise entran en la que será su mansión de vacaciones, el castillo de Lourps - donde, como ya sabemos, no solo Huysmans situó el domicilio heráldico de la familia de des Esseintes, sino lugar de veraneo de nuestro escritor, a la vera de Anna Meunier, durante tres años.

Ils pénétrèrent dans un couloir de prison. Aux lueurs d'une allumette qu'il fit craquer, Jacques aperçut d'énormes murailles en pierre de taille, fuligineuses, trouées de portes de cachots, surplombées d'une voûte en ogive, abrupte, comme taillée dans le roc. Une odeur de citerne emplissait ce couloir dont les carreaux de pavage oscillaient à tous les pas. ${ }^{733}$

Retengamos ese primer elemento, "olor de cisterna», que no hace sino confirmar la naturaleza de depósito acuático del castillo. Más adelante en la novela, Jacques es despertado de un sueño por unos extraños sonidos. Salta de la cama con un paquete de cerillas en la mano y se adentra con afán explorador en las tinieblas de la casa. Al llegar al ruinoso comedor, la tenue luz del fósforo le permite contemplar el estado de las paredes, completamente invadidas por la humedad, los mohos y las deformidades de la enorme porosidad de la vieja mansión:

des fleurs de moisissure jaspaient les cloisons arborisées par des fissures et les dalles alternées, blanches et noires, du pavé, se délitaient, tantôt bossuées et tantôt creuses.

Il ouvrit encore une autre porte, pénétra dans un salon immense, sans meubles, percé de six fenêtres barricadées de volets autrefois peints; l'humidité avait positivement éboulé les lambris de cette pièce. ${ }^{734}$

733 J.-K. Huysmans, En rade, ob. cit., p. 47.

734 Ib., p. 64. 
Todo, absolutamente todo estaba invadido y demolido por la humedad ambiente. La casa está, según el entender de Jacques, profundamente enferma, aquejada sintomáticamente de las mismas enfermedades que podrían aplicarse a una persona: vejez, catarro, fístulas, lepra... Es decir, la casa y la mujer encuentran en la obsesiva imaginación de nuestro autor una perfecta asociación. La misma repugnancia y el mismo temor que siente por la una los siente por la otra:

infirmités d'une vieillesse horrible, l'expuition catarrhale des eaux, les couperoses du plâtre, la chassie des fenêtres, les fistules de la pierre, la lèpre des briques, toute une hémorragie d'ordures, s'étaient ruées sur ce galetas qui crevait seul à l'abandon, dans la solitude cachée du bois. ${ }^{735}$

En otro ejemplo, esta vez extraído de La Cathédrale, el sentido erótico de la porosidad se ve más claramente. Durtal sube la escalera de la casa del abbé Gévresin, en Chartres, donde este santo varón vive en la única compañía de su gobernanta, Mme. Bavoil —de quien ya habíamos subrayado su appel maternal en el imaginario del heterónimo de la serie iniciada con Là-bas. Pues bien, la casa de estos dos beatos individuos reviste, a ojos de la imaginación fantasmática de Huysmans, el carácter de escenario de la dicha en la familia. Una familia únicamente compuesta por el padre y la madre donde él, el escritor abandonado, es aceptado en calidad de hijo adoptivo y bienamado. Esa casa es, pues, el lugar donde al niño se le permite contemplar — siempre desde un punto de vista fantasmático, pues no es sino el deseo oculto e inconsciente de Huysmans - la unión carnal de sus progenitores imaginarios. La casa, por eso mismo, rezuma agua, agua envejecida, que deja regueros y manchas como de orina. ¿Cabe mayor asociación con la cuestión genital?

Une indéfinissable odeur de vieille pomme et d'eau qui croupit s'échappait de la cage de l'escalier, précédé d'un court vestibule que pavaient des rangées de briques, couchées sur le flanc, rongées à la façon des madrépores, que plafonnait une sorte de carte de géographie, sillonnées de mers dessinées comme avec de l'urine par des infiltrations de pluie. ${ }^{736}$

Dentro de toda esta simbología líquida en la que se asocia las construcciones humanas con la humedad, el siguiente paso se produce a nivel

735 Ib., p. 75.

736 J.-K. Huysmans, La Cathédrale, ob. cit., p. 71. 
del pozo. El pozo es el instrumento preciso que sirve para entrar en contacto con la naturaleza líquida de la casa — que pervive oculta en las oscuridades de las mazmorras. Se trata esta de una obsesión por la profundidad que proviene en Huysmans de un temor desmedido a la castración en todo entorno invadido y dominado por el agua.

La enorme pesadilla acuática que es toda la novela de En rade gira en torno al carácter extremadamente húmedo del castillo de Lourps. Un castillo que, por sí mismo, poseía agua en sus bajos fondos, pues gracias a un pozo que había sido excavado en su patio se podía abastecer del fantasmático elemento: «'eau était rare à cette hauteur, qu'un gigantesque puits, creusé dans la cour, alimentait seul le château». ${ }^{737} \mathrm{Y}$ es que, por otra parte, el extraño sueño que discurre a lo largo del capítulo $\mathrm{X}$ de esta novela pasa, en uno de sus avatares, por la entrada del durmiente en un pozo. En él encuentra a una mujer a la que desea desesperadamente salvar de no se sabe qué peligro. El escenario cambia y el durmiente se halla en el interior de la torre de la iglesia de Saint-Sulpice, que se revela, finalmente, como un profundo pozo.

La referencia de St.-Sulpice nos comunica directamente con el domicilio del maestro campanero Carhaix, uno de los personajes faro de $L \grave{a}-b a s$. Recuérdese que, en una de las primeras ascensiones de Durtal a la torre donde reposan las campanas - a su vez fetiche de la madre entrevista desde la baja altura de un niño-, nuestro héroe se ve ligeramente afectado por una sensación de vértigo. Las vigas, las tablas, toda la estructura vertical de la torre, se le antoja a Durtal, finalmente, como un pozo. Sintomática asociación del fetiche materno con el agua cuyo recuerdo acompaña sin cesar:

en s'approchant, l'œil plongeait jusqu'au fond de l'abîme. C'était la vraie margelle en moellons d'un véritable puits; et ce puits semblait être en réparation, car l'échafaudage croisé des poutres qui soutenait les cloches paraissait être dressé, du haut en bas du tube, pour étayer les murs. ${ }^{738}$

Y es que el pozo comunica, como ya habíamos señalado antes, con las profundidades inundadas de las casas. Profundidades que adquieren carácter obsesivo y que son continuamente asociadas a ideas de muerte. Las aguas

737 J.-K. Huysmans, En rade, ob. cit., p. 50.

738 J.-K. Huysmans, Là-bas, ob. cit., p. 32. 
sepulcrales bañan la base de las casas, con todo lo que ello conlleva de peligro tanto para la construcción como para el habitante.

En esa casa atacada por la humedad que asciende día tras día por las paredes que es el castillo de Lourps, es inevitable que las habitaciones, incluso meticulosamente oreadas y limpias, huelan a bodega, a humedad, a muerte: «bien qu'on eût balayé la chambre et ouvert la fenêtre, une senteur de vieux bois, de plâtre mou, de filasse humide et de cave, s'exhalait de ce logis mort». ${ }^{739}$ En una exploración más atrevida, el panorama es desolador: la humedad se ha apoderado de todo. El agua mata los cimientos de la casa, el castillo es considerado como un sepulcro: «il aperçut d'immenses corridors, sans fond, sur lesquels se dégageaient des pièces; c'était l'abandon le plus complet, la glace du sépulcre, la dissolution des murs battus par le vent et les averses». ${ }^{740}$ Pocas páginas más adelante, Jacques vuelve a obsesionarse por la naturaleza semiacuática de la casa; el malestar se apodera de él y se siente como rodeado de agua por todas partes, como si acechara detrás de las paredes a invadir el resto de habitaciones intactas. Súbitamente, Jacques percibe a su mujer envejecida, invadida por los humores, castigada en su feminidad por la sed de venganza de su marido:

une indéfinissable sensation de malaise l'obséda; il lui semblait avoir derrière lui, dans l'obscurité, une étendue d'eau dont le souffle clapotant le glaçait.

Il se leva, secoua les épaules, s'expliquant ce frisson par la permanente humidité, par l'imperméable froid de cette pièce.

Il contempla sa femme; elle était étendue, décolorée, sur le grabat, les yeux mi-clos, vieille de dix ans par la brusque détente de ses nerfs. ${ }^{741}$

La mansión parisién de los Chantelouve reviste para Durtal un claro carácter sexual. En otras visitas que ya había hecho al domicilio de su amante y su marido el hagiógrafo, nuestro héroe se había visto solicitado sexualmente por Hyacinthe: no es extrańo que, al volver, le asalte el recuerdo de estos avances y tienda a relacionar el umbral de la casa con la excitación erótica. Por eso mismo la casa, también atacada por la porosidad propia de todas las viejas construcciones del París histórico, huele a tumba; es un olor a tumba, sin embargo, perfumada, con olor de sepelio aromatizado con incienso:

739 J.-K. Huysmans, En rade, ob. cit., p. 48.

740 Ib., p. 49.

741 Ib., p. 57. 
cette ancienne maison sentait l'eau des tombes, mais elle exhalait aussi une odeur cléricale, dégageait cette fleur d'intimité un peu solennelle que n'ont plus les bâtisses en carton-pâte de notre temps. ${ }^{742}$

Esta asociación casi positiva se podría explicar muy fácilmente si se tiene en cuenta que, poco a poco, Huysmans va buscando la reconciliación con la instancia femenina, con la figura materna. Esas profundidades comienzan a antojársele benefactoras, como habitáculo de lo más profundo que tiene la madre.

La mejor asociación positiva que Huysmans establece entre las profundidades y la bondad de lo sepulcral lo hallamos en La Cathédrale. El templo de Chartres es identificado una y otra vez con la residencia de la madre, de la renovada madre de Joris-Karl que es María la madre de Cristo. Los olores de bodega que antes eran percibidos por el heterónimo ficcional como vecinos de la muerte son ahora relacionados con la calma, con la dulzura, con la bondad de esa instancia femenina tan añorada y de la que se desea tan fervientemente el advenimiento. Por eso, cuando Durtal pasa por el contorno de la catedral, la brisa, en ese día ventoso, le acerca el aroma de las capillas subterráneas: "À Chartres, au sortir de cette petite place que balaie, par tous les temps, le vent hargneux des plaines, une bouffée de cave très douce...». ${ }^{743}$ Las profundidades del templo son redefinidas por Durtal como un lugar santo, donde la imagen de la Madre de todos los mortales es venerada. No solo por la imagen sino también —afirmamos— por el especial valor femenino que otorga a todo lo que es subterráneo, con aspecto o función de cripta, Durtal se despide de la Virgen visitándola en su espacio específico: la vieja capilla románica donde aún se conserva la tranquilidad de los viejos tiempos del cristianismo; donde los muros huelen a humedad; donde se puede respirar, puro, el paso del tiempo por esas paredes porosas; donde la muerte ha venido a instalarse definitivamente:

Et souvent avant de se séparer de la Mère, il voulait la visiter encore dans ses réduits, là où, depuis le Moyen Âge, les fidèles ne vont plus; et il allumait un bout de cierge, quittait la nef même, longeait les murs tournants du couloir d'entrée jusqu'à la sacristie de cette cave, et en face, dans la lourde muraille, s'enfonçait une porte treillagée de fer Il descendait dans un petit souterrain qui était l'ancien martyrium où l'on cachait jadis, en temps de guerre, la sainte châsse. ${ }^{744}$

742 J.-K. Huysmans, Là-bas, ob. cit., p. 161.

743 J.-K. Huysmans, La Cathédrale, ob. cit., p. 7.

744 Ib., p. 351. 
La apacible vivienda de la Madre huele a tumba: la iglesia se convierte, por acción de estos juegos de olores y de aromas, en el lugar natural de expiación para la atormentada imaginación de Durtal. Ha aprendido a convivir con la muerte, con los aromas de humedad y putrefacción:

l'église, devenue vide, effluait, mélangée à son odeur naturelle de tombe, le sédatif et le joyeux parfum des encens consumés et des cires mortes; elle symbolisait assez bien ainsi le sépulcre où la Vierge, ensevelie, s'éleva près de son Fils, dans les senteurs célestes et les chants. ${ }^{745}$

De la misma manera, ese otro templo de la felicidad en la tierra que es la casa de su familia de acogida — la casa de Gévresin y Bavoil, casa del Padre y la Madre_- las paredes huelen a tumba: «et le petit appartement de l'abbé, tendu d'un méchant papier neuf et carrelé de rouge, fleurait la tombe». ${ }^{746}$

La psicología de la tumba ha sido largamente tratada por algunos autores. Uno de los más relevantes en hacerlo ha sido la que fue traductora de Freud al francés, así como profunda comentadora de la obra de Edgar Poe: Marie Bonaparte. Una ortodoxa del psicoanálisis clásico, que vio en la profusión de lugares oscuros y cerrados del autor estadounidense síntoma de su sadismo.

Según Bonaparte, las frecuentes asociaciones que establece Poe entre un cuerpo encerrado en un continente — habitación, chimenea o bodega— están marcadas por una connotación anal: cuerpo en putrefacción, exhalaciones pestilentes de los lugares, subterráneos terroríficos, sadismo. ${ }^{77}$ Una connotación anal que tendería a operar en el sufriente escritor una obsesión de tipo regresivo: la regresión al útero materno es vivida como un enorme peligro.

Los líquidos en la obra de Huysmans — pues las reflexiones de Bonaparte acerca de Poe le son perfectamente aplicables - cumplen un papel de semáforo: el contacto con la mujer, el odor di femina, es la voz de alarma ante la posible regresión. Si tanto líquido rodea la cercanía femenina será, por una parte, porque la herida causada por la castración supura con profusión. La obsesión por las profundidades, el vértigo por todo lo vertical

745 J.-K. Huysmans, L'Oblat, ob. cit., p. 340.

746 J.-K. Huysmans, La Cathédrale, ob. cit., p. 71.

747 Vid. J. Chassenet-Smirgel, ob. cit.; y A. Clancier, ob. cit., p. 67. 
- ya sea ascendente o descendente- proviene del temor a ser engullido por la llaga sangrante y purulenta — lo que desencadenaría la regresión definitiva al útero de la madre, la no-vida, la castración completa.

Existe una posibilidad de escapar a todos estos miedos, que afirmamos que Huysmans supo tomar a tiempo. Si hacemos caso de lo que afirma Simone de Beauvoir, la asociación del útero con la tumba se produce en quien se niega a reconocer el origen materno de su existencia. ${ }^{748}$ Esto es algo que conocemos de sobra en el caso de nuestro escritor: niño expósito, su familia no es de este mundo. Le gustaría haber aparecido en el mundo como Atenea, completamente desarrollado, completamente armado, invulnerable. En ese espacio cavernoso, el sujeto-hombre pierde su pretensión de autonomía y su relación con la significación —añade Beauvoir.

En el caso de Huysmans, sostenemos que con su entrada paulatina en el ciclo religioso, se produce una reconciliación activa y efectiva con las instancias parentales que le permiten — cuando no le obligan a eso mismoaceptar siquiera que él fue concebido por una madre. La regresión es contemplada como un episodio deseable, pues con él se producirá la recomposición de la tan añorada familia del escritor.

El hijo vuelve a la madre mediante una regresión anal, acepta la castración, y se retira a un lugar de contemplación en el que vivir en la adoración de su padre y madre. Sencilla categorización de toda una vida de escritura al servicio de la búsqueda de una dolorosa emancipación; abandonada al final de sus días cuando la tensión libidinal disminuye y el escritor cree factible su emasculación definitiva.

Gaston Bachelard habla de la alcantarilla como metáfora del vientre infecto y asqueroso, de las que las persecuciones descritas por Hugo en Les Misérables son un estupendo ejemplo. «L'égout littéraire est création du dégoût», dice Bachelard ${ }^{749}$ con acierto, pues las manifestaciones del gran poeta

748 S. de Beauvoir, Le deuxième sexe, ob. cit., vol. II, p. 345. Comentado por L. Zerilli, «Un proceso sin sujeto: Simone de Beauvoir y Julia Kristeva, sobre la maternidad», en S. Tubert, Figuras de la madre, ob. cit., pp. 155-188.

749 G. Bachelard, La Terre et les rêveries du repos, José Corti, París, 1984, p. 253. Vid., asimismo, G. Durand, Les structures anthropologiques de l'imaginaire, Dunod, París, 1984, p. 130 y ss. Vid., también, G. Durand, Le décor mythique de la Chartreuse de Parme. (Les structures figuratives du roman stendhalien), ob. cit., p. 117, donde se ponen en relación la obsesión por el abismo y las consideraciones stendhalianas sobre el amor. 
romántico acerca de la repulsión temerosa que en él despierta la descripción de las aguas subterráneas son dignas comparaciones con este aspecto acuático de la obra huysmansiana.

\subsubsection{Regresión: erotismo anal}

Como ya sabemos, la fase anal es una de las tres descritas por Freud por las que atraviesa el desarrollo infantil. Es una fase en la que el goce está centrado en esa parte del cuerpo y sus funciones excretoras. Eso no significa forzosamente la consolidación de un deseo de relaciones eróticas anales: la socialización y la formación en la sexualidad reproductiva se encargan de desviar al niño de esas tendencias — con mayor o menor éxito.

Lo que nos interesa de la regresión anal es su aspecto de relación directa con la infancia de quien pretende una vuelta a ese estadio. Al ser la fase previa a la genital —en la que el niño adquiere conciencia de las capacidades lúdicas de su aparato reproductor- aún no se ha realizado la elección de objeto previa a la sexualización, al complejo de Edipo y a sus subsiguientes conflictos de orden psicosexual.

Es, por ello mismo, una fase de felicidad asexuada, en la que la unión con la madre todavía no se ha teñido de libido.

El psicoanálisis empezó a considerar las relaciones de la fase anal con la personalidad en el célebre ensayo de Freud El carácter y el erotismo anal, en el que describía la manera en que una determinada fijación del adulto a dicha fase entraña unas características fácilmente identificables con el orden y el metodismo de que hacen gala los pacientes así señalados. $\mathrm{O}$, por decirlo de manera más exacta, el orden, la economía y la tenacidad son los resultados más directos y constantes de la sublimación del erotismo anal. ${ }^{750}$

Erich Fromm, psicoanalista asociado a la Escuela de Frankfurt, describe en su obra Psicoanálisis y religión algunos síntomas de quien se halla fijado a este tipo de erotismo infantil. Afirma Fromm que uno de ellos es la obsesión por el orden y la limpieza, de tal manera que puede elegir una limpieza compulsiva como ritual dominante de su vida. Añade que esta re-

750 S. Freud, «El carácter y el erotismo anal», en Obras Completas, ob. cit., tomo IV, p. 1355 . 
ligión del orden y la limpieza no guarda muchas diferencias con algunos sistemas religiosos altamente ritualistas, en los que el practicante intenta liberarse del mal mediante rituales purificadores, y de hallar la seguridad mediante el severo mantenimiento de un orden ritual. ${ }^{751}$ Estas características suelen darse en las personas que tienen como centro de sus vidas el sentimiento de culpa y la necesidad de expiación — que no está causado por nada que el paciente haya hecho realmente, sino por impulsos destructores que no han llegado a su conciencia. El ritual del lavado le permite, pues, deshacer la destrucción que ha planeado inconscientemente y que no debe llegar jamás a su conciencia. ${ }^{752}$

Este plan de destrucción crea en el paciente una imagen inconsciente de sí mismo completamente desvalorizada y negativa, explica Gérard Mendel. ${ }^{753}$ La regresión anal se produce tanto más fácilmente cuanto más frontal es el choque con el Ideal del yo surgido tras la resolución del Edipo.

Vemos, para resumir, que las obsesiones por el orden, el metodismo, la previsión económica, la limpieza ritual y compulsiva, son síntomas de esa imagen negativa que el paciente tiene de sí mismo, y que tiene su origen en una fijación a la fase en que mayores son las necesidades de limpieza. La regresión anal se reconoce, pues, en la concreción de estos síntomas.

En el caso de Huysmans, la obsesión por la limpieza no es recurrente. Todos los tropos de naturaleza líquida que hemos señalado en el apartado anterior revelan más bien temor a esa regresión que afán de purificación. Es cierto que seńala fecuentemente la necesidad de limpiar las alcantarillas de su espíritu mediante soluciones, disolventes y demás agentes químicos. ${ }^{754}$ Eso revela, ya, un sentimiento profundo de suciedad.

751 E. Fromm, Psicoanálisis y religión, trad. de Josefina Martínez Alinari, Psique, Buenos Aires, 1967, pp. 50-52.

752 Ib., p. 140.

753 G. Mendel, ob. cit., p. 15.

754 «Mais quels phénols, quelles soultions cuivrées assainiront le grand collecteur où mes saletés charnelles gargouillent? Faudrait des muids, faudrait des foudres de désinfectants; et quel Milleriot pourrait manœuvrer une assez extraordinaire pompe pour extraire ces eaux résiduaires des vieux égoûts? N'y en a plus de pompiers divins, que de tels labeurs réjouissent. Ainsi, vieux frère, il n'y a pas de raisons pour que cela cesse». En una carta a su amigo Georges Landry en enero de 1891. Citado por R. Baldick, ob. cit., p. 215. 
Sin embargo, muy pocos son los casos en que un deseo de lavado se haga explícito en la obra de nuestro autor. Tan solo la vida de Folantin, el héroe de $A$ vau-l'eau, parece poblada por esta obsesión purificadora: «M. Folantin essaya d'un excitant qui lui réussissait dans son enfance; tous les deux jours il se rendit aux bains»" ${ }^{755}$ Ahora bien, en Durtal se produce un ejemplo altamente sintomático de las funciones purificadoras del lavado al relacionarlas sin ambajes con la confesión. Así se dirige a él su compañero oblado. M. Bruno, cuando Durtal ha terminado su tan temida y deseada confesión: «Le grand lavage vient d'avoir lieu». ${ }^{756}$

No obstante estos pocos ejemplos, hay uno hallado en la nouvelle Sac au dos que nos parece sintomático de la relación entre le regresión anal y el deseo de purificación. Como señala Tacium, ${ }^{757} \mathrm{el} \mathrm{final} \mathrm{del} \mathrm{relato} \mathrm{presenta}$ un héroe infantilizado, replegado sobre sí mismo, contento con su castración: esto conforma su vínculo estable con la madre, en cuya casa se instala tras la desagradable e inútil experiencia guerrera. Uno de los placeres que Eugène, héroe de la nouvelle, comenta con especial agrado es la posibilidad que tiene, en ese espacio de alta representación uterina, de lavarse en su propia palangana. Curiosa exaltación del lavado en alguien que ha vuelto del frente y del hospital. Según Tacium, esto no puede sino significar una recreación del auto-erotismo anal.

En lo concerniente al orden y al metodismo que revelaría una cierta fijación anal, Jean Borie señala los casos en que André, Folantin o Durtal bajan a la calle para degustar un nuevo alimento o acostarse con una nueva prostituta. ¿Acaso no lo hacen - dice Borie- como quien cumple lo expuesto en una receta médica: «Apaiser un besoin, le guérir, retrouver une bonne économie»? 758

Esta obsesión por el orden aparece claramente representada en la vida del propio Huysmans - como sabemos, no demasiado diferenciable de la vida que dio a sus heterónimos ficcionales - por el ejercicio de su función pública. Puede ser, según dice este estudioso de la literatura del XIX, un gran

755 J.-K. Huysmans, À vau-l'eau, ob. cit., p. 400.

756 J.-K. Huysmans, En route, ob. cit., p. 348.

757 D. Tacium, ob. cit., p. 187.

758 J. Borie, Un siècle démodé. Prophètes et réfractaires au XIXe siècle, ob. cit., p. 87. 
punto de ironía; pero también un testimonio de su deseo de seguridad, regularidad e incluso de reclusión. ${ }^{759}$ Maurice Barrès se burlaba de esta búsqueda de la seguridad funcionarial, tratando de "semimachos» a los funcionarios y contraponiéndolos a los de antes, que vivían «con el fusil en la mano" y en un permanente "cuerpo a cuerpo viril contra la naturaleza». ${ }^{760}$

Encontramos aquí un perfecto punto de transición hacia el siguiente aspecto que nos gustaría tratar en esta ilustración de la obsesión por la regresión de nuestro autor. Tanto la seguridad que le aportaba su puesto de funcionario del ministerio de seguridad como su obsesión por llevar una vida retirada del mundanal ruido son perfectamente asimilables dentro de un apartado común: el internamiento en un reducto cálido y seguro, al socaire de cualquier mal viento que pudiera poner en peligro su integridad física y moral, que amenazara su singularidad de hijo único. La obsesión por la soledad y el eremitismo no deja de ser la otra cara de la misma moneda.

\subsubsection{Regresión: retiro y soledad}

Una de las constantes en la escritura huysmansiana es la búsqueda continuada de la soledad y la tranquilidad a la que somete a sus personajes principales. Todos ellos, salvo los de las novelas «de juventud», como Léo, de Marthe, y Cyprien, de Les Seeurs, deciden en un momento u otro aislarse del mundo y recrearse en su encierro. Pareciera que, tras los fastos de fiestas de los personajes mencionados, el heterónimo ficcional de Huysmans se hubiera hastiado del contacto con sus semejantes y tan solo ansiara el contacto con selectos amigos y con sus libros. El escritor Alain de Botton señala este tipo de comportamiento exclusivista con la denominación de «misantropía inteligente». ${ }^{761}$

Trabajar, estudiar, dedicarse en cuerpo y alma a su obra: esa es la máxima obsesión de todos estos protagonistas. Olvidarse del mundo y que el mundo les olvidara a ellos, para concentrarse en lo que finalmente les interesa: el ensalzamiento personal a través del arte.

759 J. Borie, Huysmans, le Diable, le célibataire et Dieu, ob. cit., p. 10.

760 Vid. E. Badinter, XY, ob. cit., p. 30; y A. Maugue, L'identité masculine en crise au tournant du siècle, ob. cit., p. 73.

761 A. de Botton, ob. cit., pp. 133-137. 
Este encierro casi compulsivo del heterónimo huysmansiano no puede revelar sino una nostalgia del feliz hogar familiar en que ambos progenitores se afanaban en sus pequeñas cosas. Por Baldick sabemos que el padre de Joris-Karl era aficionado a la pintura, y que pasaba casi todas las tardes ante un lienzo copiando las obras más importantes del arte universal. Admirador de Zurbarán, Huysmans hijo guardará y conservará durante toda su vida una copia de un cuadro del maestro extremeño que le regaló su padre.

Huysmans viene a ser una especie de anacoreta ascético — que no religioso, que sí lo fue pero sur le tard - que apartó de los humanos todo su interés, salvo en contadas y honrosas excepciones. Freud comenta en su ensayo Introducción al narcisismo que este tipo de individuo que busca el apartamiento del mundo ha derivado — sublimado- su interés sexual por sus semejantes hacia otro tipo de actividades tan reconfortantes desde el punto de vista psicosexual. ${ }^{762}$ Sabemos que esta actividad no es otra que la reconstrucción de su vida a partir de la fractura edípica — tanto más satisfactoria cuanto que con ella entiende el artista erigirse no solo en padre de sus personajes literarios, sino de sí mismo.

Tacium señala que Huysmans busca, a través de este encierro continuado y voluntario, el grado cero de la sexualidad. Nosotros ańadimos que en este encierro casero - nótese que no hablamos todavía de convento ni claustro- - el imaginario huysmansiano opera una regresión al ámbito familiar primitivo, y que esto se realiza mediante una limpieza compulsiva de toda la suciedad que conlleva el contacto con la gente.

El carácter anal de esta regresión queda atestiguado por la desesperada búsqueda del orden y la limpieza en su hogar, para lo que intenta contratar - y esto se hace evidente en grado sumo en En ménage - a la mejor asistenta doméstica posible. Cuando no es así, el heterónimo debe encomendar esta función en la persona de un conserje — quien, además de hacerlo con menos profesionalidad, como vemos en Là-bas, no cumple con cierta cláusula intimamente incluida por Huysmans: sustituir al frufrú de la madre paseándose, dueña de su casa, por el salón.

Pues bien, los ejemplos abundan desde muy temprana fecha. Ya en el Drageoir cabe recordar el episodio en que se cuenta la historia del pintor ho-

762 S. Freud, Introducción al narcisismo, en Obras Completas, ob. cit., tomo VI, p. 2021. 
landés Cornélius Béga. A causa de su vida disoluta es expulsado de la familia, uniéndose a una joven en un primer tiempo, y a otra después, con quien inicia una vida tranquila y permitiéndose por fin «les tranquilles délices d'une vie calme», y recuperando «son talent... en même temps que sa jeunesse».

En el caso de Marthe, la situación se presenta similar. Una vez instalados como pareja, Léo manifiesta un contento inefable cuando, al volver a casa, se encuentra el piso caldeado e iluminado. La alegría le embarga, sobre todo, porque va a poder llevar a cabo su trabajo con total tranquilidad.

Quand il revint pour dîner il trouva bon feu, lampe ne fumant pas comme d'habitude, et, dans son fauteuil, une femme gentiment ébouriffée qui l'attendait, les pieds au feu, le dos à table. moi. $^{763}$

-Comme je vais travailler, se dit-il, maintenant que je suis si bien chez

Ya habíamos apuntado que el gran deseo de Auguste, el joven trabajador que contrae matrimonio con Désirée Vatard, es el que siempre expresará el heterónimo adulto: un puerto, una cala, un lugar donde poder descansar. Esa es la principal utilidad que encuentra al matrimonio. «Une seule idée surnageait dans cette débâcle, une idée obsédante et fixe: le mariage. Il voulait à tout prix, trouver une délivrance, un havre, où il pourrait s'échouer». ${ }^{764}$

El ansia de escapar de todo ese mundo ruidoso y maloliente, al que la ortodoxia naturalista obligaba a acudir en busca de documentación, es lo que hace añorar la calma del hogar a ese extraño narrador de los Croquis parisiens. Especialmente en esa joya del naturalismo realista que es el pasaje «Au Bal de la Brasserie Européenne». En este establecimiento se suceden las risas, las jarras vertidas, el humo de pestilentes tagarninas, el sudor de los cuerpos tras el baile, el retufo de las maniobras militares en uniformes y botas. Este narrador, que se manifiesta a través de un inhabitual «je», dice desear la tranquilidad del aire puro, de aire silencioso:

ça devenait ignoble, et j'avais suffisamment humé la pestilence militaire et le suint charnel pour ardemment désirer de cordiales bouffées d'air silencieux et pur. Je fis comme ces braves dames dont j'avais scrupuleusement épié les dits et les gestes, je sortis. ${ }^{765}$

763 J.-K. Huysmans, Marthe, histoire d'une fille, ob. cit., p. 71.

764 J.-K. Huysmans, Les Seurs Vatard, ob. cit., p. 398.

765 J.-K. Huysmans, Croquis parisiens, ob. cit., p. 51. 
Cómo no, tras el trabajo de campo y la toma de notas au vif, la vuelta al laboratorio, el trabajo de redacción en el encierro de la casa. Un ensimismamiento casero que Huysmans imaginaba en la persona del pintor medieval Grünewald —el precursor para él de ese naturalismo espiritual en que tanto abundaría desde Là-bas. Al creer encontrar en sus admirados artistas ejemplo de su retiro — para el provecho de su obra— Huysmans justifica el suyo propio, dotándole de una importancia que muchos considerarían mínima:

ce peintre qui fut le plus tumultuaire des artistes, vivotant, casanier, à l'écart, tel plus tard Rembrandt, dans un coin de faubourg et s'absorbant dans la frénétique féerie de son œuvre pour oublier ses peines. ${ }^{766}$

En Huysmans el adjetivo 'casero' toma una connotación positiva, valorando en ese retiro doméstico la paz necesaria para dedicarse a más altos menesteres que el simple intercambio, ramplón e inútil, con sus semejantes.

Esa es principalmente la filosofía que lleva al duque des Esseintes a enclaustrarse en su mansión de Fontenay-aux-Roses. Cansado de las tertulias literarias, de las cenas y fiestas mundanas, de la estupidez de todas esas reuniones sin ganancia ni fundamento, des Esseintes entiende necesario construirse un refugio, tebaida, arca inmóvil en donde guarecerse del diluvio de imbecilidad ambiente: «déjà il rêvait à une thébaïde raffinée, à un désert confortable, à une arche immobile et tiède où il se réfugierait loin de l'incessant déluge de la sottise humaine». ${ }^{767} \mathrm{Y}$ aunque él sea un anacoreta ascético — no religioso, repetimos, entiende necesario rodearse de todo el aditamento conventual para llevar la misma vida de un religioso. En primer lugar, se hizo con personal doméstico conveniente:

il fit venir à Fontenay ce ménage habitué à un emploi de garde-malade, [...], à un rigide silence de moines claustrés, sans communication avec le dehors, dans des pièces aux fenêtres et aux portes closes. ${ }^{768}$

Con apuntes vestimentarios tales que impone a su ama una cofia blanca de un tipo especial para que no le resultara agresiva: «Lombre de cette coiffe passant devant lui, dans le crépuscule, lui donnait la sensation

766 J.-K. Huysmans, Les Grünewald du musée de Colmar, ob. cit., p. 19.

767 J.-K. Huysmans, À rebours, ob. cit., p. 65.

768 Ib., p. 76. 
d'un cloître...». ${ }^{769}$ Para completar el artificio, se hacía necesario que su habitáculo fuera como el de una celda monástica - a pesar de que la austeridad monacal chocase con su innato gusto por el lujo, la calma y la voluptuosidad baudelairianas: «il fallait façonner une chambre en cellule monastique; mais alors les difficultés s'accumulaient, car il se refusait à accepter, pour sa part, l'austère laideur des asiles à pénitence et à prière». ${ }^{770}$ Aunque, finalmente, el estilo de vida que requería des Esseintes bastaba para antojársele como una existencia digna de un eremita. El escenario tan solo esbozado, la sensación estaba conseguida — sin necesitar por ello plegarse a los rigores de ninguna orden religiosa:

Et, en somme toute, l'illusion était facile, puisqu'il menait une existence presque analogue à celle d'un religieux. Il avait ainsi les avantages de la claustration et il en évitait les inconvenients: la discipline soldatesque, le manque de soins, la crasse, la promiscuité, le désœuvrement monotone. ${ }^{771}$

Las mismas obsesiones por el recogimiento y la calma precisos para llevar a cabo la obra de su vida son evidentemente patentes en En rade. Como ya hemos podido observar en otra parte, Jacques y Louise se van a Lourps no solo huyendo de sus acreedores, sino en busca de «un abri, une rade, où ils [Jacques y su mujer Louise] pourraient jeter l'ancre». ${ }^{772} \mathrm{El}$ primer intento de búsqueda se había dado ya en las intenciones de Jacques al casarse: la vida de soltero le parecía llena de pequeños detalles molestos, cuyo olvido podría significar el descanso en esa rada, al abrigo de las tempestades:

ce qu'il avait voulu, c'était l'éloignement des odieux détails, l'apaisement de l'office, le silence de la cuisine, l'atmosphère douillette, le milieu duveté, éteint, l'existence arrondie, sans angles pour accrocher l'attention sur des ennuis; c'était dans une bienheureuse rade, l'arche capitonnée, à l'abri des vents... ${ }^{773}$

La elección de Louise le ayudaba en grado sumo, pues silenciosa, sin obligaciones familiares, dejándole a su gusto hojear entre sus libros... Su sueño de quietud se cumplía con ella:

769 Ib., p. 77.

770 Ib., p. 114.

771 Ib., p. 115.

772 J.-K. Huysmans, En rade, ob. cit., p. 41.

773 Ib., p. 120. 
il avait incarné son rêve de quiétude, en épousant une bonne fille sans le sou, orpheline de père et de mère, sans famille à voir, silencieuse et dévouée, pratique et probe, qui le laissait fureter, tranquille, dans ses livres, tournant autour de ses manies, les sauvegardant sans les déranger. ${ }^{774}$

¿Acaso era culpa suya si necesitaba tanta tranquilidad y descanso? Porque él era hombre activo intelectualmente hablando, a quien la lectura de una frase inquietante le sumía en días de cavilaciones. Para ello, precisamente, requería de una mujer que le asegurara ese interior calmado y acolchado:

Était-ce de sa faute s'il s'était organisé de telle façon qu'il ne pût supporter la dérive d'une vie, et si, avec ses curiosités et ses engouements, il lui fallait à tout prix le repos? Il était l'homme qui lit dans un journal, dans un livre, une phrase bizarre, sur la religion, sur la science, sur l'histoire, sur l'art, sur n'importe quoi, qui s'emballe aussitôt et se précipite, tête en avant, dans l'étude, se ruant, un jour, dans l'Antiquité, tendant d'y jeter la sonde, se reprenant au latin, piochant comme un enragé, puis laissant tout, dégoûté soudain, sans cause, de ses travaux et de ses recherches. ${ }^{775}$

Ya el carácter especial de este heterónimo le había ayudado en su separación voluntaria del mundo: solitario, horrorizado por la gente, se había ganado una fama de ogro que le facilitaba mucho el destierro interior:

Solitaire comme il était, peu accesible aux physionomies nouvelles, peu liant, ayant le monde en horreur, étant enfin parvenu à réaliser les difficiles bienfaits de la réputation d'ours qu'il s'était acquise, car, las de ses refus, les gens lui évitaient, maintenant, la contrariété des excuses en ne l'invitant plus. ${ }^{776}$

El deseo de encierro persiste en $L \grave{a}$ - $b a s$, donde el escritor Durtal se confiesa, al mismo título que des Esseintes, un hombre cansado de tertulias literarias y de encuentros varios de sociedad. Los inconvenientes de la vida "civil», de la vida laica los conocía ya nuestro héroe y los reconocía como contrarios a sus necesidades artísticas. Envidiaba a la clase religiosa esas horas lenitivas en el fondo de un claustro, recorridas por los ejercicios rogatorios con estricta regularidad, al abrigo de los peligros de la vida ciudadana. Ya entonces Durtal solo ve posible su sueño de quietud en el fondo de un convento:

774 Ib., p. 121.

775 Ib., p. 122.

776 Ib., p. 121. 
Il enviait des heures lénitives au fond d'un cloître, des somnolences de prières éparses dans des fumées d'encens, des épuisements d'idées voguant à la dérive dans le chant des psaumes [...] Il songeait un peu à se sauver dans un couvent, ainsi que ces filles qui entrent en maison pour se soustraire aux dangers des chasses, au souci de la nourriture et du loyer, aux soins du linge. ${ }^{777}$

La Edad Media, la época del Románico, se le antoja a Durtal como el período histórico en que mayormente se dieron las condiciones para un recogimiento del tipo que a él le convence; iglesias macizas y rechonchas — nada de ese gótico grandilocuente y estirado-, la música humilde del gregoriano y el canto llano - y no las elocuentes y egotistas composiciones que verían el siglo XVI en adelante. Por eso el personaje de Carhaix, aparte de por su significación familiar en el imaginario de Durtal, cobra tanta importancia ante el héroe de Là-bas: su oficio de campanero le asocia directamente con la Edad Media; su rostro exangüe y lívido le recuerda a los encerrados en vida de los conventos: «C'était le teint livide, exsangue, des prisonnières au Moyen Âge, le teint maintenant ignoré de l'homme interné jusqu'à sa mort dans un cachot pluvieux, dans un noir in-pace sans air». ${ }^{778}$ Por todo eso, por esa melancolía de la Edad Media, le interesa en parte el rito demoníaco: por su carácter misterioso, primitivo casi, en el que todavía pervive la simbología medieval. La Edad Media no deja de ser, además, el negativo absoluto del tiempo de materialismo y positivismo que a Huysmans le tocó vivir y que tanto denostaba. Monjes orantes y demoníacos eran la prueba fehaciente de la pervivencia del medievo en la edad contemporánea:

Loin de ces prêtres tièdes, pleurent parfois encore, dans le fond des cloîtres, de véritables saints, des moines qui prient jusqu'à en mourir pour chacun de nous. Avec les démoniaques, ceux-là forment la seule attache qui relie les siècles de Moyen Âge au nôtre. ${ }^{779}$

Esta intención tímidamente esbozada cobra todavía mayor valor en En route, novela de su conversión. El ansia de paz y recogimiento le lleva a frecuentar con enfermiza regularidad la iglesia de Saint-Sulpice, donde además de escuchar buena música — sin las estridencias de otros coros—, el fiel podía recogerse en sí mismo sin temor a ser molestado por sus congéneres: «Il fréquentait volontiers cette parce que la maîtrise y était exercée et qu’il

777 J.-K. Huysmans, Là-bas, ob. cit., p. 14.

778 Ib., p. 31.

779 Ib., p. 112. 
pouvait, loin des foules, s'y trier en paix... L'on pouvait se pouiller l'âme sans être vu, l'on était chez soi». ${ }^{780} \mathrm{El}$ terreno del arte empieza a ser para Durtal el pretexto perfecto para convencerse de la necesidad de su encierro, pues solo en unos pocos conventos es posible escuchar auténtico canto gregoriano como se componía y ejecutaba en los viejos tiempos del medievo. Sin embargo, su convicción flaquea ante los rigores de cualquier orden, ante los que él se sabe inapto tanto física como espiritualmente. No poder fumar, no poder elegir sus momentos de lectura, de paseo..., eso le desarma:

Il est séduisant, au point de vue de mystique et même capiteux au point de vue de l'art, mais je n'ai pas les aptitudes physiques et encore moins les prédispositions spirituelles pour m’interner à jamais dans un cloître. ${ }^{781}$

De esta manera empieza a soñar con la creación de una nueva orden monástica, formada por artistas e intelectuales, en la que se daría buena comida, tabaco, posibilidades de airearse...:

Il faudrait —se disait-il— fonder une abbaye où l'on pourrait travailler dans une bonne bibliothèque, à l'aise; on y serait quelques-uns, avec une nourriture possible, du tabac à volonté, la permission d'aller faire un tour sur le quai, de loin en loin. ${ }^{782}$

Pero eso no sería un convento, se dice a sí mismo riendo. No obstante, qué fuerte es en él el deseo de separarse del mundo, de refugiarse en un ambiente de seguridad, sin saber qué ocurre en el mundo exterior. El antídoto, la música, la regularidad de la liturgia, el método de una vida sabiamente ordenada:

Ah! être terré chez eux, à l'abri des mufles, ne plus savoir si des livres paraissent, si des journaux s'impriment, ignorer pour jamais ce qui se passe, hors de sa cellule, chez les hommes! — et parfaire le bienfaisant silence de cette vie murée, en se nourrissant d'actions de grâce, en se désaltérant de plain-chant, en se saturant avec les inépuisables délices des liturgies. ${ }^{783}$

El abandono de su vida ordinaria, parisina, parece llegar definitivamente en La Cathédrale, novela en la que Durtal se instala en Chartres, bajo la férula del abbé Gévresin. Su sueño de convivir con una comunidad de sa-

780 J.-K. Huysmans, En route, ob. cit., p. 53.

781 Ib., p. 185.

782 Ib., p. 208.

783 Ib., p. 136. 
bios y artistas le sigue acompañando: «La chimère d'une abbaye, plus littéraire, plus artiste, régie par des règles conciliantes, dans un milieu plus doux, ce cloître idéal, fabriqué de bric de réalité et de broc de rêve». ${ }^{784}$ Claustro ideal donde un literato no echara nada a faltar, ni siquiera aquellas obras profanas que habrían sido prohibidas por la Iglesia:

Comment faire comprendre que des volumes profanes sont nécessaires dans un couvent qu'au point de vue de l'art, il est indispensable de se retremper dans la prose d'Hugo, de Baudelaire, de Flaubert. ${ }^{785}$

Los benedictinos parecen, dentro del abanico de órdenes religiosas, la más apta a sus aspiraciones: «Il se voyait moine dans un couvent débonnaire, desservi par un ordre clément, amoureux de liturgies et épris d'art». ${ }^{786}$ Una orden que practica su oficio fuera de esa oscuridad y tristeza de otras órdenes; monjes jubilatorios y alegres, que más se acercan a lo que él considera un continuo deo gratias:

Leur vocation (celle des Bénédictins) est de pratiquer l'office des anges; c'est une œuvre d'allégresse et de paix, une avance d'hoirie sur la succession jubilaire de l'au-delà, l'œuvre qui se rapproche le plus de celle des purs esprits, la plus élevée qui soit, sur la terre, en somme. ${ }^{787}$

Y, desde luego, saberse en un monasterio al abrigo de todas las inclemencias del exterior, protegido de todas las tentaciones, desconocedor de lo peor de la vida ciudadana. En una bella observación, Durtal reflexiona al ver pasar un tren cerca de un monasterio, diciéndose que las monjas que hayan envejecido entre sus muros no sentirán la llamada de la vida que para él significa el silbido de la locomotora, la llamada de los tiempos modernos de la que el tren es su máxima expresión.

Celles qui ont vieilli dans le monastère méprisent ces appels, ces invites à la vie et la quiétude de leur âme s'accroît de se savoir pour toujours à l'abri de ces périls qu'évoque, à chaque heure, la fuite bruyante des trains. ${ }^{788}$

En L'Oblat, Durtal cambia de opinión en cuanto a la orden más acorde a su idea de recogimiento. En este momento, nuestro héroe ha pasado ya

\footnotetext{
784 J.-K. Huysmans, La Cathédrale, ob. cit., p. 231.

785 Ib., p. 359.

786 Ib., p. 225.

787 Ib., p. 272.

788 Ib., p. 356.
} 
por varias experiencias religiosas y se halla en capacidad de emitir un juicio fundado. A pesar de lo antiguo, lo estricto, lo inmóvil de su regla, la soledad a que obligan a sus monjes, se permite de vez en cuando, cuando el rigor somete demasiado al fiel, a rebajar su dureza mediante comidas especiales, trabajos físicos, paseos... ${ }^{789} \mathrm{El}$ ideal, que Durtal no termina de decidirse abrazar, puesto que se ve incapaz de abandonar sus costumbres de trabajo, las comidas de Mme. Bavoil, sus erranzas a Dijon... Es el estatus de oblado - ligado al convento pero no obligado a observar todas las reglas de la orden - el que elige Durtal. Solución acomodaticia y que revela, en parte, cuáles son sus intereses en materia religiosa: beneficiarse de las ventajas del lujo, la calma y la voluptuosidad que propone el monasterio sin deber abandonar su propia vida. No abandonar nada excepto su doloroso vicio.

\subsubsection{Soluciones al fracaso: la prostitución}

Puede parecer una vuelta atrás en nuestra línea argumentativa, pero creemos necesario retomar la vía de las soluciones al fracaso que la sexualidad reviste para Huysmans —o sus varios heterónimos ficcionales.

Ya hemos visto que el matrimonio no funciona, pues la compañía continuada de una mujer impide mantener conversaciones interesantes, así como una vida sexual carente de rutinas deserotizantes. Las necesidades del soltero pasan pues, en su inaptitud para procurarse un interior habitable, por el concurso de la criada, de la bonne, quien es la encargada de mantener el hogar en condiciones de limpieza y orden necesarios para el trabajo y la contemplación.

En el plano sexual, la masturbación ocasional y las poluciones nocturnas cumplen un papel fundamental, sobre todo las últimas, pues permiten la realización de los impulsos inconscientes impedida por la conciencia despierta. De ahí la aparición de esas mujeres fálicas, campanas y demás sustitutivos en el onirismo huysmansiano — tan rico, como señalara Breton.

789 «Les Chartreux, les seuls captifs qui n'eurent jamais besoin, depuis leur fondation, de réformes, tant leur régime de solitude est habile est savamment dosé. Il prescrit, en effet, le silence et l'isolement, mais, au moment où ils deviendraient trop pénibles, il les rompt par des offices et à des jours fixés, par des repas servis non plus à part, mais dans le réfectoire et aussi par des promenades qui s'appellent, en style cartusien, des spaciements», en J.-K. Huysmans, L'Oblat, ob. cit., p. 329. 
Con sus diferentes compañeras sexuales, la constante convicción del heterónimo es la de fracaso cuando no la de incapacidad y/o insuficiencia. Esas «ridicules secousses», expresión con la que caracteriza el acto erótico, le van a acompañar durante todas sus experiencias sexuales. Sin embargo, la sensación de incapacidad para procurar placer a su compañera es posible, si no variarla, sí dominarla mediante su silenciamiento. Necesita, para ello, una compañera sexual que no le exija nada en ese sentido, ante la que él no se exija nada a sí mismo como amante performant, para la que ambos saquen una ventaja perfectamente cuantificable y visible: él, sus ridículas sacudidas, ella, una compensación económica.

Por eso la prostitución es un recurso al que acudirán tan frecuentemente los personajes de Huysmans.

Hemos tenido oportunidad de analizar la importancia de la prostitución durante el siglo XIX, y su presencia cada vez más habitual en calles y obras artísticas. Coincide ello con la llegada masiva de jóvenes campesinas a la ciudad, en busca de un trabajo en la incipiente industria. Sin embargo no todas hallaban colocación y debían, como recurso temporal, dedicarse al más viejo oficio del mundo.

Una prostituta es Marthe, la actriz con la que Léo comparte alojamiento e ilusiones de amor. En esta temprana novela nos sorprenderá el tratamiento nada carente de emociones de la práctica del oficio. La frivolidad con que había venido siendo tratado el tema hasta la fecha contrastaba plenamente con la visión que del mismo aporta Huysmans. Y no es el trabajo jocoso, alegre y de continuada orgía que pudieron pintar un Sade o un Rétif de la Bretonne. La prostituta del naturalismo es un personaje con luces y sombras. Pero, mientras en el caso de un Zola o un Goncourt, se recrimina el poder que el oficio otorga a la mujer que lo practica, Huysmans se detiene en la miseria que conlleva.

Huysmans empatiza —en la medida en que eso es posible desde la piel de un usuario- con esa terrible vida a merced de una clientela desconsiderada y brutal:

terrible vie qui vous jette, de huit heures du soir à trois heures du matin, sur un divan; qui vous force à sourire, qu'on soit gaie ou triste, malade ou non; qui vous force à vous éteindre près d'un affreux ivrogne, à le subir, à le contenter.

Una vida, en definitiva, mil veces más dura que la del poeta, que la del forzado, pues no existe estado más envilecedor que ese: 
vie plus effroyable que toutes les géhennes rêvées par les poètes, que toutes les galères, que tous les pontons, car il n'existe pas d'état, si avilissant, si misérable qu'il puisse être, qui égale en abjects labeurs, en sinistres fatigues, le métier de ces malheureuses! $!^{790}$

Aunque parezca un discurso salido de la pluma de un socialista, creemos denotar en él el aroma de un misógino empedernido que, aun reconociendo lo innoble del oficio, recrimina a las mismas mujeres dejarse llevar por la facilidad que les concede su cuerpo. Una facilidad que proviene, es claro, de la instrumentalización que de ella hace el poder masculino para la iniciación de sus jóvenes en el ritual de la sexualidad. Como si de un rite de passage se tratara, los adolescentes han sido llevados tradicionalmente al prostíbulo para aprender las prácticas eróticas. Así narra Huysmans la primera visita a un prostíbulo de André Jayant, el héroe de En ménage:

Par bravade, chacun amplifiait le récit de son allégresse. Ils regardaient les passants avec plus de fierté maintenant. Ils étaient des hommes! Ils affectaient des allures de mauvais sujets, auraient voulu crier leur aventure à tous les gens de la terre et rencontrer un ami, une connaissance pour les mettre au courant de leurs méfaits. ${ }^{791}$

El niño había dejado de serlo, y entraba en una ficticia clase adulta mediante unas prácticas sobre las que la misma sociedad le había aleccionado. Prácticas totalmente desprovistas de amor o sentimentalidad alguna, que acostumbraban, como en un círculo vicioso, a la reificación de las trabajadoras sexuales. La mujer se convierte en un objeto útil para que el macho se descargue del exceso de sus humores. De esta manera se expresa Cyprien, el amigo pintor de André, pensando en lo que habría hecho con el dinero cobrado con la venta de un prospecto: «Si j'avais touché l'argent de mon prospectus, j'aurais, peut-être bien, moi aussi, loué de la syncope pour quelques heures». ${ }^{792}$ Alquilar «síncopes». Curiosa operación en la que el agente que produce un efecto es sustituido por este último. Metáfora innoble donde las haya, y que deja bien a las claras el nivel de cosificación de las trabajadoras sexuales.

790 J.-K. Huysmans, Marthe, histoire d'une fille, ob. cit., p. 47.

791 J.-K. Huysmans, En ménage, ob. cit., p. 169.

792 Ib., p. 196. 
El recurso a la prostituta — casi continuamente desprovista de nombre, salvo en una ocasión, diríase honrosa - es habitual como práctica médica. Si los galenos de todos los tiempos creían en las sanguijuelas para extraer el exceso de sangre que fastidiaba la vida fisiológica del enfermo, la prostitución sirve para extraer el exceso de vitalidad que dificulta la vida del paciente. Recordemos al Durtal de Là-bas cuando, excitado tras la lectura de la primera carta de Hyacinthe Chantelouve, piensa en el ideal en que había sumido su existencia, consagrada al estudio y a la escritura: "Attends, je vais t'en ficher, moi, de l'Idéal!' et il courut chez une prostituée qu'il connaissait dans le Quartier Latin». Una vez llegado al cubil de su amiga, esta le reprocha tanto tiempo como hacía que no le había visitado. Durtal pierde fuelle y se deja hacer, sintiendo a continuación toda la opresión de su sentimiento de culpa:

il finit par s'abattre sur une couche et il subit, énervé jusqu'à en crier, le laborieux supplice des échinantes dragues.

Jamais il n'avait plus exécré la chair, jamais il ne s'était senti plus répugné, plus las, qu'au sortir de cette chambre! ${ }^{793}$

Más adelante en la novela, cuando analiza concienzudamente su relación con Hyacinthe, se pregunta si jamás podría encontrar algo mejor que una mujer que, como ella, no le exige salir juntos, ni llevarla a cenar ni nada por el estilo. A lo que se responde que más valdría no encontrar nada, pues con la prostitución se siente suficientemente satisfecho, mucho más y menos costoso de lo que puede satisfacerse con tan extrańa criatura como Mme. Chantelouve:

Maintenant je préférerais ne rien trouver; il me suffirait très bien de déposer entre des mains mercenaires mes pétitions charnelles; et alors, pour vingt francs, j'achèterais de plus studieuses crises! Car, il n'y a pas à dire, seules les filles savent cuisiner les petits plats des sens! ${ }^{794}$

Ese es el mejor recurso que le queda, pues, libre de quebraderos de cabeza, libre de compromisos sentimentales, libre de ataduras de ningún tipo, el fuego de su cuerpo puede ser apagado concienzudamente y hasta nueva orden por los servicios exquisitos de las bomberas del amor:

793 J.-K. Huysmans, Là-bas, ob. cit., p. 90.

794 Ib., p. 201. 
la bonne chose que d'avoir le cœur en grève! L'on ne soufrre ni des mésaises d'amour, ni des ruptures! Il me reste bien un cerveau mal famé qui, de temps en temps, prend feu, mais les postes-vigies des pompières l'eteignent, en un clin d'œil! ${ }^{795}$

Los ejemplos más dolorosos a la par que ilustrativos de esta pasión de Durtal por los servicios que le procuran las prostitutas se dan en En route. Recuérdese que se trata de la novela en que Huysmans cuenta su conversión y de todos los sacrificios que ello conllevó. El máximo de ellos, renunciar a su vida sexual, pues, como ya hemos analizado antes, lo precisaba en aras de esa reconciliación con la figura de su madre. «Il resterait à résoudre la terrible question des sens; il faudrait se déterminer à fuir les emprises de la chair, à renoncer aux filles, à accepter un éternel jeûne. Ça, je n'ya parviendrai jamais!». ${ }^{796}$ Aceptar ese ayuno eterno es lo que más trabajo le va a costar, pues, acostumbrado como estaba al ejercicio de los sentidos, su sublimación en el interior de una vida contemplativa es arduo. Durtal llega incluso a proponerse soluciones acomodaticias que le permitan quitarle importancia a su propensión al vicio. Si solo se acerca corporalmente a las mujeres su alma quedará limpia de toda mancha. Todo su amor, toda su ternura, quedarían reservados a la iglesia; su parte física, su manifestación corporal — puesto que la religión es, se convence Durtal, solo alma- podrían encontrar satisfacción en el sexo:

Vous n'avez pas le courage de vous arrêter à une décision, de rompre, une bonne fois, avec vos vices; vous en êtes arrivé à cet étrange compromis: réserver votre tendresse pour l'Église et les manifestations de cette tendresse pour les filles.

[...] L'important c'est de n'aimer que corporellement la femme. ${ }^{797}$

Y semejante compromiso ante sí mismo no se entendería si no fuera por el dominio que ejerce una prostituta sobre él. Florence debía de ser una amante prodigiosa, con una sabiduría sobre los secretos del cuerpo capaz de despertar los instintos ya dormidos del casi cincuentón que era Huysmans por la fecha de publicación de En route. Florence, «une fille aux aberrations de laquelle il était rivé», que se presenta ante él como un súcubo diurno, que invade todos los momentos de recogimiento y de ensoñación: «elle se dés-

795 Ib., p. 266.

796 J.-K. Huysmans, En route, ob. cit., p. 104.

797 Ib., p. 141. 
habille derrière le rideau baissé de mes yeux» —se confiesa Durtal. Mujer que superaba en el saber hacer y en la manera de apoderarse de su cuerpo como ninguna otra. Ninguna otra sabía, como ella, «apprêter d'aussi délicieuses immondices, conditionner d'aussi terribles plats». ${ }^{798}$ En definitiva, una perfecta profesional que había fidelizado a su cliente hasta límites insoportables. Y eso debió de ser mediante el ejercicio de una práctica que satisficiera en Durtal todas las exigencias de su libido, puesto que había contribuido a que en la memoria del escritor sólo perdurara, del cuerpo de Florence, «l'obscure région où cette créature transférait le siège de ses sens». ${ }^{799}$ Esta obscura región a la que se refiere Durtal sólo puede tratarse del ano; sexo anal que, por lo poco habituado que a él estaba nuestro escritor, debió de parecerle agradable en grado sumo. Hasta tal punto que Huysmans le escribía a su amigo Prins, en una fecha que permite señalar la carta en medio de la redacción de En route, la obsesión que esta práctica le había provocado:

J'avais découvert une jeune fille dont le vice était formidable; elle était arrivée à me l'inculquer dans le sang et c'était entre nous de fières parties. Son délicieux et terrifiant anus me hantait. Je le dévorais sans trêve et voilà qu'un cochon d'Américain me l'a enlevée!

[...] Depuis ce temps, les autres femmes, même la minette me semblent fades - La feuille de rose et décidément le seul plaisir qui reste, mais dame! là, il faut un petit trou lilas et rose —et ça ne se trouve pas, tous les jours. ${ }^{800}$

No es difícil establecer la identidad entre esa «jeune fille dont le vice était formidable» y la terrible Florence. Curiosa actitud la de nuestro autor, que ante los amigos confiesa una verdad — la verdad social-, pero que ante su confesionario personal como es su obra literaria, el escritor se lamenta de sus excesos. Excesos de los que se confiesa más tarde, en la misma En route. Así, su confesor le pregunta, ante la incapacidad de Durtal de tomar la iniciativa en el relato de sus pecados, si ha habido faltas cometidas entre personas del mismo sexo; a lo que Durtal contesta: «Depuis le collège, non»: ¿Adulterio? —Sí.

—Dois-je comprendre que, dans vos relations avec les femmes, aucun des excès possibles ne fut omis?

798 Ib., p. 155

799 Ib., p. 176.

800 Carta del 30 de septiembre de 1891. Citada por P. Buvik, ob. cit., p. 289. 
Durtal eut un geste affirmatif.

-Bien, cela suffit. ${ }^{801}$

Como vemos, la importancia de la prostituta en la vida del heterónimo ficcional está lejos de ser desdeńable. Apaga-fuegos, bombera, cocinera de pequeńos platos..., la profesional del sexo le es de gran utilidad en la medida en que la cosifica, la utiliza para unos fines muy determinados sin sentir por ello demasiadas responsabilidades para con su placer — de ella. Eso le permite bajar el nivel de exigencia y, sabedor de que la prostituta no le va a mirar con ojos críticos si, cliente pagador, no le proporciona placer físico, acallar la mala conciencia de amante insuficiente. Aseguraba Aragon en Le Paysan de Paris que el mejor regalo que una prostituta puede hacerle a un cliente es no cobrarle por haberse satisfecho ella. Nuestros héroes jamás se plantean eso, pues la prostitución es para ellos más una herramienta que un intercambio - como para la inmensa mayoría de usuarios, imaginamos.

Lo importante es que el nivel de reproche disminuye hasta el grado cero, por lo que el amante huysmansiano se halla en parte a salvo de la culpa que sentiría amplificada si una sustituta de su madre le culpara de su poco don de sí. Consideremos, pues, la prostitución como una solución —ya sabemos, de corto alcance en cuanto a su capacidad satisfactoria- al fracaso de la vida en pareja. Y tan necesaria para calmar la llamada de la libido fuera del marco 'familia' — con la disminución del sentimiento de traición que con ello consigue.

\subsubsection{Soluciones al fracaso: el artificio}

Como solución al fracaso, al tedio que es, en definitiva, el motor que mueve el afán de novedad del heterónimo ficcional (ver tesis de David Tacium a este respecto), Huysmans propone a sus personajes innovaciones de orden sexual con obsesionante frecuencia.

El individuo que fue introducido en la práctica de la sexualidad a través de una joven iniciación en la prostitución —que le llevó a frecuentar su comercio con asiduidad - debía de encontrar, finalmente, un tanto aburridas las sesiones de sexo clásico — por llamarlo de alguna manera. Por eso

801 J.-K. Huysmans, En route, ob. cit., p. 433. 
se afanaba en encontrar nuevos horizontes con los que saciar no solo su curiosidad, sino también su libido - pues, hastiada ante la falta de estímulos eficaces, debía alimentarse de nuevos elementos.

«La titilation élégante commence seulement où cesse la sexualité normale», aseguraba Max Nordau, el autor del polémico ensayo Degeneración. $\mathrm{Y}$ aunque este no sea un autor de referencia para nosotros, aquí no podemos dejar de otorgarle algo de razón. Existe un placer intrínseco a la propia búsqueda del placer, un refinamiento en la indagación de nuevas formas de satisfacción. Ya no son las prácticas convencionales — la «sexualidad normal», que diría Nordau - las que procuran un placer verdadero al individuo acostumbrado a todo tipo de ejercicios; existe un plus en la degustación de platos nuevos, o excesivamente cocinados, o especiados con aromas diversos...: «Je cherche des parfums nouveaux, des fleurs plus larges, des plaisirs inéprouvés» —en palabras de Flaubert que des Esseintes hará decir a su Quimera. ${ }^{802}$

Plonger au fond du gouffre, Enfer ou Ciel, qu'importe?

$\mathrm{Au}$ fond de l'Inconnu pour trouver du nouveau!

—le aconseja su admirado Baudelaire. ${ }^{803}$

«La nature a fait son temps» —oiremos decir al residente de Fontenay. $\mathrm{Y}$ es que hay en esa búsqueda a cualquier precio de lo nuevo un rechazo de los valores que poco a poco se iban alzando como referenciales, los de la burguesía que cree en la ética del trabajo, en la institución del matrimonio y en la observancia de una rígida moral. La búsqueda de lo nuevo será la divisa de todos los marginales, de todos los estetas fin-de-siglo, para dar al traste con un estado de opinión contrario a la experimentación personal. En ello podemos encontrar una actitud de rechazo al positivismo y materialismo imperantes, que no eran sino extensiones de la ética capitalista.

Recordemos lo que comentó Emile Zola en 1868 a propósito de esa juventud desocupada que poblaba el Bois de Boulogne al atardecer. Según aseguraba en La Tribune del 6 de diciembre de aquel año, había observado «une sorte de d'éréthisme nerveux» que amenazaba a esa juventud dorada.

802 J.-K. Huysmans, À rebours, ob. cit., p. 149.

803 Versos 7 y 8 del apartado VIII del poema «Le Voyage» (n. ${ }^{\circ}$ CII de La Mort), en C. Baudelaire, Les Fleurs du mal, ob. cit., p. 169. 
Comentario que se completaría con lo que escribiría en Le Rappel del 13 de mayo de 1870 acerca de esa juventud, cuya melancolía de "viveurs épuisés» le preocupaba enormemente pues en ella se profetizaba la degeneración de las generaciones por venir. ${ }^{804}$ Existía ya, pues, un tipo de personaje, de buena posición socioeconómica, aburrido de las convenciones parisienses, que buscaba en los placeres raros aliciente a su tediosa vida.

En materia de sexualidad, la experimentación tiene como origen no solo el hastío de las prácticas convencionales y el afán de transgresión. En el caso de Huysmans, esta búsqueda se produce por la falta de satisfacción que le procura el plato poco cocinado. El sexo dentro del matrimonio le parece algo previsto y, por lo tanto, poco atractivo. La prostitución le parece una salida honrosa, pero que requiere de renovaciones continuadas.

Va a ser el refinamiento en su ars amandi lo que le va a procurar satisfacción en el plano sexual.

En un comienzo, la búsqueda del artificio consistirá tan solo en estimular su pensamiento a base de recuerdos y de sugerencias varias. Es este un modo de acumular carga erótica en el cuerpo de tal manera que su descarga sea, si no más satisfactoria, sí más fuerte. La sensación de manipulación es, con ello, mucho más intensa. Así, podemos leer en un pasaje de En ménage cuando se narra los esfuerzos de André por salir de sus crisis falderas: "Il voulut tâter de noces guérissantes, s'aiguisa les sens par des souvenirs lascifs et, à diverses reprises il se livra, par raison, à de consciencieuses ribotes». ${ }^{805}$

Sin embargo, el mayor refinamiento en materia sexual se da, sin duda alguna, en $\grave{A}$ rebours. El duque des Esseintes, hombre que parece haber degustado todo tipo de platos ya sea solo o junto a sus compañeros de orgía, ha probado anteriormente a su encierro en Fontenay toda suerte de prácticas. Lo primero que siente el duque es el hastío sobrevenido por las juergas en que acompañó a sus compañeros estudiantes: «dont les débauches lui semblèrent basses et faciles, faites sans discernement, sans apparat fébrile, sans surexcitation de sang et de nerfs». ${ }^{806}$ Esa falta de sobreexcitación le lleva

804 Nota n. $^{\circ} 29$ de Henri Mitterrand de su edición de É. Zola, La Curée, ob. cit., p. 234.

805 J.-K. Huysmans, En ménage, ob. cit., p. 166.

806 J.-K. Huysmans, À rebours, ob. cit., p. 65. 
a buscar otro tipo de estimulantes: cenas en que las mujeres se emborrachan à mort, cantantes, prostitutas célebres y lujosas, putas de los bajos fondos. Leamos esta larga perorata del narrador de $\grave{A}$ rebours:

spacieux soupers où des femmes soûles se dégrafent au dessert et battent la table avec leur tête; il avait aussi parcoruru les coulisses, tâté des actrices et des chanteuses, subi, en sus de la bêtise innée des femmes, la délirante vanité des cabotines; puis il avait entretenu des filles déjà célèbres et contribué à la fortune de ces agences qui fournissent, moyennant salaire, des plaisirs contestables; enfin, repu, las de ce luxe similaire, de ces caresses identiques, il avait plongé dans les bas-fonds, espérant ravitailler ses désirs par le contraste, pensant stimuler ses sens assoupis par l'excitante malpropreté de la misère. ${ }^{807}$

Nada terminaba por satisfacerle. Ninguna de las prácticas aconvencionales — que dejaban de serlo a fuerza de repetidas y conocidas - le dejaba ahíto y tranquilo. Las ansias de descanso y de terminar con todo ese trajín eran más fuertes que las llamadas de la carne; ante las cuales, por otra parte, su organismo empezaba a reaccionar mediante inhibición: la impotencia empezaba a manifestarse.

En este contexto, solo el placer procurado por el intelecto puede suplir a la sensación misma. Es lo que el Huysmans de Certains llamó «onanismo espiritual», que suelen ser «visions échauffées des sens» que toman cuerpo en un «âme épuisée, par des idées solitaires, par des pensées secrètes» como dice a propósito de las mujeres pintadas por Félicien Rops y Gustave Moreau, respectivamente. ${ }^{808}$

El artificio es creado en base a ensońaciones sobre mujeres fatales de la historia santa, como Salomé, la bailarina de los siete velos que solicitó la cabeza de San Juan Bautista a Herodes. Recreando el cuadro de Moreau titulado L'Apparition, Huysmans pone en el pensamiento de des Esseintes toda una escenografía orgiástica que desemboca, para felicidad del amante de vuelta y de todo, en la excitación del patriarca judío:

elle réveillait les sens en léthargie de l'homme, ensorcelait, domptait plus sûrement ses volontés, avec son charme de grande fleur vénérienne, poussée dans des couches sacrilèges, dans des serres impies. ${ }^{809}$

807 Ib., p. 66.

808 J.-K. Huysmans, Certains, ob. cit., pp. 75 y 102.

809 J.-K. Huysmans, À rebours, ob. cit., p. 108. 
Una escenografía similar se ofrece en la reelaboración que hace el narrador de En rade de un sueño de Jacques Marle. En este caso, la adolescente núbil recibe el nombre de Esther; se ve ataviada de la misma profusión de joyas y piedras preciosas, y su función es la de despertar los sentidos adormecidos del patriarca, del rey. ${ }^{810}$

Uno de los artificios más logrados que Huysmans logra poner en escena ante uno de sus personajes es el que se da en $\grave{A}$ rebours en el episodio de la ventrílocua (capítulo IX). Tras conocer su arte y sus facultades en un café-concert, le ofrece grandes cantidades para hacer de ella su amante y someterle a la realización de "projets jusqu'alors irréalisables». En uno de esos proyectos, que es el que nos interesa ahora, des Esseintes hace colocar estratégicamente dos figuras, una esfinge y una quimera, en cada extremo de la habitación. Tras apagar las luces y contemplar la vibración de las brasas de las chimeneas en el techo, la ventrílocua pone su voz a ambas figuras, para recitar, "par des voix gutturales et profondes, rauques, plus aiguës, comme surhumaines», el diálogo flaubertiano entre estas dos figuras míticas.

Ante la declaración de búsqueda de nuevos perfumes y placeres citada más arriba, des Esseintes experimenta un placer extremo, nuevo, que le recorre la médula espinal de estremecimientos:

c'était à lui-même que cette voix aussi mystérieuse qu'une incantation, parlait; c'était à lui qu'elle racontait sa fièvre d'inconnu, son idéal inassouvi, son besoin d'échapper à l'horrible réalité de l'existence, à franchir les confins de la pensée, à tâtonner sans jamais arriver à une certitude, dans les brumes des au-delà de l'art!

Esto le sume en un ansia de abrazar a la mujer que hasta entonces no había sentido - aunque su duración es escasa y des Esseintes debe recurrir a nuevas escenografías.

La búsqueda de la novedad conduce al Durtal de Là-bas a mezclarse en círculos satánicos; y aunque la finalidad que primeramente se marca en esta vía es la de documentarse para su libro sobre Gilles de Rais, existe un afán de renovación y de gusto por los placeres sacrílegos que le empuja en ese camino. La delectación de Durtal por el mismo personaje de Gilles de Rais,

810 J.-K. Huysmans, En rade, ob. cit., pp. 61-63.

811 J.-K. Huysmans, À rebours, ob. cit., pp. 148-149. 
esa «formidable figure de ce satanique qui fut, au quinzième siècle, le plus artiste et le plus exquis, le plus cruel et le plus scélérat des hommes», ${ }^{812}$ ese "des Esseintes du quinzième siècle», es indicativa de una cierta identificación con el heterónimo. Como ya hemos apuntado más arriba, Rita Thiele asegura que Huysmans falseó sus fuentes de información para acercarse todavía más al noble medieval. ${ }^{813}$ Eso significa que Huysmans hace, en cierto modo, suyas las aberraciones y los crímenes de Gilles de Rais, siempre en busca de esa pimienta extremadamente picante que nuestro autor requería para despertar sus sentidos dormidos.

Por ello mismo, el relato de experiencias en torno a la misa negra es tan recurrente en $L \grave{a}$-bas, y el abanico de prácticas sexuales marginales tan amplio. Coprofilia:

un excellent homme appellé Psellus nous a révélé, dans un livre intitulé, De operatione Daemonium, qu'ils goûtaient, au commencement de leurs cérémonies, des deux excréments et qu'ils mêlaient de la semence humaine à leurs hosties. ${ }^{814}$

Pedofilia e infanticidio:

comme ils communiaient sous les deux Espèces, ils faisaient mieux encore, reprit des Hermies. Ils égorgeaient des enfants, mélangeaient leur sang à de la cendre et cette pâte, délayée dans un breuvage, constituait le Vin eucharistique. ${ }^{815}$

Sacrilegios varios:

Un certain abbé Guibourg s'était fait une spécialité de ces ordures; sur une table servant d'autel, une femme s'étendait, nue, ou retroussée jusqu'au menton et, de ses bras allongés, elle tenait des cierges allumés, pendant toute la durée de l'office. ${ }^{816}$

$[\ldots]$

Cette femme qui était indisposée donna de son sang; l'homme qui l'accompagnait se retirait dans la ruelle de la chambre où se passait la scène et Guibourg recueillit de sa semence dans le calice; puis il ajouta de la poudre de sang, de la farine, et, après des cérémonies sacrilèges, la Des Oeillettes partit emportant sa pâte. ${ }^{817}$

812 J.-K. Huysmans, Là-bas, ob. cit., p. 22.

813 R. Thiele, Satanismus als Zeitkritik bei Joris-Karl Huysmans, Peter D. Lang, Fráncfort del Meno, 1979, p. 184.

814 J.-K. Huysmans, Là-bas, ob. cit., p. 58.

815 Ib., p. 58.

816 Ib., p. 59.

817 Ib., p. 60. 
Lo que recibe el nombre, como señala des Hermies, de «misa del esperma». E incluso acciones que podrían ser firmadas por la mano de los libertinos del XVIII francés, como por ejemplo lo que Durtal nombra como «sodomía divina»:

Ces prêtres vont quelquefois, dans leur scélératesse, jusqu'à célébrer la messe avec de grandes hosties qu'ils coupent ensuite au milieu, après quoi ils les collent sur un parchemin arrangé de la même manière et ils s'en servent ensuite d'une façon abominable pour satisfaire leurs passions. ${ }^{818}$

Y es precisamente en ese contexto satánico, de sacrilegios múltiples, en el que Durtal se acopla a Hyacinthe Chantelouve, mujer diabólica por excelencia cuyo carácter ha sido reconstruido por Huysmans a partir de una admiradora desconocida de nombre Henriette Maillat, que le escribió encendidas cartas en $1885 .{ }^{819}$ Sin embargo, el gusto por el sacrilegio no es tan fuerte para Durtal como cabría esperar tras su encendida narración de las misas satánicas. En su último encuentro con Hyacinthe a la salida de una de estas misas, el escritor huye despavorido ante los transportes de su amante, sus espasmos incontrolables, la transformación de todo su ser; pero, sobre todo, ante los pequeños fragmentos de hostia que encuentra diseminados por el lecho: «Non, répondit-il; il n'y a vraiment pas moyen de nous entendre; vous voulez tout et je ne veux rien; mieux vaut rompre». ${ }^{820}$

Todo esto no deja de indicarnos que el gusto por el artificio es puramente intelectual, y que de él sólo espera una excitación que las prácticas convencionales apenas sí encienden. No llegaremos a afirmar lo mismo que el cineasta Buńuel contaba sobre Dalí y su manera de acudir a las prostitutas: una vez a solas en la habitación, el pintor prefería ver cómo se desnudaba la profesional mientras él se masturbaba evitando todo contacto físico indeseable. ${ }^{821}$ El caso de Huysmans es diferente: el artificio le sirve para lle-

818 Ib., p. 66. Esta experiencia la podemos encontrar ya señalada por Sade en su célebre obra sobre la persona del obispo de...: colocándose una hostia que él mismo consagraba en la boca del ano, incitaba al fouteur Giton a penetrarle. D. A. F. Sade, Les 120 Journées de Sodome, U. G. E., 10/18, París, 1975, p. 209.

819 Extremo este ya tratado más arriba y aportado en P. Cogny, J.-K. Huysmans à la recherche de l'unité, ob. cit., p. 188.

820 J.-K. Huysmans, Là-bas, ob. cit., p. 246.

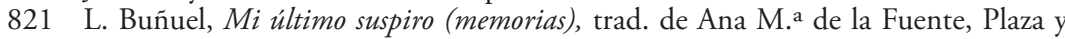
Janés, Barcelona, 1983, p. 223. 
var a cabo ese onanismo cerebral cuyo estímulo tanto ensalzó en los cuadros de Rops y Moreau.

Recurso de una mente acostumbrada a todo tipo de placeres, el artificio y la puesta en escena eran los últimos subterfugios en los que Huysmans iba a encontrar antídoto a su progresivo desapego al sexo convencional.

\subsubsection{Artificio y naturaleza}

La búsqueda del artificio revela un rechazo de la naturaleza que podríamos calificar, cuando menos, de sintomático. Síntoma de un miedo del aspecto más natural — por ello menos domeñable_ de la mujer; o, lo que es lo mismo para el inconsciente, de la madre.

Hemos podido ver cuánta protección establece el individuo en torno a sí para parapetarse de la amenaza que supone la sexualidad femenina - la sexualidad materna. Ya sea porque el individuo macho sienta temor ante la posibilidad de verse absorbido en el potente flujo libidinoso femenino, ya sea por un fantasma de castración que siempre planea, lo natural va ser sistemáticamente denostado. Una maniobra comprensible.

Muchos de los teóricos cuya obra ha sido abordada a lo largo de este estudio insisten sobre la hipótesis de que todo el progreso de la humanidad no haya sido otra cosa más que el esfuerzo masculino por sobreponerse a la imprevisibilidad de las fuerzas de la naturaleza — que son consideradas, por su capacidad de concebir frutos, femeninas. La primera herramienta de ese progreso sería el arado, cuya simbología agresiva para con la pasividad de la tierra sirve estupendamente para sustentar la tesis de la esencial violencia masculina.

También nos habíamos detenido en la definición de las imagos de la madre buena y de la madre mala, propuestas por Gérard Mendel en su obra La rebelión contra el padre. En ella, el psicoanalista francés aborda el estudio de la novela de Villers de l'Isle-Adam, L'Éve future, altamente revelador del tema que nos ocupa ahora. En él se refleja una peculiar idiosincrasia acerca de la naturaleza femenina, consistente en dividirla en dos tipos: las que no tienen ningún tipo de sexualidad, que son nobles criaturas, y las otras, que son casi animales. Edison, el científico de la novela, afirma que el hombre tiene derecho a dar muerte sin escrúpulo a esos seres que com- 
para con el vampiro y la víbora, animales que son, en lo imaginario, dos de las formas en las cuales se encarna la imago de la madre mala. Las únicas mujeres que serán aceptadas y protegidas serán las mutiladas de su sexualidad, pues no representan amenaza ninguna para la integridad, en pleno sentido del término, del hombre.

En la misma obra, Mendel pasa revista también al relato Mario y el mago, de Thomas Mann, cuya trama se puede resumir como sigue: en un balneario italiano aparece un prestidigitador, de nombre Cipolla, que hace cometer a los pacientes gran número de actos ridículos; lo peculiar es la alegría, el placer con que los enfermos se someten al dictado del mago. Según explica Mendel, «dominar la vida, el que experimenta la necesidad de ello, no goza con la armonía con las cosas, con la Madre. El deseo de dominar la vida corresponde al deseo sádico de dominar a la Madre peligrosa».

El mismo miedo a la naturaleza absorbente y oscura de la madre podemos observarlo en los Cuadernos de André Walter de André Gide. Según observa Jacques Delattre, la pesadilla en que André baila con una bella desconocida que no tiene sino un agujero bajo la falda no revela otra cosa más que la angustia ante la naturaleza plenamente sexual de la madre: castrada a la vez que castrante. ${ }^{822}$ Creencias inconscientes difíciles de dominar y que provocan numerosos traumas en el individuo.

Stéphane Michaud apunta a que los esfuerzos por esconder la naturaleza de la mujer esconden el deseo de protegerla contra las fuerzas desconocidas que la habitan: separarlas de esa animalidad castradora y altamente sexualizada. "La femme est naturelle, c'est-à-dire abominable», ${ }^{823}$ dice Baudelaire. Pero en cuanto las joyas, los perfumes y los cosméticos se apoderan de ella, la metamorfosis es infinita. Hasta la estupidez misma favorece la idolatría. La mujer, vacía así de sí misma, levanta el insoportable revestimiento de la existencia y entrega al poeta el paraíso de sus sueños. De esta manera, en esa nouvelle que es La Fanfarlo, se muestra esto con toda claridad allí donde, en el momento de poseer a la mujer amada, soberbia en su abandono, el amante reclama de la bailarina que vaya al teatro a buscar la

822 J. Delattre, trabajo presentado al Seminario de J. Chassenet-Smirgel, Institut de Psychanalyse, 1970. Citado por A. Clancier, ob. cit., p. 119.

823 C. Baudelaire, Mon cœur mis à nu, ob. cit., p. 9. 
túnica en la cual ha aparecido envuelta unas horas antes en escena, y no olvida el colorete que la cubría. ${ }^{824}$ ¿De qué estaba enamorado el dandi, si no era de una imagen, de un artificio? Y por el mismo fenómeno, cuando ha seducido a Mme. Sabatier le dice: «Hace unos días eras una divinidad... Ahora simplemente una mujer!».825

Todos los intentos de dominar a la naturaleza derivan de un deseo inconsciente de deshacerse de la latente amenaza de la sexualidad materna: amenaza de castración — tanto a sí misma como al niño. A este fantasma se le une la obsesión por la regresión, por la vuelta al útero materno. «El sexo devorador es entonces ese sexo que permite regresar al claustro materno» — señala Dominique Grisoni. ${ }^{826}$

Por ello mismo Huysmans se complacerá en mostrar una naturaleza enfermiza y atacada de apoplejía, cuyo poder amenazador queda reducido a su mínima expresión. Además, se trata frecuentemente de una naturaleza dominada por la civilización, paisajes decadentes del extrarradio parisién, en los que la feminidad del campo sólo se observa en unos riachuelos en los que el progreso ha dejado su huella, disminuyendo así su poder. «La nature n’est intéressante que débile et navrée» — declara el narrador de los Croquis parisiens a propósito de la Bièvre, ese riachuelo banlieusard. ${ }^{827} \mathrm{El}$ mismo riachuelo, con total seguridad cuyo curso enfermizo es descrito en En ménage:

campagne dont l'épiderme meurtrie se bossèle comme de hideuses croûtes, dans ces routes écorchées où des traînées de plâtres semblent la farine détachée d'une peau malade, il voyait une plaintive accordance avec les douleurs du malheureux.

$[\ldots]$

Il voyait, dans la banlieue qui s'étend autour du Paris pauvre, la maladerie de la nature, l'hôpital Saint-Louis, des paysages et des sites et de mélancoliques douceurs lui venaient, des apitoiements charitables pour cette nature souffreteuse ${ }^{828}$

824 C. Baudelaire, ob. cit.

825 S. Michaud, «Idolatrías: representaciones artísticas y literarias», en VV.AA., Historia de las mujeres, vol. 4, siglo XIX, Santillana, Madrid, 2000, pp. 164-165.

826 D. Grisoni, «El siglo XX. Las pruebas de los cuerpos», en Bardet, Cassin et ál., La primera vez, Planeta, Barcelona, 1981, p. 30.

827 J.-K. Huysmans, Croquis parisiens, ob. cit., p. 83.

828 J.-K. Huysmans, En ménage, ob. cit., p. 134. 
Una naturaleza, en definitiva, cuyo poder ha quedado puesto en entredicho por la voluntad del artista, del creador que pone y dispone sus elementos para satisfacer su necesaria concepción del mundo. "La nature a fait son temps», dice des Esseintes; «'homme a fait, dans son genre, aussi bien que le Dieu auquel il croit», afirma el noble decadente. ${ }^{829} \mathrm{El}$ artificio cuya vocación será la de sustituir a la naturaleza es la obra plena de un espíritu — que de creer a Mendel sería obligatoriamente masculino- que sintiese la necesidad de dominarla. Al no ser esto posible más que de manera limitada, el creador le antepone la artificialidad para deshacerse de su posible amenaza. Bernheimer asegurará, al respecto de la obsesión por los objetos que imitan la naturaleza en $\grave{A}$ rebours, que se trata de la sublimación en una forma simbólica de la violencia degenerativa de la naturaleza. ${ }^{830}$

Por eso, nada más ilustrativo de esta obsesión por la sustitución que la comparación que hace des Esseintes de esa obra de belleza que es la mujer con la locomotora:

est-ce que l'homme n'a pas, de son côté, fabriqué, à lui tout seul, un être animé et factice qui la vaut amplement, au point de vue de la beauté plastique?... un être dont le type soit plus éblouissant, plus splendide que celui de ces deux locomotives adoptées sur la ligne du chemin de fer du Nord. ${ }^{831}$

Comparación que, en boca del esteta decadente sólo puede provocarnos una sonrisa: él, que tamaños reniegos haría del naturalismo zoliano amigo de talleres, bajos fondos y máquinas — como se evidenciaba en $L a$ Bête humaine. Y aunque podamos creer en esta aseveración un guiño irónico al naturalismo obrero, afirmamos que, apoyándose en él, Huysmans da una muestra de su obsesión anti-natural.

Otro ejemplo, paradigmático este, reside en el episodio de la tortuga: animal que des Esseintes recibe en su casa y a la que reviste de lujosas piedras preciosas. Cuando muere, el esteta comprende que es por el exceso de

829 J.-K. Huysmans, À rebours, ob. cit., p. 80.

830 C. Bernheimer, «L'exorbitant sexuel: castration et sublimation chez Huysmans», ob. cit., p. 110.

831 J.-K. Huysmans, À rebours, ob. cit., p. 80. Compárese este pasaje con ese otro de L'Éducation sentimentale en que se señala un cuadro que $M$. Dambreuse hizo que le pintaran durante la revolución de 1848: Jesucristo conduciendo una locomotora. ¿ Obsesión de la época por la máquina?, Gustave Flaubert, L'Éducation sentimentale, ob. cit., p. 328. 
civilización a que la había sometido: «elle n'avait pu supporter le luxe éblouissant qu'on lui imposait, la rutilante chape dont on l'avait vêtue, les pierreries dont on lui avait pavé le dos, comme un ciboire». ${ }^{832}$ Según Bernheimer, se trata aquí de una técnica contra el miedo a la castración: mediante la suma de elementos diversos, el autor no hace sino recomponer el yo mutilado, mediante una estrategia clara y patente de compensación. También participará de esta técnica el collage de piezas de libros diferentes, de los que no cita ni autor ni fuente. ${ }^{833}$

Tras el manifiesto — pues así se podría considerar semejante declaración de intenciones estéticas - de $A$ rebours, Huysmans se vuelca en la redacción de la única novela que transcurre íntegramente en la naturaleza, En rade. La historia transcurre en el castillo de Lourps, al que se desplazó nuestro escritor durante tres veranos seguidos en compañía de Anna Meunier. Pues bien, pocos días antes del segundo viaje, en junio de 1884, Huysmans le escribe a Mallarmé una carta en la que le confiesa su temor por los días que se avecinan:

Je pars demain pour un authentique village; j'y resterai une vingtaine de jours, à moins que l'ennui ne devienne trop fort, car le sens de la campagne n'est pas développé en moi et j'ai toujours rêvé art et artifices devant les grands horizons. ${ }^{834}$

Pues bien, todo ese temor queda comprobado in situ, como podemos certificar tras la lectura de la novela que surgió de esos viajes a Lourps. Todos los aspectos del campo y sus labores se le antojan a Jacques Marle tremendamente fastidiosos.

La naturaleza cobra pleno poder de amenaza en Là-bas, en una ensoñación que Durtal atribuye a Gilles de Rais en un momento de lucidez frente a la concreción de sus brutalidades. Con el rostro surcado por copiosas lágrimas, Gilles sale de su castillo y se introduce en un bosque, que súbitamente se transforma en un maremágnum de ramas y raíces en forma de brazos y muslos:

Partout les formes obscènes montent de la terre, jaillissent en désordre dans le firmament qui se satanise; les nuages se gonflent en mamelons, se fen-

832 J.-K. Huysmans, À rebours, ob. cit., p. 103.

833 C. Bernheimer, ob. cit., p. 113.

834 Citada por R. Baldick, ob. cit., p. 120. 
dent en croupes, s'arrondissent en des outres fécondes, se dispersent en des trầnées épandues de lait; ils s'accordent avec la bombance sombre de la futaie. ${ }^{835}$

Un delirio en el que el satánico caballero comprueba todas las enfermedades de que se ve aquejado el bosque: tumores, úlceras, tubérculos chancrosos, caries..: toda una "maladrerie de la terre» en que el escritor transforma en pocas líneas al robledal. De la amenaza digna de la peor de las pesadillas se pasa al mismo afán de contención que habíamos observado antes en Croquis... y En ménage: suavizar la amenaza, tan presente, de la naturaleza. Más vale domarla para acallar su poder encantatorio.

Nótese, por otra parte, que el bosque ha simbolizado, en el imaginario popular, el mundo tenebroso, oculto y casi impenetrable de nuestro inconsciente — como observa Bettelheim. ${ }^{836}$ Si una personalidad aún no totalmente desarrollada entra en él saldrá, presumiblemente, con una estructura humana muy superior. Y es que el principal elemento del bosque, el árbol, es sobre todo un símbolo materno —-según señala Jung al comentar el mito germano del Totenbaum, a cuyos pies se entierra al difunto en un ejercicio de duplicación de las potencias maternas de la naturaleza: muerte y concepción. ${ }^{837}$ Por todo ello, no es de extrańar que el bosque revista una cantidad de peligros de naturaleza femenina para el inconsciente de nuestro autor: en él habitan todos los miedos a la castración y a la regresión que imaginarse puedan. El mundo es un bosque de símbolos, decía el poeta, y los símbolos construyen finalmente el mundo.

Sin embargo, qué alegría observa Durtal en En route cuando, paseando por el jardín al final de una tormenta, el sol se abre paso por entre las densas nubes:

C'était un Salut de la nature, une génuflexion d'arbres et de fleurs, chantant dans le vent, encensant de leurs parfums le Pain sacré qui resplendissait làhaut, dans la custode embrasée de l'astre.

Durtal regardait, transporté. Il avait envie de crier à ce paysage son enthousiasme et sa foi; il éprouvait enfin une aise à vivre. ${ }^{838}$

835 J.-K. Huysmans, Là-bas, ob. cit., p. 159.

836 B. Bettelheim, ob. cit., p. 103.

837 Citado por G. Bachelard, L'eau et les rêves. Essai sur l'imagination de la matière, ob. cit., p. 99.

838 J.-K. Huysmans, En route, ob. cit., p. 441. 
Expresión jubilatoria inesperada en quien hasta hacía poco se había mostrado tan poco amante del campo y sus circunstancias. Esto se puede comprender si se tiene en cuenta el proceso de reconciliación con las imagos, con las instancias parentales, que se desencadena a través de la conversión de nuestro autor. Sobre todo en el caso de la imago paterna, representada aquí con el sol que viene a sembrar la paz en medio del fragor y el peligro de la naturaleza enfadada. Pero este tema será abordado en otro apartado. Dejémoslo por ahora tan solo enunciado así.

\subsubsection{Soluciones al fracaso: homosexualidad}

La sospecha sobre la homosexualidad de Huysmans ha estado siempre presente en los estudios sobre su obra y su biografía. Y eso a pesar de que el heterónimo se hubiera declarado siempre usuario habitual y obsesivo de prostitución femenina. Tal vez a ello haya contribuido su soltería militante, en la que muchos hayan querido ver una desviación sospechosa de la norma heterosexual y reproductiva. No obstante, todos los eruditos de su obra saben que nuestro autor compartió gran parte de su vida con Anna Meunier.

Entre los más modernos, David Tacium declara que sería un error considerar a Huysmans un «homosexuel de nature», y que tal vez sería más adecuado incluirle en lo que el conde Karl-Otto Westphal denominó, en 1869, conträre Sexualempfindung. Esta no consiste precisamente en desear a individuos del mismo sexo, sino en una cierta fatiga de sí mismo, e incluso alienación de su propia sexualidad. ${ }^{839}$

Tal vez sería útil determinar, aunque fuera someramente, lo que la ciencia ha venido entendiendo por homosexualidad — término que fue propuesto en la misma fecha que apunta Tacium por el húngaro doctor Benkert, quien, en 1869, inventó el término de homosexualidad y pidió al ministro de Justicia la abolición de la vieja ley prusiana contra la misma. ${ }^{840}$

En Tres Ensayos para una teoría sexual, Sigmund Freud intenta esbozar lo que sería una tipología de los «invertidos» a partir de su conducta. Él contempla ${ }^{841}$ tres tipos: invertidos absolutos (su objeto sexual tiene necesa-

839 D. Tacium, ob. cit., p. 219.

840 Vid. E. Badinter, XY, ob. cit., p. 127.

841 S. Freud, Tres ensayos para una teoría sexual, ob. cit., p. 1173. 
riamente que ser de su mismo sexo, no siendo nunca el sexo opuesto objeto de su deseo sexual), invertidos anfígenos (su objeto sexual puede pertenecer indistintamente a uno u otro sexo) y, finalmente, invertidos ocasionales (pueden adoptar como objeto sexual a una persona de su mismo sexo y hallar satisfacción sexual en el acto con ella realizado).

Pese a lo que señalan muchos críticos de la obra freudiana, el padre del psicoanálisis se distancia conscientemente de la noción de que la homosexualidad es producto o señal de "degeneración", término preferido hacia finales del siglo XIX para describir lo «anormal». Este era, sugería Freud, solamente «un juicio de valor, una condena, en lugar de una explicación» - como señala Jeffrey Weeks en su célebre ensayo El malestar de la sexualidad. ${ }^{842}$ Freud aboga más bien por una bisexualidad universal de los seres humanos, dentro de la cual la homosexualidad sería una opción más entre varias.

En un nota de 1910, posterior a la primera publicación de Tres ensayos..., ${ }^{843}$ Freud abundaba en el estudio de la homosexualidad. Indicaba que en la mayoría de los casos investigados, los invertidos pasan en los primeros años de su infancia por una breve fase de intensa fijación a la mujer (a su madre, en la mayoría de los casos), y que después de esta fase heterosexual se identifican con la mujer y se toman a sí mismos como fin sexual; es decir, buscan, partiendo de una posición narcisista, hombres jóvenes y semejantes a su propia persona, a los que quieren amar como la madre los amó a ellos.

Eso significa, tanto por inferencia como por lo que, según Freud, arrojaba la investigación, que estos invertidos no eran insensibles a los encantos femeninos, sino que transportaban directamente a un objeto masculino la excitación producida por la mujer. Su obsesiva inclinación hacia el hombre se demostraba así condicionada por su incesante fuga de la mujer.

Esta aportación sobre la fijación a la madre por parte de los invertidos nos resulta muy interesante, pues ya conocemos hasta qué punto esta se dio en la personalidad de Huysmans, niño expósito, abandonado a los horrores e inclemencias del mundo. Y todavía más si tenemos en cuenta lo que

842 J. Weeks, El malestar de la sexualidad, ob. cit., p. 248.

843 S. Freud, Tres ensayos para una teoría sexual, ob. cit., p. 1178. 
escribió Freud al respecto en otro ensayo de ese mismo año de 1910, en relación con la personalidad del artista pluridisciplinar Leonardo da Vinci. ${ }^{844}$ En este ensayo, el padre del psicoanálisis profundizaba en la consideración de los tipos de homosexualidad. Incluyendo a Leonardo en la tercera, la de los homosexuales ocasionales, indica que la represión que suelen sufrir los individuos de este tipo consigue transferir al inconsciente un instinto parcial del deseo sexual. Por el contrario, escapa la libido a la represión, sublimándose desde un principio en ansia de saber e incrementando el instinto de investigación.

Estas dos características apuntadas en el caso de Leonardo: fijación a la madre y ansia de saber e investigar como resultado de la sublimación del deseo sexual, son perfectamente aplicables a la personalidad de nuestro autor, como hemos podido ir viendo a lo largo de esta modesta introducción a su obra. Huysmans podría ser incluido en el tipo de homosexuales ocasionales descrito por Freud sin ningún lugar a dudas. Afirmamos, además, que esta aseveración no es para nada descabellada refiriéndonos a la persona de alguien tan ávido de experiencias y, sobre todo, de soluciones a su tedio sexual.

En 1889, Huysmans confiesa en una carta a su amigo Prins haber tomado contacto con el ambiente homosexual parisién, llegando incluso a «enlever» uno de sus representantes más reconocidos: "J'ai pénétré dans le monde des tapettes et ai enlevé la Camargo, la plus chic ou le plus chic d'entr'eux ou d'entr'elles. Ah! je vous jure que c'est bien étrange et j'ai recueilli de bonnes notes». Esto podría ser una razón suficiente para afirmar su homosexualidad de facto. Sin embargo, unas cuantas líneas más adelante en la misma carta, le asegura a su amigo Prins: «Décidément je ne suis pas sodomite - pédéraste peut-être avec un jeune garçon imberbe, jamais avec des gaillards moustachus de 30 ans, ça ne me dit pas». ${ }^{845}$ Esto podría confirmar que a nuestro autor no le gustan los hombres, aunque no se puede decir lo mismo de la sodomía. Esta práctica sexual es objeto de consideraciones diferentes en otra carta escrita a este mismo amigo — que ya hemos comentado antes en el tratamiento de la prostitución. De ella dice que «son délicieux et terrifiant anus me hantait. Je le dévorais sans trêve et voilà qu’un

844 S. Freud, «Un recuerdo infantil de Leonardo de Vinci», ob. cit., pp. 1577-1619.

845 Referida por P. Buvik, ob. cit., p. 290. 
cochon d'Américain me l'a enlevée!» Continúa declarando que ni siquiera la pedofilia consigue apartarle el sexo anal de la mente: «La feuille de rose et décidément le seul plaisir qui reste, mais dame! là, il faut un petit trou lilas et rose —et ça ne se trouve pas, tous les jours». ${ }^{846}$

Estas declaraciones, que en la ficción serían atribuibles a ese oculto personaje, la prostituta Florence — que actúa desde bastidores con sabia habilidad para mover los hilos del personaje de Durtal—, parecerían desmentir la pretendida ocasionalidad de la homosexualidad de Huysmans. Se trata aquí, nada más a nuestro entender, de una cuestión de glissement en la elección de objeto, por la que nuestro autor buscaría en el comercio con varones satisfacción a su sexualidad; su motivo: ampliar su abanico de experiencias, tanto con fines literarios ("j'ai recueilli de bonnes notes») como libidinosos. El problema reside en que él busca en el objeto de su elección unas características cercanas a las de la mujer: juventud, frescura, candidez..., que no siempre encuentre en esos "gaillards moustachus de 30 ans».

Acudamos otra vez al personaje de Florence, cuyas habilidades y sabiduría para despertar los más bajos instintos de Durtal la apartarían de estas características. Sin embargo, el futuro oblado confiesa que uno de los aspectos que precisamente más aprecia en ella es, precisamente, la mezcla de picardía y candor:

Florence apparaissait et il hennissait car, malgré l'émeute ininterrompue de sa vie, elle gardait le clair sourire d'une gamine qui s'en va, les yeux baissés, les mains dans les poches de son tablier, à l'école.

$[\ldots]$

Et à son tour, Florence parut, avec son sourire de petit voyou et ses hanches de garçonne. ${ }^{847}$

Durtal es pues un homosexual ocasional reprimido, que sublima, cuando esto le es posible, su excitación en el estudio, el trabajo y el ansia de saber. Eso no le impide sufrir, de vez en cuando, esas terribles crisis falderas que tanto daño le infligían. Y esa represión no era ejercida porque considerara, finalmente, que esa vía no le parecía satisfactoria: el mismo concepto de hombría conlleva el de homofobia.

846 Carta del 30 de septiembre de 1891. Citada por P. Buvik, ib., p. 289.

847 J.-K. Huysmans, En route, ob. cit., pp. 272 y 322, respectivamente. 
Como observa Judith Butler, en el caso del hombre heterosexual melancólico, nunca ha amado a otro hombre, es un hombre, y puede recurrir a los datos empíricos que lo demuestren. El dato empírico no se refiere exclusivamente a su biografía, sino a su anatomía: su pene demuestra sobradamente su adscripción a un tipo de sexualidad que debe elegir objeto en la mujer. "De hecho — añade Butler-, la mujer-como-objeto debe ser el signo de que él no solo no sintió nunca un deseo homosexual, sino que nunca sintió el duelo por esa pérdida» ${ }^{848}$ Desde esta perspectiva se puede explicar la convivencia entre un deseo homosexual latente y su propia negación en el altar de la heterosexualidad obligatoria.

Anteriormente en este capítulo (apartado 3.6.1, «La fijación a la madre y homosexualidad») habíamos abordado la fijación a la madre como origen de la homosexualidad masculina. Tras el corte edípico, el hijo debe huir de su madre por la que siente unos afectos desmedidos; ante la posible infidelidad a su memoria, el adulto no mantiene relaciones con mujeres, sino con hombres —en los que deposita su carga libidinosa. De ahí que la heterosexualidad poseyera siempre un aura de pecado para nuestro autor —o para sus heterónimos ficcionales-, por lo que solo se podrá realizar mediando las componentes libídicas y agresivas — como indica la psicoanalista Nunziante Cesaro. ${ }^{849}$

Una salida honrosa podría ser la homosexualidad: con ella no se mancilla el honor de la madre ni se enfrenta la resistencia antes mencionada. Pero la homofobia definitoria de la virilidad lo suele impedir con fuerza desmedida. La adopción de la pedofilia puede ser una segunda solución gracias a la cual el homosexual ocasional reprimido encuentre las características de la mujer en el objeto, no traicione dolorosamente la memoria de la madre, satisfaga su ansia homoerótica y, por último, reproduzca las condiciones en que un niño fue amado en aquel lejano tiempo en que él lo fue por su madre.

No obstante esto, las recurrencias en los textos al amor pedófilo no son, en absoluto, frecuentes. Podríamos señalar una en especial que no se resuelve, sin embargo, mediante el acoplamiento entre el adulto y el joven.

848 J. Butler, ob. cit., p. 105.

849 Citada por M. Gónzalez de Chávez, ob. cit., p. 219. 
"Il y a avait de cela quelques années, il s'était croisé, rue de Rivoli, un soir, avec un galopin d'environ seize ans, un enfant pâlot et fûté, tentant de même qu'une fille». ${ }^{850} \mathrm{El}$ joven se acerca a des Esseintes, quien le da de fumar, de beber y, finalmente, le lleva a un lujoso burdel para que se acostumbre al trato con seductoras pero caras mujeres. Pagando sus cuentas en el prostíbulo durante tres meses le asegura una propensión al delito que no habría conocido antes. Es decir, que le inflige un castigo por haberse sentido atraído por él; reprime su tendencia antes siquiera de poder complacerla; antepone un sentido civilizatorio y humanista a su inclinación homosexual: el deber viril es el que se impone aquí.

En la misma novela, tan rica en sugerencias de este tipo, des Esseintes se ve "peligrosamente» atraído por un joven que le pide una dirección en la calle. A raíz de este encuentro, surge una extrańa amistad tanto más intensa cuanta mayor era la tensión sexual que le subyacía:

du hasard de cette rencontre était née une défiante amitié qui se prolongea durant des mois; des Esseintes n'y pensait plus sans frémir; jamais il n'avait supporté un plus attirant et un plus impérieux fermage; jamais il n'avait connu des périls pareils, jamais aussi il ne s'était senti plus douloureusement satisfait. ${ }^{851}$

Las sugerencias a una posible relación homosexual entre ambos caballeros quedan patentes, aunque no se sabe nada de su resolución: se sintió dolorosamente satisfecho ¿en base a la tensión de que hablábamos o se trataría, más bien, de una grosera referencia a la sodomía?, ¿cuáles eran esos peligros sin parangón: el miedo a caer en la tentación u otra cosa? Y ese insólito término en este contexto, ese "fermage» para definir una relación, ¿̇e trata de una relación puramente venal? Este párrafo, aislado en medio de dos temas diferentes, es productivo en sugerencias, pero no arroja ninguna luz sobre la posible homosexualidad de facto de nuestro autor.

Sea como fuere, el narrador de todas estas peripecias no explica en ningún momento la verdadera naturaleza de esos «amours exceptionnelles», de esas «joies déviées» a que se refiere en $\grave{A}$ rebours. ${ }^{852}$ Tan solo en algunos pasajes de las novelas de su ciclo llamado «religioso» se puede observar referencias directas al gusto por el efebo o por el amor entre hombres. Así, en

850 J.-K. Huysmans, À rebours, ob. cit., p. 118.

851 Ib., p. 150.

852 Ib., p. 66. 
La Cathédrale y en Sainte Lydwine, el narrador expresa la idea que él se hace del paraíso, con sus ángeles «aux adolescences asexuées» o «jeunes moines aux profils de jeunes filles». ${ }^{853}$

Lo que sí se puede afirmar, sin ningún lugar a dudas, es que existe una homosexualidad latente a lo largo de toda la producción huysmansiana. Latencia que se explicita en, primero, las numerosas referencias a un genitalismo masculino. El pene como vértice geodésico de la experiencia narrativa de nuestro autor. Así queda de manifiesto en, por ejemplo, ese croquis en que se relata una velada en Les Folies Bergère en 1879; el narrador parece fijarse más en la parte trasera de los mońos y las joyas que los aderezan que en las mujeres que los portan. Así como, en otro pasaje del mismo croquis, cuando el narrador dice no interesarse más que por una de las bailarinas: la que mayor sintonía mostraba con un clásico modelo masculino. Bailarina disfrazada de soldado, interesa al narrador por el borrado de sus atributos femeninos, adorable e innoble con su kepí...:

Une seule fut intéressante, celle costumée en officier de spahis, avec un large pantalon bleu flottant. De mignonnes bottes rouges, le spencer à soutaches d'or, le petit gilet écarlate collant, moulant le sein, dessinant la pointe tenue droite. Elle dansait comme une chèvre, mais elle était adorable et ignoble avec son képi galonné [...] Telle quelle, cette fille évoquait des barricades et des rues dépavées, exhalait un fumet de trois-six et de poudre, dégageait un épique de populace et une emphase de guerre civile, mitigée par des noces crapuleuses, en armes. ${ }^{854}$

Donde más patente queda esa latencia es en el fenómeno que llamaré «nostalgia del hermano», por el que se trasluce a lo largo de toda la obra de nuestro autor una continuada búsqueda de un camarada, amigo, compañero de andanzas, que ocupe un lugar destacado en la intimidad del heterónimo ficcional. Jean Borie afirma que es este un aspecto, el de la presencia del amigo que permite el recuerdo intenso de la adolescencia, que solo se da en Flaubert: «la présence de l'ami, et d'adolescence remémorée, préservée, embaumée, comme l'ironique, la douce-amère nostalgie du possible revenant hanter la certitude acquise de l'impossible». ${ }^{855}$

853 J.-K. Huysmans, La Cathédrale, ob. cit., p. 183; y J.-K. Huysmans, Ste. Lydwine de Schiedam, ob. cit., p. 123.

854 J.-K. Huysmans, Croquis parisiens, ob. cit., p. 120.

855 J. Borie, Huysmans, le Diable, le célibataire et Dieu, ob. cit., p. 40. 
Esta adolescencia preservada gracias a la presencia del camarada, del confidente profundo, empero, se da, y de manera intensa, también en Balzac: recuérdese la amistad inquebrantable de Rubempré y Séchard, el impresor; o con Lousteau, que es quien le introduce en el periodismo.

Y en Huysmans. Baste recordar la alegría de Eugène, el héroe de Sac au dos, cuando se encuentra con su camarada Francis en el hospital a donde es transferido, ipor la ausencia de lavativa y de bomba impelente!

Todavía más claro se da esto en la amistad entre Cyprien Tibaille y André Jayant en En ménage: ${ }^{856}$

Leur amitié d'enfance s'était affermie dans la lutte qu'ils soutenaient; ils avaient toujours vécu ensemble et, à part quelques bisbilles venues à la suite de cancans de femmes qui les avait comme de juste divisés, jamais aucune brouille, aucune querelle ne s'étaient élevées entre eux.

Il avait fallu le mariage d'André pour briser tout d'un coup l'intime de leurs relations; ils se manquèrent désunis.

Amistad que solo puede romper el compromiso social con el matrimonio; pero que el concubinato (Cyprien con Mélie y André con Jeanne) no acierta a disgregar.

Sin embargo, el fenómeno más curioso que se da en esta amistad fraternal es la búsqueda de la escena primordial en que el camarada aparezca como sustituto del padre. Y el inconsciente que tímidamente mueve la pluma de Huysmans desplaza la escenografía del tálamo conyugal al comedor de la familia. Así Cyprien y André servidos como verdaderos hermanos por Mélie en En ménage. ${ }^{857} \mathrm{O}$ ese personaje desconocido a cuyo lado Folantin ha comido durante más de un año codo con codo: «Il fut servi à souhait; il rencontra un jour, sur le seuil de son bureau, un monsieur qu'il connaissait. Ils avaient, pendant un an, mangé côte à côte». ${ }^{858}$ La sospecha se hace del todo patente cuando vemos aparecer en $L \grave{a}$-bas al médico des Hermies, a quien Huysmans describe con los mismos rasgos de sí mismo:

Au milieu de ces faces sournoises ou préparées, il (des Hermies) apparaissait comme un homme singulièrement distingué, mais méfiant et rétif. Grand, fluet, très pâle, il fronçait des yeux rapprochés d'un nez fureteur et bref, des yeux qui avaient le bleu foncé de la pierre divine et son éclat sec. Ses cheveux

856 J.-K. Huysmans, En ménage, ob. cit., p. 143.

857 Ib., pp. 342-345.

858 J.-K. Huysmans, À vau-l'eau, ob. cit., p. 411. 
étaient blonds, sa barbe, rasée sur les joues et taillée sous le menton en pointe, tournait au ton du liège. Il y avait en lui d'un Norvégien maladif et d'un Anglais rêche. Vêtu d'étoffes fabriquées à Londres, il semblait étriqué dans un complet quadrillé, de couleur morne, serré à la taille, montant très haut, cachant presque la cravate et le col. Très soignée de sa personne, il avait une manière à lui de retirer ses gants et de les faire imperceptiblement claquer en les roulant; puis il s'asseyait, croisait ses longues jambes en thyrse en se penchant tout d'un côté, à droite, retirait de sa poche gauche, collée au corps, une blague japonaise plate et gaufrée, qui contenait son papier à cigarettes et son tabac.

Il était méthodique, en garde, froid comme une corde à puits devant les inconnus; son attitude supérieure et avec cela gênée s'ajustait à ses rires blêmes et coupés court; il suscitait de sérieuses antipathies à première vue et il pouvait les justifier par des mots vénéneux, des mutismes méprisants, des sourires rigoureux et narquois. ${ }^{859}$

Más adelante, en un momento de intimidad, Mme. Chantelouve revelará a Durtal que des Hermies le había confesado estar enamorado de él: «un de vos amis est donc venu et il a déclaré qu'il était franchement amoureux de vous». ${ }^{860}$ Estupenda confidencia que deja abiertas las puertas a la homosexualidad latente de Durtal. Consideramos que, no obstante existir este deseo masculino, su origen se halla en una relación fantasmática con la figura del padre.

La relación de des Hermies con Durtal cobra un relieve familiar en la escena que vamos a comentar a continuación. Nos hallamos en casa, de nuevo, de los Carhaix; los cuatro personajes comparten una cena de raigambre campesina y bretona. El matrimonio Carhaix parece oficiar una misa ante los dos querubines, los dos hermanos, cuya presencia conjunta parece conformar la recreación de una escena familiar. Des Hermies es el alter ego de Durtal, que posee los mismos rasgos, los mismos gustos, la misma aversión a la ramplonería positivista. Es el hermano mayor de Durtal, cuyos conocimientos en medicina lo ponen en relación con las fuerzas ocultas que unen al hombre con la fisiología. ${ }^{861}$

859 J.-K. Huysmans, Là-bas, ob. cit., p. 26.

860 Ib., p. 87.

861 Gilbert Durand señala, gracias al concepto de «redoublement du héros» cómo el héroe stendhaliano encuentra siempre su antítesis en sus compañeros, quienes coadyuvan a la definición del personaje central: G. Durand, Le décor mythique de la Chartreuse de Parme (Les structures figuratives du roman stendhalien), ob. cit., p. 57 y ss. Nos damos cuenta, empero, de que esta contraposición héroe-compañero no se da de la misma manera en Huysmans: des Hermies, por ejemplo, es casi idéntico a su amigo Durtal. La utilidad, pues, de esta falsa contraposición es la de completar positivamente el dibujo del protagonista. 
En el ciclo religioso será el abbé Gévresin quien cumplirá las funciones de sustituto del padre-hermano del alma ante la mesa servida por maman Bavoil.

En este hermano queremos ver una melancolía del padre, un sustituto del mismo cuya presencia debe ser cubierta por un personaje de apariencia y comportamiento semejantes a la del héroe — en clara referencia a un narcisismo protector y necesario para la reconstrucción fantasmática de su vida pulsional.

Esta búsqueda del padre se da de manera evidente también en dos pasajes de importancia suprema que hemos encontrado en $\grave{A}$ rebours. Se trata, en primer lugar, del episodio de Miss Urania, la acróbata circense, «une Américaine, au corps bien découplé, aux jambes nerveuses, aux muscles d'acier, aux bras de fonte». ${ }^{862} \mathrm{El}$ encanto que le encuentra des Esseintes reside, precisamente, en su naturaleza cuasi-masculina cuando desaparecían en ella los gestos típicos de una señorita para dejar paso a los encantos ágiles y poderosos de un macho: «en un mot, après avoir tout d'abord été femme, puis avoir hésité, après avoir avoisiné l'androgyne, elle semblait se résoudre, se préciser, devenir complètement un homme». Y es precisamente con este nuevo aspecto de la personalidad de su acróbata que se dispara el deseo de des Esseintes, pues ante este "grossier hercule dont les bras le peuvent broyer dans une étreinte», el noble siente feminizarse.

Jean Starobinski insiste sobre el carácter masoquista de este encuentro sexual con Miss Urania; quien no será sino una especie de Belle Dame sans Merci, mujer fatal, «une chose, presque une victime» pero que tiene músculos de acero y «se transforme rapidement en bourreau». ${ }^{863}$ Sería esta señorita Urania un signo de los tiempos por el cual se significan los avances que en emancipación de las mujeres se habrían producido. Como señala Tacium, Miss Urania no es un accidente en el fin-de-siglo francés; señala, más bien, que el verdadero poder sexual está de lado de la mujer, ante el cual el hombre sólo puede presentarse como un mero alfeñique. "La virilidad es una impostura — dirán Bruckner y Finkielkraut—; la fuerza sexual se sus-

862 J.-K. Huysmans, À rebours, ob. cit., p. 145.

863 J. Starobinski, Portrait de l'artiste en saltimbanque, Flammarion, París, 1970, pp. 47-50. 
tenta realmente del lado de las mujeres [...] El auténtico falo, infatigable y siempre dispuesto, es el sexo de la mujer». ${ }^{864}$

El hecho de que, al verla actuar de nuevo como espécimen de género femenino, des Esseintes pierde su deseo sexual, desvirilizándose. Tacium señala que este episodio deja de manifiesto que para que nuestro héroe sea viril debe efectuar un acercamiento de ambos sexos. Esta opción resultaría muy atractiva en nuestra reivindicación del borrado de la frontera de géneros; pensamos, empero, que se trata en este episodio de otro asunto.

No es que des Esseintes debe feminizarse para erotizarse. Lo que necesita el personaje es la presencia de una instancia masculina para revitalizar su deseo erótico. Y esta presencia no puede ser otra que la del padre fantasmático, dotado en el imaginario del niño adulto de unas cualidades represivas, necesarias para conservar su primacía sobre el disfrute de la madre. Este personaje secundario, Miss Urania, que presenta una relación directa con la homosexualidad a causa de su nombre, pondría en escena un trauma infantil en el que el niño habría sido sorprendido en pleno acto masturbatorio. El episodio no deja de ser una reconstrucción de ese incidente; su vocación es la de exorcización.

Este hecho queda bien patente si se compara dicho episodio con el siguiente encontrado en $\grave{A}$ rebours. Nos estamos refiriendo, desde luego, al encuentro con la ventrílocua del café-concert. Recordemos, pues lo hemos tratado pocas páginas más arriba, que en un primer tiempo des Esseintes usaba del arte de esta artista para dar voz a la esfinge y a la quimera en un acto basado en Flaubert. El segundo «projet jusqu'alors irréalisable» consiste en revitalizar su deseo recurriendo «à l'adjuvant le plus efficace des vieux et inconstants prurits, à la peur». ${ }^{865}$ En este nuevo subterfugio des Esseintes solicitaba de la ventrílocua que, mientras él la tuviese entre sus brazos, le hiciese creer que un hombre encolerizado les gritaba detrás de la puerta: "'Ouvriras-tu? je sais bien que t'es avec un miché, attends un peu, salope!’. De esta manera, como un hombre que acomete una gran obra sintiendo un enorme peligro, este peculiar amante recobraba sus fuerzas y se lanzaba de nuevo a abrazar a su ventrílocua. El deseo renace ante la inminencia de la

864 P. Bruckner y A. Finkielkraut, ob. cit., p. 78.

865 J.-K. Huysmans, À rebours, ob. cit., pp. 148-149. 
entrada de ese personaje peligroso, de voz recia y ronca, mientras el niño adulto estaba cometiendo un acto prohibido. El temor ante la castración anima la libido porque recuerda al amante de su madre el momento en que le fue prohibido el contacto con esta. Revivir ese episodio equivale a verificar el imperio que un día tuvo el niño sobre la madre. El papel del padre es, aquí, el de actualizar los amores incestuosos — a pesar de la amenaza de castración que tanta incidencia tuvo sobre la obra huysmansiana.

Afirmamos así que estos episodios, en los que la crítica ha querido ver justificación de la feminización de Huysmans, no son sino la actualización de los amores infantiles. La castración flota sobre la escena de estos amores: su misma amenaza sirve también de reactivo, dándole visos de realidad ante el inconsciente siempre alerta de nuestro autor.

\subsubsection{Ansiedad de castración}

A lo largo de toda la obra de Huysmans asistimos a un proceso de castración progresiva del heterónimo ficcional. El motivo principal de esto es la continuada insatisfacción sexual de este personaje múltiple, que pasa por varias vicisitudes pero siempre viene a incidir en lo mismo: el ansia de que cese el impulso sexual, fuente de frustraciones, y que el individuo se libere de su imperio. Solo así podrá alcanzar su sueño de quietud y de entrega al trabajo constante en pos del arte.

El complejo de castración, como ya habíamos comentado con anterioridad, tiene como origen el complejo de Edipo. Por el mismo, el niño debe olvidar que su madre es un objeto de deseo, pues la amenaza pesa sobre él en la persona de su padre, de quien cree que le va a arrebatar eso que ambos tienen en común para impedir el robo del cuerpo de la madre. Aun groseramente esbozado, podemos ver en este resumen que la masculinidad se basa, desde sus comienzos, en una amenaza. "Una antinomia interna a la asunción por el hombre de su sexo — se pregunta Lacan—: ipor qué no debe asumir sus atributos sino a través de una amenaza, incluso bajo el aspecto de una privación?». ${ }^{866}$

La definición de la masculinidad desde la ortodoxia freudiana se plantea, pues, como una competitividad por el cuerpo de la hembra primigenia,

866 J. Lacan, «La significación del falo», en Escritos, ob. cit., p. 271. 
la madre, en la que dos generaciones de machos ponen sus aspiraciones libidinosas. Esta ortodoxia basa la amenaza en la agresión del hombre sobre el hombre, lo que no hace sino dar asiento a una concepción jerarquizada de la sociedad humana, fomentar la homofobia y, lo que es infinitamente peor, recluir a la mujer en un papel de objeto.

La psicóloga Karen Horney, sin embargo, plantea que el complejo de castración no está basado únicamente en una amenaza que el padre hace planear sobre el hijo. Ella lo plantea, directamente, como un miedo del niño a la vagina - perfectamente rastreable en los sueños de analizandos masculinos. ${ }^{867}$ Pero esta ansiedad de castración se manifiesta también en la vida despierta.

Horney relata la experiencia de una doctora de Dresde, la doctora Baumeyer, en relación con unos niños de una escuela a los que mostró un balón con una hendidura. Pidió a los niños que introdujeran los dedos en la raja, a lo cual solo accedieron seis sin temor de 28 niños varones, y no hubo manera de convencer a ocho. De 19 niñas, nueve metieron el dedo sin recelo, las demás manifestaron cierto recelo pero jamás aprensión grave.

Esta ansiedad, Horney la sitúa en un temor a la frustración de pensar que el pene del niño es demasiado pequeño para la vagina de la madre. Así reacciona con el miedo a su propia insuficiencia, a ser rechazado y puesto en ridículo. «Su miedo original a las mujeres no es — dice Horney-, en absoluto, una ansiedad de castración, sino una reacción ante la amenaza que se plantea a su amor propio». ${ }^{868}$

Este aspecto no puede parecernos demasiado descabellado tras haber encontrado en la obra huysmansiana numerosas huellas de ese sentimiento de incapacidad. La reacción, de acuerdo con lo expuesto por Horney, es claramente obsesiva. De ahí que la ansiedad de castración se pueda verificar a lo largo de toda la obra de nuestro autor.

La castración, desde esta perspectiva, supondrá un encaminamiento hacia la eliminación de esa frustración mediante la mutilación. A partir de un fenómeno inconsciente como es el descrito por el psicoanálisis, el

867 K. Horney, «El miedo a la mujer» y «La sobrevaloración del amor», en Psicología femenina, Alianza Editorial, Madrid, 1986, pp. 156-161.

868 Ib., p. 161. 
amante frustrado que es el heterónimo ficcional llega a desear la muerte de su actividad sexual a través de la pérdida de su atributo viril. La constante presencia de mujeres fálicas, de campanas y de sustitutivos fetichistas no hacen sino recordarle esta posibilidad, que a su vez él no hace sino aceptar como salida honrosa a su deficiente sexualidad.

Por otra parte, las manifestaciones de esta ansiedad de castración le acercan a las imagos de sus padres: a ambos las relaciona con su ansia de ser mutilado, como causantes de tal operación. Una vez mutilado, el niño autor volverá al paraíso infantil, asexuado y sin problemas de confrontación. A él cree llegar el Durtal de En route tras haber pasado por la experiencia de la confesión y la comunión: «Durtal finit par redevenir enfant, par pleurer sans cause définie, simplement par besoin de s'alléger de larmes». ${ }^{869} \mathrm{La}$ regresión infantil se completa; fin de los conflictos sexuales.

A lo largo de toda la obra, decíamos, se vislumbra esta ansiedad de castración; y esto, de diferentes maneras. La primera de ellas podríamos centrarla en la obsesión mutilatoria: personajes que carecen de algún miembro. El inconsciente es perfectamente capaz de operar un desplazamiento de la cosa mutilada sobre lo que realmente le interesa. El abanico es amplio.

En Croquis parisiens son numerosas las muestras de mutilaciones, que pueden ir desde una pierna — como en «Les Folies Bergère en 1879»: "Parmi des Messieurs assis, un jeune homme debout, à moustaches rousses, porteur d'une jambe de bois et d'un ruban rouge...», ${ }^{870}$ hasta el cabello, cuya pérdida agresiva será interpretada por el inconsciente como equivalente de la castración. Y si no, compruébese en el suplicio del personaje de «Types de Paris. Le Coiffeur» al visitar una peluquería:

Alors l'exorbitant supplice commence [...] Le moment est venu où le supplice va atteindre son acuité suprême.. dans une dernière prière l'on implore le ciel, l'adjurant de vous accorder un genou, une tête de veau, de vous rendre chauve. ${ }^{871}$

En otras ocasiones, la obsesión por la mutilación puede abarcar cualquier miembro — como en este croquis en que el personaje de una lámina

869 J.-K. Huysmans, En route, ob. cit., p. 308.

870 J.-K. Huysmans, Croquis parisiens, ob. cit., p. 9.

871 Ib., p. 75. 
se ve atado sobre una mesa e indefenso ante la amenaza de un grupo de soldados espada en mano:

étendu sur un matelas, ligoté par des sangles, roulant dans un visage ravagé des yeux morts. Près de lui, des soldats à perruques, coiffés de tricornes, vêtus de justaucorps galonnés et de culottes bouclées aux genoux, se tenaient, attentifs, l'épée au poing, tandis que derrière eux, deux juges à petits rabats d'abbé, regardaient, une plume en main, d'un air recueilli, la voûte du cachot où se passait la scène. ${ }^{872}$

Otras veces, la obsesión toma el tinte de un descuartizamiento, en el que la seguridad de la mutilación — de la castración— es mayor. Así se cumple en el caso del hombre que intentó asesinar a Louis XVI con un cortaplumas, y que el narrador se imagina estirado por cuatro caballos:

Mes pensées remontèrent jusqu'à cet homme qui avait si puérilement tenté d'exterminer avec une pointe de canif un Roi. J'assistai au solennel interrogatoire rappelé par la gravure, puis je me figurai le coupable écartelé comme il le fut, par quatre chevaux, sur la place de la Grève. ${ }^{873}$

Otros atributos a los que se otorga mayor importancia y que pueden aparecer mutilados son la lengua — como Paul l'Ermite, cuya leyenda se cuenta en Là-bas: santo varón que, ante la inminente tentación en presencia de una mujer, se cortó la lengua y la escupió a la cara de la tentadora:

Ce martyr, qui était tout jeune, fut étendu, pieds et poings liés, sur un lit, puis on lui dépêcha une superbe créature qui le voulut forcer. Comme il ardait et qu'il allait pécher, il se coupa la langue avec ses dents et il la cracha au visage de cette femme; et 'ainsi la douleur enchassa la tentation', dit le bon de Voragine. ${ }^{874}$

$\mathrm{O}$, incluso, la cabeza: sustituto del pene en toda la imaginería fin-desiglo que va desde Judith hasta Salomé. En este sentido y con esta intención se relata en L'Oblat la leyenda del anciano Khosroës, a quien el emperador Heraclio le deshizo de tan pesado atributo: «D'un revers de lame, l'Empereur (Héraclius) décolla le vieillard; et la tête rebondit sur les dalles». ${ }^{875}$ Pero también siega las cabezas el viento que atraviesa la iglesia en los momentos

872 Ib., p. 111. Se trata de Fantaisies et petits coins. Damiens.

873 Ib., p. 111. Episodio de la historia francesa comentado en E. Roudinesco, ob. cit., p. 40 y ss.

874 J.-K. Huysmans, Là-bas, ob. cit., p. 233.

875 J.-K. Huysmans, L'Oblat, ob. cit., p. 47. 
que anteceden a la consagración de la hostia ante el altar: «un vent passait qui fauchait d'un seul coup les têtes», ${ }^{876}$ donde podemos ver un ansia ante la posible emasculación que atraerá la conversión a la fe en Cristo. Y esto lo podemos poner perfectamente en relación con el poder de siega y de tala indiscriminada de que hace gala la iglesia —en este caso referido al edificio. Recordemos que la catedral de Chartres «tuait tout autour d'elle... Elle répandait partout dans ses alentours l'humidité et l'ombre», como nos es dicho en La Cathédrale, ${ }^{877}$ y reiterado en L'Oblat referido al jardín que cuida Mme. Bavoil —en el que un árbol, símbolo materno según Jung, ${ }^{878}$ impide el crecimiento de cualquier otra plantita:

Il avait malheureusement opéré le vide autour de lui et tué tous les arbres, trop rapprochés de ses racines ou de ses branches, si bien qu'il se dressait, seul, sur une terre nue, semée de ses écailles où nulle plante, nulle fleur, ne se hasardait à pousser. ${ }^{879}$

Como el árbol, Mme. Bavoil —no en vano simbolizada por él y representada en él en el jardín- arranca la vegetación ante la sorpresa de Durtal: «Enlever cela! Mais vous n’y pensez pas, ce sont les dernières végétations qui n'aient pas fui!». ${ }^{880}$

No obstante, la recurrencia más habitual para representar esta obsesión mutilatoria se basa en la pérdida de los dientes. Ya Freud en la Interpretación de los sueños indicó su asociación con el atributo viril, tan frecuente que casi se podría tildar de universal. Las citas son numerosas en toda la obra, de las que podríamos poner ejemplos en Les Saurs Vatard —cuando se habla de una joven del taller que sufría de dolores de muelas, lo que sirve de pretexto para que el narrador se lance a imaginar la operación odontológica:

Ouvrir la bouche, se faire tâter toutes les dents avec le manche de l'outil, laisser la pointe fouiller dans les trous et elle pleurait d'avance à l'idée qu'on lui laisserait encore du coton mouillé dans les racines. ${ }^{881}$

876 J.-K. Huysmans, En route, ob. cit., p. 172.

877 J.-K. Huysmans, La Cathédrale, ob. cit., p. 97.

878 Referido por G. Bachelard, L'eau et les rêves, ob. cit., p. 99.

879 J.-K. Huysmans, L'Oblat, ob. cit., p. 87.

880 Ib., p. 94.

881 J.-K. Huysmans, Les Seurs Vatard, ob. cit., p. 232. 
Ejemplos que tampoco faltan en Croquis parisiens: como el de ese director de orquesta de «Les Folies Bergère en 1879» que «extrait d'un geste sec des notes comme on arrache des dents». ${ }^{882} \mathrm{O}$, en Un dilemme, el caso de Mme. Champagne — amiga de Sophie que defendía supuestamente sus intereses_-, que tiene dos piezas postizas en el maxilar superior, y que su perro lame cada noche que los introduce en un vaso con agua:

Mme. Champagne possédait, en haut de la bouche, sur le devant, deux fausses dents qu'elle enlevait, chaque soir, et déposait dans un verre d'eau[...] Titi, le chien, l'avait happé, s'imaginant sans doute que c'était un os. ${ }^{883}$

Este nombre no puede sino sintomático de una práctica que a Huysmans debía de resultarle tremendamente peligrosa, y que consistía en abrir cualquier botella, ante la falta de decapsulador, con los dientes. La Sra. Champagne recibe su nombre, sin duda, de esta práctica: su principal cualidad mantiene una directa relación con su fuente. Este hecho lo vemos repetido en el croquis de "Au Bal de la Brasserie Européenne», en el que una de las jovencitas se dispone a abrir una botella de cerveza con sus dientes. El momento tiene un dramatismo que podríamos tildar de obsesivo:

'En vlà un cul!' dit l'une d'elles; elle empoigna résolument le goulot de la bouteille et voulut enlever le bouchon avec ses dents; mais elle tirait en vain, les traits contractés dans le blanc gras de sa face. ${ }^{884}$

La relación, además, de estos dos últimos ejemplos con la mutilación del atributo viril no puede ser más cercana.

Recordemos la visita que hace des Esseintes al dentista en el capítulo IV de $\grave{A}$ rebours: dramatismo al que se añade un ambiente siniestro como de tumba creado por la escalera de acceso al gabinete del odontólogo. En este episodio, Jean Borie quiere ver un individuo sacrificado a su verdugo que, al mismo tiempo que lo desposee de sus atributos, lo viola. ${ }^{885} \mathrm{O}$ el sueńo de la femme bouledogue que había perdido sus dientes y para reponerlos sacaba «de la poche de son tablier de bonne, des pipes en terre, les cassant et s'enfonçant des morceaux de tuyaux blancs dans les trous de ses gencives». ${ }^{886}$

882 J.-K. Huysmans, Croquis parisiens, ob. cit., p. 14.

883 J.-K. Huysmans, Un dilemme, ob. cit., p. 317.

884 J.-K. Huysmans, Croquis parisiens, ob. cit., p. 49.

885 J. Borie, Huysmans, le Diable, le célibataire et Dieu, ob. cit., p. 201.

886 J.-K. Huysmans, À rebours, ob. cit., p. 139. 
El carácter sexual de esta desdentación se hace patente en Là-bas cuando Durtal espera la visita de la desconocida de las cartas - que resultaría ser la esposa de su colega escritor Chantelouve-. Haciendo conjeturas sobre su belleza, sobre su físico, Durtal se pone tan nervioso ante la inminencia del encuentro que le chirrian los dientes: mutilación deseada que resultaría ser un recurso propiciatorio para evitar un frustrante encuentro sexual:

Et il se la figurait [l'inconnue des lettres] telle qu'il l'eût voulue, blonde et dure de chairs, féline et ténue, enragée et triste; et il la voyait, arrivait à une telle tension des nerfs que ses dents craquaient. ${ }^{887}$

La presencia de Pierrot en la obra de Huysmans merece que nos detengamos un momento. Extraído de la commedia dell'arte, Pierrot es una de las figuras fetiche del fin-de-siglo, desde los hermanos Goncourt hasta Jean Lorrain, pasando por una pléyade de escritores menores como Félicien Champsaur, Catulle Mendès, Paul Margueritte, Jean Richepin, Edmond Rostand, Léon Cladel, Jérôme Doucet, Achille Melandri, Albert Fleury, Jules Laforgue... Su relación con el tema que nos ocupa es que su pantomima puede asociarse con un gesto incompleto, inacabado, del que la página en blanco de su escritura se puede considerar como una confesión de su impotencia.

Su presencia es habitual en las novelas anteriores al ciclo religioso. Así, en Croquis parisiens, su importancia es notoria en "Les Folies Bergère en 1879", donde podríamos destacar su identificación con el director de orquesta citado más arriba, quien «conduit en habit noir et cravate blanche, remuant tranquillement de la musique, ennuyé et comme pris de sommeil»: su corbata blanca sobre fondo negro no representa otra cosa más que la cuerda destinada a su ahorcamiento.

Más adelante, en el mismo capítulo, aparecen en escena dos pierrots que simulan prepararse para batirse en duelo. «L'impression produite par l'entrée de ces deux hommes est glaciale et grande» — comenta el narrador. Súbitamente,

après une dernière révolte de la chair qui s'insurge contre le carnage qu'on attend d'elle, une énergie de bêtes acculées leur vient et ils se jettent, affolés, l'un sur l'autre... tombant brusquement, à bout de force, comme des mannequins dont le ressort se casse. ${ }^{888}$

887 J.-K. Huysmans, Là-bas, ob. cit., p. 89.

888 J.-K. Huysmans, Croquis parisiens, ob. cit., p. 21. 
El gesto incompleto figura aquí en toda su claridad: los personajes se averían como si su mecanismo motor se hubiese estropeado. La impotencia queda puesta de manifiesto.

En 1881, y en colaboración con Léon Hennique —a quien nuestro autor dedicaría «Les Folies Bergère»-, Huysmans escribiría un texto titulado Pierrot sceptique. En este texto, Pierrot intenta acercarse a una muñeca que le rechaza, lo que provoca un ataque de cólera cuando menos anodino: incendia su cama y la muñeca es sustituida por una "thérèse» de cartón de una mercería. Sobre este texto, y más concretamente sobre la indumentaria de Pierrot, Jean de Palacio señalará que todo ocurre «comme si le sac réceptacle recevait le corps décapité après une décollation métaphorique». ${ }^{889}$ Siguiendo la lógica dandiesca, la ropa es la sustitución del personaje a la par que el intrumento de su tortura.

En Certains podemos encontrar una nueva aparición de Pierrot en una estampa en la que se ve a una mujer cubierta por un pulpo. El dramatismo es tal que la mujer, atacada en su más profunda intimidad por los tentáculos del calamar, se convierte en un pierrot: desposeída, mutilada, castrada.

[...] de ses tentacules, l'horrible bête pompe la pointe des seins, et fouille la bouche, tandis que la tête même boit les parties basses. L'expression presque surhumaine d'angoisse et de douleur qui convulse cette longue figure de pierrot au nez busqué et la joie hystérique qui filtre en même temps de ce front, de ces yeux fermés de morte, sont admirables! ${ }^{890}$

Y cómo no mentar la pesadilla de des Esseintes en $\grave{A}$ rebours, en medio de la cual aparecen unos «immenses et blancs pierrots [qui] faisaient des sauts de lapins, dans des rayons de lune». ${ }^{891}$ Ante su visión, el durmiente se pone a llorar desconsoladamente pues cree imposible, tras eso, poder cruzar el umbral de la puerta. "Je serai écrasé, pensait-il». La presencia de la luna, que envenena el ambiente de presencia femenina — como apunta Bachelard—, ${ }^{892}$ unida al sentimiento de aniquilación del soñador, nos reenvía directamente a esa ansiedad ante la pérdida de la propia masculinidad.

889 J. de Palacio, "À rebours, ou les leçons du rangement d'une bibliothèque», en JorisKarl Huysmans. À rebours. Colloque de la Société des Etudes Romantiques, S.E.D.E.S., París, 1992 , p. 112.

890 J.-K. Huysmans, Certains, ob. cit., pp. 79-80.

891 J.-K. Huysmans, À rebours, ob. cit., p. 139.

892 G. Bachelard, L'eau et les rêves, ob. cit., p. 123. 


\subsubsection{Desvirilización anunciada}

Con todo este programa de ansiada castración podría decirse que Huysmans espera de la desvirilización una solución definitiva a sus problemas sexuales. Incapacidad, insatisfacción, tedio, sobreinvestimiento de las instancias parentales presentes en todo acto amoroso..., desembocan en la castración para ser resueltos por ella. ¿ Muerto el perro, se acabó la rabia? Si nuestro autor concede a su imposibilidad de penetración un valor terapéutico es porque cree que con ella su separación de las mujeres se hará efectiva. Y siendo posible que las crisis falderas no se presenten con la misma violencia que antaño, la libido sigue necesitando ser liberada y satisfecha de alguna manera. Lo que cabía esperar como una solución a dichas crisis y su corolario de culpabilidad puede tornarse como un obstáculo a la necesaria descarga libidinosa.

En efecto, se puede leer en toda la obra precedente al ciclo religioso una aspiración a la definitiva impotencia que le libre de los problemas del contacto carnal. Él mismo dirá en algún sitio que la impotencia es, después de todo, el comienzo de la tranquilidad beata y paradisíaca. ${ }^{893}$

Ya en En ménage se puede observar dicha ansia desde el instante mismo en que André se separa de Berthe y debe enfrentarse al cotidiano alimento de su libido. El «repas de fin de mariage» que le ofrece a su amigo Cyprien en contraste con el que ya le ofreció de entierro de su vida de soltero parece prefigurar esa cena en honor de la virilidad momentáneamente muerta de $\grave{A}$ rebours. ${ }^{894}$ Solo así, con la incapacidad aceptada y sellada de acometer el acto sexual basado en penetración-eyaculación, el niño adulto puede irse a la cama sin ningún temor: esa felicidad sin parangón en el mundo que enuncia André:

Le seul bonheur qui soit peut-être complet sur la terre, être au chaud, dans un lit solitaire, chez soi, libre d'y fumer, libre d'y lire, sans gêne d'aucune sorte, sans obligation d'écouter et de répondre. ${ }^{895}$

893 "C'est le comencement de la tranquillité béate et paradisiaque», dice en una carta a su amigo Hanon el 29 de marzo de 1881, en P. Buvik, ob. cit., p. 289. Vid. cita completa más adelante.

894 J.-K. Huysmans, En ménage, ob. cit., p. 82; J.-K. Huysmans, À rebours, ob. cit., p. 71.

895 J.-K. Huysmans, En ménage, ob. cit., p. 202. 
Nos sentimos tentados de añadir: «y el beso de buenas noches de mamá...» al que Proust daría sus letras de nobleza. La presencia de la compañera sentimental o sexual en la cama del héroe artista, del soltero vocacional, es una molestia no solo porque le impide dedicarse a las actividades que más le agradan: también porque le hace sentirse obligado a poner en marcha la maquinaria sexual —oh, $\tan$ insatisfactoria y vana.

Ese deseo de soledad en la cama calentita lo encuentra también Folantin cuando, ya convencido de que su vida sexual se ha caído por sí misma por la borda, habla de su socorrido lecho — cuyos parabienes celebra este antihéroe de la literatura contemporánea entre sábanas: «des actions de grâces s'élevèrent dans son âme, célébrant les pacifiques bienfaits du secourable lit» ${ }^{896}$ Se sobreentiende: un lecho solitario, en el que la presencia de la compañera no venga a interrumpir los sabrosos monólogos del héroe consigo mismo. Ya que esa presencia indeseable le obligaría a «la contenter alors que je souhaiterais simplement de dormir!»

Con este bagaje, Folantin es el héroe más tristón de toda la obra huysmansiana; el más desesperado ante la posibilidad de llevar una vida como los demás. En definitiva, el más reticente a compartir sus humores y su tiempo con una persona ante la que haya de sentirse obligado. Llega a esa decisión, no obstante, tras dolorosos momentos en que la soledad se le antoja opresiva. Llorando por su soltería, que una fortuna más generosa habría solucionado quizás, Folantin recibe una cantidad de dinero que le saca de la miseria que le procuraba su pobre trabajo. Y, acostumbrado como estaba a buscar disfrute y gozo en camas pobres y deshechas y en las mesas de tabernas poco cuidadosas con sus menús, ahora ya no le quedaban ganas de nada. La decepción se instala demasiado rápido —o la fortuna se le presenta demasiado tarde:

Et dire que maintenant qu'il était un peu plus riche, maintenant qu'il pouvait goûter à des meilleures pâtures et s'épuiser sur des couches plus fraîches, il n'avait plus envie de rien! L'argent était arrivé trop tard, alors qu'aucun plaisir ne le séduisait. ${ }^{897}$

La idea de rehacer su vida casándose se le presenta entonces: recomponer su vida doméstica, contar con alguien que le desembarace de esos

896 J.-K. Huysmans, À vau-l'eau, ob. cit., p. 393.

897 Ib., p. 387. 
«petits riens» que irritan al inútil soltero decimonónico, verse siempre acompańado de alguien entregado y solícito. «Incurieux, presque impuissant», ${ }^{898}$ debe declararse a sí mismo que esa idea se presenta demasiado tarde: "plus de virilité, le mariage est impossible. Décidément, j'ai raté ma vie». ${ }^{899}$ Más adelante, y haciendo uso de un típico mecanismo de defensa en este nuestro soltero compulsivo, se convence a sí mismo de que, al no casarse, ha evitado lo peor: «Eh! mon Dieu, chacun n'a-t-il pas ses ennuis? Il avait, dans tous les cas, évité les plus douloureux, les plus poignants, ceux du mariage». ${ }^{900}$ Contradicción flagrante en el espacio de pocas páginas: el mismo hombre que declaraba haber fracasado en su vida por no casarse dice, en la reflexión a la que le lleva su mancebía, sentirse afortunado por evitar ese horrible mal. Continuo debate en la mente de Folantin, el antihéroe por excelencia del siglo XIX, que se resuelve en constantes erranzas de restaurante a taberna.

Este personaje, Folantin, que tiene 40 años en la novela a él dedicada, supera en siete años la edad de su autor en el momento de su redacción. En ese mismo año de $1881-\grave{A}$ vau-l'eau se publica en 1882-, Huysmans declara a uno de sus mejores amigos haber llegado al límite de la potencia sexual, superándola largamente: la impotencia es cosa hecha para nuestro autor, y, aun lamentándola, sabe encontrar un consuelo propicio:

Je ne bande plus! je deviens gaga, ma parole d'honneur, à 33 ans! —Plus envie de rien — quelques érections de cervelle, par-ci par-là, de quéquette, pas! C'est navrant et consolant à la fois — car après tout, c'est le comencement de la tranquillité béate et paradisiaque-. ${ }^{901}$

Una dudosa tranquilidad si nos atenemos a las obras que le sucedieron: L'Art moderne (1883) y, sobre todo, À rebours, donde Folantin, apenas enriquecido por un pequeño golpe de suerte, se transmuta en el adinerado y noble des Esseintes. Poco de beata tiene la existencia que se plantea el residente de Fontenay-aux-Roses, debiendo amplificar el poder de los subterfugios sustitutivos para sublimar la siempre presente libido invasora. Ese es el papel que da a las famosas Perlas del Pirineo: bombones aromáticos y rellenos de licor con los que alimenta su mente de antiguos recuerdos:

898 Ib., p. 388.

899 Ib., p. 393.

900 Ib., p. 401.

901 Carta a Hanon, de 29 de marzo de 1881. Citada por P. Buvik, ob. cit., p. 289. 
Jadis, alors que son impuissance était acquise, alors aussi qu'il songeait, sans aigreurs, sans regrets, sans nouveaux désirs, à la femme, il déposait l'un de ces bombons sur sa langue, le laissait fondre et soudain, se levaient avec une douceur infinie, des rappels très effacés, très languissants des anciennes paillardises. ${ }^{902}$

Esto significa que des Esseintes da por extinguida su virilidad antes del momento de su reclusión en Fontenay. Observemos o no esta separación del mundo motivada por la definitiva emasculación o no, la cuestión es que la impotencia se presenta como inevitable. Los motivos que presenta des Esseintes son dos: uno, de origen familiar, debido a la decadencia de su linaje por consanguinidad abusiva y a la debilidad de su madre, le deposita en un afeminamiento que se acrecienta en su persona: «La décadence de cette ancienne maison avait, sans nul doute, suivi régulièrement son cours; l'effémination des mâles était allé en s'accentuant»; ${ }^{903}$ otro, cuyo origen se halla en la vida de disipación que ha llevado des Esseintes, siempre en busca de la esencia del placer, de la renovación de su inventario de orgías, esos "perfumes nuevos, flores más amplias, placeres sin experimentar» que le anuncia la quimera a través de su amante ventrílocua. Esta búsqueda del placer extremo y sin cortapisas va gastándole su capacidad de disfrute de las mismas, de tal manera que su paladar se embota y se extenúa («le palais s’émousse et se blase vite»); sus sentidos entran en una desagradable letargia, satisfechos tras el agotamiento de todo placer posible ("comme satisfaits d'avoir tout épuisé, ses sens tombèrent en léthargie»). La impotencia -o mejor dicho, la anafrodisia - se le presenta como una liberación: ante la imposibilidad de seguir agotando placeres, esta emasculación es como un punto final a sus correrías y, lo que es mejor, a sus sinsabores —en pleno sentido del término.

De ahí que celebre, de manera simbólica y como nuevo mecanismo de compensación, el término del sinsabor: ¿para qué seguir masticando, si la carne que las muelas despiezan no exhala ningún gusto? Invita a sus conocidos literarios y amigos de francachelas a una suntuosa cena; servida por esclavas negras desnudas de cintura para arriba; regada con los mejores caldos posibles; ambientada por una pequeńa orquesta oculta tras una cortina que ejecuta marchas fúnebres. Toda una puesta en escena del anuncio del

902 J.-K. Huysmans, À rebours, ob. cit., p. 144.

903 Ib., p. 61. 
fin de su virilidad — que el noble se encarga de hacer imprimir sobre unas tarjetas idénticas a las de los entierros. Prevista, anunciada y cantada con toda pompa a los cuatro vientos, des Esseintes acepta finalmente su impotencia declarada. Por eso mismo, ya sin necesidad del contacto humano más que para lo estrictamente necesario, se encierra en Fontenay: sus escasas nostalgias del género humano, del movimiento y de los placeres terrenales los satisfará mediante subterfugio y artificio - con las consecuencias que ya hemos visto.

Freud señala en su Introducción al narcisismo el sintomático apartamiento del mundo que presentan el histérico y el neurótico obsesivo. En todos estos enfermos no se produce, según el psicoanalista vienés, una ruptura en relación erótica con las personas y las cosas: la conservan en su fantasía; han sustituido los objetos reales por otros imaginarios, o los han mezclado con ellos, y, por otro lado, han renunciado a realizar los actos motores necesarios para la consecución de sus fines en tales objetos: lo que el psicoanálisis llama «introversión de la libido». ${ }^{904}$ La diferencia que observa Freud en su análisis de casos con el parafrénico (esquizofrenia, en su acepción más extendida) es que en este la ruptura libidinosa con el mundo exterior se produce completamente.

¿En qué categoría cabe encuadrar a des Esseintes? Creemos que en la primera, pues los mecanismos de sustitución son numerosos, así como sus vías de sublimación. Si la neurosis se presenta de manera tan aguda es, precisamente, por llevar un régimen alimenticio completamente insaludable y enfermizo. Su doctor le recomienda que vuelva al mundo, que se relacione con la gente, en una palabra: que restablezca sus vínculos libidinales con el exterior y los proyecte fuera de sí mismo con el fin de disipar la enfermedad.

Ahora bien, la ruptura libidinal con el mundo ya está efectuada en la medida en que su impotencia se ha declarado inamovible. Cabe preguntarse por la primacía de los hechos: ¿se aparta del mundo a causa de la impotencia, o esta sobreviene por haberse separado de aquel?

904 S. Freud, Introducción al narcisismo, ob. cit., p. 2015. Cabe decir que Freud, en el pasaje donde la cuestión es la introversión de la libido, se desmarca de la definición que de ella da Jung, de quien dice que lo usa indiscriminadamente. 
Sea como sea, el heterónimo ficcional se creía a salvo de esos empujes de la especie en su tebaida tranquila, en su retiro espiritual y ascético —que, por el momento, se limita a las paredes de su casa y del ministerio.

Desconocemos las verdaderas circunstancias de la vida sexual de Huysmans durante la redacción de $L \grave{a}$-bas; lo cierto es que de las cartas que le había enviado desde 1885 una tal Henriette Maillat hace nuestro autor un intercambio epistolar con el personaje de Hyacinthe Chantelouve. Y, aceptando finalmente que esta entre en su cama, Durtal se recrimina a sí mismo dejarse llevar por esas bagatelas: la importancia que, súbitamente, les otorga su instinto carnal se escapa al entendimiento del retirado escritor:

c'était incroyable, cette canicule exaspérée flambant tout à coup, dans un Novembre de corps, dans une Toussaint d'âme! Usé, vannée, sans désirs véritables, tranquille, à l'abri des crises, presque impuissant ou plutôt s'oubliant lui-même depuis des mois, il renaissait, et cela fouetté dans le vide, par le mystère de folles lettres! $!^{905}$

Sin deseos verdaderos, al abrigo de las crisis, casi impotente, aparecen las cartas y Durtal se deja llevar por el misterio, por el ansia de conocer lo desconocido, por la curiosidad ante lo que se oculta tras las cortinas que las cartas han creado entre él y esa extrańa mujer. Aunque, de vez en cuando, le sobrevengan accesos de seriedad: «Non, décidément, ce n’est plus de mon âge, ces choses-là. - Oh! et puis, pour ce que j'ai besoin maintenant des femmes!». ${ }^{906}$ Ya conocemos la continuación de estas dudas que crea en Durtal la llegada de las cartas: al grito de «je vais t'en ficher, moi, de l'Idéal», se lanza a los brazos de una prostituta a la que no había visitado en mucho tiempo. El resultado es la repugnancia definitiva — creía — de la carne, el disgusto ante sí mismo: la reconciliación fantasmática con la madre se iba produciendo, y con ella, el cortejo de culpabilidades varias.

A pesar de esta repugnancia súbita por la carne, la imagen de la desconocida corresponsal le sigue obsesionando. Su primera idea es la de recurrir al bromuro, que, como sabemos, es un potente inhibidor sexual. La ideas sobre una posible castración le sobrevienen de repente; se informa, se inquiere, lee en un volumen en casa de des Hermies que un autor del siglo

905 J.-K. Huysmans, Là-bas, ob. cit., p. 89.

906 Ib., p. 84. 
XVI, un tal Pierre du Moulin, afirma que ningún hombre castrado puede ser ordenado sacerdote, «à moins qu'il ne porte sur lui les parties qui lui défaillent». ${ }^{907}$

Vemos, pues, en este contexto, uno de los primeros pensamientos que surgen en nuestro Huysmans de abrazar la religión católica: la emasculación definitiva, que la vida monástica le ayudaría a sobrellevar con sus trabajos y sus rezos. Una emasculación que le permitiese acabar de una vez por todas con la vida de disipación a que le obligaba la urgencia de su deseo; que le permitiese acceder a la castidad. Aspiración esta que le sobreviene cada vez que sucumbía a las instancias de Hyacinthe, cada vez que debía poner en funcionamiento su vieja maquinaria sexual. $Y$ es que, con todo el esfuerzo que ponía la extraña mujer en abrazarle en su cama, Durtal se veía incapaz malgré lui de rechazarla. El malestar le asaltaba, la culpabilidad le aguijoneaba, la promesa hecha a sí mismo de abandonar todo simulacro amatorio le empujaba a dejarlo todo y recluirse en su estudio. "Pour la première fois peut-être, au souvenir de ces turpitudes, il comprit bien le sens maintenant désert de ce mot: la 'chasteté' —et il en savoura l'ancienne et délicate ampleur». ${ }^{908}$

Inmerso como estaba en el trabajo sobre Gilles de Rais, una cosa le inquietaba profundamente de este personaje. Atraído en principio por su carácter dandiesco, por sus prácticas alternativas, Durtal se asombra precisamente de que el noble medieval, tan bravo en la batalla, tan cruel con sus víctimas, retroceda ante el concepto de demonio, sienta un temor inasible cuando piensa en Cristo:

Cet homme si brave sur les champs de bataille, si courageux quand il accompagne et défend Jeanne d'Arc, tremble devant le démon, s'apeure lorsqu'il songe à la vie éternelle, lorsqu'il pense au Christ. ${ }^{909}$

Toda su fuerza, su fuerza intransigente y viril, su energía independiente y autónoma, encuentra sin embargo en lo sobrenatural motivo de temor. Qué otra cosa sino las potencias del más allá podían hacer mella en ese espíritu libre. Una vez sometido a las leyes de los hombres, el desposeído de

907 Ib., p. 93.

908 Ib., p. 179.

909 Ib., p. 151. 
su mayor y más potente atributo, su libertad, Gilles de Rais empieza a pensar en su posible salvación. Tantas libaciones ofrecidas al Maligno, tantos vientres destrozados por su avidez de sangre, le hacen temer por su salvación en el paraíso cristiano. La idea de un dios misericordioso se le aparece como un faro en medio de la deriva de su alma: a ella se aferra como el náufrago a su tabla de salvación. La fe nace en él del miedo a lo desconocido, del temor ante las llamas del infierno — que él alabaría en medio del goce de sus más bajos instintos de sangre y hiel.

Durtal, por su parte, desposeído de su atributo viril, de su anatomía desarbolada, piensa necesitar recurrir a la fe — creer en algo- que le ayude a recomponer su maltrecho bajel. Las ideas de puerto, de refugio, de tebaida reaparecen cuando compara su existencia con la de un barco desmantelado, desprovisto de mástiles que le permitan navegar a favor del viento. La fe es ese puerto, refugio, tebaida, «le seul môle derrière lequel l'homme démâté puisse s'échouer en paix!», ${ }^{910}$ como le dice su amigo des Hermies al final de la novela. Hará falta que la carne no esté en juego ya más ${ }^{911}$ para que Durtal se sienta tranquilamente asentado en su refugio; impotente, emasculado, su barco desmantelado es una nave inapta a los vaivenes del mar: más vale dejarlo en cala seca y consagrar su existencia a la sequía de la tierra firme.

\subsubsection{Dandismo de Huysmans}

Algunos estudiosos de la obra de Huysmans, como Carassus, ${ }^{912}$ afirman que la impotencia casi militante que se observa «en filigrane» en la obra de nuestro autor podría ser determinante del fenómeno del dandismo. Lo que algunos explican como simple desmayo fisiológico, otros lo justifican como la distancia que pone el dandi entre él y la mujer amada. Ser dueño de sí, idealización estética y desprecio por las pasiones vulgares estarían en la base de este alejamiento — alejamiento que preserva de los acercamientos que el fracaso convertiría en mortificaciones.

910 Ib., p. 275.

911 Como dice en L'Oblat: «La chair n'est plus en jeu...», convencido ya del fin de sus crisis falderas gracias a la recomposición que de él ha hecho el convento. J.-K. Huysmans, L'Oblat, ob. cit., p. 126.

912 E. Carassus, ob. cit., p. 148 y ss. 
Carassus duda de que se pueda aplicar indistintamente la impotencia al fenómeno del dandismo. Por lo que aboga este estudioso es por una cierta frialdad en los contactos humanos, sea cual sea su naturaleza: amistosos, amorosos, cordiales o apasionados. "Le dandy laisse volontiers percevoir, derrière son insensibilité, une sensibilité vibrante, aparemment étouffée par les deceptions et les médiocrités de la vie». En realidad, se trata de una sensibilidad a veces débil, otras simplemente introvertida. Nosotros, a pesar de la seriedad con que están formuladas estas aseveraciones de Carassus, afirmamos más bien el carácter de huida ante el fracaso - por lo menos en lo tocante a Huysmans. Coincidimos con este crítico en afirmar que el dandismo es una actitud de distanciamiento con todo lo humano, que tiene como fin preservar una sensibilidad delicada. Creemos, no obstante, que, con los datos sobre su obra que hemos expuesto hasta ahora, la impotencia de Huysmans es una estrategia tranquilizadora, un mecanismo de defensa, de retraimiento ante el peligro. Peligro, hay que decirlo ahora, no solo de fracasar, sino también de conflicto psicológico profundo.

Sin embargo, el dandismo tiene una base mucho más amplia que el simple repliegue - como hemos visto en el apartado que le hemos dedicado en el capítulo II. ${ }^{913}$ Se trata, más bien, de una actitud de plante ante la civilización en que vive el dandi, que no le contenta — antes bien le repugna.

El dandismo del siglo XIX es de tradición romántica. Su sentido de rebelión no podría entenderse sin un Byron o un Chateaubriand, incluso sin un Napoleón. En medio de la lucha por la vida que supone el nuevo estatus de orfandad para la juventud francesa, cada uno debe procurarse las condiciones para sobresalir, para triunfar o, aunque solo fuera eso, para vivir. Y esa corriente, que empezó con el siglo, se hace todavía evidente en personajes tan tardíos como el Marius Pontmercy de Les Misérables de Hugo: debe labrarse un porvenir por sí mismo, sin la ayuda de su abuelo - a quien le fue entregado en un generoso acto por su padre, militar degradado tras la caída del Imperio-, en cuanto conoce el pasado glorioso de su progenitor.

Carassus dirá sobre el dandismo que su filiación romántica es clara y patente; pero de un romanticismo que huye de la idea de Progreso impe-

913 Vid. apartado 2.5. 
rante en el siglo XIX. ${ }^{914}$ El dandismo romántico observa con melancolía la muerte de una cierta aristocracia espiritual, llevada al matadero por los aires de la sociedad mercantilista e industrial. "Il est impossible de parcourir une gazette quelconque... sans y trouver à chaque ligne... les affirmations les plus effrontées relatives au progrès et à la civilisation» — dirá Baudelaire en Mon cœur mis à nu. ${ }^{915} \mathrm{El}$ dandi aparecerá, desde su nacimiento en las postrimerías del siglo XVIII, como una figura de excepción, un héroe de los valores morales en medio de la sociedad democrática, capitalista e individualista —en lo que coincidimos con el juicio vertido por Georges Matthieu. ${ }^{916}$

El positivismo, o materialismo, es decir, el ambiente de productividad que impregnó la sociedad entera — con su cohorte de valores morales centrados en la familia, la producción y la reproducción- llevó a la humanidad del mundo industrializado, en opinión de muchos, a un malestar insoportable. El paradigma del nuevo modelo de sociedad, Estados Unidos, hizo que muchos refractarios al progreso tildaran de 'americanas' muchas de las actitudes visibles en la sociedad. El capitalismo americano se instaló en Europa mercantilizando todo lo que pudo arrastrar al mercado, convirtiendo al individuo en productor y consumidor de los bienes que él mismo producía. La alienación de la que hablaba Marx en sus escritos no era, finalmente, exclusividad de la clase trabajadora: extendía sus tentáculos a todo el conjunto de la sociedad.

«Il n'y a de grand parmi les hommes que le poète, le prêtre et le soldat, l'homme qui chante, l'homme qui bénit, l'homme qui sacrifie et se sacrifie. Le reste est fait pour le fouet», ${ }^{917}$ dirá Baudelaire con amarga lucidez. Huysmans añadirá: «Au reste, il n’y a d'intéresants à connaître que les saints, les scélérats et les fous; ce sont les seuls dont la conversation puisse valoir». ${ }^{918}$

\footnotetext{
914 Ib., pp. 246-252 (nota a pie de página n. ${ }^{\circ} 1$ ).

915 C. Baudelaire, Mon cour mis à nu, ob. cit., p. 41 (XLIV).

916 «Dans notre société démocratique, capitaliste et individualiste occidentale où le principale moteur des êtres est la compétition en vue de l'acquisition ou de l'accroissement des biens - par le travail ou par la ruse_- le dandy fait figure d'exception et apparaît comme un héros des valeurs morales», en G. Matthieu, Dandies and dandism, United States Lines, Nueva York, 1962, p. 201.

917 C. Baudelaire, Mon cour mis à nu, ob. cit., p. 27 (XXVI).

918 J.-K. Huysmans, Là-bas, ob. cit., p. 192.
} 
Quieren ambos decir con ello que tan solo aquellos individuos que se dediquen en cuerpo y alma a la puesta en práctica de unos valores humanistas son susceptibles de ser salvados de la condena de ignominia que lanzan a la sociedad. El placer fácil que sería, a la postre, condenado por gran número de escritores, aparece para toda esta nómina de artistas dandis, románticos de última hora si se quiere, para quienes el disfrute debe tener un componente altamente estetizante.

En la obra de Huysmans observamos cómo el heterónimo ficcional busca constantemente la singularidad. Desde Léo, de Marthe, hasta el Durtal del ciclo religioso, todos los personajes huysmansianos se salen del tipo de vida habitual. Sin embargo, el grado máximo de dandismo lo alcanzará el des Esseintes de $\grave{A}$ rebours, cuya separación del mundo adquiere los tintes más extremos y militantes. Para su mal, su aventura está condenada al fracaso por la simple razón de que, en un retiro como el de Fontenay-auxRoses, el motivo principal del dandi queda en entredicho: verse reflejado en el mundo y, a través del roce con él, desarrollar su espíritu y rebeldía particulares.

Del título de este libro, que iba a titularse Seul en una primera concepción, ${ }^{919}$ era justificado por Barbey d'Aurevilly por ir «a contrapelo del sentido común, del sentido moral, de la razón, de la naturaleza». Y que el panorama que mostraba de la literatura contemporánea es «como una cuchilla envenenada sobre las banalidades ineptas e impías» de la producción libresca anterior. ${ }^{920}$

Ya sea por ese deseo de protegerse del fracaso de la sexualidad o no, lo cierto es que el dandismo de Huysmans se plantea filosóficamente como un rechazo frontal al positivismo. Pero, y creemos que esta salvedad es importante, esta actitud de crítica se hace patente sobre todo a partir de Là-bas. Esta obra, como ya hemos señalado, marca un punto de inflexión, incluso más importante que el de $\grave{A}$ rebours, en la obra de Huysmans. En ella asistimos a los primeros balbuceos de un héroe que busca crear las bases de un modo de vida castrado, inmerso en el trabajo que sublima las urgencias de

919 Vid. R. Baldick, ob. cit., p. 105.

920 Le Constitutionnel, 28 junio 1884. Citado por Juan Herrero en su introducción a J.-K. Huysmans, A contrapelo, Cátedra, Madrid, 1984, p. 42. 
la libido. Algún acontecimiento debió de producirse —-más importante que la propia impotencia, deseada o no- para que Huysmans buscase con tanto ahínco la vía de la religión para solucionar sus problemas con su entorno.

Hasta entonces, el dandismo romántico de Huysmans consistía en un mero posicionamiento contra la ramplonería de sus semejantes, contra "l'humanité bestiale, populacière et campagnarde» ${ }^{921}$ que sería la base de la humanidad exquisita y aristócrata de espíritu que él no encuentra en ningún sitio. Y menos que en ningún otro en el campo, donde Jacques Marle no deja de asombrarse del nivel de animalidad, suciedad y bajeza moral que puede alcanzar el ser humano.

El odio por la humanidad ramplona parece irse acrecentando con el tiempo. A su vuelta del castillo de Tiffauges, adonde había ido a ambientarse durante la redacción de $L \grave{a}$-bas, se encuentra con un París revuelto con los fastos de la gran Exposición universal. En una carta que le envió al pintor Odilon Redon, Huysmans declara su rabia contra el común de los mortales, enfebrecidos por la exaltación de los tiempos modernos que fue dicha Exposición. Le dice en la carta, en un tono que ni Gilles de Rais ni Baudelaire habrían negado: "Tout cela nez en l'air, regardant les toits, lisant les noms des rues. Le besoin des égorgements se fait sentir... Des massacres...». ${ }^{922}$

En ese ambiente de estupidez generalizada, uno de los motivos de insatisfacción del creador es ver su obra expuesta a la mirada de todos esos paseantes que se extasían de la misma manera ante la placa de una calle que ante la Venus de Milo. Ni siquiera este acto supremo de la humanidad, que le equipara con Dios y le convierte directamente en padre de una criatura, puede satisfacer a su promotor: «Le seul dépit qu'ils puissent honnêtement ressentir, c'est, quand leur œuvre est imprimée, de la voir exposée aux salissantes curiosités des foules!» — a lo que añade el mismo Durtal pocas líneas más adelante:

Oui, c'est notre impénitent orgueil et aussi le besoin de misérables sous qui font qu'on ne peut garder ses manuscrits à l'abri des mufles; l'art devrait être ainsi que la femme qu'on aime, hors de portée, dans l'espace, loin; car enfin c'est avec la prière la seule éjaculation d'âme qui soit propre. ${ }^{923}$

921 J.-K. Huysmans, Croquis parisiens. «Fantaisies et petits coins. Le Gousset», ob. cit., p. 126.

922 Citado por R. Baldick, ob. cit., p. 178.

923 J.-K. Huysmans, Là-bas, ob. cit., p. 209. 
Esta actitud de superioridad con respecto a sus semejantes lleva a Huysmans a adoptar posturas claramente reaccionarias, que contrastarían enormemente con las expuestas por Baudelaire en su apoyo a la Comuna y en sus diferentes obras de aforismos. El pueblo ya no es una masa de individuos dejados en manos de la explotación capitalista, cuya ignorancia ha sido propiciada por el sistema para mantenerlos sometidos y dóciles. La sociedad está formada por gente voraz y ambiciosa, dotada de una moral mínima que parece sostenerles en la maledicencia y el abuso del prójimo. El matrimonio, la familia, el afán de lucro, la hipocresía de la religión, son elementos que el dandi tomará como blanco de sus flechas, pues es gracias a la moral que sustenta todo ese sistema que la sociedad se denigra poco a poco.

El progreso tanto científico como moral suscita la más viva repugnancia a nuestro dandi. Piensa Huysmans que ambos van a contribuir a la progresiva separación de la persona de todo lo que él considera importante: la belleza, el arte, la riqueza de la vida interior. Por eso su actitud es netamente reaccionaria y contra el progreso: cree que los tiempos modernos van a acabar con esa aristocracia espiritual, que será sustituida por una burguesía enriquecida por la industria y la especulación. Un ejemplo ilustrativo de ello lo encontramos en la novela La Curée de Zola, donde vemos cómo el capital transforma París y cómo el liderazgo social pasa de manos de la nobleza a las de los nuevos ricos.

Sea contra la nueva burguesía acaparadora de bienes y de creciente poder e importancia en la nueva sociedad, sea la pequeña burguesía, conservadora de sus oficios y su mezquina moral, Huysmans aprovecha cualquier ocasión para arremeter contra ella. De la misma manera que ha podido observar, en En rade, la ruindad de la gente de campo, únicamente interesada en vilipendiar al prójimo y en sacar partido económico a cualquier circunstancia, la burguesía provinciana también recibirá sus diatribas por las mismas razones. Si los campesinos se convertían en horrorosos especímenes humanos por su miseria humana, la gente de los pequeños oficios artesanos se vuelve, a ojos de Durtal, por obra de la monotonía de su ocupación, en seres horribles y deleznables. El desfile de la burguesía residente en Chartres un domingo se presenta ante la mirada atónita y superior del Durtal de La Cathédrale como un museo de los horrores: 
C'était un grouillement de larves humaines, de têtes en boulets de canons et en œufs, une série de visages vus au travers d'une bouteille, déformés par certains miroirs, échappés des albums fantastiques de Redon; c'était un musée de monstres en marche. ${ }^{224}$

La obra de la nueva sociedad, basada en el trabajo monótono, en «l'hébétude des métiers monotones», crea las condiciones para el deterioro social. La diferencia entre la crítica al ambiente que veíamos en el primer Huysmans, de filiación naturalista y denunciatoria, y este Huysmans reside en el punto de vista. Si el émulo del Zola de L'Assommoir se posicionaba como un observador al mismo nivel que los personajes por él estudiados - lo que le permitía una cierta empatía, y hasta simpatía, con ellos-, el Huysmans más tardío se pone en una esfera con mucho superior a la gente por él descrita. Todo es ataque contra la mediocridad, sin desear por nada del mundo comprender las vidas y las circunstancias de la gente que se para a contemplar.

En eso radica la mirada conservadora y reaccionaria de Huysmans: solo la existencia de una población trabajadora, ambiciosa y mediocre permite la existencia de personalidades singulares, de alta catadura, que se conviertan, a la postre, en faros de la sociedad.

Il ne peut y avoir que des gens de génie ou de talent dans le monde. Les médiocres sont nécessaires pour accomplir de médiocres labeurs; il en a toujours été ainsi et il en sera toujours ainsi. ${ }^{925}$

No obstante, sus ataques no se limitan a la burguesía pueblerina y al campesinado: la sociedad urbana está también en su punto de mira en la medida que execra toda la vida moderna, imitación de las costumbres venidas del otro extremo del Atlántico, y cuyos valores principales son la moral estrecha, el dominio sobre el débil y el poder omnímodo del dinero. Así, hablando de la obra de Zola, des Hermies exclama:

Puis, vois-tu, Durtal, il n'est pas qu'inexpert et obtus, il est fétide, car il prône cette vie moderne atroce, vanté l'américanisme nouveau des mœurs, aboutit à l'éloge de la force brutale, à l'apothéose du coffre-fort. ${ }^{926}$

924 J.-K. Huysmans, La Cathédrale, ob. cit., p. 218.

925 J.-K. Huysmans, L'Oblat, ob. cit., p. 79.

926 J.-K. Huysmans, Là-bas, ob. cit., p. 6. 
Americanismo y nueva sociedad que, como señala más adelante el mismo des Hermies, Zola alaba en su obra ensayística pero no ha incluido en su obra de ficción: «[Zola] n’a, Dieu merci, pas suivi jusqu'au bout dans ses romans les théories de ses articles qui adulent l'intrusion du positivisme en l'art».

Tal vez en este odio de lo mediocre radique su curiosidad por lo oculto y, en última instancia, por la religión. «L'exécration de l'impuissance, la haine du médiocre, c'est peut-être l'une des plus indulgentes définitions du diabolisme!», ${ }^{927}$ le hará decir a des Hermies a propósito de Gilles de Rais. Por una parte la anafrodisia ${ }^{928}$ a la que empuja la nueva sociedad — desprovista de atractivos para el artista romántico—; por la otra, la rabia contra la mediocridad: ambas llevarán al desengańado de los tiempos americanos a refugiarse en lo sobrenatural. De ahí, en parte, que Huysmans justifique su creciente importancia entre sus semejantes, que algunos oportunistas entienden deber explotar. Así se lamenta Durtal de toda esa caterva de teósofos, cabalistas y ocultistas que, como los adeptos de la Rose-Croix, pululaban en un París hastiado de verdades científicas: "Ces gens sont, pour la plupart, de vieux feuilletonistes ratés ou des petis jeunes gens qui cherchent à exploiter le goût d'un public que le positivisme harasse!». ${ }^{929}$ Dicho público, por esto mismo, adquiere una familiaridad ramplona con lo sobrenatural, que lleva a Huysmans a declarar, incluso, que el materialismo, por la seguridad que confieren sus razones científicas, es más noble. Porque lo sobrenatural se torna simplón y ridículo cuando un individuo sin sensibilidad se ve capacitado a convocar al espíritu de un gran hombre. Contradicción ambulante, nuestro autor reniega del imperio de lo desconocido en cuanto el vulgo se mezcla con ello: deben ser las ciencias ocultas monopolio exclusivo de un grupo selecto de personas. El elitismo de Huysmans choca de frente con la democratización de las creencias metafísicas. Imaginar que un carnicero pueda tratar de tú a tú a los grandes literatos del siglo XIX le resulta odioso a nuestro autor:

927 Ib., p. 51.

928 «La brute seule bande bien, et la foutrerie est le lyrisme du peuple», como dirá Baudelaire, en Mon cœur mis à nu, ob. cit., p. 37.

929 J.-K. Huysmans, Là-bas, ob. cit., p. 127. 
Quant à l'évocartion des morts, la pensée seule que le charcutier du coin peut forcer l'âme d'Hugo, de Balzac, de Baudelaire, à converser avec lui, me mettrait hors de moi, si j'y croyais. ${ }^{930}$

Por muy abyecto que sea, se replica a sí mismo Durtal, el materialismo es menos vil. Es su odio por la mediocridad lo que le lleva a expresarse así.

\subsubsection{Dandismo y misoginia}

En su proyecto de ataque a la mediocridad, la mujer juega un papel muy importante, puesto que ella representa lo natural, lo poco civilizado frente a la mente ultra-cultivada de nuestro autor. Por eso mismo, el dandi que hizo de sí mismo Huysmans — basado en un odio defensivo contra lo que podía suponer una amenaza contra su integridad- debía considerar a la mujer como un ser inferior, únicamente entregado a las servidumbres de la especie.

Si la actitud dandiesca de Huysmans era una pantalla con la que escudarse de agresiones exteriores — sobre todo en lo que concernía su posible impotencia-, es concebible que el ser causante de angustias fuera degradado. No woman, no cry: sin mujeres, la trama novelesca —ídem para la vida- pierde uno de sus componentes más obscenos, y el individuo-escritor puede así dedicarse en cuerpo y alma a su labor predilecta, el encierro en el estudio. "Moi, c'était cela qui me frappait surtout à cette époque, supprimer l'intrigue traditionnelle, voire même la passion, la femme» ${ }^{931}$ -como dice nuestro autor en su "préface écrite vingt ans après le roman». Ese tipo de novela que podía resumirse, según él, en pocas líneas, «savoir pourquoi monsieur Un tel commettait ou ne commettait pas l'adultère avec madame Une telle», ${ }^{932}$ la novela de desarrollo psicológico, no servía a sus intereses ni artísticos ni vitales: su proyecto era de transformar su vida a través de la reconstrucción de sus circunstancias. Por eso la supresión de la mujer se convirtió en uno de los leitmotiv de su obra más tardía. Sin embargo, no de cualquier tipo de mujer — pues las figuras que revisten cierto carácter maternal y casto son perfectamente admitidas y bienvenidas, cuyo máximo exponente será la Virgen María—, sino únicamente de aquellas mujeres que podían suponer un peligro, una tentación de orden sexual para

930 Ib., p. 128.

931 J.-K. Huysmans, À rebours, ob. cit., p. 55.

932 Ib., p. 46. 
nuestro autor. La última de ellas, Florence, fue objeto de largas y oscuras diatribas en la última de las obras, En route, donde aún se admitía la presencia tentadora de la fémina.

Sin embargo, hasta llegar a ese estadio de la producción huysmansiana, la mujer fue el blanco de los ataques más despiadados. Las causas son claras, pues siendo ella motivo de tentación y, por extensión, de la insatisfacción que producía en nuestros héroes, es lógico que el orgullo dolido arremeta contra quien provoca dicho dolor. Decimos lógico porque creemos comprenderlo, aunque apoyemos antes la idea de que es esa una solución fácil a la problemática de orden psicosexual que padece Huysmans. El problema no está fuera, sino dentro de sí mismo; la mujer es un chivo expiatorio, a quien se sacrifica en el altar de su propio ego.

Suprimir la pasión, suprimir la mujer. Lo que parece ser un planteamiento literario con afán de renovación de las letras de su tiempo se convierte, a la luz de nuestros argumentos, en una estrategia de defensa de la personalidad dolida.

Son dos, de esta manera, los motivos que llevan a Huysmans a menospreciar a la mujer: uno, por su filiación natural y anti-ilustrada; otro, por la amenaza que su presencia presenta para el atemorizado heterónimo. Amenaza que, como hemos explicado anteriormente, no pasa solo por el miedo al fracaso, por el miedo a la incapacidad: sucumbir a los encantos de la mujer es traicionar la memoria de la madre. Ya lo señaló Freud en su estudio sobre da Vinci, en relación con la homosexualidad latente de muchos artistas compulsivos que se refugiaban en el trabajo: a todo ello subyace una sólida fijación a la madre. Por ello mismo, cada nueva unión carnal con una mujer suponía para el ánimo de Huysmans un terrible sentimiento de culpa, en cuya base hallamos, precisamente, esta fijación materna.

Elisabeth Badinter entiende que la nostalgia del seno materno que sienten muchos hombres puede ser una amenaza contra su masculinidad; de ahí que el odio hacia el sexo femenino sea una salida clara — amén de fácilpara estos individuos. Recuérdese ese "odre... lleno de pus» a que se refería Baudelaire. ${ }^{933}$ Denigrar a la mujer será una salida, poco honrosa, pero salida al fin y al cabo, a las amenazas de castración y de regresión.

933 E. Badinter, XY. La identidad masculina, ob. cit., p. 79. 
La primera diatriba contra la mujer se basa en su cercanía a la naturaleza. "La femme est le contraire du Dandy», dirá su estimado Baudelaire: «la femme a faim et elle veut manger. Soif, elle veut boire. Elle est en rut et elle veut être foutue. Le beau mérite! La femme est naturelle, c'est-à-dire abominable». ${ }^{934}$ Por eso todas las sustituciones de lo natural por el artificio serán intentos de controlar y de sobreponerse a esa indomeñable naturaleza femenina; el mejor artificio es para Huysmans, sin duda alguna, la obra literaria.

La segunda diatriba, la que se centra en la naturaleza ultra-sexual de la mujer, será exorcizada mediante la cosificación de sus atributos. La mujer fatal es la gran protagonista de esta objetualización; la adoración de un ídolo, la definición de un ideal inalcanzable, permite la lejanía del amante y de la amada. Por extensión, la lejanía del amenazado y de su amenaza no deja de significar un refugio para el primero. «L'art devrait être ainsi que la femme qu'on aime, hors de portée, dans l'espace, loin»; ${ }^{935} \mathrm{o}$, como dice en otro pasaje de la misma novela, «il n'y a de vraiment bon que les femmes que l'on n'a pas eues»: averiguar que la mujer que se amó es inaccesible, honesta y casada, lejos, quizás muerta... «Il n’y a que ces amours irréelles et intangibles, ces amours faites de mélancolies éloignées et de regrets qui valent!».936 Ese es el tipo de "contacto» que nuestro autor desea mantener con las mujeres. Un contacto sin los aspectos más negativos del mismo, hecho a la medida de su mentor; y, cómo no, la mejor manera de llevar a cabo este tipo de contacto es, sin duda, la literatura.

La mujer, en primer lugar, en el imaginario huysmansiano aparece como un individuo que necesite constantemente ser domado. Su carácter natural la convierte en una especie de fierecilla que necesita domesticación para poder vivir sin problemas en sociedad. Este sería uno de los efectos de la socialización diferenciada de que hablaba Bourdieu, ${ }^{937}$ aunque llevado a su extremo en el siglo XIX.

Como en el ejercicio de la doma, hay que dejar bien claro al animal quién es el jefe. Solo así la bestia comprenderá que toda resistencia es inútil y, lo que es más, que es lo más conveniente para ella. Cuando la bestia se da cuenta de

934 C. Baudelaire, Mon cour mis à nu, ob. cit., p. 9.

935 J.-K. Huysmans, Là-bas, ob. cit., p. 209.

936 Ib., p. 178.

937 P. Bourdieu, La domination masculine, ob. cit., p. 87. 
que está a total merced de su dueño es posible que aparezca el amor. La admiración nace de esta sumisión, como lo ve la soberbia Mathilde de la Mole cuando el poder que ejerce Julien Sorel sobre ella es definitivo: «Il est digne d'être mon maitre, puisqu'il a été sur le point de me tuer», ${ }^{938}$ dice la joven aristócrata del secretario de su padre. El mismo fenómeno observamos en otra novela, muy del gusto de Huysmans, en la que la ligazón de la mujer al hombre se produce, precisamente, por el imperio que este demuestra tener sobre ella a base de golpes. "Entre ambos existían esos lazos de tortura que ligan a la mujer para siempre: el sacrificio, el sufrimiento, la humillación. La poseía porque había violado su conciencia, pisoteado sus ilusiones, martirizado su vida. Era suya, suya eternamente, él era el dueño de todos sus dolores». ${ }^{939}$ Germinie es completamente suya - de su amante Jupillon, quien no solo la torturaba físicamente, sino que la extorsionaba y la sometía a mil vejaciones.

En el caso que nos ocupa, la obra de Huysmans, el papel de domador está perfectamente atribuido al macho dominador, quien ejerce su autoridad ciega fuera del imperio de la razón. Se trata de un poder ciego, que exige la misma ceguera de quien lo sufre sobre sus carnes. Así se produce en la persona de Marthe, quien parece vivir las palizas que le propina su amante Ginginet con una extrańa mezcla de odio y ternura:

Cette haine attendrie que l'on porte au mâle qui vous fouaille, les révoltes furieuses contre le servage, cette allégresse à frapper son dompteur, quitte à se faire écraser par lui, rendirent Marthe preque folle. ${ }^{940}$

Sin embargo no es ella en esta la novela la única que parece mediar sus relaciones de pareja a golpes. También la nueva amante de Léo - a quien se une tras su ruptura con Marthe - viene de un pasado de amenazas y palizas; «et cependant quand elle y songeait, elle avait de grosses larmes dans les yeux, pleurant sur son sort, répétant qu'elle eût aimé à vivre près de lui et avoir des enfants». ${ }^{941}$

Los casos despiertan sin ninguna dificultad un cierto amargor en nuestro espíritu, pues en el momento en que este estudio está pasando por la im-

938 Stendhal, Le Rouge et le noir, ob. cit., p. 348.

939 E. y J. de Goncourt, Germinie Lacerteux, ob. cit., p. 221.

940 J.-K. Huysmans, Marthe, histoire d'une fille, ob. cit., p. 106.

941 Ib., p. 122. 
prenta, 2009, España conoce un incremento constante de las situaciones de violencia doméstica sobre las mujeres. Y, constatando este hecho, no podemos sino estremecernos al pensar mínimamente en la situación por la que debe atravesar una víctima que eche de menos a su torturador. En la psicología carcelaria, este fenómeno recibe el nombre de «síndrome de Estocolmo", por el cual la persona secuestrada siente una relación de dependencia con respecto a su secuestrador. Lo natural, como hacen estas obreras de Les Scours Vatard, es criticar a la mujer que se prenda de un hombre que la maltrata:

'Est-elle bête de suivre un homme qui la bat! c'est moi qui le ficherais en plan!' Et elles-mêmes arrivaient, le lendemain, avec un pochon et des ravines sur le visage et défendaient énergiquement leur maître alors que les autres le traitaient de brigand et de lâche! $!^{942}$

Difícil solución que encuentra este complicado problema. Se dan en él cuestiones de dependencia no solo económica - y los casos expuestos en la novela referida lo demuestran, pues las obreras se ganan la vida de la misma manera que sus compañeros varones (habría que añadir que con ciertas diferencias salariales, pero tal vez no venga al caso ahora); el quid del asunto es la dependencia emocional que se establece entre una mujer y a quien la sociedad otorga el título de su dueño. Ya sea éste marido, novio o amante, los roles de uno y otra pasan por la sumisión de esta a aquel; de lo contrario al situación se enrarece y los grandes fundamentos de la civilización parecen ponerse del revés. Y ese tipo de autoridad debe ejercer el novio de una de las hermanas Vatard, Auguste, a quien le recomiendan mano dura para arreglar la indisciplina de Désirée: «secouez-la comme un prunier et, au besoin, dégradez-y le portrait! criait le vieux Chaudrut... - Des gifles comme aux enfants qui crient! et voilà tout! ça allait tout seul après!».943

Es la única y verdadera manera de que lo establecido funcione: el hombre dicta y la mujer acata; de lo contrario, paliza. No hay más fina argumentación que valga en los diálogos sobre autoridad en la clase obrera pintada por Huysmans. Trabajadores que solo piensan en vaciar litros de vino y trabajadoras que solo aspiran a llenarse la tripa de patatas fritas a la caída de la tarde son los sujetos con los que nuestro autor teje sus tramas

942 J.-K. Huysmans, Les Søurs Vatard, ob. cit., p. 157.

943 Ib., p. 391. 
proletarias. Sin embargo, este escenario es perfectamente aplicable a cualquier clase social, puesto que aquí se trata más de una cuestión de dominación y estatus que de otra cosa. El dominador debe ejercer su dominación — aun malgré soi - a golpe de autoridad. Es así como se establece de la manera más clara posible la relación entre ambos miembros de la situación de dominación.

Algo más subyace a esta relación establecida mediante la fuerza. Se trata de la consideración de que la mujer pertenece al ámbito de lo natural, mientras que el hombre al de la civilización. Puesto que natural, la mano regeneradora y civilizadora del hombre debe violentar el terreno baldío para hacer de él un campo productivo. Es el sempiterno discurso de la dominación masculina sobre las fuerzas oscuras e imprevisibles de la tierra: para convertirlas en previsibles es necesario someterlas a control. Ese es el papel de la ciencia, asegurar que los hechos se repitan de una determinada manera para, mediante su conocimiento, controlarlos debidamente.

En este contexto de naturaleza y civilización, la mujer, como individuo humano sujeto a los dictados de la naturaleza imprevisible, carece de los rudimentos de lo que caracteriza al hombre civilizado: el raciocinio. Por eso mismo las mujeres del XIX pintadas por Huysmans aparecen carentes de raciocinio. Ese será uno de sus rasgos constitutivos: naturales y estúpidas. Es un planteamiento completamente sexista, que no se detiene en los motivos de semejante adocenamiento sino únicamente en sus consecuencias - que no sirven por sí mismas para explicar el fenómeno. Y como ejemplo de sexismo descarado en la concepción de la mujer tenemos a M. de Renal, quien se lamenta del poco juicio que alumbra a las mujeres —más en concreto a su esposa. Su desidia y su pereza — que han sido secularmente obligadas a hacer propias por falta de atribuciones fuera de la vida doméstica «ne vous donnent d'activité que pour la chasse aux papillons, êtres faibles et que nous sommes malheureux d'avoir dans nos familles!». ${ }^{944}$ En

944 Stendhal, Le Rouge et le noir, ob. cit., p. 138. Stendhal asegurará no obstante en De l'amour que, cuando una mujer se encarga de asuntos de contabilidad es capaz de superar en mucho al varón; su incapacidad corriente viene, como señalará este autor, de la inactividad en que ha sido sumida muy a su pesar en la mayoría de los casos. "Les femmes préfèrent les émotions à la raison; c'est tout simple: comme, en vertu de nos plats usages, elles ne sont chargées d'aucune affaire dans la famille, la raison ne leur est jamais utile, elles ne l'éprouvent jamais bonne à quelque chose». Stendhal, De l'Amour, ob. cit., p. 41. 
efecto, sometidas a la inactividad, a la única función de amas del hogar, la sumisión ignorante es uno de los rasgos de una gran mayoría de las mujeres decimonónicas.

Como corolario de esta carencia de raciocinio, las funciones del hombre que les toca en suerte a las mujeres pasan por la educación — si es que esta no ha sido llevada ya a cabo en instituciones de muy diversa índole que enseñan a las jovencitas a ser unas buenas señoritas. ${ }^{945}$ Pero, las jóvenes que acompañan a nuestro heterónimo ficcional en sus correrías son mayormente mozas del pueblo llano, sin estudios ni educación depurada. Son las grisettes y lorettes que abundan en la literatura del siglo XIX y que ambas son tomadas como mujeres de costumbres licenciosas. Por ese mismo motivo de carentes de educación y raciocinio, estas acompañantes son deliberadamente tratadas de estúpidas, merecedoras de esos aprendices de estetas que son el heterónimo y sus epígonos.

Así, Léo le comenta a un antiguo amigo en una carta si él no despreciaba tanto como él a las jovencitas de quienes se decían enamorados; «estce que, lorsque nous restions en tête à tête avec elles, tous nos instincts de gens bien élevés ne se rebellaient pas devant leur grossièreté native?». ${ }^{946} \mathrm{Ex}-$ tracto donde se observa bien a las claras la contraposición que nuestro autor intenta establecer entre las mujeres 'groseras' por naturaleza y el hombre ultracivilizado. Esa grosería natural se comunica también a las maneras de que hacen gala estas señoritas de dudosa reputación en sociedad. El Cyprien de Les Soeurs Vatard decide dejar de llevar a Céline de restaurante precisamente por la falta de etiqueta de esta a la mesa, pues: se mondaba los dientes con un hueso de conejo, llenaba los vasos hasta el borde, se estiraba en su silla cuando reía, rebuscaba en los platos las piezas más golosas... Y lo mismo hizo con las veladas en el teatro, al que dejó de llevar a su amiga por la vergüenza que le daba verla apoyarse con todo el cuerpo sobre la balaustrada, sus manías con los indiscretos, su ansia por comer chucherías... ${ }^{947}$

945 Cosette ha sido educada en unas pocas disciplinas durante su estancia en el convento de la parisién calle Picpus: «on lui avait appris la religion, et même, et surtout la dévotion; puis 'l'histoire', c'est-à-dire la chose qu'on appelle ainsi au couvent, la géographie, la grammaire, les participes, les rois de France, un peu de musique, à faire un nez, etc., mais du reste elle ignorait tout, ce qui est un charme et un péril». V. Hugo, Les Misérables, ob. cit., II, p. 465 .

946 J.-K. Huysmans, Marthe, histoire d'une fille, ob. cit., p. 138.

947 J.-K. Huysmans, Les Søeurs Vatard, ob. cit., p. 340. 
En otro pasaje, genial pasaje, en que, en medio de una reunión con los amigos de Cyprien, Céline hace un comentario ingenuo a más no poder sobre un cuadro que representaba un niño sobre un reclinatorio, ve cómo la concurrencia se parte de la risa para su incomprensión. La reacción de su amante es felicitarla con un beso de respeto "qui n'était pas vrai» para decirle: "Céline, tu es admirable! Tu es complète, ma fille!». ${ }^{948}$

Esto no puede sino indicar un gusto por el tópico de la fille estúpida que reina entre los amigos estetas de Cyprien. Mientras Céline se muestre sensata y formal, su retrato no interesa a estos epígonos del arte moderno; pero, a poco que la joven adopte las posturas típicas de la obrera de barrio, el círculo naturalista se extasía y cree estar asistiendo a un espectáculo de vida real. La mujer naturalista está sometida al dictado social más que ninguna otra: sumisa, idiotizada, previsible. Por eso cuando, pocos párrafos más adelante del pasaje comentado, Céline narra una pelea entre el capataz y su jefe, la pandilla le escucha con fervor: «Ça y est, s'écria l'auditoire, c'est nature!» ${ }^{949}$ — a partir de lo cual, Céline comenzó a ser tratada con el respeto, "convenablement, comme une grande personne», que merecía la adquisición de un estatus seguro para ella, que sobre todo no descolocaba a los jóvenes pintores de la banda de Cyprien.

La grosería e ignorancia naturales de la mujer torna al ridículo en el pasaje de $\grave{A}$ rebours en que el mismo tipo de pandilla de artistas estetas y militantes solteros hace mofa de uno de sus integrantes: decía que iba a casarse, y ello gracias a la inteligencia de su futura mujer, pretendiendo «avoir discerné chez elle d'exceptionnelles qualités de dévouement et de tendresse». Esto significa no solo que la inteligencia está abolida, desde la perspectiva del dandi decimonónico, sino que la natural constitución de la mujer le impide poseer cualquier atisbo de entrega y de ternura. Como individuo animal que es, la mujer puede albergar, en todo caso, accesos de preocupación por los demás — como cuando, por ejemplo, su prole se ve en peligro. La mujer que vive en la sociedad humana pasa por ser una desalmada que solo se preocupa de sus pequeñas cosas, en su ansia imparable de satisfacer sus caprichos. De esta manera, la obrera decimonónica es una egoísta desde el punto de vista de los literatos — de quienes no se

$\begin{array}{ll}948 & \text { Ib., p. } 343 . \\ 949 & \text { Ib., p. } 345 .\end{array}$ 
podría decir mucho más en materia de entrega. «Ah! elles ne sont pas bons enfants, clama-t-il. On ne leur demanderait pourtant que ça! Oui, mais pour être bon enfant il faut avoir été beaucoup roulé, comme toi et moi, par exemple». ${ }^{950}$ Como dice Cyprien a su amigo André, hace falta haber sufrido para conocer el sufrimiento y no infligírselo a sus semejantes. Bonito propósito pero poco creíble en boca de estos vividores natos. Es, además, un tanto ingenuo pensar que todas estas mujeres por ellos frecuentadas no hayan dejado de sufrir las vejaciones a las que nos hemos referido más arriba. Tal vez sea, eso sí, un impulso innato hacia el placer al que les empuja precisamente la violencia que pueda haber sufrido cualquier mujer en compañía de alguno de los hombres que atraviesan la obra «obrera» de Huysmans.

Sin embargo, estos estetas entienden aplicarse en los temas de amor con una generosidad elegante, que dore su condición de caballeros frente a la idiocia y falta de delicadeza de sus amantes. La cuestión es que, por no desearle daño a nadie, Cyprien y André sufren con chirriar de dientes las malas artes de sus compañeras, incapaces de llevar a término una relación de manera razonada y cortés. El recuerdo de todos esos momentos amargos, amontonados uno detrás de otro, contribuyen a la mala imagen que estos jóvenes se forjan de sus amantes: su misoginia se construye a golpe de desazón. Sin motivo aparente, una amante le deja sin decirle nada, otra sin escribirle siquiera, otra porque la vigilaba, otra porque no la vigilaba: una incomprensión completa que impide la comunión de los cuerpos y de los espíritus. La pelota está, como siempre, en el tejado ajeno: las mujeres no poseen las maneras necesarias a una buena vida en sociedad: "Je suis bête, moi aussi, murmura-t-il, je m'ètonne. Puisqu'il est entendu que toutes les femmes manquent de savoir-vivre lorsqu'elles nous lâchent». ${ }^{951}$ De ahí que el inventario que estos caballeros hacen de su experiencia galante sea más bien pobre: «les saletés que ses autres maîtresses lui avaient faites», ${ }^{952}$ «rancunes contre les femmes»... ${ }^{953} \mathrm{El}$ odio por el género femenino empieza a establecerse de manera definitiva en su imaginario; de ahí que su utilización

950 J.-K. Huysmans, En ménage, ob. cit., p. 44.

951 J.-K. Huysmans, Les Sours Vatard, ob. cit., p. 348.

952 Ib., p. 348.

953 J.-K. Huysmans, En ménage, ob. cit., p. 44 
por motivos meramente sexuales sea habitual: cuanta menos implicación con este animal peligroso e imprevisible, menos posibilidades de heridas incurables.

«Il est vrai qu'à force d'avoir étudié les femmes et d'avoir acquis pour elles un sacré mépris», ${ }^{954}$ dice este todavía epígono del naturalismo antes de que se diera al retiro del mundanal ruido y al cultivo de los placeres más refinados que hubiera. Y este es un nuevo elemento que puede diferenciar, para Huysmans, la mujer natural del hombre ultracivilizado: la manera de percibir la vida y sus vicisitudes. A fuerza de estudiarla, de intentar comprenderla, la vida se convierte en un escenario extraño en el que el pensador se vuelve un huraño incapaz de desarrollar ninguna emoción. Son los inconvenientes del pensamiento: las abstracciones intelectuales se vuelven contra la sensación -o estas adquieren un tono cultural que poco tiene que ver con el encantamiento inocente: salvo en casos incomprensibles para la mente despierta y de los que solo sabe algo el inconsciente dormido. "Et d'ailleurs, qu'importe après tout?... nous ne vivons pas, nous n'aimons pas. Nous étudions la vie, nous analysons l'amour, nous sommes des philosophes, pardieu!», exclamará Nerval durante su viaje hacia Oriente. ${ }^{955}$

Las mujeres, desde una óptica misógina, son, como hemos visto, inútiles seres solo aptos al abuso y al capricho, sin sentimientos altruistas y bien dotadas para hacer daño a sus semejantes. Pobres animalillos inconscientes, son, sin embargo, perfectas maquinadoras cuando se trata de sacarles provecho a los hombres. La literatura del siglo XIX está plagada de jóvenes seductoras que extorsionan de los ricos potentados que se prendan de ellas: prostitutas disfrazadas de grandes damas, jovencitas que hacen pagar un desorbitado precio por sus favores sexuales...

Con esto, la mujer es presentada, a causa de su dependencia económica de los hombres — que ella intenta paliar por los pocos medios que la sociedad pone a su alcance - como una carga para el hombre que la mantiene. Los ejemplos del siglo que tratamos de estudiar son numerosos: se

954 Ib., p. 33.

955 G. De Nerval, Voyage en Orient, ed. Michel Jeanneret, Garnier-Flammarion, París, 1980, tomo I, p. 112. 
trata de un hecho social antes que una moda o una anécdota. No deberíamos pararnos en esos hechos para explicarlos, sino detenernos a estudiar sus causas para comprender mejor sus consecuencias - cosa que ya creemos haber hecho unas cuantas páginas más arriba (ver «El matrimonio, dudosa solución»). ${ }^{956}$ Ya entonces habíamos recurrido a Engels para ilustrar la tendencia generalizada a considerar a la mujer burguesa, mantenida y cuya única ocupación es su propio cuidado, como una cortesana que había vendido su cuerpo de una vez por todas. ${ }^{957}$ El cuñado de Marx, Paul Lafargue, vería antes en la mujer de extracción burguesa un saca-dineros de sus hombres, primero el padre, luego el marido, a quienes convertía en acumuladores de millones que luego ellas derrocharían en caprichos. ${ }^{958}$ El encuentro de la prostituta y el acumulador se observa en esa extrańa unión que es la formada por el banquero Nucingen y Esther, la Torpille de Illusions perdues y de Splendeurs et misères des courtisanes — que si bien no es un matrimonio oficial, sí lo es como simple unión de hombre y mujer, tan habitual como eso parecía ser en los altos ambientes parisinos de los años treinta-cuarenta.

Esta consideración misógina - puesto que no se detiene a analizar las causas de tal comportamiento- se vislumbra en, sobre todo, En ménage, donde el contacto del protagonista con la esposa burguesa es más estrecho. De hecho, Berthe, la mujer de André, ha recibido el mismo tipo de educación que la mayor parte de las jovencitas de su edad: «elle était comme la plupart des jeunes filles, insignifiante» ${ }^{959}$ — dice de ella el narrador. Tocaba un poco el piano, pintaba platos, poseía un cierto gracejo y saber estar... Su padre, M. Viegois, afirmaba que, en tiempos de su mujer, los gastos que acarreaba el mantenimiento de ese tipo de feminidad - hecho de vestidos, afeites y perfumes - era más barato: «du temps de sa défunte femme, le harnais féminin coûtait moins cher», dice. Lo que esto deja vislumbrar es que siempre hay un hombre que se encarga de subvenir a esos gastos: antes del matrimonio, es el padre; tras este, el marido se encarga de sufragar esos «arreos» - como si la mujer fuera una bestia de carga. Y es que, como si estuviera dando la razón a Lafargue, Berthe ve en su padre un simple ban-

956 Apartado 3.7.2.

957 F. Engels, ob. cit., p. 69.

958 P. Lafargue, ob. cit., p. 126.

959 J.-K. Huysmans, En ménage, ob. cit., p. 36. 
quero, cuya caja debiera satisfacer todas sus necesidades y caprichos. «Et là, l'éternel féminin se retrouvait — dice el narrador-; toute la femme était là, honnête ou non, qui juge naturel de soutirer à l'homme de qui elle dépend, qu'il soit père ou son entreteneur, autant de monnaie qu' elle en peut prendre». ${ }^{900}$ Así comienzan los problemas entre Berthe y André; por motivos económicos, la brecha empieza a abrirse, encontrando como única solución o la aceptación del statu quo o la ruptura.

Otro argumento misógino importante que encontramos en la obra de Huysmans es el que llamaremos incapacidad para el arte por parte de las mujeres. Ya sea por motivos de educación o por otros de naturaleza fisiológica, el odio a lo femenino que demuestra nuestro autor se extiende hasta las posibilidades que tienen las mujeres de crear algo que no esté en relación directa con la animalidad. Desde luego, la gran obra de creación que reside en la capacidad de dar a luz es algo inalcanzable por el hombre; pero este se ve apto para producir otro tipo de obras que la humanidad precisa casi tanto - hablo desde la óptica de Huysmans - como los nacimientos. Ya sabemos de la importancia que tiene el arte para nuestro escritor.

Es este un argumento que aparece tan solo en la obra religiosa de Huysmans, y que pasa por el desprecio creciente que cobra la presencia de las mujeres en su vida monacal. Si Durtal «exècre la voix de la femme dans le lieu saint» es, sin lugar a dudas, porque su aparición en el escenario de su purgación espiritual, de su retiro ascético, pone en peligro los votos de castidad que se había propuesto a sí mismo. La visión de la hembra puede despertar súbitamente su espíritu de macho: él desea que esa tensión desaparezca de su vida, y, incapaz de controlarlo por sí mismo, culpa de ello a las féminas como instigadoras de su impuro deseo.

Las propiedades de la voz femenina para la música sacra han sido exaltadas por todo tipo de compositores a lo largo de la historia. No se puede decir que no abunden las obras vocales compuestas para mujeres, cuyos timbre y tesitura permiten unas tonalidades inalcanzables para la mayoría de los hombres - excepción hecha de los castratti, cuya capacidad para el agudo les permitía acometer repertorios típicamente femeninos, amén de las tonalidades graves propias de su sexo.

960 Ib., p. 96. 
El asunto no es de naturaleza musical o artística propiamente dicha, sin decididamente misógino. El prejuicio de Huysmans le hace creer imposible que una mujer sea capaz de alcanzar la elevación y la entrega de sí necesarias para el arte: puesto que demasiado pegada a lo terrenal, al cantar «la femme ne pleure que le médiocre idéal du plaisir terrestre qu’elle ne peut atteindre».

El motivo de esta incapacidad no está, como era de esperar, más que en su esencia natural. La mujer porta siempre con ella su carnalidad, «les miasmes permanents de ses malaises» que hace que los salmos se corten (faure «tourner les psaumes»). Por otra parte, su egoísmo, su ramplonería, su vanidad y su concupiscencia le impiden mantener un nivel artístico suficientemente alto: «ses cris d'adoration auprès de l'orgue ne sont que les cris de l'instance charnelle». De esta manera entiende Huysmans poder echar a las mujeres del templo. ${ }^{961}$

El canto gregoriano, un ejemplo puro de recogimiento medieval para mayor gloria de Jesucristo, no puede por todo ello ser perfectamente ejecutado por las monjas. Esta imposibilidad reside, en lo que abunda en $L a$ Cathédrale, en ese no poder olvidarse en el arte, en ese deber estar siempre presente característico de las mujeres, todo por obra y gracia de su vanidad inevitable: «une certaine complaisance à s'entendre quand elle n'ignore pas qu'on l'écoute». ${ }^{962}$ Lo que les da una languidez y una tendencia al arrullo inaptas para la música sacra.

Todos estos impedimentos tienen como origen, como ya hemos señalado, la imposible elevación del alma femenina por su terrenalidad — demasiado apegada a la tierra y a la instancia carnal, que es, al fin y al cabo, la carne, lo que preocupa tanto a nuestro Huysmans. Una carnalidad que él ve representada en La coronación de la Virgen de Fra Angélico, donde aparece representada una Catalina de Alejandría en loor de santidad. Su rostro, no obstante, no muestra la candidez necesaria para olvidar el aspecto carnal de su matrimonio con Cristo. Su presencia en este cuadro que Huysmans considera estupendo representa el pecado, la mancha dentro de la

961 Estas 4 citas corresponden al mismo pasaje de J.-K. Huysmans, En route, ob. cit., p. 131.

962 J.-K. Huysmans, La Cathédrale, ob. cit., p. 268. 
santidad del conjunto: «avec ses yeux pâmés, ses prunelles d'eau saumâtre, n'est ni simple, ni candide, ainsi que ses autres sœurs; celle-là voit encore la forme hominale du Christ, celle-là est encore femme, elle est, si l'on peut dire, le péché de cette œuvre». ${ }^{963}$

¿Cómo puede salvarse la mujer de esta lacra de la terrenalidad? Mediante la oración y la vida contemplativa: únicas vías para expurgar todo el pecado que hay en ella. La mujer es salvada por la religión y la vuelta a la infancia. En el convento, su voz cobra unas cualidades de castidad, de ingenuidad, que la devuelven al puro terreno de la niñez — gracias a la oración, las abstinencias y los votos, que depuran el cuerpo y «l'odeur vocale qui s'en dégage. Leurs effluves donnent à la voix des religieuses, si écrue, si mal équarrie qu'elle puisse être, ses chastes inflexions, ses naïves caresses d'amour». ${ }^{964}$ Esto significa que la acción benefactora de Dios padre y de la virgen María les permite darse al arte para mayor gloria de la santidad.

Este efecto benéfico de la religión, la confesión y la abstinencia se consigue a través de la expiación - del único y mayor pecado que tienen las mujeres: su carnalidad. Tras lo cual, la hembra se puede convertir en una mujer con pleno derecho de equipararse a un hombre. Esto significaría que solo después de haber eliminado su feminidad, su «hembritud», la esencia humana volviera al individuo femenino. Así se cantan las alabanzas de estas mujeres, madres superioras de sus conventos, que a fuerza de tormentos y privaciones han conseguido trascender su femenina condición, y acceder con ello a unas posibilidades intelectuales que jamás alcanzaría ninguna gran dama de un salón parisién: "les seules femmes vraiment intelligentes, vraiement remarquables, son, hors les salons, hors le monde, à la tête des cloîtres", dice el Durtal de En route. ${ }^{965}$ Ahora bien, muchas veces estas superioras no pueden olvidar que son la obra exclusiva de un hombre, de un alto religioso mayormente, que las han criado en condiciones especiales para entregarse a su empresa. En esos términos se refiere a santa Hildegarda, superiora de benedictinas, cuya obra es debida al ejercicio riguroso de dom Guéranger, «qui l'a prise presque enfant et lui a malaxé et lui a longuement broyé l'âme; puis il l'a transplantée dans une serre spéciale, surveillant, chaque jour, sa crois-

963 Ib., p. 186.

964 J.-K. Huysmans, En route, ob. cit., p. 131.

965 Ib., p. 520. 
sance en Dieu, et le résultat de cette culture intensive, vous le voyez». ${ }^{966} \mathrm{Ni}$ siquiera bajo la influencia de la religión la mujer es apartada de su vínculo terrestre; considerada como un ser natural, es el hombre, con su inteligencia ultracivilizada, quien debe encargarse de hacer de ella un ser humano.

En todos los casos, la misoginia huysmansiana se verifica en la convicción de que la mujer es, a todas luces, la verdadera perdición del hombre: su pecado original, su compañía tentadora, su mal primigenio: «le plus puissant engin de douleur que Dieu ait donné à l'homme». ${ }^{967} \mathrm{La}$ aureola de maldad con que se le dota durante toda la obra es verdaderamente demencial, obra de un donaferit completo - si se me permite este neologismo en la lengua de Llull. En esa pequeña nouvelle de 1887 — que por el estilo y temática podría fecharse con anterioridad- que es Un dilemme, esa aureola de artífice de la perdición del hombre toma la figura de Sophie Mouveau: la mujer que, al concebir un hijo del joven Lambois, provoca la defección de este. Los adjetivos que recibe la joven de parte de Maître Poinsart, el notario que va a embargarle todos sus bienes por orden del padre de su amante, son como mínimo denigradores. No vamos a pararnos en ellos, sino en la concepción de la mujer que deja traslucir su actitud.

Las mujeres son un obstáculo para el perfecto y deseable desarrollo del varón; cuando un hombre tropieza con él —y «les plus malins y sont pris»— puede darse por fastidiado de por vida. El hombre precisa de gran voluntad para no dejarse llevar por esa llamada de la carne, canto de las sirenas que solo un Ulises voluntarioso podría desoír: "Ah! c'est là notre point vulnérable, notre talon d'Achille», ${ }^{968}$ se dice al notario a sí mismo. Pero lo que es verdaderamente interesante es la motivación que tiene este emisario de la justicia de los hombres para actuar así: haber sido engañado por una mujer, lo que, al contextualizar en la experiencia este hecho lo hace palpable y casi real. La actitud misógina se revela, gracias a este dato, justiciera: castigo por la inevitable carnalidad de la mujer: «il était certain de juguler Sophie Mouveau, d'exercer impunément des représailles, de venger sur elle des déboires infligés par la cupidité de son sexe». ${ }^{969}$ Ahora bien, tras la confesión de haber

\footnotetext{
966 J.-K. Huysmans, La Cathédrale, ob. cit., p. 270.

967 J.-K. Huysmans, En route, ob. cit., p. 151.

968 J.-K. Huysmans, Un Dilemme, ob. cit., pp. 264 y 262, respectivamente.

969 Ib., p. 313.
} 
sido engañado la víspera hace que la sed del notario no sea de justicia, sino de venganza: debidamente explotado por una señorita, habiendo sucumbido a sus encantos, el notario hace culpable de su rabia a la joven, en lugar de a sí mismo: "Cette beauté et ce costume qui eussent sans doute attendri le vieillard, la veille, l'irritèrent par le souvenir qu'ils évoquaient d'une soirée maudite». ${ }^{970}$ Como nuestro autor, el notario descarga toda su inquina, a modo de venganza, sobre la mujer culpable de la caída en la carnalidad del joven Lambois. Simbólica vendetta sobre la madre del hijo del joven, se trata de un acto de rebeldía contra el orden establecido por el padre y la madre — aunque, desafortunadamente, solo recaiga sobre la madre.

La misoginia casi militante de Huysmans se manifestó en otras circunstancias, ya no solo literarias, sino también pertenecientes a su propia biografía. Robert Baldick nos revela que en el tiempo en que el obispo de Brujas investigaba sobre la posible identificación entre el Docre de Là-bas y el sacerdote de dicha ciudad, Van Haecke, Huysmans escribe al abbé Moeller: "Il y a des femmes mêlées à cette affaire et c'est une des causes pour lesquelles je m'en désintéresse, prévoyant bien qu'il n'y aurait que des ennuis à en attendre». ${ }^{971}$ Esto no hace sino confirmar la creciente huida de todo lo que tuviese que ver con mujeres a partir de su entrada en el mundo de lo sobrenatural — necesaria huida para preservar intacta la memoria de la persona con quien él creía necesario iniciar una reconciliación. Cualquier contacto con el otro sexo se le antojaba peligroso.

El tratamiento que en $L \grave{a}$-bas se hace de la mujer como soporte para el satanismo más salvaje es una muestra tremendamente ilustrativa del papel de perdición del hombre que ella reviste para nuestro autor. Abundan los comentarios sobre las misas negras en que una señora, desnuda por añadidura, era utilizada como altar; ${ }^{772}$ otros en que ciertas féminas, unidas en una asociación, comulgaban varias veces al día, guardaban el cuerpo de Cristo en su boca — en clara relación a su poder castrador - para escupirlas luego y someterlas a sacrílegos actos: ${ }^{973}$ acción esta que sería vivida por

970 Ib., p. 315.

971 R. Baldick, ob. cit., p. 185.

972 Por ejemplo, J.-K. Huysmans, Là-bas, ob. cit., p. 59.

973 Ib., p. 62. 
el propio Durtal en su encuentro con Hyacinthe Chantelouve tras la celebración de una misa negra, en el que encontró pedazos de hostia esparcidos por «l'abominable couche». ${ }^{974}$

La mujer es un saco de penurias y de males: «Si elle est bonne, elle est souvent par trop bête, ou alors elle n'a pas de santé, ou bien encore elle est désolamment féconde, dès qu'on la touche. Si elle est mauvaise, l'on peut s'attendre, en plus, à tous les déboires, à tous les soucis, à toutes les hontes». ${ }^{975}$ Sea como sea su relación con ella, siempre está uno sometido a su propia perdición. El mayor mal que puede ocasionar el contacto femenino es, según la interesada idea de Huysmans al respecto, la muerte. Como ya hemos visto en otro apartado, la mujer fatal por la que nuestro autor sentía contradictorios sentimientos - recuerdo de la madre castrada a la vez que castradora- que es Hyacinthe Chantelouve señala a Durtal que su primer marido se suicidó por efecto de su excesivo sentido de la libertad: «Il eut un tel chagrin qu'en une nuit ses cheveux blanchirent; il ne put jamais accepter ce qu'il appelait, à tort, selon moi, une trahison, et se tua». ${ }^{976} \mathrm{Ni}$ Durtal ni Huysmans llegarán jamás a semejante extremo, pues su apuesta se basa más bien en la separación definitiva para no ensuciar el nuevo concepto que de su madre necesitaba hacerse. Separarse del mundo y huir a un lugar donde la sola posibilidad de contacto con mujeres quede abolida: el convento, la abadía, el claustro: «La régle est formelle, si elles mettent seulement le bout du pied dans la clôture d'une abbaye, elles sont frappées d'excommunication, ipso facto». ${ }^{977}$

Como vemos, el dandismo de Huysmans es una actitud de rechazo hacia lo establecido, con el que cree ponerse por encima del común de sus semejantes. Rechazo, principalmente, hacia la sociedad industrializada y mercantilista, que cree en el materialismo de la ciencia como ideología. La aristocracia del espíritu por la que aboga este dandi romántico — uno de los últimos, pues los Montesquiou y otros antes optarían por el modelo brummelliano- le lleva a reaccionar de manera conservadora ante lo que la sociedad de su tiempo considera como progreso. Más que progreso, para

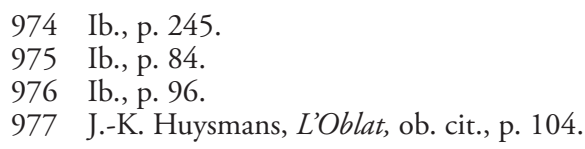


Huysmans existe una regresión hacia las posiciones más abyectas del espíritu. Por ello mismo, su postura dandiesca debía pasar, para ir verdaderamente a contrapelo de lo establecido, por abrazar las tesis contrarias al positivismo burgués. Lo sobrenatural se le antoja una salida lo suficientemente honrosa como para conseguir con ella un dorado a su dandismo; suficientemente misteriosa como para dotarle de la singularidad que siempre anduvo buscando; suficientemente contra corriente de lo que la época le dictaba.

Amén de esta postura ideológica, Huysmans hace suyas las posturas del dandi romántico como pantalla opaca a su sexualidad. Ya sea por el fracaso o por la insatisfacción, la búsqueda continuada de placeres parecerían ocultar unas exigencias estéticas en lo tocante a lo sexual cuya insatisfacción justificaran su impotencia. El dandismo de Huysmans no es sino una escapatoria, un mecanismo de defensa en el que el insatisfecho, el incapaz, el impotente se esconde.

Sin embargo, las causas fisiológicas de la impotencia no existen cuando Huysmans declara sentirla: su génesis la hallaríamos antes en su psicología profunda: un conflicto interior de corte edipiano, en el que se muestra claras ambivalencias tanto hacia el padre como hacia la madre. Hacia el padre, ensalzamiento de su figura — que tiene como base los reproches obsesivos que el hijo se hace por haberlo deseado muerto- - y posterior demonización. Hacia la madre, primero odio por haberlo abandonado - haciendo que el lugar que había dejado vacío el padre fuera ocupado por otro hombre-, más tarde fijación a ella — que sería germen de su latente homosexualidad por no querer traicionar su memoria.

A través de ambos casos, el sentimiento general de Huysmans es el de niño abandonado a su suerte - como sería paradigmático del siglo XIX y en la construcción de la nueva sociedad, individualista y forjadora de fortunas- que recrea en su obra literaria sus conflictos familiares. Esta obra literaria será el escenario ideal para quien, viviendo casi por y para los libros, vea representada su propia existencia y, lo que es más importante, que la vea reconstruida según lo que él podría considerar una justicia poética que se le debe. Por eso las circunstancias de su vida y su obra guardan tantas similitudes: Huysmans es todos esos personajes, que no dejan de ser sino expresiones variadas de sí mismo — su heterónimo ficcional, como hemos venido llamándole hasta ahora. Escribiendo la vida de ese heterónimo de acuerdo a un plan determinado, el autor escribe la suya propia en términos 
de ficción. Ahora bien, si la identificación entre personaje y autor es tal, solo cabe decir que, al final, el autor escribe para confundirse. Por eso la obra toda de Huysmans resultará ser la reconstrucción de su vida, de su pasado, de su origen — que él trastocará y restaurará por su propio bien.

El primer ladrillo de esta restauración es el del origen: al borrar o minimizar la influencia de sus padres en la biografía del heterónimo, este - tanto como el autor - se contentan con la ilusión de haber sido engendrados por generación espontánea. El hombre que se hace a sí mismo carece de historia infantil: todos sus éxitos le son debidos a su propio esfuerzo. Ningún patrimonio, ninguna fortuna —salvo en el caso de des Esseintes, último brote de una familia en decadencia- permite al heterónimo medrar en la vida: todo no es sino un desagüe por el que se escapa la existencia.

El segundo ladrillo es la construcción de la vida de adulto. La elección de no casarse no es gratuita; su odio por lo femenino tampoco lo es; sus particularidades sexuales tienen una motivación infantil — como hemos intentado demostrar a lo largo de este estudio. El sentimiento de traición hacia su madre se va acrecentando con la edad, produciendo asimismo un embotamiento de sus capacidades eróticas. Sus ensayos con hombres no parecen satisfacerle demasiado; no hace ascos, sin embargo, a la sodomía, que él prefiere practicar con mujeres jóvenes o, si la ocasión se presentara, con niños. La sexualidad convencional le satisface poco o nada, por lo que intenta vías alternativas de satisfacción: de ahí su gusto por lo artificial — ataque a lo femenino-, por los subterfugios, por la orgía estetizante. Antes de que la impotencia se instale definitivamente, des Esseintes se acoplará con señoras que le inspiren miedo — para renovar así el temor a ser mutilado que existía en su niñez. El éxito de estas tentativas es de corto alcance.

En los sueños, no obstante, la conciencia parece bajar la guardia y permitir al durmiente al realización de sus deseos más íntimos. Es imposible saber el grado de fidelidad con que Huysmans contó sus sueños en su obra, pero el análisis de los mismos parece arrojar enormes similitudes con lo relatado en la ficción despierta. El mismo miedo a ser mutilado por un personaje que tan pronto es representado por una campana, con una herida sangrante en el lugar del sexo, aparece a lo largo de todo el onirismo literario de Huysmans. Coincidencia con la enorme profusión de metáforas líquidas y referidas a profundidades húmedas que suele acompañar las escenas eróticas. Se trata aquí del recordatorio constante de que la madre ha sido 
castrada, de que no posee pene porque le ha sido extirpado en una operación de origen paterno; y esa obsesión no hace sino revelar la suya propia ante la castración.

Tal insistencia ante la posibilidad de castración da a la obra de Huysmans ese aroma de reconstrucción de un escenario infantil. El autor necesita reconciliarse con lo que en él queda de sus padres para que su sexualidad deje de atormentarle. Con ello conseguirá una cierta paz de espíritu necesaria a la vida de recogimiento que quiere llevar; vida de recogimiento donde el autor espera escuchar, tranquilizador, el frufrú de unas faldas al rozarse con los muebles. El matrimonio no le conviene; elegirá la vida conventual. Pero, antes de eso, necesita acallar su sexualidad de la única manera posible: convenciendo a su inconsciente de que todo está arreglado, de que la reconciliación está en marcha.

La religión será el instrumento que mejor servirá a esta reconciliación con las figuras paternas. Por una parte, es un alibi magnífico para justificar con ella su encierro conventual en busca de la paz necesaria a su amor por el estudio - lo que encierra, según el Freud de Introducción al narcisismo, el deseo de reconstrucción de su vida a partir de la fractura edípica (ver más arriba). Por la otra, el tratamiento que da la religión monoteísta — el cristianismo, en l'occurrence - a las figuras parentales permite a nuestro autor esbozar un ensalzamiento simbólico de ambas instancias. Por último, el refugio en un tipo de comunidad donde la sexualidad está abolida supone un verdadero «hâvre de paix» donde su barco desarbolado pudiera descansar tranquilo.

Llega pues el momento de abordar, con seriedad y rigor, la religión de nuestro autor y su papel determinante en la recomposición del escenario edípico.

\subsection{El refugio en la religión}

La conversión de escritores al catolicismo fue un fenómeno peculiar de este fin-de-siglo literario, pues varios fueron los autores que abrazaron la religión de Cristo. El ejemplo tal vez más sobresaliente sea el de Paul Claudel, quien se instaló en un catolicismo que casi podríamos calificar de militante, desde que descubriera a Cristo y a Rimbaud al mismo tiempo, y en base al cual escribiría no pocas de sus obras. No cabe, no obstante, olvidar 
a otros autores que, más o menos avanzada su vida, escribieron en clave religiosa: así Francis Jammes, Charles Guérin, Rodenbach, Ephraïm Mikhaël y Verhaeren — de quienes François Livi hace una muestra de textos en su estudio sobre $\hat{A}$ rebours. ${ }^{978}$

Los motivos de cada uno de estos escritores, aun siendo variados y personales, merecerían un estudio aparte, que creemos excede la finalidad de este trabajo. Sin embargo, y por la importancia que pueden tener estas conversiones para nuestras hipótesis, hay que detenerse un tanto en este fenómeno, en esta fiebre de conversiones de literatos en el fin-de-siglo francés.

El siglo XIX es el tiempo de la Revolución Industrial y de las verdades científicas. Europa, o mejor dicho, Francia, pierde el contacto con la política de orden divino en el momento en que guillotina a Luis XVI. Es el momento en que una nueva figura social, el ciudadano, irrumpe en la escena política y clama por sus derechos. Ese reconocimiento súbito de libertad provoca un sentimiento de zozobra en el individuo, que intentará compensar por medio de otras verdades con vocación inamovible. La ciencia será ese nuevo universo de certezas gracias a su capacidad para la previsión y el control del entorno. El materialismo cobra tanta importancia, como nuevo sistema ideológico, como lo cobra la nueva sociedad nacida a la sombra de las industrias, el naciente proletariado urbano y el abandono del campo por todos esos trabajadores empobrecidos por las sequías, una deficiente gestión agrícola y el tributo demográfico que el medio rural pagó a las guerras napoleónicas. ${ }^{979}$ Sede de la industria, la ciudad cobra una importancia que no había tenido antes, generando grandes riquezas pero también enormes bolsas de pobreza.

El siglo XIX, animado por las seguridades de la ciencia, no deja de albergar en su seno enormes avances en el ámbito de lo tecnológico. Parece haber llegado para la sociedad la salvación, protagonizada por los científicos, que debería venir a solucionar todas las causas perdidas de la humanidad. Esa es la gran Verdad — ahora, con mayúscula- que la Ciencia —ídem- intenta establecer: solo esta será capaz de prever y controlar. Su imperio no ha dejado de extenderse hasta nuestros días.

978 F. Livi, ob. cit., pp. 132-133.

979 Vid. D. I. Kertzer y M. Barbagli, ob. cit., p. 11. 
Sin embargo, muchos de esos creyentes en la omnipotencia de la Ciencia son conscientes de que esta no puede explicarlo todo, ni mucho menos preverlo ni controlarlo. Las grandes cuestiones de la humanidad de todas las épocas siguen sin respuesta, provocando su particular zozobra existencial a quienes no necesitan creer en el poder omnímodo de la nueva religión materialista — que vino a llamarse "positivismo" en boca del pensador Auguste Comte, denominación que deja a las claras el talante optimista de este siglo. El positivismo, al no poder llenar esas lagunas, adquiere las tonalidades de lo ramplón y lo simple, incapaz de abordar las grandes dudas de la humanidad con el mismo rigor que estipula el grado de ebullición del agua a nivel del mar. Esta nueva ideología adopta la estrategia del kitsch, consistente en mostrar únicamente lo que de positivo ofrece la nueva sociedad y ocultando las sombras que arroja sobre otros temas ya de por sí bastante oscuros.

Como reacción a estas sombras a las que ningún espíritu éclairé podría dar luz, sombras del positivismo, aparecen una serie de pensadores-filósofos que creen poder ocupar el espacio vacío dejado vacante por la Ciencia. Según René Girard, esto se hace perfectamente patente en el desarrollo de la novela decimonónica, especialmente en su lignée realista. Según el autor de Mensonge romantique et vérité romanesque, ${ }^{980}$ el siglo XIX ve nacer a un nuevo tipo de héroe que, tras asumir la mentira del tipo de sociedad de riesgo que exige de él entrega y voluntad de lucha, renuncia a sus creencias a causa de su necesidad de promoción. El resultado de esta renuncia pasa, en varios casos paradigmáticos (el Fabrizio de la Chartreuse stendhaliana, el Marcel de la Recherche proustiana), por retirarse del mundo en busca de una necesaria ascesis, en la muerte o en la escritura. Y este retiro será visto por Jacques Dubois como un acto de libertad. ${ }^{981}$

El materialismo empezaba a ser puesto en entredicho por una serie, pues, de autores refractarios — en denominación de Jean Borie— ${ }^{982}$ que se negaban a ver en el brillo de las luces del progreso científico equivalencia con las verdaderas luces del progreso individual en su lado más humanoespiritual, digamos.

980 R. Girard, ob. cit., p. 47.

981 J. Dubois, ob. cit., p. 55 y ss.

982 Vid. J. Borie, Un siècle démodé. Prophètes et réfractaires au XIXe siècle, ob. cit., p. 22. 
Tal vez el que mayor influencia y repercusión tuvo sobre la sociedad de las dos últimas décadas del XIX fue Arthur Schopenhauer. El autor de El mundo como voluntad y representación ${ }^{983}$ ofreció a sus lectores una nueva visión del mundo, bastante alejada de las luces del positivismo materialista. Un planteamiento que a muchos, a la postre, y entre ellos Huysmans, pareció insuficiente para llenar esas lagunas —a las que solo la religión podría ofrecer algo parecido a una cubierta.

En groseros rasgos, Schopenhauer plantea una división esencial de los sexos en virtud de la cual la mujer se convierte en ardid de la naturaleza para seducir al hombre y propagar la especie. Todo no deja de ser una gran mentira en que el instinto de supervivencia, la voluntad de vivir, es lo único verdaderamente indestructible y eterno. El tributo a la especie es ese, la necesidad no explicable ni comprensible de seguir viviendo, a pesar de que los sinsabores sean los únicos estímulos que nos empujen a ello.

Una filosofía doliente y sufriente que podría acoplarse perfectamente al Cristianismo: valle de lágrimas, expiatorio dolor de vivir, muerte simbólica en la cruz por el bien de los demás... Sin embargo, lejos de contrarrestar al papel de la religión mediante un pensamiento basado exclusivamente en el escepticismo más violento, Schopenhauer no hizo sino exacerbarlo por su carencia de soluciones al escenario que pintaba.

En el prefacio escrito por nuestro autor veinte años después de la primera edición de $\hat{A}$ rebours, las referencias al pensador alemán son numerosas, normalmente en tono de crítica. Según el Huysmans de 1903, Schopenhauer se comporta como un médico que se detuviera tras la emisión del diagnóstico para decir que para eso no existía ningún remedio. «Il vous laisse, pour ainsi dire, en plan; ses aphorismes ne sont, en somme, qu'un herbier de plaintes sèches», dirá en el prefacio; «il ne vous prônait aucune panacée, ne vous berçait, pour remédier à d'inévitables maux, par aucun leurre», señalará en la novela.

Aun admitiendo que la Iglesia y el filósofo partieran de los mismos principios («c'est vraiment une misère que de vivre sur la terre!»), la primera, por lo menos, proponía una curación a este doloroso mal: «'Église, elle, explique les origines et les causes, signale les fins, présente les remèdes; elle ne se con-

983 Publicado en 1818. 
tente pas de vous donner une consultation d'âme, elle vous traite et elle vous guérit». ${ }^{984}$ Con la diferencia añadida de que la Iglesia, con toda su liturgia tan ordenada, llena de cánticos y de arte, permite optar a una posible salvación en medio de la poesía que ella misma había creado y en la que él, Huysmans, «il avait baigné et dont il avait jadis absorbé l'essence par tous les pores».

Por otra parte, el refugio en la religión revela una incapacidad racional de explicar el motivo de esa incógnita, de por qué el hombre ha sido creado libre en medio de un mundo que solo le regala sufrimientos. Esa panacea que Schopenhauer no ofrece, esa curación tan esperada en las lecturas en busca del enigma de la vida, la iglesia la ofrece por medio de la expiación, "que l'on sent et dont on ne comprend pas la cause, l'idée que le seul but assigné à la vie est le Douleur» como dirá el Durtal de En route. ${ }^{985}$

Sea cual sea la vía elegida para hallar la solución, el sufrimiento está presente a lo largo del camino de salvación del hombre - ya sea en la necesaria expiación de sus pecados, ya por arrastrar con nuestro cuerpo ese cadáver que somos todos, para parafrasear al poeta italiano Guido Ceronetti.

Hay en Huysmans, pues, un deseo de expiación para llegar a una posible salvación ultraterrenal. Sin embargo, nosotros sostenemos que el refugio en la religión de nuestro autor esconde motivaciones más oscuras, de índole psicosexual. Las huellas de esta motivación las podemos hallar en el rastreo en sus textos de indicios de arrepentimiento y de aspiración a una vida más digna. Indicios que hemos hallado, principalmente, en clara y directa relación con la práctica de la sexualidad. La asociación es fácil y válida, y es mediante ella que nos vamos a introducir en el estudio de las convicciones metafísicas de nuestro autor.

\subsubsection{La entrada en materia}

Huysmans forma parte, como ya hemos señalado unas pocas líneas más arriba, de esos escritores que, a finales del siglo XIX, se convirtieron al catolicismo más ferviente de manera sorpresiva y militante. Y si decimos sorpresiva es porque su trayectoria previa no parecía de ningún modo prever semejante desenlace vital.

984 J.-K. Huysmans, À rebours, ob. cit., p. 49, y pp. 129-130, respectivamente.

985 J.-K. Huysmans, En route, ob. cit., p. 180. 
En el caso de nuestro autor, esa sorpresa ante la súbita conversión es grande. Ya desde el seno de su pertenencia al grupo de Médan, Huysmans recurrió rara vez a la lógica cristiana para explicar o suavizar las miserias de la clase obrera que entendía necesario describir en sus primeras obras. Tampoco su más temprano libro, Le Drageoir à épices, muestra interés ninguno por lo que él mismo calificaría, con el tiempo, "ce catholicisme si poétique». ${ }^{986}$ En plena expansión del positivismo materialista, Zola y sus seguidores habrían cometido sacrilegio contra la nueva ciencia si hubiesen intentado justificar los vaivenes de la fortuna mediante un discurso, siquiera, del tipo schopenhaueriano. Las teorías del jefe de Médan estaban religiosamente - si este adverbio cabe aquí- basadas en unos pocos tratados científicos aparecidos en la segunda mitad del siglo XIX, obra de Claude Bernard, Hyppolite Taine, Prosper Lucas y el inglés Charles Darwin.

El proyecto de Zola, ya lo conocemos, consistía en dotar de un tinte científico su obra, de tal manera que pareciera mostrar verdades basadas en la observación directa de la realidad. Y aunque el autor deseara difuminar su presencia en la construcción de la obra hasta el punto de pretender que fuera el entorno el que decidía del curso de los acontecimientos, el carácter ordenador del deus ex machina que es todo escritor deja suponer un cierto interés en la puesta en escena de los hechos.

La primera referencia que aparece sobre la religión en la obra de Huysmans la encontramos en Marthe, sin embargo - pero no utilizada como explicación de comportamientos ni de hechos. Los gustos literarios de Léo, el amante de la joven actriz, son descritos vagamente, aunque sí se dice algo sobre el tipo de escritura que realiza con mayor satisfacción: «De temps à autre, dans les bons moments, il écrivait une page fourmillant de grotesques terribles, de succubes, de larves à la Goya». ${ }^{987}$ Esta referencia nos hace pensar que Huysmans ya entreveía la posibilidad de acometer ese tipo de naturalismo místico que sería reivindicado con posterioridad. Goya debía de suponer para nuestro autor, gran admirador de Baudelaire, una referencia muy valiosa. Recordemos el poema del autor de Les Fleurs $d u$ mal titulado «Les Phares», en el que se asocia la obra del artista de Fuendetodos con ri-

986 J.-K. Huysmans, À rebours, ob. cit., p. 130.

987 J.-K. Huysmans, Marthe, histoire d'une fille, ob. cit., p. 61. 
tuales demoníacos. ${ }^{988}$ Por reminiscencias baudelairianas, Goya es un «faro» inexcusable para Huysmans —a la vez que nos sirve a nosotros para introducir su temprano gusto por los ambientes satanistas.

Entre esta cita y la siguiente median unos seis años, tiempo que transcurrió entre la publicación de Marthe y la de À vau-l'eau. Recordemos que esta breve novela narra las vicisitudes de ese soltero melancólico que es Folantin - un antecedente de des Esseintes pero sin los medios de este para llevar a cabo sus ideales; vicisitudes que consisten, en su mayor parte, en ir de restaurante en taberna. Hastiado ya de esta vida de erranzas sin satisfacciones, Folantin, mientras piensa en una tía suya, una religiosa muerta en una provincia lejana, se dice con envidia lo agradable que debe de ser una vida regulada por los hábitos del monasterio. Una vida tranquila, basada en la oración — considerada por Folantin como un "pasatiempo»-, la contemplación de sí, los cánticos y los rosarios: una vida que le permitiría huir de ese tedio, el spleen que roe su existencia y su ánimo:

Quelle occupation que la prière, quel passe-temps que sa confession, quels débouchés que les pratiques d'un culte! - Le soir, on va à l'église, on s'abîme dans la contemplation, et les misères de la vie sont de peu; puis les dimanches s'égouttent dans la longueur des offices, dans les alanguissements des cantiques et des vêpres, car le spleen n'a pas de prise sur les âmes pieuses. ${ }^{989}$

Sin embargo, hélas, la fe fue perdida hace tiempo por su espíritu formado en el positivismo materialista. Sin ella es difícil acogerse a un tipo de vida, el religioso, que podría ayudarle de manera importante. Critica en ella la intolerancia de los clérigos («l'intolérance du clergé le révoltait»), que esté hecha exclusivamente para los pobres de espíritu, y, sobre todo, que haya elevado a nivel de dogmas las creencias más absurdas («Pourquoi l’Église a-t-elle voulu ériger en dogmes les croyances les plus absurdes?»).

Qué lejos estamos aquí de las grandes alocuciones en favor de la vida eclesiástica o, para ser más exactos, de las alabanzas de los monjes; qué lejos de la envidia mostrada por los creyentes cuya fe inquebrantable les permitía extasiarse por la noche en la nave de la iglesia de Saint-Sulpice.

988 «Goya, cauchemar plein de choses inconnues, / De foetus qu'on fait cuire au milieu des sabbats, / De vieilles au miroir et d'enfants toutes nues, / Pour tenter les démons ajoutant bien leurs bas» (C. Baudelaire, Les Fleurs du mal, ob. cit., p. 89).

989 J.-K. Huysmans, À vau-l'eau, ob. cit., p. 440. 
Qué lejos y qué cerca, puesto que encontramos ya aquí el germen de las motivaciones huysmansianas para acercarse a la religión: la calma, la regularidad, el perderse a sí mismo en la contemplación de sí y el respeto a las etapas de la liturgia. «Et pourtant, reprenait-il, la religion pourrait seule panser la plaie qui me tire» — dice Folantin al final de este fragmento. Tenemos ante nosotros un individuo completamente descreído que desea con todas sus fuerzas acogerse a un tipo de vida que le permitiría huir de su ansiedad. No es de extrañar, con afirmaciones como las que nos hace Folantin, que ya en el siglo XIX ciertos estudiosos de la obra de Huysmans se preguntaran por la autenticidad de su conversión. Así, por ejemplo, al abate Belleville pone en tela de juicio dicha conversión al condenar el aspecto material de la vocación de nuestro autor. Incluso un crítico tan seguro de esa autenticidad como R. Griffiths ve en el Durtal de Là-bas una simple curiosidad de diletante. ${ }^{990}$

Cuando Gérard de Nerval estaba sufriente en el hospital parisién del Doctor Blanche escribió al comienzo de la segunda parte de Aurélia que «lorsque l'âme flotte incertaine entre la vie et le rêve, entre le désordre de l'esprit et le retour de la froide réflexion, c'est dans la pensée religieuse que l'on doit chercher des secours». ${ }^{991}$ Tal vez Huysmans no estuviese perdido entre las brumas del sueño, pero sí entre el desorden del espíritu y la fría reflexión. Porque nuestro escritor desea urgentemente el advenimiento del pensamiento religioso, de la fe, sobre él.

Como diría Freud en El porvenir de una ilusión, algunos recurren a Dios para precaverse contra riesgos psíquicos: «El verdadero creyente se encuentra en alto grado al resguardo del peligro de determinados padecimientos neuróticos; la aceptación de la neurosis universal le dispensa de la tarea de crearse una neurosis personal». Convencido de que todo creyente padece una neurosis obsesiva, el psicoanalista vienés afirma que la fe proviene, además del complejo de Edipo, de una enorme debilidad sentida ante los vaivenes de la vida.

También dirá Freud varios años antes de la obra citada más arriba, que la génesis de la religión parece estar basada igualmente en la renun-

990 R. M. Griffiths, Révolution à rebours: le renouveau catholique dans la littérature en France de 1870 à 1914, Desclée de Brouwer, París, 1971, pp. 100-101.

991 G. De Nerval, Les filles du feu suivi de Aurélia, Gallimard Folio, París, 1972, p. 322. 
cia a determinados impulsos instintivos. ${ }^{992}$ ¿Nos hallamos aquí ante unas aseveraciones aplicables a Huysmans, sin temor a equivocarnos y errar el tiro? Sabemos hasta qué punto la religión se convirtió en algo determinante en la vida de nuestro escritor; se hace todavía mayor la necesidad de establecer un diagnóstico claro y fiable de las motivaciones de JorisKarl ya que se dejó llevar por el viento del pensamiento religioso con plena voluntad.

Por una parte decimos que sí, que Huysmans deseaba que el sentimiento religioso se apoderase de él como antídoto contra la desesperanza; por la otra, el creciente sentimiento de culpabilidad que experimentaba en sus relaciones sexuales nos hacen concebir la idea de que mediante la práctica religiosa él creía poder renunciar a esos instintos.

La conversión de Huysmans reviste todas las características de la impostura - a tenor de lo visto hasta aquí, que es todavía poco.

En su retiro de Fontenay, des Esseintes confiesa haber tenido, desde niño, uno cierto gusto por los objetos religiosos: especie de levadura que predisponía favorablemente al personaje a los rituales y a la liturgia: «j’ai, depuis mon enfance, et sans que je l'aie jamais su, ce levain qui n'avait pas encore fermenté; ce penchant pour les objets religieux en est peut-être une preuve». ${ }^{993}$ Misales, libros de horas, ostensorios, incensarios,... decoran su palacete provincial, dotando a su morada de la ambientación de un retiro monacal. La predisposición está clara. Por otra parte, la inmensidad de lecturas religiosas de que hace gala des Esseintes revelan esa tendencia hacia todo lo que rodea la vida contemplativa. Sin embargo, ese regreso a la fría reflexión de que hablaba Nerval se hace patente cada vez que el taciturno noble se planteaba la posibilidad de refugiarse en las creencias sostenidas por la clase eclesiástica: «Il croyait pendant une seconde, allait d'instinct à la religion, puis au moindre raisonnement son attirance vers la foi s'évaporait, mais il restait, malgré tout, plein de trouble». ${ }^{94}$ Su problema: que jamás dispondría de ese espíritu de humildad y de penitencia cristiano. Estaba convencido de que la fe, esa iluminación, nunca le llegaría inspirada por uno de esos curas tan odiados por él.

992 S. Freud, Los actos obsesivos y las prácticas religiosas, en Obras Completas, ob. cit., 1972, tomo IV, p. 1341.

993 J.-K. Huysmans, À rebours, ob. cit., p. 125.

994 Ib., p. 124. 
Tan solo los maestros antiguos — de cuyas obras su biblioteca está repleta - parecen incitarle a abrazar los dogmas, o por lo menos el tipo de vida monástico. En una indefinible impresión de respeto y de temor —como dice él mismo_- el recuerdo de las imágenes, pinturas, esculturas, de todo el arte religioso en general, le subyuga enormemente. Sin embargo, en un acceso de rabia, ve alzarse frente a ese dios de la misericordia a su frío enemigo, el demonio. El gusto por los sacrilegios y los aquelarres se le presenta de nuevo, aderezado por todo tipo de oprobios contra los instrumentos de la liturgia y todo el aparato de la religión:

\begin{abstract}
à ces souvenirs, ses nerfs tressaillaient, puis en une subite rébellion, en une rapide volte, des idées monstrueuses naissaient en lui, des idées de ces sacrilèges prévus par le manuel des confesseurs, des ignominieux et impurs abus de l'eau bénite et de l'huile sainte [...] et une affreuse grandeur lui semblait devoir résulter d'un crime pratiqué, en pleine église par un croyant s'acharnant, dans une horrible allégresse, dans une joie toute sadique, à blasphémer, à couvrir d'outrages, à abreuver d'opprobes, les choses révérées; des folies de magie, de messe noire, de sabbat, des épouvantes de possessions et d'exorcismes se levaient. ${ }^{995}$
\end{abstract}

Es decir, las larvas y los súcubos en el estilo de Goya que Léo, el esteta de Marthe, ya anunciaba. No es sino el orgullo humano quien se rebela contra las ideas de pasividad y de bonhomía que predica la religión católica. Una rebelión casi inconsciente, visceral, que se crea en el vientre y que empuja a cometer los actos más indecentes contra lo que, pocos minutos antes, se creía estar en estado de venerar. Es esta una reacción digna de un neurótico, un enfermo que oye voces en su interior que le dictan actuar en contra de lo que su Yo, su instancia consciente, le está dictando. Porque es el niño que duerme en el inconsciente quien se despierta ante los cánticos angelicales que se oyen tras la aceptación de la religión del padre. Esta exige acercarse a él de rodillas, aceptar su autoridad y plegarse a sus dictados. Sin embargo, jay!, el miedo despierta al bello durmiente de su bonito letargo para recordar al Yo deseante de paz —el principio de realidad- que acercarse al padre significa exponerse a la castración. La explosión se declara: todos los símbolos de la figura paterna y de sus ritos de celebración son salpicados de la rabia del pecador.

995 Ib., p. 128. 
No obstante, nuestro Huysmans se sigue considerando un cristiano; incrédulo pero cristiano, quien no hace sino pedir a ese padre de cuya existencia duda la gracia de la fe:

Seigneur, prenez pitié du chrétien qui doute, de l'incrédule qui voudrait croire, du forçat de la vie qui s'embarque seul, dans la nuit, sous un firmament que n'éclairent plus les consolants fanaux du vieil espoir. ${ }^{996}$

\subsubsection{El recurso al ocultismo}

Hemos abandonado a Huysmans pidiéndole fe a un Dios en quien no cree. Pidiéndole un apoyo para paliar las insatisfacciones de su vida que él solo se veía incapaz de resistir. Un germen de neurosis obsesiva que, como aseguraría Freud, tiene por origen el complejo de Edipo, las relaciones del niño con su padre.

En $L \grave{a}$-bas, novela no consecutiva a $\grave{A}$ rebours - Huysmans escribiría entre estas dos cuatro obras: En rade, Un dilemme, Certains y La Bièvre-, es donde vuelven a aparecer los problemas religiosos con mayor virulencia. Como sabemos, es en esta novela donde comienzan a narrarse las andanzas de Durtal, heterónimo ficcional que viviría a lo largo de todas las obras que conforman lo que se ha venido a denominar el ciclo religioso de Huysmans.

Là-bas comienza con una conversación entre des Hermies y Durtal sobre literatura, más específicamente sobre Zola y el naturalismo. Al movimiento y a su líder le reprochan lo basto de sus ideas y de sus planteamientos: todo se resume en sexo y ataques de locura, en saber quién se acuesta con quién y las consecuencias que eso desencadena. Pero, sobre todo, le reprochan al naturalismo no haberse atenido más que a lo palpable, a lo material, rechazando con ello cualquier intrusión de lo suprasensible como respuesta - aunque solo fuera poética - al devenir de los personajes: «vouloir se confiner dans les buanderies de la chair, rejeter le suprasensible, dénier le rêve, ne pas même comprendre que la curiosité de l'art commence là où les sens cessent de servir!». ${ }^{997}$ Los sueños, Huysmans ya los había explotado como recurso narrativo en En rade — que le valieron, a la postre, la gran consideración de Breton en su Anthologie. ${ }^{998}$ Es, en de-

996 Ib., p. 241.

997 J.-K. Huysmans, Là-bas, ob. cit., p. 5.

998 A. Breton, Anthologie de l'humour noir, ob. cit., p. 189 y ss. 
finitiva, una apuesta por un tipo de arte no tan apegado a la tierra y a los sentidos, un arte que apueste por una apertura a otro tipo de experimentaciones que no puedan ser abarcadas por los vericuetos habituales de la razón lógica: «fuir ce territoire américain de l'art et chercher, au loin, une région plus aérée et moins plane». ${ }^{99} \mathrm{Y}$ eso es así porque, en realidad, la experiencia humana se divide forzosamente en dos partes: la vida del alma y la del cuerpo, cada una de ellas con sus características y sus componentes específicos. De ahí que para retratar la existencia se haga necesario recurrir a otro tipo de técnica que incluya la observación de ambas vidas: «de faire, en un mot, un naturalisme spiritualiste; ce serait autrement fier, autrement complet, autrement fort!». ${ }^{1000}$ Ahora bien, si a ese naturalismo de carácter espiritualista se le añade una componente religiosa, católica, se puede llegar a lo que Durtal llama sin ningún empaque «naturalismo místico». Para nuestro autor, Grünewald fue el más exagerado de los realistas de carácter espiritualista, el más exagerado de los idealistas; ${ }^{1001}$ Huysmans daría su do de pecho con Sainte Lydwine de Schiedam en 1901 — que no es sino una hagiografía como las que tanto gustaban a Joris-Karl a partir de un cierto momento de su vida. Pero nos estamos adelantando un tanto.

Durtal continúa el discurso que sobre catolicismo se hacía des Esseintes a sí mismo. Considera, como él, que la religión es el único remedio a las heridas del alma («la religion est la seule qui sache encore panser, avec le plus velouté des onguents, les plus impatientes des plaies»), ${ }^{1002}$ pero que requiere un tal adormecimiento del sentido común que se le hace imposible su adopción. A él le gusta, declara, poder conservar esa capacidad de asombro que favorece una actitud de apertura a lo no dogmático: el dogma anula toda posibilidad de maravillarse, pues sus verdades inmutables imposibilitan la creencia en ninguna otra explicación que las que este aporta. ¿ No es esa la misma acusación que vertía contra el materialismo, la falta de apertura a otras verdades?

\footnotetext{
999 J.-K. Huysmans, Là-bas, ob. cit., p. 19.

1000 Ib., p. 8.

1001 Como dice en J.-K. Huysmans, Là-bas, ob. cit., p. 12 (Vid. nota en 3.1.4). Más de veinte ańos después, decía sobre este pintor alemán: «Il [Grünewald] est à la fois naturaliste et mystique, sauvage et civilisé, franc et retors», en J.-K. Huysmans, Les Grünewald du musée de Colmar, ob. cit., p. 54.

1002 J.-K. Huysmans, Là-bas, ob. cit., p. 15.
} 
Lo mismo que a des Esseintes, a Durtal le maravilla el arte religioso, que considera una de las máximas manifestaciones de la elevación de la imaginación humana. Ese será el motivo constantemente esgrimido para justificar el acercamiento de Huysmans a la religión; ese y el deseo de escapar al ruido de la sociedad. Pero nosotros sabemos, con todo lo que hemos avanzado hasta aquí, que la conversión de Huysmans tiene un carácter psicosexual de enorme magnitud - cosa que vamos a intentar demostrar en las páginas que siguen y que hasta ahora tan solo habíamos esbozado.

Otro de los intereses de $L \grave{a}$-bas es que es uno de los primeros experimentos de novela dentro de la novela. Se trata de una novela de escritor, ya que el punto de partida es la escritura por Durtal de un estudio sobre el noble medieval Gilles de Rais. La elección del tema no es en nada baladí, pues él es la justificación de que la trama gire en torno al ocultismo y, más concretamente, al satanismo.

Como ya sabemos, Gilles de Rais fue conocido por el sobrenombre popular de Barbebleue, protagonista de leyendas con las que se atemorizaba a los niños. Gilles de Rais cometió tal suerte de tropelías en el alma y los cuerpos de los niños de la campiña bretona-vendeana que su nombre se convirtió en sinónimo de muerte y de destrucción.

Fiel soldado, buen militar, acompañó a Juana de Arco en su batallar contra los ingleses. Pero, un buen día, algo parece encenderse en su espíritu y comienza a cometer asesinatos, pedofilia, sodomías, misas negras, canibalismo... En fin, un enorme recuento de brutalidades que le hacen merecer juicio sumarísimo en la ciudad, entonces bretona, de Nantes y posterior ajusticiamiento público.

A Durtal le seduce esta figura medieval, en primer lugar, por la poesía que encierra la vida de un noble «latiniste, érudit, causeur spirituel» ${ }^{1003} \mathrm{du}$ rante la fría y oscura Edad Media. Un «satanique qui fut, au quinzième siècle, le plus artiste et le plus exquis, le plus cruel et le plus scélérat des hommes». ${ }^{1004} \mathrm{La}$ asociación con el personaje de $\grave{A}$ rebours es fácil, tanto que se le ocurre a Durtal calificarlo de «des Esseintes du quinzième siècle» en un momento de la obra.

1003 Ib., p. 46.

1004 Ib., p. 22. 
Sin embargo, lo que más llama la atención de nuestro autor es cómo un hombre tan gallardo en el campo de batalla se comporta como un apesadumbrado niñito cuando piensa siquiera en la vida eterna. Y ese temblor de pánico ante la idea del demonio es lo que atrae enormemente al Huysmans que se halla en pleno trabajo sobre el pensamiento religioso y la adquisición de la fe. No en vano dirá años más tarde que mediante su incursión en el satanismo llegó a Dios. Como señalará Alain Toumayan en su ensayo La littérature et la hantise du Mal, la historia de Gilles de Rais «devient une attestation de la présence du diable et une preuve de sa participation active et de son influence dans les événements de ce monde». ${ }^{1005}$

Una de las hipótesis principales de este libro es que el satanismo es un tipo de mística de la misma manera que la contemplación del Dios de los cristianos. Es de otra naturaleza, pues mientras el de Dios resplandece, el otro es un culto "purulento»:

Le culte du Démon n'est pas plus insane que celui de Dieu; l'un purule et l'autre resplendit [...] les affiliés du satanisme sont des mystiques d'un ordre immonde, mais ce sont des mystiques. ${ }^{1006}$

Pero nótese que el Durtal que dice eso todavía no cree en Dios ni en ningún tipo de instancia metafísica. Simplemente el primer paso se ha dado, que es el de considerar que la gente que practica un culto cualquiera no lo hace por falta de serenidad espiritual o por un ataque de locura. Si el culto del demonio no es más insano que el de Dios, lo que permite asegurar que «à ce compte-là, tous les gens qui implorent une divinité quelconque seraient déments!» — como dice en ese mismo pasaje. La religión es ya considerada por Huysmans como una puerta abierta, en lugar de ser el refugio de todos esos estúpidos de alma a que se refería des Esseintes. Là-bas supone, pues, el encaminamiento hacia las creencias metafísicas. Y si el estudio del satanismo, necesario para el trabajo de Durtal sobre Gilles de Rais, le ha llevado hasta Dios es porque las prácticas del culto diabólico se le antojan inconcebibles para la dignidad humana. Los ejemplos en la novela son numerosos.

1005 A. Toumayan, La littérature et la hantise du Mal. Lectures de Barbey d'Aurevilly, Huysmans et Baudelaire, ob. cit., p. 51.

1006 J.-K. Huysmans, Là-bas, ob. cit., p. 232. 
Se trata, en el caso del satanismo, de un impulso violento cuyo origen desconoce el individuo y que la ciencia se ve incapaz de dilucidar. Es la concreción de ese naturalismo místico por el que abogaba Durtal al comienzo de la novela y del que defiende su necesidad, precisamente, porque la naturaleza humana está compuesta por dos partes: mental y física, el alma y el cuerpo.

En la oposición que Huysmans establecerá entre el discurso científico, materialista o positivista y el discurso eclesiástico, sus deseos y sus necesidades de escritor le hacen tender más al segundo. En parte por la imposibilidad de demostración que tiene el primero para explicar todos los fenómenos que $L \grave{a}$-bas pone en escena; por otro lado, sus ansias de creer en algo indefinible, que le proponga la existencia de una poesía de lo desconocido: ambas cosas le llevan a privilegiar el discurso suprasensible en detrimento del científico.

Pero ya sabemos que sus deseos de creer se veían constantemente confrontados con esos impulsos violentos que le empujaban al sacrilegio. Un sentido de rebelión del que él mismo desconocía las razones y que, aun deseando controlarlo, le daba muestras de la existencia de algo en su interior que no correspondía al sentido común.

Según François Livi, el Huysmans que salió de la redacción de $\grave{A}$ rebours era un hombre insatisfecho, atormentado, que no eludía los problemas, «un homme en plein désarroi, travaillé par des forces obscures». ${ }^{1007} \mathrm{Al}$ esteta redomado que era se le venía a unir el imposible creyente; al hombre aburrido de sus proezas orgiásticas se le juntaba el hastiado de todo y necesitado de pureza y tranquilidad. En aquel tiempo, Huysmans frecuenta el haut lieu del decadentismo que era el café del Panier Fleuri —actual café François I. Por lo que de él cuenta Livi, ${ }^{1008}$ la selecta clientela que allí se citaba intercambiaba estupefacientes — según el uso baudelairiano; el satanismo y el ocultismo son adoptados por los habituales — eso sí, de manera un tanto discreta. Ambas creencias, junto con el catolicismo — que podría significar el lado positivo- servían a estos dandis decadentes para volver a ensalzar la orgía, que hasta entonces se había vuelto irremediablemente aburrida.

1007 F. Livi, ob. cit., p. 57.

1008 Ib., p. 60. 
El ocultismo - y su versión anticatólica, el satanismo- eran monedas de uso común entre las gentes de esta época. Poco seducidos por las insípidas verdades del materialismo científico, los escritores de esta época se lanzan de cabeza en estas poco convencionales disciplinas para entretener su sed de novedad. Las flores raras y exquisitas que buscaba des Esseintes parecen encontrar su realización en la práctica de rituales que llenan de gozo a los adeptos. ${ }^{1009}$

Por todo esto, nos hallamos en facultades de señalar que el ocultismo en todos estos autores - y razón de más en Huysmans, su más señalado mentor - no sirve más que para salpimentar su ansia de novedad, para realimentar su virilidad aburrida, para dar, en definitiva, un nuevo sabor a su vida.

Según Anatole France, en un artículo en La Vie littéraire sobre Villiers de l'Isle-Adam, varios autores de ese período habían "goûté par-dessus tout dans la religion les charmes du péché, la grandeur du sacrilège, et leur sensualisme a caressé les dogmes qui ajoutaient aux voluptés la suprême volupté de se perdre». ${ }^{1010}$ Parece pues que, aparte de ese discurso antimaterialista que subyace en su apuesta por las ciencias ocultas, hay también en el satanismo de todos estos decadentes un sentido lúdico — que su capacidad de enunciación dotaría de altura lírica. Huysmans mismo alabará en Félicien Rops haber visto en el satanismo la unión entre el sacrilegio y la pasión carnal: «il l'a exploré jusqu’à ses confins et, dans un art différent, il est vraiment celui qui a notifié la diabolique ampleur des passions charnelles».

Lo cierto es que, desde la época de Certains, y seguramente junto a varios de sus camaradas del Panier Fleuri, Huysmans frecuentaría los círculos ocultistas y esotéricos de París. ${ }^{1011}$ Los primeros con los que entraría en contacto serían los adeptos de la Rose-Croix, Stanislas de Guaïta, Oswald Wirth y Joséphin Péladan. Paralelamente, y gracias a Berthe Courrière (amante de Remy de Gourmont y, probablemente de van Haecke) y, tal vez, a Wirth,

1009 Como señala Mario Praz en su imprescindible obra La chair, la mort et le Diable, la religión - con todas sus variantes - no es sino una forma de satisfacción morbosa - su contrición no significa más que una especie de algolagnia, en M. Praz, La chair, la mort et le Diable. Le Romantisme noir, Denoël, París, 1977, p. 265.

1010 Citado por M. Praz, ib., p. 265.

1011 Vid. R. Baldick, ob. cit., p. 180 y ss. 
nuestro autor oye hablar de un tal abbé Boullan: doctor en teología que fue separado del ejercicio eclesiástico por prácticas demoníacas. Gracias a esos mentores, Huysmans entra en contacto con él por medio de una primera carta, de 7 de febrero de 1890, en la que le expresa los motivos "científicos» que le llevan a acudir a su magisterio:

Je suis las des théories de mon ami Zola, dont le positivisme me dégoûte. Je ne suis pas moins las des systémes de Charcot qui a voulu me démontrer que la démonialité était une rengaine [...] Je suis plus las encore, s'il est possible, des occultistes, des spirites, dont les phénomènes, bien que réels, sont par trop identiques. Or je veux confondre ces gens, faire une œuvre d'art, d'un réalisme surnaturel, d'un naturalisme spiritualiste. Je veux montrer à Zola, à Charcot, aux spirites et autres que rien n'est expliqué des mystères qui nous entourent. ${ }^{1012}$

Harto de las explicaciones de Charcot — precursor y profesor de Freud gracias a sus experimentos sobre la histeria en el hospital parisino de la Salpêtrière-, harto de las teorías de Zola, cansado de las demostraciones de los esotéricos... Huysmans quiere algo más. La curiosidad le empuja más allá de lo que pueden las simples ceremonias en las que, para invocar al diablo, las mujeres son utilizadas como utensilios de la liturgia. Es consciente de que el materialismo científico puede ser vencido en algunos aspectos por esa ciencia tremendamente especulativa como es el satanismo — siempre y cuando podamos considerarla como 'ciencia'.

Sea como fuere, Huysmans entra en contacto con Boullan, le visita en Lyon, en la calle de la Martinière — haut lieu de las ceremonias del abbé. Allí era llamado por la superiora de algún convento con problemas de religiosas poseídas. El abbé no solo recurría al exorcismo, sino que les inculcaba «son abominable doctrine à laquelle il était revenu avec plus d'obstination que jamais» — como refiere Baldick. ${ }^{1013}$ Les enseñaba, según testimonio del amigo de Huysmans Johnny Bricaud, «des méthodes d'auto-hypnose et d'auto-suggestion leur permettant de rêver qu'elles avaient des rapports avec les saints, avec Jésus-Christ. Il leur indiquait des poses spéciales, des procédés occultes pour que des entités de l'au-delà, ou même son propre corps astral, à lui, réussisse mieux à les visiter, à les posséder...». ${ }^{1014}$

1012 Citado por F. Livi, ob. cit., p. 138.

1013 R. Baldick, ob. cit., p. 189.

1014 J. Bricaud, Huysmans occultiste et magicien, Bibl. Chacornac, París, 1913, pp. 74-75. 
Nótese en estas demostraciones del abbé el germen de las experiencias que sobre súcubos se cuentan en Là-bas. Es más, fue cuando Huysmans tuvo a su servicio a Julie Thibault — la que hubiera sido gobernanta de Boullan-que nuestro escritor tuvo la primera experiencia personal con súcubos: «une sensation excessive, douloureuse et exquise» —-según refiere Pierre Lambert. En esta vía, Edmond de Goncourt, quien se lo había oído decir a Jean Lorrain, refirió en su Journal (15 marzo 1891) que Huysmans estaba «inquiété par des espèces d'attouchements frigides le long de son visage, presque alarmé par l'appréhension de se sentir entouré par quelque chose d'invisible». Más tarde confiaría a su amigo Descaves: «Mon chat, qui ne risque pas, lui, d'être un halluciné, a des secousses à la même heure et de la même sorte que moi». ${ }^{1015}$

Fue más tarde a visitar al Dr. Maurice de Fleury, a quien le pidió que le proyectase sobre el rostro el soplo de una máquina que produjera electricidad estática. "L'ayant ressenti, il déclara qu'il comprenait tout maintenant, qu'il recevait très fréquemment des souffles fluidiques de même sorte qu'il devait, bien certainement, à la haine de Stanislas de Guaita». ${ }^{1016}$

Por otra parte, Huysmans seguía recurriendo al consejo de Boullan, quien le enviaba instrucciones desde Lyon. Un día el ex abbéle recomendó que no acudiera al despacho en el Ministerio de Seguridad — cosa que él siguió al pie de la letra. Por lo visto, ese mismo día, un espejo se desplomó sobre la mesa de trabajo de Huysmans — según refiere Dumesnil. ${ }^{1017}$

Además, y esto según Johnny Bricaud, ante la inminencia de un ataque, Huysmans se encerraba en su casa con todas sus armas de defensa preparadas: quemaba un ungüento oloroso con «la main droite l'hostie miraculeuse» en la chimenea, trazaba un círculo de defensa en el suelo, y, «brandissant le scapulaire bénit du Carmel Eliaque, il récitait les formules conjuratoires qui devaient dissoudre les fluides et paralyser les pouvoirs des envoûteurs». ${ }^{1018}$

1015 L. Descaves, Les dernières années de J.-K. Huysmans, Albin Michel, París, 1941, p. 140.

1016 M. Fleury, «Relations», Nouvelles littéraires, 25 juillet, 8 août, 19 septembre 1931.

1017 R. Baldick, ob. cit., p. 205.

1018 J. Bricaud, Huysmans occultiste et magicien, ob. cit., p. 27. 
Son estos numerosos testimonios que dan fe de la manera en que Huysmans se había introducido en los círculos esotéricos y ocultistas y había comulgado con sus prácticas. Con todo ese conocimiento acumulado, nuestro autor se ve en condiciones de acometer la empresa de su gran libro sobre las ciencias ocultas que sería $L \grave{a}$ - $b a s$, «livre satanique, plein de messes noires». ${ }^{1019}$ Un libro que no solo daría cuenta de la existencia de círculos satánicos en el París de la Revolución Industrial, sino que ponía en escena a un curioso personaje, Gilles de Rais: dandi del siglo XV, completamente opuesto a las tesis positivistas del siglo XIX y cuya biografía sería modificada por nuestro autor — según señala Rita Thiele — ${ }^{1020}$ para cuadrarla con la suya propia. Huysmans vería en el noble medieval la concreción histórica, que él se encarga de revivir, del sentido de la orgía, del refinamiento en la consecución de placeres extremos, nuevos, y pecaminosos. De hecho, tal y como le comenta a des Hermies, Durtal ve en el diabolismo tanto una escapatoria a lo mediocre — que su sensibilidad dandi debía privilegiar a toda costa- como una salida a la impotencia que ya estropeaba su gusto por la orgía: «L'exécration de l'impuissance, la haine du médiocre, c'est peut-être l'une des plus indulgentes définitions du diabolisme!». ${ }^{1021}$ Es decir: el recurso al satanismo le sirve, en principio, a Huysmans para decorar sus pasiones carnales con el aditamento necesario para levantar su libido. Una libido medio dormida, si hacemos caso a las numerosas cartas que dirigió a sus amigos en las que les comentaba este extremo. Sabemos que eso no era del todo concluyente, pues sus aventuras sexuales continuaron a lo largo del tiempo - llegando hasta la época de En route, gracias a los exquisitos cuidados de esa profesional llamada Florence.

Con el recurso al ocultismo, Huysmans satisfacía también su deseo de singularidad propio de un dandi de su época. Y aunque se acercara a él con espíritu científico — como afirma Pierre Cogny— ${ }^{1022}$ el deseo de la distinción debía de ser suficientemente fuerte como para adentrarse en ese enmarañado ambiente con decisión — como señala Andrew Delbanco. ${ }^{1023}$

1019 Citado por H. Trudgian, ob. cit., pp. 265-266.

1020 R. Thiele, ob. cit., p. 201.

1021 J.-K. Huysmans, Là-bas, ob. cit., p. 51.

1022 P. Cogny, J.-K. Huysmans à la recherche de l'unité, ob. cit., p. 68.

1023 Andrew Delbanco, en su célebre ensayo La muerte de Satán, señala que en el universo premoderno en el que las pequeńas comunidades estructuraban la sociedad, Satán era 
Huysmans adquiría con esta adscripción al satanismo un coup de vieux que, al emparentarlo directamente con la Edad Media, lo situaba fuera del mundo fabril que él tanto odiaba. Como anacronismo era la literatura pergeñada por sus admirados Villiers de l'Isle-Adam, Barbey d'Aurevilly, Aloysius Bertrand y, sobre todo, su querido Baudelaire.

También había en este recurso a lo esotérico, como ya hemos mostrado, una intencionalidad clara de confrontación con las ideas científicas del momento: intentar mostrar cómo la Ciencia al uso se veía incapaz de demostrar numerosos aspectos de la experiencia humana. Esa «vida del alma» que Huysmans separaba de la vida del cuerpo, y cuyas manifestaciones eran difícilmente explicables por las teorías de los Charcot y otros psiquiatras de primera generación.

Las experiencias de Huysmans con el ocultismo y el satanismo continúan en la medida en que mantiene su contacto con Boullan. Con esto queremos decir que su interés por el tema fue más allá de la documentación naturalista para Là-bas. No en vano, en julio de 1891, con este opus ya publicado, tuvo la oportunidad de conocer a una tal Mme. Laure que frecuentaba la vivienda de Boullan en Lyon. Esta Mme. Laure solía tener accesos de sonambulismo, durante los cuales desarrollaba una especie de videncia. Huysmans era bastante escéptico sobre estas cosas. Pero, tras su vuelta de N.-D. d'Igny, fue a pasar quince días a Lyon y preguntó en broma a Mme. Laure si estaba ocurriendo algo en su casa de la parisina rue de Sèvres. A lo que ella respondió: "Je vois un homme malade couché dans votre lit». El novelista no pudo más que reír, pues no había nadie en su domicilio en ese momento.

Sin embargo, a su vuelta a París, el conserje le comunicó que, en el mismo momento en que se produjeron las visiones de Mme. Laure, el limpiador del parquet —el frotteur — había sufrido un súbito malestar y que había debido echarse en la cama, en la que permaneció hasta el día siguiente por olvido y descuido del conserje. ${ }^{1024}$

el necesario símbolo del interés privado frente al colectivo; sin embargo, con el dinamismo y el mercantilismo propios de la naciente sociedad industrial, el diablo dejó de ser «metáfora de un yo altivo", para pasar a convertirse en un anacronismo, en A. Delbanco, ob. cit., p. 87.

1024 Detalle referido en G. Giches, Le Banquet, Spès, París, 1926, p. 260. 
Los contactos y la amistad de Huysmans con Boullan no se terminaban allí. Ese verano del 1891, Boullan fue condenado por el tribunal de Trévoux a pagar una cuantiosa multa, bajo la inculpación de ejercicio ilegal de la medicina. Según Johnny Bricaud, el primer biógrafo de Boullan, fue Huysmans quien pagó la multa: 2000 francos. ${ }^{1025}$

Toda una continuidad de acontecimientos que dieron a Huysmans la seguridad de que existía algo superior al entendimiento humano y que se hallaba más allá de sus fuerzas. Pero no solo eso: el deseo tan frecuentemente expresado de abrazar la seguridad del credo católico - expresado incluso en esa biblia del decadentismo más acérrimo que es $\grave{A}$ rebours- le empuja a encontrar en las prácticas demoníacas motivo de repugnancia de sí mismo. $\mathrm{O}$, para decirlo más exactamente, necesidad de limpiarse de tanta impureza, de tanto rito de sangre. A la salida de la redacción de Là-bas declara su intención, que no deja de señalar una necesidad, de escribir un libro blanco que contraponer al satanismo del anterior: "Je veux en faire un autre qui soit blanc. Mais il est nécessaire que je me blanchisse moimême. Avez-vous du chlore pour mon âme?» ${ }^{1026}$ — declara nuestro autor en una carta. Antes le había comunicado a un amigo suyo, Georges Landry, su preocupación por el estado de su alma. Necesidad de limpieza y depuración por medio de todo tipo de sustancias purificadoras y limpiadoras:

Faudrait des muids, faudrait des foudres de désinfectants; et quel Milleriot pourrait manœuvrer une assez extraordinaire pompe pour extraire ces eaux résiduaires des vieux égoûts? N'y en a plus de pompiers divins, que de tels labeurs réjouissent. Ainsi, vieux frère, il n'y a pas de raisons pour que cela cesse. ${ }^{1027}$

Ante esto cabe preguntarse por los males que asolaban el espíritu de Huysmans. La respuesta la imaginamos, pero hallamos confirmación en el comienzo de esta misma carta: «Mais quels phénols, quelles soultions cuivrées assainiront le grand collecteur où mes saletés charnelles gargouillent?» Sus suciedades carnales fueron las que le llevaron a indagar en los círculos esotéricos, con el fin de buscar excitación real para su sexualidad dormida. Cabe sugerir que todas esas prácticas comentadas en $L \grave{a}$-bas fueran no solo contempladas por nuestro autor, sino que su gusto por la orgía le empuja-

1025 J. Bricaud, L’Abbé Boullan, Bibl. Chacornac, París, 1927, pp. 74-75.

1026 H. Trudgian, ob. cit., pp. 265-66.

1027 Citado por R. Baldick, ob. cit. p. 215. 
ría a participar de manera activa. En ello le iba no solo la curación de su sentido libidinoso de la existencia que le había acompańado desde siempre, sino también la experimentación de placeres nuevos y más intensos que le ayudaran a recuperar la fe en la vida y en sus escasas alegrías.

Sea como fuera, parece ser que la frecuentación de la vivienda lyonesa de Boullan haya precedido el viaje de Huysmans a Brujas para conocer personalmente al abbé Mugnier en ese mismo año de 1891 . Livi ${ }^{1028}$ afirma que ese primer encuentro sería determinante para el descubrimiento de lo sobrenatural que hizo Huysmans. Nosotros aseguramos lo contrario, pues nuestro autor estaba ya suficientemente familiarizado con el lado oculto del cristianismo. La cuestión es que Joris-Karl está convencido de que ha sido gracias al satanismo como ha conocido el verdadero cristianismo. $\mathrm{Y}$ así se lo confirmaba a su amigo Firmin van der Bosch en una carta: «C'est par la vision du surnaturel du mal que j'ai eu d'abord la perception du surnaturel du bien. Ceci dérivait de cela. De sa patte crochue, le démon m'a conduit vers Dieu». ${ }^{1029}$ La entrada en el lado claro de la religión — porque no es otra cosa sino una religión el satanismo, solo que, como afirmaba el propio Huysmans como una de las tesis principales de $L \grave{a}$-bas, de una naturaleza diferente - se va operando de manera decidida. El motivo principal es limpiarse, purificarse de toda la inmundicia que había arrojado sobre él su participación en las experiencias inducidas por el círculo de Boullan.

\subsubsection{Purificación religiosa y psicoanálisis}

La purificación que nuestro autor necesitaba realizar por medio de limpiadores múltiples y desinfectadores varios tiene, afirmamos, un carácter netamente psicosexual. Sabedores como somos de que la naturaleza de los fenómenos presenciados por Huysmans era orgiástica, el hombre hastiado de una sexualidad convencional, al acecho de la experiencia que le permitiera despertar su libido aburrida y siempre en estado de insatisfacción, debió por fuerza participar en esas misas negras y diferentes orgías de los círculos esotéricos que frecuentó.

1028 F. Livi, ob. cit., p. 138.

1029 F. Van der Bsoch, Impressions de littérature contemporaine, ob. cit. Citado por R. Baldick, ob. cit., p. 216. 
El tipo de ceremonia, vamos a decirlo, sexual, en que consistía una misa negra - mujeres utilizadas como utensilios litúrgicos, laceración de los símbolos paternos, genitalización del ritual — no deja de señalar un acto de reivindicación erótica en la que el individuo normalmente reprimido por la moral patriarcal solicita de una instancia transgresora la satisfacción de sus instintos. Para ello se ha de producir la contravención de todas las normas establecidas por el padre: es decir, la vuelta del revés de todo el rito divino. Satán se convierte, por arte de birlibirloque, en una instancia propiciadora de esta vuelta del revés, quien, al mismo tiempo que propicia, satisface sus instintos con las criaturas que le son presentadas en sacrificio: las mujeres de la comunidad satánica.

El demonio aparece, pues, como un padre alternativo que sí permitiría el disfrute de las hembras por parte de los asistentes a la misa negra. Y él es padre generoso por eso mismo, porque al mismo tiempo que disfruta permite disfrutar. Y es Dios porque sus poderes sobrenaturales y su poderío erótico están por encima de toda capacidad humana. Él es un padre que, desde la perspectiva del conflicto edípico, sí permite la apropiación de la madre por parte del hijo.

Tal vez hayamos atraído el tema hacia la esfera de las teorías psicosexuales de Freud, pero lo cierto es que la cercanía entre los ritos satánicos y el asesinato del padre a manos de la horda primordial que planteó el psicoanalista vienés en Tótem y tabú es evidente.

Según el relato que crea Freud a partir de las observaciones de algunos etnólogos, la humanidad se habría creado a partir del asesinato del padre dominador, dueño del harén de hembras, a manos de sus hijos — machos jóvenes que respetaban la ley del padre y no se atrevían a copular con las hembras. De este acto primordial se habrían generado las religiones, sobre todo las monoteístas, pues consisten en un continuo duelo por la muerte del dios padre. Un caso evolucionado de este duelo sería el de la religión cristiana, pues, escenificando la muerte del hijo, este expiaba el crimen cometido y recomponía así la figura del padre. ${ }^{1030}$

1030 S. Freud, Tótem y tabú, ob. cit., p. 180. Es una idea que el padre del psicoanálisis dice deber a Frazer y su obra Eating the God (sin referencia bibliográfica). 
La misa negra permite resarcirse del asesinato del padre que el rito católico tradicional intenta expiar. No solo no aparece muestra alguna de asesinato del primer padre, sino que el nuevo adorado, Satán, podría aparecer como una excrecencia de ese padre, como el hijo que ha propiciado que los hermanos de la horda primordial tengan acceso a las hembras de la comunidad. Todo ello aderezado con la revolución de las normas prescritas por el padre para su recuerdo y la expiación de tal crimen. La misa negra insiste en el crimen y en la ignominia lanzada sobre Dios que, neutralizado por la mayor fuerza del hijo, deja de tener poder en el imaginario del adepto a estas prácticas.

El satanismo se presenta, pues, como una vía perfecta para la satisfacción de los instintos fuera de los dictados de la sociedad — que indica precisamente la necesidad de su represión para la vida en comunidad. Sin embargo, esta satisfacción sin trabas presenta una serie de inconvenientes de rango psicosexual que no son para nada desdeńables.

Ya habíamos comentado que en la enunciación de la teoría sobre el complejo de Edipo, Freud comenta que, tras la muerte del padre, se produce una demonización del difunto para contrarrestar de esta manera los deseos que albergaba el niño de que esto ocurriera; estos deseos no encerraban otra cosa más que la apropiación de la madre por parte del hijo. Este, el hijo, cree expedito el camino para su acoplamiento definitivo con su progenitora, pero, existen ocasiones en que la llegada de un nuevo adversario con el que el niño, en su pequeñez, no puede enfrentarse. La fijación libidinosa que el hijo experimenta hacia la madre — no limitada por la resolución del edipo a causa de la temprana muerte del padre- encuentra una cortapisa de suficiente potencia como para reprimir esa tendencia al acoplamiento con ella. De la fijación, el niño pasa a una situación de ambivalencia por la cual el niño buscará, por una parte, no traicionar la memoria de la madre; por la otra, mancillar su recuerdo por sentirse traicionado.

La misa negra y la práctica de los rituales satánicos permiten el apoderamiento libidinoso de la madre - o por lo menos ofrecen un simulacro de que eso ocurre. El fiel de esta contra-religión — si es que podríamos denominarla de esta guisa - pone en escena la muerte del padre, ya sea este ficticio o real, y cree factible el acoplamiento con la madre. Las consecuencias fantasmáticas de esta operación no son pequeñas. El hijo se considera completamente responsable de la muerte del padre, con lo cual los repro- 
ches obsesivos que se lanza a sí mismo se hacen todavía más insoportables que para cualquier neurótico normal. La descarga de tales males debe realizarse por medio de la negación de sí mismo, cosa que solo se consigue mediante la enfermedad. Huysmans optó, felizmente, por la reconciliación con el padre al que volvía a asesinar en cada acto sexual alumbrado por las velas del ritual satánico.

Otra posibilidad de interpretación del satanismo desde un punto de vista psicoanalítico es el que desarrollamos a partir de Jung. En su estudio sobre los arquetipos subyacentes a toda práctica religiosa, Psicología y religión, plantea la exclusión del diablo de la figura del dios tripersonal. Citando a Dorneus, Jung señala que el día de la creación, cuando separó las aguas superiores de las inferiores, Dios creó justamente al binario (dualidad), y, por tal motivo, habría omitido decir al atardecer del segundo día —lo que había dicho en todos los demás — «que era bueno». De esta dualidad surgió lo que Dorneus llamó «sua proles quaternaria»: el número tres corresponde a Adán; por eso el diablo primero tentó a Eva, pues armado de cierta semejanza de binario a binario, atacó a la mujer. «Dorneus, con gran astucia, descubre que el binario es el secreto parentesco entre el diablo y la mujer» — según asevera finalmente Jung. ${ }^{1031}$

Con esto queremos significar que, si el diablo propiciador de la posesión de otras hembras es la mujer, los rituales satánicos permiten también la muerte de la instancia paterna mediante los sacrilegios acometidos contra sus símbolos. Uno de los símbolos que la misa negra ensucia mayormente es la hostia, el cuerpo de Cristo que se ingiere en el rito católico como continuación evolucionada de la comida totémica: reproducción conmemorativa del acto criminal y memorable, que constituyó el punto de partida de las organizaciones sociales, de las restricciones morales y de la religión - como pudo ser el asesinato del padre a manos de la horda primordial. ${ }^{1032}$ Los sacrilegios cometidos contra esta conmemoración del asesinato eliminan la posibilidad de asimilación de la personalidad del padre muerto y, por ello, no se realiza la reconciliación con su figura.

1031 C. G. Jung, Psicología y religión, ob. cit., p. 101.

1032 S. Freud, Tótem y tabú, ob. cit., p. 167 y ss. Huysmans comprenderá perfectamente el secreto sentido de la comunión, de ahí que mantenga tantas reservas a la hora de aceptarla. 
En ambos casos se produce un ataque a la figura del padre que es enormemente agresiva para el hijo que cree, en su fuero interno, que él ha sido el propiciador del asesinato. Esta afirmación contrastada con la biografía de nuestro autor nos permite aseverar que los reproches obsesivos que debía lanzarse Huysmans así mismo debieron de ser de intensidad suma.

La reconciliación con el padre permite a Huysmans no sucumbir a la neurosis obsesiva, que evita mediante la aceptación de otra neurosis, esta universal. Freud afirmaba en El porvenir de una ilusión que el creyente encuentra remedio en la religión a los padecimientos neuróticos sobrevenidos por los conflictos edípicos. Las necesidades religiosas se nos presentan, de esta manera, como un remedio a estas dolencias mediante la petición al padre de protección absoluta. Nostalgia del padre y estado infantil de dependencia coinciden en la práctica religiosa. La regresión al escenario de la infancia en el que nació el conflicto de tipo edípico es clara en el ámbito de la religión: la renovación regresiva de los poderes protectores infantiles. «La protección que la fe religiosa ofrece a los creyentes contra la neurosis queda fácilmente explicada por el hecho de que los despoja del complejo paternomaterno, del que depende la conciencia de la culpabilidad», asegura Freud en Un recuerdo infantil de Leonardo de Vinci. ${ }^{1033}$

Jung comentará que la religión es un sustitutivo que sirve de manera portentosa para reemplazar la experiencia inmediata por una selección de símbolos adecuados envueltos en un dogma y ritual firmemente organizados. Si le ocurre algo inmediato al creyente, puede acudir a la iglesia, que está en condiciones de decidir si la experiencia provino de Dios o del diablo, si hay que aceptarla o rechazarla. En medio de esta propiedad sustitutiva, el dogma y el ritual adquieren una importancia extraordinaria como métodos de higiene espiritual. ${ }^{1034}$ Así los consideró Huysmans, tan necesitado como estaba de limpiarse por fuera y por dentro.

\subsubsection{En route hacia el Padre}

El libro decisivo en lo relativo a la cara blanca de la religión de Huysmans es, sin duda alguna, En route. El año de su publicación - 1895, cua-

1033 S. Freud, Un recuerdo infantil de Leonardo de Vinci, ob. cit., p. 1611.

1034 C. G. Jung, Psicología y religión, ob. cit., p. 75. 
tro más tarde que Là-bas-, Huysmans pasaba por ser un especialista en materia satánica. Tanto era así que Jules Bois le invitó a que escribiera el prólogo a su célebre obra Le satanisme et la magie. ${ }^{1035}$ En el primer párrafo de este prólogo, nuestro autor establece una clara oposición entre los hechos explicables por medio de la Ciencia y aquellos que solo aceptan una interpretación religiosa. Mientras antaño, parece decir Huysmans, todo era atribuible a la acción del Maligno, hoy todo es susceptible de ser curado con las duchas frías de la Salpêtrière. La verdad aparece en medio de estos dos campos, sobre todo en lo concerniente al estudio de las enfermedades nerviosas. ${ }^{1036}$

En route, libro que «cuenta sin ningún tapujo su conversión»-como diría él mismo en una carta ya citada—, significa en el itinerario personal de Huysmans la decisión inquebrantable de adoptar el tipo de vida tan deseado durante los años precedentes. Amén de operar esa reconciliación tan necesitada por su inconsciente con las instancias parentales.

Como obra de aprendizaje que es, podríamos hablar de En route de dos niveles: uno, la búsqueda de Dios; otro, el ansia de purificación personal. Ambos son igualmente importantes pues, lo hemos visto, esos son dos de los objetivos que persigue nuestro autor mediante su conversión al cristianismo - el tercero sería la reconciliación con la instancia materna, que completaría el ciclo edípico, que trataremos más adelante.

Durtal, el heterónimo ficcional definitivo de Huysmans en el ciclo religioso, es un creyente un tanto sui generis. Sabedor de lo débil que es ante la tentación, su ansia por convertirse choca siempre con el empuje tremendo de su deseo carnal. Aun habiendo cantado las alabanzas del hombre démâté, celebrado mediante fiesta el final de su virilidad, el cuadragenario ${ }^{1037}$ que es

\section{J. Bois, ob. cit.}

1036 «Pendant plusieurs siècles, les démonologues confondirent plusieurs épisodes de la grande hystérie avec les phénomènes du satanisme. Aujourd'hui les médecins attribuent à la grande hystérie des accidents qui relèvent exclusivement du domaine des exorcistes. On a jadis brûlé pas mal de gens qui n’étaient nullement possédés par l'Esprit du Mal; maintenant, on noie sous les douches ceux qui le sont. Nous dignostiquons au rebours du moyen âge; tout était diabolique dans ce temps-là; maintenant tout est naturel. La vérité semble surgir entre ces deux excès; mais, il faut bien l'attester sans ambages, rien n'est plus malaisé que de tracer une ligne de démarcation entre les attaques variées de la grande névrose et les états différents du satanisme». Citado por A. Toumayan, ob. cit., p. 47.

1037 "Vous avez quarante ans», le dice el abbé Gévresin en una entrevista previa a su internamiento en la trapa de Igny. J.-K. Huysmans, En route, ob. cit., p. 141. 
Durtal en En route ha visto renacer su libido gracias a la aparición de esa terrible y tentadora muchacha que es Florence — largamente comentada en pasajes precedentes de nuestro estudio. Los inconvenientes a su definitiva conversión son enormes a causa de la aparición en su vida de esta señorita -que le depara tan picantes momentos de placer de los que no sabe, de ningún modo, separarse. Se sabe débil, sabe que el poder de la tentación es demasiado grande como para oponerle resistencia; cede con una facilidad y un dejarse llevar extremos, incomprensibles para quien desea profundamente acabar con ese tipo de vida y comenzar otra nueva.

Pero, aun cuando no sucumba, el recuerdo de los favores de Florence le rondará en la cabeza. Y es tal el sentimiento de culpabilidad que crea en él la práctica de la sexualidad que la confesión se le antoja imposible — sacramento que la iglesia considera imprescindible para acceder al cuerpo de Cristo, a la eucaristía. "Vous n'avez point une âme humble, une âme simple; vous êtes une sorte de sensitive que la moindre imprudence, que la moindre maladresse d'un confesseur fera se replier sur elle», ${ }^{1038}$ le dice de nuevo el abbé Gévresin. Lo que teme por encima de todo es la crítica venida de alguien que no tenga la misma sensibilidad que él, pecador consciente de las injurias cometidas contra las instancias creadoras de su ser. Y Durtal desconfía plenamente del criterio del sacerdote común; no cree que un confesor cualquiera pueda confesarle y aplicarle penitencia con la suavidad que él necesita en esos primeros momentos.

En vista de las dificultades que la conversión suscita en él, Durtal espera que el trabajo más duro sea realizado por otros. No queremos decir con esto que él espere que alguien le diga repentinamente que «ya, ya es usted un miembro de nuestra comunidad». Nada de eso. Perfecto conocedor de la literatura eclesiástica clásica, Durtal es consciente de que existe la posibilidad de que otras personas carguen con el dolor del esfuerzo que supone cambiar de vida. Sabiéndose débil, cree firmemente en la posibilidad de aplicación de las leyes de substitución sobre su alma, de tal manera que alguien fuerte cargue con sus males para que él pueda sentirse desembarazado de ellos y avanzar con paso más decidido hacia la liberación de su alma. "Cette substitution d'une âme forte débarrassant celle qui ne l'est

1038 Ib., p. 149. 
point, de ses périls et de ses craintes, est une des grandes règles de la Mystique» ${ }^{1039}$ - le asegura de nuevo el abbé. El proceso de las leyes de substitución es complejo, y merece que nos detengamos un poco en él. Es un gran instrumento de pacificación de las almas ocupadas por las constantes tentaciones, de tal manera que los ya curtidos en la vida religiosa pueden descargar a los que entran con paso temeroso en la nueva vida de privaciones. Durtal se convence, gracias a los comentarios de su amigo, de que los monjes son perfectos conocedores de esta herramienta mística.Y para ello, Gévresin le comenta que sí, incluso el penitente sucumbe a la tentación, siempre habrá un convento de provincia especialmente dedicado a estos menesteres que se ocupe de su caso.

Eux seuls [les moines] connaissent les lois de la substitution et s'ils voient que, malgré ses efforts, le pénitent succombe, ils finissent par le délivrer, en prenant à leur compte ses tentations ou en les expédiant dans un couvent de province où des gens résolus les usent. ${ }^{1040}$

Ya sabemos que Durtal sucumbe repetidamente a sus tentaciones; el sentimiento de culpa se acrecienta por eso mismo, por el hecho de sucumbir unido a saberse tan débil de espíritu que son otros los que deben encargarse de su limpieza. Y, en realidad, eso es lo que sucede: viendo que su pupilo no podía por sí solo expulsar al demonio de la carne de su interior, Gévresin transfiere su caso a unos monasterios de carmelitas y de clarisas que rezarán por él denodadamente, con el fin de liberarle de ese inmenso peso. Durtal parece convencerse de esta solución, ya que refiere que sus tentaciones se hicieron menos frecuentes y que se encontró con más fuerzas para soportarlas. Ahora bien, su convencimiento no es pleno, pues alberga la posibilidad de que ese cambio en su espíritu y en su ánimo se deba antes a un cambio en el tiempo. Escéptico creyente que este Huysmans:

Et le fait est qu'à partir de ce jour-là, les attaques les plus lancinantes cessèrent. Cette accalmie, cette trêve, la dut-il à l'intercession des ordres cloîtrées ou au changement du temps qui se produisit, à la défaillance du soleil qui se submergea sous de flots de pluie; il ne le sut; une seule chose était certaine, c'est que les tentations s'espacèrent et qu'il put impunément les subir. ${ }^{1041}$

1039 Ib., p. 111.

1040 Ib., p. 114.

1041 Ib., p. 179. 
Los rezos no deben de parecerle suficiente expiación a Durtal como para creer que es mediante ellos que se va a completar la limpieza de su alma. Como su caso es de orden psicosexual, en el que el deseo carnal está plenamente implicado, él necesita que haya un componente físico en el asunto de la expiación. El tormento debe ser sufrido por el artífice de tanto sufrimiento, por el depositario de la tentación: el cuerpo. Es una especie de flagelación corporal en la que el físico sufre por sus exigencias: esa es la verdadera penitencia para Huysmans. El cuerpo debe sufrir. Pero mejor si no es el suyo propio. ¿Cómo proceder a una expiación flagelatoria si no es sobre el propio organismo? Haciéndolo actuar sobre el cuerpo de otras personas. Y si se trata mujeres, mucho mejor, porque así no solo el penitente es consciente de que la flagelación se está llevando a cabo, sino de que la reciben los seres que él cree que han hecho su perdición.

Los rezos de las carmelitas y las clarisas no son, pues, suficientemente poderosos. A Durtal le convence la penitencia propuesta por las benedictinas de Tournefort: como sus lágrimas no son lo bastante santas ni sus almas lo bastante puras, el castigo se realiza sobre sus cuerpos: instrumentos de la tentación utilizados por el diablo. Las monjas sufren, por esta ley de la substitución, largas enfermedades inaprensibles para los médicos:

comme nos larmes ne sont pas assez saintes, comme nos âmes ne sont pas encore assez pures, Dieu nous éprouve dans notre corps. Il y a, ici, des maladies longues et dont on ne guérit pas, des maladies que les médecins renoncent à comprendre; nous expions pour les autres, beaucoup ainsi. ${ }^{1042}$

Los ejemplos mayores del sentido expiatorio de la vida que son referidos en En route son santa Lidwina de Schiedam - a quien Huysmans le dedicó toda una obra de carácter hagiográfico_ - y santa Ángela de Foligno. A ellas volveremos más adelante cuando sea el momento de hablar del papel femenino en la religión.

La entrada en la conversión es un proceso, como hemos visto, doloroso para este penitente. Alma sensible delicada y propensa a sucumbir en la tentación, Durtal sabe de los sufrimientos que le esperan antes de adquirir la santidad necesaria para ser un religioso convencido. La ascesis necesaria al proceso religioso, él está dispuesto a sufrirla y a seguir sus reglas.

1042 Ib., p. 220 
Pero es perfectamente consciente de que esa iluminación, ese attouchement divin ${ }^{1043}$ de que le habla Gévresin, solo se producirá mediante un proceso de dolor. La conversión llegará al día después de que haya padecido lo que San Juan de la Cruz vino a llamar «la noche obscura del alma» —o "noche del alma» como se complace en llamarla Durtal: «Saint Jean vous fait frissonner quand il s'écrie que cette nuit de l'âme est amère et terrible, que l'être qui la subit est plongé, vivant, dans les enfers!» Una experiencia trágica al cabo de la cual el hombre, completamente desgastado por el sufrimiento, cree entrever la luz que brota de la imagen de Dios: «Mais quand le vieil homme est émondé, quand il est raclé sur toutes les coutures, sarclé sur toutes les faces, la lumière jaillit et Dieu paraît». ${ }^{1044}$ La conversión de Durtal, su necesario ingreso en la religión castradora y limitadora, se tiene que realizar a través del sufrimiento. Solo así, mediante su paso por una situación de flagrante sumisión a la ley del Padre se puede siquiera vislumbrar. Y la sumisión, la presentación de sí mismo como objeto del que el amo puede hacer uso indiscriminado se verificará más efectivamente a través de una via dolorosa de expurgación física. Por lo mismo que habíamos seńalado antes, Huysmans debe purgar sus pecados de orden carnal con su propia carne, con el dolor físico. Se plantea así nuestro escritor la religión como una incursión en el masoquismo como única vía para presentarse limpio ante la autoridad del Padre. La noche oscura del alma - esa vigilia nocturna pasada en medio de temblores, de miedos, de replanteamientos personales- decide finalmente de la conversión o no del fiel a la ley. Un ejemplo claro de ello lo vemos en el sufrimiento de Cristo en el Monte de los Olivos, en Getsemaní, durante la cual sudaba gotas de sangre y se debatía entre la posibilidad de escapar a la muerte que había exigido de él su Padre.

Porque la penitencia del hijo es necesaria para que el Padre lo acepte en su seno, para que el afecto de este se haga cargo del hombre démâté, del barco desarbolado, del adulto regresado a la fragilidad del nińo. Para mostrar y demostrar esa fragilidad es por lo que el hijo se presta a esta operación de dolor puramente simbólico. El masoquismo es el deseo de

1043 «La façon dont s'est opérée votre conversion ne peut me laisser aucun doute. Il y a eu ce que la Mystique appelle un attouchement divin», le dice el abbé. Ib., p. 147.

1044 Ib., p. 163. 
sufrimiento en aras de una más alta concepción de sí mismo: haciéndose objeto para el Padre instituye a este como sujeto en una sencilla operación bipolar amo-siervo.

La purificación solo se hará necesaria en caso de que se demuestre plenamente su culpa y su falta. Por eso mismo el miedo que muestra Durtal ante la confesión. Deseoso pero temeroso al mismo tiempo de hacerse digno a través de la purificación de su objetualización como Hijo — porque sabe que eso llevará a su necesario sufrimiento como vía de expurgación-, la enunciación de sus pecados ante el representante del Padre en la tierra de los hijos se le aparece como una transacción tremendamente conflictiva.

Se confesser? Oui, j’y consens; je suis si las de moi, si dégoûté de ma misérable vie que cette expiation m’apparaît comme méritée, comme nécessaire; je désire m'humilier, je veux bien demander sincèrement pardon. ${ }^{1045}$

Este Durtal necesitado de expiación acogerá con deseo pero también con temor la práctica del sacramento, pues sabe que para acceder a ella debe proponerse como víctima expiatoria, como cordero pascual dispuesto al sacrificio. Así, al leer el reglamento de la Trapa no ve más que esta palabra como si fuera un letrero de obsesivo poder de atracción: «La confession! Il ne voyait plus que ce mot dans cette série d'articles. Il allait pourtant falloir y recourir! Et il se sentit froid dans le dos». ${ }^{1046} \mathrm{Y}$ ello porque al confesarse se presta a la enunciación de sus suciedades, a la confidencia sobre el constante sacrilegio que ha cometido en la figura de la madre, habiéndola traicionado con otras señoras. Su sentimiento de culpa, que le persigue a lo largo de toda su obra literaria, entabla una de sus primeras relaciones con la dinámica religiosa en En rade, cuando Jacques Marle observa, anonadado, esa pequeña iglesia en que solo queda en pie la cruz y el cristo - aunque completamente mancillado por los excrementos de las palomas.

Les chats-huants et les corbeaux entraient librement dans l'église par les trous des vitres, perchaient sur ce Christ et, battant de l'aile, le balançaient, en l'inondant de leurs jets digérés d'ammoniaque et de chaux. ${ }^{1047}$

\footnotetext{
1045 Ib., p. 235.

1046 Ib., p. 294.

1047 J.-K. Huysmans, En rade, ob. cit., p. 202.
} 
Jean Borie se pregunta obstinado por la significación de este «immense crucifix abondamment souillé par les oiseaux» en la obra: «Que représente en ce lieu ce symbole? Un Christ aux outrages?», a lo que él mismo se responde: «Plutôt un Christ aux ordures, jeté au rebut. Non pas le sacrilège, mais l'indifférence, et l'oubli». ${ }^{1048}$ Nosotros afirmamos que se trata de todo menos del olvido. Es, efectivamente, un "Christ aux ordures», sometido a la mancillación realizada por las aves. Un Cristo ultrajado por su propio Padre, como es el deseo expreso del Hijo necesitado de esta mancha, de su objetualización, de su reducción a víctima.

Esta afirmación puede parecer un tanto atrevida para la mente racional. Lo es menos para el inconsciente que, en su búsqueda continuada de símbolos de substitución, ve en las aves una referencia clara al padre. El psicoanálisis averiguó hace mucho tiempo que la hostilidad del niño hacia su progenitor es frecuentemente desplazada hacia un animal — como asegura Freud en Tótem y tabú. ${ }^{1049}$ Las aves, especialmente, son utilizadas por el niño como sustitutivos del padre, como refiere el médico vienés a partir de sus investigaciones, en Psicoanálisis aplicado y Técnica psicoanalítica ${ }^{1050} \mathrm{y}$ en Un recuerdo infantil de Leonardo de Vinci. ${ }^{1051}$ Ese crucifijo es, como símbolo del Hijo, ensuciado por el Padre para que el primero se sienta reducido al estatus de objeto.

Pero la confesión comporta, como ya lo hemos señalado ampliamente, la enumeración de los hechos en que se ha mancillado el recuerdo de la madre: la inmensa mayoría de los actos que Huysmans-Durtal considera pecaminosos están referidos al sexo. La ambivalente fijación a la madre que tenía nuestro autor le llevaba por una parte, a considerar como traiciones dolorosas todos los actos sensuales cometidos por él en el cuerpo de otras mujeres. Se trata en este caso de una fijación, como desvela el psicoanálisis, típica en los homosexuales.

Por eso la confesión de todas estas acciones de traición es doblemente difícil de llevar a cabo en el seno de la religión, el ámbito por excelencia de la ley del Padre. Al narrar a este las aberraciones que se han cometido en la

1048 P. 18 de su prólogo a J.-K. Huysmans, En rade. Ib.

1049 S. Freud, Tótem y tabú, ob. cit., p. 152.

1050 S. Freud, Psicoanálisis aplicado y Técnica psicoanalitica, Alianza, Madrid, 1979, p. 71.

1051 S. Freud, Un recuerdo infantil de Leonardo de Vinci, ob. cit., pp. 1588 y ss. 
persona de la Madre — es el inconsciente, desde luego, quien piensa así-, la penitencia fantasmática no puede consistir más que en la eliminación de eso que Padre e Hijo tienen en común, el pene, y que es donde se centran las expectativas libidinosas del niño. La confesión es el acto expiatorio por excelencia. Por eso cuando le anuncian a Durtal que ya tiene una fecha y una hora fijadas, el miedo se apodera de él:

Durtal aurait reçu un coup de maillet sur la tête qu'il n'eût été mieux assommé. Tout l'échafaudage si rapidement exhaussé de ses joies croula. Ce fait étrange avait lieu; dans cet élan d'allégresse qui le portait depuis l'aube, il avait complètement oublié qu'il fallait se confesser. Et il eut un moment d'aberration. ${ }^{1052}$

«Y tuvo un momento de aberración». El comentario se detiene allí y no merece mayor explicación. Esa aberración que casi se apodera de Durtal es el mismo tipo de deseo que le sobreviene en $\grave{A}$ rebours cuando se le presentaba la posibilidad de someterse a la Ley de la religión: esa «subite rébellion, [...] rapide volte, des idées monstrueuses naissaient en lui, des idées de ces sacrilèges prévus par le manuel des confesseurs» ${ }^{1053}$ que se apoderaba de él ante la sola idea de someterse a la ley del Padre. En En route esa llamada de la rebelión es perfectamente controlable por el penitente en que ya se ha convertido Huysmans-Durtal, gracias a la acción benefactora del régimen monacal. "Je ne peux pourtant pas narrer au confesseur ce qui se brassait dans l'ombre parfumée de ses vices, s'écria Durtal; je ne peux pourtant pas lui faire gicler à la face ces filets de pus». ${ }^{1054}$ Ya sabemos que esos hilos de pus que Durtal teme lanzar a la cara del confesor tienen un carácter esencialmente sexual. Y sin embargo es consciente de la necesidad de la confesión, único modo de abrir el espíritu a la entrada completa del Padre en el creyente: "désinfecter le logis, de le passer au chlore des prières» para estar preparado para esa llegada: «l'Hôte viendra et nous ordonnera de nous transvaser en lui, tandis que lui-même se fondra en nous». ${ }^{1055}$ La explicación que da Durtal de su entrada en la religión, en la Ley del Padre, realizada mediante tal profusión de símiles líquidos, nos ilustra sobre la objetualización que hace de sí mismo. Durtal se hace recipiente, se hace habitáculo, y ello

1052 J.-K. Huysmans, En route, ob. cit., p. 320.

1053 J.-K. Huysmans, À rebours, ob. cit., p. 128.

1054 J.-K. Huysmans, En route, ob. cit., p. 322.

1055 Ib., p. 107. 
por medio del recurso al masoquismo. Como dice Tacium en su tesis, el ciclo religioso de la obra de nuestro autor es el que aboga más a menudo por el valor del hombre femenino. ${ }^{1056} \mathrm{Y}$ eso porque Huysmans cree que únicamente mediante su feminización va a poder completar plenamente el ritual de asimilación del Padre: la eucaristía.

Con la comunión, el creyente renueva un rito antiquísimo, el del banquete totémico. Ya hemos disertado ampliamente sobre esto en páginas anteriores, pero merece hacerlo de nuevo, no fuera más que sucintamente, por razón de su importancia.

Según varios investigadores como Robertson Smith, Atkinson y Frazer, a partir de cuyos trabajos conformó Freud su teoría sobre la horda primordial en Tótem y tabú, la humanidad se fundó en un asesinato. Asesinato del macho dominante y padre de todos los jóvenes de una comunidad de primates que no podían acoplarse con las hembras de la misma. Para hacer precisamente esto debieron contravenir la autoridad del padre matándolo, lo que les permitió dar rienda suelta a su libido pero, al mismo tiempo, les castigó con un enorme sentimiento de culpa que deshizo la antigua cohesión del clan.

En conmemoración de este acto se instituyeron una serie de ceremonias expiatorias, de entre las cuales la más importante es el banquete totémico. Gracias a este, el celebrante come de su cuerpo —o lo que simbólicamente cumple este papel-, asimilando así las características del padre e identificándose con él. La eucaristía permite asimilar simbólicamente no solo el cuerpo del padre, sino que en realidad se come el del hijo, sacrificado en la cruz para redimir los pecados del mundo y aplacar la ira del padre.

Por ello, la eucaristía es el rito expiatorio por antonomasia, en el que el hijo pide perdón al Padre abriéndole de par en par las puertas de su cuerpo para que entre en él. "Oser s'avancer, oser Lui offrir comme un tabernacle son égoût à peine clarifié par le repentir, son égoût drainé par l'absolution mais encore à peine sec, c'est monstrueux!». ${ }^{1057}$ El hijo arrepentido, que desea ser poseído por el Padre, jamás se sentirá suficientemente limpio, suficientemente digno, para recibirlo en su seno. Las metáforas líquidas

1056 D. Tacium, ob. cit., p. 231.

1057 J.-K. Huysmans, En route, ob. cit., p. 236. 
persisten, Durtal sigue poniéndose a sí mismo como ejemplo de humedad, de ser invadido por los humores y los fluidos: la indignidad de esa propensión al líquido, que le acerca al líquido propio de las mujeres - leche, flujos diversos, sangre de la herida resultado de la mutilación edípica-, le hace difícil aceptarse a sí mismo como invadible por el perdón que vendrá del Padre.

Un esfuerzo casi sobrehumano le es necesario a nuestro héroe para sentirse digno de que el Señor entre en su casa, de que le posea. Ante los preparativos de su primera comunión, Durtal se pone tenso, debiendo por ello calmar su ansiedad y disminuir el peso de su culpabilidad: «Devant les préparatifs qui lui rappelaient l'imminence du Sacrifice, Durtal se roidit et parvint, d'un effort, à renverser ses anxiétés, à culbuter ses troubles». ${ }^{1058}$

Cuando llega el momento de que el Padre se introduzca en su cuerpo vía oral, Durtal se siente invadido por una sensación de torpeza absoluta; como si estuviera anestesiado, no sabe reconocer muy bien qué es lo que actúa en su interior.

Durtal était dans un état de torpeur absolue; le Sacrement lui avait, en quelque sorte, anesthésié l'esprit; il gisait, à genoux, sur son banc, incapable même de démêler ce qui pouvait se mouvoir au fond de lui, inapte à se rallier et à se ressaisir. ${ }^{1059}$

Una vez la misa terminada, nuestro creyente cree faltar de aire, por lo que sale al jardín, donde, si recordamos, hay un estanque en medio del cual se alza una inmensa cruz. Ese Cristo en medio de las aguas recuerda a Durtal la condición acuática, la condición forzosamente sexual, del hijo independizado del padre: «Et devant l'étang en croix dans l'eau duquel se noyait le Christ, il éprouva une mélancolie infinie, une tristesse immense». ${ }^{1060} \mathrm{El}$ Cristo se ahogaba, y Durtal, hijo de su Padre él también, teme el ahogo de nuevo en las aguas de la perdición. De repente, como para acrecentar su dolor, se detiene ante un molesto recuerdo: «sur le côté trop humain de la déglutition d'un Dieu; il avait eu l'hostie, collée au palais, et il avait dû la chercher et la rouler, ainsi qu'une crêpe, avec la langue, pour l'avaler». ${ }^{1061}$

$\begin{array}{ll}1058 & \text { Ib., p. } 340 . \\ 1059 & \text { Ib., p. } 372 . \\ 1060 & \text { Ib., p. } 372 . \\ 1061 & \text { Ib., p. } 372 .\end{array}$


Ese lado demasiado humano de este hecho de tan enorme simbología asusta a nuestro creyente, pues le devuelve a, precisamente, el aspecto de su vida que más daño le hace: el aspecto carnal de la relación con su(s) Padre(s). Siente entonces lo ignominioso de su acto, que la oblea haya sido maltratada, violentada, en la boca del hijo. La comida de asimilación del cuerpo del Padre pierde, con ello, parte de su fuerza: el hijo no es redimido, cree que ha cometido un sacrilegio por una falta de respeto. Su angustia proviene, única y exclusivamente, de este hecho.

El cuerpo físico, o el sustitutivo que el Hombre ha creado para simbolizar esa comida totémica de la eucaristía, la hostia, se convierte finalmente en un nuevo significante del Padre. De la misma manera que el pene paterno se convierte en un motivo de peleas entre progenitor e hijo - por lo que se convierte en cetro que determina el poder del padre sobre el hijola hostia recubre el mismo campo semántico. La hostia se convierte en el falo del padre — en el sentido de que representa su poder, su fuerza, el cetro que dicta la ley y ante la que el siervo debe arrodillarse. Por eso mismo no podemos ver en ese impulso que siente el Durtal de La Cathédrale de esconderse en el momento en el que el sacerdote eleva la hostia para consagrarla: el monaguillo que acompaña al cura siente miedo de ver la hostia, y por ello cierra los ojos: «Et l'enfant prit un flambeau et il précéda le prêtre, les yeux clos, de peur de voir l'hostie». ${ }^{1062}$ Este miedo —que de seguro es el que Durtal proyecta sobre el ayudante a la misa- es el mismo que siente el niño ante la presencia del pene paterno. En el conflicto edípico, el atributo fálico es el que determina la diferencia de roles, y el que asegura al niño que su rebelión puede costarle cara. Por eso la comunión, simbolizada en la liturgia que lleva a deglutir el falo, no es sino la puesta en escena de la sumisión del Hijo al Padre: regresión al orden infantil en que la escena primitiva de felicidad familiar puede ser reconstruida. Como señala Gérard Mendel, el acto de asmilación de la figura del Padre tiene una función de desculpabilización: ${ }^{1063}$ Huysmans no buscará otra cosa en su contacto con la religión.

La novela familiar del neurótico cobra valor renovado en el ciclo religioso de Huysmans: reconstrucción, renovación, reprogramación. Solo mediante estas tres premisas puede el adulto hecho niño por su regresión

1062 J.-K. Huysmans, La Cathédrale, ob. cit., p. 95.

1063 G. Mendel, ob. cit., p. 20. 
reconciliarse con su historia personal. Y en esta historia personal, el padre que fue demonizado primero y deseado después, cobra un papel esencial. Él es quien aceptará que el niño se sienta miembro de la familia o no; es él quien determinará si el niño puede unirse a esa pareja en principio indivisible formada por el padre y la madre. El trío esencial se formará siempre y cuando el niño haya sido integrado en la Ley paterna, la que determina el papel de cada uno dentro de este triángulo edípico.

La recuperación de la figura paterna es de vital importancia para el desarrollo de Durtal-Huysmans, pues de ello depende poder terminar con el inmenso dolor que le provocan sus relaciones carnales con las mujeres que reemplazan a su madre. Él, en su fuero interno, sabe que hay algo - alguien-que le recrimina esa conducta sexual — que en el caso de Huysmans es una doble recriminación: paterna, por pecar contra su imperio familiar, materna, por traicionar su amor con otras mujeres. La conciencia - el Superyó en la denominación psicoanalítica - es el resultado de la interiorización de las reglas paternas. De la misma manera que esa conciencia — el Superyó — dicta reglas al individuo — al Yo_- es la regla del Padre la que dice al hijo qué está bien o qué está mal. De ahí que el individuo pueda revelarse contra la imagen que se hace del Padre. ${ }^{1064}$ Matar al padre es borrar su influencia en el ámbito de las decisiones que el hijo pueda tomar de manera autónoma e independiente. El problema es que la conciencia siempre guarda un resquemor, una violencia callada, contra el asesinato cometido contra el Padre - lo que le crea un sentimiento de culpabilidad que se logra acallar con mayor o menor éxito. Como comenta de nuevo Gérard Mendel, «la culpabilidad ligada al asesinato del padre suscitaría imágenes paternas sociales, religiosas o laicas, detentadoras del poder». ${ }^{1065}$ En base a esta autonomía buscada, el individuo se siente culpable.

¿Qué ocurre en el caso de Huysmans? Que el poder que se otorga al Padre le da capacidad de juicio en la redención del hijo —en su admisión en el triángulo edípico. En esta equiparación de la instancia divina con el Padre, Dios es Juez, que dicta leyes y aplica castigos. En la medida en que

1064 Nótese que llevamos varias páginas poniéndole una mayúscula al término 'padre'. Esto no esconde otro motivo que el de hallarnos en un contexto religioso, en el que el nombre del padre es siempre identificado a Dios - el padre de todos los creyentes.

1065 G. Mendel, ob. cit., p. 165. 
la ley del padre aplique estos últimos, el hijo sentirá que su conciencia actúa agresivamente contra él: esta sería la imago «maléfica» del Padre. Cuando el hijo desea alcanzar esa ansiada comunión con su progenitor, busca la imago paterna «buena»: padre justo, fuerte, libre y benévolo, heredero del narcisismo primario, que después de esta recomposición se llama Ideal del Yo. ${ }^{1066}$

Después de estas afirmaciones solo podemos coincidir con Bruno Bettelheim cuando afirma que los dioses son representaciones supremas del Superyó, pues no son sino encumbraciones de la imagen del padre que hace el niño. ${ }^{1067}$ En el sentido de la ansiada regresión de que hemos venido hablando, los intentos que hace el niño adulto por volver a la infancia pasan por sustituir a los padres en sus fantasías novelescas - de las que lo que Freud llamó «la novela familiar del neurótico» no es sino una expresión extrema. El encumbramiento de la imago del Padre hasta el estatus de Dios no es, como afirma el médico vienés, sino «la expresión de la añoranza que el niño siente por aquel feliz tiempo pasado, cuando su padre le parecía el más noble y fuerte de los hombres, y su madre la más amorosa y bella mujer». ${ }^{1068}$

Por eso Dios es considerado por nuestro autor como una instancia a la que hay que venerar y reverenciar, sea cual sea el medio que se utilice — «['art du catholicisme n'avait qu'une seule fin:] révérer, adorer, servir le Dispensateur». ${ }^{1069} \mathrm{Tal}$ vez por eso la inclinación antigua de Huysmans por todas las expresiones del arte sacro, en las que encontraba una poesía cuya belleza inmensa solo puede ser percibida por alguien que entre en la dinámica amo-siervo, o Padre-hijo. "Quel immense bien-fonds de poésie, quel incomparable fief d'art l'Église possède! ${ }^{1070}$ — dice Durtal extasiado ante la lectura de un libro de mística. La sumisión y la reverencia a Él mostradas permitirán al creyente pedirle dádivas, perdón, que en lugar de juez impla-

\footnotetext{
1066 Ib., pp. 10 y 91.

1067 B. Bettelheim, ob. cit., p. 44.

1068 S. Freud, La novela familiar del neurótico, ob. cit., p. 1363. Davidoff y Hall señalan que según la educación cristiana tradicional del siglo XIX, «el padre ocupaba el lugar de Dios para los hijos»: L. Davidoff y C. Hall, Family Fortunes: Men and Women of the English Middle Class, 1780-1850, University of Chicago Press, Chicago, 1987 (versión española: Fortunas familiares, Cátedra, Madrid, 1994). Citado por L. Guttormsson, ob. cit., p. 392.

1069 J.-K. Huysmans, En route, ob. cit., p. 59.

1070 Ib., p. 477.
} 
cable se erija como el Padre amoroso que la religión cristina empezó a forjar a partir del iracundo y vengativo Dios de los judíos.

Por eso Durtal se extraña un tanto ante el Dies Irae que se cantaba en la liturgia: sus acentos dramáticos le sugieren más la incomprensión de un Padre temible que la misericordia de un padre comprensivo y razonable:

Elles semblaient s'adresser moins au Dieu de miséricorde, à l'inexorable Fils qu'à l'inflexible Père, à Celui que l'Ancien Testament nous montre, bouleversé de fureur, mal apaisé par les fumigations des bûchers, par les incompréhensibles attraits des holocaustes. Dans ce chant il se dressait, plus farouche encore, car il menaçait d'affoler les eaux, de fracasser les monts, d'éventrer, à coups de foudre, les océans du ciel. Et la terre épouvantée criait de peur. ${ }^{1071}$

Es la admonición de un Padre, de un Juez que vendrá «dans le hourra des foudres, châtier le monde». ${ }^{1072}$ La iglesia se convierte, por su carácter de receptáculo, de acogedora de gentes, por su naturaleza femenina, en mediadora entre el culpable y el Juez implacable: "par la bouche de son prêtre, adjure le Seigneur de pardonner à la pauvre âme». ${ }^{1073}$ Esa será la novedad de la religión católica frente a la hebraica que es su germen. El papel de esta como mediadora, como procuradora en el tribunal presidido por Dios, empieza a forjarse en la obra de Huysmans a partir de La Cathédrale: novela de ensalzamiento de la arquitectura religiosa en Chartres.

\subsubsection{La Madre mediadora}

En su papel de mediadora, la Madre —o su sustituta, la mujer en general - ofrece al hijo la posibilidad de intercesión por él ante el Padre, juez implacable. Como en el caso del padre, la madre puede verse revestida por una serie de imagos «maléficas» o "buenas». En ambas, la madre está investida de un carácter puramente natural, hecho de naturaleza en la que la humanidad no deja de sumergirse constantemente. La diferencia con el padre es que, el carácter nominal de este hace que su relación con el inconsciente esté más basado en un código de leyes y reglas — en la cultura, en definitiva. La relación con la madre es siempre más directa, sin cortapisas: o por lo menos mientras no intervenga en ella, en esta relación, la autoridad del padre.

$\begin{array}{ll}1071 & \text { Ib., p. } 63 \\ 1072 & \text { Ib., p. } 69 \\ 1073 & \text { Ib., p. } 68\end{array}$ 
El padre, en base a la ley patriarcal que establece que el hijo no se puede apoderar libidinosamente de la madre so pena de mutilación, es el que determina el tipo de imago de la madre. Es la ley paterna la que frustra al niño en su impulso libidinoso hacia la madre, lo que desencadena, según Gérard Mendel, ${ }^{1074}$ una agresividad reaccional dirigida contra la madre: la interiorización, la personificación y la unificación de estas pulsiones agresivas son la base de la formación de la imago de la Madre «mala».

Por otra parte, el impulso libidinal hacia la madre, considerada como fuente de vida, de calor, de alimento, de satisfacciones sensoriales diversas, y la respuesta gratificadora de la madre a estas necesidades-deseos van a ser interiorizados y unificados en el Inconsciente en una imago de la Madre «buena».

En el ámbito de la religión profesada por Huysmans, las mujeres van a tener esta doble posibilidad: aparecer como ambas caras de una misma moneda, cuyo valor y utilidad para nuestro creyente es el de interceder ante el todopoderoso Padre para que permita al niño volver a esa familia feliz, «aquel feliz tiempo pasado» — como decía Freud.

En este contexto de reconciliación familiar, la madre no podrá aparecer explícitamente tachada como "mala»: la imago de la mujer «mala» deberá ser revestida por toda una serie de mujeres «buenas» pero que, cargadas con el estigma de la maldad, carguen sobre ellas el castigo merecido por la madre «mala». En el caso de la religión huysmansiana, este papel se ve cumplido por unas cuantas mujeres que, por efecto de las leyes de substitución cristianas, cargan con el peso de los pecados del mundo. Son las santas místicas que, como santa Ángela de Foligno y, sobre todo, santa Lidwina de Schiedam, sufrieron en sus carnes las acometidas violentas de la rabia y la ira del Padre.

En la exposición casi morbosa de los efectos de la ira de Dios sobre estas mártires se puede detectar el deseo de aplicar sobre ellas una agresividad excepcional: como si con su lancinamiento, el escritor reparara un mal que ellas previamente le habían infligido. En la relación de las fases del desarrollo infantil que Mendel establece con su teoría de las imagos, la imago de

1074 G. Mendel, ob. cit., pp. 77 y ss. 
la madre «mala» recibe todos los golpes de una especie de sadismo oral. Se trata de una angustia de muerte por la cual el individuo alberga un deseo canibalesco de comerse a la madre, de destruirla por completo y, correlativamente, de ser completamente destruido por ella. ${ }^{1075}$ Solo así podrá tener lugar la expiación de las faltas cometidas por madre e hijo contra la ley del Padre.

La madre «buena» aparecerá, por contra, dotada de todas las cualidades paradigmáticas de la madre. Este papel será cumplido, en el ciclo religioso de Huysmans, por la figura de la Virgen María, a quien nuestro autor demuestra profesarle una devoción incluso superior a la que demuestra ante el Padre.

\subsubsection{Mujeres mártires: mística femenina}

Del sadismo oral con el que Mendel comentaba que el sujeto la tomaba con la mujer revestida con la imago de la madre «mala» cabe extraer como consecuencia que esta, al considerarse como sujeto ella misma, lo observe desde una postura de masoquismo. Desde esta perspectiva es activa su aceptación de convertirse en objeto pasivo - lo que, junto al narcisismo, son los tres rasgos principales de la personalidad femenina según Freud: el sujeto se encuentra en una situación propia del sexo femenino, ya que se imagina estar siendo castrado, estar representando un papel pasivo en el coito, o estar dando a luz.

Kate Millet, en Politica sexual, colige de esta conclusión freudiana que, en sus últimas consecuencias lógicas, la violación se convierte en un auténtico anhelo de toda mujer y no puede resultarle sino fructífera. ${ }^{1076}$ Cabe albergar la idea, dentro de un contexto patriarcal, que todos los ataques sobre el cuerpo de las mujeres sean aplaudidos de buena gana, e incluso aceptados como formadores del verdadero espíritu femenino.

No nos atreveríamos de ningún modo a hacer nuestra esta aseveración. Únicamente señalamos que el background patriarcal en que está basada la religión cristiana ve como aceptables estas relaciones sangrientas de la mujer

1075 Ib., p. 78.

1076 K. Millet, Politica sexual, ob. cit., p. 346. Señala esta autora que la novela Historia de $O$ de Pauline Réage «produce una situación extrema basada en tales supuestos». 
con su Dios. Y es precisamente en ese contexto en el que se asienta la idea de la mujer en el credo patriarcal: masoquista, pasiva y narcisista.

La mística cristiana es principalmente narcisista porque está convencida de que posee las condiciones necesarias para ser amada de manera extrema. Es una especie de erotomanía a la inversa. Simone de Beauvoir ${ }^{1077}$ supo observar extraordinariamente las relaciones existentes entre mística y erotomanía. Centrada en su narcisismo, la erotómana se siente revalorizada por el amor de un ser soberano; pero, como su impulso hacia el ser amado es negativo, de espera, pasivo, es el ser superior quien toma la iniciativa. Su amor es más apasionado que el de la elegida, da a conocer sus sentimientos por signos evidentes pero secretos, se pone celoso ante la falta de fervor amoroso de la elegida — no dudando en castigarla en este caso.

Todas estas condiciones se cumplen en el caso de las místicas, que se abandonan sin ningún tipo de problema a los peligrosos abrazos de su amo. Pero, añade Beauvoir, como la pobreza del lenguaje no permite nombrar este tipo de efusiones divinas, la mística tiene que tomar prestado al vocabulario amoroso la mayor parte de su terminología: por eso toma del amor terrestre no solo palabras sino también actitudes físicas.

De ahí que algunas de las místicas estudiadas por la pensadora francesa se dediquen a expandir amorosamente la palabra de Dios mediante acciones femeninas. Frecuentemente, estas acciones pasan por el cuidado de los miserables y, sobre todo, por las labores de limpieza que la mística lleva a cabo con ellos. Así, Marie Alacoque limpiaba con su lengua los vómitos de una enferma, o recibe en su boca los excrementos de un hombre que padecía diarrea. Su premio fue permanecer durante tres horas con los labios pegados al sagrado corazón.

La mística que más comentarios suscita entre algunos es, poniendo aparte a santa Teresa de Jesús, santa Ángela de Foligno, de la que Huysmans exclamará con arrobo: «Quelles effusions et quelles tendresses! Quelle chatte caressante d'âme! Quelle Bacchante de l'amour divin, quelle Ménade de pureté!». ${ }^{1078}$ Sus efusiones y ternuras revisten el mismo carácter que las de

1077 S. de Beauvoir, Le deuxième sexe, ob. cit., vol. II, pp. 585 y ss.

1078 J.-K. Huysmans, En route, ob. cit., p. 162. 
María Alacoque: bebe con placer la misma agua con que ha lavado a los leprosos; en una ocasión en que apareció un pedazo de piel despegada de la piel de un leproso, en lugar de escupirla, intentó tragarla por medio de grandes esfuerzos: «Il me sembla que je venais de communier. Jamais je n'exprimerai les délices dont j'étais noyée». ${ }^{1079}$

Se trata, en todos estos casos, de un placer extremo el que es experimentado por estas mártires cristianas. Mártires no por obra de sus congéneres, sino del mismo Dios al que ellas veneran. Como dirá Françoise Collin comentando a Beauvoir, nos hallamos aquí ante una renovación de la relación amo-siervo, superándola por arriba. ${ }^{1080}$ La sierva siente una verdadera delicia al ser así mancillada por el amo, quien se convierte, en cierto modo, objeto de la pasividad activa de la sierva. Permítasenos este juego de oximorones, necesario para mostrar hasta qué punto para Collin y Beauvoir la posición mística pasa por una neutralización de las relaciones entre amo y siervo. No obstante esto, excesivo tributo es el que paga esta doliente sierva al inmolarse en el altar del amor de su amo.

Luce Irigaray también encuentra en la posición de la mística una renovación de esta relación amo-siervo. Según ella, la experiencia mística permite que la feminidad se descubra precisamente mediante la aceptación más profunda de la dominación del hombre. Toril Moi comenta a propósito que el misticismo ofrece a la mujer una posibilidad real, aunque limitada, de descubrir algunos aspectos del placer —a los que el acceso le habría estado vedado fuera en condiciones normales. ${ }^{1081}$ Así, y por seguir a Lacan, el más-allá-del-placer no es todavía, en esta caso, el más-allá-del-falo que sería formulado más tarde. ${ }^{1082}$

Sea como una liberación o como una de las pocas posibilidades de placer que se le abren a la mujer atenzada por el sistema ideológico del patriarcado, la postura mística es perfectamente integrada por Huysmans en su cultura religiosa. La mujer mística sufre porque con ello redimirá los pecados del Hijo, intercederá con ello ante el Padre — gracias a la posición pri-

1079 S. de Beauvoir, ob. cit., p. 589.

1080 F. Collin, «Nom du père. On de la mère. De Beauvoir à Lacan», ob. cit., p. 27.

1081 T. Moi, ob. cit., p. 146.

1082 Citado por F. Collin, «Nom du père. On de la mère. De Beauvoir à Lacan», ob. cit., p. 26. 
vilegiada que Este le otorga — y, además, se purificará ante los ojos del niño que veía en su profusión de fluidos, mucosas y heridas motivo para temer por su propia seguridad. Que la mujer se desangre, que pierda todos sus humores en un constante sufrimiento, no puede ser sino grato ante el hijo, quien ya verá indicios de que la agresividad contra él esgrimida en el seno de la familia feliz ha terminado. Que la mujer haya perdido todos los líquidos que la caracterizan fantasmáticamente ante el hijo significa que pierde su condición femenina a favor de su ingreso en un estatus asexuado, gracias al cual el conflicto edípico deja de tener validez. Por eso santa María de Ágreda se desfeminiza gracias a la acción divina:

Elle est sans âge; ce n'est pas une femme et ce n'est déjà plus une enfant. Et l'on ne sait même pas si Elle est une adolescente, à peine nubile, une fillette, tant elle est sublimée, au-dessus de l'humanité, hors le monde, exquise de pureté, à jamais chaste! ${ }^{1083}$

Exquisitamente pura, casta para siempre jamás: este es el programa jubilatorio que Durtal espera de la mujer mediadora. Al acabar con su condición femenina, que le empujaría sin duda a cometer pecado de impureza con el Padre, el peligro de caer en la tentación de la carne parece difuminarse. Por eso Durtal no ve con buenos ojos al retrato que hizo Fra Angélico de Santa Catalina de Alejandría en su cuadro La coronación de la Virgen:

avec ses yeux pâmés, ses prunelles d'eau saumâtre, n'est ni simple, ni candide, ainsi que ses autres sœurs; celle-là voit encore la forme hominale du Christ, celle-là est encore femme, elle est, si l'on peut dire, le péché de cette œuvre. ${ }^{1084}$

Su capacidad para el éxtasis sigue siendo femenina, puesto que su tendencia hacia el goce es todavía de naturaleza carnal: todavía ve la forma «hominale» de Cristo, su forma masculina si pudiésemos decir. No es como santa Ángela de Foligno, quien permanece pasiva ante la llegada del Señor: «Ma douce fille, ma fille, mon aimée, mon temple», le dice Jesús, entrando en ella como quien entra en una habitación desprovista de muebles. El problema reside en la actividad, en la necesaria inmovilidad de la mística, que debe esperar paciente-mente en lugar de proceder como ac-

1083 J.-K. Huysmans, La Cathédrale, ob. cit., p. 188.

1084 Ib., p. 186. 
tante, como agente — a pesar de la dinámica de oximorones opuestos que habíamos presentado antes.

Los ejemplos más interesantes de Huysmans sobre la depuración femenina - o, mejor dicho, desfeminización a través del sufrimiento místico- los hallamos, como era de esperar, en su pequeño libro de santos que es Sainte Lydwine de Schiedam. Es aquí donde se evidencia los mayores esfuerzos de depuración genérica de toda la producción huysmansiana. Lidwina exuda líquidos por todos sus poros, por sus innumerables heridas, que se renuevan apenas una de ellas se ha cerrado al secarse.

La primera manifestación de su carácter plenamente femenino aparece mediante una hidropisia extrema: «il la mua en un squellette et bomba sur cette consternante maigreur le dôme ridicule d'un ventre rempli d'eau; il la promut, pour ceux qui ne voient que les apparences, hideuse». ${ }^{1085}$ Apestosa para quien no ve más allá de las apariencias. Pero, claro, Huysmans —aquí ya no hay mediación de heterónimo- sabe fehacientemente que detrás de todo esto está el Padre que la vulnera ignominiosamente. Al llenarla de líquido la devuelve a su condición de madre-mujer, con el vientre repleto que puede estallar en cualquier momento. Sin embargo, lo que podría ser asqueroso de no mediar la actuación divina, se convierte en algo delicioso, tanto como la piel escamosa que tragaba con delectación Marie Alacoque. El agua rebosa por todos los poros, estalla por mil heridas, pero exhala esta agua santa un delicado aroma del que participan también el pus y los gusanos:

En un constant miracle, il fit de ces blessures des cassolettes de parfums; les emplâtres que l'on enlevait, pullulant de vermines, embaumaient; le pus sentait bon, les vomissements effluaient de délicats aromes. ${ }^{1086}$

Y no es nada extraña esta transformación deliciosa de los humores infectos si se tiene en cuenta que ha sido el propio Padre quien los ha transformado en puros, cristalinos y edificantes. Porque esos líquidos eran el equivalente material del alma de la mujer, que Dios ha licuado para llenar

1085 J.-K. Huysmans, Sainte Lydwine de Schiedam, ob. cit., p. 53.

1086 Ib., p. 54. De este pasaje dirá Charles Bernheimer que se trata de «la restauration d'une image de la totalité purement fantasmatique, celle de la mère phallique», en C. Bernheimer, ob. cit., p. 109. 
el molde nupcial de su cruz: «Jésus saisit l'âme pour la liquéfier dans la forge de l'Amour et la verser, alors qu' elle entre en fusion, dans le moule nuptial de sa croix». ${ }^{1087}$

La condición femenina, en este caso, no ha sido desecada, sino que ha conservado su ser acuático pero transformando su esencia. Lydwine continúa, a lo largo de toda su amable agonía, supurando líquidos que harán las maravillas de cuantos acuden a verla. Pero líquidos que ya no manan de ella misma, sino del propio Padre. Por eso, cuando comulga, su cuerpo se desborda de amor y de gratitud, como si fuera una verdadera eyaculación del alma — como Huysmans refería tan a menudo de sus amados pintores en Certains, especialmente Rops. El éxtasis de la joven holandesa no es por ello sino mayor, inmenso, equiparable al dolor del hijo en la cruz:

Immédiatement son âme craqua et l'amour jaillit en une explosion, fusa en une gerbe de feux qui nimbèrent la suradorable Face qu' elle contemplait, au plus profond de ses aîtres, dans la source même de sa personne; et folle de douleur et folle de joie, elle ne savait même plus ce qu'était son malheureux corps. ${ }^{1088}$

Y puesto que estas dos posiciones de agonía son perfectamente equiparables, Jesús le pregunta a su amada terrenal si desea acompañarle al Gólgota para sufrir como él en el cadalso. A lo que ella responde poseída por un arrebato de dicha: «O Seigneur, s'écria-t-elle, je suis prête à vous accompagner sur cette montagne et à y pâtir et à y mourir avec vous!» El Señor se la lleva y, al devolverla a su cama de enferma, sin haberle arrebatado por completo la vida, Lydwine aparece magullada, destrozada, con llagas en la boca, con heridas en los brazos, incluso con las magulladuras de la corona de espinas sobre la frente...

Il la prit donc avec Lui et lorsqu'elle retourna dans son lit qu'elle n'avait pas corporellement évacué, l'on aperçut des ulcères sur ses lèvres, des plaies sur ses bras, des déchirures d'épines sur son front... ${ }^{1089}$

El matrimonio se ha consumado y la mujer ha sido castigada por su naturaleza corporal, por ser un ente entregado a la carnalidad y a la concu-

1087 J.-K. Huysmans, Sainte Lydwine de Schiedam, ob. cit., p. 56.

1088 Ib., p. 69.

1089 Ib., p. 124. 
piscencia. La limpieza de la madre se completa así, mediante toda una vida dedicada a la expiación por el dolor. El hijo se sabe ahora nacido de una hembra limpia, lo que permite su regreso a la familia pre-edípica, previa al conflicto de intereses del triángulo primordial, en la que su seguridad y su aceptación están aseguradas. Y toda la humanidad gana con ello, pues, según las leyes de la substitución, toda la desdicha del mundo puede caer sobre estas madres-mujeres. De no ser por ellas, la humanidad entera sería anegada por los pecados, por las aguas sucias de la carnalidad — de las que ella, siendo, agua, se ha liberado gracias a la acción licuante de Jesús.

Si ces âmes n'existaient pas, il en serait de l'univers de même que de notre pays, sans l'abri des digues. Il serait englouti par la crue des péchés, ainsi que la Hollande par le flux des vagues. ${ }^{1090}$

Esta es una de las posibilidades que la lógica vengativa de Huysmans, perfectamente enclavada en el sistema ideológico de dominación del patriarcado, concede a la mujer en la religión. La expiación es necesaria siempre y cuando haya comisión del pecado de carne. Una falta de alto nivel, como la considera Huysmans a juzgar por los tremendos conflictos en que le sumía cada vez que sucumbía a ella.

Sin embargo, es posible contemplar un segundo papel femenino en la dinámica religiosa de Huysmans. La Virgen María, como sustituta perfecta de la madre de cada uno, es el ejemplo a seguir por toda madre que se quiere pura y casta —espejo de todas las mujeres. En la oposición sujeto-objeto, María es un curioso sujeto. Por una parte, haciendo al hijo objeto de su amor, ella se convierte en sujeto decisorio: ella decide esta cosa y no otra, velar por los cuidados de su hijo - lo que deja a las claras las perfectas relaciones que mantienen las religiones con la divisón de roles en la sociedad, connivencia de los poderes fácticos. Por la otra, al ser virgen y no ser poseída por ningún macho en su feminidad, su objetualización es peculiar. Es utilizada como madre - lo que no deja de proporcionarle un inmenso placer- por el espíritu santo, pero sin dejarle mancha alguna.

Su objetualización es el sufrimiento puro —en el sentido de 'pureza'. María sufre por la suerte de su hijo y por la de todos los hijos de la tierra; pero lo hace interiormente, sin que ninguna llaga ni herida per-

1090 Ib., p. 64. 
mita dejar al descubierto su naturaleza femenina. Ella no es agua, no está hecha de líquido, su cuerpo no es de este mundo — si se nos permite esta paráfrasis.

\subsubsection{Virgen y Madre}

Y sin embargo, Huysmans la imagina perfectamente con su seno cargado de líquido. Pero un líquido tan aromático con el que el Señor cargaba las excrecencias purulentas de Lidwina. Por mucho que su cuerpo no sea de este mundo, por mucho que se insista y se desee que su papel sea divino en el imaginario humano, la Virgen María es gustosamente presentada como una instancia humana — de la que Dios, el Señor, el Hijo, han tomado posesión para sus fines.

Así, en la parte de Certains dedicada a «La Vierge du Maître de Flémalle», Huysmans admira y aprecia el carácter terrestre de la madre de Dios. Dice que el autor, para concebir esta obra, ha necesitado del influjo de la Gracia, lo que hace que el cuadro sea único en su género: «Influx de la Grâce pour réaliser ce tableau qui est, en son genre, unique car jamais la Maternité divine n'avait cette grandeur familière». Tamaño familiar que permite al creyente asimilar perfectamente esa madre a la suya propia.

Elle n'est nullement incorporelle, ni émaciée ...; elle est grasse et elle est forte; elle n'est pas non plus une jeune fille, mais bien une mère et le sein mol est gonflé de lait dont l'Enfant tient la pointe dans sa bouche.

Ahí tenemos ese seno lleno de leche que asocia a la madre con su naturaleza líquida habitual. Como cuando en L'Oblat, el libro que debería contar sin ambages su camino hacia la oblatura — si parafraseamos aquella carta en que se refería a En route-, Durtal habla enternecido por los sufrimientos de la madre durante la lectura de la Segunda Lección de Tinieblas: sufrimientos que se deben a su naturaleza líquida, a su herida — en cuyo sangrado se sentía implicado él mismo por el recordatorio infantil del peligro de castración.

Et Durtal gémissait avec elle, lorsqu’à la deuxième Leçon du Nocturne du Vendredi Saint [...]. Et comment pourrais-je te consoler, ô Vierge, fille de Sion? Ta blessure est large comme la mer; qui y pourra appliquer le remède? ${ }^{1091}$

1091 J.-K. Huysmans, L’Oblat, ob. cit., p. 282. 
Es esta, no obstante, una inesperada recurrencia de la madre de Dios en relación con su sempiterna asociación a los líquidos para quien se cree por fin reconciliado con ella. Puesto que el Huysmans-Durtal de la época de L'Oblat ha conseguido aparentemente frenar los empujes del instinto sexual mediante su sublimación en la liturgia católica.

Porque Huysmans no se atiene únicamente a implorar el perdón o la magnificencia de la madre de Dios, quien, por el mismo hecho de serlo, podría conceder un poco de paz a su espíritu. Se refiere en innumerables ocasiones a la Virgen María como a su propia madre, en amplio contraste con lo que había venido haciendo a lo largo de toda su obra, en donde la presencia de figuras maternas está siempre oculta tras sus numerosas representaciones fantasmáticas. Es en virtud de esta deseada identificación que Durtal se dirige al Señor pidiéndole disculpas por pensar en Ella como si fuera su propia progenitora, como si al hijo que él mismo nunca fue le estuviera arrebatando lo que le convierte precisamente en hijo.

Ah! Seigneur, poursuivait Durtal, certainement lorsque j'invoque votre Mère, j'oublie à ce moment ses souffrances et ses liesses; je ne vois plus qu'une mère à moi à qui je dis ce que je pense, à qui je raconte mes petites affaires, que je supplie de me tirer moi et ceux auxquels je tiens des mauvais pas! ${ }^{1092}$

Como ya habíamos señalado más arriba, el principal papel que Huysmans atribuye a la mujer en la religión es el de intercesora. A ella se le pide que medie en el necesario conflicto sexual que surgió en la antigüedad de la historia del individuo entre el padre y el niño por la posesión de la madre. Una vez liquidado el complejo de Edipo, cabe esperar que el niño ya no vea en la madre la representación de la herida — por medio de metáforas líquidas. Hemos visto sin embargo que sí, que incluso en la forma más depurada y casta de representación de la madre en el ciclo religioso de Huysmans esta aparece con el seno hinchado de nutritiva leche. Es esta una diferencia que es necesario subrayar con la hidropisia generalizada de Lydwine, o la repugnante relación que mantenían con las aguas las otras místicas comentadas. La madre de Dios —o la madre del hijo, representada en el imaginario por toda mujer- debería no tener que sufrir los mismos tormentos que las mártires que aspiran a la divinidad gracias al privilegio que se les concede. María madre ya es divina. Pero su divinidad no es del mismo

1092 Ib., p. 346. 
rango que la del Padre; ni es sujeto de decisión al ciento por ciento; ella es divinidad pasiva, que sufre com-pasiva-mente. Completando los rasgos femeninos esbozados por la psicología, María madre es también masoquista, pues su definición es la de sufrir por el hijo. Su sufrimiento ya no es, no obstante, físico, sino de orden mental. La mejor representación de ese sufrimiento de la madre por el hijo es la pietà romana, en la que llora la muerte de su retońo bajado de la cruz. Por eso Durtal se siente regalado durante la semana santa cristiana, representación de la pasión del hijo y de la compasión de la madre:

La semaine pieuse était celle qui convenait le mieux à ses aspirations et à ses goûts; il ne voyait bien Notre Seigneur qu'en croix et la Vierge en larmes, La "pietà» surgissait devant lui avant la crèche. ${ }^{1093}$

De ahí que la llame según su deseo «Notre-Dame des Larmes», ${ }^{1094}$ poniendo en su nombre la cualidad que debe cumplir por definición. Llanto que va a servir, precisamente, para intentar que el Padre sienta piedad del pobre hijo inmolado en el altar de su autoridad.

Es esta necesidad de intercesión que el hijo pone en la madre por la que su presencia en el imaginario religioso va a ser imprescindible. Es lo que la hace diferente del Padre, cuyo carácter iracundo es temido por el hijo. Es esta una herencia del catolicismo de la religión que lo originó, el hebraismo, del cual el texto en común con la Biblia, el Antiguo Testamento, presenta un Padre que predica el amor a golpe de plagas, rabias, muertes y sacrificios. El crimen cometido por la humanidad en la persona del padre primordial se purga en el judaísmo por medio del castigo; el catolicismo supone una evolución en el sentido de que el sacrificio del hijo ante el padre se da por cumplido, con lo cual el creyente puede esperar la influencia por fin amorosa del Padre.

Esta parece ser la lógica religiosa. Para quien, como Durtal, guarda celosamente su sentimiento de culpa ante el Padre, solo puede sentir miedo. Y así, en una de las cartas que envió a la Priora del Carmelo de Argel, Huysmans se deshace en cumplidos hacia la bondad de María madre - gracias a su comparación con el Padre todopoderoso:

1093 Ib., p. 283.

1094 Ib., p. 346. 
La bonté de la Sainte Vierge est une chose certainement incompréhensible; mais elle est patiente et flagrante; quand on est un vieux pécheur, on a toujours un petit peu peur du Père, encore qu'on le sache régulièrement miséricordieux, tandis qu'Elle, on y va sans crainte, sachant bien qu'Elle interviendra et arrangera les choses... ${ }^{1095}$

Hacia ella el pecador se dirige sin ningún temor porque, bondadosa como es por definición, mediará ante el Padre «et arrangera les choses».

Este papel de mediadora para el que se instituyó la figura de la Virgen — recordemos que la mujer está excluida de la Trinidad — ha sido muy importante para acercar la religión a la vida real de los fieles. La Virgen María viene a condensar todas las características femeninas «deseables», es decir, previamente desprovistas de poder, en que la sociedad estructurada en torno al hombre deseaba instalarla. Además de carecer de poder verdadero, puesto que, como la mujer en la familia occidental, ella solo tiene poder «por procuración»——irando de los hilos en la oscuridad», como comenta Bourdieu de la mujer actual. ${ }^{1096}$

Según señala M. a Asunción González de Chávez, la madre de Dios es virgen por exigencia filial, «asexuada al servicio exclusivo de su hijo». ${ }^{1097} \mathrm{Se}$ trata de una madre buena, benevolente, protectora y disponible, cuyas funciones principales son las de obedecer, servir y consolar. La asunción de todas estas características supone una derrota para la mujer, quien ya ni siquiera cuenta con la única capacidad de que le había dotado el patriarcado: María es avisada de que será madre, como si no fuera de su propio cuerpo de donde partiría el aviso, aprovechando además la ocasión para ponerla a disposición del Creador. "He aquí la suprema victoria masculina que se consuma en el culto de María: es esta la rehabilitación de la mujer mediante la realización de su derrota», como apunta Beauvoir.

1095 L. Descaves, Deux amis. J.-K. Huysmans et l'Abbé Mugnier. Documents inédits, Plon, París, 1942, p. 62.

1096 P. Bourdieu, La domination masculine, ob. cit., p. 87. En ese mismo pasaje, el sociólogo francés se refiere a Kant en ese mismo sentido de delegación y procuración (la cursiva es mía): «Les femmes ne peuvent pas plus défendre personnellement leurs droits et leurs affaires civiles qu'il leur appartient de faire la guerre; elles ne peuvent le faire que par l'intermédiaire d'un représentant», en I. Kant, Anthropologie du point du vue pragmatique, Vrin, París, 1964, p. 77.

1097 M. González de Chávez, ob. cit., p. 38. 
En la imagen que de la madre de Dios se hace Huysmans desaparecen todas aquellas características de la esencia femenina que podían causar sufrimiento en el hijo: su asexuación definitiva es la mejor prueba de amor que puede encontrar nuestro pobre creyente.

El ensalzamiento de sus funciones es la mejor manera que tiene el hijo de dar importancia a la madre de Dios — pues la sabe de poder escaso y de tímida intercesión ante el Creador: esta se producirá porque el Padre lo decida, la madre poco tiene que decidir sobre el asunto si no es, como ya hemos señalado, por procuración. En este ensalzamiento de la madre de Dios como gran dama, Celia Amorós halla un interesante paralelismo con el amor cortés. En este arte tan extendido entre los trovadores provenzales se pretendía no solo la casta aceptación de la señora a quien se elevaban sus cuitas en forma de canciones y bellos poemas, sino la aprobación del amo, del gran señor. "Hay que conquistar su dilectio — amistad condescendiente» de la dama, como dice Georges Duby. La dama, ante esta perspectiva, no hace sino llenar la función del Padre, a través de la cual se puede conquistar la dilectio del esposo. ${ }^{1098}$

Et le Christ cède à cette douce violence, et s'il se fait prier, s'il a l'air d'accepter une certaine contrainte, c'est qu'il veut enseigner ainsi que tout ce qu'il accorde, il ne l'accorde que par l'entremise de sa Mère. ${ }^{1099}$

— dice Durtal a propósito de la intercesión materna. En otras ocasiones, la violencia a la que la madre somete a su esposo consiste simplemente en aleccionar al niño — el alma - para aparecer ante el magnánimo Padre decorado y limpio; sus peticiones serán así escuchadas con mayor atención. En esta operación de preparación del hijo para la presentación ante el Padre, el alma es comparada a la masa de pan que la madre trabaja de su hábil mano: "C'est elle qui vous pétrit et vous remet entre les mains du Fils; mais ses doigts sont si légers, si fluides, si caressants que l'âme qu'ils ont retournée n'a rien senti». ${ }^{1100}$ Se trata, desde luego, de una ma-

1098 G. Duby, «Entretien sur la litterature courtoise, avec Alain Richard, Jean-Charles Huchet, Régis Labourdette, Eric Laurent, Alexandre Leupin et Charles Méla», Ornicar?, n. ${ }^{\circ}$ 26-27, 1983, citado por C. Amorós, ob. cit., pp. 199 y ss.

1099 J.-K. Huysmans, L'Oblat, ob. cit., p. 216.

1100 J.-K. Huysmans, En route, ob. cit., p. 77. 
nipulación carente de toda intencionalidad sexual, como si esas manos con las que la virgen madre amasa el alma del hijo fueran manos de una inconsistencia angelical.

La instancia de que ruegue ante el padre por la expiación de los pecados de carne del hijo sólo puede hallarse, como hemos sugerido más arriba, libre de toda falta debida a su naturaleza femenina. Su glorificación como mujer desexualizada vendrá acompañada del menosprecio de la mujer sexual — de ahí que la reconciliación posea esa doble vertiente. «El ángel que te saluda con un AVE invierte el pecador nombre de Eva, y nos aparta, joh Santa Virgen!, de donde procede el pecado original». Así invertía el poeta y reformador Pedró Damián el anagrama con el que se invoca a María: de AVE a EVA, como dos caras de la misma moneda, la castidad y el pecado. ${ }^{1101}$ La reconciliación de Huysmans con su imago materna pasa, pues, por su necesaria desexualización, para lo cual se refugia en el seno de la religión - cuyo credo requiere de la aceptación de este dogma virginal.

La Venus profunda y terrible de que habla en Croquis parisiens, ${ }^{1102}$ esa Venus cristiana ante la que el joven Huysmans se siente atemorizado, es una figura materna que todavía lleva consigo el estigma de la sexualidad. La madona del ciclo religioso, sobre todo a partir de L'Oblat, es una mujer que hace posible el milagro de ser esposa del Padre y del Hijo, conservando sus cualidades de Virgen. María madre, como señala Per Buvik, es la instancia que permite el «au dépassement par la Sainte Famille du drame psychosexuel inévitable sur la terre»: ${ }^{1103}$ la liquidación del Edipo sin demasiadas consecuencias traumáticas para el nińo llegado al estado adulto pero arrastrando las mismas dolencias de la infancia.

La mistificación decimonónica de la virgen María ha sido comentada por varios autores, que vieron en el vigor que recobraba la figura religiosa un hecho de época. En efecto, el advenimiento de la sociedad industrial modifica por completo las estructuras familiares, haciendo que se tambalee el sistema patrilineal de filiación. El centro de gravedad se traslada desde el padre hacia la madre, debido a que el cabeza de familia

1101 E. Bornay, ob. cit., p. 44.

1102 J.-K. Huysmans, Croquis parisiens, ob. cit., p. 157. Se trata del 'croquis' Paraphrases. L'Ouverture du Tannhauser.

1103 P. Buvik, ob. cit., p. 218. 
se viera obligado a salir a ganar el sustento del grupo, mientras la madre permanece en el hogar ocupándose de los niños y de la respetabilidad del conjunto. ${ }^{1104}$ Este es el motivo, según Yvonne Kniebehler, de que la madre fuera motivo de semejante exaltación lírica, llegando al paroxismo de su consagración definitiva como mediadora divina ante el desaparecido padre.

Jean Borie añadirá que el siglo XIX y, en especial, los escritores más grandilocuentes de la época — Hugo, Michelet, Zola—, se sirvieron de esta figura materna hecha de suavidad y ternura para contrarrestar la violencia del productivismo industrial. ${ }^{1105}$

Son estas ideas que ya tratamos con más profundidad en nuestro capítulo dedicado a la masculinidad. Pero, por la importancia de la transformación de la figura de la mujer durante el capitalismo decimonónico, hemos vuelto a ello. Un ejemplo de este hecho de época lo podemos encontrar en la novela de Flaubert L'Éducation sentimentale. Si hacemos memoria, recordaremos que gran parte de la obra se mueve por entre los vaivenes del pensamiento de Frédéric acerca de Mme. Arnoux. El joven vive y se desvive por los pequeños indicios que mantienen viva la llama de su pasión. Su amada es, por todo ello, ensalzada hasta unos límites que casi podríamos calificar de religiosos: madre amantísima de sus hijos, abnegada esposa que soporta y acepta las infidelidades de su marido... Cuando Frédéric logra por fin arrancar un beso de sus labios, la cosa se detiene allí, en la contemplación estática de ese momento tan buscado. Por eso, cuando Mme. Arnoux vuelve a París desde Bretaña con el único fin de ver por última vez a Frédéric, y le da a entender que ha venido para entregársele, el joven zozobra: "Cependant, il sentait quelque chose d'inexprimable, une répulsion, et comme l'effroi d'un inceste. Une autre crainte l'arrêta, celle d'en avoir dégoût plus tard». ${ }^{106}$ Frédéric prefirió, con este gesto, conservar la visión de una madre casta y amantísima, cuya imagen temía emborronar mediante la comisión de un acto impuro. Se trata, podríamos decir, del esfuerzo del joven burgués por impedir que del «ave» pase a la «Eva».

1104 L. Guttormsson, «Las relaciones paterno-filiales», ob. cit., pp. 389-399.

1105 J. Borie, Un siècle démodé. Prophètes et réfractaires au XIXe siècle, ob. cit., p. 32.

1106 G. Flaubert, L'Éducation sentimentale, ob. cit., p. 454. 
Uno de los aspectos que nos parecen más interesantes de esta aprehensión del concepto de la Virgen María por parte de Huysmans es el que hemos tomado a partir de la lectura de una obra de Alberto Savinio - el hermano del pintor di Chirico- sobre Guy de Maupassant. Hablaba Savinio en Maupassant y «el otro» de la fijación del escritor francés por su madre, lo que le hacía considerar «únicamente mujer a su madre y hembras al resto de las mujeres». ${ }^{1107}$ Este fenómeno se producía porque el escritor sentía por su madre un amor que excede el amor natural que siente todo hijo comúnmente por su progenitora; y así se convierte en una especie de marianismo homosexual, es decir, un amor que no hace más que acrecentarse con ese amor de la «mujer ideal» que depositan los heterosexuales en las mujeres, pero que ni los homosexuales ni los carnales pueden depositar en ellas, dado que no las aman sino que las odian.

Ese amor desmedido por la madre puede equipararse al amor ideal que el Dante daba a su Beatrice «y que los católicos dan a la Virgen» —señalará acertadamente Savinio. Esa «merveille de chair ronde et douce qu'habite l'infamie» con que definió una vez a la mujer revela un doble sentido: la infamia con que ve el peligroso interior femenino, y las redondeces acogedoras y protectoras de la superficialidad femenina.

Esta sugerencia de extrema fijación a la madre hasta llegar a su idealización cuasi divina, fijación típicamente homosexual, como sugiere Savinio, encuentra perfecto eco en las afirmaciones de Freud al respecto.

En dos escritos fechados en 1910 (Un recuerdo infantil de Leonardo de Vinci y una nota añadida en ese año a Tres ensayos para una teoría sexual, de 1905) refieren el concepto que se hace el padre del psicoanálisis de la fijación a la madre. Pone Freud en relación la homosexualidad de Leonardo da Vinci con la idealización que hace de su madre, lo que le habría llevado a pintar su sonrisa con extraña insistencia. Así, esa enigmática sonrisa que encontramos en la Monna Lisa di Giocondo es la misma que en la obra inmediatamente posterior, Virgen con el Niño y santa Ana. Todas reproducciones amorosas del rostro de Catalina, su madre. ${ }^{108}$

1107 A. Savinio, Maupassant y «el otro», Bruguera, Barcelona, 1983, p. 51.

1108 S. Freud, Un recuerdo infantil de Leonardo de Vinci, ob. cit., pp. 1598 y ss. 
En la mencionada nota a Tres ensayos..., Freud parece afirmar con mayor vehemencia científica lo que antes no era sino una mera especulación. Es aquí donde afirma rotundamente que la fijación a la madre desencadena el paso de esa fase heterosexual a otra en que el «invertido» se toma a sí mismo como objeto sexual. ${ }^{1109}$

La homosexualidad latente ya rastreada en Huysmans nos ayuda, en este caso, a aherrojar la fijación que tenía por su madre. Es, precisamente, en la edad adulta, que esa fijación puede volver hacia su objeto original, cuando puede volverse de nuevo hacia la madre, pero esta vez despojada de todo componente sexual. Como hemos visto, es necesario que esta madre de Dios interceda ante él por el perdón del hijo. Para conseguirlo deberá pasar por una serie de ritos que a la manera de los rites de passage, le despojen de su vestimenta femenina. Aun siendo mujer, las señoras de la dinámica religiosa de Huysmans han perdido toda su hembritud a través del secado de sus fluidos sexuales —o de su transformación en líquidos bienolorosos y/o nutrientes, que se acercan más al ámbito de la fábula que la de la realidad-, y que han purgado con un severo castigo su pertenencia a su sexo. Se consigue así que la mujer cumpla con los tres preceptos que la ideología patriarcal espera de ella: que sea pasiva, que sea masoquista y que sea narcisista.

Es así como merece la denominación de madre de Dios, de esposa del padre severo, como la que aparece en uno de los paneles de la Crucifixión de Grünewald que Huysmans contempló durante su viaje a la iglesia alemana de Colmar. Ese realista místico que era para nuestro autor el pintor germano, representa a un hijo completamente abatido, desposeído de la santidad que le habría permitido levantarse de la cruz y sentarse junto a su padre. San Juan es un "desclasado", el Anunciador un truhán; sola entre tanta prodredumbre brilla la madre de Dios: «Elle, elle est d'une extraction toute différente, elle est une reine entrée dans un cloître, elle est une merveilleuse orchidée poussée dans une flore de terrain vague». ${ }^{1110} \mathrm{Y}$ aunque coincida con el pintor alemán en la concepción de sus cuadros y de los personajes que los integran, solo en el contexto de una extrema fijación a la madre se puede comprender que se enfade con él cuando la pinta con los

1109 S. Freud, Tres ensayos para una teoría sexual, ob. cit., p. 1178.

1110 J.-K. Huysmans, Les Grünewald du musée de Colmar, ob. cit., p. 27. 
rasgos de una humanidad demasiado manifiesta. Y así es en su Anunciación, en la que aparece una madre de Dios envuelta en los ropajes habituales de una hembra:

L’on se demande comment l'artiste qui a créé la petite Vierge blanche a pu incarner la Mère du Sauveur en cette désagréable maritorne aux lèvres gonflées, qui marivaude, endimanchée dans sa toilette d'apparat, une robe d'un vert somptueux relevé par les traits d'une doublure en vermillon vif. ${ }^{111}$

«Desagradable maritornes» — referencia cervantina — envuelta en su bello vestido de domingo. Como de "maritorne» trata también a la virgen de Melchior Broederlam, de Ypres (en L'Oblat): barriguda, traviesa, de lejos las exquisitas madonas pintadas por uno de sus ídolos del renacimiento flamenco, Roger van der Weyden:

Ce n'était plus la Mère bedonnante et folâtre, la maritorne de Jacques de Bars; celle-là, avec ses prunelles du ton de la fleur des lins, ses chairs laiteuses, son nez qui s'amenuisait déjà plus droit, s'anoblissait, se patricisait, si l'on peut dire, en s'effilant; ce n'était pas encore la Vierge exquise de Roger Van der Weyden et de Memling, mais c'était déjà un peu Marie, la mère d'un Dieu. ${ }^{1112}$

Una exigencia más que añadir a la lista de la idealización divina de la madre: la elegancia en los rasgos — que no en la ropa-, que podría llegar a una necesaria distinción que, como sabemos, se encuentra menos en lo que uno se pone que en lo que lleva siempre puesto...

\subsubsection{Hacia la pureza por el convento}

Ya habíamos visto las continuas aspiraciones a una vida de recogimiento expresadas por el heterónimo ficcional huysmansiano. Ya desde el Drageoir, el hijo de Cornélius Béga sueña con «les tranquilles délices d'une vie calme» que le procurase el sosiego necesario para completar su obra pictórica.

Léo, el amante de Marthe, busca en su compañera el tipo de confort doméstico que le permita olvidarse de esos «petits riens» de la casa y dedicarse, así, a su oficio de escritor.

1111 Ib., p. 29.

1112 J.-K. Huysmans, L'Oblat, ob. cit., p. 224. 
Lo mismo con el pintor Cyprien, tanto como protagonista en Les Sæeurs Vatard como secundario en En ménage, no desea otra cosa más que la tranquilidad en el hogar para cumplir su eterno sueño: trabajar en paz. Idéntica aspiración la de André Jayant en la última de estas dos novelas, quien debe volver al hogar conyugal aun a pesar de la comprobada infidelidad de su esposa por verse incapaz de alcanzar esa calma doméstica.

El narrador del croquis «Au Bal de la Brasserie Européenne» desea escapar de la mundanidad y acceder a un lugar de «cordiales bouffées d'air silencieux et pur». ${ }^{113}$

La suerte de Folantin es terrible en su búsqueda del interior en $\grave{A}$ vaul'eau: se considera ya fuera del mercado marital que le permitiría alcanzar esa feliz tranquilidad en el matrimonio.

Estas aspiraciones se hacen más patentes en el encierro de $\grave{A}$ rebours, en el que des Esseintes intenta encontrar su «thébaïde raffinée», su «désert confortable» en el que refugiarse de la estupidez humana. Decora su interior de motivos religiosos, como una celda conventual, e, incluso, viste a sus domésticos de manera a semejar las vestimentas de los habitantes de un claustro. Todo con el objeto de llevar una «existence presque analogue à celle d'un religieux», pero sin sus inonvenientes: «la discipline soldatesque, le manque de soins, la crasse, la promiscuité, le désœuvrement monotone». ${ }^{114}$

En Là-bas, el heterónimo definitivo que será Durtal sueña despierto con la somnolencia de las oraciones reverberadas por los muros de un templo gótico. Del mismo modo que Gilles de Rais, desea «se recenser dans une atmosphère pacifique, près de ses livres». ${ }^{115}$

En route permite cumplir en parte ese sueño, pues Durtal se instala durante unos días en la Trapa de Igny para vivir en sus propias carnes la existencia monacal. «Ignorer pour jamais ce qui se passe, hors de sa cellule, chez les hommes! —et parfaire le bienfaisant silence de cette vie murée» es el anhelo más ardiente de nuestro héroe. Sin embargo, se sigue reconociendo inapto tanto física como moralmente para llevar tan rígido sistema de existencia. Él necesitaría vivir en una comunidad amable, selecta, do-

1113 J.-K. Huysmans, Croquis parisiens, ob. cit., p. 51.

1114 J.-K. Huysmans, À rebours, ob. cit., pp. 65 y 115.

1115 J.-K. Huysmans, Là-bas, ob. cit., p. 49. 
tada de una buena biblioteca, con una comida aceptable, tabaco, y régimen abierto - a lo que él mismo se responde con ironía «ce serait un couvent de Dominicains, avec les dîners en ville et le flirt de la prédication en moins!». ${ }^{116}$

Sus indagaciones, en La Cathédrale sobre las diferentes órdenes monásticas le llevan a albergar la posibilidad de integrarse en un "ordre clément, amoureux de liturgies et épris d'art» que le acogiera y le permitiera llevar un régimen menos estricto. Y, para llevar a cabo su idea de obra necesitaría que en esa biblioteca de ensueño hubiera algo más que volúmenes religiosos, sino también volúmenes profanos: «au point de vue de l'art, il est indispensable de se retremper dans la prose d'Hugo, de Baudelaire, de Flaubert». ${ }^{1117}$

En L'Oblat, Durtal ya parece estar convencido de sus preferencias en materia monacal. Está convencido de la excepcionalidad de Solesmes, por su arte y su sobriedad. Los Cartujos le parecen, por otra parte, los monjes que viven en la disciplina más humana, «les seuls captifs qui n’eurent jamais besoin, depuis leur fondation, de réformes, tant leur régime de solitude est habile est savamment dosés: ${ }^{1118}$ rupturas de la rutina laboral y paseos se le antojan a Durtal antídotos contra la angustia claustral.

Todos estos ejemplos, puestos los unos detrás de los otros, no tienen otro objeto que mostrar la continuidad de ideas referentes al retiro en soledad de que hace gala la obra de Huysmans. Desde la primera hasta la última plantean el ansia de escapar del mundo para retirarse a un lugar tranquilo en el que: sea «s'absorbant dans la frénétique féerie de son œuvre pour oublier ses peines» ${ }^{1119}$ —imitando al pintor Grünewald_-, sea llevando «une existence, abîmée en Dieu, et aboutissant, par l'aide des prières liturgiques, à des oraisons colorées d'art» ${ }^{1120}$ — como imagina poder llevar en Gante o Brujas cuando las órdenes monásticas deban abandonar suelo francés.

Es decir, vida que se abandona en la realización de una obra que el artista considera de vital importancia, o vida que se abandona en la contem-

1116 J.-K. Huysmans, En route, ob. cit., pp. 136 y 208.

1117 J.-K. Huysmans, La Cathédrale, ob. cit., pp. 225 y 359.

1118 J.-K. Huysmans, L'Oblat, ob. cit., p. 329.

1119 J.-K. Huysmans, Les Grünewald du musée de Colmar, ob. cit., p. 19.

1120 J.-K. Huysmans, L'Oblat, ob. cit., p. 331. 
plación de Dios. La cuestión es el abandono del modo de existencia que había planteado la vulgata capitalista y productivista durante el siglo XIX - de la que el XX todavía está viendo los efectos por mucho que los sociólogos llamen "post-capitalismo» a la época que nos está tocando vivir. Como oposición contra la producción de bienes para el consumo, en contra de una ética del trabajo basada en compartir el producto de su trabajo con el resto de la sociedad, Huysmans se plantea una existencia al margen, en la que su trabajo no tenga nada que ver con sus semejantes — esos mufles, como dice él.

Los ejemplos que le alumbran en la literatura y el pensamiento de su siglo son numerosos. Su admirado Baudelaire esperaba ansioso la separación del mundo gracias a su actitud espantosa — en pleno sentido del término. "Quand j'aurai inspiré le dégoût et l'horreur universels, j'aurai conquis la solitude», decía el poeta en Fusées. ${ }^{1121}$ La repulsión no, pero sí la soledad del sabio en su torre de marfil consigue M. Athanassiadis, un griego experto en la tragedia clásica al que acude la Faustin para captar en su idioma natal las entonaciones de la Fedra clásica: de noviembre a mayo, el sabio se encierra, cual prisionero, en su morada, pues los aires helados del invierno parisién podrían matarle. ${ }^{1122}$ Más hacia atrás, un caso similar se da en el héroe de La Peau de chagrin, de Balzac, pues Raphaël, para evitar que el famoso pedazo de piel le comiese la vida a pedazos, se había retirado en busca de la abolición completa de sus deseos: «Il abdiquait la vie pour vivre, et dépouillait son âme de toutes les poésies du désir. Pour mieux lutter avec la cruelle puissance dont il avait accepté le défi, il s'était fait chaste à la manière d'Origène, en châtrant son imagination». ${ }^{1123}$ ¿No somos capaces de ver, en este propósito brutal de Raphaël, una equivalencia con nuestro Huysmans?

Tanto en el héroe balzaciano como en el sacerdote que los Goncourt dibujan en Germinie Lacerteux, queda mucho del hombre en el anacoreta.

1121 C. Baudelaire, Fusées, ob. cit., p. 61, fusée n. ${ }^{\circ}$ XI.

1122 E. de Goncourt, La Faustin, ob. cit., p. 42: «Du mois de novembre jusqu’à la fin de mai, je suis prisonnier dans cette chambre... et vous comprenez un peu le plaisir que j'ai à avoir autour de moi ces oiseaux... Tout ce long temps, il m'est absolument interdit de sortir... l'air de votre hiver me tuerait».

1123 H. de Balzac, La Peau de chagrin, ob. cit., p. 259. 
El retiro no consigue en su totalidad apagar la voz intensa del deseo, sino que esta puede surgir, insistente, en cualquier momento.

El sacerdote era joven. Era bueno. Había vivido la vida mundana. Una gran pena le había hecho refugiarse, destrozado, en esa sotana que llevaba el luto de su corazón. Quedaba mucho del hombre en él, y escuchaba, con una piedad entristecida a aquel infeliz corazón de criada. ${ }^{1124}$

De esta afirmación sobre el mencionado sacerdote podríamos extraer ejemplo para ilustrar la vida ascética de nuestro autor. Porque Huysmans, ya lo hemos señalado en su correspondiente capítulo, va buscando en el convento acallar la voz del deseo —el grado cero de la sexualidad, como dice David Tacium en su tesis_-, parafraseando a Barthes. Huir, en primer lugar, del recuerdo lacerante de Florence, la prostituta que envenenaba los sueños de Durtal en En route; sumirse, después, en la contemplación de Dios, en el trabajo sin cesar adornado por aquí y por allá de los momentos de liturgia.

Una vida de abandono.

Si antes nos habíamos ocupado de los motivos que llevaban a Huysmans a abrazar una vida retirada, ahora vamos a hacerlo pero desde una óptica tal vez diferente. Sí, las causas expuestas anteriormente se basaban en ese afán de abandono de todo lo humano para dedicarse a la perfección de todo lo intelectual.

En realidad, el ansia de Durtal-Huysmans por entrar en una comunidad monástica no se basa únicamente en el deseo de aislamiento necesario para llevar a cabo una obra. Su finalidad es, ante todo, sexual. Hay que apagar esa energía sexual que agota la mente del hombre y desviarla hacia otros menesteres que permitan, por lo menos, bajar el volumen de su voz. Ya sabemos que todo el ciclo religioso de la obra de Huysmans encierra la resolución de los conflictos edípicos mediante un ensayo de regresión simbólica. La sumisión al padre, el ensalzamiento de la madre, el deseo de que esta interceda ante aquel para perdón de las faltas cometidas por el hijo..., y todo para volver a la vida feliz de la familia original en la que el hijo se sabía amado de sus padres: a una existencia preedípica.

1124 E. y J. de Goncourt, Germinie Lacerteux, ob. cit., p. 90. 
El convento simboliza un poco esa existencia preedípica de hombres unidos en la realización de un trabajo absorbente. Evidentemente, en el caso de los frailes, no se trata de hombres en el sentido sexual, ya que su forma de vida y sus intereses por los bienes materiales, excluyendo el amor, así lo sugieren. Sin embargo, su programa frecuentemente basado en el trabajo de la tierra indica una cierta existencia fálica: su sexualidad no está extinta, sino temporalmente apagada. Empero, los monjes parecen libres de conflictos internos y no tienen deseo alguno de ir más allá de esa existencia fálica, en busca de relaciones íntimas: se sienten satisfechos con la rutina de sus actividades.

Esta exposición de la vida monacal encuentra muchos paralelismos con la explicación que da el psicoanalista Bruno Bettelheim de la vida dedicada al trabajo de los enanitos a cuya casa llega Blancanieves en el cuento de Andersen. ${ }^{125}$ Tanto la hermandad de los enanitos del cuento como la de los hermanos en la fe de Cristo son comunidades asexuadas que abogan por la abolición de la sexualidad en el desarrollo de sus vidas. Comunidades reunidas en torno a un concepto moral que entiende necesario matar al hombre que vive en cada uno de ellos. Las comunidades religiosas femeninas intentarán lo mismo, aun cuando las monjas se digan a sí mismas «esposas del Señor». En el caso de las comunidades masculinas no se produce, ni mucho menos, el mismo fenómeno. Por una parte, el sistema ideológico del patriarcado prohibe siquiera imaginar una sexualidad - aunque sea una sexualidad a abolir - fuera de la obligatoria heterosexualidad: por ello, los monjes jamás se dirán esposos del Señor. Pero, oponiendo el caso femenino, tampoco van a considerarse «esposos de la Virgen». Por ello podemos ver en las comunidades religiosas masculinas una abolición de la masculinidad para mayor gloria del Padre, quien va a considerar a sus hijas como esposas suyas pero, a los hombres, como productores de los bienes de la tierra, sin relación carnal con ninguna de las instancias del triángulo edípico.

Una regresión en sentido pleno - que se da en el caso masculino pero no en el femenino, pues la regresión de las religiosas al estado preedípico no se produce totalmente poniéndose a disposición del Padre todopoderoso. Este, como

1125 B. Bettelheim, ob. cit., p. 217. 
en la comunidad primigenia en que un macho disponía en exclusividad de todas las hembras, las tiene a su alrededor como potenciales objetos de deseo.

Así, relacionando de nuevo la religión con el asesinato primordial enunciado por Robertson Smith, Atkinson y Frazer y reelaborado en clave psicoanalítica por el Freud de Tótem y tabú, podemos concebir las comunidades religiosas de la siguiente manera. Se trata de machos que, por obra de la ideología del gran Padre, se encierran para asexuarse y no mostrar oposición alguna al imperio del macho dominante. Que se trate de un estricto encierro deja a las claras el componente carcelario y disciplinario de la ideología del padre: separados de la sociedad en cuyo vértice está el padre-semental, la violación de las reglas que la sostiene significan el destierro, la excomunión - la excomunicación, como preferirá decir la lengua francesa con mayor fidelidad al concepto de exclusión.

Esta relación con el relato sobre la horda primordial reafirma la definición de comunidad asexuada que habíamos lanzado a propósito de las hermandades religiosas. Ahora bien, si seguimos en esta vía, la comunidad de machos jóvenes sin acceso a las hembras que describía Freud debía satisfacer su libido por medio de relaciones homosexuales. ¿Cabe decir algo parecido de las comunidades religiosas?

La presunción de homosexualidad conventual ha sido siempre emitida por la sociedad, sabedora del poderoso impulso sexual que sufren los machos de la especie. También sabe la sociedad que la vida monástica entiende contrarrestar el empuje de la libido mediante el trabajo y una rígida disciplina de oficios litúrgicos -el ora et labora benedictino. Sin embargo, el aislamiento de la sociedad a que se someten los hombres de una comunidad de frailes les separa únicamente de las mujeres, a quienes ellos culpan de la excesiva sexualización de la humanidad: los hombres quedan encerrados entre ellos en una sociedad de tipo secreto, de gran confidencialidad e inasibles códigos secretos. Para alcanzar ese grado cero de la sexualidad es necesario castrarse de cuerpo y alma — simbólicamente, desde luego. «Ne m'oubliez pas auprès de la Madone dans vos prières, ah! j'en aurai besoin car l'on a beau être religieux, l'on n'en est pas moins homme et c'est affreusement dur que de s’arracher à tout cela». ${ }^{1126}$ Así le dice Durtal a Dom

1126 J.-K. Huysmans, L'Oblat, ob. cit., p. 395. 
Felletin en la abadía: no se es menos hombre por entrar en una comunidad de vocación asexual. Lo que hay que hacer es, precisamente, matar ese hombre, arrancárselo de dentro para poder llevar una vida asexuada. Un año después de su adopción de los hábitos de oblado, Huysmans le escribe a la priora del Carmelo de Argel — con quien mantuvo una intensa relación epistolar: "Voilà plus d'un an que je mène cette vie quotidienne de messe, d'offices. J'ai tout au plus engourdi mon vieil homme, sans parvenir à le tuer, et cependant j'ai un peu de paix». ${ }^{1127}$ "Y, sin embargo», dice nuestro autor, «he conseguido un poco de paz». Huysmans duda de que la naturaleza pueda ser acallada de manera tan drástica y violenta; el hombre queda apegado a ella aun a su pesar. Uno no deja nunca de ser hombre, aunque no halle mujeres a su alrededor que le permitieran cimentar el concepto de masculinidad en base a una oposición bipolar. Es decir, que el hombre puede seguir sintiéndose como tal aun rodeado exclusivamente de hombres. El género desaparece como categoría separadora en el seno de una comunidad monogenérica. Pero no por ello se elimina el impulso sexual, simplemente se debe redireccionarlo en el sentido de la sublimación o en el de la homosexualidad. Ahora bien, ¿cabe hablar de homosexualidad en un contexto en que las diferencias de género han sido abolidas?

Michel Foucault, trazando la historia de Herculine Barbin, pone de relieve la posible felicidad que existe cuando la definición ya no se hace por oposición sexual. Recordemos que Herculine era un andrógino de genitales dudosos que fue alternativamente calificado como hombre y mujer. En un momento de su historia, descrita por Foucault, Herculine recuerda el tiempo en que estaba en el internado masculino, en el que la diferencia sexual no es determinante para la identidad - puesto que se trata de un medio de igualdad sexual: "Lo que entonces evoca en su pasado son los limbos felices de una no identidad que, paradójicamente, se amparaba en la vida de estas sociedades cerradas, estrechas y cálidas que conocían la extraña felicidad, a la vez obligatoria y prohibida, de no conocer más que un solo sexo». ${ }^{1128}$

1127 L. Descaves, Deux amis. J.-K. Huysmans et l'Abbé Mugnier. Documents inédits, ob. cit., p. 99.

1128 M. Foucault, Herculine Barbin, Llamada Alexina B, Revolución, Madrid, 1985, p. 17. 
Canta el pensador francés, a través de la historia de Herculine, a una especie de paraíso sin confrontaciones por motivos de sexo, donde la ausencia de diferencias permitiría una convivencia libre de la conflictividad propia de las diferencias sexuales. Esa «extraña felicidad de no conocer más que un solo sexo" podría dar al traste con la tensión sexual de la sociedad - entendida como la tensión existente entre los sexos, con lo cual tal vez cabría más decir «genérica».

André Green comenta que en ciertas estructuras psicopatológicas en las que la sexualidad es rechazada en bloque, radicalmente, sin matiz ni distinción, el sujeto alimenta y construye sin cesar el fantasma de una asexualidad: no se ve a sí mismo ni como masculino, ni como femenino, sino como neutro. Es lo que Green llama un fanstasma de neutralidad, que estaría poseído por un narcisismo inveterado, así como por un Yo megalómano y tiránico. ${ }^{1129}$ ¿Qué queremos seńalar con este comentario? Que la obligación en que se pone a sí mismo el sujeto de aspirar a la neutralidad no esconde sino unas excesivas exigencias hacia su Yo —impuestas, desde luego, por su Ideal del Yo, que quiere que sea casto y limpio como un niñito. Con lo cual volvemos a la regresión a la que aspira nuestro autor, que no tiene como objeto sino reconciliarse con las fuerzas fantasmáticas de que ha dotado a las instancias parentales.

Sin embargo, este deseo de neutralidad en Huysmans no es sino un espejismo, porque durante su período conventual, son numerosas las referencias que encontramos a una cierta nostalgia genérica. La neutralidad que el oblado necesita para guiar su vida se aparece como un subterfugio desde el momento en que él se pone en relación de oposición con la sexuación de que dota a sus compañeros de convento. El espejismo de la neutralidad se disipa en cuanto el entorno del 'neutro' se sexualiza adquiriendo los atributos genéricos de los que dicho 'neutro' pretendía huir.

Así, vemos una referencia fálica al apéndice protuberante y proyectado hacia adelante que tiene el Dom Pelletin de L'Oblat: un «le nez protubérant et remuant, lorsque le visage s'égayait, du bout». ${ }^{1130} \mathrm{La}$ figura paterna que tiene este fraile de rango superior para Durtal se ve acompañada de esa re-

1129 Citado por F. Coblence, «Le dandy, androgyne de l'histoire?», ob. cit., p. 110.

1130 J.-K. Huysmans, L'Oblat, ob. cit., p. 32. 
ferencia anatómica, tan fácilmente asociable al falo que blande el Padre como autoridad psicosexual.

Sin embargo, son más numerosas las referencias a una sexualidad feminizante de los compańeros frailes, quienes se ven frecuentemente engalanados con adjetivos y actitudes típicamente femeninas. Así nos presenta al père hôtelier, Dom Badole, "qui avait la figure d'une vieille dévote»; ;131 o a otro fraile, Dom de Fonneuve, "la 'mère grand' du cloître». ${ }^{1132} \mathrm{El}$ caso del sacerdote del pueblo, aun poseyendo algunos atributos comunes con el resto de la clase religiosa, es considerado como un mundano, contaminado precisamente por eso con todos los defectos de la vida exterior. Su manera de sentarse, de esbozar algunos gestos de jovencita, le hacen a ojos de Durtal indigno de pertenecer a la corte de Dios en la tierra y a la comunidad eclesiástica. Su caracterización sexual es la de un homosexual, amigo de poses amaneradas:

Il m'a produit l'effet d'une jeune paysanne assez mal élevée mais qui ferait ce qu'on appelle en argot parisien sa tata. Il a une façon de se tortiller sur sa chaise, de coqueter, de jouer de l'éventail, d'esquisser des gestes de fillette appréhendant, tout en le désirant, un rapt, qui ne me dit rien qui vaille. ${ }^{1133}$

Hay que comprender como «tata» un homosexual exageradamente afeminado. Estos son tal vez los efectos de una convivencia demasiado estrecha, en la que cada individuo confía sus fuerzas a la solidez de la comunidad: mientras esta permanezca sólida e impenetrable, cada uno de sus miembros podrá estar seguro de que la estructura que lo sustenta va a seguir haciéndolo. Por ello mismo cada uno de esos frailes cumple con el papel de ser vértice de un poliedro que da sentido a la comunidad; si falta uno de ellos, la estructura poliédrica se ve afectada: uno de los vértices se hunde, las caras que confluían en él se deforman, todo se estropea... Por eso, en la soledad, Durtal no habría dudado ni un solo momento de lanzarse a los pies de un compañero en una situación de extrema debilidad como la que vamos a comentar a continuación.

En el proceso de su "purificación» previa a la comunión, Durtal se somete a dolorosos momentos de duda. En el silencio de su celda, durante lo

1131 Ib., p. 61.

1132 Ib., p. 62.

1133 Ib., p. 207. 
que él llamaba «sa nuit obscure de l'âme», por ejemplo, sufría el ataque de su sexualidad jamás extinta. «Des fluides lui passaient devant a face, peuplaient l'espace des priapées». ${ }^{134}$ Personajes priápicos que poblaban su imaginación durante los momentos de recogimiento - es un decir, porque poco sosiego hallaba Durtal en ellos. Y lo mismo, si no algo parecido, le ocurre durante una misa cantada a la que asiste en régimen externo al coro. Escuchando los salmos puestos en música, «des nudités lui dansaient dans la cervelle»:

et il sortait de ces rêveries, haletant, énervé, capable, si un prêtre s'était trouvé là, de se jeter en pleurant, à ses pieds, de même qu'il se fût rué aux plus basses ordures si une fille eût été près de lui, dans sa chambre. ${ }^{1135}$

El impulso no ha sido todavía acallado, ni nunca lo será del todo.

Pretendemos dar aquí una visión de esa comunidad asexuada que no lo es tanto. La neutralización de los géneros no entraña precisamente la neutralidad de los sexos. La convivencia entre individuos pertenecientes a la misma categoría sexual no asegura la desaparición de los conflictos de sexo, sino únicamente de género. Por eso es interesante acudir al convento como último jalón de la trayectoria vital y literaria de Huysmans - lo que vendría a ser, como defendemos, lo mismo: es aquí donde se completa el proceso de difuminación del género sin que por ello se elimine el contenido de tipo sexual. El hombre no termina de ser dominado - como le escribe a su amiga la priora del Carmelo de Argel: el impulso libidinoso continúa haciendo de las suyas, lo que significa que su sublimación a nivel inconsciente no ha sido realizada con éxito. La libido de Durtal-Huysmans sigue girando en torno a un fantasma femenino que el Ideal del Yo tiende a condenar; este Super-Yo que es ensalzado hasta límites divinos, cuya autoridad sigue siendo muy importante en el inconsciente del personaje y que no concede tregua al castigo que impone a la libido de proyección heterosexual.

Sin embargo, qué poca gratitud, qué poca justicia poética parece ejercer Huysmans cuando dedica tan solo dos líneas a la muerte de su gran confidente, mentor y consejero espiritual que era el abbé Gévresin. Cómo no ver en ello una necesaria ruptura con todo lo que le ataba a lo terrenal

$\begin{array}{ll}1134 & \text { Ib., p. } 428 . \\ 1135 & \text { Ib., p. } 79 .\end{array}$ 
con el propósito de aspirar a lo divino. Huysmans comete un acto de lesa ingratitud a quien, en el espacio novelístico dándole tan poca importancia a la desaparición de ese gran amigo: «il apprenait, par un télégramme, la mort subite de l'abbé Gévresin... l'homme qu'il avait peut-être le plus aimé». ${ }^{1136} \mathrm{El}$ hombre a quien quizás más había amado. Su defunción súbita, carente de todo homenaje que le puedan hacer Durtal o Huysmans, es sintomática de algo. Con la muerte de Gévresin, considerado por el oblado como su padre espiritual sin ningún tipo de dudas, se acerca Huysmans a la realización de esa gran obsesión que es presentarse a sí mismo ante su propia conciencia como hijo espontáneo o de padres desconocidos. La vida religiosa de Huysmans pierde con ello toda huella de su génesis: es únicamente el hijo quien se presenta ante ese enorme Ideal del Yo que es para él la figura de Dios Padre. La sumisión, ahora, del cordero ante su pastor es completa y definitiva: los impulsos narcisistas — por haber sido elegido y no formado, pues el mentor ha sido eliminado-, masoquistas — se somete a la voluntad terrible del iracundo padre- y de pasividad son satisfechos de esta manera. El niño des-sexualizado ha vuelto por fin al hogar familiar en el que reina el Padre y la Madre se sienta a su lado, inaccesible, des-corporizada, inviolable. La regresión ha sido completada. El niño ha interiorizado con éxito un concepto del padre con el que, no pudiendo arrebatarle la autoridad, puede identificarse a distancia. La Madre permanece en un pedestal inalcanzable para la escasa estatura del niño: sólo el Padre podrá llegar hasta ella y hacer suyo el derecho del todopoderoso.

La reconstrucción de sus orígenes y de sus circunstancias vitales llevan a Huysmans, finalmente, a un callejón en el que la única salida es la emasculación —o la homosexualidad. Mientras se rebeló contra el orden patriarcal, el heterónimo ficcional intentó construir los parámetros de su existencia al margen de los dictados de la sociedad patriarcal, que necesita formar a sus miembros en los hábitos conducentes a la producción y a la reproducción de bienes y de individuos. En el caso de la reproducción, la adecuación a ella del individuo masculino no se produce sin una cierta violencia, pues el hombre debe reafirmarse en lo que primeramente le ha sido negado: tras repudiar a la madre bajo la amenaza de la castración por parte del padre, debe reconducir su deseo hacia otros objetos que le permitan ol-

1136 Ib., p. 34. 
vidarse de su progenitora. La heterosexualidad obligatoria conducente a la reproducción le impide deshacerse del concepto de bienestar orgánico que conoció al lado de su madre, por lo que su amor por las mujeres estará siempre teñido de un halo de prohibición tremendamente inquietante. La única posibilidad de eliminar la amenaza siempre latente de castración por parte del padre es huir de la feminidad como objeto sexual; con esa huida se accede a la elección de objeto en otros hombres o, en última instancia, a la negación de toda elección. ${ }^{1137}$

La narración de la existencia de Huysmans parece ir en el sentido de esta última. Tras un largo discurrir por la duda electiva, el autor de En route parece abogar definitivamente por la negación de su libido, refugiándose en las sombras de un convento en el que evitar el influjo del deseo sexual. Cree alcanzar de esta manera el fin de las hostilidades de su conciencia contra él mismo, educada como estaba en la ley paterna y realimentada por las especiales características de la historia familiar del escritor. Su sumisión a la ley del Padre es, con esto, definitiva.

1137 Robert Baldick revela los esfuerzos de Huysmans por deshacerse de las peticiones eróticas de una jovencita en busca de consejo espiritual - a la que consiguió finalmente convencer de que ingresara en un convento. R. Baldick, ob. cit., p. 346. 


\section{CONCLUSIÓN HUYSMANS: IDENTIDAD Y GÉNERO}

Como decíamos en la introducción, puede parecer paradójico recurrir a Huysmans para ilustrar un ensayo sobre la difuminación del género en la literatura. Para quien no haya profundizado en la psicología de su obra literaria, para quien haya permanecido en la superficie de la misma, este recurso se le antojará curiosamente elegido. Huysmans, el misógino por excelencia, el gran refractario ${ }^{1138}$ al progreso de la sociedad decimonónica...; cómo albergar siquiera la idea de que este reaccionario pudiera servir un día como ilustración de la eliminación de unas barreras que le colocaban a él en posición privilegiada — como son las separadoras barreras del género. Et pourtant...

Un discurso que ponga en tela de juicio las categorías de género debe pretender, a nuestro juicio, ser emancipatorio; es decir, que intente eliminar el componente de sometimiento con que dichas barreras actúan sobre los individuos. Cierto es que, además, el discurso sobre el género de Huysmans no parece propenso a abogar por la emancipación — sino todo lo contrario en el caso de las mujeres.

\subsection{La sexualidad de Huysmans: de la destrucción del triángulo edípico a su reconstrucción}

Lo más interesante del discurso implícito sobre el género que podemos hallar en los textos de Huysmans reside, en primer lugar, en su rebe-

1138 Recordemos que de tal lo tacha Jean Borie, junto a Baudelaire y Flaubert, en J. Borie, Un siècle démodé. Prophètes et réfractaires au XIXe siècle, ob. cit., p. 23. 
lión contra unos usos sexuales normativos. Hombre heterosexual, el heterónimo ficcional huysmansiano se rebela contra la relación convencional convirtiendo su tedio en materia literaria. Como todos los individuos en mayor o menor medida, ha sido programado para vehicular su libido y proyectarla no solo sobre un tipo de objeto determinado, sino para establecer su relación con este mediante una serie de prácticas sexuales socialmente sancionadas.

Podría parecer extraño, pero el mismo tedio le lleva a buscar una y otra vez la compañía de profesionales del sexo que no solo prometan azuzar su deseo progresivamente extinto, sino que le aseguren que el vínculo afectivo con el objeto no se va a producir. El comercio que Huysmans establece con la prostituta es una especie de «amor libre» alumbrado por la economía de mercado que ya se había instalado definitivamente en la sociedad y en la mentalidad de la época. Sobre esta argumentación implícita en la obra de Huysmans podemos encontrar una explicitación atrevida y polémica en la obra de Michel Houellebecq, por ejemplo. ${ }^{1139}$

Intentemos analizar el gusto por la prostitución de nuestro autor a través de estos dos aspectos: la ausencia de vínculos afectivos con el objeto y la promesa de nuevos estímulos.

Según la teoría psicoanalítica, la elección de objeto es necesaria a todo ser deseante para salir del autoerotismo y el narcisismo inherentes a la infancia. Freud creía esta salida necesaria para la socialización del individuo, puesto que siendo el Hombre social por naturaleza y definición, su reclusión en una constante autorreferencia puede empujarle a lo que él llama «introversión de la libido", pudiendo conducir a la neurosis. ${ }^{1140} \mathrm{El}$ primer objeto que encuentra el niño en su relación con el entorno es, en una sociedad de corte patriarcal, la madre: recluida en el hogar, sometida a la división de roles que le impone la ideología del padre, era ella —o la nodriza contratadaquien se encargaba casi exclusivamente del cuidado de los niños durante el siglo XIX. Así, la madre es la primera persona en quien el infante cree poder proyectar su deseo, ya que, además de ser la persona más presente en su en-

1139 Vid. nuestras consideraciones al respecto en F. Domínguez, «Houellebecq: de le necesidad de gestionar el sexo", Trébede, Zaragoza, febrero 2002; y en "Hoeullebecq: amor y política», en Tonos Digital, Universidad Complutense, Alcalá de Henares, 2008.

1140 S. Freud, Introducción al narcisismo, ob. cit., p. 2015. 
torno, es quien le procura las gratificantes sensaciones de calor, alimento y protección. De ahí que esa proyección de objeto recaiga sobre el ser que le promete la continuación de dichos estímulos gratificantes. Es más, el padre del psicoanálisis llegó a aconsejar la manipulación masturbatoria, por parte de la madre, de los genitales del niño para que este adquiriera cuanto antes constancia de la existencia de un ser ajeno a sí mismo que le proporciona placer: la necesaria proyección se ve así potenciada. ${ }^{1141}$

La elección de objeto es necesaria, pues, para crear en el niño la sensación de alteridad, y, dotarle de una conciencia de sujeto - ya que el sujeto sólo se instituye como tal en la medida en que es capaz de objetualizar. Pongamos que, por las condiciones de la sociedad contemporánea -máxime en el siglo XIX-, la elección de objeto recae sobre la madre —o sobre la niñera, cosa harto frecuente en la época en que centramos nuestro estudio. ${ }^{1142}$ El objeto elegido por el nińo, sea cual sea su sexo, tiene más posibilidades de ser femenino en el estado preedípico: la madre —o su sustituta— será depositaria del deseo de gratificación fisiológica en la primera infancia.

Ahora bien, he aquí que se introduce la figura del padre en el hasta ahora idílico escenario de las relaciones maternofiliales. De la relación bipolar se pasa a una triangulación en la que el padre cumple un papel de intruso. Portador del logos que tiende a crear la diferencia de los sexos y a introducir la cultura normativa en la relación hasta ahora natural del niño con su madre, ${ }^{1143}$ el padre determina hasta qué punto es lícito el comercio establecido entre ellos dos. Y esto lo hace en base a la separación sexual: si se trata de una niña, la ley del Padre permite que esta permanezca en cierto modo fusionada a su madre hasta que la socialización le indique el camino para cambiar su natural objeto femenino por el masculino; si se trata de un niño, la presencia del padre le indica que la posesión definitiva y exclusiva del cuerpo de la madre no es posible, so pena de verse amenazado por la mutilación de ese apéndice, el pene, donde él ya ha centrado su placer.

1141 S. Freud, Introducción al Psicoanálisis, ob. cit., p. 247.

1142 En 1869, el índice de los bebés nacidos en París que estaban siendo criados por una nodriza giraba en torno al 41\% (frente al 49\% en 1801-1802), en G. D. Sussman, Selling Mother's Milk: the wet-nursing business in France 1715-1914, University of Illinois Press, Urbana, 1982, pp. 110-112.

1143 Vid. a este respecto el interesante estudio de E. Roudinesco, ob. cit., p. 30 y ss. 
La niña y el niño se separan paulatinamente de su madre en función de la diferente influencia que tiene sobre cada uno de ellos el complejo de Edipo. En el caso del niño, la separación de la madre se completa en base a una amenaza de castración. En el de la niña, Freud dirá saber de antemano que "su destino es perecer, dejando el puesto a su vinculación con el padre»; ${ }^{1144}$ esto se realizará gracias a lo que él mismo llamó la «envidia del pene», que le hace separarse de su progenitora para encontrar en un hombre lo que esta le ha negado. En ambos casos, la solución pasa por la diferente relación que niños y niñas tienen con ese símbolo del poder patriarcal que es el falo, medida de todas las cosas en el escenario planteado por Freud.

El niño que fue Huysmans había pasado por varios episodios que determinarían su posterior sexualidad. Tras una fijación libidinosa a la madre, el padre aparecería como ese intruso al que nadie ha invitado, pero que haría valer su ley como cabeza de familia de su época. El niño alberga hacia él sentimientos de hostilidad pues su presencia amenaza no solo con arrebatarle a su madre - a su objeto elegido, fuente de placer y de gratificaciones_-, sino con mutilarle su precioso pene. El niño desea ver morir a su padre para continuar fusionado con su progenitora. Sin embargo, es determinante la desaparición de Victor Huysmans, el padre, cuando su hijito contaba nada más que con ocho ańos (1856); los sentimientos de hostilidad se convierten en un ensalzamiento de su figura, puesto que el niño carga con la creencia de que sus deseos de ver morir al padre han sido cumplidos. No solo el niño Georges-Charles se siente culpable de la desaparición de su padre, sino que el complejo de Edipo no se liquida: la fijación a la madre no es interrumpida por la acción de un padre autoritario, pues este muere antes de que el infante haya llegado a aceptar la imposibilidad de su acoplamiento materno.

El pequeño Georges es, no obstante, separado de su madre para ser internado en l'Institution Hortus ${ }^{1145}$ — por lo que él adquiere una doble convicción de orfandad: huérfano de padre por muerte natural, huérfano de madre por abandono. ${ }^{1146}$ Esta convicción se acrecienta cuando la viuda de Huysmans,

1144 S. Freud, La feminidad, ob. cit., p. 3169.

1145 Episodio que será recreado en J.-K. Huysmans, En ménage, ob. cit., p. 66 y ss.

1146 Este mito del niño expósito será tratado por Marthe Robert como germen de la novela familiar (en los términos expuestos por Freud): M. Robert, ob. cit., p. 74. 
Élisabeth Malvina Huysmans (Badin es su apellido de soltera) contrae matrimonio con Jules Og: la fractura edípica se realiza entonces de manera violenta, pues la madre ha introducido en el triángulo a un individuo que nada tenía que ver con ellos dos. La figura del padre - como símbolo de la autoridad que le impide acoplarse con la madre - se le aparece como una instancia prohibitiva y ajena a él mismo. Por eso mismo, de ser entronizada, la representación inconsciente del padre pasa a ser demonizada: el odio al padre es tal que el niño intenta crear en su interior un relato alternativo sobre sus orígenes, en el que él se vea a salvo de cualquier influencia de sus progenitores. «La sensación de que su propio afecto no es plenamente retribuido — dice Freud sobre el niño que se desarrolla en tales situaciones - se desahoga entonces en la idea, a menudo conscientemente recordada desde la más temprana infancia, de ser un hijastro o un hijo adoptivo». ${ }^{1147}$ Este será el programa de novela familiar ${ }^{1148}$ que realizará Huysmans para suplir esas carencias.

Pero sigamos con nuestra argumentación sobre la relación maternofilial. Es plausible considerar que el Edipo jamás haya sido debidamente liquidado en Huysmans, puesto que fue eliminado del escenario triangular por el padre putativo, Jules Og. La fijación a la madre subsistió a la demonización del padre y a la creación de ese relato ficticio de los orígenes. De ahí que, cuando iniciara sus tratos carnales con las mujeres persistiera en el joven Georges-Charles el recuerdo de su progenitora.

Como señala Freud a propósito de Leonardo da Vinci, la fijación a la madre crea en el amante de mujeres un sentimiento de traición hacia ella. ${ }^{1149}$ Cree que cada vez que realiza el acto sexual con una mujer está traicionando su representación inconsciente, por lo que desvía su atracción hacia las mujeres en la dirección de los hombres —en quienes no deja de buscar la misma excitación que antaño encontrara en las féminas.

Esto tal vez creara en Huysmans la presencia de una tendencia homosexual latente que jamás sería plenamente satisfecha —y que, en realidad,

1147 S. Freud, La novela familiar del neurótico, ob. cit., p. 1361.

$1148 \mathrm{O}$ "novela familiar de la cultura patriarcal», como prefiere llamarla Silvia Tubert en S. Tubert, «Sacralización y ocaso de la figura paterna», ob. cit., pp. 183-202.

1149 S. Freud, Un recuerdo infantil de Leonardo de Vinci, ob. cit., pp. 1577-1619. Y, sobre todo, una nota fechada en 1910 ańadida a Tres ensayos para una teoría sexual, ob. cit., p. 1178 . 
es perfectamente rastreable en su obra escrita. La consecuencia de que el joven Huysmans siguiera en su trato carnal con las mujeres a pesar de su fijación materna le debió de crear no pocos problemas, el primero de los cuales sería la imposibilidad de elegir un objeto femenino definitivo en la persona de una novia o amante continua. La mejor solución a esto era hallar una relación de objeto en la que se aboliera cualquier posibilidad de fijación afectiva. Con ello se conseguiría buscar la satisfacción de la pulsión sexual sin por ello traicionar completamente la fijación a la madre. Una salida no demasiado honrosa ni, a largo plazo, satisfactoria, con tremendas consecuencias psicológicas.

El comercio con prostitutas cumplía a la perfección esa función de evitar la fijación afectiva a un objeto femenino; la memoria de la madre quedaba, en parte, respetada. La única fijación posible a una prostituta es la que relata el autor en En route: los favores y servicios que le dispensa Florence son de tal poder que no puede, de ningún modo, arrebatársela de la mente. ${ }^{1150}$

Esa prohibición, altamente fantasmática, de establecer vínculos afectivos con cualquier mujer con la que tuviera relaciones carnales determinaría la política sexual de nuestro autor. Por una parte, los biógrafos de Huysmans han mostrado cómo su unión sentimental con Anna Meunier tuvo poco de carnal - y ello parece quedar patente con la lectura de En rade, crónica novelada de uno de los viajes que la pareja hiciera en común al castillo de Lourps. ${ }^{151}$ Por la otra, sin abandonar la heterosexualidad, la militante misoginia del autor le permitía acercarse a las mujeres invalidando cualquier posible fijación afectiva ulterior.

El siguiente de los aspectos anunciados, la promesa de nuevos estímulos sexuales como pretexto para hacer uso de la prostitución, está íntimamente relacionado con el que acabamos de detallar. El mismo disgusto que el joven amante sentía por todo contacto heterosexual le llevaba a considerar el comercio carnal como generador de insatisfacciones y frustraciones. "La fatigue des caresses exigées, l’ennui des baisers prévus!» ${ }^{1152}$ —exclama el

1150 Vid. J.-K. Huysmans, En route, ob. cit., p. 155 y ss.

1151 "Il en souffrait à la fin des fins de cette abstinence de la chair que le maladie de sa femme lui faisait subir!», refiere el narrador sobre el protagonista, Jacques Marle, a propósito de su esposa Louise. J.-K. Huysmans, En rade, ob. cit., p. 125.

1152 J.-K. Huysmans, En ménage, ob. cit., p. 27. 
protagonista de En ménage, no menos atribulado ante el sexo que el personaje de $\grave{A}$ vau-l'eau, quien ve en el matrimonio la condena a «subir le contact d'une femme, à toutes les époques, de la contenter alors que je souhaiterais simplement de dormir!». ${ }^{153}$

Las juergas curativas —las «noces guérissantes» de En ménage_, ${ }^{1154}$ lejos de satisfacerle, le sumen en un estado de insatisfacción que solo puede ser tratado mediante nuevas recaídas en lo que él llamará "crisis falderas» —las «crises juponnières» de la misma novela. Círculo vicioso en el que la misma frustración sexual genera su propio alimento, desencadenando sucesivas insatisfacciones únicamente curables mediante el mismo veneno que las creó. «Loin de l'égayer, ces amours au grand trot, l'affligèrent; ses ennuis devinrent même plus impérieux et plus aigus, dans cette langueur de cerveau qui laissent après eux les excès charnels». ${ }^{1155} \mathrm{La}$ consecuencia a medio plazo de esta política sexual es el hartazgo definitivo, junto a la convicción de lo negativo de tales prácticas: «Toutes laissaient un arrière-goût aigre, une soif nouvelle de douceurs propres» — dice el narrador sobre André Jayant. "La répugnance qui le prit accéléra encore sa hâte de posséder quelque chose de féminin qui simulait un plaisir, une grâce». ${ }^{1156}$ La búsqueda del amante insatisfecho tras el uso continuado de la relación despersonalizante debiera centrarse a partir de esta declaración en las «dulzuras limpias», en la posesión de "algo femenino que simulara un placer, una gracia». Es decir, la búsqueda de estímulos que la nostalgia por el contacto materno podría procurarle.

Observemos que la heterosexualidad realizada a pesar de las dos prohibiciones - una, la ley del padre, otra, la propia que le impide traicionar a la madre - no puede ser sino altamente frustrante. La socialización en base a la ideología patriarcal —que exige la heterosexualidad obligatoria de hombres y mujeres - le conmina a proyectar su libido en mujeres que podrían sustituir a su madre. El heterónimo ficcional de Huysmans se acuesta con ellas aun a riesgo de traicionar su memoria. Ahora bien, la nueva his-

1153 J.-K. Huysmans, À vau-l'eau, ob. cit., p. 401.

1154 «Il voulut tâter de noces guérissantes, s'aiguisa les sens par des souvenirs lascifs et, à diverses reprises il se livra, par raison, à de consciencieuses ribotes». J.-K. Huysmans, En ménage, ob. cit., p. 166.

1155 Ib., p. 167.

1156 Ib., p. 169. 
toria de sus orígenes, construida al margen de su pasado infantil real, le empuja a minimizar la influencia que su progenitora pueda tener sobre él. Es más, la actividad sexual realizada con otras mujeres no deja de conservar la esencia de su rebelión contra los orígenes. La descarga libidinal se convierte en una ficción; de ahí la insatisfacción múltiple que sufre el personaje.

Pero la heterosexualidad normativa es más fuerte que el deseo de romper la convención. El heterónimo ficcional huysmansiano insiste en su vía heterosexual en lugar de librarse a la búsqueda del placer en la homosexualidad — que tal vez le hubiera deparado mayores parabienes. «Décidément je ne suis pas sodomite — pédéraste peut-être avec un jeune garçon imberbe, jamais avec des gaillards moustachus de 30 ans, ça ne me dit pas» ${ }^{157}$ — dirá él mismo en 1899 tras haber intentado por fin la incursión en ese terreno. La cuestión es que, en esa intención heterosexualizante, Huysmans deberá recurrir a todo tipo de refinamientos para sentirse cerca de estar satisfecho. El placer sencillo basado en «la syncope» — como hará decir al pintor amigo de André, Cyprien Tibaille (quien fuera personaje relevante en Les Soeurs Vatard) — ${ }^{1158}$ no le llena, pues es precisamente el refinamiento de la puesta en escena la que le va a permitir la necesaria excitación de los sentidos previa al acto sexual.

Su búsqueda en pos del refinamiento de la puesta en escena llega hasta curiosos ejemplos, por los que diferentes doctores de su época le tacharon de histérico y, sobre todo, de degenerado - como fue el caso de Max Nordau en su célebre obra Dégénérescence. ${ }^{1159} \mathrm{Y}$ es que ese compendio de actitudes autorreferenciales, solipsistas y narcisistas que se daban cita en $\grave{A}$ rebours solo podían proceder, a ojos de todos estos especuladores de la mente humana, de alguien tremendamente enfermo, o condenado a la enfermedad.

Recordemos los dos episodios de esta novela en que des Esseintes recurre a los servicios de personal especializado para intentar saciar su ansia de novedad. En el primero de ellos, el que narra el encuentro con Miss Urania: acróbata americana — no se detalla país— de músculos de acero que

1157 Referida por P. Buvik, ob. cit., p. 290.

1158 Dice Cyprien: «Si j'avais touché l'argent de mon prospectus [quelques aquarelles qu'on lui avait demandé de faire], j'aurais, peut-être bien, moi aussi, loué de la syncope pour quelques heures». J.-K. Huysmans, En ménage, ob. cit., p. 196.

1159 M. Nordau, ob. cit., p. 115. 
«après avoir tout d'abord été femme, puis avoir hésité, après avoir avoisiné l'androgyne, elle semblait se résoudre, se préciser, devenir complètement un homme». ${ }^{1160}$ En el intercambio sexual con esta mujer hombruna y fortachona, Huysmans-des Esseintes siente cómo sus sentidos se despiertan y comienzan de nuevo a ilusionarse por la consecución del placer. El personaje se somete, masoquistamente, a la fuerza bruta de su partenaire, feminizándose en el acto. ${ }^{1161}$ Este artificio no deja de ser la puesta en escena de un acto sexual homoerótico, que el personaje no se atreve a acometer con plena seguridad, debiendo por ello esconder su decisiva importancia en su naturaleza heterosexualizante. Acto homosexual realizado con un individuo que, para estar a la altura del amante que requiere des Esseintes, debe esconder su feminidad y convertirla en agresiva masculinidad. La necesidad hace al monje, y tal y como la siente nuestro personaje, consigue que la acróbata se convierta, por arte de un wishful thinking, en temible forzudo. El sexo/género es una máscara, como diría Lacan, y una máscara es la que le pone des Esseintes a Miss Urania.

Acto homosexual, sí, pero no del tipo que permitiría desviar la fijación libidinosa a la madre hacia hombres de cualidades casi femeninas que evitasen la fantasmática traición a la madre. El tipo de hombre en que des Esseintes pide a la acróbata que se transforme es un hombre forzudo y sin piedad, que se impone al protagonista de $\grave{A}$ rebours mediante el vigor de sus músculos. Cualidades estas que acercan a Miss Urania al papel represivo del padre, cuya presencia imaginaria para revitalizar el deseo erótico de des Esseintes no puede ser sino reveladora. Ya hemos sostenido en el tercer capítulo que, en relación con su nombre, Miss Urania hace referencia directa a la homosexualidad. Este episodio, en el que la libido de des Esseintes se despierta ante la amenaza paterna, podría ser una exorcización del recuerdo de una escena primitiva en que el niño hubiera sido sorprendido por su padre en pleno acto homosexual.

Reveladora, sobre todo, si se tiene en cuenta el segundo y decisivo episodio en que se realiza un "projet jusqu'alors irréalisable». Esta vez se trata

\footnotetext{
1160 J.-K. Huysmans, À rebours, ob. cit., p. 145.

1161 Freud asegura que el masoquismo, junto con el narcisismo y la pasividad, es un rasgo definitorio de la feminidad. Vid. el interesante comentario que hace al respecto Kate Millet, en K. Millett, ob. cit., p. 344 y ss.
} 
de una ventrílocua a la que pide que, durante el acto sexual, ponga voz a un imaginario personaje que aporrearía la puerta de la habitación: “'Ouvrirastu? je sais bien que t'es avec un miché, attends un peu, salope!'». ${ }^{1162}$ Todo esto con el fin de despertar la sensación de miedo, «l'adjuvant le plus efficace des vieux et inconstants prurits» — como dice el propio des Esseintes-, tras lo cual, el asustado amante se lanza con más furor si cabe a los brazos de su amada. No es nada difícil relacionar el imaginario personaje que grita detrás de la puerta con el padre fantasmático, que estaría, precisamente, tratando de impedir que se completara el acoplamiento entre el hijo y su madre. El papel del padre es, aquí, el de actualizar los amores incestuosos - a pesar de la amenaza de castración que tanta incidencia tuvo sobre la obra huysmansiana.

Porque la amenaza de castración está presente a lo largo de toda la obra de nuestro autor, sobre todo en aquellos pasajes en que se da importancia a la actividad sexual. Por una parte, la constante presencia de las mujeres fálicas, ${ }^{1163}$ dotadas o no de heridas, provistas o no de atributo fálico, quienes recuerdan a ese niño adulto que vive en el heterónimo ficcional la posibilidad de ser mutilado en caso de que se acerque a la madre. De allí que aparezcan siempre en paisajes acuáticos, que no serían sino la transposición fantasmática tanto del líquido amniótico materno como de la sangre de la herida producida por la castración. ${ }^{1164}$ Por otra parte, estos paisajes acuáticos suelen acompañar escenas en que se hace referencia a un posible encuentro con una mujer. Muros humedecidos, estanques, pozos..., toda una imaginería de elementos acuáticos puestos en relación con un temor innato a la sexualidad femenina como promotora de la castración y del complejo de muerte.

El recurso a la figura del padre como coadyuvante en la representación de la relación maternofilial se hace cada vez más frecuente a medida que avanzamos cronológicamente en la obra escrita de nuestro autor. La utilización de elementos diabólicos en la puesta en escena de los amores edípicos no deja de ser sino el enmascaramiento de dicha figura. El miedo a lo

\footnotetext{
1162 Ib., p. 149.

$1163 \mathrm{O}$ «madres combinadas», en terminología de Melanie Klein.

1164 En este sentido es interesantísima la aparición de las campanas en la obra de Huysmans. Fetiche total, pues la forma de su cuerpo recuerda a las faldas femeninas, bajo las cuales se descubre ese sustituto del pene que es el badajo. La campana es la representación más depurada de la mujer fálica, con una recurrencia destacable en el onirismo de Huysmans.
} 
desconocido impregna la relación de Huysmans con lo sobrenatural, viendo en toda la parafernalia de las misas negras un acicate de especial importancia para su sexualidad aburrida. En ellas, el heterónimo ficcional, nada interesado en establecer relaciones de cercanía emocional con sus amantes, encuentra el escenario natural para su misoginia. La mujer es, además, utilizada en la demonología y las ciencias ocultas como un catalizador de las fuerzas del averno: tan pronto propiciadoras, tan pronto portadoras de la energía del demonio, Huysmans puede depositar en estas mujeres demoníacas el mismo interés sexual que en toda la panoplia de mujeres fatales y castradoras que pueblan su universo: Salomé, Judith, Esther...

Sin embargo, el aspecto más relevante del recurso al demonio es su perfecta identificación con el padre - necesaria presencia a partir de $L \grave{a}$-bas para dotar a la relación heterosexual de pleno valor a través de, como ya hemos visto, el miedo a causa de su valor como reactivador de los amores incestuosos. La lectura que se puede efectuar sobre este personaje de reparto es múltiple. Por una parte, y tal y como señaló Freud, ${ }^{1165}$ su identificación con el padre demonizado de la niñez es perfectamente factible: en él se dan las condiciones para esperar una vuelta del padre al escenario edípico bajo la máscara que el niño le puso por impedirle su acoplamiento con la madre. Por otra parte, y como ya hemos visto, procura el estímulo necesario para azuzar la sexualidad dormida - lo que no deja de indicar una incipiente nostalgia del triángulo edípico que se había creído abandonado por la particular biografía de nuestro autor. Por último, y aunque parezca contradictorio con lo expuesto hasta aquí, la figura del diablo favorece la deseada identificación del hijo con el ángel caído de la vera del Padre. Imagen de enorme utilidad para el escritor neurótico que reconstruye sus orígenes al margen de su verdadera historia personal, el carácter rebelde del diablo permite recrear una vida independiente del dictado paterno. El diablo es, por lo tanto, a la vez padre e hijo al margen de la dinámica familiar, expulsado del hogar y convertido en un niño expósito.

Con el paso del tiempo, las investigaciones de Huysmans sobre el fenómeno sobrenatural le llevan a darse cuenta, antes que muchos psiquiatras de primera hora, de la existencia de un impulso violento en el hombre

1165 Vid. S. Freud, «Una neurosis demoniaca del siglo XVII», en Psicoanálisis aplicado y Técnica psicoanalitica, ob. cit., p. 58 y ss. 
que la ciencia se ve incapaz de explicar. Y tan duras son sus experiencias en el ambiente demoníaco del París del fin-de-siècle que Huysmans no sale indemne de ellas: súcubos, hipnotismo, adivinación..., diversas actividades en las que nuestro autor se siente manchado y sucio. Después de la redacción de Là-bas, el estado de ánimo de Huysmans es tal que le confiesa a un amigo necesitar limpiar su alma mediante la creación de un libro «blanco» que contrarrestara la influencia de ese libro «negro» con que comienza Durtal sus andaduras: "Je veux en faire un autre qui soit blanc. Mais il est nécessaire que je me blanchisse moi-même. Avez-vous du chlore pour mon âme?».1166

Nosotros creemos que las experiencias vividas por Huysmans eran de naturaleza no solo a asustarle; en ellas se ponían en entredicho los papeles que todavía jugaban en su inconsciente las figuras parentales del triángulo edípico. Habiendo extremado los papeles negativos tanto de la mujer fatalmadre como del diablo-padre, la historia infantil del individuo Huysmans se ve completamente trastocada por esta reconsideración. El siguiente paso en la reconstrucción de esa historia familiar convertida en novela es reparar las imagos de ambos progenitores, con el fin de pasar de unas imagos «malas» a unas imagos «buenas». ${ }^{1167} \mathrm{Y}$ para ello, nada mejor que el proceso de divinización de las instancias parentales que permite la religión.

El mismo Huysmans confesaría a un contemporáneo suyo que fue gracias al ocultismo como entró en el ámbito de la religión católica: el mismo demonio le condujo hacia Dios. «C'est par la vision du surnaturel du mal que j'ai eu d'abord la perception du surnaturel du bien. Ceci dérivait de cela. De sa patte crochue, le démon m'a conduit vers Dieu»». ${ }^{1168}$ Ese proceso de lavado de sí mismo que tan ansiosamente esperaba Huysmans de la religión consistía, en una enorme medida, en el lavado de las imagos de los padres. El sucesivo desnortamiento que nuestro autor sintió a lo largo de su vida debía encontrar su camino en la reconstrucción de estas imagos en el

1166 Carta citada por Hélène Trudgian en su ensayo H. Trudgian, ob. cit., pp. 265-266. 1167 El concepto de imagos, creado por Jung, designa una supervivencia de los participantes en la vida familiar en el imaginario del individuo. Gérard Mendel desarrolla este concepto en G. Mendel, ob. cit. Vid. para ello también J. Laplanche y J.-B. Pontalis, ob. cit., p. 196.

1168 F. Van der Bosch, Impressions de littérature contemporaine, ob. cit. Señalado por R. Baldick, ob. cit., p. 216. 
interior del Ideal del Yo — que sería al Yo lo que la conciencia es al sujeto: solo una conciencia favorable permite al individuo vivir consigo mismo en paz y armonía. No era otra cosa lo que pedía Huysmans.

Sin embargo, en esta mistificación del padre y la madre, nuestro autor aún debería someter a lo materno en su inconsciente a un severo proceso de purificación. El paradigma de la madre buena es, sin ningún lugar a dudas, la Virgen María: inmaculada, no ha conocido hombre, por lo que ha eliminado de sí la feminidad que, para nuestro autor, equivale a sexualidad incestuosa. La mujer deberá verse desprovista de cualquier atisbo de su condición femenina para ser digna de entrar en el nuevo imaginario familiar huysmansiano. Por eso, las mujeres que son admiradas por Durtal (el alter ego definitivo de Huysmans a partir de Là-bas (1891) — son aquellas que son sometidas a un violento proceso de purificación- normalmente asociado a la pérdida de líquidos internos a través de las numerosas llagas que adornan sus cuerpos. Estas llagas de las místicas (santa Ángela de Foligno, Marie Alacoque, santa María de Ágreda y, sobre todo, santa Lidwina de Schiedam, a cuyos tormentos celestiales dedica todo un libro) rezuman ámbares de delicioso perfume, que permiten concebir una recuperación de la herida resultado de la mutilación a la que el Padre ha sometido a la mujer como advertencia de la amenaza de castración que pesa sobre el niño.

Una vez desprovista de sus ropajes humanos, desfeminizada por completo, la mujer puede actuar como mediadora entre el hijo y el Padre, quien será el que, en última instancia y con su ley en la mano, dicte sentencia en favor del niño. ¿Cuál es el fin que persigue Huysmans con esta reconciliación?

$\mathrm{Al}$ verse aprobado por un padre y una madre que han dejado de mirarle con la sospecha de quien puede inmiscuirse en su vida sexual, el niño pretende volver a un tiempo remoto, de felicísimo concepto, en el que convivía dichoso en compañía de sus dos progenitores. Tras eliminar en sus padres todo atisbo de comprometedora sexualidad, Huysmans ha debido sufrir asimismo un procedimiento de purificación para poder completar esa tan deseada regresión al seno de la familia nuclear. El personaje se emascula, desproviéndose de su sexo, que era, en definitiva, el causante de todo mal. El individuo se autocastra para evitar todo conflicto posible, tan doloroso, con su Ideal del Yo — que no es sino la interiorización de la ley del padre. 
Para ello se retira a una comunidad religiosa en la que debe vivir apartado del mundo, sometido a unas rígidas reglas de convivencia, ${ }^{1169}$ negadas sus circunstancias personales para la mayor gloria del concepto del padre. Una comunidad en que las diferencias sexuales han sido abolidas, y donde el individuo puede volcarse en la realización de unas tareas sublimantes. La sublimación de la libido a través del trabajo y la oración no es completa, pues la erotización de su entorno sigue siendo evidente tanto desde un punto de vista psicoanalítico como vivencial. Durtal-Huysmans señala en sus compañeros de convento atributos feminizantes, los dota de características homoeróticas: es el único tipo de relación que escapa a la sublimación puesto que es permitida por la ley del Padre, que estipula que la mujer — como el macho dominador de la horda primigenia— ${ }^{1170}$ es propiedad exclusiva suya.

\subsection{La posición intermedia de Huysmans}

La mutilación simbólica a que se somete Durtal-Huysmans no es sino el respeto a una legislación paterna que prohibe el acoplamiento con mujeres - a menos que este se produzca con el fin de aumentar la población bajo la férula del Padre dominante. Esa emasculación supondría su feminización en términos de lógica reproductiva y patriarcal; sin embargo, desde una perspectiva contemporánea, en la que la reasignación de género es práctica habitual, Durtal podría entrar a formar parte de la opción «transgenérica» - tal y como la describe Dallas Denny, director de la AEGIS (American Educational Gender Information Service): ${ }^{171}$ "personas que cambian sus roles de género, pero que no pretenden realizar una cirugía de reasignación. Han sido definidos como personas con una posición intermedia, que viven con los rasgos físicos de ambos géneros. Los transgene-

1169 No tan rígidas para él, pues nunca aceptó someterse a la totalidad de las reglas de la Orden, por lo que hizo que le nombraran oblado en lugar de fraile.

1170 Concepto desarrollado por S. Freud, Tótem y tabú, ob. cit., p. 148 y ss.

1171 Dallas Denny, "Deciding what to do about your gender dysphoria», en AEGIS Transition Booklet Series, Decatur, Georgia, 1990, p. 6. Cf., asimismo, A. Bolin, «La transversalidad de género. Contexto cultural y prácticas de género», trad. de Carlo A. Aranci, en J. A. Nieto (ed.), Antropología de la sexualidad y diversidad cultural, Talasa, colección Ágora, Madrid, 2003, p. 253 y ss. 
ristas pueden alterar su anatomía con hormonas o con cirugía, pero pueden conservar deliberadamente muchas de las características del género al que estaban asignados originariamente. Muchos llevan, a tiempo parcial una vida en ambos géneros; la mayoría cultiva una apariencia andrógina».

Reasignación quirúrgica aparte, la posición intermedia de Huysmans se realiza por medio de la figura del dandi. El dandi aboga por un transgenerismo en la medida que aborrece de la producción, de la reproducción, y de todos los dictados de la sociedad nacida sobre la base del capitalismo y la lógica mercantilista. No cabe posición de mayor individualismo ante la expansión sin obstáculo de ese señuelo de individualismo generalizado que es el capitalismo. ${ }^{1172}$ El dandi se individualiza del proceso individualizador de la sociedad capitalista — que es individualista en términos estrictamente económicos, pues a la lógica mercantil le interesa la uniformización de los gustos en la sociedad-convirtiéndose en un refractario del progreso de la nueva sociedad.

Como decíamos en el capítulo 2 de este trabajo, tal vez sea el dandismo una de las construcciones de la masculinidad más originales que haya dado la naciente sociedad industrial. Desde su germen en los salones del XVIII francés - los précieux — pasando por los episodios de inspiración byroniana o brummelliana, el dandi es una opción vital ante la uniformización social. Siendo más una actitud filosófica que una bandera, ${ }^{1173} \mathrm{el} \mathrm{dandismo} \mathrm{aspira} \mathrm{a}$ la libertad de opción genérica; el dandi, aun a pesar de su profesión de fe masculinizante, opta tanto por la práctica hétero como homosexual, sin que la una ni la otra determinen su modo de mostrarse. El dandismo significa distanciamiento, enigma, secreto y misterio ante lo que podría ser la demostración demasiado clara de una opción sexual determinada.

En realidad, el dandi, sin abandonar ciertas actitudes viriles como el ejercicio de las armas (en el caso del vicomte de Brassard, de Le Rideau cramoisi de Barbey d'Aurevilly) ${ }^{1174}$ no descarta ninguna posibilidad sexual. Su

1172 Esta es una de las conclusiones de Bernard Stiegler en su artículo «El deseo asfixiado o cómo la industria cultural destruye al individuo», Le Monde Diplomatique, edición española, junio 2004, p. 26.

1173 Una ruptura tanto estética como ética, como dice el sociólogo Pierre Bourdieu sobre Baudelaire en P. Bourdieu, Les règles de l'art. Genèse et structure du champ littéraire, ob. cit., p. 98.

1174 J. Barbey d'Aurevilly, ob. cit., pp. 27-84. 
apuesta es por la libertad de costumbres, en base a la cual se siente en capacidad de transgredir las normas sociales y presentarse tan pronto extremadamente masculino como femenino. Todo cubierto por una espesa capa de artificio, que no hace sino proteger una intimidad quebradiza a la que difícilmente se accede.

Empero, puede parecer difícil hacer del dandismo una opción liberadora, habida cuenta de la misoginia casi militante que reflejó durante el que fue su siglo, el XIX. Creemos que hay que entender esta misoginia - cuya extensión sería la misantropía también militante- dentro del rechazo a la sexualidad reproductiva. Afirmaba el dandismo que la diferencia sexual solo era válida dentro de los límites de la reproducción; fuera de ella, la mujer solo es denostada por ser extremadamente natural. "La femme est naturelle, c'est-à-dire abominable», decía Baudelaire. ${ }^{1175}$ Como dandi, es decir, fuera de la dinámica productiva y reproductiva, la mujer es perfectamente aceptada; un ejemplo extraordinario lo tenemos en la diabólica Mme. Hauteclaire de «Le Bonheur dans le crime» de Barbey d'Aurevilly. ${ }^{1176}$

En el caso de Huysmans, su misoginia militante era producida por su historia familiar y por las especiales condiciones de la liquidación de su complejo de Edipo. Su odio a la mujer no deja de ser, asimismo, un mecanismo de defensa ante el peligro que para él significa la instancia femenina.

El dandismo es, en definitiva, una actitud vital que reivindica un nuevo tipo de identidad individual, al margen —o en contra-, en primer lugar, de la socialización marcada por el poder y cuyo fin primero es la instrumentalización del sujeto para la producción; en segundo lugar, al margen de la sexuación indicada por ese mismo poder que tiene, como fin segundo, la instrumentalización del sujeto para la reproducción. El dandismo rebasa por arriba el proceso de individualización de la sociedad capitalista, pues aboga por una super-individualización que entiende convertir al sujeto en dueño de su vida y su destino — al margen de todos los proyectos diseñados por los poderes fácticos.

Está el dandismo, por otra parte, perfectamente enclavado en la evolución del concepto de masculinidad del siglo XIX. Con la familia a la deriva

1175 C. Baudelaire, Mon cœur mis à nu, ob. cit. (III), p. 9.

1176 J. Barbey d'Aurevilly, ob. cit., pp. 27-84. 
y la autoridad del padre desgastándose, ${ }^{1177}$ los hombres ven cómo su principal modelo de comportamiento social se va difuminando. El hiper-normativo modelo masculino - basado en una serie de importantes renuncias afectivas - crea otro nuevo en el que las exigencias a nivel de política sexual son menos severas. Por lo pronto, la sexuación de los individuos no se establece, en el dandismo, en base a una dinámica dominante-dominado que tiñe la relación heterosexual clásica, sino que permite cualquier revisión del modelo.

En la obra de Huysmans se observa un empeño decidido y continuado por revisar este modelo. El heterónimo ficcional huysmansiano se debate sin cesar entre la norma que hereda de la sociedad y un proyecto diferente más acorde con sus propias inquietudes. Su masculinidad es constantemente revisada, así como las ventajas que obtiene con ella — sobre todo a título libidinal. La opción de una masculinidad alternativa queda permanentemente abierta, lo que ofrece tímidas entradas en la feminidad normativa del siglo XIX. La pasividad, el narcisismo y el masoquismo con que Freud «regaló» a las mujeres son perfectamente asumidas por el heterónimo, quien las hace suyas en base a su propio proyecto de economía libidinal y a sus necesidades verdaderas de sujeto deseante.

Es el suyo un continuado proceso de auto-reasignación de sexo, que, lejos de pasar por el quirófano, cree en la posibilidad de una opción intermedia. Un empuje "transgenérico» —en los términos expuestos por Denny Dallas - es el que opera Huysmans y, en general, el dandismo. Empuje que no deja de abogar por la redefinición de los géneros, que ya no estarían basados en una asignación anatómica sino sobre un proyecto personal. Con ello, los conceptos clásicos de homo y heterosexualidad dejan de tener validez, pues la sexualidad se abre dando pie a todo tipo de unión. Manuel Puig, el autor de El beso de la mujer araña, dirá en una entrevista que ni la homosexualidad ni la heterosexualidad existen en la naturaleza, siendo solo conceptos creados por la mente reaccionaria. ${ }^{178}$ Bruckner y Finkielkraut

1177 Esta es la tesis pricipal de E. Roudinesco, ob. cit., p. 74 y ss.

1178 «Homosexuality doesn't exist in nature and heterosexuality doesn't either. The concept as they are now are just figments of the reactionnary mind». ("An interview with Manuel Puig», en P. Bacarisse (ed.), Carnal Knowledge. Essays on the flesh, sex and sexuality in Hispanic letters and film, Tres Ríos, Pittsburgh, 1986). Vid. I. Rodríguez (comp.), Cánones literarios masculinos y relecturas transculturales (lo trans-femenino/masculinolqueer), Anthropos, Barcelona, 2001, p. 215. 
afirman también que la heterosexualidad no existe, que nuestros sistemas sociales solo estimulan un cierto tipo de homosexualidad masculina falo-genital. ${ }^{1179}$ Poco queda de la tradicional división de los géneros si desaparece la clásica diferenciación de las prácticas sexuales.

Si desaparece la división tradicional de los géneros, la sexualidad basada en el principio de dominación sobre las mujeres se disipa, abriendo una amplia vía de relaciones personales que ya no son mecánicas, sino contradictorias y complejas. Fuera de este esquema de dominación, al margen de la desconfianza recíproca que provoca, se posibilita todo tipo de actitudes lúdicas, que tienen como fin la desdramatización del juego de fuerzas. Este programa sería perfectamente señalable en Huysmans, pero, hijo de su tiempo, la colección de miedos y angustias — que ordena el discurso y el comportamiento masculinos - aparece en el horizonte en el momento en que se evoca la antigua imagen de la virilidad. El encierro, el retiro, la sumisión a la ley mediante la regresión infantil, no dejan de ser reacciones ante ese miedo.

Lo que parece quedar patente tras el análisis de las categorías de género es que la sexualidad se construye socialmente en base a ellas; la homosexualidad y la heterosexualidad son consecuencias de dichas categorías. Ahora bien, si la práctica sexual se abre, haciendo inútil la clásica división, el género se abre también haciendo innecesaria la eterna división masculinofemenino. Como ya comentó Freud en su época y Butler en la nuestra, el género no deja de ser una construcción social interesada, creada sobre todo como soporte de una sociedad establecida en base a un grupo de poder, masculino par surcroît. La antropóloga Holly Boswell lo señalaba al decir que «desde la sustitución de la Madre Naturaleza por Dios Padre (hace unos 5000 años), las construcciones de género han sido definidas de manera más estrecha y rígida con el fin de que se adaptasen a los fines de quienes controlaban cada sociedad concreta». ${ }^{180}$ Con la deconstrucción sistemática de ese poder, se llegaría tal vez a una situación que es, hoy por hoy, necesaria: la revisión de arriba abajo de las categorías genéricas, apta para acoger las múltiples propuestas surgidas de las numerosas prácticas sexua-

1179 P. Bruckner y A. Finkielkraut, ob. cit., p. 56.

$1180 \mathrm{H}$. Boswell, Reviving the tradition of alternative gender, AEGIS, Decatur, Georgia, p. 2. Traducido por A. Bolin, ob. cit., p. 256. 
les realmente existentes. Solo así seríamos capaces de albergar una sociedad respetuosa para con sus miembros.

La deconstrucción sistemática a la que hemos sometido a la masculinidad de Huysmans convierte al autor francés, por lo menos desde nuestra perspectiva, en un paradigma de escritura liberadora y emancipadora, que tendría como efecto - menos como objetivo - la relectura de la construcción de la identidad en base al género. Con sus constantes oscilaciones, el heterónimo ficcional huysmansiano evidencia la existencia de una continua "máquina deseante» (como dirían Deleuze y Guattari), ${ }^{1181}$ cuyo único problema reside en la elección de objeto — $\mathrm{o}$, más bien antes, en el género del objeto elegido. La verdadera identidad del individuo Jayant-FolantinDurtal, por ejemplo, está en esa constante disposición a la satisfacción libidinal, aun a pesar de todo el cortejo de insatisfacciones y culpabilidad que le acompańa — por los motivos de corte edípico ya expuestos anteriormente. Poco importa que venga de una mitad u otra del cielo - para parafrasear la célebre frase de Mao-, que sea hombre o mujer el objeto elegido: el individuo deseante sigue siendo el mismo. Es antes bien la ideología centrada en la producción y, sobre todo, en la reproducción la que crea las categorías de género. Podríamos afirmar que, sin reproducción, el género no tiene razón de ser; esa es la gran paradoja, pues vivimos en una sociedad en la que tras la normalización de las prácticas de planificación familiar, tras la comprensión del hecho reproductivo como una opción libre, tras la defección de la eterna identificación entre mujeres y madres, ${ }^{1182}$ siguen existiendo los géneros creados en base a la división de los roles reproductivos.

\section{G. Deleuze y F. Guattari, ob. cit., p. 50, por ejemplo.}

1182 Simone de Beauvoir diría: «Mâles et femelles sont deux types d'individus qui à l'intérieur d'une espèce se différencient en vue de la réproduction; on ne peut les définir que corrélativement", en S. de Beauvoir, Le deuxième sexe, ob. cit., vol. II, p. 38. Para abundar en esta idea, cabe señalar un estudio que fue llevado a cabo en los años setenta por la socióloga J. E. Veever en los Estados Unidos. En el mismo se hacía patente que la programación coercitiva a que están sometidas las mujeres es hasta tal punto intensa, que el no cumplimiento con ese papel que la sociedad le ha asignado secularmente les sume en un malestar, en una sensación de traición para con el mundo y la especie. Escribía Veever que, en un grupo de 52 esposas entrevistadas, todas se sentían: «estigmatizadas hasta cierto punto por su impopular decisión de evitar su reproducción biológica y (declaraban) que existe por todas partes un estereotipo negativo concerniente a las características de una mujer que voluntariamente no tiene descendencia, incluyendo rasgos desfavorables como los de ser anormal, egoísta, inmoral, irresponsable, inmadura, no feliz, no realizada y no femenina», en J. 
Huysmans, con su obra, evidencia la fragilidad del dictado genérico en un individuo desligado de la finalidad reproductiva. Las oscilaciones del género que sufren sus personajes protagonistas no son sino muestras de la contradictoria violencia que el complejo de Edipo (que no es sino la denominación de un efecto de la ideología heterosexual centrada en la familia) inflige a los individuos. Cansado de los continuos embates de corrientes de signo opuesto, el heterónimo ficcional de Huysmans termina por agotarse, abogando finalmente por la inhibición completa como toma de posición sexual: el grado cero de la sexualidad puede ser también una práctica, acometida de manera activa. La identidad de quien opta por ella no tiene por qué verse influida; para parafrasear a Monique Wittig y su defensa del «humanismo de la persona», el individuo que opta por la indefinición deja de ser hombre o mujer, para ser única y exclusivamente persona, individuo, ciudadano. No es un mal programa cuando se es consciente de las terribles consecuencias que la división de roles ha tenido para una de las mitades de la sociedad. ${ }^{1183}$ Comenzar a considerar a nuestros semejantes como personas antes que como a individuos dotados de unas capacidades u otras en el escenario de la reproducción no deja de ser un proyecto plausible.

E. Veever, «Voluntary childless Wives: an exploratory study», Sociology and social Research, abril de 1973, p. 360. Lo que deja a las claras hasta qué punto impone severas coerciones el sometimiento de las mujeres a las cuestiones de orden reproductivo; tras ellas no es difícil comprender las bases de la división de roles sexuales.

1183 Esa mitad es la femenina, se entiende. Sin embargo, los imperativos de la marca genérica sobre los hombres no son menos productores de problemas. Los antropólogos lo saben bien, consignadores de los numerosos rites de passage, que deben cumplir los jóvenes para adquirir el estatus de 'hombre', existentes en todas las sociedades, primitivas o no. Y también la psicología: el psicoterapeuta argentino afincado en Madrid, y director del Instituto de la Condición masculina, Luis Bonino, refiere en «Varones, género y salud mental: deconstruyendo la 'normalidad'», una tipología de procesos depresivos exclusivamente masculinos, cuyo factor de formación reside en la asunción de mejor o peor grado de los condicionantes de la virilidad, en L. Bonino, "Varones, género y salud mental: deconstruyendo la normalidad masculina», en M. Segarra y A. Carabì (eds.), Nuevas masculinidades, ob. cit., pp. 41-64. Por otra parte, como refieren Tomé y Rambla, la construcción de la virilidad en los adolescentes en base a los ritos de paso convencionales desemboca en una serie de consecuencias difíciles de atajar para los pedagogos y orientadores escolares: fracaso académico, absentismo escolar, suicidios[...], son mayoritariamente masculinos en los centros escolares, en A. Tomé y $\mathrm{X}$. Rambla, La coeducación de las identidades masculinas en la educación secundaria, Cuadernos para la coeducación, Institut de Ciències de la Educació, Universitat Autònoma de Barcelona, Barcelona, 2001. 
Como señala el sociólogo Castells sobre la «identidad proyecto», esta se da «cuando los actores sociales, basándose en los materiales culturales de que disponen, construyen una nueva identidad que redefine su posición en la sociedad». ${ }^{1184}$ Huysmans ejemplifica un nuevo posicionamiento en la sociedad, una posición intermedia entre los géneros, adoptada tras el hartazgo de la masculinidad normativa, o, yendo más lejos, tras el cansancio de las normas que sobre sexualidad impone la sociedad patriarcal: es este un paso hacia la liberación, hacia la difuminación de las barreras del género.

Los movimientos feministas han influido de manera notable, desde su aparición, en la redefinición de la identidad y los roles de las mujeres en la sociedad. Algunos de esos movimientos han abogado por la dignificación de la condición femenina, desde los valores con que el patriarcado la definió: pasividad frente a actividad masculina; naturaleza frente a la masculina cultura; abnegación y don de sí frente al egoísmo masculino... Una postura que cree en la existencia de una esencia femenina basada en esos tres grandes rasgos, una lógica del esclavo que hace finalmente suyas las razones de los dominadores, de quienes dictan las leyes. La emancipación de las mujeres en esas constantes femeninas se hace solo de puertas hacia dentro: hacia el interior del paritorio, o del harén, o del hogar donde las han recluido las labores domésticas. Las mujeres, con ello, no se liberan hacia afuera, con lo que no implican en su liberación a los mismos agentes de la dominación, los hombres interesados en conservar su posición hegemónica. El feminismo llamado de la diferencia — del que la francesa Luce Irigaray es una de sus grandes exponentes y la Librería de Mujeres de Milán uno de sus epígonos actuales - no aporta una redefinición de la condición femenina: más bien, como dice Rosa Cobo, produce un «enquistamiento en la diferencia». ${ }^{1185}$ Comprende esta autora que, antes de optar a la emancipación definitiva, un movimiento como el de la diferencia abogue por construirse una identidad contingente, afirmarla hasta que se conquisten los derechos de los individuos de ese colectivo y, al mismo tiempo, tiene que negar ontológicamente esa identidad si aspira a la realización de la universalidad. La Librería de Mujeres de Milán, empero, parece más bien com-

1184 M. Castells, ob. cit., p. 30. Los otros dos tipos de identidades son la identidad legitimadora y la identidad de resistencia.

1185 R. Cobo, «Democracia paritaria y radicalización de la igualdad», en Utopías, Nuestra Bandera, n. ${ }^{\circ}$ 195, «Feminismos», P.C.E., Madrid, 2003, p. 23. 
placerse en la eternidad de los valores de las mujeres que el patriarcado les ha otorgado, antes que proponer una «identidad proyecto» —en el sentido apuntado por Castells - que les permita redefinir verdadera y definitivamente su posición en la sociedad. La diferencia no propone una redefinición, sino que subraya y fortalece la definición ya existente.

Frente al feminismo de la diferencia — aparte de otras interesantes pero no menos esencialistas opciones, como el ecofeminismo - se halla el feminismo llamado ilustrado o de la igualdad, en el que podríamos inscribir a la mencionada Rosa Cobo, Amalia Valcárcel y Celia Amorós entre otras, que reivindican de nuevo la figura de Simone de Beauvoir — rechazada por el feminismo llamado 'cultural' de los Estados Unidos en los años noventa. Lo que plantea, a grandes rasgos, el feminismo de la igualdad es la equiparación de todos los individuos sea cual sea su género mediante la modificación de las capacidades enunciativas de cada uno de ellos. De lo contrario, siempre se definirán hombres y mujeres en base a su anatomía o, lo que viene a ser lo mismo, en base al destino que esta les marque en su relación con la reproducción.

En ambos casos, el feminismo ha creado un interesante aparato teórico en torno a la crítica literaria, entendiendo principalmente la lectura como un ejercicio de rastreo de identidades con que se equipa a los personajes literarios. Los ya mencionados trabajos de Sandra Gilbert y Susan Gubar, de Biruté Ciplijauskaité o de Annete Kolodny se plantean como campo de estudio la especificidad de una escritura de corte femenino, según la cual las mujeres plasmarían en sus obras una visión del mundo diferente de la masculina hegemónica, debida a su especial posición en el sistema de valores marcado por la androcéntrica sociedad patriarcal.

Sin embargo, ¿no cabe plantearse la diferencia ontológica entre la visión de hombres y mujeres como una consecuencia más de la división de roles establecida por el poder masculino? ¿No podríamos pensar que abundar en estas diferencias estructurales significaría confirmar la dominación de hombres sobre mujeres? No pretendemos, ni mucho menos, negar la legitimidad de las reivindicaciones emancipatorias de los movimientos feministas, ni, con ello, ocultar la dominación que aún hoy día sufre esa mitad de la humanidad. Nada más lejos de nuestra intención, pues solo pretendemos señalar la inanidad de unos planteamientos que, sedicentemente liberadores, se recrean en dignificar unos valores esclavizantes y que, par surcroit, han sido puestos en circulación por los artífices de la esclavitud. 
Solo el efectivo abandono de la complaciente ideología de la diferencia puede abrir las puertas de la igualdad de facto. La reivindicación de los valores del esclavo como válidos — que, además, le recluyen con mayor ahínco en su condición - no constituye, a nuestros ojos, un programa sólido para optar a la emancipación. La sospecha y la denuncia deben presidir la lectura de la totalidad de las producciones culturales, como paso previo a la exigencia real de igualdad de género.

Por ello mismo, apostamos desde este trabajo por la adopción de un tipo de lectura en el que se analicen las obras literarias desde una nueva constante: la posible igualación de los géneros gracias a la difuminación de sus barreras.

\subsection{Sentido y aportación de este trabajo a la crítica huysmansiana}

$\mathrm{Al}$ inscribir nuestro estudio en la vía de la crítica que tiene en la psicología su principal herramienta de trabajo, nos comparamos forzosamente con la obra de otros ensayistas de enorme repercusión y difusión. Desde doctores en medicina como Lavelée y Rollands - que indagaron en la personalidad y la obra de Huysmans para detectar sus aspectos psicopatológicos- a la autoridad de un Pierre Cogny, de Michel Raimond y Philippe Roger - quienes, en las Actas del Coloquio de Basilea sentaron unos precedentes de gran exigencia para nuestra manera de trabajar. ${ }^{186}$

Por otra parte, los británicos Lowrie y Garber, quienes hablaron de la expiación y del "ello" en la obra de varios escritores (Richardson, Balzac, Barbey d'Aurevilly, Bloy y Huysmans), han constituido excepcionales referentes en la lectura psicologizante. Charles Bernheimer, con sus ensayos sobre la castración, la sublimación y la teoría fálica, se inscribe en una tradición psicoanalítica que respeta tanto a Freud como a la inglesa Melanie Klein: sus observaciones nos han sido de gran ayuda para la delimitación de nuestro campo de estudio psicológico.

1186 Vid. el subapartado 1.8, «La crítica huysmansiana hasta nuestros días», donde se hace hincapié en algunos de los autores citados aquí. 
Es de necesaria mención la deuda que hemos contraído con las interesantes lecturas de Alain Toumayan centradas en la escritura del mal ( $L a$ littérature et la hantise du Mal. Lectures de Barbey d'Aurevilly, Huysmans et Baudelaire, Kentucky, 1987), la de Jean-Pierre Vilcot sobre la intimidad del escritor (Huysmans et l'intimité protégée, París, 1988), la de Nathalie Limat-Lethellier sobre Le désir d'emprise dans À rebours de J.-K. Huysmans (París, 1990), y la de Pierre Jourde y su Huysmans, À rebours, l'identité impossible (Ginebra, 1991). Pero, sobre todo, nuestra deuda es especial con el excelente ensayo del sueco Per Buvik en que analiza los intentos de un sensualista por conseguir una inalcanzable pureza espiritual a través de la mística y la ascesis. Publicada en Oslo en 1989, La luxure et la pureté. Essai sur l'euvre de Joris-Karl Huysmans es un antecedente inexcusable de nuestro estudio y al que debemos el germen de muchos de los caminos iniciados aquí.

Toda esta crítica de raigambre psicológica, cuando no psicoanalítica, trata muy tangencialmente la cuestión del género y su construcción. Siendo un asunto de importancia creciente y de gran actualidad — las mejores universidades occidentales se van dotando de un departamento de estudios sobre género-, creemos que una perspectiva de este tipo le faltaba a la consideración crítica sobre la obra de Huysmans. Ya hemos comentado en la introducción las enormes posibilidades que las especiales personalidad y obra de nuestro autor abrían a este tipo de lectura; sin embargo, tan solo una aportación hemos encontrado en el universo erudito en torno a Huysmans. Se trata de la tesis presentada en 1998 por David Tacium en la Universidad de Montreal, Le dandysme et la crise de l'identité masculine à la fin du XIXe siècle, que traza un estudio comparado de Huysmans, Pater y Dossi, como ejemplos de una masculinidad reconducida o redefinida a finales del siglo XIX.

En la segunda parte de su tesis, «L'ennui, la castration et le fétichisme: le cycle négatif du dandysme de Huysmans», Tacium analiza la crisis de la masculinidad en Huysmans con el tedio (l'ennui) como motor principal de evolución. Según el canadiense, sería el aburrimiento del funcionario el que habría llevado a Huysmans a investigar sobre nuevos placeres, lo que haría de su erotismo el marco de una sexualidad performativa: el hombre no es sino lo que hace; de ahí que tan pronto se ponga en posición pasiva-femenina como activa-masculina. Ahora bien, esta última no resultándole en absoluto satisfactoria a Huysmans, Tacium señala que nuestro autor es un 
claro ejemplo de personalidad homosexual que, rebosante, se manifiesta tan solo en sus excesos. La masculinidad, con ejemplos como el de Huysmans, entra en una franca situación de crisis en relación con su definición más convencional —lo que abre las puertas de su redefinición.

Nosotros, al proponer una lectura desde la perspectiva de género de la obra de Huysmans, transitamos por caminos ora convergentes ora divergentes a los de Tacium. No planteamos el tedio como motor de la vida sexual de Huysmans, sino, siguiendo de cerca la ortodoxia freudiana, planteamos la existencia de un conflicto infantil que, tras años de represión (refoulement) consigue salir a la superficie en su contacto con lo sobrenatural. La masculinidad de Huysmans sufre entonces una forzosa redefinición cuya única salida es la emasculación definitiva: con ella, el alter ego huysmansiano consigue acallar las voces que hacen de su masculinidad una constante culpabilidad. Las diferencias de género se difuminan en pro de una existencia que evolucionara, como diría Foucault, en «la extraña felicidad, a la vez obligatoria y prohibida, de no conocer más que un solo sexo». ${ }^{1187}$ La religión aparece, en fin, como un horizonte de reconciliación con las instancias parentales que no habían dejado de culpabilizarle de sus excesos eróticos.

Nuestra aportación a la crítica huysmansiana, en definitiva, reside en la propuesta de una lectura en la que el género no es sino el fruto de un terrible conflicto - consecuencia de la biografía del autor- de indeleble marca. De ella se desprende, finalmente, que la conversión de Huysmans al catolicismo más militante no solo sea producto de la «fiebre» de conversiones del fin-de-siglo francés, sino de un personalísimo modo de vivir la sexualidad. Huysmans se convierte, en última instancia, en un ejemplo - de entre tantos otros posibles - de la inutilidad del género como categoría definitoria de la personalidad: siendo cambiante y performativa, la sexualidad ya no es factor decisivo sobre la identidad, sino de nuestras posibles relaciones con los demás. El grado cero de la sexualidad, que es, al final, la opción de Huysmans, no afecta la identidad profunda de la persona: él conservó, tras su elegida y esperada emasculación, su identidad de artista, cuyo proyecto residía en la ascética persecución de la excelencia de su arte.

1187 M. Foucault, Herculine Barbin, Llamada Alexina B, ob. cit. p. 17. 



\section{BIBLIOGRAFÍA}

En este apartado figuran las obras utilizadas durante la construcción de nuestro estudio, de obligada referencia y consulta. Aparecen, no obstante, muchas otras a las que no se hace referencia directa en el texto, aun a pesar de habernos servido como referencia; y otras más cuya relación con el tema de estudio es tangencial pero no inexistente. Todo ello se debe a nuestra voluntad de presentar un corpus bibliográfico lo más amplio posible, que pueda servir de consulta en los aspectos en que la hemos dividido. Sirva, pues, esta aclaración para justificar la inclusión de obras cuya presencia pueda parecer un tanto enigmática.

\section{Apartados:}

1) Ediciones utilizadas de Huysmans

2) Sobre Huysmans

3) Narratología y crítica literaria

4) Napoleón

5) Dandis y dandismo

6) Vampiros, diablos y diablesas, mujeres fatales, misoginia

7) Psicología, psicoanálisis y literatura

8) Antropología

9) Sociología

10) Sociología de la familia

11) Feminismos y Estudios de género

Crítica literaria feminista

Feminismos y crítica del androcentrismo

Maternidad

Estudios sobre hombres

Paternidad

Transversalidad

Otros 
12) Religión

13) Miscelánea

\section{1) Ediciones utilizadas de Huysmans}

Huysmans, J.-K., Croquis parisiens, Plon, París, 1908.

- Un dilemme, Plon, París, 1908.

- La Bièvre, Ferroud, París, 1914.

- Sainte Lydwine de Schiedam, Plon, París, 1952.

- Là-bas, Plon-Le Livre de Poche, París, 1961.

- La Cathédrale, Plon-Le Livre de Poche, París, 1964.

- Certains, en Cuvres complètes de J.-K. Huysmans, vol. X, Slatkine Reprints, Ginebra, 1972.

- De tout, en CEuvres complètes de J.-K. Huysmans, vol. XVI, Slatkine Reprints, Ginebra, 1972.

- L'Art moderne, en Euvres complètes de J.-K. Huysmans, vol. VI, Slatkine Reprints, Ginebra, 1972.

- La Bièvre y Le Quartier Saint-Séverin, en Cuvres complètes de J.-K. Huysmans, vol. XI, Slatkine Reprints, Ginebra, 1972.

- Les Foules de Lourdes (inédito hasta 1928-34), en Euvres complètes de J.-K. Huysmans, vol. XVIII, Slatkine Reprints, Ginebra, 1972.

- Pierrot sceptique (con Léon Hennique), en Euvres complètes de J.-K. Huysmans, vol. v, Slatkine Reprints, Ginebra, 1972 (2. a impresión).

- Sac au dos, en Euvres complètes de J.-K. Huysmans, vol. I, Slatkine Reprints, Ginebra, 1972.

- Trois Eglises: La Bièvre, les Gobelins, Saint Séverin, en Euvres complètes de J.K. Huysmans, vol. XI, Slatkine Reprints, Ginebra, 1972.

- À vau-l'eau, Union Générale d'Éditeurs, Collection 10/18, París, 1975.

- En ménage, Union Générale d'Éditeurs, Collection 10/18, París 1975.

- Les Socurs Vatard, Union Générale d'Éditions, París, 1975.

- Marthe, histoire d'une fille, Union Générale d'Éditions, París, 1975.

- À rebours, Garnier-Flammarion, París, 1978.

- Le Drageoir à épices, Union Génerale d'Éditions, París, 1978.

- En rade, Gallimard, París, 1984.

- Les Grünewald du musée de Colmar, Hermann, Éditeurs des Sciences et des Arts, París, 1988.

- L'Oblat, Pirot, París, 1992.

- En route, Gallimard, París, 1996. 


\section{Correspondencia}

Huysmans, J.-K., Lettres inédites à Émile Zola, Librairie Droz, Ginebra, 1953.

- Lettres inédites à Edmond de Goncourt, Nizet, París, 1956.

- Lettres inédites à Camille Lemonnier, Droz, Ginebra, 1957.

- Lettres inédites à Jules Destrée, Librairie Droz, Ginebra, 1957.

- Une etape de la vie de J.-K. Huysmans: lettres inédites de J.-K. Huysmans à l'abbé Ferret, Nizet, París, 1973.

- Lettres inédites à Arij Prins: 1885-1907, Droz, Ginebra, 1977.

- Lettres: correspondance à trois. Léon Bloy, J.-K. Huysmans, Villiers de l'sle-Adam, Thot, Vanves, 1980.

- Vingt lettres à Théo Hannon (1876-1878), À l'Écart, París, 1984.

- Lettres inédites à Théodore Hannon (1876-1886), C. Pinot, París, 1985.

— Soixante-huit lettres inédites à Gabriel Thyébaut, À l'Écart, Chartres, 2002.

\section{Otros}

BoIs, J., Le satanisme et la magie (préface de J.-K. Huysmans), Léon Challey, París, 1895.

Seillan, J.-M. (ed.), Interviews (avec J.-K. Huysmans), Honoré Champion, París, 2002.

\section{2) Sobre Huysmans}

\section{Libros}

Aimery, C., Huysmans, Caritas, París, 1956.

Armagnac, Mlle. D', Huysmans ou les frontières du Chrétien, Maison de la Bonne Presse, París, 1937.

Aubault de la Haute Chambre, G., J.-K. Huysmans (souvenirs), Eugène Figuière, París, 1924.

Audoin, P., Huysmans, Éditions H. Veyrier, coll. Les Plumes du temps, París, 1985.

BaChelin, H., J.-K. Huysmans. Du naturalisme littéraire au naturalisme mystique, Perrin, 1926.

Baldick, R., La vie de J.-K. Huysmans, trad. de M. Thomas, Denoël, París, 1958. Belleville, A. F., La conversion de M. Huysmans, Bourges, 1898.

Belval, M. M., Des ténèbres à la lumière: étapes de la pensée mystique de J-K. Huysmans, Maisonneuve et Larose, París, 1968. 
Bertrand, J.-P., M. Biron, J. Dubois y J. Paque, Le roman célibataire. D’«À rebours» à «Paludes», José Corti, París, 1996.

BESSE, R. P. D., Joris-Karl Huysmans, Librairie de l'Art Catholique, París, 1917.

BiLLY, A., J.-K. Huysmans et ses amis lyonnais, Lardanchet, Lyon, 1942.

- Huysmans et Cie, La renaissance du livre, coll. La lettre et l'esprit, Bruselas, 1963.

Blandin, A. H., Joris-Karl Huysmans, l'homme, l'écrivain, l'apologiste, París, 1912.

Blasco IbáŃEZ, V., «Prólogo» a J.-K. Huysmans, Al revés, trad. de Germán Gómez de la Mata, Prometeo, Valencia, 1919.

BLOY, L., Le sang du pauvre; sur la tombe de Huysmans; la resurrection de Villiers de L'sle-Adam, Union Générale d'Éditions, París, 1983.

- Sur J.-K. Huysmans, Complexe, Bruselas, 1986.

Bonnefis, P., y A. Buisine (eds.), La chose capitale: essai sur les noms de Barbey, Barthes, Bloy, Borel, Huysmans, Maupassant, Paulhan, Université de Lille, 1981.

Bonnet, G., L'écriture comique de J.-K. Huysmans, Honoré Champion, París, 2003. BORIE, J., Le célibataire français, Sagittaire, París, 1976.

- Un siècle démodé. Prophètes et réfractaires au XIXe siècle, Essais Payot, París, 1989.

- Huysmans, le Diable, le célibataire et Dieu, Grasset, París, 1991.

- Archéologie de la modernité, Grasset, París, 1999.

Bosch, F. van der, Impressions de littérature contemporaine, Vromant, Bruselas, 1905.

Bossier, H., Un personnage de roman: le chanoine Docre de Là-bas, Les Écrits, París, 1943.

Bouyssou, R., La singulière route de J.-K. Huysmans, À la Belle Étoile, París, 1978.

Breton, A., Anthologie de l'humour noir, Jean-Jacques Pauvert-Livre de Poche, París, 1966.

Bricaud, J., J.-K. Huysmans et le satanisme, Bibliothèque Chacornac, París, 1912.

- Huysmans occultiste et magicien, Bibl. Chacornac, París.

- L'Abbé Boullan, Bibl. Chacornac, París.

Bron, L., J.-K. Huysmans, Alsatia, París, 1937.

BROOKNER, A., The genius of the future: studies in French art criticism: Diderot, Stendhal, Baudelaire, Zola, the brothers Goncourt, Huysmans, Phaidon, Londres, 1971.

Brunner, P., y M. De Conninck, En marge d'À rebours, Derbon-Aimé, París, 1928.

BuviK, P., La luxure et la pureté. Essai sur l'œuvre de Joris-Karl Huysmans, Didier Erudition-Solum Forlag, Oslo, 1989. 
Chastel, G., Huysmans et ses amis, Grasset, París, 1957.

Cogny, P., J.-K. Huysmans à la recherche de l’unité, Nizet, París, 1953.

- Le "Huysmans intime» de Henry Ceard et Jean de Caldain, Nizet, París, 1957.

- (ed.), Mélanges Pierre Lambert, Nizet, París, 1975.

- Huysmans: de l'écriture à l'Écriture, Tequi, París, 1987.

CONTRERAS, F., Los modernos: Eugenio Carriere, Pablo Verlaine, Enrique Ibsen, Joris-Karl Huysmans, Augusto Rodin, J. M. de Heredia, Juan Lorrain, Mauricio Barrés, los pintores franceses de hoy, Sociedad de Ediciones Literarias y Artísticas, París, 1909. Coquiot, G., Le vrai J.-K.Huysmans, prólogo de J.-K. Huysmans, C. Bosse, París, 1912.

Court-Perez, F., Joris-Karl Huysmans, "À rebours», Presses Universitaires de France, París, 1987.

Cressot, M., La phrase et le vocabulaire de J.-K. Huysmans: contribution à l'Histoire de la Langue Française pendant le dernier quart du XIXe siècle, Slatkine Reprints, Ginebra, 1975.

Crosnier, A., Apologétique vivante. 2, Les convertis d'hier/Alexis Crosnier, François Coppé, J.-K. Huysmans, Paul Bourget, Ferdinand Brunetière, Levé, París, 1913. DaOust, J., Les débuts bénédictins de J.-K. Huysmans, Fontenelle, París, 1950.

- J.-K. Huysmans directeur de conscience. Lettres inédites, Plaquette, París, 1953. Daudet, L., À propos de J.-K. Huysmans, Du Cadran, París, 1947.

DefFoux, L., J.-K. Huysmans sous divers aspects, Cès, París, 1927.

- Flaubert, Zola, Huysmans, Critique et morceaux choisis, Cès, París, 1935.

Descaves, L., Les dernières années de J.-K. Huysmans, Albin Michel, París, 1941.

- Deux amis: J.-K. Huysmans et l'Abbé Mugnier. Documents inédits, Plon, París, 1946.

Diesbach, G. de, L’abbé Mugnier, Perrin, París, 2004.

Doumic, R., Les jeunes: études et portraits: Édouard Rod, J. H. Rosny, Paul Hervieu, J.-K. Huysmans, Maurice Barrès, Paul Marguerie, Léon Daudet, Le Comte Robert de Montesquiou, Perrin et Cie, París, 1891.

Du Bourg, D. A., Huysmans intime, Librairie des Saints-Pères, París, 1908.

DuMESNIL, R., La publication d'«En route», SFELT, París, 1931.

DuployÉ, P., Huysmans, Desclée de Brouwer, Brujas, 1968.

Engstrom, A. G., Darkness and light: lectures on Baudelaire, Flaubert, Nerval, Huysmans, Racine, and time and its images in literature, University of Mississippi, 1978.

Gallot, H.-M., Explication de J.-K. Huysmans, Agence parisienne de Distribution, París, 1954.

GARBER, F., The autonomy of the self from Richardson to Huysmans, Princeton University Press, Princeton, N. J., 1982. 
Garçon, M., Huysmans inconnu, Albin Michel, París, 1941.

Garreau, A., J.-K. Huysmans, Casterman, París, 1947.

GRIFFITHS, R. M., Révolution à rebours: le renouveau catholique dans la littérature en France de 1870 à 1914, Desclée de Brouwer, París, 1971.

GROJNOWSKI, D., Edición crítica (presentación, notas, dossier, cronología y bibliografía) de À rebours, Garnier-Flammarion, París, 2004.

Grolleau, P., y A. Garnier, Un logis de J.-K. Huysmans. Les prémontrés de la Croix Rouge, Crès, París, 1928.

Guillemain, C., J.-K. Huysmans et Lyon, Albums du Crocodile, París, 1958.

Harry, M., Trois ombres: Huysmans-Lemaître-France, Flammarion, París, 1932.

Herrero, J., «Introducción» a J.-K. Huysmans, A contrapelo, trad. de Juan Herrero, Cátedra, Madrid, 1984.

IsSACHAROFF, M., Huysmans devant la critique en France (1874-1960), Klincksieck, París, 1970.

- L'espace et la nouvelle: Flaubert, Huysmans, Ionesco, Sartre, Camus, José Corti, París, 1976.

JaCQuinot, J., Huysmans et la médecine, Chez Durtal, París, 1951.

- En marge de J.-K. Huysmans, Chez Durtal, París, 1952.

- Un procès de J.-K. Huysmans: l'affaire du journal "La Comédie Humaine», Chez Durtal, 1953.

Jourde, P., Huysmans, À rebours, l'identité impossible, Slatkine, Ginebra, 1991.

LABARrÈre, A, Une visite avec Huysmans, Réunion des musées nationaux, coll. Carnets parcours du Musée d'Orsay, n. ${ }^{\circ}$ 17, París, 1989.

LAngle, G.-U., Au pays d'En rade, Fécamp, París, 1930.

- Itinéraires huysmansiens, Fécamp, París, 1933.

LefÈVRe, F., Entretiens sur J.-K. Huysmans, Horizons de France, París, 1931.

Limage Conde, A., Papel de Armenia en la Farmacia benedictina de Joris-Karl Huysmans, Sepúlveda, 1988.

Limat-Letellier, N., Le désir d'emprise dans À rebours de J.-K. Huysmans, Lettres Modernes, París, 1990.

Livi, F., J.-K. Huysmans. À rebours et l'esprit décadent, La Renaissance du Livre, Bruselas, 1976.

LLOYD, C., J.-K. Huysmans and the fin-de-siècle novel, University Press for the University of Durham, Edimburgo, 1990.

LOBET, M., Huysmans ou le témoin écorché, E. Vitte, coll. Singuliers et mal connus, Lyon, 1960.

Locmant, P., Édition critique présentée, établie et annotée de Le Drageoir aux épices suivi de textes inédits, Honoré Champion, París, 2003. 
LOWRIE, J. O., The violent mystique: thematics of retribution and expiation in Balzac, Barbey d'Aurevilly, Bloy, and Huysmans, Droz, Ginebra, 1974.

Maingon, C., L’univers artistique de J.-K. Huysmans, Nizet, París, 1977.

- La médecine dans l'ouvre de J.-K. Huysmans, Nizet, París, 1994.

Martineau, R., Autour de J.-K. Huysmans, Desclée de Brouwer, París, 1946.

Meurgey De Tupingy, C., Le sentiment héraldique dans l'oeuvre de J.-K. Huysmans, París, 1946.

Monnoyeur, D. J.-B., J.-K. Huysmans convers et oblat de Ligugé, fotocopia aparecida en Ligugé en 1934.

Mugnier, A., J.-K. Huysmans à La Trappe, Le Divan, París, 1927.

- Journal de l'Abbé Mugnier 1879-1939, Mercure de France, París, 1942.

PaCheu, J., De Dante à Verlaine. Études d'idéalistes et mystiques: Dante-SpenserBunyan-Shelley-Verlaine-Huysmans, A. Tralin, París, 1912.

Paul-Courant, P., «Souvenirs huysmansiens», À rebours, n.o 44, 1988.

Peries, A. G., La littérature religieuse de M. Huysmans, Lamulle et Poisson, París, 1898.

Pevel, H., Henriette: «Pour l'amour de Huysmans», Atelier du Gué, Villelongue d'Aude, 1984.

PeYLeT, G., J.-K. Huysmans: la double quête, L'Harmattan, París, 2002.

PHALÈSE, H. de, Comptes à rebours: l'cuvre de Huysmans à travers les nouvelles technologies, Nizet, París, 1991.

Poinsot, R., y M. Langé, Les logis de Huysmans, La Maison Française, París, 1919.

RibeS, C.-B., Joris-Karl Huysmans, l'homme et l'oblat de Saint-Benoît, París, 1932.

Rigaud, A., L'abbé Gabriel-Eugène Ferret et J.-K. Huysmans, S.I., París, 1948.

Saint-Brice, R., y L. Marfée, J.-K. Huysmans et Léon Bloy, Histoire d'une amitié orageuse, À rebours, París, 1987.

SÄNGER, J., Aspekte dekadenter Sensibililität: J.-K. Huysmans' Werk von "Le Drageoir aux épices» bis zu «À rebours», Lang, Fráncfort del Meno, 1978.

Seillière, E., J.-K. Huysmans, Grasset, París, 1931.

SMEETS, M., Huysmans l'inchangé: histoire d'une conversion, Rodopi, ÁmsterdamNueva York, 2003.

ThérIVE, A., J.-K. Huysmans, son œuvre, Nouvelle Revue Critique, París, 1924.

Thiele, R., Satanismus als Zeitkritik bei Joris-Karl Huysmans, Peter D. Lang, Fráncfort del Meno, 1979.

TOUMAYAn, A., La littérature et la hantise du Mal. Lectures de Barbey d'Aurevilly, Huysmans et Baudelaire, French Forum Publishers, Lexington, Kentucky, 1987.

Trudgian, H., L'esthétique de J.-K. Huysmans, Conard, París, 1934. 
Vanwelkenhuyzen, G., J.-K. Huysmans et la Belgique, Mercure de France, París, 1935.

- Insurgés des lettres: Verlaine-Bloy-Huysmans, La Renaissance du Livre, París, 1953. VIEgnes, M., Le milieu dans la trilogie de J.-K. Huysmans: En route, La Cathédrale, L’Oblat, Nizet, París, 1986.

Vilcot, J.-P., Huysmans et l'intimité protégée, Lettres modernes, coll. Archives des lettres modernes, París, 1988.

Vircomdelet, A., Joris Karl Huysmans, Plon, París, 1990.

- Huysmans, entre grace et péché, Beauchesne, París, 1995.

Vroncourt, R., Huysmans et l'âme des foules de Lourdes, Menard, Tours, 1910.

ZAYED, F., Huysmans, peintre de son époque, Nizet, París, 1973.

\section{Artículos}

ARnaUd, N., «Huysmans le précurseur», Magazine Littéraire, n. ${ }^{\circ}$ 288, 1991, pp. 25-29.

BEM, J., "Le Sphinx et la Chimère dans À rebours», en Huysmans. Une esthétique de la décadence. Actes du Colloque de Bâle, Mulhouse et Colmar de novembre 1984, Slatkine, Ginebra-París, 1987.

BERNHEIMER, C., «L'exorbitant sexuel: castration et sublimation chez Huysmans», Romantisme, n. ${ }^{\circ}$ 45, 1984.

— "Penile Reference in Phallic Theory», Differences: A Journal of Feminist Cultural Studies, vol. 4, n. ${ }^{\circ}$ 1, 1992.

Bertrand, J.-P., S. Duran y F. Grauby, Huysmans, à côté et au-delà, Actes du Colloque de Cerisy, Peetres-Vrin, 2001.

BORIE, J., "La conversion d'un esthète», Magazine Littéraire, n. ${ }^{\circ}$ 288, 1991.

BRUNEL, P. "À rebours: du catalogue au roman", en Actes du colloque de Bâle, 1987, pp. 13-21.

CognY, P., «Le pessimisme 'physiologique' de J.-K. Huysmans», Bulletin, n. o 21, 1949.

Colin, R.-P., «Huysmans et les saluts du vieux garçon», en R. Bellet (ed.), La femme au XIXe siècle. Littérature et idéologie, Presses Universitaires de Lyon, 1979.

DOMíNGUEZ, F., «El placer del desplazamiento que no existe. Diálogo viajero entre Huysmans y Baudelaire», L'Ull Critic, n. ${ }^{\circ}$ 9, Universidad de Lérida, 2008.

— «Huysmans et le Plain-Chant», en Laurence Richer, Littérature et Musique aux XIXe et XXe siècles, Université Jean Moulin, Lyon, 2005.

- "La deserción de Huysmans del Naturalismo zoliano», Çédille. Revista de estudios franceses, n. ${ }^{\circ}$ 3, 2007.

- «Los Croquis parisiens como primera formulación de algunas obsesiones de Huysmans», Anales de Filología, n. ${ }^{\circ}$ 16, Universidad de Murcia, Murcia, 2008. 
DomínGUeZ, F., «El Búho del desván», Francofonía, n. 17, Universidad de Cádiz, Cádiz, 2008.

- «Dandismo y misoginia en Huysmans», Cuadernos de Filología, n. ${ }^{\circ}$ 19, Universidad de Extremadura, Cáceres, 2008.

Fleury, M., «Relations», Nouvelles littéraires, 25 julio, 8 agosto, 19 septiembre 1931.

Gourmont, R. de, «M. Huysmans, écrivain pieux», Promenades littéraires, vol. 3, Mercure de France, París, 1963.

LAMBerT, P., «Un culte hérétique à París, 11 rue des Sèvres», La Tour Saint-Jacques, mayo-junio, 1957.

- Mélanges Pierre Lambert (consacrés à Huysmans), Nizet, París, 1975.

Laurens, M., "Pour une édition d'À rebours», en P. Cogny (ed.), Mélanges Pierre Lambert (consacrés à Huysmans), Nizet, París, 1975.

LeLIÈVRE, G., «Les notions d'extériorité et d'intériorité dans À rebours de Huysmans», en X. L. Couceiro et ál., Homenaxe ó profesor Camilo Flores, Universidad de Santiago de Compostela, Servicio de Publicacións e Intercambio Científico, Santiago de Compostela, 1999, 2. ${ }^{\circ}$ vol., pp. 434-441.

LETHÈVE, J., «Le thème de la décadence dans les lettres françaises à la fin du XIXe siècle», Revue d'Histoire littéraire de la France, 1963, n. ${ }^{\circ} 1$.

Mathias, P., "De l'imaginaire au psychosomatique dans la sensibilité décadente», L'Esprit de décadence, I, Minard, Nantes, 1980.

PALACIO, J. de, "À rebours, ou les leçons du rangement d'une bibliothèque», en Joris-Karl Huysmans. À rebours. Colloque de la Société des Études Romantiques, SEDES, París, 1992.

RAIMOND, M., "Huysmans et le discours psychologique», en Huysmans. Une esthétique de la décadence. Actes du Colloque de Bâle, Mulhouse et Colmar de novembre 1984, Slatkine, Ginebra-París, 1987.

Roger, A., "Huysmans et Schopenhauer», en Huysmans. Une esthétique de la décadence. Actes du Colloque de Bâle, Mulhouse et Colmar de novembre 1984, Editions Slatkine, Ginebra-París, 1987.

Roger, P., «Huysmans entre Sade et 'sadisme'», en Huysmans, Une esthétique de la décadence, Actes du Colloque de Bâle, Mulhouse et Colmar de novembre 1984, Slatkine, Ginebra-París, 1987.

\section{Tesis doctorales y tesinas}

AmezÚa AmezÚA, J., Huysmans en el fin de siglo hispánico, tesis de la Universidad de Valladolid, 2002.

BRENNAN, D., La conversion de J.-K. Huysmans et son œuvre religieuse, Montpellier, 1993. 
Estevan Sanchiz, M. ${ }^{a}$ L., La crisis del naturalismo en Joris Karl Huysmans, Universidad de Valencia, Facultad de Filología, 1982.

JimÉNEZ TOMÉ, M. ${ }^{a}$ J., J.-K. Huysmans, del naturalismo al misticismo, Universidad de Málaga, Málaga, 1988.

LAVELÉE, G., Essai sur la psychologie morbide de Huysmans (tesis para el doctorado en Medicina), París, 1917.

Medrano Dorantes, A. M., La inscripción pictórica en la obra de Joris Karl Huysmans (tesis doctoral), Universidad de Sevilla, 1998.

Morales Gil, F. J., Un exemple de décadentisme: Huysmans et la cuisine (tesina de licenciatura), Universidad de Sevilla, 1984.

Rolland, P., Étude psychopathologique sur le mysticisme de J.-K. Husymans (tesis para el doctorado en Medicina), París, 1932.

TACIUM, D., Le dandysme et la crise de l'identité masculine à la fin du XIXe siècle: Huysmans, Pater, Dossi, Université de Montréal, Département de littérature comparée, Faculté des arts et sciences, tesis para el doctorado en literatura comparada, 1998 (consultada en Internet). S. d.

VeYsSET, G., Huysmans et la médecine, Université de Lyon G. de Bussac, ClermontFerrand, 1950.

\section{Otros}

Los 96 números del Bulletin de la Société J.-K. Huysmans, editados entre 1927 y 2003.

\section{3) Narratología y crítica literaria}

\section{Libros}

Alberes, R. M., Histoire du roman moderne, Albin Michel, París, 1962.

AuERBACH, E., Mimésis. La représentation de la réalité dans la littérature occidentale, Gallimard Tel, París, 1990.

BADESCO, L., La génération poétique de 1860, Nizet, París, 1971.

Barthes, R., Plaisir du texte, Seuil, París, 1982.

CASSAGNE, A., La théorie de l'art pour l'art en France chez les derniers romantiques et les premiers réalistes, Slatkine Reprints, Ginebra, 1979.

Charle, C., La crise littéraire à l'époque du naturalisme, PENS, París, 1979.

CiplijausKaité, B., La novela femenina contemporánea (1790-1985), Anthropos, Barcelona, 1994.

Cobos Castro, E., La paradoja interna del Naturalismo francés, Córdoba, 1982. 
Dотоli, G., Situation des études bloyennes, Nizet, París, 1970.

- Autobiographie de la douleur: Léon Bloy écrivain et critique, Klincksieck, París, 1998.

Dubois, J., Les romanciers du réel, Seuil Points, París, 2000.

Duffoux, L., y E. ZaVIE, Le groupe de Médan, Payot, París, 1920.

FetTERLEY, J., The Resisting reader. A feminist approach to American fiction, Indiana University Press, Bloomington, 1978.

GIRARD, R., Mensonge romantique et Vérité romanesque, Grasset, París, 1961.

Huret, J., Enquête sur l'évolution littéraire, Charpentier, París, 1891 (reeditado con notas y prefacio de Daniel Grojnowski en la editorial Thot, Vanves, 1982).

HutcheOn, L., A poetics of Postmodernism: Theory, History, Fiction, Routledge, Nueva York y Londres, 1995.

IsER, W., L'acte de lecture. Théorie de l'effet esthétique, Pierre Mardaga, Bruselas, 1984.

Laforgue, R., Leechec de Baudelaire, Denoël et Steele, París, 1931.

Lejeune, P., Le pacte autobiographique, Seuil, París, 1975.

LuKaCs, G., La théorie du roman, Gonthier, Médiations, París, 1975.

Martino, P., Le roman réaliste sous le Second Empire, Hachette, París, 1913.

Mitterrand, H., Le discours du roman, P.U.F. Écriture, París, 1980.

- Lillusion réaliste. De Balzac à Aragon, P.U.F. Écriture, París, 1994.

Moers, E., Literary Women: the great writers, Doubleday, Nueva York, 1976.

MoI, T., Critica literaria feminista, Cátedra, Madrid, 1988.

Molloy, S., entrevista en Gabriela Speranza, Primera persona. Conversaciones con quince narradores argentinos, Grupo Editorial Norma, Buenos Aires, 1997.

Mondor, H., Vie de Mallarmé, Gallimard, París, 1941.

Noulet, É., L'oeuvre poétique de Stéphane Mallarmé, París, Droz, 1940.

Pater, W., Plato and Platonism: a series of lectures, Macmillan, Londres, 1910.

Raimond, M., Le roman depuis la Révolution, A. Colin, París, 1967.

- Le roman depuis la Révolution, A. Colin, París, 1971.

RaYNAUd, E., La mêlée symboliste, vol. 1, La Renaissance du Livre, París, 1920.

RichARD, J.-P., Littérature et sensation, Le Seuil, París, 1954.

ROBERT, M., Roman des origines et origines du roman, Grasset, París, 1972.

Rodríguez, I. (comp.), Cánones literarios masculinos y relecturas transculturales (lo trans-femenino/masculinolqueer), Anthropos, Barcelona, 2001.

SAVINIO, A., Maupassant y «el otro», Bruguera, Barcelona, 1983.

SHOWALTER, E., A Literature of their own. British women novelists from Brontë to Lessing, Princeton University Press, Princeton, N. J., 1971.

STAROBINSKI, J., Portrait de l'artiste en saltimbanque, Flammarion, París, 1970. 
Steiner, G., Dans le Château de Barbe-Bleue. Notes pour une redéfinition de la culture, trad. de Lucienne Lotringer, Gallimard Folio, París, 1973.

SteinmetZ, J.-L., «Notes» a Conde de Lautréamont, Les Chants de Maldoror y Poésies, Garnier-Flammarion, París, 1990.

Weber, J.-P., Genèse de l'ouvre poétique, Gallimard, París, 1960.

- Néocritique et paléontocritique ou contre Picard, J. J. Pauvert, París, 1966.

YURKIÉVICH, S., Fundadores de la nueva poesía latinoamericana, Ariel, Barcelona 1984, pp. 193-194.

\section{Artículos}

AsholT, W., «La question de l'argent. Quelques remarques à propos du premier texte littéraire de Vallès», Revue d'études vallésiennes, n. ${ }^{\circ}$ 1, 1984, pp. 5-15.

Collin, F., «Poética y política, o los lenguajes sexuados de la creación», en N. Ibeas y M. A. Millán (eds.), La conjura del olvido. Escritura y feminismo, Icaria Antrazyt, Barcelona, 1997, pp. 61-74, traducción de las editoras.

— «Nom du père. On de la mère. De Beauvoir à Lacan», Lectora. Revista de Dones i Textualitat, Universitat Autònoma de Barcelona, 1998, pp. 23-35.

Dupont, J., "Contre le Naturalisme», Magazine Littéraire, n. o 288, 1991, pp. 23-25.

REGISTER, C., «American feminism literary Criticism: a bibliographical introduction", en J. Donovan (ed.), Feminist literary Criticism. Explorations in theory, The University Press of Kentucky, Lexington.

Rossi, R., «La diferencia sexual y los escritores de sexo masculino», en N. Ibeas y M. A. Millán (eds.), La conjura del olvido. Escritura y feminismo, Icaria Antrazyt, Barcelona, 1997, pp. 137-142, traducciones de las editoras.

SHOWALTER, E., "Towards a feminist poetics», en M. Jacobus (ed.), Women writing and writing about women, Croom Helm, Londres.

- «Feminist criticism in the wilderness», Critical Inquiry, 8, 1, pp. 22-41.

— «Comment on Jehlen», Signs, 8, 1, pp. 160-164.

\section{4) Napoleón}

\section{Libros}

Guillemin, H., Napoléon tel quel, Éditions de Trévise-Le Livre de Poche, París, 1969. Heine, H., Reisebilder, Hoffmann y Campe, Dusseldorf, 1827 (versión al español: Cuadros de viaje, traducción y edición de Isabel García Adánez, Gredos, Madrid, 2003). 
Parinaud, M.-H., Vidocq, le Napoléon de la police, Taillandier, París, 2001.

Tulard, J., L'anti-Napoléon, la légende noire de l'Empereur, Julliard, París, 1965.

\section{Artículos}

VAlero GANCEDO, A., «Napoleón Bonaparte y el mito de la paternidad en el romanticismo francés», pp. 277-292, en A. Ramos Santana (ed.), La identidad masculina (en los siglos XVIII y XIX), Servicio de Publicaciones de la Universidad de Cádiz, Cádiz, 1997, pp. 23-34.

\section{5) Dandis y dandismo}

\section{Libros}

AnNunZio, G. D', L'Enfant de volupté, 1895.

BAlZAC, H. de, Les Illusions perdues, Gallimard Folio, París, 1961, 1971, 1974.

- Splendeur et misères des courtisanes, G. F. Flammarion, París, 1968.

- Le Père Goriot, Générale Française-Le Livre de Poche, París, 1983.

- La Recherche de l'absolu, Librairie Générale Française-Le Livre de Poche, París, 1999.

- Eugénie Grandet, Maxi-Livres, París, 2002.

- La Peau de chagrin, Gallimard, coll. Folio Classique, París, 2003.

Barbey D’aurevilly, J., Les Diaboliques, Gallimard Folio, París 1973.

BAudelaire, C., Les Fleurs du mal, Librairie Générale Française-Le Livre de Poche, París, 1972.

- Le Spleen de París, G. F.-Flammarion, París, 1987.

- Le Dandy, «Le peintre de la vie moderne», en Écrits sur l'art, Librairie Générale Française-Le Livre de Poche, París, 1992.

Bulwer-Lytton, E., Pelham ou Aventures d'un gentleman, Hachette, París, 1883.

CAMUS, A., L'Homme révolté, Gallimard, París, 1951.

CARAssus, É., La mythe du dandy, Armand Colin, París, 1971.

François, S., Le dandysme et Marcel Proust, de Brummell au baron de Charlus, Palais de l'Académie, Bruselas, 1956.

Hugo, V., Les Misérables, Maxi-Livres, París, 2002.

L'isle-Adam, V. de, Contes cruels, Booking International, París, 1995.

LORRAIn, J., Monsieur de Phocas, Ollendorf, París, 1901.

Matthieu, G., Dandies and dandism, United States Lines, 1962.

STENDHAL, Le Rouge et le noir. Chronique du XIXe siècle, Gallimard Folio, París, 1972. 
StendHal, De l'Amour, ed. de V. Del Litto, Gallimard Folio, París, 1980.

- La Chartreuse de Parme, Librairie Générale Française-Le Livre de Poche, París, 1983.

WALDBERG, P., «Les rois frivoles», en Dandies and dandism, United States Lines, 1962.

\section{Artículos}

Coblence, F., «Le dandy, androgyne de l'histoire?», en H. Amigorena y F. Monneyron (eds.), Le masculin. Identité, fictions, dissémination, L'Harmattan, ParísMontreal, 1998.

Dolto, F., «Dandy-Solitaire et singulier», en Dandies and dandism, United States Lines, 1962.

Monneyron, F., "Le dandy fin de siècle: entre l'androgyne et le mysogine», en A. Montandon, L'honnête homme et le dandy, Gunter Narr Verlag, Tubinga, 1993.

Puelles Romero, L., "La voluntad de apariencia: estética del dandysmo», en A. Ramos Santana (ed.), La identidad masculina (en los siglos XVIII y XIX), Servicio de Publicaciones de la Universidad de Cádiz, Cádiz, 1997, pp. 23-34.

6) Vampiros, diablos y diablesas, mujeres fatales, misoginia

\section{Libros}

Auraix-Jonchière, P., Les diaboliques de Barbey D'Aurevilly, Gallimard, col. Foliothèque, 1999.

- Lilith, avatars et métamorphoses d'un mythe entre romantisme et décadence, Presses Universitaires Blaise Pascal, Clermont-Ferrand, 2002.

BADE, P., Femme Fatale. Images of evil and fascinating women, Mayflower Books, Nueva York, 1979.

Ballesteros, A., Vampire Chronicle. Historia natural del vampiro en la literatura anglosajona, Unaluna, Zaragoza, 2000.

Barina, A., et ál., Melusina. Mito e leggenda di una donna serpente, Utopia, Roma, 1986.

BlatTY, W. P., The Exorcist, Bantam Books, Nueva York, 1972 (versión española de Raquel Albornoz, El exorcista, Planeta, Barcelona, 1984) (Film The Exorcist: dir. William Friedkin, guion de W. P. Blatty, WB, 1973).

BoIs, J., Le satanisme et la magie, Léon Challey, París, 1895.

BornaY, E., Las hijas de Lilith, Ensayos Arte Cátedra, Madrid, 1995. 
Delbanco, A., La muerte de Satán, trad. de Jaime Collyer, Andrés Bello, Barcelona, 1997.

Études Carmélitaines, Satán. Estudios sobre el adversario de Dios, trad. de Luis Miguel Rodríguez Condal, Labor, colección Maldoror, Barcelona, 1975.

Frayling, C., Vampyres, Faber, Londres, 1991.

Goncourt, E. de, La Faustin, coll. Babel, Actes Sud, Arles, 1995.

LEDERER, W., La peur des femmes ou Gynophobia, Payot, París, 1970.

LE Rider, J., Le cas Otto Weininger, P.U.F., París, 1982.

MärTin, R.-P., Los Drácula. Vlad Tepes, el Empalador, y sus antepasados, Tusquets Andanzas, Barcelona, 2001.

Milner, M., Le diable dans la littérature française. De Cazotte à Baudelaire, José Corti, París, 1960.

- L’homme et le diable, Mouton, París-La Haya, 1965.

Pommeroy, S. B., Diosas, rameras, esposas y esclavas, Akal, Madrid, 1987.

Praz, M., La chair, la mort et le Diable. Le Romantisme noir, trad. de Constance Thompson Pasquali, Denoël, París, 1977.

Rogers, K. M., The trouble some Helpmate. A History of misogyny in literature, University of Washington Press, Seattle, 1966.

Stoker, B., Dracula, Penguin Books, Londres, 1994.

THIele, R., Satanismus als Zeitkritik bei Joris-Karl Huysmans, Peter D. Lang, Fráncfort del Meno, 1979.

VignY, A. de, Poésies, ed. de A. Bouvet, Éditions de Cluny, París, 1937.

\section{Artículos}

BuZZATI, G., "L'invenzione dell'isterica», en Verso: il luogo delle origini, Centro Documentazione Donna di Firenza, La Tartaruga, Milán, 1992.

CALDAIN, J., «Le satanisme est-il pratiqué aujourd'hui?», Le Matin, 21 de abril de 1908.

Dottin-Orsini, M., «Mysoginies fin-de siècle», Magazine Littéraire, n. ${ }^{\circ}$ 288, 1991, pp. 20-23.

Lemoine-Luccioni, E., "Review of Spéculum», Esprit, 43, 3, pp. 466-469, París, 1975.

LE RIDER, J., «Thomas Bernhard: La mysoginie d'un poète maudit», Repères, n. ${ }^{\circ}$ 4, Lausana, 1997.

SERNA, J., "Simpatía por el vampiro», Claves de Razón Práctica, n. ${ }^{\circ}$ 125, Madrid, septiembre, 2002. 


\section{7) Psicología, psicoanálisis y literatura}

\section{Libros}

BaCHelard, G., L'eau et les rêves. Essai sur l'imagination de la matière, José Corti, París, 1942.

- La Terre et les rêveries du repos, José Corti, París, 1984.

Bellemin-NoËL, J., Vers l'inconscient du texte, P.U.F., París, 1979.

Bettelheim, B., Psicoanálisis de los cuentos de hadas, trad. de Silvia Furió, Crítica, col. Drakontos, Barcelona, 1995.

BlanCHOt, M., L'Entretien infini, Gallimard, París, 1969.

Bleichmar, E., Género, psicoanálisis y subjetividad, Paidós, Buenos Aires, 1996.

Bleichmar, H., Angustia y fantasma, Madrid, Adotraf, 1986.

Bonaparte, M., Edgar Poe, París, 1933.

- La sexualité de la femme, P.U.F., París, 1951.

Bourget, P., Essais de psychologie contemporaine, Gallimard, París, 1953.

Burgin, V., J. Donald y C. Kaplan (comps.), Formations of fantasy, Methuen, Londres, 1986.

Buss, D. M., The Evolution of Desire: Strategies of Human Mating, Basic Books, Nueva York, 1994.

CAMPBell, J., El héroe de las mil caras: psicoanálisis del mito, Fondo de Cultura Económica, Méjico DF, 1989, 2001.

Chassenet-Smirgel, J., Female sexuality, University of Michigan Press, Ann Harbor, 1970.

- Pour une Psychanalyse de l'art et de la créativité, Payot, París, 1971.

Clancier, A., Psicoanálisis. Literatura. Crítica, trad. de M. a José Arias, Cátedra, Madrid, 1976.

Delattre, J., trabajo presentado al Seminario de J. Chassenet-Smirgel, Institut de Psychanalyse, París, 1970.

Dubet, F., y M. Wieviorka (eds.), Penser le sujet, Fayard, París, 1995.

Durand, G., Le décor mythique de la Chartreuse de Parme. (Les structures figuratives du roman stendhalien), José Corti, París, 1983.

- Les structures anthropologiques de l'imaginaire, Dunod, París, 1984.

Freud, S., Abrégé de psychanalyse, P.U.F., París, 1967.

- L'avenir d'une illusion, P.U.F., París, 1971.

- Tres ensayos para una teoría sexual, en Obras Completas, traducción de Luis López-Ballesteros y de Torres, edición de Jacobo Numhauser Tognola, Biblioteca Nueva, Madrid, 1972, vol. IV, pp. 1169-1237. 
Freud, S., Los actos obsesivos y las prácticas religiosas, en Obras Completas, ib., vol. IV, pp. 1337-1342.

- La moral sexual «cultural» y la nerviosidad moderna, en Obras Completas, ib., vol. IV, pp. 1249-1261.

- La novela familiar del neurótico, en Obras Completas, ib., vol. IV, pp. 1361-1363.

- Las fantasías histéricas y su relación con la bisexualidad, en Obras Completas, ib., vol. VII, pp. 1349-1353.

- «Un recuerdo infantil de Leonardo de Vinci», en Obras Completas, ib., vol. v, pp. 1577-1619.

- Introducción al narcisismo, en Obras Completas, ib., vol. vI, pp. 2017-2033.

- Duelo y melancolía, en Obras Completas, ib., vol. VI, pp. 2091-2101.

- Disolución del complejo de Edipo, en Obras Completas, ib., vol. vII, pp. 27482751.

- Fetichismo, en Obras Completas, ib., vol. vIII, pp. 2993-2996.

- Dostoyevski y el parricidio, en Obras Completas, ib., vol. vIII, pp. 3004-3015.

- "La feminidad», en Nuevas lecciones introductorias al psicoanálisis, en Obras Completas, ib., vol. vIII, pp. 3164-3178.

- Psicoanálisis aplicado y Técnica psicoanalítica, Alianza Editorial, Madrid, 1979.

- Introducción al Psicoanálisis, trad. de Luis López Ballesteros y de Torres, Alianza Editorial, Madrid, 1994.

- El malestar en la cultura, Alianza Editorial, Madrid, 1997.

- Conférences d'introduction à la psychanalyse, Gallimard, París, 1999.

- Tótem y tabú, trad. de Luis López-Ballesteros y de Torres, Alianza Editorial, Madrid, 2000.

GARBER, F., The autonomy of the selffrom Richardson to Huysmans, Princeton University Press, Princeton, N. J., 1982.

JONES, E., La vie et l'oeuvre de Sigmund Freud, trad. de Anne Berman, P.U.F., París, 1972.

JunG, C.-G., Arquetipos e inconsciente colectivo, Paidós, Barcelona, 1991.

- Psicología y simbología del arquetipo, Paidós, Barcelona, 1992.

- Símbolos de transformación, Paidós, Barcelona, 1993.

- Psicología y religión, Paidós, Barcelona, 1994.

KLEIN, M., Essais de Psychanalyse, Payot, París, 1989.

- El Psicoanálisis de niños, Paidós, Barcelona, 1994.

Kofman, S., L'enfance de l'art. Une interprétation de l'esthétique freudienne, Petite Bibliothèque Payot, París, 1975.

- L'enigme de la femme: la femme dans les textes de Freud, Galilée, París, 1980.

LACAN, J., "La significación del falo», en Escritos, trad. de Tomás Segovia, Siglo XXI, Madrid, 1972. 
LaCan, J., El Seminario XX. Aún, Paidós, Barcelona, 1981.

Laplanche, J., Hölderlin et la question du Père, P.U.F., París, 1961.

Laplanche, J., y J.-B. Pontalis, Vocabulaire de la psychanalyse, P.U.F., París, 1981.

Mauron, C., L'inconscient dans la vie et l'auvre de Jean Racine, Gap., Ophrys, 1957.

- Psychocritique du genre comique, José Corti, París, 1963.

- Des métaphores obsédantes au mythe personnel, José Corti, París, 1966.

- Le dernier Baudelaire, José Corti, París, 1966.

- Phèdre, José Corti, París, 1968.

Mendel, G., La rebelión contra el Padre. Una introducción al Sociosicoanálisis, Península, Barcelona, 1971.

MiLner, M., Freud et l'interprétation de la littérature, SEDES, París, 1997.

Mitchell, J., Psicoanálisis y feminismo, Anagrama, Barcelona, 1975.

- Feminine Sexuality. Jacques Lacan and the Ecole Freudienne, Macmillan, Londres, 1982 (con Jacqueline Rose, eds.).

Musil, R., "Oedipe menacé», en R. Musil, Euvres posthumes, Seuil, París, 1931.

PonTAlis, J. B., Vigencia de Sigmund Freud, trad. de Léon Rozitcher, Siglo XX, Buenos Aires, 1957.

Raymond, M., De Baudelaire al Surrealismo, trad. de J. J. Domenchina, Fondo de Cultura Económica, Méjico, 1960.

- Renversements psychiques et permanence de l'être, vol. 29, Annales J. J. Rousseau, José Corti, 1962.

ROSE, J., La sexualité féminine dans la doctrine freudienne, Seuil, París, 1976.

TUBERT, S., La sexualidad femenina y su construcción imaginaria, Fundación José Ortega y Gasset, El Arquero, Madrid, 1988.

- Deseo y representación. Convergencias de psicoanálisis y teoría feminista, Síntesis, Madrid, 2001.

\section{Artículos}

BESANÇON, A., «Vers une histoire psychanalytique», Annales, mayo de 1969.

FERnAndeZ, D., «Incidences de la psychanalyse», Nouvelle Revue de Psychanalyse, n. ${ }^{\circ}$ 1, París, 1970.

Jones, A. R., "Writing the Body: towards an understanding of l'Écriture féminine», Feminist Studies, n. ${ }^{\circ}$ 2, verano de 1981.

Mauron, C., «La psychocritique et sa méthode», Orbis litterarum. Revue Internationale d'Études littéraires, Copenhague, 1958.

M'UZAN, M. de, "Observaciones sobre el proceso de la creación literaria», Revue Française de Psychanalyse, n. ${ }^{\circ}$ 1, 1965, pp. 43-64. 
Parker, I., "Hombre, mito y subjetividad psicoanalítica», Archipiélago, n. ${ }^{\circ} 30$, 1997.

PlAZA, M., "'Phallomorphic power' and the psychology of 'woman'», Ideology and Consciousness, 4, otońo, Nueva York, 1978, pp. 4-36.

Rose, J., «Feminity and its Discontents», Feminist Review, n. ${ }^{\circ}$ 14, 2002 (revista electrónica).

STOLLER, R., «Faits et hypothèses: un examen du concept freudien de bisexualité», Nouvelle Revue de Psychanalyse, 1973, n. ${ }^{\circ}$ 7, pp. 135-155.

TUBERT, S., «Introducción a la edición española», en J. Flax, Psicoanálisis y feminismo. Pensamientos fragmentarios, Feminismos Cátedra, Madrid, 1995, pp. 7-41.

- «Los monstruos femeninos de la cultura europea», en Vidal, Alarcón y Lolas (comps.), Enciclopedia Iberoamericana de Psiquiatría, Editorial Médica Panamericana, Buenos Aires, 1995, pp. 976-979.

- «Sacralización y ocaso de la figura paterna», en C. Sánchez-Palencia y J. C. Hidalgo (comps.), Masculino plural: construcciones de la masculinidad, Universidad de Lérida, 2001, pp. 183-202.

Vidal, Alarcón y Lolas (comps.), Enciclopedia Iberoamericana de Psiquiatría, Editorial Médica Panamericana, Buenos Aires, 1995, pp. 976-979.

\section{8) Antropología}

\section{Libros}

BAteson, G., Naven: the culture of the Iatmul People of New Guinea as revealed through a study of the 'Naven' ceremonial, Stanford University Press, Stanford, California, 1958. Traducción española: Naven. Un ceremonial iatmul, Júcar, Gijón, 1990.

BнaвHA, H. K., The Location of Culture, Routledge, Londres y Nueva York, 1994.

Gilmore, D., Hacerse Hombre. Concepciones culturales de la masculinidad, Paidós, Barcelona, 1994.

Harris, O., y K. Young (comps.), Antropología y feminismo, Anagrama, Barcelona, 1979, pp. 153-180.

KaNT, I., Anthropologie du point du vue pragmatique, trad. M. Foucault, Vrin, París, 1964.

KIRKPATRICK, L., The Marquesan Notion of the person, University of Michigan Research Press, 1983.

LÉVI-STRAuss, C., Las estructuras elementales del parentesco, Paidós, Buenos Aires, 1969. 
LÉVI-STrauss, C., Antropología estructural, Eudeba, Buenos Aires, 1980.

Martin, M. K., y B. Voorhies, Female of the species, Columbia University Press, Nueva York, 1975.

Moia, M. I., El no de las niñas. Feminario antropológico, Lasal, Edicions de les Dones, Barcelona, 1981.

MorGan, L. H., Sociedad antigua, o Investigaciones sobre el progreso humano desde el salvajismo a través de la barbarie hasta la civilización, Macmillan, Londres, 1877.

NANDA, S., Neither man nor woman: the hijras of India, Wadsworth, Belmont, California, 1990.

Nieto, J. A., Antropología de la sexualidad y diversidad cultural, Talasa, colección Ágora, Madrid, 2003.

\section{Artículos}

Bolin, A., "La transversalidad de género. Contexto cultural y prácticas de género», trad. de Carlo A. Aranci, en J. A. Nieto, Antropología de la sexualidad y diversidad cultural, Talasa, colección Ágora, Madrid, 2003.

EDgERTON, R. B., «Pokot intersexuality: an East African example of the resolution of sexual incongruity", American Anthropologist, vol. 66, n. ${ }^{\circ}$ 6, Pt. I (diciembre de 1964).

GodeliER, M., "Le sexe en tant que fondement dernier de l'ordre social et cosmique chez les Baruya de Nouvelle Guinée», en Sexualité et pouvoir, Congreso internacional de psicoanálisis de noviembre de 1975 en Milán, Payot, París, 1976.

HERDT, G., y A. BOXER, «Bisexualidad. Hacia una teoría comparativa de las identidades y la cultura", trad. de Carlo A. Aranci, en J. A. Nieto, Antropología de la sexualidad y diversidad cultural, Talasa, colección Ágora, Madrid, 2003.

HILL, W. W., «The Status of the hermaphrodite and travestite in Navajo culture», American Anthropologist, vol. 37, abril de 1935.

KEESING, R. M., «Introduction», en G. Herdt (comp.), Rituals of Manhood, University of California Press, Berkeley, 1982.

LEWIS, O., "Manly-hearted Women amongst the North Piegan», American Anthropologist, vol. 43, abril-junio de 1941.

NANDA, S., "Hijra y Sādhin. Ni hombre ni mujer en la India», trad. de Carlo A. Aranci, en J. A. Nieto, Antropología de la sexualidad y diversidad cultural, Talasa, colección Ágora, Madrid, 2003.

Rosaldo, M., "Mujer, cultura y sociedad: una visión teórica», en O. Harris y K. Young (comps.), Antropología y feminismo, Anagrama, Barcelona, 1979, pp. 153-180. 
SLADE, D. L., «Status marital e identidad sexual», en O. Harris y K. Young (comps.), Antropología y feminismo, Anagrama, Barcelona, 1979, pp. 153-180.

WIKAN, U., «Man becomes woman: transexualism in Oman as a key to gender roles», Man, nueva serie, vol. 12, n. ${ }^{\circ}$ 2, agosto de 1977.

\section{9) Sociología}

\section{Libros}

Berger, P., y T. Luckmann, The Social Construction of reality, Doubleday, Nueva York, 1966.

Bourdieu, P., Notions de sociologie, Éditions de Minuit, París, 1984.

- Les règles de l'art. Genèse et structure du champ littéraire, Seuil, París, 1992 (versión española: Las reglas del arte, trad. de Thomas Kauf, Anagrama Ensayo, Barcelona, 1995).

- La domination masculine, Seuil, París, 1998.

CASTELls, M., La era de la información. Economía, sociedad y cultura, vol. 2: El poder de la identidad, trad. de Carmen Martínez Gimeno, Alianza Editorial, Madrid, 1999.

Giddens, A., Modernity and Self-identity: Self and Society in the Late Modern Age, Polity Press, Cambridge, 1991 (versión española: La transformación de la identidad, Cátedra, Madrid, 1996).

GODELIER, M., Sur les sociétés précapitalistes, Éd. Sociales, París, 1970.

LAUfER, J., C. MARRY y M. MARUANI (dirs.), Le travail du genre. Les sciences sociales du travail à l'épreuve des différences de sexe, La Découverte, París, 2004.

Marcuse, H., L’homme unidimmensionel, Minuit, París, 1968.

Parsons, T., y R. F. BALES, Family, socialization, and Interaction process, Free Press, Glencoe, Illinois, 1955.

SENNETT, R., La corrosión del carácter. Las consecuencias personales del trabajo en el nuevo capitalismo, Anagrama, col. Argumentos, Barcelona, 2000.

Sensat, R., Les ciències en la vida de la llar, Associació Protectora de l'Ensenyança Catalana, Barcelona, 1923.

Tilly, L., y J. SCOTT, Women, Work and Family, Holt, Rinehart and Winston, Nueva York, 1978.

Van Caegenem, R. C., An Historical Introduction to Private Law, Cambridge University Press, Cambridge, 1991.

Weber, M., La ética protestante y el «espiritu» del capitalismo, Sociología Alianza Editorial, Madrid, 2001. 


\section{Artículos}

ARENDT, H., "¿Qué es la autoridad?", en Entre el pasado y el futuro. Ocho ejercicios sobre la reflexión política, Península, Barcelona, 1996.

Bourdieu, P., "Célibat et condition paysanne», Études rurales, n. ${ }^{5}$ 5-6, 1962, pp. 33-135.

— «Les stratégies matrimoniales», Annales: économies, sociétés, civilisations, vol. 27, pp. 1105-1126, París, 1972.

DurkHEIM, É., "La famille conjugale», L’Année sociologique 1892, pp. 35-49.

Godelier, M., «Mode de production. Relations de parenté et structures démographiques», La Pensée, n. ${ }^{\circ} 172$, diciembre 1973.

Marcuse, H., "A Critique of Norman O. Brown», en Negations: essays on critical theory, Macmillan, Londres, 1968, pp. 227-247.

Minchinton, W., "Patterns of Demand 1750-1914», en C. M. Cipolla (comp.), The Fontana Economic History of Europe: The Industrial Revolution, Collins/Fontana Books, Nueva York, 1973, pp. 738-820.

PiÑERo Auguet, L., «Embarazarse para ser alguien. Planteando un debate acerca de la anatomía como único destino de las mujeres pobres», en Utopías, nuestra bandera, n. ${ }^{\circ}$ 195, «Feminismos», P.C.E., Madrid, 2003.

Touraine, A., "La formation du sujet», en F. Dubet y M. Wieviorka (eds.), Penser le sujet, Fayard, París, 1995.

VEever, J. E., "Voluntary childless Wives: an exploratory study», Sociology and Social Research, abril de 1973.

\section{0) Sociología de la familia}

\section{Libros}

ArIÈs, P., y G. DuBY, Historia de la vida privada, tomo 7, La Revolución francesa y el asentamiento de la sociedad burguesa, dirigido por Michelle Perrot, Taurus, Madrid, 1991.

Brissaud, J., A History of French Private Law, Little, Brown and Co., Boston, 1912. Davidoff, L., y C. Hall, Family Fortunes: Men and Women of the English Middle Class, 1780-1850, University of Chicago Press, Chicago, 1987 (versión española: Fortunas familiares, Cátedra, Madrid, 1994).

ELLIS, S. S., The Women of England: Their Social Duties, and Domestic Habits, Fisher, Londres, 1839. 
Engels, F., L'origine de la famille, de la propriété privée et de l'État, Éd. Sociales, París, 1971.

LLOYD, R., The Land of lost content: children and childhood in Nineteenth-Centruy french litterature, Clarendon Press, Oxford, 1992.

LYNCH, K., Family, Class and Ideology in Early Industrial France: Social Policy and the Working-Class Family, 1825-1848, University of Wisconsin Press, Madison, Wisconsin, 1988.

RoudinesCo, E., La familia en desorden, trad. de Óscar Luis Molina, Anagrama, Barcelona, 2004.

Stone, L., y J. C. FaWtier, An open elite? England 1540-1880, Clarendon Press, Oxford, 1984.

Sussman, G. D., Selling Mother's Milk: the wet-nursing business in France 17151914, University of Illinois Press, Urbana, 1982.

\section{Artículos}

Augustins, G., «La perpetuación de las familias y la estructuración de los destinos personales», en D. I. Kertzer y M. Barbagli (comps.), La vida familiar desde la Revolución francesa hasta la Primera Guerra Mundial (1789-1913), trad. de Ramón Ibero, Paidós Orígenes, Barcelona, 2003, pp. 463-495.

BonfIELD, L., «La familia en la legislación europea», en D. I. Kertzer y M. Barbagli (comps.), La vida familiar desde la Revolución francesa hasta la Primera Guerra Mundial (1789-1913), trad. de Ramón Ibero, Paidós Orígenes, Barcelona, 2003.

EKLOF, B., "Worlds in conflict: patriarchal authority, discipline and the Russian school, 1861-1914», en B. Eklof (comp.), School and society in Tsarist and Soviet Russia, St. Martin's Press, Nueva York, 1993, pp. 95-120.

GutTormsson, L., "Las relaciones paterno-filiales», en D. I. Kertzer y M. Barbagli (comps.), La vida familiar desde la Revolución francesa hasta la Primera Guerra Mundial (1789-1913), trad. de Ramón Ibero, Paidós Orígenes, Barcelona 2003, pp. 369-409.

Hall, C., «Sweet Home», en P. Ariès y G. Duby (comps.), Historia de la vida privada, tomo 7: La Revolución francesa y el asentamiento de la sociedad burguesa, dirigido por Michelle Perrot, trad. de Francisco Pérez Gutiérrez y Beatriz García, Taurus, Madrid, 1991.

HunT, L., «La vida privada durante la Revolución francesa», en P. Ariès y G. Duby (comps.), Historia de la vida privada, tomo 7: La Revolución francesa y el asentamiento de la sociedad burguesa, dirigido por Michelle Perrot, trad. de Francisco Pérez Gutiérrez y Beatriz García, Taurus, Madrid, 1991. 
KerTZER, D. I., «Vivir en familia», en D. I. Kertzer y M. Barbagli (comps.), La vida familiar desde la Revolución francesa hasta la Primera Guerra Mundial (17891913), trad. de Ramón Ibero, Paidós Orígenes, Barcelona 2003, pp. 97-137.

Kertzer, D. I., y M. BARBAGLI, «Introducción», en D. I. Kertzer y M. Barbagli (comps.), La vida familiar desde la Revolución francesa hasta la Primera Guerra Mundial (1789-1913), trad. de Ramón Ibero, Paidós Orígenes, Barcelona 2003, pp. $9-47$.

MAYNES, M. J., "Culturas de clase e imágenes de la vida familiar correcta», en D. I. Kertzer y M. Barbagli (comps.), La vida familiar desde la Revolución francesa hasta la Primera Guerra Mundial (1789-1913), trad. de Ramón Ibero, Paidós Orígenes, Barcelona 2003, pp. 297-340.

Perrot, M., «Figuras y funciones», en P. Ariès y G. Duby (comps.), Historia de la vida privada, tomo 7, La Revolución francesa y el asentamiento de la sociedad burguesa, dirigido por Michelle Perrot, Taurus, Madrid, 1991, pp. 184-191.

\section{1) Feminismos y Estudios de género}

\section{Crítica literaria feminista}

\section{Libros}

Ciplijauskaité, B., La novela femenina contemporánea (1790-1985), Anthropos, Barcelona, 1994.

Cornillon, S. K. (ed.), Images of women in fiction: feminist perspectives, Bowling Green University Popular Press, Bowling Green, Ohio.

GILBERT, S. M., y S. GUBAR, The Madwoman in the attic. The woman writer and the nineteenth-century literary imagination, Yale University Press, New Haven, 1979.

Kristeva, J., Sémiotiké. Recherches pour une sémanalyse, Seuil, París, 1969.

- Des chinoises, Des Femmes, París, 1974.

- La révolution du langage poétique, Seuil, París, 1974.

- Polylogue, Seuil, París, 1977.

- Soleil noir: Dépression et mélancolie, Gallimard, París, 1987.

- Histoires d'amour, Denoël, París.

\section{Artículos}

Collin, F., «Poética y política, o los lenguajes sexuados de la creación», en N. Ibeas y M. A. Millán (eds.), La conjura del olvido. Escritura y feminismo, Icaria Antrazyt, Barcelona, 1997, pp. 61-74, traducción de las editoras.

— «Nom du père. On de la mère. De Beauvoir à Lacan», Lectora. Revista de Dones i Textualitat, Universitat Autònoma de Barcelona, 1998, pp. 23-35. 
GirOna Fibla, N., «Veinte propuestas para una relectura nerudiana», pp. 105134, en I. Rodríguez (comp.), Cánones literarios masculinos y relecturas transculturales (lo trans-femenino/masculinolqueer), Anthropos, Barcelona, 2001.

Holy, M., "Conciousness and authenticity: towards a feminist aesthetic», en J. Donovan (ed.), Feminist Literary Criticism. Explorations in Theory, The University Press of Kentucky, Lexington.

KAPLAN, C., "Radical feminist and litterature rethinking Millet's Sexual Politics», Red Letters, 9, pp. 4-16.

Kolodny, A., "Some notes on defining a 'feminist literary criticism'», Critical Inquiry, 2, 1, pp. 75-92.

KristeVA, J., «La femme, ce n'est jamais ça», Tel Quel, 59, otoño 1974, pp. 19-24.

— «Un nouveau type d'intellectuel: le dissident», Tel Quel, París, 1977.

- «Hérétique de l'amour», Tel Quel, 74, invierno 1977, pp. 30-49. Reeditado con el título de «Stabat mater», Histoires d'amour, Denoël, París, 1983.

LORENZANO, S., «Del melodrama a la experimentación: la búsqueda de una poética gozosa», pp. 201-234, en I. Rodríguez (comp.), Cánones literarios masculinos y relecturas transculturales (lo trans-femenino/masculinolqueer), Anthropos, Barcelona, 2001.

NOUZeilles, G., «La Rayuela del sexo según Cortázar», en I. Rodríguez (comp.), Cánones literarios masculinos y relecturas transculturales (lo trans-femenino/masculinolqueer), Anthropos, Barcelona, 2001, pp. 63-84.

\section{Feminismos y critica del androcentrismo}

\section{Libros}

Alzón, C., Mujer mitificada, mujer mistificada, trad. de J. M. Arancibia, Ruedo Ibérico-Ibérica de Publicaciones, París-Barcelona, 1982.

Amorós, C., Hacia una crítica de la razón patriarcal, Anthropos, Barcelona, 1985.

- 10 palabras clave sobre mujer, Verbo Divino, Pamplona, 1995.

- Tiempo de feminismo, Cátedra, Madrid, 1997.

- Feminismo y filosofía, Síntesis, Madrid, 2000.

BAKer Miller, J., Towards a new Psychology of Women, Beacon Press, Boston, 1976. Barrett, M. (ed.), Virginia Woolf: women and writing, The Women Press, Londres, 1979.

- Women's oppression today, Verso, Londres, 1980.

Beauvoir, S. de, Le deuxième sexe, Gallimard, París, 1949. 
Beauvoir, S. de, Simone de Beauvoir today. Conversations with Alice Schwartzer 1972-1982, Chato, Londres.

BEBEL, A., La femme et le socialisme, Dietz Verlag, Berlín, 1964.

Birulés, F. (comp.), Filosofía y género. Identidades femeninas, Pamiela, Pamplona, 1992.

Bleichmar, E., Género, psicoanálisis y subjetividad, Paidós, Buenos Aires, 1996.

Butler, J., El género en disputa. El feminismo y la subversión de la identidad, Paidós, Méjico DF, 2001.

CAMPs, V., El siglo de las mujeres, Cátedra-Feminismos, Madrid, 1998.

Cigarini, L., La politica del deseo, Icaria, Barcelona, 1996.

Cirillo, L., Mejor huérfanas, Anthropos, Barcelona, 2002.

Cixous, H., Prénoms de personne, Seuil, París, 1974.

- La jeune Née (en colaboración con Catherine Clément), UGE 10/18, París, 1975.

- La venue à l'écriture (en colaboración con Annie Leclerc y Madeleine Gagnon), UGE, 10/18, París, 1977.

- Le rire de la Méduse, L’Arc, 61, pp. 39-54, 1975 (versión española: La risa de la medusa. Ensayos sobre la escritura, trad. Anna Maria Moix, Anthropos, Direción General de la Mujer, Editorial de la Universidad de Puerto Rico, Barcelona, 1995).

Cobo, R., Fundamentos del patriarcado moderno, Cátedra Feminismos, Madrid, 1995.

Conley, V. A., Hélène Cixous: writing the feminine, University of Nebraska Press, Lincoln y Londres, 1984 (incluye el apéndice «An Exchange with Hélène Cixous»).

COWARD, R., Desideri di donna, Riuniti, Roma, 1984.

Daly, M., Gyn/Ecology, Beacon Press, Boston, 1978.

Dinnerstein, D., The Mermaid and the minotaur, Harper and Row, Nueva York, 1976.

Eaubonne, F. D., Les femmes avant le patriarcat, Payot, París, 1967.

Ellmann, M., Thinking about women, Harcourt, Nueva York, 1968.

Evans, M., Simone de Beauvoir: a feminist Mandarin, Tavistock, Londres y Nueva York, 1985.

Fernández, A. M., La mujer de la ilusión, Barcelona, Paidós, 1993.

Firestone, S., La dialectique du sexe, Stock, París, 1972.

FlaX, J., Psicoanálisis y feminismo. Pensamientos fragmentarios, Cátedra, Univ. de Valencia, Instituto de la Mujer, Madrid, 1995.

Friedan, B., La femme mystifiée, Gonthier, París, 1964.

FULFORD, R., Votes for Women, Faber, Londres, 1957. 
Gianni Gallino, T., La ferita e il re, Raffaelo Cortina, Milán, 1986.

- (comp.) Le grandi madri, Feltrinelli Editore, Milán, 1989.

Gilligan, C., In a different Voice. Psychological theory and women's development, Harvard University Press, 1982.

Gil Calvo, E., Medias miradas. Un análisis cultural de la imagen femenina, Anagrama Argumentos, Barcelona, 2000.

González de Chávez Fernández, M. A., Feminidad y masculinidad. Subjetividad y orden simbólico, Biblioteca Nueva, Madrid, 1998.

GonZÁlez Duro, E., Represión sexual, dominación social, Akal, Madrid, 1976.

Greer, G., La femme eunuque, Laffont, París 1971.

Histoire des Femmes, vol. 4, siglo XIX: L'Ève nouvelle et le vieil Adam, Plon, París, 1991.

IrIARTE, A., Las redes del enigma. Voces femeninas en el pensamiento griego, Taurus, Madrid, 1990.

IRIGARAY, L., Le langage des déments, Mouton, París, 1973.

- Spéculum de l'autre femme, Minuit, París, 1974.

- Ce sexe qui n'en est pas un, Minuit, París, 1977.

- Et l'une ne bouge pas sans l'autre, Minuit, París, 1979.

- Amante marine de Friedrich Nietzsche, Minuit, París, 1980.

- Parler n'est jamais neutre, Minuit, París, 1985.

- Sexes et parentés, Minuit, París, 1987.

- Je, tu, nous, Grasset et Frasquelle, París, 1992 (Yo, tú, nosotros, trad. de Pepa Linares, Cátedra, colección Feminismos, Madrid, 1992).

- J'aime à toi, Grasset et Frasquelle, París, 1992 (Amo a ti, trad. Goldstein, Icaria, Barcelona, 1994).

Joran, T., Le mensonge du féminisme, Jouve, París, 1905.

- Autour du féminisme, Plon, París, 1906.

- Au cour du féminisme, A. Savaète, París, 1907.

- Le suffrage des femmes, A. Savaète, París, 1913.

Kaplan, L., Perversiones femeninas, Paidós, Barcelona, 1994.

LAUfer, J., C. MARrY y M. MARUANi (dirs.), Le travail du genre. Les sciences sociales du travail à l'épreuve des différences de sexe, La Découverte, París, 2004.

LaUrent, A. (y le Groupe des Dix), Féminin-masculin: le nouvel équilibre, Le Seuil, París, 1975.

Laurentis, T. de, Alice doesn't. Feminism, semiotics, Cinema, Indiana University Press, Bloomington, 1984.

LeClerc, A., Parole de femme, Grasset, París, 1970.

Librería de Mujeres de Milán, No creas tener derechos, Horas y Horas, Madrid, 1991. 
Li DZeH DJen, La presse féministe en France de 1869 à 1914, París, 1934.

LiLAR, S., Le malentendu du deuxième sexe, P.U.F., París, 1997.

Lipovetsky, G., La troisième femme. (Permanence et révolution du féminin), Gallimard, París, 1997.

Magli, I., La femina dell'uomo, Laterza, Roma, 1985.

Maugue, A., Littérature antiféministe en France de 1871 à 1914, tesis doctoral, París III, inédita, 1983.

Mead, M., Male and Female. L'un et l'autre sexe, Denoël-Gonthier, París, 1966.

Meillassoux, C., Femmes, guerriers et capitaux, Maspero, París, 1975.

Millet, K., Politica sexual, Cátedra, Instituto de la Mujer, Madrid, 1995.

Mitchell, J., Psicoanálisis y feminismo, Anagrama, Barcelona, 1975.

- Feminine Sexuality. Jacques Lacan and the Ecole Freudienne, Macmillan, Londres, 1982 (con Jacqueline Rose, eds.).

MONEY, J., y A. A. EHRDHARDT, Man \& Woman, boy \& girl: the differentiation and dimorphism of gender identity from conception to maturity, The John Hopkins University Press, Baltimore, Ohio, 1993.

Mongrécien, G., Les précieux et les précieuses, Mercure de France, París, 1939.

MORENO SARDÀ, A., El arquetipo viril protagonista de la historia, Lasal, Edicions de les Dones, Barcelona, 1987.

Muraro, L., El orden simbólico de la madre, trad. Beatriz Albertini, Horas y Horas, Madrid, 1994.

Osborne, R., La construcción sexual de la realidad, Cátedra Feminismos, Madrid, 1993.

Pateman, C., El contrato sexual, trad. M. ${ }^{a}$ Luisa Femaninas, Anthropos, Madrid, 1995.

Pommier, G., L'exception féminine. Essai sur les impasses de la jouissance, Point Hors Ligne, París, 1985.

Posada Kubissa, L., Sexo y esencia. De esencialismos encubiertos y esencialismos hereditarios: desde un feminismo nominalista, Horas y Horas, Madrid, 1998.

Preciado, B., Manifiesto contra-sexual, Pensamiento Opera Prima, Madrid, 2002.

PuleO, A. H., Filosofia, género y pensamiento crítico, Universidad de Valladolid, Valladolid, 2000.

QUÉRÉ, F., La femme avenir, Seuil, París, 1976.

Richard, N., Masculinolfemenino: Prácticas de la diferencia y cultura democrática, Francisco Zegers, Santiago de Chile, 1993.

- Residuos y metáforas. (Ensayos de critica cultural sobre el Chile de la Transición), Cuarto Propio, Santiago, 1999.

Rivera GARRETAS, M.-M., El fraude de la igualdad. Los grandes desafíos del feminismo hoy, Planeta, Barcelona, 1997. 
Rivera Garretas, M.-M., Mujeres en relación. Feminismo 1970-2000, Icaria Más Madera, Barcelona, 2001.

Rodríguez, R. (ed.), Fin de siglo. Género y cambio civilizatorio, Ediciones de las Mujeres, n. ${ }^{\circ}$ 17, Isis Internacional, 1992.

Sanvitale, F., L’Eros nell'imaginario delle donne, Le Mélusine, Milán, 1992.

SAU, V., Diccionario ideológico feminista, Icaria, Barcelona, 1981.

SEGAL, L., Is the Future female?, Virago Press, Londres, 1987.

- Slow Motion. Changing Masculinities. Changing Men, Rutgers University Press, New Brunswick, N. J., 1990.

Sertillanges, A.-D., Féminisme et christianisme, Lecoffre, París, 1908.

SLEDZIEWSKI, E. G., «Revolución francesa. El giro», en Historia de las mujeres, vol. 4, siglo XIX, Santillana, Madrid, 2000.

SOlsOna I PAIRÓ, N., El saber científico de las mujeres, Talasa, colección Ágora, Madrid, 2003.

Trebilcot, J. (ed.), Mothering: Essays on Feminist Theory, Rowman \& Allanheld, Totowa, 1983.

VAlCÁRCEL, A., Sexo y Filosofía. Sobre 'mujer' y 'poder', Anthropos, Barcelona, 1991. VogT, W., Le sexe faible, M. Rivière, París, 1908.

Wittig, M., Les guerillères, Minuit, París, 1969.

- Le corps lesbien, Minuit, París, 1973.

Wollstonecraft, M., Vindicación de los derechos de la mujer, trad. Carmen Martínez Gimeno, ed. Isabel Burdiel, Cátedra Feminismos, Madrid, 1994.

Woolf, V., Al Faro, trad. José Luis López Muńoz, Alianza Editorial, Madrid, 1993.

- Orlando, trad. de Jorge Luis Borges, Diario El País, Madrid, 2002.

\section{Artículos}

Amorós, C., «Feminismo y perversión", en L. Posada Koubissa, Sexo y esencia. De esencialismos encubiertos y esencialismos heredados: desde un feminismo nominalista, Horas y Horas, colección Cuadernos Inacabados, Madrid, 1998, pp. 130-141.

BARTHES, R., «L'étrangère», La Quinzaine Littéraire, 94, 1-15 de mayo, París, 1970, pp. 19-20.

Beauvoir, S. de, Le Nouvel Observateur, 14 febrero 1972.

Birulés, J., C. Corral, M. Larrauri, M. M. MarÇAl y R. Ríus, «Fragmentos del discurso sobre la autoridad femenina», Archipiélago, n. o 30, 1997.

BuCi-GlucKsman, C., «Les femmes et la philosophie», en Etats Généraux de la Philosophie (16 et 17 juin 1979), Flammarion, París, 1979.

CaVAna, M.a L., «Diferencia», en C. Amorós (dir.), 10 palabras clave sobre mujer, Verbo Divino, Pamplona, 1995. 
Cixous, H., "Le sexe ou la tête?», Les Cahiers du GRIF, 13, 1976, pp. 5-15.

- «Entretien avec Françoise van Rossum-Guyon», Revue des Sciences Humaines, 168, octubre-diciembre 1977, pp. 479-493.

CoвO, R., «Democracia paritaria y radicalización de la igualdad», en Utopías, nuestra bandera, n. ${ }^{\circ}$ 195, «Feminismos», P.C.E., Madrid, 2003.

Echols, A., "The new Feminism of Ying and Yang», en A. Snitow et ál., Powers of Desire. The Politics of sexuality, Monthly Review Press, Nueva York, 1983.

FULLER, N., «Pensamiento feminista y los estudios sobre la identidad de género», Anuario de Hojas Warmi, n. ${ }^{\circ} 8$, Universidad de Barcelona, Centro Interdisciplinar Mujeres y Sociedad, Barcelona, 1997.

Goldman-Amirav, A., «Mira, Yahveh me ha hecho estéril», en S. Tubert (ed.), Figuras de la madre, Cátedra Feminismos, Madrid, 1996, pp. 41-51.

GrISONI, D., «El siglo XX. Las pruebas de los cuerpos», en J. P. Bardet, E. Cassin et ál., La primera vez, Planeta, Barcelona, 1981.

HARICH, W., «La mujer en el Apocalipsis», en ¿Comunismo sin crecimiento?, Materiales, Barcelona, 1978.

Hervé, J., «Dans l'ardeur du sentiment», Le Monde, 14-15 agosto 1977, p. 16.

HorneY, K., «El miedo a la mujer», en Psicología femenina, trad. de María Luisa Balseiro, Alianza Editorial, Madrid, 1986.

IRIARTE, A., "Ser madre en la cuna de la democracia o el valor de la paternidad», en S. Tubert (ed.), Figuras de la madre, Cátedra Feminismos, Madrid, 1996, pp. 73-93.

IrIGARAY, L., "Donne divine», en A. Barina et ál., Melusina. Mito e leggenda di una donna serpente, Utopia, Roma, 1986.

JEHLEN, M., «Archimedes and the paradox of feminist criticism», Signs, 6, 4, 1981, pp. 575-601.

Lemoine-LuCCiOni, E., «Review of Spéculum», Esprit, 43, 3, 1975, pp. 466-469.

Librería DE MujerES DE MiLÁN, «Fin del patriarcado. Ha ocurrido y no por casualidad», El Viejo Topo, n. ${ }^{\circ}$ 96, trad. M. ${ }^{a}$ Milagos Rivera Garretas, Barcelona, 1996.

MALDONADO, T., «Il movimento moderno e la questione post», Casabella, n. ${ }^{\circ} 463-$ 464, 1980.

MARINI, M., «La place des femmes dans la production culturelle. L'exemple de la France», en G. Duby y M. Perrot, Histoire des femmes. Le XXe siècle, 1992.

MARQUÈS, J. V., «Los dos campos ideológicos del sistema de dominación masculina», en VV.AA., Sexismo en la Ciencia, U.A.B., Barcelona, 1982.

Maugue, A., «La nueva Eva y el viejo Adán. Identidades sexuales en crisis», en Historia de las mujeres, vol. 4, Siglo XIX, Santillana, Madrid, 2000. 
Muraro, L., «Sobre la autoridad femenina», en F. Birulès (comp.), Filosofía y género. Identidades femeninas, Pamiela, Pamplona, 1992.

— «El Amor como práctica política», El Viejo Topo, n. ${ }^{\circ}$ 74, Barcelona, abril de 1994.

— «Más allá de la igualdad», en L. Posada Koubissa, Sexo y esencia. De esencialismos encubiertos y esencialismos heredados: desde un feminismo nominalista, Horas y Horas, colección Cuadernos Inacabados, Madrid, 1998, pp. 117-129.

ORTNER, S., "Is Female a male as nature is to culture?», en M. Rosaldo y L. Lamphere (eds.), Woman, culture and society, Stanford University Press, Stanford, 1989.

- y H. WhiteHEAD, «Indagaciones acerca de los significados sexuales», en Marta Lamas (comp.), Género: la construcción cultural de la diferencia sexual, Universidad Autónoma de México, Programa Universitario de Estudios de Género, Méjico DF, 1996.

Perry, F., Woman's Journal, 12 de noviembre de 1889, p. 29.

PLANTÉ, C., «La sospecha del género», en N. Ibeas y M. A. Millán (eds.), La conjura del olvido. Escritura y feminismo, Icaria Antrazyt, Barcelona, 1997, pp. 75-88.

Posada Kubissa, L., El Viejo Topo, n. ${ }^{\circ}$ 118, mayo 1998, Barcelona, 1998.

- «De discursos estéticos, sustituciones categoriales y otras operaciones simbólicas: en torno a la filosofía del feminismo de la diferencia», en C. Amorós (dir.), Feminismo y filosofía, Síntesis, Madrid, 2000.

- "Diferencia sexual y feminismo: una aproximación general», en Utopias, nuestra bandera, n. ${ }^{\circ}$ 195, «Feminismos», P.C.E., Madrid, 2003.

Puleo, A. H., «De 'eterna ironía de la comunidad' a sujeto del discurso: mujeres y creación cultural», en M. Segarra y A. Carabì (eds.), Nuevas masculinidades, Icaria, col. Mujeres y Culturas, Barcelona, 2000, pp. 65-82.

- «Feminismo y ecología. Un repaso a las diversas corrientes del ecofeminismo», El Ecologista, n. ${ }^{\circ}$ 31, verano 2002, Ecologistas en Acción, Madrid, 2002, pp. 36-39.

RICHARD, N., «Feminismo, experiencia y representación», Revista Iberoamericana, n. ${ }^{\circ}$ 176-177, Pittsburgh, 1996, p. 743.

Río, S. del, «Globalización y feminismo», en A. Morán (coord.), El movimiento antiglobalización en su laberinto, CAES-La Catarata, Madrid, 2003.

Riviere, J., "Womanliness as a Masquerade», en V. Burgin, J. Donal y C. Kaplan (comps.), Formations of fantasy, Methuen, Londres, 1986.

Sabuco CanTó, A., "Hacia una crítica del falocentrismo" (comunicación en el simposio sobre Violencia y cultura del Congreso sobre Antropología de Barcelona, en 2002), en Utopías, nuestra bandera, n. ${ }^{\circ} 195$, «Feminismos», P.C.E., Madrid, 2003. 
SAU, V., "De la facultad de ver al derecho de mirar», en M. Segarra y A. Carabì (eds.), Nuevas masculinidades, Icaria, col. Mujeres y Culturas, Barcelona, 2000, pp. 29-40.

STOLCKE, V., "Feminismo, pacifismo y antimilitarismo», The Report of the Commission on obscenity and pornography, Bantam Books, Londres, 1970.

SusI, E., "Las felices anomalías», en Hipatía. Autoridad científica, autoridad femenina, Horas y Horas, Cuadernos Inacabados, 30, Madrid, 1998.

VILA, F., «Por una Sociología de la conversación, feminista y descentrada», Contrastes, oct.-novbre. de 2002, pp. 107-111.

ZAmbONI, C., «Ordine simbolico e ordine sociale», en Diotima, Oltre l'uguaglianza. Le radici femminili dell'autorità, Liguori, Nápoles, 1995.

ZaVAlA, I., "Reflexiones sobre el feminismo en el milenio», Quimera, febrero de 1999, pp. 58-64.

\section{Maternidad}

\section{Libros}

Allen, A. T., Feminism and Motherhood in Germany, 1800-1914, Rutgers University Press, New Brunswick, N. J., 1991.

Burger, H., Die künstliche Mutter, Fisher, Hamburgo, 1982.

Burín, M., Programa Postgrado género, salud y subjetividad, Universidad Argentina Bat Ilan, 1997.

CHodorow, N., The Reproduction of mothering, The University of California Press, Berkeley y Los Ángeles, 1978 (versión espańola: El ejercicio de la maternidad, trad. Óscar Molina, Gedisa, Barcelona, 1984).

RicH, A., OfWoman born: motherhood as experience and institution, Norton, Nueva York, 1976.

Tubert, S. (ed.), Figuras de la madre, Cátedra Feminismos, Madrid, 1996.

Vegetti FinZI, S., Il Bambino della notte, Arnoldo Mondadori, Milán, 1992.

\section{Artículos}

BADINTER, E., "The Gap between Myth and reality», en Mother love, myth and reality. (Motherhood in modern History), Macmillan, Nueva York, 1981.

GimeneZ, M. E., «Feminism, pronatalism, and motherhood», en J. Trebilcot (ed.), Mothering: Essays on Feminist Theory, Rowman \& Allanheld, Totowa, 1983.

KNibiehler, Y., «Madres y nodrizas», en S. Tubert (ed.), Figuras de la madre, Cátedra Feminismos, Madrid, 1996, pp. 95-118. 
LORAuX, N., «La Madre, la Tierra», en S. Tubert (ed.), Figuras de la madre, Cátedra Feminismos, Madrid, 1996, pp. 53-69.

PARENTI, F., «La duttilità transculturale della simbologia materna e le sue componenti immutabili», en G. Gallino (comp.), Le grandi Madri, Feltrinelli, Milán, 1989.

Percovich, L., «Posiciones amorales y relaciones éticas», en S. Tubert (ed.), Figuras de la madre, Cátedra Feminismos, Madrid, 1996.

RudDick, S., «Maternal Thinking», en J. Trebilcot (ed.), Mothering: Essays on Feminist Theory, Rowman \& Allanheld, Totowa, 1983.

VEGETTI FINZI, S., «Paradossi della maternità e costruzione di un'ettica femminile», en G. Buzzatti y A. Salvo (comps.), Corpo a corpo, Laterza, Roma-Bari, 1995.

ZerilLi, L. M. G., «Un proceso sin sujeto: Simone de Beauvoir y Julia Kristeva, sobre la maternidad», en S. Tubert (ed.), Figuras de la madre, Cátedra Feminismos, Madrid, 1996, pp. 155-188.

\section{Estudios sobre hombres}

\section{Libros}

BADINTER, E., XY. La identidad masculina, trad. de Montserrat Casals, Alianza Editorial, Madrid, 1993.

BLY, R., Iron John: a book about men, Element Books, Shaftesbury, Dorset, 19901991.

Bruckner, P., y A. Finkielkraut, Le nouveau désordre amoureux, Points Seuil, París (versión española: El nuevo desorden amoroso, trad. de Joaquín Jordá, Anagrama, Barcelona, 1989).

Falconnet, G., y N. Lefaucheur, La fabrication des mâles, Seuil, París, 1975.

Fogel, G., F. M. LANE y R. S. LieberT, The Psychology of Men: new psychoanalytic perspectives, Basic Books, Nueva York.

Gil Calvo, E., El nuevo sexo débil. Los dilemas del varón posmoderno, Temas de Hoy, Madrid, 1997.

Maugue, A., L'identité masculine en crise au tournant du siècle, Rivages/Histoire, París, 1987.

Ramos Santana, A. (ed.), La identidad masculina (en los siglos XVIII y XIX), Servicio de Publicaciones de la Universidad de Cádiz, Cádiz, 1997.

Rauch, A., Le premier sexe. Mutations et crise de l'identté masculine, Hachette, París, 2000.

Reynaud, E., La sainte virilité, Syros, París, 1981. 
Schwenger, P., Phallic Critiques: Masculinity and Twentieth-Century literature, Routledge and Kegan Paul, Londres, 1984.

SeGal, L., Is the Future female?, Virago Press, Londres, 1987.

- Slow Motion. Changing Masculinities. Changing Men, Rutgers University Press, New Brunswick, N. J., 1990.

Segarra, M., y A. Carabì (eds.), Nuevas Masculinidades, Icaria, col. Mujeres y Culturas, Barcelona, 2000.

Stoller, R. J., Presentations of Gender, Yale University Press, New Haven, Connecticut, 1985.

StoltenberG, J., Refusing to be a man, A Meridian Book, 1990.

Thompson, K., Ser hombre, Kairós, Barcelona, 1993.

TOMÉ, A., y X. RAmBLA, La coeducación de las identidades masculinas en la educación secundaria, Cuadernos para la coeducación, Institut de Ciències de la Educació, Universitat Autònoma de Barcelona, Barcelona, 2001.

Valdés y Olavarría (ed.), Masculinidades. Poder y crisis, Ediciones de las Mujeres, n. ${ }^{\circ} 24$, Isis Internacional, FLACSO-Chile, 1997.

\section{Artículos}

BACARISSE, P. (ed.), «An interview with Manuel Puig», en Carnal Knowledge. Essays on the flesh, sex and sexuality in Hispanic letters and film, Tres Ríos, Pittsburgh, 1986.

BONINO, L., "Varones, género y salud mental: deconstruyendo la normalidad masculina», en M. Segarra y A. Carabì (eds.), Nuevas masculinidades, Icaria, col. Mujeres y Culturas, Barcelona, 2000, pp. 41-64.

— «Varones y comportamientos temerarios», Act. Psicológica, n. o 210 (6), 1994, pp. 24-26.

- «Micromachismos en la vida conyugal», en J. Corsi, Violencia masculina en la pareja, Paidós, Buenos Aires, 1995.

— «La identidad masculina a debate», Área, n. ${ }^{\circ} 3-4,1996$, pp. 16-20.

- Programa Varones, género y salud mental (en prensa), 1997.

- "Los varones frente al cambio de las mujeres», Lectora, Revista de Dones i Textualitat, 4: "Hombres y feminismo», Universidad Autónoma de Barcelona, 1998, pp. 7-22.

CARABì, À., "Construyendo nuevas masculinidades: una introducción", en M. Segarra y A. Carabì (eds.), Nuevas masculinidades, Icaria, col. Mujeres y Culturas, Barcelona, 2000, pp. 15-27. 
Cooper, A. M., "What Men fear: the façade of castration anxiety», en G. Fogel, F. M. Lane y R. S. Liebert, The Psychology of Men: new psychoanalytic perspectives, Basic Books, Nueva York, 1986.

FinkielKRaUt, A., «La nostalgie de l'épreuve», en Le genre humain, n. ${ }^{\circ}$ 10, París, 1984.

Hallman, R., «The Archetypes of Peter Pan», Journal of Analytic Psychology, n. ${ }^{o} 14$, 1969.

KIMMEL, M., «La producción teórica sobre masculinidad: nuevos aportes», en R. Rodríguez (ed.), Fin de siglo. Género y cambio civilizatorio, Ediciones de las Mujeres, n. ${ }^{\circ}$ 17, Isis Internacional, 1992.

- «Homofobia, Temor, Vergüenza y Silencio en la Identidad Masculina», en Valdés y Olavarría (ed.), Masculinidades. Poder y crisis, Ediciones de las $\mathrm{Mu}-$ jeres, n. ${ }^{\circ}$ 24, Isis Internacional, FLACSO-Chile, 1997.

LORAUX, N., «Blessures de la virilité», Le genre humain, n. ${ }^{\circ}$ 10, Le Masculin, junio de 1984, pp. 39-56.

WhiteHEAD, H., «The Bow and the burden strap: a new look at institutionalized homosexuality in native North America», en S. B. Ortner y H. Whitehead, Sexual Meanings: the cultural construction of gender and sexuality, Cambridge University Press, Cambridge, 1981.

\section{Paternidad}

\section{Libros}

Аввот, C. G., The Correspondence of G. Manley Hopkins and Richard Watson Dixon, Oxford University Press, Londres, 1935.

Corneau, G., Père manquant, fils manqué, Les Éditions de l'Homme, Quebec, 1989.

Osherson, S., Finding our father, The Free Press, 1986.

Tubert, S. (ed.), Figuras del padre, Cátedra, col. Feminismos, Madrid, 1997.

\section{Artículos}

KnibieHLer, Y., «Padres, patriarcado, paternidad», en S. Tubert (ed.), Figuras del padre, Cátedra, col. Feminismos, Madrid, 1997, pp. 117-136.

Mulliez, J., «La désignation du père», en J. Delumeau y D. Roche (eds.), Histoire des pères et de la paternité, Larousse, París, 2000. 


\section{Transversalidad}

\section{Libros}

Boswell, H., Reviving the tradition of alternative gender, AEGIS, Decatur, Georgia, 2002.

\section{Artículos}

ARIAS, A., «Sujetos sexualizados, representatividad ambigua: articulación de lo masculino/femenino e identidad étnica en Miguel Ángel Asturias», en I. Rodríguez (comp.), Cánones literarios masculinos y relecturas transculturales (lo trans-femenino/masculinolqueer), Anthropos, Barcelona, 2001, pp. 179-200.

Bolin, A., «La transversalidad de género. Contexto cultural y prácticas de género», trad. de Carlo A. Aranci, en J. A. Nieto, Antropología de la sexualidad y diversidad cultural, Talasa, colección Ágora, Madrid, 2003.

DENnY, D., «Deciding what to do about your gender dysphoria», en AEGIS Transition Booklet Series, Decatur, Georgia, 1990.

\section{Otros}

\section{Libros}

Altables, C., Educación sentimental y erótica para adolescentes, Miño y Dávila, Madrid, 2000.

ARdrey, R., Les enfants de Caïn, Stock, París, 1977.

BACHOFEN, J. J., El matriarcado. Una investigación de la ginecocracia en el mundo antiguo según su naturaleza religiosa y jurídica, Akal, Madrid, 1987.

BARDET, J. P., E. CASSIN et ál., La primera vez, Planeta, Barcelona, 1981.

Cim, A., L'emancipée, Flammarion, París, 1899.

Deleuze, G., y C. Parnet, Diálogos, trad. José Vázquez Pérez, Pre-Textos, Valencia, 1980.

- y F. Guattari, El Anti-Edipo. Capitalismo y esquizofrenia, trad. de Francisco Monge, Paidós Estudio, Barcelona, 1985.

Guillebaud, J.-C., La tyrannie du plaisir, Seuil, coll. Points, París, 1998.

LE Rider, J., Le cas Otto Weininger, P.U.F., París, 1982.

- Modernité viennoise et crises d'identité, P.U.F., París, 1990. 
Nordau, M., Dégénérescence, Alcan, París, 1894.

WeeKs, J., El malestar de la sexualidad, trad. de Alberto Magnet, Talasa, Madrid, 1985.

Weininger, O., Sexe et caractère, L'Âge de l'Homme, París, 1989 (traducción al español de Felipe Jiménez de Asúa; Losada, Madrid, 2004).

\section{Artículos}

BLESA, T., «Sé más que un hombre, menos que una mujer», en N. Ibeas y M. A. Millán (eds.), La conjura del olvido. Escritura y feminismo, Icaria Antrazyt, Barcelona, 1997, pp. 17-38.

Chiland, C., y S. Lebovici, «Psychopathologie différentielle des sexes», Enfance, n. ${ }^{\circ} 1,1981$.

Derrida, J., "Choréographies», entrevista con Christie V. MacDonald, Diacritics, 12, 2, 1982, pp. 66-76.

Jameson, F., «Pleasure: A Political Issue», en Formations of Pleasure, Routledge y Kegan Paul, Londres, 1983.

— «Postmodernidad y sociedad de consumo», en H. Foster (ed.), La Posmodernidad, Kairós, Barcelona, 1985.

LaClaU, E., "Populist Rupture and Discourse», Screen Education, n. ${ }^{\circ} 34$, prim. 1980, pp. 87-93

Lafargue, P., «La femme et le communisme», en Anthologie des grands textes $d u$ marxisme, Éd. Sociales, París, 1951.

LE RIDER, J., "Otto Weininger: Féminisme et virilité à Vienne», L'Infini, 1983, n. ${ }^{\circ}$ 4, pp. 5-20.

\section{2) Religión}

\section{Libros}

Bellet, M., Fe y psicoanálisis, Sociedad de Educación Atenas, Madrid, 1974.

Bonnefoy, G., La pensée religieuse et morale d'A. de Vigny, Hachette, París, 1944.

Caballero Arencibia, A., Psicoanálisis y Biblia, Universidad Pontificia, Salamanca, 1994.

Fromm, E., Psicoanálisis y religión, Psique, Buenos Aires, 1990.

Graves, R., Los mitos griegos, Losada, Buenos Aires, 1967.

- y R. PATAI, Los mitos hebreos, Alianza Editorial, Madrid, 1986. 
GRIFFITHS, R. M., Révolution à rebours: le renouveau catholique dans la littérature en France de 1870 à 1914, Desclée de Brouwer, París, 1971.

JunG, C.-G., Arquetipos e inconsciente colectivo, Paidós, Barcelona, 1991.

- Psicología y simbología del arquetipo, Paidós, Barcelona, 1992.

- Símbolos de transformación, Paidós, Barcelona, 1993.

- Psicología y religión, Paidós, Barcelona, 1994.

Sertillanges, A.-D., Féminisme et christianisme, Lecoffre, París, 1908.

Warner, M., Seule entre toutes les femmes. Mythe et culte de la Vierge Marie, Rivages, París, 1989 (Tú sola entre las mujeres. El mito y el culto de la Virgen María, Taurus, Madrid, 1991).

\section{3) Miscelánea}

\section{Libros}

Adorno, T. W., y M. Horkheimer, Dialéctica de la Ilustración. Fragmentos filosóficos, Trotta, Madrid, 1994.

Ballesteros, J., Postmodernidad: decadencia o resistencia, Tecnos, Madrid, 1989.

BotTon, A. de, Ansiedad por el estatus, trad. de Jesús Cuéllar, Taurus Pensamiento, Madrid, 2004.

Breton, A., Nadja, Gallimard-Folio, París, 1964.

- Anthologie de l'humour noir, Jean-Jacques Pauvert-Livre de Poche, París, 1966. Buñuel, L., Mi último suspiro (memorias), trad. de Ana M. a de la Fuente, Plaza y Janés, Barcelona, 1983.

- y J.-C. CARRIÈre, Là-bas (guión cinematográfico), Instituto de Estudios Turolenses, Diputación Provincial de Teruel, Teruel, 1990.

Cassou, J., Les sources du XXe siècle, les Arts en Europe de 1884 à 1914, Jean Cassou Editorial-Réunion des musées nationaux, París, 1990, pp. XX-XXI.

Chateaubriand, F.-R., Mémoires d'outre-tombe, Librairie Générale Française-Le Livre de Poche, París, 2000.

Courtade, P., Pour connaître la pensée de Darwin, Les Éditions Françaises Nouvelles, Grenoble, 1945.

Dictionnaire des sciences médicales, Panckoucke, París, 1819.

Dostoyevski, F., Humillados y ofendidos, Nauta, Barcelona, 2002.

Flaubert, G., Correspondance, Gallimard Folio Classique, París, 1998.

Foster, H. (ed.), La Posmodernidad, Kairós, Barcelona, 1985.

Foucault, M., Histoire de la folie à l'âge classique, Plon, París, 1961. 
Foucault, M., Histoire de la sexualité, I. La volonté de savoir, Gallimard, París, 1978.

- Herculine Barbin, llamada Alexina B., Revolución, Madrid, 1985.

Frampton, K., Historia crítica de la arquitectura moderna, Gustavo Gili, Barcelona, 1994.

Freymond, J. (comp.), La lère. Internationale, Droz, Ginebra, 1962.

Guiches, G., Le Banquet, Spès, París, 1926.

Habermas, J., El discurso filosófico de la modernidad, Taurus, Madrid, 1993.

HinterhäUser, H., Fin de siglo. Figuras y mitos, trad. de M. a Teresa Martínez, Taurus, Madrid, 1980.

HobBes, T., Le Léviatan, trad. de Gérard Mairet, Gallimard Folio/Essais, París, 2000.

IBSEn, H., Casa de muñecas, en Teatro completo, vol. I, Aguilar, Madrid, 1959, pp. 1235-1282.

JenCKs, C., Arquitectura tardomoderna y otros ensayos, Gustavo Gili, Barcelona, 1982.

LYOTARD, J.-F., La condición postmoderna. Informe sobre el saber, Cátedra, Madrid, 1984.

Mann, T., Schopenhauer, Nietzsche, Freud, Bruguera, Barcelona, 1984.

Mannoni, J., Clefs pour l'imaginaire ou l'autre scène, Seuil, París, 1969.

Mansuy, M., Études sur l'imagination de la vie, J. Corti, París, 1970.

Martineau, H., Le roman scientifique d'Émile Zola. La médecine et les "RougonMacquart», Lib. J. B. Baillières et fils, París, 1961.

Miquel, P., Histoire de la France, Marabout Université, París, 1976.

MORÁN, A. (coord.), El movimiento antiglobalización en su laberinto, CAES-La Catarata, Madrid, 2003.

Nerval, G. de, Les Filles du feu suivi de Aurélia, Gallimard Folio, París, 1972.

- Voyage en Orient, Garnier-Flammarion, París, 1980.

NieTZSCHe, F., El nacimiento de la tragedia, Espasa-Calpe, Madrid, 1969.

Nin, A., Journal, III, Stock, París, 1971.

Ormesson, J. de, Revue de métaphysique et de morale, oct.-dic., París, 1963.

RACCHINI, P., La neurosis del poder, Alianza Editorial, Madrid, 1992.

Rousseau, J.-J., Les Confessions, Gallimard-Folio, París, 1979.

SADE, D. A. F., Marqués de, Les 120 Journées de Sodome, U.G.E., 10/18, París, 1975.

SÁinz GutiérRez, V., La cultura urbana de la posmodernidad. Aldo Rossi y su contexto, Alfar, Sevilla, 1999.

SarduY, S., La simulación, Monte Ávila Editores, Caracas, 1982.

Sarraute, N., Nathalie Sarraute. Qui êtes vous? Conversations avec Simone Benmussa, La Manufacture, Lyon, 1987. 
SARTre, J.-P., L'Être et le Néant, Gallimard, París, 1943.

Séances du Congrès ouvrier socialiste de France, 3. ${ }^{a}$ reunión llevada a cabo en Marsella,

del 20 al 31 de octubre de 1879, en la sala Folies-Bergère de Marsella, 1880.

Semprún, J., La escritura o la vida, Tusquets Andanzas, Barcelona, 1995.

StrindberG, A., El padre, M. K., Madrid, 1979.

TuRner, V. W., The Ritual Process: structure and anti-structure, Cornell University

Press, Ithaca, Nueva York, 1977.

VerCellone, F., L'Estetica dell'Ottocento (versión española: Estética del siglo XIX, trad. de Francisco Campillo, Antonio Machado Libros, colección La Balsa de la Medusa-Léxico de Estética, Madrid, 2004).

Zambrano, M., Hacia un saber sobre el alma, Alianza Editorial, Madrid, 1987. ZolA, É., La Curée, Gallimard-Folio, París, 1981.

\section{Artículos}

DomíngueZ, F., «Houellebecq: de la necesidad de gestionar el sexo», Trébede, Zaragoza, febrero de 2002.

— «Hoeullebecq, deseo y revolución», en Riff Raff, n. 22, Mira, Zaragoza, 2003.

- «Poeticidad del poema en prosa: Baudelaire, Le Spleen de París, Rimbaud, Illuminations", Flumen, n. ${ }^{\circ}$ 8, Facultad de Ciencias Humanas y de la Educación, Huesca, 2003.

- "¿Hay alguien ahí arriba? Ascensiones enigmáticas al altillo de la casa», Flumen, n. ${ }^{\circ}$ 10, Facultad de Ciencias Humanas y de la Educación, Huesca, 2005 (en prensa).

- «Houellebecq: amor y política», en Tonos Digital, n. ${ }^{\circ}$ XV, Universidad Complutense, Alcalá de Henares, 2008.

- «Ginecotopía y exclusión. Sobre el pensamiento de La Librería de Mujeres de Milán» (inédito).

DubY, G., «Entretien sur la litterature courtoise, con Alain Richard, Jean-Charles Huchet, Régis Labourdette, Erc Laurent, Alexandre Leupin y Charles Méla», Ornicar?, n.o 26-27, 1983.

Habermas, J., «La modernidad, un proyecto incompleto», en H. Foster (ed.), La Posmodernidad, Kairós, Barcelona, 1985.

STIEgler, B., «El deseo asfixiado o cómo la industria cultural destruye al individuo", Le Monde Diplomatique, edición española, junio de 2004.

Wilde, O., Le Portrait de Dorian Gray, trad. de Edmond Jaloux et Félix Frapereau, préface de Dominique Fernandez, Stock-Le Livre de Poche, París, 1983.

Zambrano, M., "Eloísa o la existencia de la mujer», Anthropos/Suplementos, 2, 1987. 


\section{ÍNDICE}

PRÓlOGO, por Àngels Santa . . . . . . . . . . . . . . . . 9

1. INTRODUCCIÓN $\ldots \ldots \ldots \ldots \ldots \ldots \ldots \ldots \ldots \ldots . \ldots \ldots$

1.1. El autor Huysmans $\ldots \ldots \ldots \ldots \ldots \ldots \ldots \ldots$

1.2. Revolución de la modernidad en Huysmans ......... 23

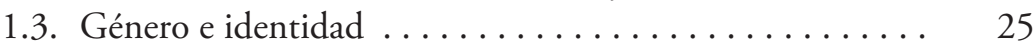

1.4. La masculinidad en su evolución ............ 32

1.5. La novela familiar de Huysmans. . . . . . . . . . . . 33

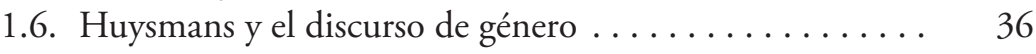

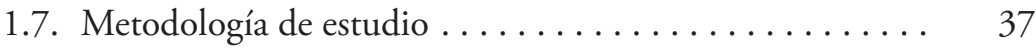

1.8. La crítica huysmansiana hasta nuestros días ......... 39

1.8.1. La crítica huysmansiana en los últimos quince años $\quad 50$

1.8.2. Huysmans en España................ 53

2. EVOLUCIÓN DE LA MASCULINIDAD EN EL SIGLO XIX 57

2.1. El ejemplo de Napoleón. . . . . . . . . . . . . . . . 60

2.2. El hijo bastardo que niega al padre............ 65

2.2.1. Negación del nombre del padre ........... 66

2.2.2. Negación del patrimonio del padre . . . . . . . . . 67

2.2.3. Régimen de sucesiones. . . . . . . . . . . . . . 69

2.2.4. Normas de respetabilidad ............. 74

2.2.5. Responsabilidad del triunfo . ............ 80

2.2.6. Hijo de una generación necesariamente espontánea 82

2.2.7. Nuevo código masculino . . . . . . . . . . . 83 
2.3. Causas de la misoginia decimonónica. . . . . . . . . 85

2.3.1. La rivalidad laboral . . . . . . . . . . . . 85

2.3.2. El avance del feminismo ............ 88

2.3.3. Avance de la prostitución............. 93

2.4. La mujer fatal como construcción misógina ......... 99

2.4.1. La caja de Pandora. . . . . . . . . . . . . . . . . 104

2.4.2. Diablesas y mujeres fatales en los Testamentos: Eva, Lilith y otras. . . . . . . . . . . . . . . 105

2.4.3. Otras manifestaciones de la reacción misógina... 111

2.5. El dandismo. . . . . . . . . . . . . . . . 117

2.5.1. La corriente brummelliana del dandismo...... 118

2.5.2. La corriente byroniana del dandismo ........ 128

a) El dandi facineroso: el Vautrin de Balzac .... 131

b) Dandismo y romanticismo: la figura clave de Baudelaire .................. 133

El vampiro .................. 136

Satán: modelo viril por excelencia . . . . . . 141

2.5.3. Filosofía del dandismo baudelairiano......... 146

2.5.4. El dandi, el amor y el género ............ 149

3. HUYSMANS Y LA MASCULINIDAD CULPABLE . . . . . . 155

3.1. Huysmans y su evolución desde el naturalismo . . . . . . 155

3.1.1. Evolución de la novela realista en el siglo XIX . . . . 157

3.1.2. Zola y el método científico ............. 161

3.1.3. Reacción antinaturalista............... 163

3.1.4. Deserción de Huysmans . . . . . . . . . . . 166

3.2. Autobiografía novelada. . . . . . . . . . . . . . . 176

3.3. La novela familiar de Huysmans. . . . . . . . . . . . 185

3.4. El niño abandonado. . . . . . . . . . . . . . . 188

3.5. Sobrevaloración de la figura paterna............ 200

3.6. Valoración de la madre.................... 207

3.6.1. La fijación a la madre y homosexualidad ...... 210

3.6.2. Las imagos como representaciones de la madre... 211

3.7. La sexualidad como resolución de conflictos edípicos.... 214

3.7.1. La mujer, compañera sexual. ............ 218

3.7.2. El matrimonio, dudosa solución .......... 225 
3.7.3. Soltería y restaurantes . . . . . . . . . . . 238

3.7.4. Importancia de la bonne. . . . . . . . . . 241

3.7.5. La convicción del fracaso en la práctica sexual . . 247

3.7.6. Soluciones al fracaso: la masturbación ........ 255

3.7.7. Fetichismos: mujeres fálicas y campanas. ...... . 257

3.7.8. Poluciones nocturnas................ 262

3.7.9. Súcubos: poluciones demoníacas . . . . . . . . 266

3.7.10. La sexualidad culpable . . . . . . . . . . . . 273

3.7.11. Angustias líquidas . . . . . . . . . . . . . . . 279

3.7.12. Regresión: erotismo anal . . . . . . . . . . . . 299

3.7.13. Regresión: retiro y soledad . . . . . . . . . . . 302

3.7.14. Soluciones al fracaso: la prostitución ........ 311

3.7.15. Soluciones al fracaso: el artificio. . . . . . . . . . 317

3.7.16. Artificio y naturaleza . . . . . . . . . . . . . 324

3.7.17. Soluciones al fracaso: homosexualidad ....... 330

3.7.18. Ansiedad de castración. . . . . . . . . . . . . 341

3.7.19. Desvirilización anunciada . . . . . . . . . . . 349

3.7.20. Dandismo de Huysmans . . . . . . . . . . . . . . 356

3.7.21. Dandismo y misoginia................ 364

3.8. El refugio en la religión $\ldots \ldots \ldots \ldots \ldots \ldots \ldots \ldots . \ldots \ldots$

3.8.1. La entrada en materia . . . . . . . . . . . . . 387

3.8.2. El recurso al ocultismo. . . . . . . . . . . . 393

3.8.3. Purificación religiosa y psicoanálisis......... 404

3.8.4. En route hacia el Padre................ 408

3.8.5. La Madre mediadora ... . . . . . . . . . . . . 422

3.8.6. Mujeres mártires: mística femenina . . . . . . . . 424

3.8.7. Virgen y Madre . . . . . . . . . . . . . . . . 431

3.8.8. Hacia la pureza por el convento. . . . . . . . . . 440

4. CONCLUSIÓN. HUYSMANS: IDENTIDAD Y GÉNERO. 453

4.1. La sexualidad de Huysmans: de la destrucción del triángulo edípico a su reconstrucción . . . . . . . . . . . . . 453

4.2. La posición intermedia de Huysmans. . . . . . . . . . 466

4.3. Sentido y aportación de este trabajo a la crítica huysmansiana 475 BIBLIOGRAFÍA . . . . . . . . . . . . . . . . . . . . 479 

Este libro se terminó de imprimir en el taller del Servicio de Publicaciones de la Universidad de Zaragoza en mayo de 2009

$\cos$ 



\section{Títulos de la colección Humanidades}

1 Joaquín Lomba Fuentes, El oráculo de Narciso. (Lectura del Poema de Parménides), 2. ${ }^{\mathrm{a}}$ ed. (1992).

2 Luis Fernández Cifuentes, García Lorca en el Teatro: La norma y la diferencia (1986).

3 Ignacio Izuzquiza Otero, Henri Bergson: La arquitectura del deseo (1986).

4 Gabriel Sopeña Genzor, Dioses, ética y ritos. Aproximación para una comprensión de la religiosidad entre los pueblos celtibéricos (1987).

5 José Riquelme Otálora, Estudio semántico de purgare en los textos latinos antiguos (1987).

6 José Luis Rodríguez García, Friedrich Hölderlin. El exiliado en la tierra (1987).

7 José María Bardavío García, Fantasías uterinas en la literatura norteamericana (1988).

8 Patricio Hernández Pérez, Emilio Prados. La memoria del olvido (1988).

9 Fernando Romo Feito, Miguel Labordeta. Una lectura global (1988).

10 José Luis Calvo Carilla, Introducción a la poesía de Manuel Pinillos. Estudio y antología (1989).

11 Alberto Montaner Frutos, Política, historia y drama en el cerco de Zamora. La Comedia segunda de las mocedades del Cid de Guillén de Castro (1989).

12 Antonio Duplá Ansuategui, Videant consules. Las medidas de excepción en la crisis de la República Romana (1990).

13 Enrique Aletá Alcubierre, Estudios sobre las oraciones de relativo (1990).

14 Ignacio Izuzquiza Otero, Hegel o la rebelión contra el limite. Un ensayo de interpretación (1990).

15 Ramón Acín Fanlo, Narrativa o consumo literario (1975-1987) (1990).

16 Michael Shepherd, Sherlock Holmes y el caso del Dr. Freud (1990).

17 Francisco Collado Rodríguez (ed.), Del mito a la ciencia: la novela norteamericana contemporánea (1990).

18 Gonzalo Corona Marzol, Realidad vital y realidad poética. (Poesía y poética de José Hierro) (1991).

19 José Ángel García Landa, Samuel Beckett y la narración reflexiva (1992).

20 Ángeles Ezama Gil, El cuento de la prensa y otros cuentos. Aproximación al estudio del relato breve entre 1890 y 1900 (1992).

21 Santiago Echandi, La fábula de Aquiles y Quelone. Ensayos sobre Zenón de Elea (1993).

22 Elvira Burgos Díaz, Dioniso en la filosofía del joven Nietzsche (1993).

23 Francisco Carrasquer Launed, La integral de ambos mundos: Sender (1994).

24 Antonio Pérez Lasheras, Fustigat mores. Hacia el concepto de la sátira en el siglo XVII (1994).

25 M. ${ }^{a}$ Carmen López Sáenz, Investigaciones fenomenológicas sobre el origen del mundo social (1994).

26 Alfredo Saldaña Sagredo, Con esa oscura intuición. Ensayo sobre la poesía de Julio Antonio Gómez (1994).

27 Juan Carlos Ara Torralba, Del modernismo castizo. Fama y alcance de Ricardo León (1996).

28 Diego Aísa Moreu, El razonamiento inductivo en la ciencia y en la prueba judicial (1997).

29 Guillermo Carnero, Estudios sobre teatro español del siglo XVIII (1997). 
30 Concepción Salinas Espinosa, Poesía y prosa didáctica en el siglo XV: La obra del bachiller Alfonso de la Torre (1997).

31 Manuel José Pedraza Gracia, Lectores y lecturas en Zaragoza (1501-1521) (1998).

32 Ignacio Izuzquiza, Armonia y razón. La filosofía de Friedrich D. E. Schleiermacher (1998).

33 Ignacio Ińarrea Las Heras, Poesía y predicación en la literatura francesa medieval. El dit moral en los albores del siglo XIV (1998).

34 José Luis Mendívil Giró, Las palabras disgregadas. Sintaxis de las expresiones idiomáticas y los predicados complejos (1999).

35 Antonio Armisén, Jugar y leer. El Verbo hecho tango de Jaime Gil de Biedma (1999).

36 Abū ț Tāhir, el Zaragozano, Las sesiones del Zaragocí. Relatos picarescos (maqāmāt) del siglo XII, estudio preliminar, traducción y notas de Ignacio Ferrando (1999).

37 Antonio Pérez Lasheras y José Luis Rodríguez (eds.), Inventario de ausencias del tiempo despoblado. Actas de las Jornadas en Homenaje a José Antonio Rey del Corral, celebradas en Zaragoza del 11 al 14 de noviembre de 1996 (1999).

38 J. Fidel Corcuera Manso y Antonio Gaspar Galán, La lengua francesa en España en el siglo XVI. Estudio y edición del Vocabulario de los vocablos de Jacques de Liaño (Alcalá de Henares, 1565) (1999).

39 José Solana Dueso, El camino del ágora. Filosofía politica de Protágoras de Abdera (2000).

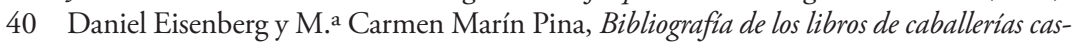
tellanos (2000).

41 Enrique Serrano Asenjo, Vidas oblicuas. Aspectos históricos de la nueva biografía en España (192-1936) (2002).

42 Daniel Mesa Gancedo, Extraños semejantes. El personaje artificial y el artefacto narrativo en la literatura hispanoamericana (2002).

43 María Soledad Catalán Marín, La escenografía de los dramas románticos españoles (1834-1850) (2003).

44 Diego Navarro Bonilla, Escritura, poder y archivo. La organización documental de la Diputación del reino de Aragón (siglos XV-XVIII) (2004).

45 Ángel Longás Miguel, El lenguaje de la diversidad (2004).

46 Niall Binns, ¿Callejón sin salida? La crisis ecológica en la poesía hispanoamericana (2004).

47 Leonardo Romero Tobar (ed.), Historia literaria / Historia de la literatura (2004).

48 Luisa Paz Rodríguez Suárez, Sentido y ser en Heidegger. Una aproximación al problema del lenguaje (2004).

49 Evanghélos Moutsopoulos, Filosofía de la cultura griega, traducción de Carlos A. Salguero-Talavera (2004).

50 Isabel Santaolalla, Los «Otros». Etnicidady «raza» en el cine español contemporáneo (2005).

51 René Andioc, Del siglo XVIII al XIX. Estudios histórico-literarios (2005).

52 María Isabel Sepúlveda Sauras, Tradición y modernidad: Arte en Zaragoza en la década de los años cincuenta (2005).

53 Rosa Tabernero Sala, Nuevas y viejas formas de contar. El discurso narrativo infantil en los umbrales del siglo XXI (2005).

54 Manuel Sánchez Oms, L'Écrevisse écrit: la obra plástica (2006). 
55 Agustín Faro Forteza, Películas de libros (2006).

56 Rosa Tabernero Sala, José D. Dueñas Lorente y José Luis Jiménez Cerezo (coords.), Contar en Aragón. Palabra e imagen en el discurso literario infantil y juvenil (2006).

57 Chantal Cornut-Gentille, El cine británico de la era Thatcher. ¿Cine nacional o "nacionalista»? (2006).

58 Fernando Alvira Banzo, Martín Coronas, pintor (2006).

59 Iván Almeida y Cristina Parodi (eds.), El fragmento infinito. Estudios sobre "Tlön, Uqbar, Orbis Tertius" de J. L. Borges (2007).

60 Pedro Benítez Martín, La formación de un francotirador solitario. Lecturas filosóficas de Louis Althusser (1945-1965) (2007).

61 Juan Manuel Cacho Blecua (coord.), De la literatura caballeresca al Quijote (2007).

62 José Julio Martín Romero, Entre el Renacimiento y el Barroco: Pedro de la Sierra y su obra (2007).

63 M. ${ }^{a}$ del Rosario Álvarez Rubio, Las historias de la literatura española en la Francia del siglo XIX (2007).

64 César Moreno, Rafael Lorenzo y Alicia M. ${ }^{a}$ de Mingo (eds.), Filosofía y realidad virtual (2007).

65 Luis Beltrán Almería y José Luis Rodríguez Garcia (coords.), Simbolismo y hermetismo. Aproximación a la modernidad estética (2008).

66 Juan Antonio Tello, La mirada de Quirón. Literatura, mito y pensamiento en la novela de Félix de Azúa (2008).

67 Manuela Agudo Catalán, El Romanticismo en Aragón (1838-1854). Literatura, prensa $y$ sociedad (2008).

68 Gonzalo Navajas, La utopia en las narrativas contemporáneas (Novela/CinelArquitectura) (2008).

69 Leonardo Romero Tobar (ed.), Literatura y nación. La emergencia de las literaturas nacionales (2008).

70 Mónica Vázquez Astorga (ed.), La pintura española en los museos y colecciones de Génova y Liguria (Italia) (2009).

71 Jesús Rubio Jiménez, La fama póstuma de Gustavo Adolfo y Valeriano Bécquer (2009).

72 Aurora González Roldán, La poética del llanto en sor Juana Inés de la Cruz (2009).

73 Luciano Curreri, Mariposas de Madrid. Los narradores italianos y la guerra civil española (2009). 
rancisco Dominguez propone leer la totalidad de la producción de Joris-Karl Huysmans (París, 18481907) como una reconstrucción de sus coordenadas vitales y familiares, en el sentido del familienroman freudiano. Su separación del Naturalismo zoliano se produce en base a esa necesidad reconstructiva, su búsqueda de la espiritualidad a una reconciliación con las instancias parentales y su emasculación voluntaria a una huida de la heterosexualidad normativa. Este es el punto capital del estudio de Domínguez, pues ve en el hartazgo viril de los personajes masculinos de Huysmans una propuesta novedosa de definición identitaria a través de la sexualidad $\multimap$, mejor dicho, en su inhibición.
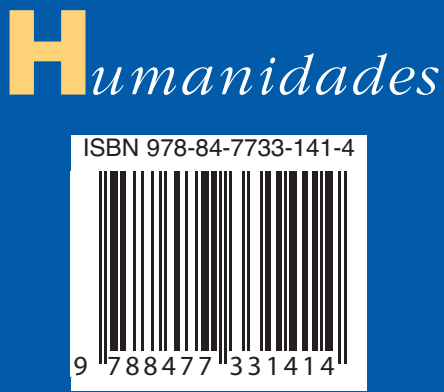